\section{0) Wiadomości Lekarskie \\ Czasopismo Polskiego Towarzystwa Lekarskiego}

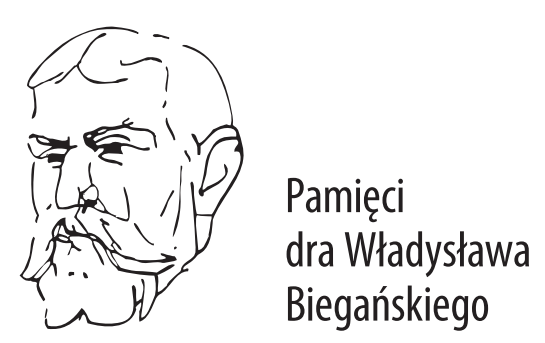

Rok założenia 1928 
Wiadomości Lekarskie is abstracted and indexed in: PubMed/Medline, EBSCO, SCOPUS, Index Copernicus, Polish Medical Library (GBL), Polish Ministry of Science and Higher Education.

Copyright: $\odot$ ALUNA Publishing.

Articles published on-line and available in open access are published under Creative Common Attribution-Non Commercial-No Derivatives 4.0 International (CC BY-NC-ND 4.0) allowing to download articles and share them with others as long as they credit the authors and the publisher, but without permission to change them in any way or use them commercially.

\section{Zasady prenumeraty miesięcznika Wiadomości Lekarskie na rok 2019}

Zamówienia na prenumeratę przyjmuje Wydawnictwo Aluna:

- e-mailem: prenumerata@wydawnictwo-aluna.pl

- listownie na adres:

Wydawnictwo Aluna

ul. Z.M. Przesmyckiego 29, 05-510 Konstancin-Jeziorna

Prosimy o dokonywanie wpłat na numer rachunku Wydawnictwa: Credit Agricole Bank Polska S. A.: 82194010763010740700000000

Cena prenumeraty dwunastu kolejnych numerów: 240 zł/rok (w tym 5\% VAT)

Cena prenumeraty zagranicznej: 120 euro/rok.

Cena pojedynczego numeru - $30 \mathrm{zl}$ (w tym 5\% VAT) + koszt przesyłki.

Przed dokonaniem wpłaty prosimy o złożenie zamówienia. 


\section{2) Wiadomości Lekarskie}

\section{Editor in-Chief:}

Prof. Władysław Pierzchała

\section{Deputy Editor in-Chief:}

Prof. Aleksander Sieroń

\section{Statistical Editor:}

Dr Lesia Rudenko
Polskie Towarzystwo Lekarskie:

Prof. Waldemar Kostewicz - President PTL

Prof. Jerzy Woy-Wojciechowski - Honorary President PTL

Prof. Tadeusz Petelenz

\section{International Editorial Board - in-Chief:}

Marek Rudnicki

Chicago, USA

\section{International Editorial Board - Members:}

Kris Bankiewicz

Christopher Bara

Krzysztof Bielecki

Zana Bumbuliene

Ryszarda Chazan

Stanislav Czudek

Jacek Dubiel

Zbigniew Gasior

Andrzej Gładysz

Nataliya Gutorova

Marek Hartleb

Roman Jaeschke

Andrzej Jakubowiak

Oleksandr Katrushov

Peter Konturek

Jerzy Korewicki

Jan Kotarski
San Francisco, USA

Hannover, Germany

Warsaw, Poland

Vilnius, Lithuania

Warsaw, Poland

Ostrava, Czech Republic

Cracow, Poland

Katowice, Poland

Wroclaw, Poland

Kharkiv, Ukraine

Katowice, Poland

Hamilton, Canada

Chicago, USA

Poltava, Ukraine

Saalfeld, Germany

Warsaw, Poland

Lublin, Poland
George Krol

Krzysztof Łabuzek

Henryk Majchrzak

Ewa Małecka-Tendera

Stella Nowicki

Alfred Patyk

Palmira Petrova

Krystyna Pierzchała

Tadeusz Płusa

Waldemar Priebe

Maria Siemionow

Vladyslav Smiianov

Tomasz Szczepański

Andrzej Witek

Zbigniew Wszolek

Vyacheslav Zhdan

Jan Zejda
New York, USA

Katowice, Poland

Katowice, Poland

Katowice, Poland

Memphis, USA

Gottingen, Germany

Yakutsk, Russia

Katowice, Poland

Warsaw, Poland

Houston, USA

Chicago, USA

Sumy, Ukraine

Katowice, Poland

Katowice, Poland

Jacksonville, USA

Poltava, Ukraine

Katowice, Poland

\section{Managing Editor:}

Agnieszka Rosa

International Editor:

Lesia Rudenko

I.rudenko@wydawnictwo-aluna.pl

Distribution and Subscriptions:

Bartosz Guterman prenumerata@wydawnictwo-aluna.pl

\section{Graphic design / production:}

Grzegorz Sztank

www.red-studio.eu

\section{Publisher:}

ALUNA Publishing

ul. Przesmyckiego 29, 05-510 Konstancin - Jeziorna www.aluna.waw.pl www.wiadomoscilekarskie.pl www.medlist.org 


\section{REGULAMIN PRZYJMOWANIA I OGŁASZANIA PRAC W WIADOMOŚCIACH LEKARSKICH}

1. Miesięcznik Wiadomości Lekarskie jest czasopismem Polskiego Towarzystwa Lekarskiego, ma charakter naukowo-edukacyjny. Zamieszczane są w nim prace oryginalne, kliniczne i doświadczalne oraz poglądowe w języku polskim lub angielskim oraz innych językach (za zgodą redakcji).

2. Publikacja pracy w Wiadomościach Lekarskich jest płatna. Od stycznia 2017 roku koszt opublikowania artykułu wynosi 1000 zł plus 23\%VAT. Jeżeli pierwszym autorem pracy jest członek Rady Naukowej czasopisma lub zespołu recenzentów - za druk nie pracy nie pobieramy opłaty, jeśli zaś jest kolejnym współautorem - opłata wynosi 500 zł plus 23\%VAT. Wydawca wystawia faktury. Opłatę należy uiścić po otrzymaniu pozytywnej recenzji, przed opublikowaniem pracy. Z opłaty za publikację zwolnieni są członkowie Polskiego Towarzystwa Lekarskiego z udokumentowaną opłatą za składki członkowskie za ostatnie 3 lata.

3. Prace zapisane w formacie DOC (z wyłączeniem rycin, które powinny stanowić osobne pliki) należy przesłać pocztą elektroniczną na adres redakcji: Agnieszka Rosa-amarosa@wp.pl.

4. Objętość prac oryginalnych - łącznie z rycinami i piśmiennictwem - nie może przekraczać 21600 znaków (12 stron maszynopisu), prac poglądowych - do 36000 znaków (20 stron).

5. Strona tytułowa powinna zawierać:

- tytuł w języku angielskim i polskim,

- pełne imiona i nazwiska autorów,

- afiliację autorów,

6. Praca oryginalna powinna mieć następującą strukturę: wstęp, cel pracy, materiał i metody, wyniki, dyskusja i wnioski, które nie mogą być streszczeniem pracy. Przy zastosowaniu skrótów konieczne jest podanie pełnego brzmienia terminu przy pierwszym użyciu. W pracach doświadczalnych, w których wykonano badania na ludziach lub zwierzętach, a także w badaniach klinicznych, należy umieścić informację o uzyskaniu zgody komisji etyki badań naukowych.

7. Streszczenia zarówno w języku polskim, jak i angielskim powinny zawierać 200250 słów. Streszczenia prac oryginalnych, klinicznych i doświadczalnych powinny posiadać następującą strukturę: cel, materiał i metody, wyniki wnioski. Nie należy używać skrótów w tytule ani w streszczeniu.

8. Słowa kluczowe (3-6) należy podawać w języku angielskim i polskim, zgodnie z katalogami MeSH (Medical Subject Headings Index Medicus http://www.nim. nih.gov.mesh/MBrower.html). Słowa kluczowe nie mogą być powtórzeniem tytułu pracy.

9. Materiał ilustracyjny - ryciny, wykresy, rysunki, fotografie, slajdy - powinien być opisany cyframi arabskimi i zapisany jako pliki JPG, TIFF lub EPS o rozdzielczości 300 DPI (nie w plikach tekstowych). Ich opisy należy przesłać w osobnym pliku. W tekście muszą znajdować się odniesienia do wszystkich rycin (w nawisach okrągłych).

10. Tabele - ich tytuły (nad tabelą) i treść - powinny być zapisane w programie Microsoft Word, ponumerowane cyframi rzymskimi. Wszystkie stopki dotyczące tabeli powinny znajdować się poniżej tekstu tabeli. W tekście pracy należy umieścić odniesienia do wszystkich tabel (w nawiasach okrągłych).

11. W wykazie piśmiennictwa ułożonym według kolejności cytowania należy uwzględnić wyłącznie te prace, na które autor powołuje się w tekście. W pracach oryginalnych nie powinno być więcej niż 30 pozycji, a w poglądowych nie więcej niż 40 pozycji. Każda pozycja powinna zawierać: nazwiska wszystkich autorów, pierwsze litery imion, tytuł pracy, skrót tytułu czasopisma (wg Index Medicus), rok, numer, stronę początkową i końcową. Przy pozycjach książkowych należy podać: nazwisko autora (autorów), pierwszą literę imienia, tytuł rozdziału, tytuł książki, wydawnictwo, miejsce i rok wydania. Dopuszcza się cytowanie stron internetowych z podaniem adresu URL i daty użycia artykułu oraz o ile to możliwe nazwisk autorów. Każda pozycja piśmiennictwa powinna mieć odwo- łanie w tekście pracy umieszczone w nawiasie kwadratowym, np. [1], [3-6]. Pozycje zapisuje się w sposób zaprezentowany w Załączniku nr 1 do niniejszego regulaminu.

12. Po piśmiennictwie należy podać adres do korespondencji, nazwisko i imię pierwszego autora, adres, numer telefonu oraz adres e-mail.

13. Do pracy należy dołączyć oświadczenie podpisane przez wszystkich autorów określające udział poszczególnych autorów w przygotowaniu pracy (np. koncepcja i projekt pracy, zbieranie danych i ich analiza, odpowiedzialność za analizę statystyczną, napisanie artykułu, krytyczna recenzja itd.), a także oświadczenie, że biorą oni odpowiedzialność za treść. Ponadto należy zaznaczyć, że praca nie była publikowana ani zgłaszana do druku w innym czasopiśmie.

14. Jednocześnie autorzy powinni podać do wiadomości wszelkie inne informacje mogące wskazywać na istnienie konfliktu interesów, takie jak:

- zależności finansowe (zatrudnienie, płatna ekspertyza, doradztwo, posiadanie akcji, honoraria),

- zależności osobiste,

- współzawodnictwo akademickie i inne mogące mieć wpływ na stronę merytoryczną pracy,

- sponsorowanie całości lub części badań na etapie projektowania, zbierania, analizy i interpretacji danych lub pisanie raportu.

Konflikt interesów ma miejsce wtedy, gdy przynajmniej jeden z autorów ma powiązania lub zależności finansowe z przemysłem bezpośrednie lub za pośrednictwem najbliższej rodziny. Jeśli praca dotyczy badań nad produktami częściowo lub całkowicie sponsorowanymi przez firmy, autorzy mają obowiązek ujawnić ten fakt w załączonym oświadczeniu.

15. Każda praca podlega weryfikacji w systemie antyplagiatowym (zapora ghostwriting).

16. Redakcja przestrzega zasad zawartych w Deklaracji Helsińskiej, a także w Interdisciplinary and Guidlines for the Use of Animals In Research, Testing and Education, wydanych przez New York Academy nof Sciencees' Adhoc Resarch. Wszystkie prace odnoszące się do zwierząt lub ludzi muszą być zgodne z zasadami etyki określanymi przez Komisję Etyczną.

17. Czasopismo recenzowane jest $w$ trybie podwójnej, ślepej recenzji. Nadesłane prace są oceniane przez dwóch niezależnych recenzentów, a następnie kwalifikowane do druku przez Redaktora Naczelnego. Recenzje mają charakter anonimowy. Krytyczne recenzje autorzy otrzymują wraz z prośbą o poprawienie pracy lub z decyzją o niezakwalifikowaniu jej do druku. Procedura recenzowania artykułów jest zgodna z zaleceniami Ministerstwa Nauki i Szkolnictwa Wyższego zawartymi w opracowaniu "Dobre praktyki w procedurach recenzyjnych w nauce" (Warszawa 2011) i szczegółowo została opisana na stronie http://www.nauka. gov.pl/g2/oryginal/2014_02/307f933b1a75d6705a4406d5452d6dbf.pdf

18. Redakcja zastrzega sobie prawo redagowania nadesłanych tekstów (dokonywania skrótów i poprawek). Prace są wysyłane do akceptacji autorów. Poprawki autorskie należy przesłać w terminie 3 dni od daty wysłania wiadomości e-mail (pocztą elektroniczną). Brak odpowiedzi w podanym terminie jest równoznaczny z akceptacją przez autora nadesłanego materiału.

19. Przyjęcie pracy do druku oznacza przejęcie praw autorskich przez Redakcję Wiadomości Lekarskich.

20. Autorzy otrzymują nieodpłatnie plik PDF wydania, w którym znajduje się ich praca, a na życzenie - egzemplarz drukowany. Plik elektroniczny przeznaczony jest do indywidualnego użytku autora, bez prawa do rozpowszechniania bez zgody redakcji.

21. Prace przygotowane niezgodnie z regulaminem zostaną zwrócone autorom do poprawienia.

22. Redakcja nie odpowiada za treść zamieszczanych reklam. 


\section{SPIS TREŚCI}

PRACE ORYGINALNE/ ORIGINAL ARTICLES

Aidyn G. Salmanov, Anna V. Kolesnik, Dmytro V. Andriuschenko

EPIDEMIOLOGY OF INTRA-ABDOMINAL INFECTIONS IN UKRAINE: RESULTS OF A MULTICENTER STUDY (2014-2015)

Taras I. Griadil, Ivan V. Chopey, Ksenia I. Chubirko

PECULIARITIES OF DIAGNOSTICS OF DEPRESSIONS AND CLINICAL MANIFESTATIONS IN PATIENTS WITH OBESITY AND CONCOMITANT TYPE 2 DIABETES MELLITUS

Oksana S. Khukhlina, Alona A. Antoniv, Olha Ye. Mandryk, Vitaliy S. Smandych, Marta R. Matushchak

THE ROLE OF ENDOTHELIAL DYSFUNCTION IN THE PROGRESSION MECHANISMS OF NON-ALCOHOLIC STEATOHEPATITIS IN PATIENTS WITH OBESITY AND CHRONIC KIDNEY DISEASE

Marta 0. Kondratyuk, Olena 0. Sorokopud, Larysa M. Stril'chuk, Iryna B. Zhakun, Oksana R. Slaba, Olesya M. Besh, Olena M. Radchenko, Yaryna L. Leshchuk

CHRONIC HEART FAILURE COURSE PROGNOSIS DEPENDING ON BODY WEIGHT AND ENDOGENOUS INTOXICATION SYNDROME

Sergii V. Shevchuk, Kateryna P. Postovitenko, Iryna A. lliuk, Halyna V. Bezsmertna, Yurii O. Bezsmertnyi, Iryna V. Kurylenko, Alina V. Biloshytska, Iryna V. Baranova

THE RELATIONSHIP BETWEEN HOMOCYSTEINE LEVEL AND VITAMINS $B_{12}$, $B_{9}$ AND $B_{6}$ STATUS IN PATIENTS WITH CHRONIC KIDNEY DISEASE

Viktoriia A. Pinchuk, Galyna Ya. Sylenko, Yurii I. Sylenko, Angelina M. Kryvchun, Tetiana V. Pilugina

FEATURES OF CLINICAL MANIFESTATIONS, FREE RADICAL, COAGULATION AND AGGREGATION PROPERTIES OF BLOOD IN PATIENTS WITH CRANIOCEREBRAL TRAUMA

Andrii I. Semenenko, Bogdan 0. Kondratsky, Galyna I. Hrebtiy, Svitlana L. Malyk, Mykola G. Hinhuliak, Roksolana Ya. Bodnar, Alexandr M. Hinhuliak, Lesia M. Zheliba

CORRECTION OF NEUROLOGICAL DEFICIENCY IN PATIENTS WITH ACUTE ISCHEMIC STROKE BY APPLICATION OF DIFFERENT QUALITATIVE COMPOSITION OF INFUSION SOLUTIONS

Viktor A. Ognev, Oleg A. Korop, Andriy M. Zinchuk

THEORETICAL SUBSTANTIATION OF THEWAYS OF INCREASING THE EFFICIENCY OF SPECIALIZED MEDICAL AID IN PATIENTS WITH LUNG CANCER

Iryna M. Tkachenko, Yaroslav Y. Vodoriz, Iryna Y. Marchenko, Maryna A. Shundryk, Dmytro M. Korol, Olena V. Gurzhiy

CHANGES IN ELECTROMYOGRAPHY TEST RESULTS OF PATIENTS WITH PATHOLOGICAL ABRASION OF TEETH. THE ROLE OF ANTERIOR TEETH IN THE PROCESS OF REHABILITATION

Roman V. Filimonov, Inna V. Filimonova, Serghey D. Shapoval, Yury Yu. Kobeliatskyi

COMPARATIVE ANALYSIS OF THE METHODS OF ANESTHETIC MAINTENANCE IN PATIENTS WITH DIABETES WITH THE SYNDROME OF DIABETIC FOOT REQUIRING OPERATIVE INTERVENTION

Volodymyr K. Likhachov, Yanina V. Shymanska, Yulia S. Savelieva, Viktoriya L. Vashchenko, Ludmyla M. Dobrovolska

CHANGES OF PSYCHO-EMOTIONAL STATE IN THE INFERTILE PREGNANT FEMALES DUE TOTHE ANAMNESIS AND IVF

Юлія 0. Сміянова, Людмила Н. Приступа, Вікторія Ю. Гарбузова, Єлізавета А. Гарбузова

АСОЦІАЦІЯ LYS198АSN-ПОЛІМОРФИЗМУ ГЕНА ЕНДОТЕЛІНУ-1 (EDN1) З РОЗВИТКОМ АРТЕРІАЛЬНОї ГІПЕРТЕНЗІЇ В УКРӒ̈НСКІЙ ПОПУЛЯЦІЇ

THE ASSOCIATION OF LYS198ASN -POLYMORPHISM OF ENDOTHELIN-1 GENE (EDN1) WITH DEVELOPMENT OF ARTERIAL HYPERTENSION IN UKRAINIAN POPULATION

Oleksandr V. Kharchenko, Nataliya V. Kharchenko, Inna Y. Shaparenko, Lyudmyla M. Sakharova, Yulia P. Yushchenko

ANALYSIS OF THE PHYSICAL DEVELOPMENT OF YOUTH AND THE STATE OF ITS HEALTH

Ulyana B. Mykhaylyshyn

SOCIAL-PSYCHOLOGICAL FEATURES OF VALUE ORIENTATIONS OF PATIENTS WITH ALCOHOL DEPENDENCE

Olena 0. Karlova, Olena V. Kuzminska, Alina I. Baryshnik

CHANGES IN THE SECRETARY ABILITY OF MONONUCLEAR CELLS IN PATIENTS WITH ATHEROSCLEROSIS AND ACCOMPANYING PATHOLOGY, DEPENDING ONTHE C-PEPTIDE BLOOD PLASMA

Orysya 0. Syzon, Tetyana I. Rudnyk, Marianna 0. Dashko

COMBINED DIFFERENTIATED THERAPY IN PATIENTSWITH URTICARIA

Liliya S. Babinets, Olena R. Shaihen, Halyna 0l. Homyn, Iryna M. Halabitska

SPECIFIC ASPECTS OF CLINICAL COURSE IN CASE OF COMBINATION OF CHRONIC PANCREATITIS AND CONCOMITANT VIRAL HEPATITISC

Olexander Ye.Kononov, Larysa F. Matiukha, Ganna V. Batsiura, Olha V. Protsiuk, Liliana V. Klymenko, Tatyana V. Veselova

CLINICAL AND AUDIOLOGICAL VALUES IN THE EARLY DIAGNOSIS OF HEARING IMPAIRMENTS AND RISK GROUPS AMONG SHIP REPAIR WORKERS

Sergii Melashchenko, Viacheslav Chernobrovyi, Oleg Ksenchyn

PREVALENCE OF ACIDIC AND NON-ACIDICREFLUXES IN PATIENTSWITH FUNCTIONAL DYSPEPSIA AND ITS RISKFACTORS INVESTIGATED BY MEANS OF MULTICHANNEL INTRALUMINAL PH-MONITORING

Nataliia I. Sheiko, Volodymyr P. Feketa

DYNAMICS OF HEART RATEVARIABILITY UNDER THE INFLUENCE OF COURSE YOGA BREATHING EXERCISES ON HEALTHY YOUNG PEOPLE 
Victoria S. Sukhan

ALLERGIC RHINITIS AND ASTHMA CO-MORBIDITY

Oleksandr V. Liksunov, Nataliya R. Prysyazhna, Andriy V. Ratushnyuk, Pavlo I. Nikulnikov

IMPROVEMENT OF THE METHODS OF SURGICAL TREATMENT IN PATIENTS WITH INFRALENAL ANEURYSM OF THE ABDOMINAL AORTA

Sergii D. Khimich, Orest M. Chemerys

ROLE OF THE FAMILY PHYSICIAN IN THE TREATMENT OF PATIENTS WITH POLYTRAUMA ON THE OBESITY BACKGROUND ON AN AMBULATORY STAGE

631

Natalia V. Zhovanyk, Mariana I. Tovt-Korshynska

INTERACTION BETWEEN CLINICAL AND PSYCHOLOGICAL CHANGES AMONG PATIENTS WITH CHRONIC OBSTRUCTIVE PULMONARY DISEASE AND PULMONARYTUBERCULOSIS CO-MORBIDITY

Sergiy l. Ivashchuk, Larysa P. Sydorchuk

THE PARAMETERS OF LIVER FUNCTIONAL STATE AS A RISK FACTOR OF EDEMATOUS PANCREATITIS DEVELOPMENT PROVIDING OF GENETIC DETERMINATION OF IL-4 PRODUCTION

Khrystyna B. Kvit, Natalya V. Kharchenko, VyacheslavV. Kharchenko, Olga I. Chornenka, Romania I. Chornovus, Uljana S. Dorofeeva, Oksana B. Draganchuk, Oksana M. Slaba

THE ROLE OF SMALL INTESTINAL BACTERIAL OVERGROWTH IN THE PATHOGENESIS OF HYPERLIPIDEMIA

Snizhana V. Feysa, Ivan V. Chopei

COMORBIDITY SEVERITY INDEX AS A NEW TOOL FOR ASSESSMENT OF CO-EXISTING DISEASES IN PATIENTS WITH NON-ALCOHOLIC FATTY LIVER DISEASE

AT THE CARBOHYDRATE METABOLISM DISORDER BACKGROUND AND CONCOMITANT SUBCLINICAL HYPOTHYROIDISM

Oksana V. Bakun, Oksana I. Yurkiv, Ksenia V. Slobodian, Oksana V. Kolesnik, Aliona V. Maruschak

THE LEVEL OF SOME HORMONES IN THE BLOOD WOMEN WITH ENDOMETRIOSIS WHICH ASSOCIATED WITH INFERTILITY

Valentyna I. Velichko, Yana I. Bazhora, Galyna 0. Danilchuk, Larysa I. Kolotvina

PSYCHOEMOTIC FEATURES, STATUS OF COGNITIVE FUNCTIONS AND ASSESSMENT OF BRONCHIAL ASTHMA PATIENTS'QUALITY OF LIFE

Oleksandr Bredun, Oleg Melnikov, Oleksandr Kononov

INTEGRAL SCORING SCALE AS A BASIS FOR AN OBJECTIVE ASSESSMENT OF THE STATE OF PATIENTS WITH CHRONIC TONSILLITIS AND THE EFFECTIVENESS OF THEIR TREATMENT

Natalia Y. Osovska, Yulia V. Mazur, Olga M. Bereziuk, Serhii P. Dmytryshyn, Maryna M. Velychkovych, Larysa A. Perebetiuk, Olena V. Temna, Oksana M. Honcharenko,

Oksana V. Furman, Oleksiy R. Balatskyi

CARDIOVASCULAR REMODELING IN PATIENTS WITH HYPERTENSION WITH DIFFERENT DEGREES OF COGNITIVE IMPAIRMENT

Iryna V. Chekhovska, Olha M. Balynska, Roman I. Blahuta, Valeriy V. Sereda, Serhii 0. Mosondz

EUTHANASIA OR PALLIATIVE CARE: LEGAL PRINCIPLES OF THE IMPLEMENTATION IN THE CONTEXT OF THE REALIZATION OF HUMAN RIGHTS TO LIFE

PRACE POGLĄDOWE / REVIEW ARTICLES

Volodymyr 0. Shaprynskyi, Oleg Y. Kanikovskyi, Yevhen V. Shaprynskyi, Yaroslav V. Karyi

EXPERIENCE IN TREATMENT OF PATIENTS WITH ESOPHAGEAL ACHALASIA

Borys 0. Lohvynenko, Roman V. Myroniuk, Olexander P. Svitlychnyy, Aleksey Y. Prokopenko, Lidija I. Kalenichenko

THEWAY THE HEALTH CARE SYSTEM IN UKRAINE LOOKS LIKE: INTERNATIONAL PRACTICES WITHIN NATIONAL REALITIES

Tetyana B. Vilchyk, Hrihorii S. Krainyk, Oleksandr O. Shandula

LEGAL ENFORCEMENT AND DEVELOPMENT DIRECTIONS OF HEALTH LAW IN UKRAINE

Nataliia V. Nikitchenko, Andrii M. Khankevych, Dmytro V. Slynko, Tetiana I. Savchuk, ViktorV. Lazariev

A MEDICAL ERROR: DOES LAW HELP OR HINDER

Natalia Y. Lemish

MODERN METHODS OF GREAT OBSTETRICAL SYNDROMES PROGNOSTICATION (LITERATURE REVIEW)

Nadiia V. Shulzhenko

LEGAL BASES FOR IMPROVING LEGISLATION ON THE TRANSPLANTATION OF HUMAN ANATOMICAL MATERIALS

Vladislav I. Teremetskyi, Serhii V. Knysh, Vasyl M. Stratonov, Oleksandr M. Khramtsov, Mykola V. Stashchak

ORGANIZATIONAL AND LEGAL DETERMINANTS OF IMPLEMENTING INTERNATIONAL EXPERIENCE IN THE HEALTH CARE SECTOR OF UKRAINE

Nadiya B. Kuryltsiv, Kateryna M. Halei

THE ROLE OF INTERLEUKINS AND THEIR INHIBITORS IN THE DEVELOPMENT OF AUTOIMMUNE UVEITIS

OPIS PRZYPADKU / CASE REPORT

Ivan P. Katerenchuk, Lidiya A. Tkachenko, Tetyana I. Yarmola, Viktoriya V. Talash, Savetik T. Rustamyan, Anna L. Pustovoyt, Oleksandr I. Katerenchuk

CHURG-STRAUSS SYNDROME: CLINICAL CASE AND ITS FEAUTURES 
PRACA ORYGINALNA

ORIGINAL ARTICLE

\title{
EPIDEMIOLOGY OF INTRA-ABDOMINAL INFECTIONS IN UKRAINE: RESULTS OF A MULTICENTER STUDY (2014-2015)
}

\author{
Aidyn G. Salmanov ${ }^{1}$, Anna V. Kolesnik ${ }^{2}$, Dmytro V. Andriuschenko ${ }^{3}$ \\ ISHUPYK NATIONAL MEDICAL ACADEMY OF POSTGRADUATE EDUCATION, KYIV, UKRAINE \\ ¿LUTSK ACADEMY OF RECREATION TECHNOLOGIES AND LAW, LUTSK, UKRAINE \\ ${ }^{3}$ DANYLO HALYTSKY LVIV NATIONAL MEDICAL UNIVERSITY, LVIV, UKRAINE
}

\begin{abstract}
Introduction: Intra-abdominal infections are a common cause of morbidity and mortality worldwide. Early clinical diagnosis and appropriate antimicrobial therapy are the cornerstones in the management of all infections.

The aim: Aim of our work was to obtain the first national estimates of the current prevalence of intra-abdominal infections and resistance of their causative agents to antibiotics in Ukrainian hospitals.

Materials and methods: In total of 1986 patients with microbiologically proven IAI were included in the study. The identification and antimicrobial susceptibility to antibiotics of cultures were determined, using automated microbiology analyzer and Kirby - Bauer antibiotic testing.

Results: Among 1986 patients, 1404 (70.7\%) community-acquired and 582 (29.3\%) nosocomial infections were observed. Death during hospitalization was reported in 4.1\% community-acquired cases and 7.7\% nosocomial cases. The distribution of the microorganisms differed according to the nosocomial or community origin of the infection but not according to their location. In nosocomial patients were observed with increased proportions of Enterococcus faecalis and Pseudomonas aeruginosa. The carbapenems and amikacin were the most consistently active against Enterobacteriaceae. Against $P$. aeruginosa, amikacin, imipenem, ceftazidime and ciprofloxacin were the most active agents in community-acquired infections, while imipenem, cefepime and amikacin were the most active agents in nosocomial cases.

Conclusions: The significant risk factors defined should be addressed preoperatively to decrease the risk for nosocomial infections. Antibiotics application tactics should be determined in accordance with the local data of resistance to them in each surgical hospital.
\end{abstract}

KEY WORDS: peritonitis, nosocomial infection, death, antimicrobial resistance

Wiad Lek 2019, 72, 4, 513-518

\section{INTRODUCTION}

Intra-abdominal infections (IAIs), encompassing a wide spectrum of pathological conditions from uncomplicated appendicitis to fecal peritonitis, are a common cause of morbidity and mortality worldwide [1-3].

A complete classification that includes the origin of source of infection, the anatomical extent of infection, the presumed pathogens involved and risk factors for major resistance patterns, and the patient's clinical condition does not exist [4]. A simple and universally accepted classification divides IAIs into complicated and uncomplicated [5]. In the event of uncomplicated IAIs, the infection only involves a single organ and does not extend to the peritoneum. When the focus of infection is controlled by surgical excision, post-operative antibiotic therapy is not necessary $[6,7]$. In the event of complicated IAIs, the infectious process proceeds beyond the organ into the peritoneum, causing either localized or diffuse peritonitis [4]. Early clinical diagnosis and appropriate antimicrobial therapy in critically ill patients are the cornerstones in the management of IAIs. An insufficient or otherwise inadequate antimicrobial regimen is one of the variables most strongly associated with unfavorable outcomes $[9,10]$.

In the past few decades, an increased prevalence of infections caused by antibiotic-resistant pathogens, including methicillin-resistant Staphylococcus aureus (MRSA) [11], vancomycin-resistant enterococci (VRE) [12], carbapenem-resistant Pseudomonas aeruginosa [13], extended-spectrum $\beta$-lactamase (ESBL)-producing Escherichia coli [14] and Klebsiella species, and multidrug-resistant Acinetobacter species, has been observed [15], especially in IAIs $[3,16]$. Current guidelines recommend a wide range of antimicrobial regimens based on patient characteristics, expected involved pathogens and local resistance epidemiology [17]. In this setting, epidemiological surveys are of paramount importance to ensure adequacy of empirical antimicrobial treatment.

\section{THE AIM}

Aim of our work was to obtain the first national estimates of the current prevalence of IAIs and resistance of their causative agents to antibiotics in Ukrainian hospitals. 
Table I. Type, localization and diagnosis of infections at surgery in community-acquired and nosocomial IAls

\begin{tabular}{|c|c|c|c|}
\hline Parameters & $\begin{array}{l}\text { Community-acquired } \\
\text { infections }(n=1404)\end{array}$ & $\begin{array}{l}\text { Nosocomial infections } \\
\qquad(\mathrm{n}=582)\end{array}$ & $P$-value \\
\hline \multicolumn{4}{|l|}{ Type of peritonitis } \\
\hline generalized & $492(35.0)$ & $318(54.6)$ & $<0.001$ \\
\hline localized & $912(65.0)$ & $264(45.4)$ & $<0.001$ \\
\hline purulent & $1044(74.4)$ & $420(72.2)$ & NS \\
\hline stercoral & $318(25.6)$ & $138(23.7)$ & NS \\
\hline \multicolumn{4}{|l|}{ Localization of lesions } \\
\hline below transverse mesocolon & $996(70.9)$ & $414(71.1)$ & NS \\
\hline appendix & $480(34.2)$ & $42(7.2 \%)$ & $<0.001$ \\
\hline colon & $414(29.5)$ & $246(42.3)$ & $<0.05$ \\
\hline diverticulitis & $132(9.4)$ & $36(6.2)$ & NS \\
\hline cancer & $108(7.7)$ & $84(14.4)$ & NS \\
\hline small intestine & $168(12.0)$ & $138(23.7)$ & $<0.01$ \\
\hline biliary tract & $276(19.7)$ & $66(11.3)$ & NS \\
\hline stomach/duodenum & $96(6.8)$ & $78(13.4)$ & NS \\
\hline
\end{tabular}

Note: NS, not statistically significant

\section{MATERIALS AND METHODS}

\section{STUDY POPULATION}

Over a 24 month period (January 2014 to December 2015), this multicentre retrospective study was performed in 9 Ukrainian acute care hospitals that are similar in terms of medical equipment, laboratory facilities and number of surgeries performed. Adult patients undergoing surgery or interventional drainage for IAI with positive microbiological culture (intra-abdominal samples from surgery or interventional drainage procedures) and identification of microorganisms were included in the database.

\section{ETHICS}

According to Ukrainian law, as this retrospective study did not modify the laboratory or clinical practices of the physicians, no informed consent and no approval of an Ethics Committee were required.

\section{DATA COLLECTION}

In each centre, the microbiologist identified as the centre coordinator and the attending physician collected the data in an electronic case report form. Case identification was triggered by the microbiologist after a positive peritoneal culture. After verification, microbiological and clinical data were recorded on the case report form.

\section{DEFINITIONS}

IAIs were classified as community-acquired or nosocomial infections. Nosocomial IAI was defined as an infection absent upon admission that became evident $48 \mathrm{~h}$ or more after admission in patients hospitalized for a reason other than IAI [18]. Only patients with post-operative infections were considered as nosocomial cases.

\section{MICROBIOLOGICAL SAMPLING}

The intraoperative specimens of abdominal fluid were collected during laparotomy in sterile containers using all aseptic precautions. The identification and antimicrobial susceptibility of the cultures were determined, using auto-mated microbiology analyzer Vitek 2 Compact (BioMerieux, France). Some antimicrobial sus ceptibility test used Kirby - Bauer antibiotic testing. Interpretative criteria were those suggested by the CLSI [19].

\section{STATISTICAL ANALYSIS}

The analysis of statistical data was performed using Microsoft Excel for Windows. Results are expressed as median (range), mean \pm standard deviation for continuous variables and the number with the corresponding percentage for qualitative variables. The primary endpoint was the epidemiology of the microorganisms isolated in intra-abdominal samples and their resistance to antibiotics. Statistical significance was defined as $\mathrm{P}<0.05$.

\section{RESULTS}

\section{PATIENT AND DISEASE CHARACTERISTICS}

Over the studied period, 1986 patients (52.8\% female, $61 \pm 20$ years, range $19-87$ years) with microbiologically proven IAI were included, with a mean of 14.8 patients per centre (range 2-36 patients). Among these patients, 
Table II. Microorganisms isolated from peritoneal fluid in IAls

\begin{tabular}{|c|c|c|c|}
\hline Microorganism & $\begin{array}{c}\text { Community-acquired } \\
\text { infections }\end{array}$ & $\begin{array}{c}\text { Nosocomial } \\
\text { infections }\end{array}$ & $P$-value \\
\hline Aerobes & $2226(70.9 \%)$ & $1321(75.9 \%)$ & $<0.05$ \\
\hline Gram-negative bacilli & $1338(42.6 \%)$ & $751(43.1 \%)$ & NS \\
\hline Escherichia coli & $954(71.3 \%)$ & 390 (51.9\%) & $<0.001$ \\
\hline Klebsiella spp. & $90(6.7 \%)$ & $78(10.4 \%)$ & NS \\
\hline Enterobacter spp. & $168(12.6 \%)$ & $138(18.4 \%)$ & NS \\
\hline Proteus mirabilis & $54(4.0 \%)$ & $42(5.6 \%)$ & NS \\
\hline Pseudomonas aeruginosa & $66(4.9 \%)$ & $96(12.8 \%)$ & $<0.01$ \\
\hline Acinetobacter spp. & $6(0,4 \%)$ & $7(0.9)$ & NS \\
\hline Gram-positive cocci & $888(28,3 \%)$ & $570(32.7 \%)$ & NS \\
\hline Enterococcus faecalis & $168(18.9 \%)$ & $186(32.6 \%)$ & $<0.05$ \\
\hline Enterococcus faecium & $96(10.8 \%)$ & $48(8.4 \%)$ & NS \\
\hline Enterococcus (other) & $78(8.8 \%)$ & $78(13.7 \%)$ & NS \\
\hline Streptococcus spp. & $444(50.0 \%)$ & $174(30.5 \%)$ & $<0.01$ \\
\hline Staphylococcus aureus & $66(7.4 \%)$ & $36(6.3 \%)$ & NS \\
\hline Coagulase-negative Staphylococcus (CNS) & $36(4.1 \%)$ & $48(8.4 \%)$ & NS \\
\hline Anaerobes & $798(25.4 \%)$ & $342(20 \%)$ & NS \\
\hline Anaerobes spp. & $240(30.1 \%)$ & $102(29.8 \%)$ & NS \\
\hline Bacteroides spp. & $444(55.6 \%)$ & $180(52.6 \%)$ & NS \\
\hline Clostridium spp. & $114(14.3 \%)$ & $60(17.4 \%)$ & NS \\
\hline Fungi & $114(3.6 \%)$ & $78(4 \%)$ & NS \\
\hline Candida albicans & $84(73.7 \%)$ & $48(61.5 \%)$ & NS \\
\hline Other & $30(26.3)$ & $30(38.5)$ & \\
\hline Total & $3138(100.0)$ & $1741(100 \%)$ & \\
\hline
\end{tabular}

Note: NS, not statistically significant.

1404 community-acquired $(70.7 \%)$ and 582 nosocomial (29.3\%) infections were observed, yielding a total of 4879 intraperitoneal specimens. Type and location of peritonitis differed in nosocomial and community-acquired cases (table I). Death during hospitalization was reported in 57 (4.1\%) community-acquired cases and 45 (7.7\%) nosocomial cases.

\section{MICROBIOLOGICAL RESULTS}

Positive blood cultures were reported in 78 community-acquired $(6.1 \%)$ and 48 nosocomial $(8.7 \%)$ patients in the peri-operative period. The number of peritoneal microorganisms per sample was $\geq 3$ in $33.7 \%$ and $54.4 \%$ of cases, respectively, for community-acquired and nosocomial infections $(\mathrm{P}<0.001)$. A total of 4879 microorganisms were cultured. The distribution of the microorganisms differed according to the nosocomial or community origin of the infection (table II) but not according to their location (data not shown). In nosocomial patients, increased proportions of aerobic bacteria were observed $(\mathrm{P}<0.05)$ with increased proportions of Enterococcus faecalis (32.6\% vs. $18.9 \%$ in community-ac- quired patients; $\mathrm{P}<0.05)$ and Pseudomonas aeruginosa strains ( $12.8 \%$ vs. $4.9 \%$ in community-acquired patients; $\mathrm{P}<0.01)$. Conversely, decreased proportions of Escherichia coli (51.9\% vs. $71.3 \%$ in community-acquired patients, $\mathrm{P}<0.001)$ and streptococci strains were observed in nosocomial patients $(30.5 \%$ vs. $50.0 \%$ in community-acquired patients, $\mathrm{P}<0.01)$. When taking into account prior antibiotic therapy, we did not observe any change in the type or proportion of the cultured organisms, whatever the type of infection.

\section{ANTIBICROBIAL RESISTANCE}

Among the antimicrobial agents tested, the carbapenems (imipenem and ertapenem) and amikacin were the most consistently active in vitro against Enterobacteriaceae in both community-acquired and nosocomial infections (table III). Against $P$. aeruginosa, amikacin, imipenem, ceftazidime and ciprofloxacin were the most active agents in community-acquired infections, while imipenem, cefepime and amikacin were the most active agents in nosocomial IAI cases (table III). No MRSA or VRE strains were cultured. When taking into account the global activity 
Table III. Antibiotic susceptibilities (\% susceptible) of aerobic Gram-negative bacteria isolated from patients with community-acquired (CA) and nosocomial (N) IAls

\begin{tabular}{|c|c|c|c|c|c|c|c|c|c|c|c|c|}
\hline \multirow[t]{2}{*}{ Antibiotic } & \multicolumn{2}{|c|}{$\begin{array}{l}\text { Escherichia coli } \\
(n=1344)\end{array}$} & \multicolumn{2}{|c|}{$\begin{array}{c}\text { Klebsiella } \\
\text { spp. }(n=168)\end{array}$} & \multicolumn{2}{|c|}{$\begin{array}{l}\text { Enterobacter } \\
\text { spp. }(n=306)\end{array}$} & \multicolumn{2}{|c|}{$\begin{array}{l}\text { Proteus mirabilis } \\
\qquad(\mathrm{n}=96)\end{array}$} & \multicolumn{2}{|c|}{$\begin{array}{c}\text { P.aeruginosa } \\
(n=162)\end{array}$} & \multicolumn{2}{|c|}{$\begin{array}{c}\text { Acinetobacter } \\
\text { spp. }(n=13)\end{array}$} \\
\hline & CA & $\mathbf{N}$ & CA & $\mathbf{N}$ & CA & $\mathbf{N}$ & CA & $\mathbf{N}$ & CA & $\mathbf{N}$ & CA & $\mathbf{N}$ \\
\hline AMX & 65.2 & 45.8 & 0 & 0 & 0 & 0 & 71.4 & 50.1 & 0 & 0 & 0 & 0 \\
\hline AMC & 78.1 & 58.2 & 85.2 & 80.2 & 39.8 & 33.2 & 84.3 & 75.5 & 0 & 0 & 0 & 0 \\
\hline TIC & 69.9 & 48.2 & 0 & 0 & 92.7 & 64.1 & 86.5 & 77.8 & 81.9 & 60.1 & 89.2 & 74.5 \\
\hline TZP & 97.3 & 86.1 & 100 & 92.3 & 96.5 & 64.2 & 100 & 100 & 88 & 72.8 & 81.9 & 51.8 \\
\hline IPM & 100 & 100 & 100 & 100 & 100 & 100 & 100 & 100 & 98.2 & 94.1 & 100 & 93.9 \\
\hline EPM & 100 & 100 & 100 & 100 & 100 & 100 & 100 & 100 & 100 & 100 & 100 & 100 \\
\hline CTX & 99.1 & 90.2 & 100 & 98.8 & 96 & 61 & 100 & 97.3 & 0 & 0 & 37.2 & 12.0 \\
\hline CAZ & 99.4 & 88.7 & 100 & 94.5 & 96 & 64 & 100 & 97.5 & 87.8 & 78.6 & 39 & 17 \\
\hline FEP & 99.3 & 96.1 & 100 & 96.7 & 100 & 90 & 100 & 77.6 & 51.2 & 37.1 & 81.2 & 63.1 \\
\hline GEN & 98.5 & 88.7 & 100 & 99.2 & 100 & 91 & 100 & 98.8 & 70 & 53 & 55.9 & 37.8 \\
\hline AMK & 99 & 88.5 & 100 & 88.6 & 100 & 91 & 100 & 100 & 98.9 & 84.7 & 71.4 & 67.1 \\
\hline CIP & 94.8 & 87.2 & 100 & 98.1 & 100 & 100 & 75 & 100 & 96.8 & 81.2 & 87.7 & 72.1 \\
\hline LVX & 100 & 67.3 & 100 & 96.7 & 100 & 67 & 0 & 0 & 0 & 0 & 0 & 0 \\
\hline
\end{tabular}

Notes: AMX, amoxicillin; AMC, amoxicillin/clavulanic acid;TIC, ticarcillin; TZP, piperacillin/tazobactam;IPM, imipenem; EPM, ertapenem; CTX, cefotaxime; CAZ, ceftazidime; FEP, cefepime; GEN, gentamicin; AMK, amikacin; CIP, ciprofloxacin; LVX, levofloxacin.

against the Gram-positive bacteria, vancomycin and teicoplanin were the most consistently active in vitro in both community-acquired and nosocomial infections, due to the strains of E. faecium (table IV).

\section{DISCUSSION}

To our knowledge, this is the first IAI surveillance multicenter study in Ukraine, which describes incidence of community-acquired and nosocomial IAI. This epidemiological multicenter retrospective study, performed over a short period of time (2014-2015), investigated the microbiological findings in a mixed group of patients with community-acquired and nosocomial IAIs. We assume that this descriptive study reflects 'real-life' conditions. The principal results are a higher diversity of microorganisms isolated in nosocomial infections and decreased susceptibility among these strains.

Several epidemiological studies addressing susceptibility testing in the course of IAIs published over recent years at an international level $[2,20-22]$ or a single centre level have made important contributions to the description of enteric microorganisms. In the studies by Paterson et al.[20] and Baquero et al. [22], E. coli peritoneal isolates were $-50 \%$ community-acquired and 50\% hospital-acquired (isolated $>48 \mathrm{~h}$ after hospitalization). However, from the perspective of clinicians in the field, these results are either too broad [20-22] or too restrictive $[23,24]$ to be useful in clinical practice. Each type of study has its own deficiencies and strengths. Larger studies may show regional or even global trends that may not be apparent in smaller studies [2, 20-22]. Single centre studies have their own value by demonstrating local resistance patterns [23, 24]. Our study provides data situated between the two.

Our results confirm the difference in clinical and microbiological features between community-acquired and nosocomial peritonitis already observed in the rare comparative data available in the literature $[23,25]$. The disease data referring to the source of infection, organs involved or type or source of peritonitis do not substantially differ from the data in the literature for either community-acquired or nosocomial infections [23-26].

The bacterial spectrum observed in patients with community-acquired peritonitis matches the previous reports well, with E. coli, Streptococcus spp. and Bacteroides fragilis group as the most frequently isolated microorganisms [23, 26]. ESBL-producing E. coli collected from IAIs may not be very prevalent in Europe or the USA, but have been reported with a relatively high prevalence in Latin America (16\%) and Asia (25\%) [22]. However, this feature was not observed in the present study conducted during the same period (2014-2015), for either community-acquired or nosocomial IAIs. This discrepancy between urinary tract and peritoneal samples has been previously described in Spain with $92 \%$ of ESBL-producing E. coli isolated from urine cultures and $1 \%$ from peritoneal fluid [27]. The low rate of ESBL strains and the low severity of the cases could explain the frequent prescription of amoxicillin/ clavulanic acid in monotherapy in community-acquired peritonitis as reported previously [26]. Such an empirical policy should be revised and the antibiotic spectrum broadened.

Overall, enterococci accounted for more than $10 \%$ of the isolates in community-acquired infections, a higher 
Table IV. Antibiotic susceptibilities (\% susceptible) of aerobic Gram-positive bacteria isolated from patients with community-acquired (CA) and nosocomial (N) IAls

\begin{tabular}{|c|c|c|c|c|c|c|c|c|}
\hline \multirow[t]{2}{*}{ Antibiotic } & \multicolumn{2}{|c|}{$\begin{array}{l}\text { Staphylococcus } \\
\text { aureus }(n=102)\end{array}$} & \multicolumn{2}{|c|}{$\begin{array}{c}\text { Coagulase-negative } \\
\text { Staphylococcus (CNS) }(n=84)\end{array}$} & \multicolumn{2}{|c|}{$\begin{array}{c}\text { Enterococcus } \\
\text { faecalis }(\mathrm{n}=354)\end{array}$} & \multicolumn{2}{|c|}{$\begin{array}{c}\text { Enterococcus } \\
\text { faecium }(n=144)\end{array}$} \\
\hline & CA & $\mathbf{N}$ & CA & $\mathbf{N}$ & CA & $\mathbf{N}$ & CA & $\mathbf{N}$ \\
\hline$A M X$ & 92.4 & 82.1 & 0 & 0 & 100 & 86.7 & 67.8 & 60.1 \\
\hline EPM & 100 & 0 & 100 & 91.7 & 0 & 0 & 0 & 0 \\
\hline $\mathrm{CLI}$ & 0 & 0 & 79.9 & 60.1 & 0 & 0 & 62.1 & 50.1 \\
\hline GEN & 100 & 88.7 & 100 & 14.4 & 37.1 & 15.4 & 14.7 & 71.0 \\
\hline PEF & 100 & 88.9 & 80 & 40 & 0 & 0 & 0 & 0 \\
\hline LVX & 0 & 0 & 0 & 0 & 67.4 & 60.1 & 81.1 & 68.1 \\
\hline VAN & 100 & 100 & 100 & 100 & 100 & 97.2 & 100 & 100 \\
\hline TEC & 100 & 100 & 75 & 0 & 100 & 100 & 100 & 100 \\
\hline OXA & 100 & 98.2 & 100 & 100 & 0 & 0 & 0 & 0 \\
\hline
\end{tabular}

Notes: AMX, amoxicillin; EPM, ertapenem; CLI, clindamycin; GEN, gentamicin; PEF, pefloxacin; LVX, levofloxacin; VAN, vancomycin; TEC, teicoplanin; OXA, oxacillin.

proportion than usually reported in the literature. In line with previous studies, the proportion of enterococci was increased in nosocomial cases when compared with community-acquired peritonitis [23-25]. However, the enterococcal proportions in nosocomial cases appear to be low when compared with other studies in nosocomial infections [28]. The low incidence of VRE in Ukraine was confirmed by its absence during this survey.

The susceptibility of anaerobic organisms towards usual treatments remains good. However, the poor susceptibility of bacteroides against clindamycin should be stressed. This drug is no longer recommended for empirical treatment of community-acquired peritonitis because of its low efficacy. On the other hand, the efficacy of carbapenems remains remarkable both in community-acquired and nosocomial infections. These features raise the issue of routine identification and susceptibility testing of anaerobes in peritoneal samples. Susceptibility testing is the only way to report the prevalence of resistance and to detect trends over time.

The mortality rate reported in our study was in the range of those reported in the literature for community-acquired infections but appeared low for post-operative nosocomial infections. In the Roehrborn et al.[23] study, 9\% of patients with community-acquired peritonitis died of complications versus $39 \%$ of patients with nosocomial peritonitis. In a recent study, focused on ICU patients, reported $24 \%$ mortality in community-acquired peritonitis and $28 \%$ in nosocomial infection [25].

\section{LIMITATIONS IN THE OUR STUDY}

Retrospective studies have their own limitations. This is the case in the current investigation as a limited number of centres participated in the survey. Results from these centres may not necessarily always be relevant to other Ukrainian hospitals. The lack of centralized microbiological analysis of the strains in a reference laboratory, which would have allowed complete susceptibility data availability, has to be mentioned. However, all microbiological laboratories follow the same guidelines issued by the Ministry of Health of Ukraine, decreasing the heterogeneity. As this was an retrospective study, the treatment response was not monitored, which is a weakness in a study of a polymicrobial infection where the isolated microorganisms are not all responsible for the host response. As a consequence, our results should be considered cautiously.

\section{CONCLUSIONS}

The significant risk factors defined should be addressed preoperatively to decrease the risk for nosocomial infections. Early detection and treatment is essential to minimize complications of IAIs. Antibiotics application tactics should be determined in accordance with the local data of resistance to them in each surgical in-patient institution. Taking into account the constant changes and significant differences of the resistance levels observed in various hospitals and regions, the constant monitoring of antibiotic resistance to antimicrobials in every in-patient medical institution is required and on the base of the local obtained results to elaborate the hospital record sheets.

\section{REFERENCES}

1. Guyatt G, Gutterman D, Baumann MH, Addrizzo-Harris D, Hylek EM, Phillips $B$, et al. Grading strength of recommendations and quality of evidence in clinical guidelines: report from an American College of Chest Physicians task force. Chest. 2006;129:174-81.

2. Montravers P, Lepape A, Dubreuil L, Gauzit R, Pean Y, Benchimol D, Dupont H. Clinical and microbiological profiles of community-acquired and nosocomial intra-abdominal infections: results of the French prospective, observational EBIIA study. J Antimicrob Chemother. 2009;63(4):785-94. 
3. Salmanov AG, Usenko AYu. Intraabdominal infections and resistance of their causative agents towards antibiotics in surgical stationaries in the City of Kyiv. Klinichna khirurhiia. 2018;85(9):42-49 [in Russian].

4. Sartelli M, Catena F, Abu-Zidan FM, Ansaloni L, BifflWL, Boermeester MA, et al. Management of intra-abdominal infections: recommendations by the WSES 2016 consensus conference. World J Emerg Surg. 2017; 12: 22. doi: 10.1186/s13017-017-0132-7.

5. Menichetti F, Sganga G. Definition and classification of intra-abdominal infections. J Chemother. 2009; 21(Suppl 1):3-4. doi: 10.1179/ joc.2009.21.Supplement-1.3.

6. Mazeh H, Mizrahi I, Dior U, Simanovsky N, Shapiro M, Freund HR, et al. Role of antibiotic therapy in mild acute calculus cholecystitis: a prospective randomized controlled trial. World J Surg. 2012;36:1750-9.

7. Regimbeau JM, Fuks D, Pautrat K, Mauvais F, Haccart V, Msika S, et al. Effect of postoperative antibiotic administration on postoperative infection following cholecystectomy for acute calculous cholecystitis: a randomized clinical trial. JAMA. 2014;312:145-54.

8. Montravers P, Dupont $H$, Leone M, Constantin JM, Mertes PM, Société française d'anesthésie et de réanimation (Sfar) et al. Guidelines for management of intra-abdominal infections. Anaesth Crit Care Pain Med. 2015;34:117-30. doi: 10.1016/j.accpm.2015.03.005.

9. Dellinger RP, Levy MM, Carlet JM, Bion J, Parker MM, Jaeschke R, Reinhart K, Angus DC, Brun-Buisson C, Beale R, et al. Surviving Sepsis Campaign: international guidelines for management of severe sepsis and septic shock: 2008. Crit Care Med. 2008 Jan; 36(1):296-327.

10. Cattan P, Yin DD, Sarfati E, Lyu R, De Zelicourt M, Fagnani F. Cost of care for inpatients with community-acquired intra-abdominal infections. Eur J Clin Microbiol Infect Dis. 2002 Nov;21(11):787-93.

11. Salmanov AG, Usenko AYu. Antibiotic resistance of nosocomial strains of Staphylococcus aureus in surgical stationaries of Ukraine: results of multicenter investigation (2015 - 2016yrs). Klinichna khirurhiia. 2018; 85(5):5-9. [in Russian].

12. Salmanov AG, Usenko AYu. Antibiotic resistance of nosocomial strains Enterococcus faecalis in Ukrainian surgical departments: results of multicenter study (2011 - 2015). International Journal of Antibiotics and Probiotics. 2017; 1 (2): 30-47. [in Ukrainian].

13. Salmanov AG, Verner OM. Antibiotic resistance nosocomial strains of Pseudomonas aeruginosa in Ukrainian surgical department: results of prospective multicenter study (2011-2015). International Journal of Antibiotics and Probiotics. 2017; 1 (1): 49-63. [in Ukrainian].

14. Salmanov AG. Antibiotic resistance of nosocomial stranis Escherichia coli in Ukrainian surgical departments: results of multicenter study (2011-2015). International Journal of Antibiotics and Probiotics.2017; 1 (1): 29-48. [in Ukrainian].

15. Salmanov AG. Antimicrobial resistance of nosocomial strains of Acinetobacter spp. in surgical departments in Ukraine: results of prospective multicenter study (2009-2015). International Journal of Antibiotics and Probiotics. 2017; 1 (1): 70-82. [in Russian].

16. Sartelli M, Catena F, Coccolini F, Pinna AD. Antimicrobial management of intra-abdominal infections: literature's guidelines. World J Gastroenterol. 2012;18(9):865-71.

17. Wong PF, Gilliam AD, KumarS, Shenfine J, O'Dair GN, Leaper DJ. Antibiotic regimens for secondary peritonitis of gastrointestinal origin in adults. Cochrane Database Syst Rev. 2005 Apr 18; (2):CD004539.

18. Horan TC, Andrus M, Dudeck MA. CDC/NHSN surveillance definition of health care-associated infection and criteria for specific types of infections in the acute care setting. Am J Infect Control. 2008; 36:309-32.
19. Clinical and Laboratory Standards Institute.Performance Standards for Antimicrobial Susceptibility Testing: Eighteenth Informational Supplement M100-S18. Wayne, PA, USA: CLSI; 2008.

20. Paterson DL, Rossi F, Baquero F, Hsueh PR, Woods GL, Satishchandran $V$, et al. In vitro susceptibilities of aerobic and facultative Gramnegative bacilli isolated from patients with intra-abdominal infections worldwide: the 2003 Study for Monitoring Antimicrobial Resistance Trends (SMART). J Antimicrob Chemother. 2005 Jun;55(6):965-73.

21. Rossi F, Baquero F, Hsueh PR, Paterson DL, Bochicchio GV, Snyder TA, et al. In vitro susceptibilities of aerobic and facultatively anaerobic Gramnegative bacilli isolated from patients with intra-abdominal infections worldwide: 2004 results from SMART (Study for Monitoring Antimicrobial Resistance Trends). J Antimicrob Chemother. 2006;58(1):205-10.

22. Baquero F, Hsueh PR, Paterson DL, Rossi F, Bochicchio GV, Gallagher G, et al. In vitro susceptibilities of aerobic and facultatively anaerobic gramnegative bacilli isolated from patients with intra-abdominal infections worldwide: 2005 results from Study for Monitoring Antimicrobial Resistance Trends (SMART). Surg Infect (Larchmt). 2009;10(2):99-104.

23. Roehrborn A, Thomas L, Potreck O, Ebener C, Ohmann C, Goretzki PE, et al. The microbiology of postoperative peritonitis. Clin Infect Dis. 2001 Nov 1;33(9):1513-9.

24. Seguin P, Laviolle B, Chanavaz C, Donnio PY, Gautier-Lerestif AL, Campion JP, et al. Factors associated with multidrug-resistant bacteria in secondary peritonitis: impact on antibiotic therapy. Clin Microbiol Infect. 2006;12(10):980-5.

25. Montravers P, Dupont H, Gauzit R, Veber B, Auboyer C, Blin P, et al. Candida as a risk factor for mortality in peritonitis. Crit Care Med. 2006;34(3):646-52.

26. Montravers P, Chalfine A, Gauzit R, Lepape A, Marmuse JP, Vouillotet C, et al. Clinical and therapeutic features of nonpostoperative nosocomial intra-abdominal infections. Ann Surg. 2004 Mar; 239(3): 409-416.

27. Rodríguez-Baño J, Alcalá JC, Cisneros JM, Grill F, Oliver A, Horcajada $J P$, et al. Community infections caused by extended-spectrum beta-lactamase-producing Escherichia coli. Arch Intern Med. 2008;168(17):1897-902.

28. Sitges-Serra A, López MJ, Girvent M, Almirall S, Sancho JJ. Postoperative enterococcal infection after treatment of complicated intra-abdominal sepsis. Br J Surg. 2002;89(3):361-7.

The authors wish to express their grateful acknowledgement to Ukrainian Association of Infection Control and Antimicrobial Resistance for their organizational support of the study and all the physicians who contributed to this study.

\section{Authors' contributions:}

According to the order of the Authorship.

\section{Conflict of interest:}

The Authors declare no conflict of interest.

\section{CORRESPONDING AUTHOR}

\section{Aidyn Salmanov}

tel: +38066 7997631

e-mail:mozsago@gmail.com

Received: 15.02 .2019

Accepted: 02.04.2019 
PRACA ORYGINALNA

ORIGINAL ARTICLE

\title{
PECULIARITIES OF DIAGNOSTICS OF DEPRESSIONS AND CLINICAL MANIFESTATIONS IN PATIENTS WITH OBESITY AND CONCOMITANT TYPE 2 DIABETES MELLITUS
}

\author{
Taras I. Griadil, Ivan V. Chopey, Ksenia I. Chubirko \\ UZHHGOROD NATIONAL UNIVERSITY, UZHHGOROD, UKRAINE
}

\begin{abstract}
Introduction: According to the World Health Organization, depression is a common mental disorder characterized by despair, loss of interest or joy, feelings of guilt and low self-esteem, sleep disturbance or appetite, lethargy, and poor concentration. There is a series of studies that show the presence of depressive disorders in patients with obesity concomitant type 2 diabetes mellitus, but in our study, we wanted to demonstrate the degree of severity of these changes.

The aim: Diagnose depression in patients with obesity and concomitant type 2 diabetes mellitus.

Materials and methods: Examine patients with obesity and concomitant type 2 diabetes mellitus and select them for research. For the diagnosis of depression were used: Patient Health Questionnaire - 2 and 9, Hospital Anxiety and Depression Scale and Hamilton Depression Scale. Along with hypoglycemic therapy, all patients with diagnosed depression were given individual psychotherapy: cognitive behavioral therapy - 12 sessions per week, interpersonal therapy - 12 sessions per week and bibliotherapy. Results: Using the questionnaires scales, we found depressive disorders in patients with obesity and concomitant type 2 diabetes mellitus. Along with the diagnosis of depression, we managed to correct it using individual psychotherapy.

Conclusions: Patients with obesity and concomitant type 2 diabetes mellitus are in a cohort with an increased risk of depression and should be diagnosed early. Given these patients polypharmacotherapy, treatment for depression should begin with non-drug therapy.
\end{abstract}

KEY WORDS: obesity, type 2 diabetes mellitus, depression, diagnostics

Wiad Lek 2019, 72, 4, 519-522

\section{INTRODUCTION}

Depression is a common illness worldwide, with more than 300 million people affected [1]. Depression is different from usual mood fluctuations and short-lived emotional responses to challenges in everyday life. Especially when long-lasting and with moderate or severe intensity, depression may become a serious health condition [1].

As of 2016, the worldwide estimated prevalence of diabetes mellitus (DM) was $8.5 \%$ (422 million) [2] whilst that of depression was estimated to affect 350 million [3]. Depression risk is 1.33 times higher in people with DM [4]. A $10-25 \%$ DM reduction could prevent $930,000-2.34$ million depressions [4].

MEDLINE and PsycINFO databases and published references were used to identify studies that reported the prevalence of depression in DM. The prevalence of comorbid depression was significantly higher in diabetic women (28\%) than in diabetic men (18\%), in uncontrolled $(30 \%)$ than in controlled studies $(21 \%)$, in clinical $(32 \%)$ than in community (20\%) samples, and when assessed by self-report questionnaires (31\%) than by standardized diagnostic interviews (11\%) [5].

Some researchers have argued that diabetes precedes depression and increases the risk of developing depression due to the psychological trauma following diagnoses of diabetes and its burdens such as hyperglycemia leading to altered glucose transport or treatment of the disease itself or both combined as they pose significant challenges for clinical practice $[6,7]$.

A growing body of evidence suggests that obesity and metabolic syndrome (MetS) are associated with depression and that inflammation may play a role [8]. Participants with metabolic unhealthy obese (MUO) had the highest prevalence of depression compared to the healthy group $(14.8 \%$ vs $6.8, \mathrm{P}<0.001)$. The mean Patient Health Questionnaire (PHQ) - 9 score was also highest among the MUO group (4.16 \pm 0.09$)$. While both obesity and MetS were independently associated with depression, there was a significant interaction between the two $(\mathrm{P}<0.001)$ Both obesity and MetS are associated with depression independent of each other, but participants with both conditions have the highest odds of depression. These findings underscore the importance of cardiometabolic disturbances as correlates of mental health status [8].

In the next study, which included 157 adults, which were divided into three groups (non-obese metabolic healthy group, Metabolically healthy obese ( $\mathrm{MHO}$ ) phenotype 
and MUO) according to the BMI cutoff and MetS criteria. MUO participants had significantly higher Beck depression score $(\mathrm{P}=0.036)$ compared to $\mathrm{MHO}$ and non-obese metabolic healthy groups. There was a significant association between waist circumference $(\beta=0.142, p=0.023), \mathrm{BMI}(\beta=$ $0.347, p=0.037)$, and the number of Met $S$ components $(\beta=$ $1.71, \mathrm{p}=0.002$ ) with depression score. MHO was a benign phenotype in relation to depression [9].

A 10-year longitudinal study, evaluated 269 elderly Japanese individuals aged $\geq 70$ years, indicated that high serum adiponectin levels and low body mass index (BMI) were both associated with worsening depressive symptoms, detected with a short form of the Geriatric Depression Scale (GDS) [10]. Furthermore, the combination of high adiponectin levels and low BMI was associated with worsening depressive symptoms [10].

Hospital Anxiety and Depression Scale (HADS) focuses on non-physical symptoms, it can be used to diagnose depression in people with significant physical ill-health. Any overlap, for instance impaired concentration secondary to pain rather than depression, is usually easy to separate on an individual basis. HADS does not include all of the diagnostic criteria of depression (Diagnostic and Statistical Manual of Mental Disorders, Fourth / Fifth Edition (DSM IV/V)) or all those required by the Health and Work Development Unit (HWDU) National Depression and Long Term Sickness Absence Screening Audit [11].

\section{THE AIM}

Diagnose depression in patients with obesity and concomitant type 2 diabetes mellitus. To note the peculiarities of the occurrence of depression in this group of patients.

\section{MATERIALS AND METHODS}

Patients were selected based on the hospital of the Therapeutic Department of the Communal Institution «Uzhhorod District Hospital» and the outpatient department of therapy and family medicine of the Faculty of Postgraduate And Pre-University Education of the Institute of higher education «Uzhhorod National University». In the course of the survey were selected 47 patients with obesity and concomitant type 2 diabetes mellitus (group 1) and 22 patients with obesity (group 2).

According to the American Diabetes Association and standards of Medical Care in Diabetes 2017, criteria for the diagnosis of type 2 diabetes mellitus, we used 2 criteria: 1 ) Glycated hemoglobin $>6.5 \%$, or 2 ) In a patient with classic symptoms of hyperglycemia or hyperglycemic crisis, a random plasma glucose $>200 \mathrm{mg} / \mathrm{dL}(11.1 \mathrm{mmol} / \mathrm{L})$ [12] Obesity was defined as body mass index $\geq 30 \mathrm{~kg} / \mathrm{m}^{2}$.

The research design for diagnostic depression was developed in accordance with the recommendations of the Unified clinical protocol of primary, secondary (specialized) and tertiary (highly specialized) medical care (Order of the Ministry of Health of Ukraine dated December 25, 2014, No. 1003). For the diagnosis of depression were used: Patient Health Questionnaire - 2, Patient Health Questionnaire - 9, Hospital Anxiety and Depression Scale and Hamilton Depression Scale - 17. First testing on a scale we provide with Patient Health Questionnaire - 2 [13], if we received one positive response on this scale, then we switched to the Patient Health Questionnaire -9 scale. Patient Health Questionnaire - 9 scale includes 9 questions, each of which is rated 0 to 3 , interpretation of total score: 1-4 - Minimal depression, 5-9 - Mild depression, 10-14 - Moderate depression, 15-19 - Moderately severe depression, 20-27 - Severe depression [13].

Hospital Anxiety and Depression Scale score for both scales, scores of less than 7 indicate non-cases: 8-10 - Mild (subclinically expressed anxiety / depression), (11 and above is a clinically expressed anxiety / depression), 11-14 - Moderate, 15-21 - Severe. Score anxiety and depression separately [11].

Hamilton Rating Scale for Depression - 17 comprises 17 items, which have been rated on a 3- or 5-point scale. The Hamilton Rating Scale for Depression - 17 total score ranges from 0 to 52 [14]. The 17-item Hamilton Rating Scale for Depression -17 Anxiety/Somatization factor includes six items: Anxiety (psychic), Anxiety (somatic), Somatic Symptoms (gastrointestinal), Somatic Symptoms (general), Hypochondriasis and Insight [15]. Clinicians have to assess intensity and frequency of depressive symptoms [14]. The total score of the first 17 points: $\bullet$ 0-7 - normal, $\bullet$ 8-13 - mild depressive disorder, $\bullet 14$-18 years - moderate depressive disorder, $\bullet 19-22$ - severe depressive disorder, $\bullet$ more than 23 - extremely severe depressive disorder.

Along with hypoglycemic therapy by metformine 850 mg per day for patient with type 2 diabetes mellitus. All patient were on a hypocaloric diet, and also adhered to the recommended physical activity (at least 30 minutes per day). All patients with diagnosed depression were given individual psychotherapy: cognitive behavioral therapy - 12 sessions per week and interpersonal therapy - 12 sessions per week and bibliotherapy. Participants were divided into two groups: healthy normal weight, metabolic unhealthy obese with type 2 diabetes mellitus.

The statistical processing of the research results was performed using Excel spreadsheets for Windows 2003, which is part of the Microsoft Office 2003 suite of programs, and the STATISTICA 8.0 software. Statistical analysis of materials, summary and summary of conclusions are made by the method of variation statistics, taking into account the average values (mod, median, arithmetic mean) and average error $(\mathrm{M} \pm \mathrm{m})$, with the estimation of the reliability of the values by the Student's t-criterion, as well as with the determination of the correlation coefficient using Pearson's paired method to identify the relationships between the obtained indicators. For a minimum threshold of probability, values $\mathrm{p}<0.05$ were taken.

\section{RESULTS}

Patients included in these studies were adult ( $\geq 45$ years of age). 
The average age of patients in the $1^{\text {st }}$ group was $54,1 \pm 1,2$ years, compared with $52,6 \pm 1,3$ years in patients in the $2^{\text {nd }}$ group ( $\mathrm{p}>0,05)$.

BMI in group 1 was $32,11 \pm 0,15 \mathrm{~kg} / \mathrm{m}^{2}$, instead of $2^{\text {nd }}$ group $34,09 \pm 0,13 \mathrm{~kg} / \mathrm{m}^{2}(\mathrm{p}>0,05)$.

Glucose levels in the $1^{\text {st }}$ group are $4,6 \pm 0,2 \mathrm{mmol} / \mathrm{l}$, whereas in the $2^{\text {nd }}$ group $5,9 \pm 0,1 \mathrm{mmol}(\mathrm{p}<0,05)$. Glycated hemoglobin (HbAlc) in the $1^{\text {st }}$ group are $5,1 \pm 0,2 \%$, instead of $2^{\text {nd }}$ group $5,8 \pm 0,1 \%(p<0,05)$.

The data from the PHQ-2 questionnaire in group 1 revealed one positive response from two questions in 14 patients, while in the 33 patients two positive responses were found. Instead, in the patients of group 2, according to the results of the PHQ-2 questionnaire, one positive response was found out of two questions in 7 patients, and two positive responses were revealed in 2 patients. 15 patients in group 2 were excluded from this study because they did not pass a positive response questionnaire PHQ-2.

The data from the PHQ-9 questionnaire in group 1 patients in the group dominated Moderate depression $(13,5 \pm 2,1, n=24)$, followed by patients in the group of Mild depression (7,3 $\pm 0,2, \mathrm{n}=15)$, and patients in the group Moderately severe depression $(17,6 \pm 0,3, \mathrm{n}=6)$, and patients in the group of Severe depression $(22,1 \pm 0,6, \mathrm{n}=2)$.

The data from the PHQ-9 questionnaire in group 2 in the group dominated patients in the group Mild depression $(5,9 \pm 1,2, \mathrm{n}=5)$, and patients in the group of Moderate depression $(11,4 \pm 1,3, \mathrm{n}=2)$.

At the beginning of the study on a scale HADS in patients of $1^{\text {st }}$ group: 15 patients (31.91\%) had clinically expressed (CE) anxiety (A) / depression (D), A - 16,07 $\pm 0,83$ points, D - 15,68 $\pm 0,8$ points, instead 23 patients $(48,94 \%)$ had subclinically expressed (SE) A/D, A - 8,2 $\pm 0,74$ points, D $-9,1 \pm 0,74$ points, in 9 patients $(19,15 \%)$ values were within normal limits.

At the beginning of the study on a scale HADS in patients of $2^{\text {nd }}$ group: 3 patients had clinically expressed $(\mathrm{CE})$ anxiety (A) / depression (D), A - 12,19 $\pm 0,74$ points, D $11,82 \pm 0,71$ points, instead 4 patients had subclinically expressed (SE) A/D, A - 8,1 $1 \pm 0,63$ points, $\mathrm{D}-8,3 \pm 0,67$ points.

At the beginning of the study on a scale HAM-D-17 in patients of $1^{\text {st }}$ group: in 13 patients $(27.66 \%)$ - the rates were within the norm, 18 patients $(38.3 \%)-10,61 \pm 0,42$ points - depressive disorder (DD) mild severity (MS), 11 patients $(23,40 \%)-16,09 \pm 0,41$ points DD middle degrees of severity (DS), 5 patients $(10,64 \%)-20,2 \pm 0,58$ points DD heavy DS.

At the beginning of the study on a scale HAM-D-17 in patients of $2^{\text {nd }}$ group: in 2 patients - the rates were within the norm, 3 patients - 9,24 $\pm 0,31$ points - depressive disorder (DD) mild severity (MS), 2 patients $-15,37 \pm 0,33$ points DD middle degrees of severity (DS).

Instead, after treatment on a scale HADS in patients of 1st group: 7 patients had CE A/D, 30 patients $(48,94 \%)$ had subclinically expressed (SE) A/D, in 10 of patients were within the normal range.

Instead, after treatment on a scale HADS in patients of $2^{\text {nd }}$ group: 7 patients had CE A/D, 2 patients had subclin- ically expressed (SE) A/D, in 5 of patients were within the normal range.

Instead, the data is on a scale HAM-D-17 in patients of $1^{\text {st }}$ group: in 24 patients - the rates were within the normal range, in 21 patients DD easy DS, 2 patients - DD middle DS.

Instead, the data is on a scale HAM-D-17 in patients of $2^{\text {nd }}$ group: in 4 patients - the rates were within the normal range, in 2 patient DD easy DS, 1 patient - DD middle DS.

When comparing the indicators of the $1^{\text {st }}$ and $2^{\text {nd }}$ groups on the PHQ-2 scale, we found statistically significant changes $(p<0,05)$. When comparing the indicators of the $1^{\text {st }}$ and $2^{\text {nd }}$ groups on the PHQ-9 scale, statistically significant data were not available ( $p>0,05)$. When comparing the indicators of the $1^{\text {st }}$ group and the $2^{\text {nd }}$ group on a scale HAM-D-17 and HADS we found statistically significant changes $(p<0,05)$.

\section{DISCUSSION}

The world-wide practice of diagnosing depressive disorders is based on the Diagnostic and Statistical Manual of Mental Disorders, the Fourth / Fifth Edition (DSM IV / V). However, today there are no optimal scales that take into account all the features of the diagnosis and the course of depression.

Depression risk is 1.33 times higher in people with DM. A 10-25\% DM reduction could prevent 930,000-2.34 million depressions [4]. Participants with metabolic unhealthy obese (MUO) had the highest prevalence of depression compared to the healthy group $(14.8 \%$ vs $6.8, \mathrm{P}<0.001)$ [8]. The prevalence of comorbid depression was significantly higher in diabetic women $(28 \%)$ than in diabetic men $(18 \%)$, in uncontrolled (30\%) than in controlled studies (21\%), in clinical (32\%) than in community (20\%) samples, and when assessed by self-report questionnaires (31\%) than by standardized diagnostic interviews (11\%) [5].

In our study for the diagnosis of depressive disorders, we used the following questionnaires: Patient Health Questionnaire - 2, Patient Health Questionnaire - 9, Hospital Anxiety and Depression Scale and Hamilton Depression Scale - 17. Comparison of data obtained using the PHQ-2, PHQ-9 and BMI questionnaires we have confirmed world data that obese people are more prone to obesity. Instead, the HADS and HAM-D-17 questionnaires made it possible to detail the severity of depressive disorders, and these changes were worse in people with concomitant type $2 \mathrm{DM}$.

Prospects for further research is the comparison of biochemical, anthropometric data with questionnaires on the scale of depression in this patient cohort.

\section{CONCLUSIONS}

Patients with obesity and concomitant type $2 \mathrm{DM}$ are in a cohort with an increased risk of depression and should be diagnosed early. Given these patients polypharmacotherapy, treatment for depression should begin with non-drug therapy. Health-care providers may offer psychological 
treatments (such as behavioural activation, cognitive behavioral therapy (CBT) and interpersonal therapy (IPT)) or antidepressant medication (especially selective serotonin reuptake inhibitors and tricyclic antidepressants).

\section{REFERENCES}

1. Depression - World Health Organization. 22 March 2018. https://www. who.int/news-room/fact-sheets/detail/depression

2. NCD Risk Factor Collaboration (NCD-RisC) Worldwide trends in diabetes since 1980: a pooled analysis of 751 population-based studies with $4 \nabla 4$ million participants. Lancet, 387 (10027) (2016), pp. 1513-1530.

3. WHO.Depression:Factsheet. www.who.int/mediacentre/factsheets/s369/ en/World Health Organization (2012) (Accessed 10 September 2017).

4. Batholomew Chireha, Muzi Li, Carl D'Arcy. Diabetes increases the risk of depression: A systematic review, meta-analysis and estimates of population attributable fractions based on prospective studies. Preventive Medicine Reports. Volume 14, June 2019. https://doi. org/10.1016/j.pmedr.2019.100822

5. Ryan J. Anderson, BA1, Kenneth E et al. The Prevalence of Comorbid Depression in Adults With Diabetes. Diabetes Care. 2001 Jun; 24(6): 1069-1078. https://doi.org/10.2337/diacare.24.6.1069.

6. Anderson R.J., Freedland K.E., Clouse R.E. et al. The prevalence of comorbid depression in adults with diabetes: a meta-analysis. Diabetes care, 2001, 24.6: 1069-1078.

7. Engum A. The role of depression and anxiety in onset of diabetes in a large population-based study. Journal of psychosomatic research, 2007, 62.1:31-38.
8. Moazzami, K., Lima B., Sullivan S. et al. Abstract P247: Combination of Obesity and Metabolic Syndrome is Associated With Highest Rate of Depression Secondary to Increased Inflammation. 2019; Circulation, 139(Suppl_1), AP247-AP247. https://doi.org/10.1161/circ.139. suppl_1.P247

9. Yosaee, S., Djafarian, K., Esteghamati, A. et al. Depressive symptoms among metabolically healthy and unhealthy overweight/obese individuals: a comparative study. Medical journal of the Islamic Republic of Iran, 2018:32, 95.

10. Huang C, Kogure M, Tomata $Y$ et al. Association of serum adiponectin levels and body mass index with worsening depressive symptoms in elderly individuals: a 10-year longitudinal study. Aging Ment Health. 2019 Mar; (18)1-7. doi: 10.1080/13607863.2019.1584877.

11. Stern A. F. "The hospital anxiety and depression scale". Occupational Medicine 64.5 (2014): 393-394.

12. American Diabetes Association. "Standards of medical care in diabetes - 2017 abridged for primary care providers." Clinical diabetes: a publication of the American Diabetes Association 35.1 (2017): 5.

13. Patient Health Questionnaire (PHQ-2\& PHQ-9) - Alberta Health Services. https://www.albertahealthservices.ca/frm-19825.pdf

14. Wagner S., Helmreich I., Lieb K. et al. Standardized Rater Training for the Hamilton Depression Rating Scale (HAMD17) and the Inventory of Depressive Symptoms (IDSC30). Psychopathology, (2011): 44(1), 68.

15. Farabaugh A., Mischoulon D., Fava, M. et al. The relationship between early changes in the HAMD-17 anxiety/somatization factor items and treatment outcome among depressed outpatients. International clinical psychopharmacology (2005), 20(2), 87-91.

\section{Authors' contributions:}

According to the order of the Authorship.

\section{Conflict of interest:}

The Authors declare no conflict of interest.

\section{CORRESPONDING AUTHOR Taras I. Griadil \\ Uzhhgorod National University \\ 71 Mynaiska St., 88009 Uzhhgorod, Ukraine \\ tel: +380990080218 \\ e-mail: t.duxowi41992@gmail.com}

Received: 10.02 .2019

Accepted: 02.04 .2019 
PRACA ORYGINALNA

ORIGINAL ARTICLE

\title{
THE ROLE OF ENDOTHELIAL DYSFUNCTION IN THE PROGRESSION MECHANISMS OF NON-ALCOHOLIC STEATOHEPATITIS IN PATIENTS WITH OBESITY AND CHRONIC KIDNEY DISEASE
}

\author{
Oksana S. Khukhlina, Alona A. Antoniv, Olha Ye. Mandryk, Vitaliy S. Smandych, Marta R. Matushchak \\ HIGHER STATE EDUCATIONAL INSTITUTION OF UKRAINE, "BUKOVINIAN STATE MEDICAL UNIVERSITY”, CHERNIVTSI, UKRAINE
}

\begin{abstract}
Introduction: The study increase in the incidence of non-alcoholic steatohepatitis (NASH) on the background of obesity and chronic kidney disease (CKD) in people of working age in Ukraine and in the world necessitates the research into mechanisms of mutual burden and the search for new factors in the pathogenesis of this comorbidity progression .

The aim: To establish the role of endothelial dysfunction in the mechanisms of mutual burden and progression of non-alcoholic steatohepatitis and chronic kidney disease in patients with obesity.

Materials and methods: 135 patients were examined: of which 52 patients with non-alcoholic steatohepatitis with obesity I degree (1 group), 53 patients with nonalcoholic steatohepatitis with comorbid obesity of the I degree and chronic kidney disease of the I-II stage (group 2). The control group consisted of 30 practically healthy persons of the corresponding age and sex. The average age of patients was (45.8 \pm 3.81$)$ years.

Results: The results of the study showed that in patients with NASH, a significant increase in the content of N0 in the blood was detected in comparison with the index in PHP $(p<0,05)$ in group 1 - in 2,1 times, in the $2^{\text {nd }}$ group - in 2,6 times $(p<0,05)$. The role of nitrosative stress in the pathogenesis of NASH was proved, the confirmation of which is the increase in the concentration of nitrosothiols, peroxynitrite and other metabolites $\mathrm{NO}$ in the blood. Increased peroxynitrite formation due to the generation of NO by leukocytes is an important aspect of the damaging effect and inflammation process in NASH. Pathological hyperproduction of NO by endothelial cells and leukocytes from inflammatory infiltrates in the liver contributes to the development of nitrosative stress in NASH. The established hypernitrate in blood may also be considered compensatory in response to hyperproduction of ET-1 in all observational groups.

Conclusions: Confirmation of the presence of endothelial dysfunction (ED) in patients with NASH with CKD resulted in a probable growth of the number of desquamated endothelial cells (DEC) in the $2^{\text {nd }}$ group of patients in 1.9 times $(\mathrm{p} 2<0.05)$. Generation by neutrophils during the exacerbation of NASH of a significant number of active forms of oxygen and nitrogen and hyperproduction of endothelial cells and endometrial lymphocytes with progressive damage to the endothelium (growth of DEC) leads to significant ED, accompanied by mosaic angiospasm of the arteries due to hyperproduction of ET-1 and parectic vasodilatation of the veins of the portal vein system because of the hyperproduction of $\mathrm{N}$.
\end{abstract}

KEY WORDS: nonalcoholic steatohepatitis, chronic kidney disease, obesity, endothelial dysfunction

Wiad Lek 2019, 72, 4, 523-526

\section{INTRODUCTION}

The comorbidity of non-alcoholic steatohepatitis (NASH) and chronic kidney disease (CKD) on the background of obesity is often recently drawn to the attention of both practitioners and researchers $[1,2$, 3]. Schematically, the development of NASH can be presented in several stages: fatty infiltration of the liver, oxidative stress, mitochondrial dysfunction, TNF / endotoxin-mediated injury, aseptic inflammation, diffused liver fibrosis, development of liver-cellular insufficiency (LCI) $[3,4,5]$. The first place among the causes of the development of NASH is insulin resistance syndrome. NASH most often occurs in obesity $(20-81 \%)$. The prevalence of NASH in the world is 10\% (600 million people). In the last 5 years in Ukraine, the incidence of steatohepatitis has increased by $76.6 \%$. In the $12-40 \%$ of patients with liver steatosis during 8-13 years, NASH develops with early liver fibrosis (LF). Chronic kidney disease (CKD) is an important problem in Ukraine and the world today, and the incidence rate has increased by $17 \%$ in recent years $[6,7]$.

The frequency of occurrence of NASH in patients with CKD is unknown. The mechanisms of their joint development are described in isolated works, which were conducted mainly in the experiments..

\section{THE AIM}

To establish the role of endothelial dysfunction in the mechanisms of mutual burden and progression of non-alcoholic steatohepatitis and chronic kidney disease in patients with obesity 


\section{MATERIALS AND METHODS}

135 patients with non-alcoholic steatohepatitis (NASH) with comorbid obesity I degree and chronic kidney disease (CKD) of the $1^{\text {st }}$ and $2^{\text {nd }}$ stage, were examined. Patients were divided into 2 groups: of which 52 patients with non-alcoholic steatohepatitis with obesity I degree (group 1), 53 patients with non-alcoholic steatohepatitis with comorbid obesity of the $1^{\text {st }}$ degree and chronic kidney disease of the I-II stage (chronic uncomplicated pyelonephritis with latent phase in subsiding exacerbation phase) (group 2). The control group consisted of 30 practically healthy persons of the corresponding age and sex. The average age of patients was $(45.8 \pm 3.81)$ years, men were 48, and women 57 persons.

The diagnosis of NASH was established in accordance with a unified clinical protocol approved by the Ukranian Ministry Of Health, Order No. 826 dated on November 6, 2014 , in the presence of criteria for the exclusion of chronic diffuse liver disease of viral, hereditary, autoimmune or medicinal origin as causes of cytolytic, cholestatic syndromes, as well as the results of the ultrasonography survey. Diagnosis and treatment of CKD were performed according to the recommendations of the clinical guidelines of the State Institute «Institute of Nephrology, NAMS of Ukraine» (2012).

The functional state of the endothelium was studied by the content of stable metabolites of nitrogen monoxide (NO) (nitrites, nitrates) in the blood by L.C.Green et al. The number of desquamated endothelial cells in the blood was determined by the method of J.Hladovec in the modification of N.N. Petrischev et al. The lipid blood spectrum was studied based on the content of common lipids (TL), total cholesterol, triacylglycerols (TG), low density lipoprotein (LDL) and high-density lipoprotein (HDL) (Danish Ltd, Lviv), and also calculated the index of atherogenicity (IA) by the formula: IA = total cholesterol / HDL. The degree of carbohydrate compensation was determined by the level of glycemia in the onset and 2 hours after glucose loading (glucose tolerance test) by the glucose oxidase method, the content of insulin in the blood (DRG System) - by the immunoassay (ELISA) method, the content of glycosylated hemoglobin (HbA1c) using standard sets of reagents (DanishLtd, Lviv) by the method of V.A. Koroleva.

The statistical analysis of the results was carried out in accordance with the type of research carried out and the types of numerical data that were obtained. Distribution normality was verified using Liliefors, Shapiro-Uilka tests and the direct visual evaluation of eigenvalues distribution histograms. Quantitative indices having a normal distribution are represented as mean $(\mathrm{M}) \pm$ standard deviation (S). Discrete values are presented in the form of absolute and relative frequencies (percentage of observations to the total number of surveyed). For comparisons of data that had a normal distribution pattern, parametric tests were used to estimate the Student's t-criterion, Fisher's F-criterion. In the case of abnormal distribution, the median test, Mann-Whitney
Rank U-Score, and Wilcox's T-criterion (in the case of dependent groups) were used for multiple comparison. Statistica for Windows version 8.0 (Stat Soft inc., USA), Microsoft Excel 2007 (Microsoft, USA) software packages were used for statistical and graphical analysis of the obtained results.

\section{RESULTS AND DISCUSSION}

Analysis of the lipid profile of the blood in patients with NASH and obesity showed a number of changes that differed depending on the presence of CKD (Table I). Indicators of concentration in blood of total lipids in patients of $1^{\text {st }}$ and $2^{\text {nd }}$ groups exceeded the norm by $26.4 \%$ and $34.2 \%$, respectively, with a statistically significant difference between the groups $(\mathrm{p}<0.05)$.

The content of total cholesterol in blood indicated that it increased by 37.4 and 46.7 ( $p<0.05)$ compared with PHPs in patients of $1^{\text {st }}$ and $2^{\text {nd }}$ groups (Table I). Changes in the concentration of TG in the form of a significant increase (respectively, 2.2 and 2.0 times $(\mathrm{p}<0.05)$ ) were recorded in the $1^{\text {st }}$ and $2^{\text {nd }}$ groups of patients. That is, the content in TG in the blood in the comorbid flow of NASH with CKD and obesity were significantly lower than in patients with NASH and obesity.

The study of blood concentrations of proatherogenic lipoprotein fractions indicated a number of changes: the concentration of LDL in the patients of the $1^{\text {st }}$ group was 1.5 times higher than the control group $(\mathrm{p}<0.05)$, and in patients of the $2^{\text {nd }}$ group LDL increased in 1.7 times $(\mathrm{p}<0.05)$ (Table I). It is also necessary to point out that with the increase in the activity of cytolysis, the content of the cholesterol and LDL in the blood in NASH with comorbidity with CKD and obesity - increased, which may be an important prognostic factor in the progression of atherosclerosis in these patients. Concentration in blood of antiatherogenic lipoproteins - HDL in patients of both groups was significantly lower in comparison with control: in patients of the $1^{\text {st }}$ group - in 1,5 times $(p<0,05)$, in $2^{\text {nd }}$ group - 1,7 times $(p<0.05)$. As can be seen from the results of the study, the maximum suppression of HDL synthesis (Table I) was observed in patients of the $2^{\text {nd }}$ group, indicating a minimum level of protection of endothelial vessels from free radical aggression and atherogenic fractions of blood lipids. The result of these changes was a significant increase in the index of atherogenicity in patients of both groups of observation: the $1^{\text {st }}$ group -2.2 times, the 2 nd group - 2.0 times with the maximum changes in the index in patients with NASH, CKD and obesity, which testifies on the one hand, the presence of significant risk factors for the progression of atherosclerosis in these patients on the background of obesity, and on the other - on the favorable pathogenetic situation with regard to the progress of NASH. Thus, the development of NASH in patients with CKD and obesity is accompanied by a significant disorder of dis-hyperlipidemia with the highest among groups comparing with the increase in 
Table I. Indicators of endothelial dysfunction and lipid spectrum of blood in patients with non-alcoholic steatohepatitis, obesity of the I-II degree and with comorbidity with chronic kidney disease of the I-II stage $(\mathrm{M} \pm \mathrm{m})$

\begin{tabular}{cccc}
\hline \multirow{2}{*}{$\begin{array}{c}\text { Indicators, units } \\
\text { measurement }\end{array}$} & PHP & Groups of patients surveyed \\
\cline { 2 - 4 } & $4,72 \pm 0,11$ & $\begin{array}{c}\text { Group 1 } \\
\text { (NASH+Obesity) }\end{array}$ & $\begin{array}{c}\text { Group 2 } \\
\text { (NASH with CKD + Obesity) }\end{array}$ \\
\hline Total Cholesterol, mmol / & $2,54 \pm 0,02$ & $6,89 \pm 0,38^{*}$ & $6,93 \pm 0,39^{*} * *$ \\
\hline $\mathrm{LDL}, \mathrm{mmol} / \mathrm{I}$ & $1,28 \pm 0,05$ & $4,05 \pm 0,022^{*}$ & $4,58 \pm 0,04^{*} / * *$ \\
\hline $\mathrm{HDL}, \mathrm{mmol} / \mathrm{I}$ & $1,47 \pm 0,03$ & $0,72 \pm 0,02^{*}$ & $0,76 \pm 0,04 * *^{* *}$ \\
\hline $\mathrm{TG}, \mathrm{mmol} / \mathrm{I}$ & $15,32 \pm 1,225$ & $2,42 \pm 0,03^{*}$ & $3,19 \pm 0,07 * / *$ \\
\hline $\mathrm{NO}, \mathrm{mmol} / \mathrm{I}$ & $6,17 \pm 0,854$ & $30,49 \pm 1,318^{*}$ & $40,51 \pm 1,173 * / * *$ \\
\hline $\mathrm{ET}-1, \mathrm{pmol} / \mathrm{I}$ & $3,03 \pm 0,204$ & $11,25 \pm 0,457^{*}$ & $18,83 \pm 0,559 * / * *$ \\
\hline $\mathrm{DEC} \times 104 / \mathrm{L}$ & $3,87 \pm 0,123^{*}$ & $5,80 \pm 0,127 * / *$ \\
\hline
\end{tabular}

Notes: * - changes are probable in comparison with the index in $\mathrm{PHP}(\mathrm{P}<0,05)$;

** - changes are probable when comparing the indices in patients with NASH $(P<0.05)$;

the content of cholesterol and low-density proatherogenic lipoprotein, a possible decrease in high-density anti-atherogenic lipoprotein and an increase in the atherogenicity index.

The results of the study showed that in patients with $\mathrm{NASH}$, a significant increase in the content of $\mathrm{NO}$ in the blood was detected in comparison with the index in PHP $(\mathrm{p}<0,05)$ (Table I) in group 1 - in 2,1 times, in the $2^{\text {nd }}$ group - in 2,6 times $(p<0,05)$. The role of nitrosative stress in the pathogenesis of NASH was proved, the confirmation of which is the increase in the concentration of nitrosothiols, peroxynitrite and other metabolites $\mathrm{NO}$ in the blood $[8,9,10]$. Increased peroxynitrite formation due to the generation of NO by leukocytes is an important aspect of the damaging effect and inflammation process in NASH. Pathological hyperproduction of NO by endothelial cells and leukocytes from inflammatory infiltrates in the liver contributes to the development of nitrosative stress in NASH. The established hypernitrate in blood may also be considered compensatory in response to hyperproduction of ET-1 in all observational groups. Thus, the content of ET- 1 exceeded the index in PHP, respectively, in patients in the $1^{\text {st }}$ group in 1.7 times, in the $2^{\text {nd }}$ group - in 3.0 times ( $\left.\mathrm{p} 1-2<0.05\right)$.

\section{CONCLUSIONS}

Confirmation of the presence of endothelial dysfunction (ED) in patients with NASH with CKD resulted in a probable growth of the number of desquamated endothelial cells (DEC) in the $2^{\text {nd }}$ group of patients in 1.9 times ( $\mathrm{p} 2<0.05)$. Generation by neutrophils during the exacerbation of NASH of a significant number of active forms of oxygen and nitrogen and hyperproduction of endothelial cells and endometrial lymphocytes with progressive damage to the endothelium (growth of DEC) leads to significant ED, accompanied by mosaic angiospasm of the arteries due to hyperproduction of ET- 1 and parectic vasodilatation of the veins of the portal vein system because of the hyperproduction of NO.

The prospect of further scientific research in this direction is the development of a method for the early prevention of non-alcoholic steatohepatitis on the background of obesity and the accompanying CKD of the $1^{\text {st }}$ and $2^{\text {nd }}$ stage.

\section{REFERENCES}

1. Chitturi S, Farrell GC. Etiopathogenesis of nonalcoholic steatohepatitis. Semin. Liver Dis. 2001;1(21):27-41.

2. Bueverov A0, Bogomolov P0. Non-alcoholic fatty liver disease: rationale for pathogenetic therapy. Clinical perspectives in gastroenterology, hepatology. 2009; 1:3-9.

3. Almeda-Valdés P, Cuevas-Ramos D., Aguilar-Salinas CA. Metabolic syndrome and non-alcoholic fatty liver disease.Ann. Hepatol. 2009; 1(8):18-24.

4. Bambha $K$, Belt $P$, Abraham $M$, et al. Ethnicity and nonalcoholic fatty liver disease. Hepatology. 2012;55(3):769-780. [PubMed]

5. Anstee QM, Targher G, Day CP. Progression of NAFLD to diabetes mellitus, cardiovascular disease or cirrhosis. Nat Rev Gastroenterol Hepatol. 2013; 10: 330-44. PMID: 23507799. D0I: 10.1038/ nrgastro.2013.41

6. Baumgarten M., Gehr T. Chronic kidney disease: detection and evaluation. American Family Physician. 2011;84(10):1138-48.

7. Yasui K, Sumida Y, Mori Y et al. Nonalcoholic steatohepatitis and increased risk of chronic kidney disease. Metabolism. 2011;60:735-739.

8. Brunt E.M., Kleiner D.E., Wilson L.A. et al. Nonalcoholic fatty liver disease (NAFLD) activity score and the histopathologic diagnosis in NAFLD: distinct clinicopathologic meanings. Hepatology. 2011;53(3):810-20.

9. Chalasani N., Younossi Z., Lavine J.E. et al. Diagnosis and Management of Non-alcoholic Fatty Liver Disease: Practice Guideline by the American Association for the Study of Liver Diseases, American College of Gastroenterology, and the American Gastroenterological Association. Am. J. Gastroenterol. 2012;107:811-26.

10. Nascimbeni F., Pais R., Bellentani S. et al. From NAFLD in clinical practice to answers from guidelines. J. Hepatol. 2013;59(4):859-71. 
This work is a fragment of the research work "Pathogenetic mechanisms of mutual burden and clinical features of nonalcoholic fatty liver disease and chronic kidney disease, justification of differentiated treatment", registration number 0117U002351 (2017-2019).

\section{Authors' contributions:}

According to the order of the Authorship.

\section{Conflict of interest:}

The Authors declare no conflict of interest.

\section{CORRESPONDING AUTHOR}

Alona A. Antoniv

Higher Educational Establishment of Ukraine

„Bukovinian State Medical University”

Chernivtsi, Ukraine

tel: +380992321861

e-mail: antonivalona@ukr.net

Received: 07.02 .2019

Accepted: 01.04 .2019 
PRACA ORYGINALNA

ORIGINAL ARTICLE

\title{
CHRONIC HEART FAILURE COURSE PROGNOSIS DEPENDING ON BODY WEIGHT AND ENDOGENOUS INTOXICATION SYNDROME
}

\author{
Marta 0. Kondratyuk, Olena 0. Sorokopud, Larysa M. Stril'chuk, Iryna B. Zhakun, Oksana R. Slaba, Olesya M. Besh, \\ Olena M. Radchenko, Yaryna L. Leshchuk \\ DANYLO HALYTSKY LVIV NATIONAL MEDICAL UNIVERSITY, LVIV, UKRAINE
}

\begin{abstract}
Introduction: 0ver the years, heart failure remains one of the most common and prognostically unfavorable conditions.

The aim of our study was to determine the frequency of complications in patients with CHF depending on the body weight and intoxication syndrome of varying degrees of severity. Materials and methods: A complete clinical examination was performed in 58 patients ( 41 (70.6\%) men and 17 (29.4\%) women) with CHF. In addition to the standard examination in accordance with the protocol, the level of endogenous intoxication was determined by the level of medium-weight molecules (MWM254) and leptin. The patients were randomized into $4 \mathrm{groups}$ depending on their body mass index and the degree of endogenous intoxication. Statistical processing of the results was carried out using the methods of variation statistics "Statistica 6.0". Results: It was revealed that the worst survival rate is observed in patients with normal body mass against the background of the expressed endogenous intoxication syndrome, the best survival rate is observed provided that there are a normal body mass and endogenous intoxication of a minimum degree. An inverse correlation between the body mass index and the endogenous intoxication indicator (blood MWM) was detected. Patients with CHF should have their leptin level evaluated. An increase in its level was associated with arterial hypertension, an increase in blood glucose levels and lipid metabolism disorders.

Conclusions: Increased level of blood MWM worsens the forecast of CHF. The unfavorable outcome was observed in patients with the combination of hypoleptinemia with severe endogenous intoxication.
\end{abstract}

KEY WORDS: CHF, endogenous intoxication, obesity, prognosis

Wiad Lek 2019, 72, 4, 527-531

\section{INTRODUCTION}

Over the years, heart failure remains one of the most common and prognostically unfavorable pathological conditions [1] and the final stage of virtually all heart diseases. It is predetermined not only by its overload but also by the complex interaction between genetic, neurohumoral, metabolic, inflammatory and other factors having a direct impact on the heart [2]. Despite the fact that at present, the survival of patients with chronic heart failure (CHF) has improved, primarily due to modern medication, nevertheless the mortality rate remains very high [3]: more than $30 \%$ of patients die within 5 years of diagnosis [4]. That is why the search for pathogenic and prognostic factors influencing the duration of CHF remains relevant. One of these factors is obesity, which is recognized as a non-infectious pandemic of our time. According to literature data, in 2014 about 1.9 billion adults worldwide were overweight and more than 600 million were suffering from obesity [5].

However, the effect of obesity on the course of a cardiovascular disease is ambiguous. The phenomenon described in literature data is known as the "paradox of obesity" [6], which suggests that overweight patients with cardiovascular disease have a better prognosis than those with normal body weight [7]. Another factor that has an effect on the course and may worsen the condition of patients with chronic heart failure is endogenous intoxication syndrome (EIS) characterized by a complex of metabolic, morphological and functional disorders in various vital organs and systems of the body [8]. The influence of each of these factors separately on the course of CHF is actively discussed in the literature. However, in practice, we often encounter a situation where several factors simultaneously influence the course of the disease.

Prognosis of the CHF course in clinical practice, depending on the body mass index and the degree of endogenous intoxication has not yet been reflected in the available literature, which determined the relevance and feasibility of our study.

\section{THE AIM}

The aim of our study was to determine the frequency of complications in patients with CHF, provided the combined influence of different BMI and endogenous intoxication levels. 


\section{MATERIALS AND METHODS}

A complete clinical examination was performed in 58 patients (41 (70.6\%) men and 17 (29.4\%) women) with CHF. The formation of clinical groups of CHF was performed in accordance with the classification of the New York Heart Association (NYHA, 1964), considering the guidelines of the Ukrainian Association of Cardiology (2017), defining the clinical stage of $\mathrm{CHF}$, its type and the $\mathrm{FC}$ in accordance with the Ministry of Health of Ukraine Order of 03.07.2006, No. 436. The study was based on the ethical principles for research (Helsinki Declaration). The study was approved by the Ethics Committee of the Lviv National Medical University named after Danylo Halytsky. All participants have signed an informed consent form.

The main cause $(84.5 \%)$ of $\mathrm{CHF}$ was coronary heart disease, in $15.5 \%$ - chronic rheumatic heart disease. The most common form of coronary artery disease was angina pectoris (69.1\%). A permanent form of atrial fibrillation was observed in $29.1 \%$ of patients, and $15.5 \%$ had diabetes mellitus. In addition to standard clinical examinations, the determination of body mass index (BMI), N-terminal brain fraction of natriuretic propeptide by qualitative method (CITO TEST NT-proBNP, Pharmasco), endogenous intoxication evaluation by the level of medium-weight molecules $\left(\mathrm{MWM}_{254}\right)$ spectrophotometrically in the ultraviolet region of the spectrum by N.I. Gabrielyan et al. (1985), leptin determination by means of enzyme-linked immunosorbent assay using "DRG Leptin ELISA" reagents (Germany) were performed. The structural-functional parameters of the heart were determined using the ultrasound machine Aloka SSD-500 (Japan) in accordance with the standard technique.

Statistical processing of the results was carried out using the methods of variation statistics "Statistica 6.0" (USA), the correlation analysis was performed by the Kendall method. Nonparametric indicators were compared using the Mann-Whitney criterion and were represented as a median [lower; upper quartile]. Prognosis of the CHF severity and survival analysis were performed by Kaplan-Meyer: the cumulative survival rate at 24 months of follow-up with the evaluation of significance by Gehan-Wilcoxon test and Cox test F-criteria were estimated. Re-hospitalization due to decompensation of $\mathrm{CHF}$ or death of the patient were considered an event.

\section{RESULTS AND DISCUSSION}

In order to evaluate the combined effect of the body mass index (BMI) and endogenous intoxication syndrome on the CHF prognosis, we have randomized the examined patients into 4 groups: $1^{\text {st }}$ group (6 patients, 5 men and 1 woman) patients with normal body mass and MWM less than the median (<0.67 CU), $2^{\text {nd }}$ group (7 patients, 6 men and 1 woman) with normal body mass and MWM $>0.67 \mathrm{CU}, 3^{\text {rd }}$ group ( 22 patients, 15 men and 7 women) - patients with excessive body weight and obesity and MWM <0.67 CU, $4^{\text {th }}$ group (23 patients, 15 men and 8 women) - overweight and obese patients and MWM>0.67 CU.
Survival analysis in the studied groups of patients indicates that the incidence of non-event survival was highest in patients of the $1^{\text {st }}$ group and was $100 \%$, while in the $2^{\text {nd }}$ group it was $25.0 \%$, in the $3^{\text {rd }}-76.2 \%$ and the $4^{\text {th }}-62.5 \%$ (table I, fig. 1). The worst $\mathrm{CHF}$ prognosis was found in patients with normal body mass against the background of a severe syndrome of endogenous intoxication. In this group, $75 \%$ of patients were reported to have complications or death of a patient, that significantly differed from the group of patients with lower MWM levels and normal body weight (Gehan-Wilcoxon criteria $p=0.01$ ), overweight and obese patients with $\mathrm{MWM}<0.67 \mathrm{CU}$ (Cox test F-criterion, $\mathrm{p}=0.008$, Gehan-Wilcoxon test $\mathrm{p}=0.02)$ and even patients with excess body weight, obesity and MWM $>0.67 \mathrm{CU}$ (Cox F-criterion $\mathrm{p}=0.04$ and Gehan-Wilcoxon criterion $\mathrm{p}=0.1)$.

The best prognosis was observed in CHF patients with normal body weight and low MWM <0.67 CU.

An analysis of clinical, laboratory and instrumental data on their correlation with BMI and MWM was performed. Our study had revealed that a number of parameters were dependent on the level of MWM and BMI. Partially better prognosis in obese patients may be explained by the fact that patients with concomitant obesity (groups 3 and 4) were significantly younger than the patients with normal body weight (groups 1 and 2) (Table II).

Patients with the highest percentage of non-event survival had the lowest levels of fibrinogen, the highest levels of systolic and diastolic pressure, less pronounced left ventricular hypertrophy, the lowest degree of endogenous intoxication and the highest levels of triglycerides in the blood.

According to the results presented in the table, the worst prognosis in patients of the $2^{\text {nd }}$ group may be due to the fact that in patients with normal body mass, in the presence of severe endogenous intoxication, hypoleptinemia was observed. The level of leptin in such patients was $0.48 \mathrm{ng} /$ $\mathrm{ml}$, compared with $3.99 \mathrm{ng} / \mathrm{ml}$, provided the excess body mass and expressed EIS ( ${ }^{\text {th }}$ group), $3.6 \mathrm{ng} / \mathrm{ml}$ in patients with normal body mass and low levels of intoxication $\left(1^{\text {st }}\right.$ group), and $10.7 \mathrm{ng} / \mathrm{ml}$ in patients with excess body weight and obesity and low degree of endogenous intoxication ( $3^{\text {rd }}$ group).

According to the literature data [9], the synthesis of leptin is suppressed by the sympathoadrenal system. The leptin deficiency impairs the regulation of lipids in peripheral organs and results in the intracellular accumulation of lipids by reducing the synthesis of fatty acids and triglycerides, which ultimately causes lipotoxicity and apoptosis. In our study, this is confirmed by the low level of TG in patients of the $2^{\text {nd }}$ group, in which the TG level is the lowest and is $78.8 \mathrm{mg} / \mathrm{dl}$ (significantly lower than in patients of the $1^{\text {st }}$ group $\mathrm{p}_{1-2}=0.008,3^{\text {rd }}$ group $\mathrm{p}_{2-3}=0.005$ and $4^{\text {th }}$ group $\mathrm{p}_{2-4}$ $=0.01)$. As for triglycerides, they are non-specific acceptors of toxins, and in conditions of hypotriglyceridemia, the body becomes more sensitive to endotoxins, which is how negative prognosis can be explained. In patients with obesity and without intoxication, the level of leptin is 
Table I. The incidence of non-event survival in patients with CHF depending on the MWM and body weight

\begin{tabular}{ccc}
\hline \multirow{2}{*}{ Group } & \multicolumn{2}{c}{ Proportion of patients } \\
\cline { 2 - 3 } & with reported event & without reported event \\
\hline 1 & - & $100 \%$ \\
\hline 2 & $75 \%$ & $25.0 \%$ \\
\hline 3 & $23.8 \%$ & $76.2 \%$ \\
\hline 4 & $37.5 \%$ & $62.5 \%$ \\
\hline
\end{tabular}

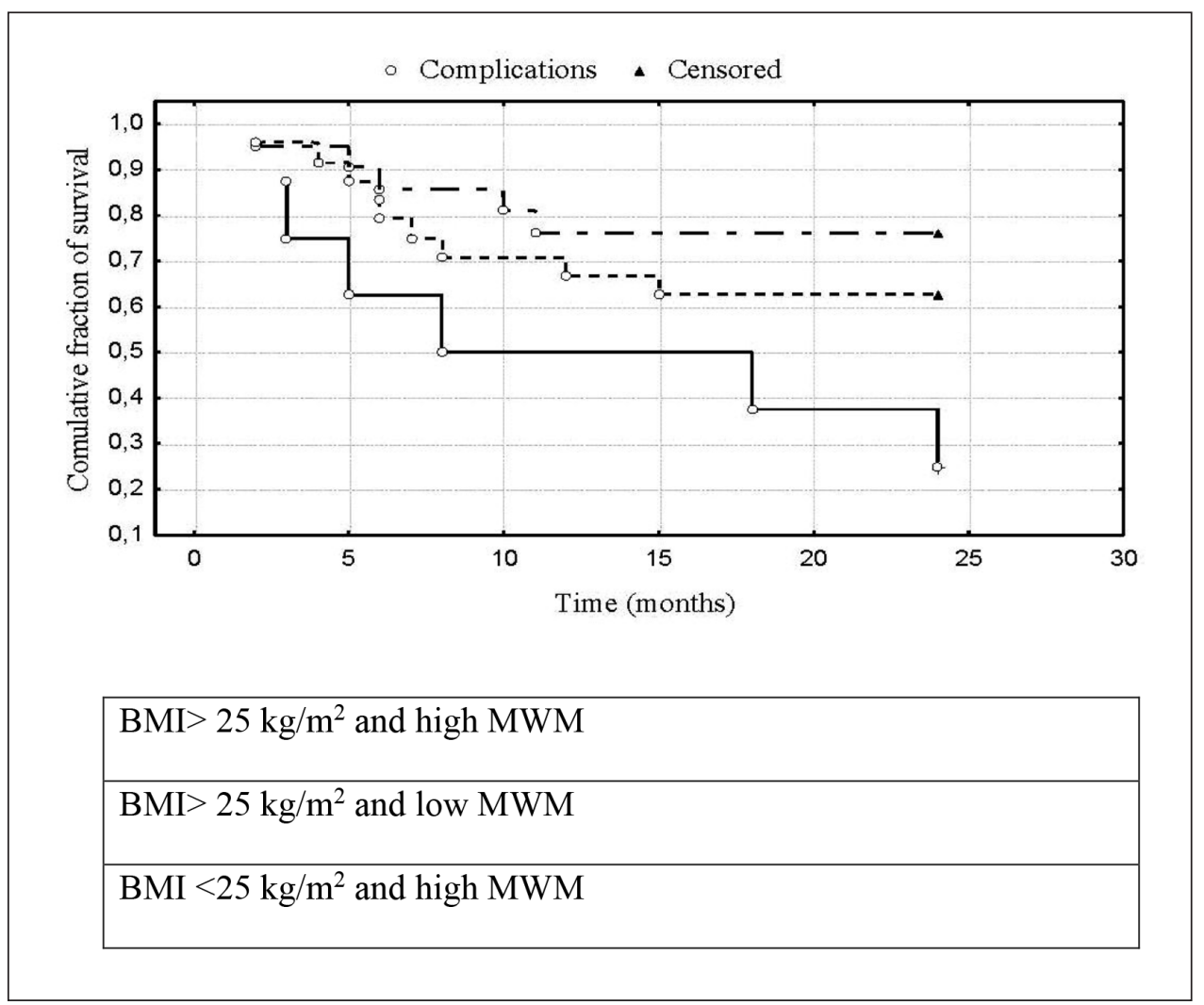

Figure 1. Survival curves of patients with CHF for 24 months depending on BMI and blood MWM

Note: The difference is significant between patients in $1^{\text {st }}$ and $2^{\text {nd }}$ groups (Gehan-Wilcoxon $p=0.02$ ),

$2^{\text {nd }}$ and $3^{\text {rd }}$ groups (Cox F-criterion $p=0.008$, Gehan-Wilcoxon $p=0.02$ ),

$2^{\text {nd }}$ and $4^{\text {th }}$ (Cox F-criterion $\left.p=0.04\right)$.

increased to $10.7 \mathrm{ng} / \mathrm{ml}$, and in patients with intoxication, apparently decreases due to the activation of the sympathoadrenal system and its level approaches normal, $3.99 \mathrm{ng} /$ $\mathrm{ml}$. It alleviates the cardiotoxic effects of hyperleptinemia in obese patients and is associated with a better prognosis.

The level of leptin depends on many factors - such as gender, body weight, hormonal background and the influence of environmental factors [9]. Most researchers affirm that CHF is accompanied by an increase in the blood level of leptin $[10,11]$, which has a deleterious effect on the myocardium, vascular wall, and renal tissue by activating the transforming growth factor and receptors to it. Although, according to other data, in severe $\mathrm{CHF}$ its content is reduced [12]. According to some studies [13], the level of leptin in patients with CHF was $9.2 \pm 7.5 \mathrm{ng} / \mathrm{ml}$. In our study, CHF patients had a blood leptin level of $6.94 \mathrm{ng} / \mathrm{ml}$. The level of leptin directly correlated with the magnitude of both systolic blood pressure $(\tau=0.4 ; \mathrm{p}=0.005)$ and diastolic blood pressure $(\tau=0.3 ; \mathrm{p}=0.03)$, hemoglobin $(\tau=0.3 ; \mathrm{p}=$ $0.02)$, blood glucose $(\tau=0.4 ; p=0.008)$, relative interventricular septum thickness $(\tau=0.4 ; p=0.04)$, cholesterol $(\tau$ $=0.5 ; \mathrm{p}=0.001)$, HDL cholesterol $(\tau=0.4 ; \mathrm{p}=0.02), \mathrm{LDL}$ cholesterol $(\tau=0.4 ; p=0.004)$, TG $(\tau=0.4 ; p=0.004)$. Consequently, the increase in the level of leptin will be associated with arterial hypertension, increased blood glucose levels and lipid metabolism disorders, which is particularly unfavorable for the CHF course.

Thus, the discrepancies in the indicator of non-event survival of patients with CHF with different BMI, obviously, cannot be explained by varying degrees of systolic dysfunction, since by the LV EF magnitude patients with the best prognosis did not differ significantly from those with the worst prognosis. In our opinion, the severity of endogenous intoxication, in particular, may be the determining factor affecting the survival 
Marta O. Kondratyuk et al.

Table II. Clinical and laboratory parameters in patients with CHF depending on BMI and MWM

\begin{tabular}{|c|c|c|c|c|c|}
\hline Parameter & $1^{\text {st }}$ group & $2^{\text {nd }}$ group & $3^{\text {rd }}$ group & $4^{\text {th }}$ group & $P$ \\
\hline Age, years & $79[74 ; 83]$ & $78[67 ; 81]$ & $64[50 ; 73]$ & $67[49 ; 73]$ & $\begin{array}{l}P_{1-3}=0.006 \\
P_{1-4}=0.007 \\
P_{2-3}=0.02 \\
P_{2-4}=0.04\end{array}$ \\
\hline \multicolumn{6}{|c|}{ Cardiovascular risk factors } \\
\hline $\mathrm{AH}, \%(\mathrm{n})$ & $66.6(4)$ & $28.6(2)$ & $81.8(18)$ & $56.5(13)$ & $P_{2-3}=0.009$ \\
\hline $\begin{array}{c}\text { Diabetes mellitus, } \\
\%(\mathrm{n})\end{array}$ & $16.6(1)$ & $0(0)$ & $18.1(4)$ & $17.3(4)$ & $\begin{array}{l}P_{2-3}=0.03 \\
P_{2-4}=0.03\end{array}$ \\
\hline \multicolumn{6}{|c|}{ Heart failure cause } \\
\hline $\mathrm{CHD}, \%(\mathrm{n})$ & $100 \%(6)$ & $100 \%(7)$ & $72.7 \%(16)$ & $86.9(20)$ & $\begin{array}{l}P_{1-3}=0.008 \\
P_{2-3}=0.008\end{array}$ \\
\hline $\begin{array}{l}\text { Chronic rheumatic } \\
\text { heart disease, \% (n) }\end{array}$ & 0 & 0 & $27.3(6)$ & $13.1(3)$ & $\begin{array}{l}P_{1-3}=0.008 \\
P_{2-3}=0.006\end{array}$ \\
\hline \multicolumn{6}{|c|}{ Clinical laboratory parameters } \\
\hline $\begin{array}{l}\text { Incidence } \\
\text { of } E F<30 \%\end{array}$ & $16.7(1)$ & $28.6(2)$ & $13.6(3)$ & $13.0(3)$ & $\mathrm{p}>0.05$ \\
\hline NYHA I, \%, (n) & $16.7(1)$ & $14.3(1)$ & $22.7(5)$ & $13.0(3)$ & $p>0.05$ \\
\hline NYHA II, \%, (n) & $50(3)$ & $14.3(1)$ & $54.6(12)$ & $43.5(10)$ & $P_{2-3}=0.02$ \\
\hline $\begin{array}{l}\text { NYHA III-IV, } \\
\%,(n)\end{array}$ & $33.3(2)$ & $71.4(5)$ & $22.7(5)$ & $43.5(10)$ & $P_{2-3}=0.01$ \\
\hline $\begin{array}{c}\text { Systolic arterial } \\
\text { pressure, mm Hg }\end{array}$ & $160[140 ; 180]$ & $110[110 ; 125]$ & $145[130 ; 170]$ & $140[130 ; 160]$ & $\begin{array}{c}P_{1-2}=0.001 \\
P_{2-3}=0.0008 \\
P_{2-4}=0.002\end{array}$ \\
\hline $\begin{array}{l}\text { Diastolic arterial } \\
\text { pressure, } \mathrm{mm} \mathrm{Hg}\end{array}$ & $90[90 ; 100]$ & $75[70 ; 80]$ & $90[85 ; 100]$ & $87[77 ; 95]$ & $\begin{array}{c}P_{1-2}=0.01 \\
P_{2-3}=0.0007 \\
P_{2-4}=0.04\end{array}$ \\
\hline Fibrinogen, g/L & $2.4[2.4 ; 2.9]$ & $2.7[2.6 ; 3.3]$ & $3.5[2.8 ; 4.4]$ & $3.3[2.4 ; 3.8]$ & $P_{1-3}=0.04$ \\
\hline $\begin{array}{l}\text { White blood cells, } \\
\qquad{ }^{*} 10^{9} / \mathrm{L}\end{array}$ & $7.9[7.3 ; 8.4]$ & $6.3[4.8 ; 8.7]$ & $7.8[6.5 ; 8.5]$ & $8.2[6.7 ; 9.8]$ & $P>0.05$ \\
\hline $\mathrm{ESR}, \mathrm{mm} / \mathrm{hr}$ & $11[8 ; 12]$ & $7[4 ; 15]$ & $13.5[5 ; 20]$ & $7[5 ; 20]$ & $P>0.05$ \\
\hline Lymphocytes, \% & $21[20 ; 24]$ & $17[14 ; 33]$ & $24[20 ; 30]$ & $21[17 ; 26]$ & $\mathrm{P}>0.05$ \\
\hline $\mathrm{RV}, \mathrm{cm}$ & $2.43[2.25 ; 3.19]$ & $2.67[2.40 ; 3.62]$ & $2.47[2.24 ; 2.89]$ & $2.60[2.50 ; 3.34]$ & $P>0.05$ \\
\hline IVST, cm & $1.18[0.83 ; 1.21]$ & $1.26[1.21 ; 1.44]$ & $1.42[1.21 ; 1.58]$ & $1.40[1.29 ; 1.70]$ & $\begin{array}{l}P_{1-4}=0.01 \\
P_{2-3}=0.01\end{array}$ \\
\hline LVPWT, cm & $1.2[1.1 ; 1.2]$ & $1.4[0.6 ; 1.4]$ & $1.4[1.3 ; 1.6]$ & $1.2[1.2 ; 1.3]$ & $\begin{array}{l}P_{1-3}=0.02 \\
P_{1-4}=0.04\end{array}$ \\
\hline LVEDD, cm & $5.52[4.86 ; 6.77]$ & $6.07[5.17 ; 6.18]$ & $5.44[5.30 ; 6.30]$ & $5.99[5.09 ; 6.50]$ & $P>0.05$ \\
\hline $\mathrm{EF}, \%$ & $52.5[33.0 ; 63.0]$ & $36.5[27.9 ; 55.5]$ & $57.0[39.0 ; 62.0]$ & $44.5[41.0 ; 64.0]$ & $P>0.05$ \\
\hline MWM, CU & $0.4[0.4 ; 0.5]$ & $0.9[0.6 ; 1.1]$ & $0.5[0.3 ; 0.6]$ & $0.9[0.7 ; 1.2]$ & $\begin{array}{c}P_{1-2}=0.001 \\
P_{1-4}=0.000004 \\
P_{2-3}=0.000001\end{array}$ \\
\hline $\mathrm{HDL}, \mathrm{mg} / \mathrm{dl}$ & $42.1[35.9 ; 59.6]$ & $47.1[24.7 ; 80.0]$ & $44.1[38.6 ; 51.0]$ & $36.3[28.6 ; 46.8]$ & $P_{3-4}=0.04$ \\
\hline $\mathrm{LDL}, \mathrm{mg} / \mathrm{dl}$ & $118.3[67.8 ; 148.4]$ & $97.8[64.9 ; 112.5]$ & $96.6[84.3 ; 116.7]$ & $84.6[68.4 ; 120.6]$ & $P>0.05$ \\
\hline $\mathrm{TG}, \mathrm{mg} / \mathrm{dL}$ & $\begin{array}{c}\text { 155.1[100.9; } \\
190.0]\end{array}$ & $78.3[51.3 ; 95.4]$ & $120.4[87.6 ; 192.0]$ & $132.7[77.8 ; 159.2]$ & $\begin{array}{l}P_{1-2}=0.008 \\
P_{2-3}=0.005 \\
P_{2-4}=0.01\end{array}$ \\
\hline Leptin, ng/mL & $3.6[2.2 ; 5.5]$ & $0.48[0.15 ; 0.81]$ & $10.7[3.8 ; 18.5]$ & $3.99[2.5 ; 7.1]$ & $P_{2-3}=0.02$ \\
\hline L-arginine, $\mu \mathrm{g} / \mathrm{ml}$ & $10.5[2.5 ; 12.8]$ & $7.7[5.1 ; 10.1]$ & $6.6[5.6 ; 9.1]$ & $8.6[6.4 ; 11.0]$ & $P>0.05$ \\
\hline
\end{tabular}

${ }^{*}$ RV - right ventricle dimensions, IVST - interventricular septum thickness, LVPWT - thickness of left ventricular posterior wall, LVEDD - left ventricle end-diastolic diameter, EF - ejection fraction, HDL - high-density lipoprotein cholesterol, LDH - low-density lipoprotein cholesterol, TG - triglycerides 
rate and the incidence of complications in such cases. The inverse correlation between BMI and the level of MWM in the blood $(\tau=-0.2, p=0.01)$ serves in favor of this opinion.

In addition, the controversial issue about the normal level of leptin in patients with CHF should be considered in the context of the underlying disease, taking into account all factors that have an effect on it, in particular, endogenous intoxication syndrome.

\section{CONCLUSIONS}

The worst prognosis was observed in patients with normal body mass on the background of the expressed syndrome of endogenous intoxication, and the best - provided a normal weight and low level of intoxication.

Patients with CHF should have their leptin level evaluated. An increase in its level was associated with arterial hypertension, an increase in blood glucose levels and lipid metabolism disorders.

The worst prognosis was observed in patients with the combination of hypoleptinemia with severe endogenous intoxication.

\section{REFERENCES}

1. Voronkov LG, Filatova OL, Lyashenko AV, Parashchenyuk LP. Vygyvannya uprodovg 12 misyaciv ta yogo predyktory v pacientiv $z$ chronichnoyu sercevoyu nedostatnistyu I znygenoyu frakciyeyu vykydu livogo shlunochka zalegno vid stati. Ukrainsyy terapevtychnuu gurnal. 2017.4: 86-89. [in Ukrainian]. Voronkov LG, Filatova OL, Lyashenko AV, Parashchenyuk LP. 12 months survival and its predictors in patients with chronic heart failure and low left ventricular ejection fraction depending on gender. Ukrainian Therapeutic Journal. 2017;4:86-89.

2. Smith JG. Molecular Epidemiology of Heart Failure: Translational Challenges and Opportunities. JACC Basic TransI Sci. 2017; Vol 25,2(6):757-769.

3. Roger VL. Epidemiology of Heart Failure. Circ Res. 2013; 113(6): 646-659.
4. Mozaffarian D, Benjamin EJ, Go AS et al. American Heart Association Statistics Committee; Stroke Statistics Subcom-mittee. Heart disease and stroke statistics 2016 update: a report from the American Heart Association. Circulation. 2016.133(4):38-48.

5. World Health Organization. Obesity and overweight fact sheet. World Health Organization website. http://www.who. int/mediacentre/ factsheets/fs311/en/. (2016, accessed July 15 2016).

6. Oga EA, Eseyin OR. The Obesity Paradox and Heart Failure: A Systematic Review of a Decade of Evidence. Journal of Obesity. 2016; 2016: 9040248.

7. HainerV, Aldhoon-Hainerová I. Obesity Paradox Does Exist. Diabet Care. 2013; 36: $276-281$.

8. Yuji Nagatomo, Tang W. Intersections between Microbiome and Heart Failure: Revisiting the Gut Hypothesis. J Card Fail. 2015; 21(12): 973-980.

9. Radchenko OM, Filipyuk AL, et al. Vplyv ogyrinnya na perebig hvorob sercevo-sudynnoi, dyhalnoi, travnoi ta vydilnoi system. Lviv; 2016.324 p. [in Ukrainian] Radchenko OM, Filipyuk AL, et al. Influence of obesity on the course of diseases of the cardiovascular, respiratory, digestive and excretory systems. Lviv; 2016. 324 p.

10. Karbowska J, Kochan Z. Leptin as a mediator between obesity and cardiac dysfunction. Postepy Hig Med Dosw. 2012; 23(66): 267-274.

11. Palanivel R, Eguchi M, Shuralyova I. Distinct effects of short- and longterm leptin treatment on glucose and fatty acid uptake and metabolism in HL-1 cardiomyocytes. Metabolism. 2006;55:1067-1075.

12. Buttner $A$, Eisenhofer $G$, Friberg $P$, et al. Serum leptin levels in heart failure patients may be altered differently according to clinical stage. Eur. Heart. J. 2000; 21:334 - 335.

13. Straburzyńska-Migaj E, Gwizdała A, Siniawski A. et al. Leptin and inflammation in patients with chronic heart failure. Kardiologia Polska. 2010; 68 (11):1243-1247.

\section{Authors' contributions:}

According to the order of the Authorship.

\section{Conflict of interest:}

The Authors declare no conflict of interest.

\author{
CORRESPONDING AUTHOR \\ Marta 0. Kondratyuk \\ Danylo Halytsky Lviv National Medical University \\ 69 Pekarska St., Lviv, Ukraine \\ tel: +380677372989 \\ e-mail:marta_kondratjuk@ukr.net
}

Received: 10.11 .2018

Accepted: 27.02.2019 


\title{
THE RELATIONSHIP BETWEEN HOMOCYSTEINE LEVEL AND VITAMINS $B_{12}, B_{9}$ AND $B_{6}$ STATUS IN PATIENTS WITH CHRONIC KIDNEY DISEASE
}

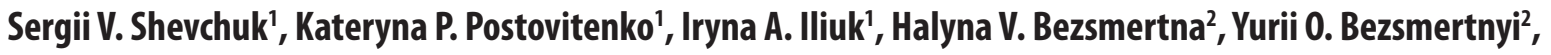 \\ Iryna V. Kurylenko² ${ }^{2}$ Alina V. Biloshytska', Iryna V. Baranova' \\ 'NATIONAL PIROGOV MEMORIAL MEDICAL UNIVERSITY, VINNYTSIA, UKRAINE \\ 2SCIENTIFIC AND RESEARCH INSTITUTE OF INVALID REHABILITATION (EDUCATIONAL SCIENTIFIC TREATMENT COMPLEX) OF NATIONAL PIROGOV \\ MEMORIAL MEDICAL UNIVERSITY, VINNYTSIA, UKRAINA
}

\begin{abstract}
Introduction: According to present knowledge, hyperhomocysteinemia is one of the risk factors of cardio-vascular pathology. Patients with chronic kidney disease are known to develop hyperhomocysteinemia more often than those in general population. Important cause of hyperhomocysteinemia is the deficiency of vitamins $\mathrm{B}_{6^{\prime}} \mathrm{B}_{9}$ and $\mathrm{B}_{12}$ that are involved in homocysteine metabolism. Vitamins deficiency, we believe, can be one of the causes of hyperhomocysteinemia in the patients with chronic renal failure.

The aim: To analyze the plasma homocysteine level in patients with chronic kidney disease and its assosiation with the levels of vitamins $B_{6^{\prime}} B_{9^{\prime}} B_{12}$ in Ukraine.

Materials and methods: The study involved 148 persons with different stagesis of chronic kidney disease who underwent immunoenzyme determination of total plasma homocysteine, $B_{9}$ cobalamin and vitamin $B_{6}$ status.

Results: It was found that in ukrainian patient population with chronic kidney disease $58.7 \%$ of patients have hyperhomocysteinemia. Homocysteine level was shown to increase with the increase of chronic kidney disease stage. Supply of vitamins $B_{6^{\prime}} B_{9}$ тa $B_{12}$ in the patients with chronic kidney disease was lower than in apparently healthy persons, but there was significant decrease of folic acid level proportionally to the increase of chronic kidney disease stage. There was close relationship between homocysteine level and folic acid status in the patients with chronic kidney disease, but it appeared to be independent on cobalamin and pyridoxin status.

Conclusions: The obtained data are promising for finding effective means of correction of hyperhomocysteinemia in patients with chronic kidney disease by normalizing the vitamin status of such patients.
\end{abstract}

KEY WORDS: hyperhomocysteinemia, cobalamin, pyridoxine, folic acid, renal failure

Wiad Lek 2019, 72, 4, 532-538

\section{INTRODUCTION}

According to present knowledge, hyperhomocysteinemia (HHC) is one of the risk factors of cardio-vascular pathology $[1,2,3]$. Patients with chronic kidney disease (CKD) are known to develop HHC more often than those in general population $[4,5]$. Today it is proved that in general population total homocysteine (HC) levels depend on age, sex, race and ethnic factors as well as on the rate of enzyme genetic polymorphism, involved in $\mathrm{HC}$ metabolism [6]. Equelly important cause of HHC development is the deficiency of vitamins $B_{6}, B_{9}$ and $\mathrm{B}_{12}$, involved in $\mathrm{HC}$ exchange, providing enzymes with cofactors involved in $\mathrm{HC}$ exchange and degradation [7, 8]. Taking into consideration rather high prevalance of vitamin deficiency even among people with rather high material status $[9,10]$, it is suggested to be one of the major reasons of $\mathrm{HHC}$ both in normal population and in the patients with chronic renal failure (CRF). It should be noted that in Ukraine neither the supply of those vitamins in the patients with CRF nor the relationship between their status and the level of $\mathrm{HC}$ in blood plasma have been previously studied.

\section{THE AIM}

In view of this, the aim of the study was to study homocystein contents in blood plasma of the patients with chronic kidney disease and to evaluate its association with vitamins $\mathrm{B}_{6}, \mathrm{~B}_{9}$ та $\mathrm{B}_{12}$ levels.

\section{MATERIALS AND METHODS}

148 in-patients and/or outpatients with CKD were examined at Vinnytsia Regional Pirogov Memorial Clinical Hospital, the clinical basis of Vinnytsia National Pirogov Memorial Medical University. The patients gave an informed consent to participate in the study. Chronic glomerulonephritis was diagnosed in $99(66.9 \%)$ and 
Table I. Total plasma homocysteine level in the patients with different stages of chronic kidney disease and in healthy individuals (M $\pm m, P)$

\begin{tabular}{|c|c|c|c|c|}
\hline \multirow[b]{2}{*}{ Studied individuals } & \multirow{2}{*}{$\begin{array}{l}\text { Homocysteine } \\
\text { level, } \mathbf{m c m o l} / \mathrm{l} \\
\qquad \mathbf{M} \pm \mathbf{m}\end{array}$} & \multicolumn{3}{|c|}{ Homocysteine level ranking , number of patients, $\%$} \\
\hline & & $\begin{array}{c}\text { Normal level } \\
<10.0 \mathrm{mcmol} / \mathrm{l}\end{array}$ & $\begin{array}{l}\text { Subnormal level } \\
10-15 \mathrm{mcmol} / \mathrm{l}\end{array}$ & $\begin{array}{c}\text { Hyperhomo-cysteinemia } \\
\geq 15 \mathrm{mcmol} / \mathrm{l}\end{array}$ \\
\hline Practically healthy, $\mathrm{n}=30$ & $9.35 \pm 0,57$ & $24(80 \%)$ & $4(13.3 \%)$ & $2(6.7 \%)$ \\
\hline CKD-I, n=35 & $10.7 \pm 0,72$ & $17(48,6 \%)^{*}$ & $10(28.6 \%)$ & $8(22.8 \%)^{*}$ \\
\hline CKD-II, $\mathrm{n}=31$ & $15.4 \pm 1.45^{*} \#$ & $6(19,4)^{*} \#$ & $16(51.6 \%)^{*} \#$ & $9(29.0 \%)^{*}$ \\
\hline CKD-III, $\mathrm{n}=43$ & $21.9 \pm 0.43^{*} \# \$$ & $3(7 \%)^{*} \#$ & $6(14 \%) \# \$$ & $34(79.0 \%)^{*} \# \$$ \\
\hline CKD-IV, $n=14$ & $26.7 \pm 2.1 * \# \$$ & 0 & 2 (14.3\%)\#\$ & $12(85.7 \%)^{*} \# \$$ \\
\hline CKD-V, $\mathrm{n}=25$ & $27.3 \pm 1.83^{*} \#$ & 0 & $1(4 \%) \#$ & $24(96.0 \%)^{*} \# \wedge \wedge$ \\
\hline
\end{tabular}

Notes: * - significance of differences with the group of healthy individuals; \# - significance of differences with the group of patients with CKD-I; $\$$ - significance of differences with the group of patients with CKD-II; $\wedge$ - significance of differences with the group of patients with CKD-III. The mark is indicated only in case of significant differences $(P<0.05)$.

Table II. Vitamin $B_{6}$ supply in the patients with various degrees of CKD and in healthy individuals $(M \pm m)$

\begin{tabular}{|c|c|c|c|c|c|c|}
\hline \multirow{3}{*}{ GroupNo } & \multirow{3}{*}{$\begin{array}{c}\text { Studied } \\
\text { individuals }\end{array}$} & \multirow{3}{*}{$\begin{array}{c}\text { Erythrocytes ASAT, } \\
\mathrm{mcmol} / \mathrm{h} \mathrm{ml}\end{array}$} & \multirow{3}{*}{ PLP-effect, \% } & \multicolumn{3}{|c|}{ Pyridoxin supply } \\
\hline & & & & Normal & Marginal & Deficiency \\
\hline & & & & $<70 \%$ & $70-80 \%$ & $>80 \%$ \\
\hline 1 & $\begin{array}{l}\text { Practically healthy, } \\
\qquad n=30\end{array}$ & $27.2 \pm 0.49$ & $65.8 \pm 1.17$ & $\begin{array}{c}22 \\
73.3 \%\end{array}$ & $\begin{array}{c}8 \\
26.7 \% \\
\end{array}$ & 0 \\
\hline 2 & CKD-I, n=35 & $26.1 \pm 0.34$ & $67.8 \pm 1.02$ & $\begin{array}{c}25 \\
71.4 \%\end{array}$ & $\begin{array}{c}9 \\
25.7 \%\end{array}$ & $\begin{array}{c}1 \\
2.9 \%\end{array}$ \\
\hline 3 & CKD-II, n=31 & $27.3 \pm 0.31$ & $66.9 \pm 1.0$ & $\begin{array}{c}23 \\
74.2 \%\end{array}$ & $\begin{array}{c}8 \\
25.8 \%\end{array}$ & 0 \\
\hline 4 & CKD-III, n=43 & $24.8 \pm 0.30$ & $67.3 \pm 0.83$ & $\begin{array}{c}32 \\
74.4 \% \\
\end{array}$ & $\begin{array}{c}11 \\
25.6 \% \\
\end{array}$ & 0 \\
\hline 5 & CKD-IV, n=14 & $24.2 \pm 0.96$ & $64.3 \pm 2.77$ & $\begin{array}{c}11 \\
78.6 \%\end{array}$ & $\begin{array}{c}3 \\
21.4 \%\end{array}$ & 0 \\
\hline
\end{tabular}

Note: $P>0,05$ in all cases.

chronic pyelonephritis - in 49 patients $(33.1 \%)$. There were 77 females (52\%) and 71 males (48\%). All the patients were divided into two groups: the first one included 113 patients in whom underlying disease was accompanied by decreased glomerular filtration rate (GFR), and the second group consisted of 35 patients with no GFR impairement (CKD-I). In the group of patients with impaired GFR the following stages of CKD were diagnosed: stage II - in 31patients with impaired GFR, stage III - in 43 , stage IV - in 14, stage V (terminal) - in 25 patients. The age of patients in the group with decreased GFR ranged from 18 to 60 years, the average age being 39.6 \pm 1.13 years. The average age of the patients was $40.3 \pm$ 2.33 years in CKD-II group, $45.4 \pm 2.0$ years in CKD-III group, $45.5 \pm 3.38$ years in CKD-IVgroup and $37.8 \pm 2.53$ years in CKD-V group. Average age of the patients in CKD-I group was $36.9 \pm 2.4$ years. 30 apparently healthy individuals (14 men and 16 women) aged 21-57 years (average age $40.6 \pm 2.38$ years) served as representative control group.

The stage of CKD was determined according to the classification adopted by the Second Ukrainian Congress of Nephrologists (2005).
Total plasma HC level was determined by immunoenzyme method using "Axis-Shield" set (UK) on immunoenzyme analyzer "Santinaile". Plasma level of folic acid (FA) was determined by microbiological method using folate-deficient strain Lactobacillus casei ATCC 7469. Cobalamin status was established by quantitation of urinary methyl-malonic acid excretion, vitamin $B$ status - by pyridoxal-dependent enzymes ALAT and ASAT as well as by PLP-effect [11].

The study was carried out in compliance with the provisions of the Council of Europe Convention on Human Rights and Biomedicine, Declaration of Helsinki and recommendations of the Committee on Bioethics of the Presidium of National Academy of Medical Sciences of Ukraine.

Statistical analysis of obtained data was performed with application package STATISTICA (StatSoft, USA, v6.0). Nonparametric Mann-Whitney U-test was used to assess the difference between groups, Pearson correlation analysis - to determine the relationships between the indices, Fisher's test - to compare the frequency of changes. $\mathrm{P}<0.05$ was considered to be significant difference. 
Table III. Vitamin $\mathrm{B}_{9}$ supply in the patients with various degrees of chronic kidney disease and in healthy individuals $(\mathrm{M} \pm \mathrm{m})$

\begin{tabular}{|c|c|c|c|c|c|}
\hline \multirow{3}{*}{ GroupNo } & \multirow{3}{*}{ Studied individuals } & \multirow{3}{*}{$\begin{array}{l}\text { Serum folate level, } \\
\text { mcg/l }\end{array}$} & \multicolumn{3}{|c|}{ Folate supply } \\
\hline & & & Normal & Marginal & Deficiency \\
\hline & & & $>6 \mathrm{mcg} / \mathrm{l}$ & 3-6 mcg/l & $<3 \mathrm{mcg} / \mathrm{l}$ \\
\hline 1 & Practically healthy, $n=30$ & $7.67 \pm 0.25$ & $\begin{array}{c}26 \\
86.7 \%\end{array}$ & $\begin{array}{c}3 \\
10 \%\end{array}$ & $\begin{array}{c}1 \\
3.33 \%\end{array}$ \\
\hline 2 & CKD-I, n=35 & $7.29 \pm 0.17$ & $\begin{array}{c}31 \\
88.6 \%\end{array}$ & $\begin{array}{c}4 \\
11.4 \%\end{array}$ & 0 \\
\hline 3 & CKD-II, n=31 & $6.88 \pm 0.17^{*}$ & $\begin{array}{c}26 \\
83.9 \%\end{array}$ & $\begin{array}{c}5 \\
16.1 \%\end{array}$ & 0 \\
\hline 4 & CKD-III, $\mathrm{n}=43$ & $6.42 \pm 0.13^{*} \#$ & $\begin{array}{c}28 \\
65.1 \%\end{array}$ & $\begin{array}{c}15 \\
34.9 \%^{*} \#\end{array}$ & 0 \\
\hline 5 & CKD- IV, $\mathrm{n}=14$ & $6.1 \pm 0.29 * \#$ & $\begin{array}{c}9 \\
64.3 \%\end{array}$ & $\begin{array}{c}5 \\
35.7 \%^{*} \#\end{array}$ & 0 \\
\hline
\end{tabular}

Notes: * - significance of differences with the group of healthy individuals; \# - significance of differences with the group of patients with chronic glomeruloand pyelonephritis without CKD. The mark is indicated only in case of significant differences $(P<0.05)$.

Table IV. Vitamin $B_{12}$ supply in the patients with chronic renal failure and in healthy individuals by urine excretion of methyl-malonic acid ( $\left.\mathrm{M} \pm \mathrm{m}\right)$

\begin{tabular}{|c|c|c|c|c|c|}
\hline \multirow{3}{*}{ GroupNo } & \multirow{3}{*}{ Studied individuals } & \multirow{3}{*}{$\begin{array}{l}\text { Creatinine MMA, } \\
\mathrm{mcg} / \mathrm{g}\end{array}$} & \multicolumn{3}{|c|}{ Cobalamin supply } \\
\hline & & & Normal & Marginal & Deficiency \\
\hline & & & $<20 \mathrm{mcg} / \mathrm{g}$ & $20-25 \mathrm{mcg} / \mathrm{g}$ & $>25 \mathrm{mcg} / \mathrm{g}$ \\
\hline 1 & Practically healthy, $n=30$ & $18.0 \pm 0.29$ & $\begin{array}{c}26 \\
86.7 \% \\
\end{array}$ & $\begin{array}{c}4 \\
13.3 \% \\
\end{array}$ & 0 \\
\hline 2 & CKD-I, n=35 & $17.8 \pm 0.26$ & $\begin{array}{c}31 \\
88.6 \%\end{array}$ & $\begin{array}{c}4 \\
11.4 \%\end{array}$ & 0 \\
\hline 3 & CKD-II, n=31 & $18.2 \pm 0.36$ & $\begin{array}{c}25 \\
80.6 \%\end{array}$ & $\begin{array}{c}6 \\
19.4 \%\end{array}$ & 0 \\
\hline 4 & CKD-III, n=43 & $18.3 \pm 0.25$ & $\begin{array}{c}36 \\
83.7 \%\end{array}$ & $\begin{array}{c}7 \\
16.3 \%\end{array}$ & 0 \\
\hline 5 & CKD-IV, n=14 & $18.6 \pm 0.51$ & $\begin{array}{c}10 \\
71.4 \%\end{array}$ & $\begin{array}{c}4 \\
28.6 \%\end{array}$ & 0 \\
\hline
\end{tabular}

Note: $P>0.05$ in all cases.

\section{RESULTS}

The first stage of the study was devoted to evaluation of HC level in the patients with CRF and comparison of the data received with those in apparently healthy persons (Table I). Only $6.7 \%$ of practically healthy persons appeared to have increased HC level (above $15 \mathrm{mcmol} / \mathrm{l}$ ). Increase of HC level in blood plasma was proportional to the severity of CKD which, in its turn, lead to the increase of $\mathrm{HHC}$ cases with higher $\mathrm{HC}$ concentrations. Among the patients with CRF the following $\mathrm{HC}$ levels were determined: normal - in 26 patients (17.6\%), subnormal - in 35 patients (23.6\%), and HHC - in 87 persons $(58.7 \%)$.

The level of vitamin $\mathrm{B}_{6}$ in the studied patients was assessed indirectly by PLP-effect value related to aspartat transaminase (ASAT) activity (Table II). Decreased level of
ASAT in erythrocytes by $15 \%$ with simultaneous increase of PLP-effect (by 15\%) was considered to be a significant sign of vitamin $\mathrm{B}_{6}$ deficiency as compared to the control group. As no distinct relationship between ASAT activity value and PLP-effect rate was detected in the patients with various degrees of CKD, Table II gives the data on vitamin $\mathrm{B}_{6}$ stores according to enzyme activation by pyridoxal phosphate. Average indices of ASAT activity as well as those of PLP-effect were found to be normal with no differences between them in all studied groups.

Vitamin $\mathrm{B}_{6}$ deficiency was found in only one patient with CKD-I, while marginal deficiency (PLP-effect - 70-80\%) was observed in all studied groups with equal frequency. Overall 32 cases of vitamin $\mathrm{B}_{6}$ deficiency or marginal deficiency were diagnosed in the patients with CKD-I - CKD-IV (26\%). The data obtained suggested that the level of vitamin $B_{6}$ stores 
Table V. Vitamin $B_{6}, B_{9}, B_{12}$ supply depending on plasma homocysteine level in studied individuals $(M \pm m)$

\begin{tabular}{|c|c|c|c|c|}
\hline \multirow[b]{2}{*}{ Groups } & \multirow[b]{2}{*}{$\mathbf{n}$} & \multicolumn{3}{|c|}{ Indices of vitamins supply } \\
\hline & & PLP-effect, \% & $\begin{array}{l}\text { Serum folate, } \\
\text { mcg/l }\end{array}$ & $\begin{array}{l}\text { MMA, urine excretion, } \\
\text { mcg/g of creatinine }\end{array}$ \\
\hline $\begin{array}{c}1 \\
\text { Patients with } \mathrm{HC}<10 \\
\mathrm{mcmol} / \mathrm{l}\end{array}$ & 50 & $68.0 \pm 0.96$ & $7.82 \pm 0.12$ & $18.1 \pm 0.20$ \\
\hline $\begin{array}{l}2 \\
\text { Patients with HC 10-15 } \\
\text { mcmol/l }\end{array}$ & 38 & $67.6 \pm 1.22$ & $7.06 \pm 0.13^{*}$ & $18.0 \pm 0.27$ \\
\hline $\begin{array}{c}3 \\
\text { Patients with HC 15-25 } \\
\text { mcmol/l }\end{array}$ & 31 & $67.8 \pm 1.28$ & $6.51 \pm 0.15^{*} \#$ & $17.7 \pm 0.32$ \\
\hline $\begin{array}{c}4 \\
\text { Patients with } \mathrm{HC}>25 \\
\mathrm{mcmol} / \mathrm{l}\end{array}$ & 29 & $68.7 \pm 1.6$ & $5.92 \pm 0.08^{*} \# \$$ & $18.8 \pm 0.34$ \\
\hline
\end{tabular}

Notes: * - significance of differences with group 1, \#- significance of differences with group 2, \$ - significance of differences with group 3.

Table VI. Correlation relationship between total plasma homocysteine level and vitamins $B_{6}, B_{9}, B_{12}$ status in the patients with chronic kidney disease of various degrees and in apparently healthy individuals of the control group ( $r$ )

\begin{tabular}{|c|c|c|c|c|}
\hline \multirow{2}{*}{$\begin{array}{l}\text { Group } \\
\text { No }\end{array}$} & \multirow[b]{2}{*}{ HC level, mcmol/l } & \multicolumn{3}{|c|}{ Vitamin supply indices } \\
\hline & & PLP-effect, \% & $\begin{array}{l}\text { Serum folate, } \\
\mathrm{mcg} / \mathrm{l}\end{array}$ & $\begin{array}{l}\text { MMA, urine excretion, } \\
\text { mcg/g of creatinine }\end{array}$ \\
\hline \multicolumn{5}{|c|}{ Apparently healthy individuals, $n=30$} \\
\hline 1 & $9.35 \pm 0.57$ & 0.23 & $-0.41^{*}$ & -0.22 \\
\hline \multicolumn{5}{|c|}{ Patients with CKD-I, n=35 } \\
\hline 2 & $10.7 \pm 0.72$ & 0.18 & $-0.38^{*}$ & 0.16 \\
\hline \multicolumn{5}{|c|}{ Patients with CKD -II, n=31 } \\
\hline 3 & $15.4 \pm 1.45$ & 0.13 & $-0.48^{*}$ & 0.19 \\
\hline \multicolumn{5}{|c|}{ Patients with CKD - III, n=43 } \\
\hline 4 & $21.9 \pm 0,43$ & -0.10 & $-0.43^{*}$ & -0.02 \\
\hline \multicolumn{5}{|c|}{ Patients with CKD -IV, n=14 } \\
\hline 5 & $26.7 \pm 2.1$ & 0.05 & $-0.4^{*}$ & 0.12 \\
\hline
\end{tabular}

Note: * - significance of correlation relationship.

was equal in the studied healthy persons and in the patients with CKD and was not influenced by CKD degree.

Somewhat different data were obtained after evaluation of vitamin $\mathrm{B}_{9}$ status determining its serum level by direct (microbiologic) method. The test with high diagnostic value for detecting vitamin $\mathrm{B}_{9}$ deficiency proved to be serum folic acid contents and that for vitamin $B_{12}$ deficiency - excretion of methyl-malonic acid [12]. The data received, presented in Table III, are indicative of the fact that folic acid level gradually decreased insignificantly in the patients with CKD proportionally to the degree of renal insufficiency.

Significant decrease of folic acid concertration was revealed in CKD-III and CKD-IV patients. Those patients had higher frequency of marginal folate deficiency - in 34.9\% and 35.7\% of cases, respectively ( $\mathrm{P}<0.05$ according to Chi-squre test when compared to groups 1 and 2). Folate deficiency was found only in one person of the control group. A total of 29 cases of folate deficiency or marginal deficiency (23.6\%) were diagnosed in the patients of groups 2-5 (123 individuals).

Supply of vitamin $B_{12}$ was determined by methyl-malonic acid (MMA), its urine excretetion increased in inverse proportion to concentration of that vitamin in blood. The MMA excretion indices were not found to vary among all the patients, in no occasion deficiency was revealed (Table IV). Higher proportion of persons with marginal deficiency was found only in CKD-IV patients. The total number of patients having marginal deficiency of vitamin $\mathrm{B}_{12}$ was $21(17.1 \%)$.

Additional statistical analysis found no relationship between $\mathrm{HC}$ level in blood plasma and indices of vitamins $\mathrm{B}_{6}$ and $B_{12}$ supply (Table V), unlike folate - its level appeared to be the least in the persons with higher $\mathrm{HC}$ level. 
Table VII. Vitamin $B_{9}$ supply in dialysis patients, the control and in the patients with no signs of renal failure $(M \pm m, P)$

\begin{tabular}{|c|c|c|c|c|}
\hline \multirow{3}{*}{ Studied individuals } & \multirow{3}{*}{ Serum folate level, mcg/l } & \multicolumn{3}{|c|}{ Folate supply } \\
\hline & & Normal & Marginal & Deficiency \\
\hline & & $>6 \mathrm{mcg} / \mathrm{l}$ & 3-6 mcg/l & $<3 \mathrm{mcg} / \mathrm{l}$ \\
\hline $\begin{array}{l}\text { Practically healthy individuals, } \\
\qquad \mathrm{n}=30\end{array}$ & $7.67 \pm 0.25$ & $\begin{array}{c}26 \\
86.7 \%\end{array}$ & $\begin{array}{c}3 \\
10 \%\end{array}$ & $\begin{array}{c}1 \\
3.33 \%\end{array}$ \\
\hline $\begin{array}{l}\text { CKD-I, } \\
\mathrm{n}=35\end{array}$ & $7.29 \pm 0.17$ & $\begin{array}{c}31 \\
88.6 \%\end{array}$ & $\begin{array}{c}4 \\
11.4 \%\end{array}$ & 0 \\
\hline $\begin{array}{l}\text { CKD-V, } \\
\mathrm{n}=25\end{array}$ & $6.0 \pm 0.24^{*} \#$ & $\begin{array}{c}11 \\
44 \% * \#\end{array}$ & $\begin{array}{c}14 \\
56 \% * \#\end{array}$ & 0 \\
\hline
\end{tabular}

Notes: * - significance of differences with the group of healthy individuals; \# - significance of differences with the group of patients with chronic glomerulo- and pyelonephritis with no CKD.

In addition, potential correlation relationship between three factors - plasma HC level (factor 1), vitamin status (separately by vitamins $\mathrm{B}_{6}, \mathrm{~B}_{9}$ and $\mathrm{B}_{12}$ - factor 2 ), and degree of CKD (factor 3) - was studied in comparison with apparently healthy individuals. The data received are given in Table VI, they are indicative of the absence of correlation between all three factors concerning vitamins $B_{6}$ and $B_{12}$ (in all cases index $t$ was less than 2.2, $\mathrm{P}>0.05$ ). But there was significant inverse relashionship between plasma levels of $\mathrm{HC}$ and folic acid even in healthy individuals. Similar relationship between those indices by its direction and intensity, was observed in CKD-I, CKD -II and CKD -III groups of patients $(\mathrm{t}=2.38,2.36,2.95$ and 2.56 , respectively; $\mathrm{P}<0.05$ in all cases). Only in group 5 (CKD-IV) the tendency or weak correlation between them was revealed $(r=0.4$; $t=1.51)$, possibly because of a small number of patients in the group (14 persons). Even in the same index $r=0.4$ the result would have been significant if the group had consisted of 28 persons $(\mathrm{n}=28, \mathrm{t}=2.23, \mathrm{P}<0.05)$.

Significant inverse relashionship between plasma levels of $\mathrm{HC}$ and folic acid detected in studied patients made it possible to calculate the role of folate in $\mathrm{HC}$ concentration decrease. Actually, with augmentation of renal failure signs, plasma $\mathrm{HC}$ level in the patients with CKD increased in the group as a whole, but in some individuals it was partially dependent on folic acid level, and its high concentration inhibited the indicated action of CKD. After absolute difference between folate and HC concentrations had been determined in each group as compared to the next one with higher degree of CKD, relative percentage concentration of folic acid and its specific gravity were calculated. Hypohomocysteinemic contribution of folic acid was found to be $15.8 \%$.

Because of direct assosiation of HC metabolism with folate status, Table VII presents the data on the level of that vitamin supply in dialysis patients.

Folate supply in dialysis patients appeared to be $22 \%$ lower than in the control group and $18 \%$ lower than in the patients with CKD-I. It is noteworthy that more than a half dialysis patients (56\%) had marginal folate deficiency, while there were only $10 \%$ of such persons in the control group.

\section{DISCUSSION}

Thus, the study of plasma HC concentration first conducted in Ukrainian population of patients with CKD revealed nomal HC level in 26 (17.6\%), subnormal - in $35(23.6 \%)$, and HHC - in 87 patients (58.7\%). HHC was found to increase together with the increase of CKD stage. For example, an average $\mathrm{HC}$ contents in the patients with CKD-IV was significantly higher by $21.9 \%$ and $73.4 \%$ than in those with CKD-III and CKD-II, respectively, and the number of persons with HHC among the patients with CKD-IV significantly exceeded the proportion of those with HHC among the patients with CKD-II and CKD-I in 2.9 and 3.8 times, respectively.

According to the data from literature, homocystein level is closely correlated to the severity of kidney damage, and it is significantly higher in the patients with terminal than initial stage of renal failure. An important role of kidneys in elimination of $\mathrm{HC}$ from blood plasma has been shown in other studies as well [13].

The study of vitamins $\mathrm{B}_{6}, \mathrm{~B}_{9}, \mathrm{~B}_{12}$ status revealed unsatisfactory supply of those vitamins in both practically healthy individuals and in the patients with CKD. Deficiency, or marginal supply of vitamins $B_{6}, B_{9}, B_{12}$ was found in $26.7 \%-13.3 \%$ of apparently healthy individuals and in $26 \%, 23.5 \%$ and $17.1 \%$ of patients with CKD, respectively. The deficiency of those nutrients (except folate) proved to be independent of renal insufficiency stage. There were no significant differences in average indices of pyridoxin and cobalamin as well as in proportion of persons with marginal supply of those vitamins among the patients with various stages of renal failure. Only the level of folic acid significantly decreased proportionally to the increase of renal failure. While marginal folate supply occurred in one of ten patients among those with CKD-I, it was detected in one of two dialysis patients.

Literature data indicate the deficiency of B vitamins to be a common occurrence among the patients with CKD [14]. Glomerular filtration rate in the patients with CRF was shown to be assosiated with low folic acid level [15] while vitamin $B_{12}$ supply is not assosiated with microalbuminuria [16]. It is noteworthy that some authors showed an addition- 
al administration of folate and vitamin $\mathrm{B}_{12}$ to prevent the progression of CKD in a high proportion of patients $[17,18]$.

At the second stage of the study we tried to find the relationship between the changes in vitamin $\mathrm{B}_{6}, \mathrm{~B}_{9}, \mathrm{~B}_{12}$ status and plasma homocystein level. Plasma homocystein level in CKD patients was proved to be closely assosiated with folic acid status but not with cobalamin and pirydoxin ones. Among the patients with optimal supply of vitamin $\mathrm{B}_{9}$ and $\mathrm{B}_{12}$ hyperhomocysteinemia occurred in $30.6 \%$ and $26.4 \%$ of patients, respectively, while in the patients with deficiency of one of the vitamins - in $63.6 \%$ and $75.8 \%$ of cases. Pathogenetic role of vitamin $\mathrm{B}_{9}$ in $\mathrm{HHC}$ formation among CKD patients was additionally confirmed by correlation analysis $(\mathrm{r}=-0.38--0.48)$. Therefore, a large proportion of studied patients with CRF was believed to have marginal, i.e. virtually moderate folate deficiency which can be partially the reason of HHC syndrome development. So, folate-independent and folate-dependent ways of HC metabolism were suggested in renal insufficiency.

\section{CONCLUSIONS}

1. In the patients with chronic renal failure normal homocysteine level was revealed in 26 patients (17.6\%), subnormal - in 35 (23.6\%), and hyperhomocysteinemia - in 87 persons (58.7\%). Hyperhomocysteinemia was found to increase together with the increase of chronic kidney disease stage.

2. Supply of vitamins $B_{6}, B_{9}, B_{12}$ was lower in the patients with chronic kidney disease than in apparently healthy individuals. Deficiency, or marginal supply of vitamins $\mathrm{B}_{6}, \mathrm{~B}_{9}, \mathrm{~B}_{12}$ was detected in $26.7 \%\left(\mathrm{~B}_{6}\right)$ and $13.3 \%\left(\mathrm{~B}_{9}\right)$ of apparently healthy individuals and in 26\%, 23.6\% and $17.1 \%$, respectively, of chronic kidney disease patients. At the same time only the level of folic acid significantly decreased proportionally to the increase of chronic kidney disease stage.

3. In the patients with chronic kidney disease homocystein level was found to be closely associated with folic acid status but it was independent of pyridoxin and cobalamin status.

Directions for future research involve the search for effective means of hypercysteinemia correction in the patients with chronic kidney disease by normalization of vitamin status in such patients.

\section{REFERENCES}

1. Silva de Almeda C, Guerra DC, Vannucchi MT et al. What is the meaning of homocysteine in patients on dialysis? J Ren Nutr. 2011;21(5):394-400. doi: 10.1053/j.jn.2010.12.005.

2. Qin $X$, Huo $Y, X i e ~ D$ et al. Homocysteine-lowering therapy whith folic acid is effective in cardiovascular diseaseprevention in patients whith kidney disease: a meta-analysis of randomized controlled trials. Clin Nutr. 2013;32(5):722-727. doi: 10.1016/j.clnu.2012.12.

3. Zhao M, Wang X, He M et al. Homocysteine and Stroke Risk: Modifying Effect of Methylenetetrahydrofolate Reductase (677T Polymorphism and Folic Acid Intervention. Stroke. 2017;48(5):1183-1190. doi: 10.1161/STROKEAHA.116.015324.
4. Nigwekar SU, Kang A, Zongas S et al. Interventions for lowering plasma homocysteine levels in dialysis patients. Cochrane Database Syst Rev. 2016;31(5):CD004683. doi: 10.1002/14651858.

5. Tak YJ, Jeong DW, Kim YJ et al. Hyperhomocysteinaemia as a potential marker of early renal function decline in middle-aged Asian people without chronic kidney disease. Int Urol Nephrol. 2016;48(2):239-248. doi: 10.1007/s11255-015-1180-0.

6. Antunes $L A$, Machado $C M$, Couto AC et al. Polymorphism in the MTRR Gene Is Associated with Early Childhood Caries and Underweight. Caries Res. 2017;51(2):102-108. doi: 10.1159/000451037.

7. Chiarello PG., Vannucchi MT, Moyses Neto et al. Hyperhomocysteinemia and oxidative stress in hemodialysis: effects of supplementation with folic acid. Int JVitam Nutr Res. 2003;73(6):431-438. doi:10.1024/03009831.73.6.431.

8. Lind M, Jansson JH, Nilsson TK et al. High homocysteine and low folate plasma concentrations are associated with cardiovascular events but not bleeding during warfarin treatment. Clin Chem Lab Med. 2016;54(12):1981-1986. doi: 10.1515/clm-2016-0092.

9. Wu CC, Zheng $C M$, Lin YF et al. Role of homocysteine in end-stage renal disease. Clin Biochem. 2012;45(16-17):1286-1294. doi: 10.1016/j. clinbiochem. 2012.05.031.

10. Xu X, Qin X, LiY et al. Efficacy of Folic Acid Therapy on the Progression of Chronic Kidney Disease: The Renal Substudy of the China Stroke Primary Prevention Trial. JAMA Intern Med. 2016;176(10):1443-1450. doi: 10.1001/jamainternmed.2016.4687.

11. Spirichev VB. Methods of assessment and control of vitamin security of the population. Moscow: Nauka;1984 $170 \mathrm{p}$.

12. Carmel R, Green R, Rosenblatt DS et al. Update on cobalamin, folate, and homocysteine. Hematology (Am Soc Hematol Educ Program). 2003;62-81.

13. Hadj-Taieb S, Feki M, Hammami MB et al. Plasma total homocysteine: usual values and main determinants in adults living in the Great Tunis region. Clin Lab. 2014;60(6):897-902.

14. Heilmann RM, Grutzner N, lazbik MC et al. Hyperhomocysteinemia in Greyhounds and its Association with Hypofolatemia and Other Clinicopathologic Variables. JVet Intern Med. 2017;31(1):109-116. doi: 10.1111/jvim.14597.

15. Hassan K. Association of low potassium diet and folic acid deficiency in patients with CKD. Ther Clin Risk Manag. 2015;18(11):821-827. doi: 10.2147/TCRM.S83751.

16. McMahon GM, Hwang SJ, Tanner RM et al. The association between vitamin B12, albuminuria and reduced kidney function: an observational cohort study. BMC Nephrol. 2015;2:16-17. doi: 10.1186/1471-2369-16-7.

17. Mazur P, Kozynacka A, Duraiski L et al. N $\varepsilon$-homocysteinyl-lysine isopeptide is associated with progression of peripheral artery disease in patients treated with folic acid. Eur J Vasc Endovasc Surg. 2012;43(5):588-593. doi: 10.1016/j.juvs.2012.02.022.

18. Haarmann A, Mayr M, Kölker $S$ et al. Renal involvement in a patient with cobalamin A type (cbIA) methylmalonic aciduria: a 42-year follow-up. Mol Genet Metab. 2013;110(4):472-476. doi: 10.1016/j. ymgme.2013.08.021.

The work was done as part of the research work of Scientific and Research Institute of Invalid Rehabilitation (Educational Scientific Treatment Complex) of National Pirogov Memorial Medical University: "To substantiate scientific approaches to definition of components of rehabilitation potential in 
patients with chronic kidney disease I-V D, T", state registration number 0116U00142. Financing - own funds.

Authors' contributions:

According to the order of the Authorship.

\section{Conflict of interest:}

The Authors declare no conflict of interest.

\section{CORRESPONDING AUTHOR}

Iryna A. Iliuk

National Pirogov Memorial Medical University

56 Pirigova St., Vinnytsya, Ukraine

tel: +380950764700

email:irynailiuk@gmail.com

Received: 18.11 .2018

Accepted: 08.03.2019 
PRACA ORYGINALNA

ORIGINAL ARTICLE

\title{
FEATURES OF CLINICAL MANIFESTATIONS, FREE RADICAL, COAGULATION AND AGGREGATION PROPERTIES OF BLOOD IN PATIENTS WITH CRANIOCEREBRAL TRAUMA
}

\author{
Viktoriia A. Pinchuk, Galyna Ya. Sylenko, Yurii I. Sylenko, Angelina M. Kryvchun, Tetiana V. Pilugina \\ UKRAINIAN MEDICAL STOMATOLOGICAL ACADEMY, POLTAVA, UKRAINE
}

\begin{abstract}
Introduction: In recent years in Ukraine, as in the entire world, there has been an increase in cases of domestic injuries with a raise in the number of patients with craniocerebral trauma and its consequences.

The aim of our research was to study clinical symptoms, the state of free radical oxidation, aggregate and hemocoagulative properties of blood in patients with mild craniocerebral trauma.

Materials and methods: We conducted comprehensive clinical and laboratory examination of 34 patients with mild craniocerebral trauma and 20 apparently healthy patients (the control group). The diagnosis was made under ICD-10. The verification of the diagnosis was based on data from clinical examination, neurological status of neuroimaging (computer tomography and magnetic resonance imaging). The study group included 24 men and 10 women aged from 19 to 40 . In addition, 20 apparently healthy individuals of the same age were examined, who comprised the control group (14 men and 6 women). In the blood parameters of all patients, we examined free radical oxidation, hemostasis and aggregation properties of platelets.

Results: The conducted study revealed clinical disturbances, changes in the parameters of free radical lipid oxidation, coagulation and microcirculatory hemostasis. Conclusions: All patients with mild craniocerebral trauma, develop disturbances in the form of symptoms of microorganic lesion of the central nervous system: convergence weakness in $100 \%$ of patients, Mann's symptom (76.4\%), disruption of the function of the cranial nerves (58.8\%), signs of pyramidal insufficiency (68.4\%), vestibular disorders (94.1\%), autonomic vascular dysfunction (100\%). Mild craniocerebral trauma is accompanied by the activation of free radical lipid oxidation processes, decreased activity of antioxidant enzymes, hypercoagulation, and increased aggregation properties of platelets.
\end{abstract}

KEY WORDS: mild craniocerebral trauma, free radical oxidation, hemostasis

Wiad Lek 2019, 72, 4, 539-542

\section{INTRODUCTION}

In recent years in Ukraine, as in the entire world, there has been an increase in cases of domestic injuries with a raise in the number of patients with craniocerebral trauma and its consequences $[1,2]$. Increasing urbanization and industrialization, a sharp increase in the number of vehicles, increased population migration, rising frequency of military conflicts, widespread engagement of young people in traumatic sports, and other circumstances, characteristic of the modern way of life, led to a progressive increase in injuries, especially craniocerebral traumas [3]. According to the World Health Organization, more than 10 million people are traumatized every year in the world, and the number of patients with craniocerebral trauma (CCT) increases by $2 \%$ every year. CCT annually constitutes from 2.3 to 6 cases in different regions of Ukraine (an average of 4-4.2 per 1000 of population) [4]. In Ukraine, from 10 to 11 thousand people die of craniocerebral injury every year, that is, the mortality rate is 2.4 per 10 thousand [3]. Over the past 10 years, the incidence of CCT in Ukraine has more than doubled, with the annual number of victims of up to 200.000 .
The consequences of CCT lead to a reduction in working capacity and disability in patients depending on the severity of the injury and related injuries. Only $7 \%$ of survivors recover [5]. Within 2-10 years after the trauma, $90 \%$ of patients with CCT have neurological deficits and psychiatric disorders [6]. Therefore, neurotraumaticism remains a relevant social problem [1-6].

One of the main causes of brain function impairment is the disruption of blood flow as a result of increased local intracerebral pressure. Changes in the intracranial pressure are possible in the direction of its increase or decrease. In clinical practice, there is most often a stable, or short-term increase in pressure, the so-called hypertension syndrome. Less common, but with no less importance, one can observe pressure decrease (hypotension syndrome). The liquor-distension syndrome occurs in various diseases of the brain, including those with traumatic lesions [7].

In the pathogenesis of CCT, hydrodynamic forces and liquor wave affect the limbic-hypothalamic-reticular system, which leads to neurohumoral and vegetative-vascular disorders. Clinically, this is manifested by the development of cerebral symptoms, symptoms of cerebral dysfunction, 
Table I. Clinical manifestations of liquor-distension syndrome

\begin{tabular}{cc}
\hline Complaints & Patients, $\%(\mathbf{n}=\mathbf{3 4})$ \\
\hline Headache & 100 \\
\hline Vertigo & 89.5 \\
\hline Nausea & 63.2 \\
\hline Vomiting & 26.3 \\
\hline Head noises & 21 \\
\hline Pain in the eyeballs & 26.3 \\
\hline Grogginess & 15.8 \\
\hline Loss of consciousness & 21 \\
\hline
\end{tabular}

Table II. Indicators of the prooxidant-antioxidant system and lipid metabolism

\begin{tabular}{ccc} 
Indicators & $\begin{array}{c}\text { Healthy people } \\
\mathbf{n = 2 0}\end{array}$ & $\begin{array}{c}\text { CCT patients } \\
\mathbf{n = 3 4}\end{array}$ \\
\hline PRE, $\%$ & $1.88 \pm 0.17$ & $1.33 \pm 0.11 ; \mathrm{p}_{1}<0.05$ \\
\hline MDA before incubation, $\mathrm{mmol} / \mathrm{I}$ & $5.26 \pm 0.57$ & $8.2 \pm 0.6 ; \mathrm{p}_{1}<0.05$ \\
\hline MDA after incubation, $\mathrm{mmol} / \mathrm{I}$ & $9.8 \pm 0.4$ & $14.56 \pm 0.73 ; \mathrm{p}_{1}<0.05$ \\
\hline DC, mmol/I & $49.79 \pm 0.55$ & $56.23 \pm 1.21 ; \mathrm{p}_{1}<0.05$ \\
\hline Atherogenic lipoproteids, $\mathrm{g} / \mathrm{l}$ & $4.21 \pm 0.19$ & $6.12 \pm 0.78 ; \mathrm{p}_{1}<0.05$ \\
\hline SOD, c.u. & $1.17 \pm 0.04$ & $0.94 \pm 0.05 ; \mathrm{p}_{1}<0.05$ \\
\hline Catalytic index, c.u. & $3.25 \pm 0.14$ & $2.43 \pm 0.25 ; \mathrm{p}_{1}<0.05$ \\
\hline Ceruloplasmin, $\mathrm{mg} / \mathrm{l}$ & $163.2 \pm 4.23$ & $142.15 \pm 8.21 ; \mathrm{p}_{1}<0.05$
\end{tabular}

Note: $p_{1}$ - comparison of the indicators of the main group with the indicators of the control group

neurasthenic and psychopathic syndromes [8]. There are generalized vascular disorders due to changes in homeostasis, antioxidant defense with the development of hypertension syndrome [9].

Despite numerous studies conducted, many issues in this direction remain understudied. Among the mechanisms of the development of liquor-distension syndrome, the relationship between processes of lipid peroxidation, antioxidant enzymes, coagulation and microcirculatory hemostasis is becoming increasingly important and relevant.

\section{THE AIM}

The aim of the research: to study the clinical symptoms, the state of free radical oxidation, aggregation and hemocoagulative properties of blood in patients with mild craniocerebral trauma.

\section{MATERIALS AND METHODS}

A comprehensive clinical and laboratory examination of 34 patients with mild craniocerebral trauma was conducted. The diagnosis was made in accordance with ICD-10. The verification of the diagnosis was based on the data of clinical examination, neurological status of neuroimaging (computer tomography and magnetic resonance imaging). The main group included 24 men and 10 women aged from
19 to 40 years. In addition, we examined 20 apparently healthy persons of the same age (14 males and 6 females), who constituted the control group.

Indicators of free radical blood oxidation, hemostasis and platelet aggregation properties were studied in the blood of all patients. In conducting research, we defined the methods that characterize platelet aggregation, lipid peroxidation, antioxidant enzymes activity, blood coagulation. We conducted statistical processing of the results of the study. The basis for choosing research methods was the manual in experimental and clinical studies in biology and medicine [10].

\section{RESULTS}

When conducting a comprehensive clinical examination, the main complaints of patients with mild CCT were as follows: diffuse headache, which intensified in the morning, accompanied by nausea, vomiting, dizziness, grogginess, pain when moving the eyeballs; in some cases there was an asymmetry of the face, diplopia. In addition, patients complained of marked general weakness, fast fatigability, absent-mindedness, worsening of sleep, decreased working ability, and sometimes attacks of loss of consciousness (short-term, without seizures). Characteristics of clinical manifestations of liquor-distension syndrome are presented in Table I. 
Table III. Indicators of blood coagulation and microcirculatory hemostasis

\begin{tabular}{ccc} 
Indicators & $\begin{array}{c}\text { Healthy people } \\
\mathbf{n = 2 0}\end{array}$ & $\begin{array}{c}\text { CCT patients } \\
\mathbf{n = 3 4}\end{array}$ \\
\hline Fibrinolysis,sec & $200 \pm 3$ & $235 \pm 9 ; \mathrm{p}_{1}<0.05$ \\
\hline Recalcification time, sec & $128.5 \pm 1.8$ & $117.5 \pm 4.1 ; \mathrm{p}_{1}<0.05$ \\
\hline Thrombin time, sec & $12.82 \pm 1.07$ & $10.31 \pm 0.68 ; \mathrm{p}_{1}<0.05$ \\
\hline Prothrombin time, sec & $17.18 \pm 0.9$ & $17.11 \pm 0.7 ; \mathrm{p}_{1}>0.05$ \\
\hline AT-III, sec & $19.82 \pm 0.78$ & $19.23 \pm 0.64 ; \mathrm{p}_{1}>0.05$ \\
\hline Fibrinogen, $\mathrm{g} / \mathrm{l}$ & $2.11 \pm 0.19$ & $3.14 \pm 0.21 ; \mathrm{p}_{1}<0.05$ \\
\hline Platelets, $\mathrm{x}$ 10 & $215.8 \pm 4.2$ & $200.1 \pm 4.3 ; \mathrm{p}_{1}>0.05$ \\
\hline Aggregation height, cm & $3.9 \pm 0.13$ & $4.32 \pm 0.19 ; \mathrm{p}_{1}>0.05$ \\
\hline Aggregation time, min & $11.6 \pm 0.96$ & $4.58 \pm 0.28 ; \mathrm{p}_{1}<0.05$ \\
\hline Aggregation angle (degree) & $30.85 \pm 0.98$ & $45.7 \pm 0.94 ; \mathrm{p}_{1}<0.05$ \\
\hline TAl, $\%$ & $51.78 \pm 1.65$ & $53.35 \pm 1.15 ; \mathrm{p}_{1}>0.05$ \\
\hline
\end{tabular}

Note: $p_{1}$ - comparison of the indicators of the main group with the indicators of the control group

During the objective neurological examination, the symptoms of microorganic lesion of the central nervous system were revealed: weakness of convergence in $100 \%$ of patients, Mann's symptom (76.4\%), craniocerebral nerve function disorder $(58.8 \%)$, signs of pyramidal insufficiency $(68.4 \%)$, vestibular disorders $(94.1 \%)$, vegetovascular dysfunction (100\%).

In analyzing the parameters of free radical lipid oxidation, the following changes were found in patients: the level of malondialdehyde accumulation increased reliably by $55.8 \%$ as compared with the control group, the level of diene conjugates - by $12.9 \%$, peroxide resistance of erythrocytes was reliably reduced by $29.6 \%$. At the same time, there was a significant decrease in the activity of superoxide dismutase $(24.5 \%)$, catalase $(33.7 \%)$ and ceruloplasmin $(14.8 \%)$. In patients of the main group, we observed disrupted lipid metabolism, in particular, increased level of atherogenic lipoproteins by $45.4 \%$ as compared with the control group (Table II).

As our studies have shown, the main group of patients develops a tendency to hypercoagulation and a decrease in the process of fibrinolysis. This is indicated by the reduction of recalcification time by $8.6 \%$, thrombin time - by $24.3 \%$, reduction of fibrinolytic activity by $17.5 \%$, increased amount of fibrinogen by $48.8 \%$. We did not detect reliable changes in prothrombin time and antithrombin III (Table III).

When studying the indicators of microcirculatory hemostasis, we found that in the main group, the time of platelet aggregation reduced by 2.5 times, and the aggregation angle increased by $48.1 \%$. The obtained results allowed us to establish the fact of increased platelets pro-aggregation activity. However, the total index of platelet aggregation did not significantly differ in patients of the main and control groups. This suggests that the percentage of platelets that formed aggregates was virtually unchanged in the examined groups.

\section{DISCUSSION}

It is known that pathogenesis of structural and functional changes in the brain due to craniocerebral trauma is associated with a mechanical factor. Under the influence of trauma, hydrodynamic forces and liquor wave affect the limbic-hypothalamic-reticular region, which leads to various neurohumoral metabolic and endocrine, vegetative and vascular disorders. After the injury, patients report varying degrees of cerebrospinal symptoms: cerebral dysfunction, intellectual and mnestic impairment, changes in the psycho-emotional sphere, which include a wide range of disorders within neurasthenic and psychopathic syndromes.

Injury directly affects membranes, ion channels of axons, neurons and astrocytes, as well as cerebral blood flow and brain metabolism, which can be clinically manifested by various neurological disorders, including complete disintegration of brain activity.

In the process of injury, there is a disruption of both oxygenation and perfusion of the brain. In direct damage to neurons at the time of injury, there is a massive ion output and neurotransmitters into the extracellular space.

At the moment of injury, there is an excessive intake of glutamate, which launches the excitotoxicity mechanisms. Excessive stimulation of the NMDA receptors leads to active intake of calcium into the cell, followed by edema of the organelles and membranes, to necrosis or apoptosis, leading to death of the nerve cells.

All this leads to the fact that the sustained craniocerebral trauma, even at its easy degree, is far from always passing without a trace. Various consequences of the injury can appear both during the acute period and many years after the sustained craniocerebral trauma.

The consequences of craniocerebral trauma are extremely diverse, they include neurological pathology, which is manifested in the form of individual residual effects of trauma. The process can last from several months to several years and is accompanied by the emergence of new neurological 
and neuropsychological symptoms, including cognitive impairment. Significant activation of lipid peroxidation and depletion of the antioxidant enzyme system, associated structural and functional changes characterize the post-traumatic stage of traumatic brain damage of moderate severity.

Our research using the experimental model (emotional-pain stress) in other diseases, such as generalized periodontitis and galvanosis, revealed disorders as a state of free radical oxidation, activity of antioxidant enzymes and hemostasis [11-16]. The above-mentioned studies prove the interrelation between the processes of free radical oxidation and hemocoagulative properties of blood. It has been established that the high level of free radical reactions against the background of reduced level of antioxidant defense can lead to significant disorders of the hemostasis and fibrinolysis system up to the development of local disseminated intravascular blood coagulation. Similar data were obtained in patients with mild craniocerebral trauma, indicating the need for correction of these processes in patients.

\section{CONCLUSIONS}

1. All patients with mild CCT develop disturbances in the form of symptoms of microorganic lesion of the central nervous system: weakness of convergence in $100 \%$ of patients, Mann's symptom (76.4\%), dysfunction of cranial nerves (58.8\%), signs of pyramidal insufficiency (68.4\%), vestibular disorders (94.1\%), vegetovascular dysfunction (100\%).

2. Craniocerebral trauma of a mild degree is accompanied by activation of processes of free radical oxidation of lipids, decreased activity of antioxidant enzymes, hypercoagulation, increase in the aggregation properties of platelets.

\section{REFERENCES}

1. Majdan M. Epidemiology of traumatic brain injuries in Europe: a cross -sectional analysis. Lancet Public Health. 2016; 1(2): 76-83.

2. Akhanov G.Zh., Dyusembekov Ye.K., Nurbakyt A.N. Klinikoepidemiologicheskiye aspekty cherepno-mozgovoy travmy [Clinical and epidemiological aspects of traumatic brain injury] Neyrokhirurgiya i nevrologiya Kazakhstana. 2017; 2 (47): 65-71. (In Ruusian)

3. P'yatykop V.0., Masalitin I.M. Porivnyal'na otsinka klinichnykh osoblyvostey tyazhkoyi cherepno-mozkovoyi travmy za spryyatlyvoho i fatal'noho naslidku [Comparative assessment of clinical peculiarities of severe cerebrocranial trauma in benign and mortal outcome] Ukrainian Neurosurgical Journal. 2017;(2):39-43.(in Ukrainian)

4. Peeters W., Brande R.van den, Polinder S. etal. Epidemiology of traumatic brain injury in Europe. Acta Neurochir. 2015; 157(10): 1683-1696.

5. Chernenko I.I., Chukhno I.A. Epidemiolohichni ta klinichni aspekty naslidkiv cherepno-mozkovoyi travmy. [Epidemiological and clinical aspects of the craniocereberal trauma] Bulletin of Social Hygiene and Health Care Organizations of Ukraine. 2017; 4 (74):5-11. (In Ukrainian)

6. Polischuk M. Y., Goncharuk 0. M. Zakryta cherepno-mozkova travma. Suchasnyy pohlyad na problemu [Closed craniocerebral trauma. Modern view on the problem ] International neurological journal. 2015;6:72-80. (In Ukrainian)
7. Cherniy V.I. Diahnostyka i likuvannya nabryaku ta nabukhannya holovnoho mozha [Diagnosis and treatment of swelling and swelling of the brain]. In: Kardash A.M., Horodnyk H.A., Drobotko V.F.Kiyiv: Zdorov'ya; 1997. 228 s. (In Ukrainian)

8. Kasumova S.Yu. Patolohichna anatomiya cherepno-mozkovoyi travmy [Pathological anatomy of the craniocerebral trauma.] In: Konovalova 0.M., Potapova 0.0. Moskva: «Antydor»; 2002320 s. (In Ukrainian)

9. Karpov S.M., Herasymova M.M., Reshetnyak N.0. et al. Stan tserebralnoyi hemodynamiky v hostromu i viddalenomu periodakh cherepnomozkovoyi travmy [Condition of cerebral hemodynamic in acute and distant periods of craniocerebral trauma]. Nevroloh.vestn. 2004; 1-2: 8-12. (In Ukrainian)

10. Berkalo L.V. Posibnyk z eksperymentalno-klinichnikh doslidzhena v biolohiyi ta medytsyni [The manual for experimental and clinical studies is in biology and medicine]. In: Bobovych O.V., Bobrova N.O. Kaydashev I.P. et al. Poltava: 1996, $271 \mathrm{s.}$

11. Sokolenko VN, Silenko lul. The free-radical involvement of the salivary gland in stress Stomatologiia. 1995;74(2):17-9.

12. Silenko lu.I., Mishchenko V.P., Tokar' D.L., et al. The effect of periodontal cytomedin on free-radical lipid oxidation and on antiaggregation activity in the periodontium in chronic stress. Stomatologiia. 1994;73(4):6-8.

13. Mishchenko VP, Silenko lul, Khavinson VKh et al. Periodontal cytomedin effect on lipid peroxidation and hemostasis in rats with spontaneous periodontitis. Stomatologiia. 1991; 5: 12-14.

14. Tarasenko L.M., Grebennikova V.F., Tarasenko V.V. et al. The proteinase and alpha 1-antitrypsin activities in the tissues during emotional stress in rabbits. Fiziol Zh. 1992;38(1):115-117.

15. Mishchenko V.P., Silenko lu.I., Khavinson V.Kh. The effect of periodontal cytomedin on lipid peroxidation and hemostasis in spontaneous periodontitis in rats. Stomatologiia. 1991;5:12-14.

16. Sylenko Y.I,Perepelova T.., Khrebor M.V.etal Reaktsiyivil'noradykal'noho okyslennya lipidiv, hemokoahulyantni vlastyvosti rotovoyi ridyny u patsiyentiv $z$ hal'vanichnymy strumam [The reactions of lipid's free radical oxidation, hemocoagulant properties of oral fluid in patients with galvanic currents in the mouth]. Wiad Lek. 2018;71(4):879-882. (In Ukrainian).

\section{Authors' contributions:}

According to the order of the Authorship.

\section{Conflict of interest:}

The Authors declare no conflict of interest.

\section{CORRESPONDING AUTHOR Yurii I. Sylenko}

Ukrainian Medical Stomatological Academy

23 Shevchenka St., 36011 Poltava, Ukraine

e- mail: silenko@gmail.com

Received: 07.12 .2018

Accepted: 25.03 .2019 
PRACA ORYGINALNA

ORIGINAL ARTICLE

\title{
CORRECTION OF NEUROLOGICAL DEFICIENCY IN PATIENTS WITH ACUTE ISCHEMIC STROKE BY APPLICATION OF DIFFERENT QUALITATIVE COMPOSITION OF INFUSION SOLUTIONS
}

\author{
Andrii I. Semenenko', Bogdan 0. Kondratsky², Galyna I. Hrebtiy ${ }^{3}$, Svitlana L. Malyk ${ }^{1}$, Mykola G. Hinhuliak³ \\ Roksolana Ya. Bodnar', Alexandr M. Hinhuliak ${ }^{3}$, Lesia M. Zheliba' \\ 'NATIONAL PIROGOV MEMORIAL MEDICAL UNIVERSITY, VINNYTSYA, UKRAINE \\ ${ }^{2}$ INSTITUTE OF BLOOD PATHOLOGY AND TRANSFUSION MEDICINE, LVIV, UKRAINE \\ 3HIGHER EDUCATION INSTITUTION IN UKRAINE"BUKOVINIAN STATE MEDICAL UNIVERSITY", CHERNIVTSI, UKRAINE \\ ${ }^{4}$ HORBACHEVSKY TERNOPIL STATE MEDICAL UNIVERSITY, TERNOPIL, UKRAINE
}

\begin{abstract}
Introduction: Infusion therapy is an important component in the treatment of patients with acute ischemic stroke (AIS).

The aim: Compare the dynamics of changes neurological deficiency in the application of solutions: $0.9 \% \mathrm{NaCl}, \mathrm{HES} 130$, HAES-LX-5\% and mannitol $15 \%$ in patients with AIS.

Materials and methods: The study included 100 patients with AIS. As the investigated solutions were used: isosmolar $0.9 \% \mathrm{NaCl}$, hyperosmolar mannitol $15 \%$, colloid-isoosmolar HES 130, colloid-hyperosmolar HAES-LX-5\%. The control group received only $0.9 \% \mathrm{NaCl}$ compared: $0.9 \% \mathrm{NaCl}+\mathrm{HES}$ 130, $0.9 \% \mathrm{NaCl}+\mathrm{HAES}-\mathrm{LX}-5 \%, 0.9 \% \mathrm{NaCl}+$ mannitol $15 \%$. The evaluation of treatment efficacy (magnitude of neurological deficiency) was performed daily for 7 days using the Glasgow Coma Scale (GCS), Full Outline of UnResponsiveness (FOUR) Score, National Institutes of Health Stroke Scale (NIHSS) and BIS-index.

Results: The conducted research showed that the application of $0.9 \% \mathrm{NaCl}$ and mannitol did not have a significant effect on the dynamics of neurological deficits according to the GCS, FOUR and NIHSS scales for 7 days of observation ( $p>0.05$ ). The use of HES 130 contributed to a statistically significant improvement in the parameters of the $G C S$ ( $p<0,05)$, which is confirmed by significant changes in the BIS-index $(p<0,05)$ during a seven-day infusion therapy. The most significant positive changes were observed in the group with HAES-LX-5\%, which was marked by an improvement in the neurological state during 7 days treatment acoording to the GCS, FOUR and BIS index $(p<0.05)$.

Conclusions: The intergroup analysis of the neurological deficiency confirmed the worst result of treatment in the group with mannitol $(p<0,05)$ and the best result with HAES-LX-5\% $(p<0,05)$.
\end{abstract}

KEY WORDS: acute ischemic stroke, infusion therapy, 0.9\% NaCl, HES 130, mannitol, HAES-LX-5\%

Wiad Lek 2019, 72, 4, 543-547

\section{INTRODUCTION}

Today mortality from acute ischemic stroke (AIS) is one of the leading causes of mortality worldwide $[1,2]$. Neurological examination of patients with acute stroke is a compulsory component of not only diagnosis of stroke, but also objectification of the severity of AIS, the dynamics of treatment efficacy, the severity of neurological changes. Today's most popular neurologycal scales are NIHSS (National Institutes of Health Stroke Scale), FOUR (Full Outline of UnResponsiveness), Glasgow Scale [3, 4].

Infusion therapy is an important component in the treatment of patients with AIS and at the same time one of the most difficult problems in the complex of conservative treatment of these patients. As modern literary sources show, the clear principles of infusion therapy in patients with AIS have not yet been established by evidence-based medicine $[5,6]$. Today, the question of choosing an optimally effective infusion strategy in patients with AIS remains open: the optimum composition, dose, control of the infusion volume, the definition of the endpoints of the effectiveness of therapy is the subject of discussion. At present, there are no clear recommendations for the infusion therapy algorithm in the treatment of AIS $[3,5,6]$.

The problem of determining the optimal qualitative composition of infusion solutions with AIS remains unresolved and requires additional research. It is still unclear whether should use the one solution or combination of several when conducting intensive care in patients with AIS $[5,6]$.

Taking into account the above-mentioned information the problem remains little-known about the influence of different types qualitative composition infusion solutions on the neurological deficits in patients with AIS .

\section{THE AIM}

Compare the dynamics of changes neurological deficiency in the application of solutions: $0.9 \% \mathrm{NaCl}$, HES 130, HAESLX-5\% and mannitol 15\% in patients with AIS. 


\section{MATERIALS AND METHODS}

The study included 100 patients with AIS (non-differentiated by pathogenetic subtype). Randomization was performed using random numbers. The average age of patients was $71.84 \pm 1.67$ years, of which 47 were men and 53 women. The study included patients whose body weight did not exceed $120 \mathrm{~kg}$. The study groups did not differ in age composition, severity of disease and other outcomes that could affect the final results of the study.

Diagnosis of AIS was established on the basis of computer tomography data. The main criterion for the selection of patients was the presence of AIS in patients and disturbances of consciousness on a scale of Glasgow 12 points and below, but not less than 4 points at admission (average was 12 points). Investigated solutions:

An isosmolar $0.9 \% \mathrm{NaCl}$ solution in $1 \mathrm{ml}$ as a crystalloid base contains sodium chloride $0.009 \mathrm{~g}$, theoretical osmolarity - 308 mosmol/l.

The colloid-isosmolar solution hydroxyethylcrystal $6 \%$ 130/04 (HES 130) contains $1000 \mathrm{ml}$ of colloidal base (O-2-hydroxyethyl) starch (molar substitution degree - 0.4; average molecular weight - $130000 \mathrm{Da}$ ) $60.0 \mathrm{~g}$, sodium chloride $9.0 \mathrm{~g}$, auxiliary substances: sodium hydroxide (for $\mathrm{pH}$ correction), hydrochloric acid (for $\mathrm{pH}$ adjustment), water for injection up to $1000 \mathrm{ml}$, electrolytes: $\mathrm{Na}^{+}-154 \mathrm{mmol} / \mathrm{l} ; \mathrm{Cl}^{-}-154 \mathrm{mmol} / \mathrm{l}$, theoretical osmolarity - $308 \mathrm{mosmol} / \mathrm{l}$.

The colloid-hyperosmolar HAES-LX-5\% solution (registered in Ukraine in 2013 under the name "Gekoton»), which contains as a colloidal basis poly (0-2-hydroxyethyl) starch (average molecular weight of 130,000 Daltons, the degree of molecular substitution 0.4 ) - 5\%, as well as polyether alcohol xylitol - 5\%, sodium lactate - $1,5 \%$, sodium chloride - $0,8 \%$, potassium chloride - $0,03 \%$, calcium chloride $-0,02 \%$, magnesium chloride $-0.01 \%$. The ionic composition of the drug: $\mathrm{Na}^{+}-270.7 \mathrm{mmol} / \mathrm{l}, \mathrm{K}^{+}-4.0$ $\mathrm{mmol} / \mathrm{l}, \mathrm{Ca}^{++}-1.8 \mathrm{mmol} / 1, \mathrm{Mg}^{++}-1.1 \mathrm{mmol} / \mathrm{l}, \mathrm{Cl}^{-}-146.6$ $\mathrm{mmol} / \mathrm{l}, \mathrm{CH} 3 \mathrm{CH}(\mathrm{OH}) \mathrm{COO}^{-}-133.8 \mathrm{mmol} / \mathrm{l}$. Theoretical osmolarity - 890 mosmol/l.

A hyperosmolar solution of mannitol 15\% (mannitol) - hyperosmolyar crystalloid solution $1000 \mathrm{ml}$ contains of mannitol solution $150 \mathrm{~g}$, auxiliary substances: sodium chloride - $9 \mathrm{~g}$, water for injections to 1 liter, theoretical osmolarity - 1131 mosmol/l.

Patients with AIS were divided into 4 groups: group of $0.9 \% \mathrm{NaCl}$ (25 patients): patients receiving $0.9 \%$ of $\mathrm{NaCl}$ in addition to baseline therapy for 7 days; group of HES 130 (25 patients): patients who received $0.9 \% \mathrm{NaCl}+\mathrm{HES} 130$ in addition to baseline therapy for 7 days; group of HAES-LX-5\% (25 patients): patients who received $0.9 \% \mathrm{NaCl}+\mathrm{HAES}-\mathrm{LX}-5 \%$ in addition to baseline therapy for 7 days; group of mannitol (25 patients): patients who received $0.9 \% \mathrm{NaCl}+$ mannitol in addition to baseline therapy for 7 days.

Infusion solutions were injected intravenously (i/v) at a dose of $2.5 \mathrm{ml} / \mathrm{kg}$ at a frequency of 2 times a day; infusion was started immediately upon confirmation of the diagnosis, and then every other day every 12 hours during 7 days. The control group patients received only $0.9 \%$ $\mathrm{NaCl}$ from infusion solutions were taken, the comparison groups patients received: $0.9 \% \mathrm{NaCl}+\mathrm{HES} 130$ or $0.9 \% \mathrm{Na}-$ $\mathrm{Cl}+\mathrm{HAES}-\mathrm{LX}-5 \%$ or $0.9 \% \mathrm{NaCl}+$ mannitol. The comparison groups received not only the test solution at a fixed dose, but also a $0.9 \%$ solution $\mathrm{NaCl}$, as, in general, to refuse this solution is impossible. The amount of $0.9 \% \mathrm{NaCl}$ and the daily volume of infusion $(\mathrm{i} / \mathrm{v})$ in each study group did not differ significantly. The total volume of intravenous infusion per day amounted to an average of 1000 [800; 1300]. Basic therapy was determined according to the Order of the Ministry of Health of Ukraine dated 03.08.2012 № 602.

The evaluation of treatment efficacy (level of neurological deficiency) was performed daily for 7 days using the Glasgow Coma Scale (GCS) [7], Full Outline of UnResponsiveness (FOUR) Score/Scale [8], National Institutes of Health Stroke Scale (NIHSS) [9], and BIS-index [10]. Statistical processing of the results was carried out using methods of variation statistic and using a program StatSoft «Statistica» v. 6.0. The parametric criterion $t$ Student was used for normal distribution, the non-parametric Mann-Whitney U test, was used - in its absence, the Wilcoxon matched pairs test - to determine significant changes in the dynamics of inside the group. The statistical significance of the difference between the comparative values was considered probable at $\mathrm{p}<0.05$.

\section{RESULTS}

The conducted study showed that manifestations of neurological deficiency were noted in all observation groups on $1^{\text {st }}$ day (table I). Thus, for the GCS the average level of consciousness was 12 points for 3 groups, except for the HAES-LX-5\% group, where the average score was 10 points. The evaluation of the GCS in groups with $0.9 \% \mathrm{NaCl}$ and patients with mannitol showed no significant difference in the variation of this indicator within 7 days of treatment ( $p>0.05)$. What can not be said by analyzing the group of HES 130, which shows a significant difference in the evaluation of seven-day therapy from the $1^{\text {st }}$ to the $4^{\text {th }}$ day $(p=0.05)$ and from the $1^{\text {st }}$ to $7^{\text {th }}$ day $(\mathrm{p}=0.01)$. The similar positive dynamics of the GCS, as in the HES 130 group, was observed in the group with HAES-LX-5\%, but more indicative: the assessment of the seven-day therapy in this group from $1^{\text {st }}$ to $4^{\text {th }}$ day showed a statistical significance of changes $(p=0.01)$ and from the $1^{\text {st }}$ to $7^{\text {th }}$ day $(\mathrm{p}=0.004)$.

Analysis of the scale FOUR in groups with $0.9 \% \mathrm{NaCl}, \mathrm{HES}$ 130 , and mannitol showed no significant difference in the variation of this indicator within 7 days of treatment $(p>0.05)$. Only patients with HAES-LX-5\% received a positive, significant neurological dynamics according of the scale FOUR from the $1^{\text {st }}$ to the $4^{\text {th }}$ day of treatment $(p=0.009)$ and from the $1^{\text {st }}$ to the $7^{\text {th }}$ day $(p=0.0006)$.

The intra-group analysis of NIHSS scores in patients of all 4 groups did not show a significant difference of this indicator within 7 days of treatment $(\mathrm{p}>0.05)$.

Dynamic analysis of the BIS-index showed that there was a significant positive dynamics in the treatment from the $1^{\text {st }}$ to the $7^{\text {th }}$ day for the groups: $0.9 \% \mathrm{NaCl}(\mathrm{p}=0.04)$, HES $130(p=0.01)$ and HAES-LX-5\% $(p=0.005)$. In the group 
Table I. Dynamics of changes in the neurological status of patients with acute ischemic stroke on the background of seven-day therapy with investigated infusion solutions

\begin{tabular}{|c|c|c|c|c|c|c|}
\hline \multirow[t]{2}{*}{ Indexes } & \multicolumn{3}{|c|}{ Days } & \multicolumn{3}{|c|}{$\begin{array}{l}\text { Multiple comparisons of mean ranks for all } \\
\text { groups, p-values (2-tailed) }\end{array}$} \\
\hline & $1(n=25)$ & $4(n=25)$ & $7(n=25)$ & $1-4$ & $1-7$ & 4-7 \\
\hline \multicolumn{7}{|c|}{$\mathrm{NaCl} 0,9 \%$} \\
\hline GCS (points) & $12(11 ; 12)$ & $12(8 ; 14)$ & $14(10 ; 15)$ & 1.00 & 0.27 & 0.72 \\
\hline FOUR (points) & $14(13 ; 15)$ & $15(11 ; 16)$ & $16(12 ; 16)$ & 1.00 & 0.78 & 1.00 \\
\hline NIHSS (points) & $17(13 ; 20)$ & $17(10 ; 22)$ & $13(4 ; 20)$ & 1.00 & 0.73 & 0.95 \\
\hline BIS-index (\%) & $80(72 ; 84)$ & $84(65 ; 92)$ & $90(80 ; 98)$ & 0.74 & 0.04 & 0.53 \\
\hline \multicolumn{7}{|c|}{ HES 130} \\
\hline GCS (points) & $12(9 ; 12)$ & $13(11 ; 15)$ & $13(10 ; 15)$ & 0.05 & 0.01 & 1.00 \\
\hline FOUR (points) & $14(12 ; 15)$ & $15(13 ; 16)$ & $15(12 ; 16)$ & 0.27 & 0.37 & 1.00 \\
\hline NIHSS (points) & $16(12 ; 22)$ & $16(10 ; 23)$ & $14(10 ; 23)$ & 1.00 & 1.00 & 1.00 \\
\hline BIS-index (\%) & $76(70 ; 80)$ & $81(72 ; 98)$ & $87(73 ; 98)$ & 0.04 & 0.01 & 1.00 \\
\hline \multicolumn{7}{|c|}{ HAES-LX-5\% } \\
\hline GCS (points) & $10(9 ; 12)$ & $13(12 ; 15)$ & $14(12 ; 15)$ & 0.01 & 0.004 & 1.00 \\
\hline FOUR (points) & $13(11 ; 14)$ & $15(13 ; 16)$ & $16(14 ; 16)$ & 0.009 & 0.0006 & 1.00 \\
\hline NIHSS (points) & $18(16 ; 21)$ & $13(8 ; 17)$ & $12(5 ; 15)$ & 0.32 & 0.21 & 1.00 \\
\hline BIS-index (\%) & $73(70 ; 80)$ & $84(80 ; 90)$ & $80(72 ; 86)$ & 0.002 & 0.005 & 0.04 \\
\hline \multicolumn{7}{|c|}{ Mannitol } \\
\hline GCS (points) & $12(10 ; 12)$ & $10(8 ; 12)$ & $12(10 ; 14)$ & 0.90 & 1.00 & 0.29 \\
\hline FOUR (points) & $13(12 ; 14)$ & $11(10 ; 14)$ & $11(10 ; 14)$ & 0.47 & 0.50 & 1.00 \\
\hline NIHSS (points) & $21(14 ; 23)$ & $22(19 ; 24)$ & $20(15 ; 23)$ & 0.77 & 1.00 & 0.41 \\
\hline BIS-index (\%) & $78(70 ; 82)$ & $70(60 ; 78)$ & $74(70 ; 88)$ & 0.44 & 1.00 & 0.15 \\
\hline
\end{tabular}

with mannitol was not observed a significant intra-group difference in the changes of this indicator during 7 days of observation ( $\mathrm{p}>0.05)$.

Analyzing the initial level of intergroup neurological deficits (table II) for all studied groups, we can say that there is no statistically significant difference amoung the groups $(p>0,05)$ according to the GCS, FOUR, NIHSS and BIS-index. It shows the relative initial intergroup identity of patients according to neurological deficits.

On the $4^{\text {th }}$ day of study should be noted statistically significant deterioration of the neurological status of patients who receive mannitol compared to HAES-LX-5\%: GCS $(\mathrm{p}=0.02)$, FOUR $(\mathrm{p}=0.01)$, NIHSS $(\mathrm{p}=0.001)$, BIS-index $(\mathrm{p}=0.008)$, and HES 130: GCS $(\mathrm{p}=0.03)$, FOUR $(\mathrm{p}=0.03)$, BIS-index $(p=0.05)$. Comparison of other groups did not show a significant difference in neurological deficit during 4-days observation period.

Dynamic intergroup analysis of the neurological deficit at the $7^{\text {th }}$ day of observation confirmed a similar picture, as in the $4^{\text {th }}$ day. Thus, the statistical deterioration of the neurological status of patients in the intergroup analysis was reliably noted only in the group with mannitol compared to HAES-LX-5\% by the indicators: FOUR $(\mathrm{p}=0.02)$, NIHSS ( $p=0.02)$, HES 130: FOUR $(p=0.04), 0.9 \% \mathrm{NaCl}$ : FOUR ( $\mathrm{p}=0.02)$. Other intergroup indices did not have a significant difference $(\mathrm{p}>0.05)$.

\section{DISCUSSION}

The modern treatment tactics of patients with AIS requires a multimodal approach, both in diagnostics and in treatment. The main endpoints of infusion therapy in such patients are the normalization of fluid balance and blood pressure levels to restore optimal perfusion in the area of ischemic brain damage.

Undoubtedly, the main points of infusion therapy in neurointensive therapy are reducing mortality and disability in patients with AIS. The level of neurological deficits in patients with severe ischemic stroke can today be one of the main markers of effectiveness of treatment. Today, determination of the level of neurological deficits precisely with help of scales: FOUR and NIHSS has proven validity and faithfulness. The use of the abovementioned scales from the onset of treatment and the analysis in the dynamics provides the opportunity to predict the possible outcome of the treatment of neurological patients [4].

Assessing the efficiency of the scales used today, we can say that the FOUR scale has some advantages over the Glasgow coma scale, namely: it details the neurological status more precisely, gives an assessment of the respiratory pattern. The evaluation of the FOUR scale was one of the main points in the analysis of the effectiveness of the therapy, as this scale provides additional information on the prognosis in patients with low score of the GCS. 
Table II. Overall dynamics of changes GSC, FOUR, NIHSS and BIS index in different groups

\begin{tabular}{|c|c|c|c|c|c|c|c|c|c|c|}
\hline \multirow{3}{*}{ Indexes } & \multicolumn{4}{|c|}{ Groups } & \multirow{2}{*}{\multicolumn{6}{|c|}{$\begin{array}{l}\text { Multiple comparisons of mean ranks for all groups, } \\
\text { p-values (2-tailed) }\end{array}$}} \\
\hline & 1 & 2 & 3 & 4 & & & & & & \\
\hline & $\begin{array}{l}\mathrm{NaCl} \\
\mathrm{n}=25\end{array}$ & $\begin{array}{c}\text { HES } 130 \\
n=25\end{array}$ & $\begin{array}{c}\text { HAES- } \\
\text { LX-5\% } \\
n=25\end{array}$ & $\begin{array}{c}\text { Mannitol } \\
\mathrm{n}=\mathbf{2 5}\end{array}$ & P1-2 & P1-3 & P1-4 & P2-3 & P2-4 & P3-4 \\
\hline \multicolumn{11}{|c|}{1 day } \\
\hline GCS (points) & $12(11 ; 12)$ & $12(9 ; 12)$ & $10(9 ; 12)$ & $12(10 ; 12)$ & 1,00 & 0,10 & 1,00 & 1,00 & 1,00 & 0,86 \\
\hline FOUR (points) & $14(13 ; 15)$ & $14(12 ; 15)$ & $13(11 ; 14)$ & $13(12 ; 14)$ & 1,00 & 0,10 & 0,62 & 1,00 & 1,00 & 1,00 \\
\hline NIHSS (points) & $17(13 ; 20)$ & $16(12 ; 22)$ & $18(16 ; 21)$ & $21(14 ; 23)$ & 1,00 & 1,00 & 0,51 & 1,00 & 1,00 & 1,00 \\
\hline BIS-index (\%) & $80(72 ; 84)$ & $76(70 ; 80)$ & $73(70 ; 80)$ & $78(70 ; 82)$ & 0,24 & 0,33 & 1,00 & 1,00 & 1,00 & 1,00 \\
\hline \multicolumn{11}{|c|}{4 day } \\
\hline GCS (points) & $12(8 ; 14)$ & $13(11 ; 15)$ & $13(12 ; 15)$ & $10(8 ; 12)$ & 1,00 & 1,00 & 0,90 & 1,00 & 0,03 & 0,02 \\
\hline FOUR (points) & $15(11 ; 16)$ & $15(13 ; 16)$ & $15(13 ; 16)$ & $11(10 ; 14)$ & 1,00 & 1,00 & 0,29 & 1,00 & 0,03 & 0,01 \\
\hline NIHSS (points) & $17(10 ; 22)$ & $16(10 ; 23)$ & $13(8 ; 17)$ & $22(19 ; 24)$ & 1,00 & 1,00 & 0,13 & 1,00 & 0,07 & 0,001 \\
\hline BIS-index (\%) & $84(65 ; 92)$ & $81(72 ; 98)$ & $84(80 ; 90)$ & $70(60 ; 78)$ & 1,00 & 1,00 & 0,12 & 1,00 & 0,05 & 0,008 \\
\hline \multicolumn{11}{|c|}{7 day } \\
\hline GCS (points) & $14(10 ; 15)$ & $13(10 ; 15)$ & $14(12 ; 15)$ & $12(10 ; 14)$ & 1,00 & 1,00 & 1,00 & 1,00 & 1,00 & 0,50 \\
\hline FOUR (points) & $16(12 ; 16)$ & $15(12 ; 16)$ & $16(14 ; 16)$ & $11(10 ; 14)$ & 1,00 & 1,00 & 0,02 & 1,00 & 0,04 & 0,02 \\
\hline NIHSS (points) & $13(4 ; 20)$ & $14(10 ; 23)$ & $12(5 ; 15)$ & $20(15 ; 23)$ & 1,00 & 1,00 & 0,33 & 0,84 & 0,81 & 0,02 \\
\hline BIS-index (\%) & $90(80 ; 98)$ & $87(73 ; 98)$ & $80(72 ; 86)$ & $74(70 ; 88)$ & 1,00 & 1,00 & 0,61 & 1,00 & 1,00 & 0,56 \\
\hline
\end{tabular}

The FOUR scale is a modification of the Glasgow scale for neurological patients, it allows an objective assessment of consciousness in patients with aphasia and/or with mechanical ventilation device through an intubation tube. The probability of an inpatient mortality is higher in patients with the lowest score of the FOUR scale than in patients with the lowest score on the Glasgow coma scale [11]. Analysis of FOUR scores groups of patients: $0.9 \% \mathrm{NaCl}$, HES 130 and mannitol showed no significant difference in changes in the given index within 7 days of treatment $(\mathrm{p}>0.05)$. Only patients with HAES-LX-5\% received a positive, reliable neurological dynamics of the FOUR scale from the $1^{\text {st }}$ to the $4^{\text {th }}$ day of treatment $(\mathrm{p}=0.009)$ and from the $1^{\text {st }}$ to the $7^{\text {th }}$ day $(\mathrm{p}=0.0006)$.

Today, one of the most commonly used and popular is National Institute of Health stroke severity scale that can reflect a general stroke severity profile (level of evidence A) [3]. The data obtained from our intra-group analysis of NIHSS scores in patients of all 4 groups did not show a significant difference in the changes of this indicator within 7 days of treatment ( $p>0.05$ ). However, the intergroup analysis of NIHSS scores showed a significantly better result on the $4^{\text {th }}$ and $7^{\text {th }}$ day of observation in patients with HAES-LX-5\% compared to the mannitol group $(\mathrm{p}<0.05)$, which most likely is due to the better ability of the colloid-hyperosmolar solution HAES-LX-5\% to restore and stabilize brain perfusion in the zone of ischemic lesion.

The dynamics of neurological status in patients with AIS has shown that in the group with colloidal-hyperosmolar solution the most likely dynamics of restoration of the neurological status during the acute period of ischemic stroke was observed in comparison with other investigated solutions, which is in full agreement with the data we have received regarding the effect of this solution on the mortality of patients with AIS [12].

Based on the data obtained in our study of intensive care in patients with acute ischemic stroke, one of the possible and recommended strategies for infusion support in acute cerebral ischaemia in patients with AIS may be the use of isosomolyar $0.9 \% \mathrm{NaCl}$ solution and polyfunctional solutions (possibly colloidal-hyperosmolar), which combining a number of polypharmacological effects that are so necessary to combat acute cerebral ischemia.

\section{CONCLUSIONS}

1. The application of $0.9 \% \mathrm{NaCl}$ and mannitol did not have a significant effect on the dynamics of neurological deficits according to the GCS, FOUR and NIHSS scales 
for 7 days of observation ( $p>0.05$ ). The use of HES 130 contributed to a statistically significant improvement in the parameters of the GCS ( $p<0,05)$, which is confirmed by significant changes in BIS-index $(\mathrm{p}<0,05)$ during a seven-day infusion therapy. The most significant positive changes were observed in the HAES-LX-5\% group, which was marked by an improvement in the neurological state during 7 days treatment acoording to the GCS, FOUR and BIS-index $(\mathrm{p}<0.05)$.

2 . The intergroup analysis of the neurological deficiency confirmed the worst reliable result in the mannitol group: on the $4^{\text {th }}$ day compared to HAES-LX-5\% with the following indices: GCS $(\mathrm{p}=0.02)$, FOUR $(\mathrm{p}=0.01)$, NIHSS $(\mathrm{p}=0.001)$, BIS-index $(\mathrm{p}=0.008)$ and HES-130: GCS ( $\mathrm{p}=0.03)$, FOUR $(\mathrm{p}=0.03)$, BIS-index $(\mathrm{p}=0.05)$; on the $7^{\text {th }}$ day in comparison with HAES-LX-5\%: FOUR $(\mathrm{p}=0.02)$, NIHSS $(\mathrm{p}=0.02)$, HES 130: FOUR $(\mathrm{p}=0.04)$ and $0.9 \% \mathrm{NaCl}$ : FOUR $(\mathrm{p}=0.02)$.

\section{REFERENCES}

1. Li Y., Zhong W., Jiang Z., et al. New progress in the approaches for blood-brain barrier protection in acute ischemic stroke. Brain Res Bull, 2018; 144;46-47.

2. Rasouli, M.R., Tabatabaee, R.M., Maltenfort, et.al. Acute stroke after total joint arthroplasty: a population-based trend analysis. J. Clin. Anesth, 2016; 34:15-20.

3. Eskes G.A., Lanctôt K.L., Herrmann N., et al. Canadian Stroke Best Practice Recommendations: Mood, Cognition and Fatigue Following Stroke Practices Guidelines, update 2015. Int. J. Stroke, 2015; (29):1-356.

4. Mansour O.Y., Megahed M.M., Elghany E.H.S. Acute ischemic stroke prognostication, comparison between Glasgow Coma Score, NIHS Scale and Full Outline of UnResponsiveness Score in intensive care unit. Alexandria Journal of Medicine, 2015;51(3): 247-253.
5. Oddo M., Poole D., Helbok R., et al. Fluid therapy in neurointensive care patients: ESICM consensus and clinical practice recommendations. Intensive Care Med, 2015, Mar 2. doi: 10.1007/s00134-018-5086-z.

6. Powers W.J., Rabinstein A.A., Ackerson T., et al. 2018 Guidelines for the Early Management of Patients With Acute Ischemic Stroke: A Guideline for Healthcare Professionals From the American Heart Association/ American Stroke Association. Stroke, 2018; 49(3): 46-110.

7. Teasdale G., Jennett B. Assessment of coma and impaired consciousness. A practical scale. Lancet, 1974;2(7872):81-84.

8. Wijdicks E.F., Bamlet W.R., Maramattom B.V., et al. Validation of a new coma scale: the FOUR score. Ann Neurol, 2005;58(4):585-593.

9. Brott T.G., Adams H.P., Olinger C.P., et al. Measurements of acute cerebral infarction: a clinical examination scale. Stroke, 1989;20(7):864-870.

10. Yolkina T.A., Osetrov A.S. Dinamika pokazateley klinicheskikh otsenochnykh shkal v ostreyshem i ostrom periodakh pri otdelnykh podtipakh ishemicheskogo insulta [Dynamics of indicators of clinical assessment scales in the acutest and acute periods with individual subtypes of ischemic stroke]. Modern problems of science and education, 2013;5:8. (In Russia)

11. Travinichev D.V., Kuznetsova E.B., Salina E.A., et al. Shkala FOUR kak kriteriy otsenki sostoyaniya soznaniya u bolnykh $\mathrm{s}$ ishemicheskim insultom v ostreyshem periode [The FOUR scale as a criterion for assessing the state of consciousness in patients with ischemic stroke in the acute period]. Bulletin of Medical Internet Conferences, 2014; 4(2):120. (In Russia)

12. Semenenko A.I. The analysis of mortality rates in patients with acute ischemic stroke in a hospital at differentiated infusion therapy. Journal of Education, Health and Sport, 2016;6(6);300-307.

Authors' contributions:

According to the order of the Authorship

Conflict of interest:

The Authors declare no conflict of interest

\section{CORRESPONDING AUTHOR Andrii I. Semenenko \\ National Pirogov Memorial Medical University 56 Pirogova st., 21000, Vinnitsa, Ukraine \\ tel: +380973541664 \\ e-mail: semenenk005@gmail.com}

Received: 03.12 .2018

Accepted: 18.03 .2012 


\title{
THEORETICAL SUBSTANTIATION OF THE WAYS OF INCREASING THE EFFICIENCY OF SPECIALIZED MEDICAL AID IN PATIENTS WITH LUNG CANCER
}

\author{
Viktor A. Ognev' ${ }^{1}$ Oleg A. Korop ${ }^{2}$, Andriy M. Zinchuk ${ }^{1}$ \\ 'KHARKIV NATIONAL MEDICAL UNIVERSITY, KHARKIV, UKRAINE \\ 2KHARKIV MEDICAL ACADEMY OF POSTGRADUATE EDUCATION, KHARKIV, UKRAINE
}

\begin{abstract}
Introduction: Organizational changes in the context of the transformation of the health system in Ukraine are based on deep and consistent structural and functional transformations and directed to the providing of specialized care of appropriate quality and efficiency, which are the main target function and a prominent criterion for the functioning of the national health system.

The aim: Theoretical substantiation of the ways of increasing the efficiency of specialized medical aid in patients with lung cancer.

Materials and methods: Accounting medical records were the main source for the investigation, along with that the results of sociological researches in oncological patients with lung cancer and the results of expert estimation of the ways of increasing the efficiency of specialized aid for such kind of patients. Some methods were also used, such as system approach and analysis, sociological method, methods of conceptual modeling and expert values.

Results: An increase of integral efficiency of a specialized medical aid for cancer patients in Ukraine could be reached by expected medical one (introduction of preventive, diagnostic and therapeutic technologies); social one (healthy way of life; satisfaction by the quality and availability as primary as specialized medical aid) and economic efficiency (reduction of economic losses because of disability; shortening of inpatient medical aid financing because of less number of patients with neglected stages of the disease). All of that is grounded on the development and introduction of organizational medical technologies, directed on the early detection of lung cancer and provides justification and development of an optimized model for the early detection of this disease.

Conclusions: The disadvantages and lack of efficiency of the existing system of specialized cancer care in Ukraine have identified the necessity of a systematic and integrated solution of the problem of early detection of lung cancer based on the optimization of its model, based on the principles of systemicity and complexity, the use of modern science and practice achievements in the management and organization of specialized medical care, application between sector interaction and improvement of its information and communication and organizational-economic components.
\end{abstract}

KEY WORDS: specialized medical care, efficiency of medical aid, lung cancer

Wiad Lek 2019, 72, 4, 548-552

\section{INTRODUCTION}

Nowadays lung cancer in Ukraine is one of the most spread oncological diseases in able-bodied age patients. In the structure of oncological morbidity this kind of ailment has $12,8 \%$ [1]. In a global scale, lung cancer is diagnosed in 1,2 million patients annually, and more than 1 million deaths are caused by this kind of sickness $[2,3]$. There is an interesting fact that 5 -year survival rate is lower in the states with the high standards of health care is only $15 \%$, in the countries with a middle level of medical development this number is barely reachable 5-7\%. National Cancer Institute published the data of survival rate in patients with lung cancer in Ukraine. Mortality of oncological patients in the period under one year is $63,9 \%$, in comparison with $60 \%$ in the USA, and 5 -year survival rate in the USA is higher than in Ukraine respectively $15 \%$ and $9,4 \%$ [4].

It is important to note the difference in the incidence of lung cancer in different geographical regions, ranging from 5.3 to 99.7 per 100,000 population [5], according to sex - the incidence is 6-10 times higher among men than among women [6] and according to the place of residence - among urban inhabitants, the incidence of lung cancer is $15 \%$ higher than that of people living in rural areas [7]. In addition, numerous studies identified the main risk factors for lung cancer, among which the most important are tobacco use, chronic obstructive pulmonary disease, industrial hazards, ionizing radiation and low physical activity $[8,9]$, and high mortality from lung cancer among major nosological forms of malignant neoplasms, which is largely due to the inadequate effectiveness of the existing system of specialized medical care for cancer patients, which is largely depends on the volume of financing, organizational and technological provision of the system of specialized cancer services, the level of public confidence in the health care sector, the socio-economic development of the country and its regions, the economic differentiation of the population 


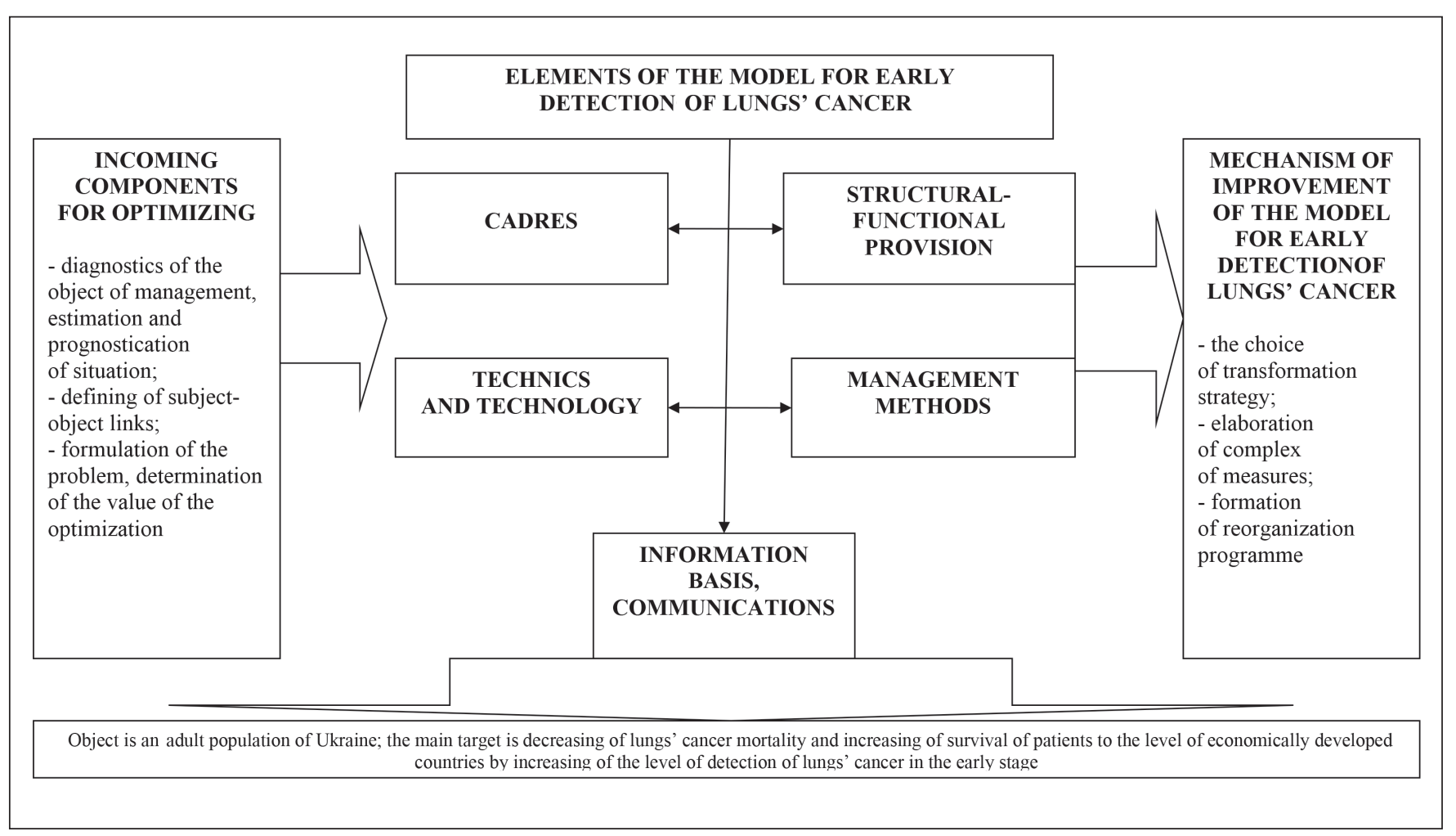

Figure 1. Optimized model for the early detection of lungs' cancer for the population of Ukraine.

and its belonging to certain socio-economic groups, living and working conditions, adherence to a healthy lifestyle and a stage of disease detection [10].

Taking into account all above-mentioned problems it is necessary to reform health care system of Ukraine. Specialized medical aid has to be accessible, qualitative and effective. Morbidity and mortality because of different reasons (including cancer ones) have to be reduced. Public health has to re-orient onto the preventive sphere and propaganda of advantages of healthy lifestyle, improvement of personnel policy and innovation development of medical science.

\section{THE AIM}

Theoretical substantiation of the ways of increasing the efficiency of specialized medical care for lung cancer patients, working out and introduction of optimized model of the early cancer detection are the main goals of this publication.

\section{MATERIALS AND METHODS}

Organization of medical and sanitary care of lung cancer patients is an object of research, an information bases is accounting medical records of lung cancer patients (1,306 observations), results of sociological investigations of this kind of patients (339 observations), expert value of the ways for increasing the efficiency of specialized medical care for lung oncological patients (32 expert conclusions).
Adequate scientific methods for Social Medicine were used, such as system approach and analysis for the complex investigation of lung cancer morbidity, sociological method for the study and estimation of risk factors caused this kind of disease, quality of medical care, way and quality of life and their medical-social characteristics, conceptual modeling for optimization of organizational and functional model of the early detection of lung cancer among the population of Ukraine and an expert values' method for the estimation of grounded and optimized model of the early detection of lung cancer among the Ukrainian population, and prediction of its effectiveness. All the methods applied in the research got the positive conclusions of the Ethics Committee of the Kharkiv National Medical University regarding their expediency and the possibility of using it.

\section{RESULTS AND DISCUSSION}

Complex medical and social research has revealed and proved the presence of restrictions in the system of medical and sanitary provision of patients with lung cancer, which is manifested, in particular, in reducing the effectiveness of specialized medical care on the late stages of detection. Accordingly, one of the main directions of increasing the efficiency and positive results of the treatment of lung cancer among the Ukrainian population should be the introduction of an effective model of its early diagnostics, which will overcome the problem of late detection of the disease, significantly improve the efficiency of treatment for patients with 


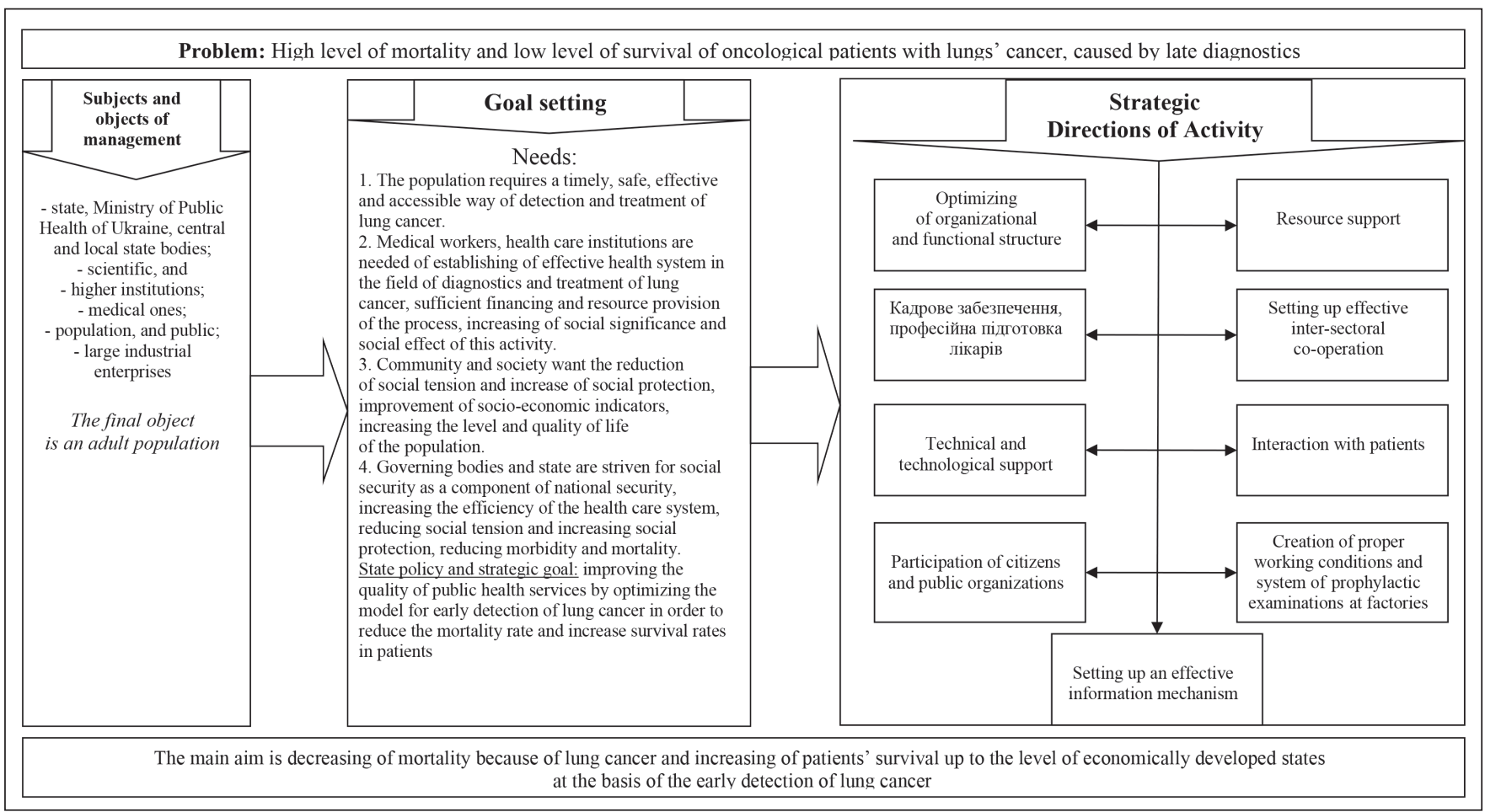

Figure 2. Incoming components of optimized model for the early detection of lung cancer among the population of Ukraine

lung cancer, reduce of mortality and increasing the level of survival.

The modern system of cancer control in Ukraine is created in accordance with the existing regulatory framework in this area, but it should be noted that the structure of health facilities that provide cancer care to the population involves the division into a specialized oncology network and the provision of assistance in institutions of general non-oncology profile. Taking into account the high medical and social value of timely detection and effective treatment of cancer in general, and lung cancer, in particular, this process should be considered not only as a medical, but as a comprehensive medical and social process for ensuring of qualitative and timely medical care in the modern socio-economic and the social conditions of the development of Ukraine, which depends on the aspects of organizational, structural and institutional provision of the process and unconditional compliance with the necessary organization and medical technologies based on current achievements in the organization of health care, public administration and management.

Increasing the effectiveness of specialized medical care for patients with lung cancer presupposes, first of all, the necessity of applying the principles of systemicity and complexity in optimizing of the model of early detection of lung cancer among the Ukrainian population, which should mean the consideration of all components of the model in the connection and interdependence, taking into account the efficiency of components, which have both direct and indirect effects, including the influence of each of these components on the effectiveness of the entire system of specialized medical care for patients with lung cancer. The main components of the model for the early detection of lung cancer among the population are shown in Fig. 1 and 2. Determination of the essence of the model, the necessity and objectives of its optimization is determined in the first block - the input components of the optimization model, which involves analysis to identify the problem, the assessment of the situation, the definition of the subject, the object and the links between them, and as well as the definition of stakeholders interested in solving the problems of the parties, the objectives of optimizing the model and strategic directions for improving the model.

The effectiveness of specialized medical care for patients with lung cancer is achieved through the use of modern organizational and medical technologies, among which the achievement of maximum results with a spending of minimum cost for their realization in obtaining of medical, social and economic effects in the context of preservation and increase of human capital. The indicators of effectiveness reflect the interconnectedness of numerous medical, social and economic aspects of innovation, which can be increased by intensifying the improved use of all available resources - personnel, financial, material, etc.

Developed and scientifically substantiated optimized model for the early detection of lung cancer in adult patients has new elements. It is based on the contemporary approaches to the organization of health system, state management including principles of systematic and 
complex investigation directed on the earliest stages of cancer before the appearance of clinical manifestations. It is available, provides integrity, phasing and continuity. The use of the proposed model allows to obtain the expected medical effect (by reducing the rates of detection of oncological pathology at later stages of the disease, reducing hospitalization, increasing the coverage of adult population by targeted preventive examinations and the quality of dispensary surveillance of cancer patients, shortening the timing of treatment, lowering the level of invalidation, decreasing the mortality from this disease), social effect (increase in life expectancy and its quality, decrease in prevalence of risk factors, including a reduction in smoking, satisfaction of the population by qualitative and accessible of health care, reduce of disability, dissemination and promotion of a healthy lifestyle), and the economic effect (reduction of payments for temporary and permanent disability, reduction of losses from decreasing of labour productivity of the adult population, weakened by oncological diseases, shortening of expenses for medical care in health care facilities due to decrease in the number of patients with $3^{\text {rd }}$ and $4^{\text {th }}$ stages of lung cancer).

The introduction of the offered optimized model for early detection of lung cancer among the adult population at the primary level of provision of medical care (family doctors) provides an opportunity to identify people with risk factors, provide multiplicity and scope of diagnostic prophylactic examinations taking into account individual patient's characteristics, conduct the diagnosis at early stages of the lung cancer disease, which in turn should determine the optimal and adequate treatment program with individual consideration in general, helps to prevent an increase in the rate of primary disability, increase the 5 -year survival of patients, and reduce the cost for temporary disability.

In this paper, the detailed theoretical substantiation of ways to increase the efficiency of specialized medical care for patients with lung cancer on the basis of an optimized model of early detection of lung cancer among the adult population is presented and prospects for further research related to the study of qualitative changes in specialized medical aid for patients during the reform process are given. The healthcare sector of Ukraine is directed on reaching of maximum level of the integral indicator of the effectiveness of diagnostics and treatment of lung cancer in clinical practice.

\section{CONCLUSIONS}

1. The urgency of the problem of lung cancer is characterized by an increase in the incidence and prevalence rates, the presence of risk factors for the disease, the peculiarities of the provision of medical and sanitary care to patients, and the development of research in the field of studying the quality of life of patients with lung cancer.

2. Disadvantages and the lack of efficiency of the existing system of specialized cancer services in Ukraine determined the need for a systematic and integrated solution of the problem of early diagnostics of lung cancer based on the optimization of its model, grounded on the principles of systemicity and complexity, the use of modern scientific and practical achievements in the management and organization of specialized medical assistance, application between sector interaction and improvement of its information and communication and organizational-economic components.

3. Implementation of this model in practical health care is aimed the achievement of the maximum efficiency of specialized oncology medical care through the improvement and use of modern organizational, preventive and medical diagnostic medical technologies, observance and promotion of healthy lifestyles, population satisfaction with the quality and availability of specialized medical care, the reduction of payouts and decreasing the number of patients with abnormal stages of lung cancer.

\section{REFERENCES}

1. Vynnychenko I.0., Moskalenko Yu.V.,Tarasenko S.V et al.. Analiz poshyrenosti raku legeniv sered zhinok Sumskoyi oblasti [Analysis of the prevalence of lung cancer among women in the Sumy region.]. Journal of Clinical and Experimental Medical Research. 2017,3:881-890. (In Ukraine)

2. Cheng T.Y., Cramb S.M., Baade P.D., Youlden D.R., Nwogu C., Reid M.E. The International Epidemiology of Lung Cancer: Latest Trends, Disparities, and Tumor Characteristics. J Thorac Oncol. 2016 Oct; 11(10): 1653-71.

3. Ferlay J., Steliarova-Foucher E., Lortet-Tieulent J., Rosso S., Coebergh J.W., Comber H., Forman D., Bray F. Eur J Cancer. 2013 Apr; 49 (6): 1374-403.

4. Buleten nationalnogo kancer-reestru Ukrainy №19 [Bulletin of the National Chancery Register of Ukraine №19]. Kyiv, 2018: 34-37. (In Ukraine)

5. Zinchuk A.N., Urazova L.F., Zinchuk 0.G. Ocinka vplyvu raku legeniv na demografichnu sytuatsiyu v Ukrayini [Evaluation of the impact of lung cancer on the demographic situation in Ukraine.] Topical issues of theoretical and practical medicine: a collection of abstracts of the 4th International Scientific and Practical Conference of Students and Young Scientists. Sumy, 2016: 97-98. (In Ukraine)

6. Romaniv M.P. Medyko-statystycha ocinka statevo-vikovoyi grupy zahvoruvanosti ta smertnosti vid onkologichnuh zahvoryuvan'v Ukrayini [Medico-statistical evaluation of the sex-age structure of morbidity and mortality from oncological diseases in Ukraine]. Bulletin of scientific research. 2017; 1: 85-90. (In Ukraine)

7. Ryngach N.O., Luschik L.V. Regionalny osoblyvosti vtrat rokiv potencienogo zhyttya cherez peredchasnu smertnist vid osnovnuh prychin v Ukrayini [Regional peculiarities of losses of years of potential life due to premature mortality from the main causes in Ukraine]. Demography and Social Economy. 2018; 3: 39-56. (In Ukraine)

8. Shushpanov D. Determinanty zdorovya naselennya Ukrayiny: ekologichy vymir [Determinants of Health of the Population of Ukraine: Environmental Dimension]. Regional aspects of the development of the productive forces of Ukraine. 2017; 22: 132-142. (In Ukraine)

9. Kim H.B., Shim J.Y., Park B., Lee Y.J. Long-Term Exposure to Air Pollutants and Cancer Mortality: A Meta-Analysis of Cohort Studies. Int J Environ Res Public Health. 2018 Nov 21; 15(11). 
10. Kolomiyets 0.0 . Systema ohorony zdorov'ya v Ukrayini: nedoliky organizatsiyi ta ryzyky reformuvannya [Health care system in Ukraine: disadvantages of its organizational structure and the risks of reforming]. Economic bulletin of national technical university of Ukraine «kyiv polytechnical institute». 2018: doi: https://doi.org/10.20535/23075651.15. 2018.135920. (In Ukraine)

\section{Authors' contributions:}

According to the order of the Authorship.

\section{Conflict of interest:}

The Authors declare no conflict of interest.

\section{CORRESPONDING AUTHOR}

Viktor A. Ognev

Kharkiv National Medical University

Aveniu Nauki 4, Kharkiv, Ukraine

e-mail: olegkorop@ukr.net

Received: 11.02 .2019

Accepted: 29.03.2019 
PRACA ORYGINALNA

ORIGINAL ARTICLE

\title{
CHANGES IN ELECTROMYOGRAPHY TEST RESULTS OF PATIENTS WITH PATHOLOGICAL ABRASION OF TEETH. THE ROLE OF ANTERIOR TEETH IN THE PROCESS OF REHABILITATION
}

\author{
Iryna M. Tkachenko, Yaroslav Y. Vodoriz, Iryna Y. Marchenko, Maryna A. Shundryk, Dmytro M. Korol, Olena V. Gurzhiy \\ UKRAINIAN MEDICAL STOMATOLOGICAL ACADEMY, POLTAVA, UKRAINE
}

\begin{abstract}
Introduction: Abrasion of teeth significantly affects electromyography results. Analyzing electromyograms of patients who needs complex rehabilitation, it is necessary to note absence of dissociation of the structure, appearance of spontaneous activity in one of the muscles, presence of the prevailing chewing side, appearance of low-amplitude oscillations in biocurrents.

The aim: The purpose of this study was to determine the role of anterior teeth in the rehabilitation of patients with increased abrasion.

Material and methods: The experimental group involved patients (men and women) aged 20 to 59 years with increased abrasion of teeth I-III degrees. Patients were provided with all the necessary complexes of rehabilitation measures: direct restorations with composite materials using the adhesive system of the $V^{\text {th }}$ generation (in case of light abrasion), indirect ceramic restorations (severe abrasion). All work was conducted in accordance with the Declaration of Helsinki (1964) and was approved by the Ethical Committee of the academy.

Results: Activity of the right masseter muscle was slightly higher than that of the left one ( $313.42 \pm 97.96 \mathrm{~ms}$. against $226.69 \pm 35.39 \mathrm{~ms}$. respectively). At the same time the resting time of the left and right masseter muscles slightly differs ( $300.57 \pm 30.93 \mathrm{~ms}$. and $307.96 \pm 49.47 \mathrm{~ms}$. respectively).

Conclusions: Rehabilitation of patients with increased abrasion using combined methods (direct composite restorations with the adhesive system of $V^{\text {th }}$ generation and indirect ceramic restorations), give the possibility to restore the masticatory function (evidenced by an increase in the activity of right and leftmasseter muscle on $2 \%$, a decrease in the rest phase on $20 \%$ almost and an increase in amplitude on $2.9 \%$ ).
\end{abstract}

KEY WORDS: myography, tooth abrasion, dental restoration

Wiad Lek 2019, 72, 4, 553-557

\section{INTRODUCTION}

The idea of the qualified treatment of patients with increased abrasion of teeth and the rehabilitation of masticatory function can appear only on the basis of data on the nature of the movements of masticatory muscles, their tone and bioelectric activity. Undoubtedly, the main occlusal load is taken by posterior teeth (premolars, molars). However, the efficacy of rehabilitation cannot be reviewedconsidering only lateral teeth.

Abrasion of teeth significantly affects electromyography results [1-3]. Analyzing electromyograms of patients who needs complex rehabilitation, it is necessary to note absence of dissociation of the structure, appearance of spontaneous activity in one of the muscles, presence of the prevailing chewing side, appearance of low-amplitude oscillations inbiocurrents (Fig.1).

Treatment of patients with increased tooth abrasion requires a multidisciplinary and individual approach for each patient and demands the concerted efforts of several specialists. In order to succeed, rehabilitation measures cannot be carried out on isolated teeth, but should extend to dental arches, masticatory muscles, and temporomandibular joint. [4].

\section{THE AIM}

The purpose of this study was to determine the role of anterior teeth (central and lateral incisors, canines) in the rehabilitation of patients with increased abrasion. The data was represented by the electromyograms, which were recorded 6 months after the completion of the comprehensive treatment.

\section{MATERIALS AND METHODS}

The experimental group involved patients (men and women) aged 20 to 59 years with increased abrasion of teeth I-III degrees. Total number of participants was 25 people. Patients were provided with all the necessary complexes of rehabilitation measures: direct restorations with composite materials using the adhesive system of the $\mathrm{V}^{\text {th }}$ generation [5] (in case of light abrasion) (6), indirect ceramic restorations (severe abrasion) $[7,8]$.

Clinically healthy individuals (men and women), without any sign of increased abrasion and periodontal disease, were included into the control group. Age of participants ranged from 20 to 59 years. Totally 25 peoplewere included. 


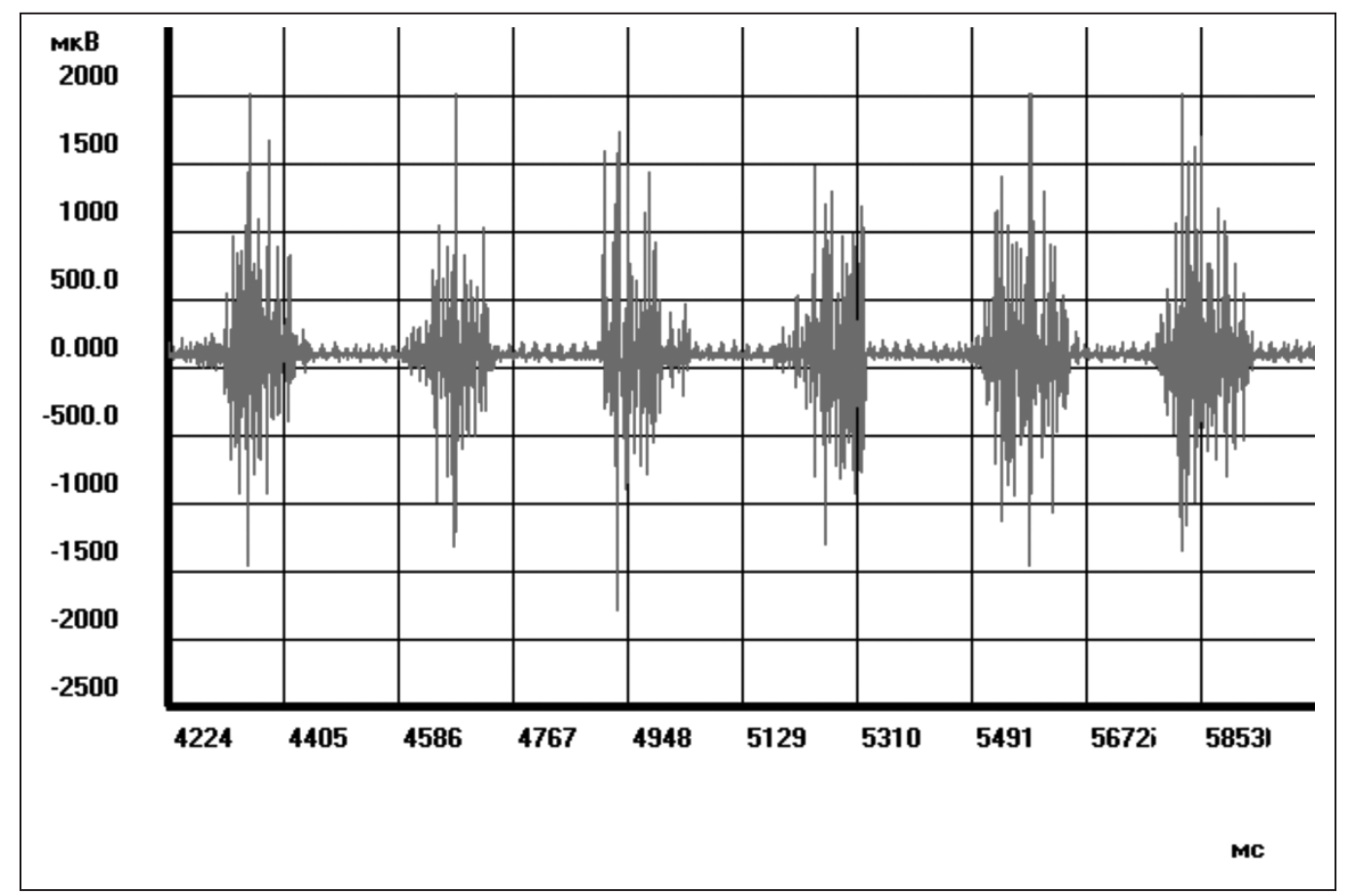

Figure 1. Fragment of an electromyogram of the left masseter muscle of the patient from the control group, 23 years old.

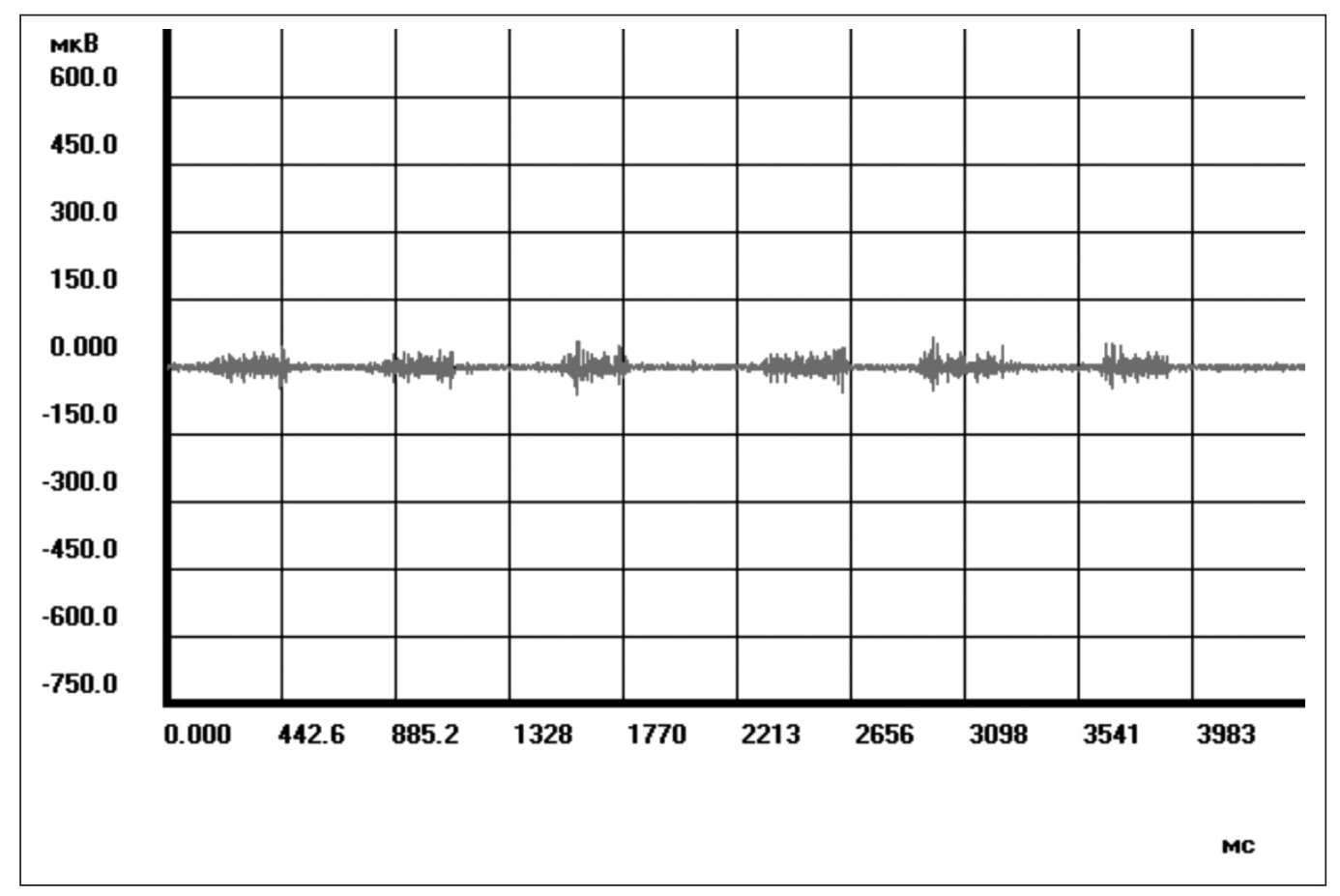

Figure 2. Fragment of an electromyogram of the left person's own masticatory muscle 47 years before treatment.

An electromyography was recorded from every participant of the study before the beginning of rehabilitation. For the patients of the experimental group the procedure was repeated 6 months after the completion of rehabilitation. During the electromyographic study the patients were offered to take a functional test "arbitrary chewing" $[2,3]$. Using the masticatory efficacy table, the portion of anterior teeth was determined $[9,10]$.

\section{RESULTS AND DISCUSSION}

\section{CONTROL GROUP}

Analyzing the digital data of the electromyograms of the control group, we drew attention to the fact that the time of activity and rest time of both the left and right masseter muscles almost did not differ.

The activity of the left masseter muscle was $148.06 \pm 4.95$ milliseconds, while the right one was $135.98 \pm 3.59 \mathrm{~ms}$. The 
Table I. Electromyography results

\begin{tabular}{|c|c|c|c|c|c|}
\hline \multirow{2}{*}{ Group } & \multirow{2}{*}{$\begin{array}{l}\text { Masseter } \\
\text { muscles }\end{array}$} & \multicolumn{4}{|c|}{ Investigated parameters ( $M \pm m)$} \\
\hline & & activity (ms.) & rest (ms.) & "K index" & amplitude $(\mu \mathrm{V})$ \\
\hline \multirow{4}{*}{ Control } & \multirow{2}{*}{ left } & 148,06 & 152,37 & 0,98 & 207,58 \\
\hline & & $\pm 4,95$ & $\pm 4,71$ & $\pm 0,03$ & $\pm 3,38$ \\
\hline & \multirow{2}{*}{ right } & 135,98 & 155,02 & 0,91 & 288,41 \\
\hline & & $\pm 3,59$ & $\pm 6,06$ & $\pm 0,06$ & $\pm 22,67$ \\
\hline \multirow{4}{*}{$\begin{array}{c}\text { Experimental } \\
\text { (before treatment) }\end{array}$} & \multirow{2}{*}{ left } & 226,69 & 300,57 & 0,64 & 284,67 \\
\hline & & $\pm 35,39$ & $\pm 30,93$ & $\pm 0,063$ & $\pm 34,21$ \\
\hline & \multirow{2}{*}{ right } & 313,42 & 307,96 & 0,74 & 405,55 \\
\hline & & $\pm 97,96$ & $\pm 49,47$ & $\pm 0,060$ & $\pm 27,36$ \\
\hline \multirow{4}{*}{$\begin{array}{c}\text { Experimental } \\
(6 \mathrm{~m} \text {. after treatment })\end{array}$} & \multirow{2}{*}{ left } & 326,47 & 276,66 & 0,75 & 304,20 \\
\hline & & $\pm 7,61$ & $\pm 26,23$ & $\pm 0,034$ & $\pm 30,46$ \\
\hline & \multirow{2}{*}{ right } & 225,11 & 230,73 & 0,74 & 405,55 \\
\hline & & $\pm 19,15$ & 29,19 & $\pm 0,060$ & $\pm 27,36$ \\
\hline
\end{tabular}

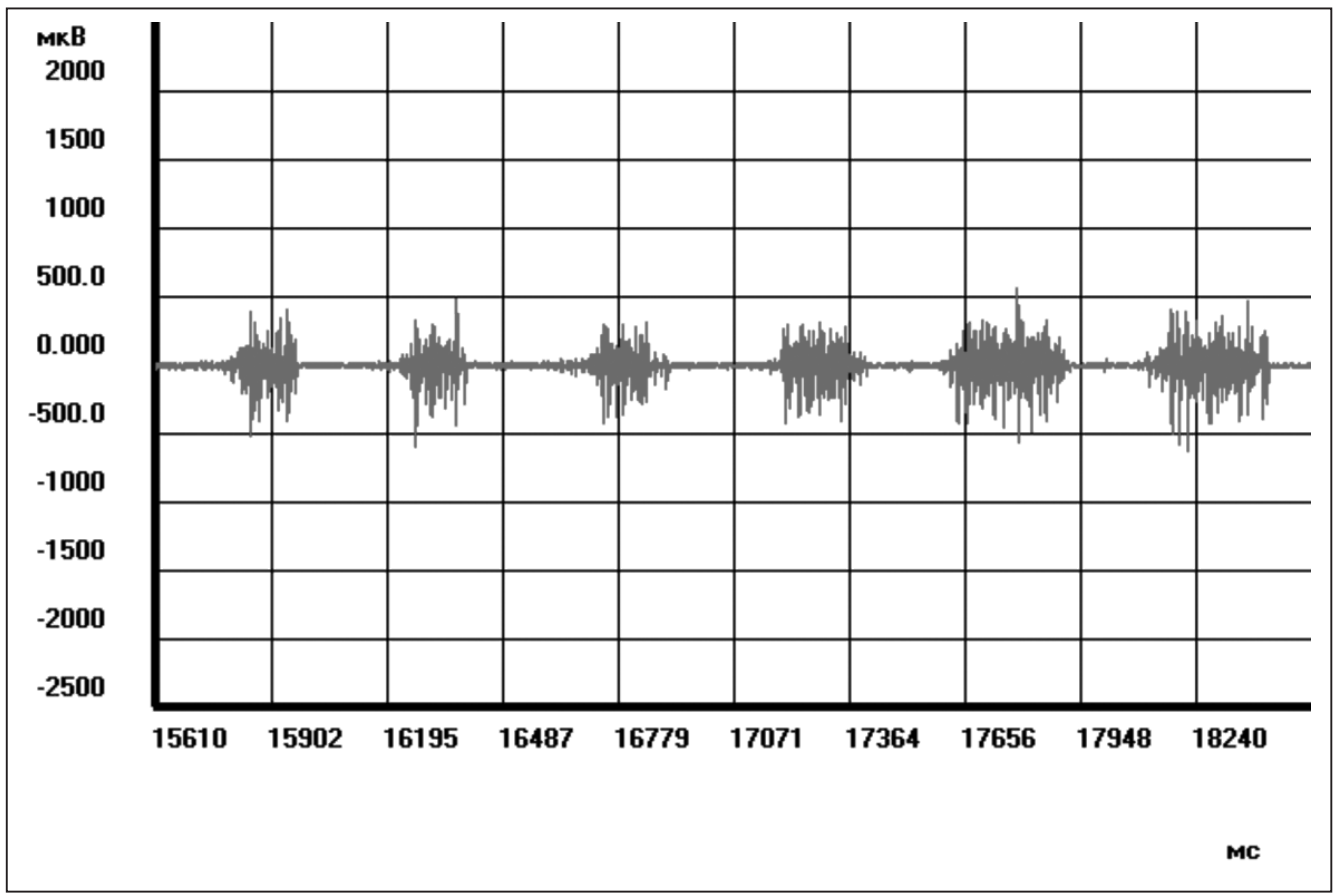

Figure 3. Fragment of the electromyogram of the right masseter muscle of the patient, 48 years old, 6 months after treatment.

resting time of the left chewing muscle was $152.37 \pm 4.71$ $\mathrm{ms}$. and the right muscle was $155.02 \pm 6.06 \mathrm{~ms}$.

Notably that the coefficient of activity "K" for left and right masseter muscles is different and makes $0.98 \pm 0.03 \mathrm{~ms}$. and $0.91 \pm 0.06 \mathrm{~ms}$. respectively but this difference is not significant and indicates a lack of functional asymmetry. There is a significant difference in the indices of the amplitude of the left and right masseter muscles. The amplitude of the left masseter muscles is $207.58 \pm 3.38 \mu \mathrm{V}$, while the right is only $288.41 \pm 22.67 \mu \mathrm{V}$. This may indicate a more active movement of the right muscle compared to the left one.

\section{EXPERIMENTAL GROUP BEFORE TREATMENT}

Before conducting any treatment, the rates of electromyographic test are different from those results of the control group. In our opinion, this fact indicates a decrease in masticatory efficacy due to the pathology of hard tissues of teeth and the decrease occlusion height (Fig. 2).

The results of electromyograms analysis of experimental group patientsare presented in Table I.

It should be noted that the coefficient of chewing activity in the experimental group is much lower for the left muscle than for the right one $(0.64 \pm 0.063$ and $0.74 \pm$ 0.0660 respectively). The amplitude of the electromyogram amplitude of the left masseter muscle in the experimental group is $284.67 \pm 34.21 \mu \mathrm{V}$, while the right one is 405.55 $\pm 27.36 \mu \mathrm{V}$.

Therefore, we suggest that the difference in electromyography rates of the experimental group is associated with a different degree of manifestation of increased 
tooth abrasion, as well as a violation of the masticatory function.

\section{EXPERIMENTAL GROUP (6 MONTHS RECALL)}

Six months after rehabilitation of patients a clearer structure of electromyograms can be determined (Fig. 3).

The activity of the left and right masseter muscles of patients slightly increased compared to the data obtained prior to treatment. The activity of the left masseter muscle in the experimental group is $326.47 \pm 7.61 \mathrm{~ms}$., the activity of the right one is $225.11 \pm 19.15 \mathrm{~ms}$. (Tab. I).

The rest time of the left and right muscles slightly decreased comparing to the results obtained before the treatment, but the difference between the scores was not significant.

It should be noted that the amplitude of the electromyogram of the left masseter muscle increased in comparison with the results obtained before the treatment (304.20 \pm $30.46 \mu \mathrm{V})$ while the amplitude of the right muscle remained unchanged $(405.55 \pm 27.36 \mu \mathrm{V})$.

\section{THE ROLE OF FRONTAL TEETH IN RESTORING THE MASTICATORY FUNCTION}

According to Agapov's table the following percents are assigned to the anterior teeth: central incisors - 2, lateral incisors - 1, and eagles - 3. [2,3] Total portion of anterior teeth on both jaws makes $24 \%$.

Grace to the data obtained from the control group we can conclude that during the execution of chewing movements muscles are capable to perform an instantaneous active inclusion into action and to the same rapid transition to a state of rest. From the obtained data it is obvious that muscles do not play the equal role in the act of mastication. There is a difference in functional asymmetry.

The data gained from the patients of the experimental group demonstrates the difference between of the left and right sides. Thus, the activity of the right masseter muscle is slightly higher than that of the left one (313.42 \pm 97.96 ms. against $226.69 \pm 35.39$ ms.respectively). At the same time the resting time of the left and right masseter muscles slightly differs ( $300.57 \pm 30.93 \mathrm{~ms}$. and $307.96 \pm 49.47 \mathrm{~ms}$. respectively).

According to the analyzed data the percentage part of anterior teeth in masticatory function rehabilitation makes $24 \%$.

\section{CONCLUSIONS}

During the study, it was found that the rehabilitation of patients with increased abrasion using combined methods (direct composite restorations with the adhesive system of $\mathrm{V}^{\text {th }}$ generation and indirect ceramic restorations), give the possibility to achieve certain results, namely: not only to restore the shape of lost teeth, but also to restore the masticatory function (evidenced by an increase in the activity of right and leftmasseter muscleon $2 \%$, a decrease in the rest phase on $20 \%$ almost and an increase in amplitude on $2.9 \%$ ).

Masticatory pressure spread evenly over the whole tooth arch. Electromyography data confirms that a local approach or incomplete/partial restoration of dentition can negatively affect the effectiveness of masticatory function efficacy. Particularly, in the case of exclusion of anterior teeth from the treatment plan, the potential effectiveness of restoration of masticatory function decreases on $24 \%$.

\section{REFERENCES}

1. Tkachenko IM., Brailko NN., Kovalenko VV. [et al.] Morfolohycheskoe yssledovanye emaly y dentyna zubov s karyoznym protsessom y nekaryoznymy porazhenyyamy. [Morphological study of enamel and dentin of teeth with carious process and non-carious lesions]. Wiadomości Lek. 2018; (5): 1001-5. (Ru)

2. Tkachenko I. Doslidzhennya funktsionalnoho stanu zhuvalnykh myaziv u normi elektromiohrafichnym metodom. [Research of the functional state of masticatory muscles in normal electromyographic method]. Ukrainian Dental Almanac. 2012; 55-7. (Ua).

3. Zaporozhchenko I. Porivnyalna kharakterystyka suchasnykh metodiv vyznachennya zhuvalnoyi efektyvnosti [Comparative characteristic of modern methods of chewing efficiency determination]. Actual problems of modern medicine. 2018; 18 (2): 326-31. (Ua).

4. Tkachenko IM, Shlikova OA, Kaidashev IP. Vyznachennya polimorfizmu heniv kalekreyinu-4 ta matryksnoyi metoloproteinazy-20 u patsiyentiv z pidvyshchenoyu stertistyu zubiv [Determination of the polymorphism of genes of calrein- 4 and matrix metoproteinase-20 in patients with increased tooth erosion]. Problems of ecology and medicine. 2012; 16 (5): 65-8. (Ua)

5. Tkachenko I, Kovalenko V, Skrypnikov P, Vodoriz Y. Reasoning of the adhesive system for treatment of patients with increased tooth wear. Wiadomości Lek. 2018; 71 (6): 1129-34. Available from: https://www. ncbi.nlm.nih.gov/pubmed/30267488

6. Shilenko D, Gasanov R, Toncheva E [et al.]. Byomekhanycheskyy analyz faktorov vlyyayushchykh na dolhovechnost' restavratsyy zhevatel'noy hruppy zubov[Biomechanical analysis of factors influencing durability of restorations of chewing group of teeth]. World of Medicine and Biology. 2009; 2 (2): 72-7. (Ru).

7. Vodoriz YY., Marchenko IY.,Shyndryk MA. [et al.] Review of treatment methods of patients with uncomplicated teeth fractures. Wiadomości Lek. 2018; 71 (7): 1360-4. Available from: https://www.ncbi.nlm.nih. gov/pubmed/30448811

8. Vodoriz Y.Y. Fizychni vlastyvosti restavratsiynykh materialiv pry rizniy hlybyni preparuvannya tverdykh tkanyn zubiv [Physical properties of restorative materials at different depth of preparation of tooth hard tissues]. News of problems in biology and medicine. 2018;4 (1). 186-188.

9. Mitin N, Vasilieva T, Grishin M. Sovremennye metody otsenky zhevatel'noy éffektyvnosty na étapakh ortopedycheskoho lechenyya (obzor lyteratury).[Modern methods of evaluation of chewing efficacy during stages of orthopedic treatment (literature review)]. Vesner new medical technology. 2015; 9 (4): 43. (Ru).

10. Scubiy I, Korol D., Kindy D. [et al.] Sposib funktsionalnoho vyznachennya zhuvalnoyi efektyvnosti u patsiyentiv molodoho viku (eksperymentalna model)[A method of functional determination of chewing efficacy in young patients (experimental model)]. Bulletin of Biology and Medicine. 2015; 2 (119): 217-21. (Ua). 
This investigation is a fragment of the research of the Ukrainian stomatological academy "Morpho functional characteristics of oral cavity tissues and their impact on therapeutic measures and the choice of treatment materials. Registration number 01145U001112. No external funding was received during for this investigation. There is no conflict of interests between authors and other organizations.

\section{Authors' contributions:}

According to the order of the Authorship.

\section{Conflict of interest:}

The Authors declare no conflict of interest.

\section{CORRESPONDING AUTHOR}

\section{Yaroslav Y. Vodoriz}

17 Zalizna Street, 36001 Poltava, Ukraine tel: +380505420497

e-mail:yaroslavvodorez@gmail.com

Received: 05.02.2019

Accepted: 29.03.2019 


\title{
COMPARATIVE ANALYSIS OF THE METHODS OF ANESTHETIC MAINTENANCE IN PATIENTS WITH DIABETES WITH THE SYNDROME OF DIABETIC FOOT REQUIRING OPERATIVE INTERVENTION
}

\author{
Roman V. Filimonov' ${ }^{1}$ Inna V. Filimonova', Serghey D. Shapoval', Yury Yu. Kobeliatskyi ${ }^{2}$ \\ 'DEPARTMENT OF ANESTHESIOLOGY AND INTENSIVE CARE, STATE ESTABLISHMENT «ZAPOROZHYE MEDICAL ACADEMY OF POSTGRADUATE EDUCATION \\ OF HEALTH MINISTRY OF UKRAINE», ZAPOROZHYE, UKRAINE \\ 2DEPARTMENT OF ANESTHESIOLOGY AND INTENSIVE CARE, STATE ESTABLISHMENT“DNIPROPETROVSK MEDICAL ACADEMY OF HEALTH MINISTRY OF \\ UKRAINE", DNIPRO, UKRAINE
}

\begin{abstract}
Introduction: In the present article we draw a comparison between such types of regional anesthesia (RA) as unilateral spinal anesthesia (USA), traditional spinal anesthesia (SA) and block anesthesia of peripheral nerve trunk (block anesthesia of sciatic nerve (BASN) on the side of operative intervention) during surgical treatment of patients with the syndrome of diabetic foot.

The aim of the article is to compare effectiveness, reliability and safety of such methods of RA as unilateral and traditional spinal anesthesia, as well as block anesthesia of sciatic nerve on the side of operative intervention.

Materials and methods: 96 patients with the syndrome of diabetic foot, who received treatment in the department of purulent surgery, were examined. All patients underwent operative interventions of varying degrees of complexity depending on the nature and seriousness of damage degree of extremities, in terms of RA types under investigation. Effectiveness of regional block anesthesia, the time when anesthesia takes effect, duration and deepness were evaluated.

Results: It should be noted that USA, as a variant of pain management during operations of foot, provides the most adequate level of surgical pain management in comparison with the other types of anesthesia. During block anesthesia of sciatic nerve more than half of patients are not provided with $100 \%$ surgical analgesia, which can lead to additional medicamentous analgosedation. According to the results obtained, pain sensitivity in patients after BASN is reliably higher than in patients after USA and SA in all stages of the study. Conclusions: RA is the main method of choice during operations on foot in comparison with the methods of general anesthesia. Unilateral spinal anesthesia is carried out with the use of smaller amount of anesthetic than traditional spinal anesthesia and block anesthesia of peripheral nerve trunk, which significantly reduces sympathectomy area and leads to the stable hemodynamic during the peri-operative period.
\end{abstract}

KEY WORDS: regional anesthesia, unilateral spinal anesthesia, diabetes, syndrome of diabetic foot

Wiad Lek 2019, 72, 4, 558-561

\section{INTRODUCTION}

Diabetic foot syndrome (DFS) is the most difficult late complication of diabetes mellitus. This pathology, which in half of cases ends with amputation of one or both extremities, occurs in about $80 \%$ of patients $15-20$ years after the onset of a diabetes disease [1]. Every fourth patient suffering from a carbohydrate metabolism disorder is in the risk group of DFS development [2]. Diabetic foot syndrome is one of the main causes of disability and mortality in diabetics $[3,4]$.

The main task of anesthetic support surgery is adequate anesthesia [5]. The risk of perioperative complications increases by accompanied: coronary artery disease, heart failure, cardiac arrhythmias, hypertension, renal failure, mitral and aortic stenosis, and history of stroke. The risk may be due to obesity, difficulties in the respiratory tract, the full stomach, the position of the patient on the abdomen, and so on.
Sympathetic blockade has not been still identified in the pain treatment of DFS patients. Changes in peripheral circulation during regional anesthesia caused by artificial sympathectomy are manifested by vasoplegias with accompanying slowing of microcirculatory blood flow. As a result of the blockade of paravertebral sympathetic trunks $[6,7]$ the microcirculation improves, the total peripheral vascular resistance (TPVS) decreases, the venous redelivery to the heart increases, which decreases pre- and post-loading.

The myocardium works in more comfortable conditions (the type of circulation in the conditions of regional anesthesia is normodynamic, in contrast to endotracheal anesthesia, where the type of circulation, as a rule, is hyperdynamic) [8]. Due to this the renal blood circulation, cerebral perfusion, pulmonary gas exchange improves. The manifestations and frequency of arterial hypotension, bra- 
dycardia, postoperative urinary retention become reduced, and the motor activity recovers faster $[9,10]$.

The following advantages of using regional anesthesia in patients with DFS can be distinguished [11,12]:

a) the possibility of maintaining a normal diet;

b) the absence of the need for correction of the usual schemes of insulin therapy;

c) high adequacy of anesthesia during surgery;

d) minimization of catabolic response of an organism to surgical aggression with limitation of hyperglycemic reaction;

e) reduction of intra- and postoperative blood loss;

e) decrease in the number of pulmonary artery thromboembolism (PATE);

g) decrease in the number of deep vein thromboses;

h) effective postoperative analgesia;

i) opioid-preserving effect;

k) decrease in the number of intra- and postoperative complications.

\section{THE AIM}

To compare the effectiveness, reliability and safety of such methods of regional anesthesia as one-sided and traditional spinal anesthesia, as well as blockade of the sciatic nerve on the side of surgical intervention.

\section{MATERIALS AND METHODS}

96 patients diagnosed with diabetes mellitus, DFS, who were treated at the $3^{\text {rd }}$ city hospital in Zaporizhia, in the Department of Purulent Surgery from 2017 to 2018, were examined. Patients were divided into 3 groups (32 patients in each), depending on the method of analgesia:

Group 1 - patients operated under unilateral spinal anesthesia conditions;

Group 2 - patients operated under the conditions of traditional spinal anesthesia;

Group 3 - patients operated under conditions of blockade of the sciatic nerve.

Inclusion criteria:

1. Necessity of operative treatment;

2. Different forms of complicated DFS in patients with diabetes type 2 ;

3. Stable condition of the patient, which allows conducting a differential approach to treatment;

The criteria for not including in the study were:

1. Type 1 diabetes;

2. Patients with DFS, stage 1 and 4 classified by CZE (Uzhhorod 2012);

3. Patients on hemodialysis.

All patients underwent surgical intervention of varying degrees of complexity, depending on the nature and degree of damage to the lower extremity, in conditions of the types of regional anesthesia we study.

The age of patients included in the study was 39-86 years, the average age of patients was $62,72 \pm 9,19$ years. In each group, $50 \%$ of male and female patients were respectively.
Most patients had accompanying pathology of varying degrees and stages (Table I).

\section{PATIENTS' PAIN RELIEF PROTOCOL DEPENDING ON THE GROUP}

Group 1: Before performing a unilateral spinal anesthesia, a solution of crystalloids in a volume of $6-8 \mathrm{ml} / \mathrm{kg}$ is dripped to the patient intravenously. The patient is in Fowler's position, lying on the side (on the side of the operative limb). After a 3-fold treatment of the place of the anticipated puncture $\mathrm{L}_{\text {II }}-\mathrm{L}_{\text {III }} 70 \%$ with the solution of ethanol, a puncture of the subarachnoid space with a needle G-25 with an aperture directed downwards (towards the operative limb) is performed, and a solution of bupivacaine is given in a dose of $10 \mathrm{mg}$. The rate of anesthetics injection is 0,5 $\mathrm{ml} / \mathrm{min}$. The control of the rate of anesthetic injection was carried out: directly - by the apparatus of ultrasound (Doppler mode), indirectly - by using a three-way tap for 2 -ml syringe, with $1 \mathrm{ml}$ of air and in their combination. At the place of the puncture, an aseptic bandage was applied to the skin. The patient's turn for operative intervention was performed in 20 minutes. The proposed technique avoids the development of a bilateral blockade in the vast majority of cases and provides adequate anesthetic support. The risk of development of possible complications is minimized. Control of hemodynamic parameters during the surgerical intervention is indicative of the fact that the blood pressure, pulse and oxygen saturation values are within normal limits and do not require medical correction.

Group 2: Prior to the performance of spinal anesthesia, the patient was given infusion therapy with crystalloids in the volume of $8-10 \mathrm{ml} / \mathrm{kg}$ dripped intravenously. The patient is in a position lying on the side, in some cases, in the sitting position (given anatomical features, overweight). After a 3 -fold treatment of the puncture site with a $70 \%$ ethanol solution at the level of $\mathrm{L}_{\mathrm{III}}-\mathrm{L}_{\mathrm{IV}}$ or $\mathrm{L}_{\mathrm{II}}-\mathrm{L}_{\mathrm{III}}$, a puncture was performed. After the appearance of cerebrospinal fluid in the needle's lumen the patient was injected $2,5-3 \mathrm{ml}$ of a hyperbaric solution of $0,5 \%$ bupivacaine. At the place of the puncture, on the skin, was applied aseptic bandage. During the operation, constant monitoring of hemodynamic parameters was carried out. With a decrease in systolic blood pressure below $85 \mathrm{~mm} \mathrm{Hg}$. and diastolic below $60 \mathrm{~mm} \mathrm{Hg}$. hemodynamics was corrected medically and by infusion of colloids and crystalloids to normalize the indicators.

Group 3: The blockade of the sciatic nerve was carried out at a point which is $5 \mathrm{~cm}$ in the perpendicular drawn from the middle of the line connecting trohanter major and spina iliaca posterior superior, skin was anesthetized prior in aseptical conditions and subcutaneous tissue was anesthetized by solution of lidocaine $0,5 \%-10,0 \mathrm{ml}$. The puncture was carried out with a long needle at the indicated point till appearance of paresthesia and after aspiration a $30 \mathrm{ml}$ of $0,25 \%-0,5 \%$ anesthetic solution was injected perineuronally. At the place of the puncture, the aseptic bandage was applied to the skin. If surgical intervention is performed on the foot, then this type of anesthesia is enough 
Table I. The structure of concomitant pathology in the examined patients, $n(\%)$.

\begin{tabular}{|c|c|c|c|c|c|c|}
\hline \multirow{3}{*}{ Concomitant pathology } & \multicolumn{6}{|c|}{ Groups of patients } \\
\hline & \multicolumn{2}{|c|}{1} & \multicolumn{2}{|c|}{2} & \multicolumn{2}{|c|}{3} \\
\hline & number & $\%$ & number & $\%$ & number & $\%$ \\
\hline Coronary artery disease & 29 & 91 & 30 & 94 & 28 & 88 \\
\hline Hypertonic disease, stage $2-3$ & 26 & 81 & 25 & 78 & 23 & 72 \\
\hline Postinfarction cardiosclerosis & 3 & 9 & 1 & 3 & 2 & 6 \\
\hline
\end{tabular}

Table II. Duration of the intra-and post-operative period $(M \pm m)$.

\begin{tabular}{cccccc}
\hline \multirow{2}{*}{ Indicator } & \multicolumn{3}{c}{ Group of investigated patients } & P 1-2 & P 1-3 \\
\cline { 2 - 4 } & $\mathbf{1}$ & $\mathbf{2}$ & $\mathbf{3}$ & & \\
\hline Duration of operation, min. & $48,44 \pm 9,54$ & $49,53 \pm 11,24$ & $41,25 \pm 8,13$ & 0,00 & 0,31 \\
\hline $\begin{array}{c}\text { Duration of anesthesia, min. } \\
\text { Regression of anesthesia, } \\
\text { min. }\end{array}$ & $161,09 \pm 6,93$ & $139,53 \pm 10,50^{*}$ & $163,13 \pm 8,68$ & 0,00 & 0,01 \\
\hline
\end{tabular}

${ }^{*} p<0,05$

to provide adequate surgical pain relief. At the place of the puncture, the aseptic bandage was applied to the skin. In the course of surgery, patients in this group did not require a medical correction of hemodynamic parameters. The values of blood pressure, heart rate, blood saturation with oxygen were within normal limits.

\section{METHODS OF PATIENT'S EXAMINATION}

The effectiveness of the regional block, its time of occurrence, duration and depth were evaluated. The intensity of the pain was determined using the standard visual analog scale (VAS). The estimation of the sensory blockade was performed in points (E. Lanzet al., 1979). The estimation of motor blockade was also performed in points (P.R. Bromage, 1976). For statistical data processing was used descriptive statistics (Excel), Student's t-test.

\section{RESULTS AND DISCUSSION}

On the basis of the estimation of the sensory blockade level of the operative limb, we demonstrate in Table II the duration of adequate surgical anesthesia, and when combined with the level of motor blockade less than 3 points, the calculated time of anesthesia "regression" (time from the beginning of the anesthesia to the beginning of the restoration of the sensitivity in the operated limbs), depending on the method of analgesia of patients. Significant differences were not found only when comparing the duration of anesthesia in 1 and 3 groups, in all other cases, the results are reliable $(\mathrm{p}<0.05)$. During the 3 subsequent postoperative days, patients of all the study groups were given anesthesia by intramuscular injection of analgesics.

The controlled level of glucose concentration (presented in Table III) in patients who underwent operative foot intervention in regional anesthesia conditions indicates the beneficial effects of this anesthetic method on carbohydrate metabolism and diabetes mellitus in the postoperative period, since patients retain normal diet and supplementary insulin therapy schemes are not needed. There was no significant difference in glucose levels from the method of regional anesthesia ( $p>0,05$ in all groups). In the first postoperative day, the level of glucose decreased in the $1^{\text {st }}$ group by $28,3 \%$, in the $2^{\text {nd }}$ - by $22,2 \%$, in the $3^{\text {rd }}$ group - by $19,7 \%$. At the $3^{\text {rd }}$ postoperative day, glucose levels decreased by $6,8 \%$ in group 1 , by $5 \%$ in the $2^{\text {nd }}$ group and by $7,2 \%$ in the third group of patients.

It should be noted that unilateral spinal anesthesia, as an option for pain relief in operations on the foot, has the most adequate level of surgical anesthesia compared with other types of regional anesthesia that we used in our work, as shown in the Table IV by measuring of pain sensitivity on the VAS (Visual Analogue Scale). During the 4 and 10 hours of anesthesia, the effect of unilateral spinal anesthesia and spinal anesthesia is almost the same ( $p>0,05)$, however, after 4 hours, after the onset of anesthesia, the pain is felt less in patients after the unilateral spinal anesthesia by almost $50 \%$.

In performance of the sciatic nerve blockade, more than half of the patients do not receive $100 \%$ of surgical analgesia, which can lead to additional medical analgosedation. From the obtained results it can be seen that the pain sensitivity in patients after sciatic nerve blockade is significantly higher than in patients after unilateral spinal anesthesia and spinal anesthesia at all stages of the study $(p<0,05)$.

\section{CONCLUSIONS}

1. Regional anesthesia is the main method of choice in operations on the foot in comparison with the methods of general anesthesia regarding to the high risk of the patients with DFS on ASA scale and the many concomitant pathologies associated with the underlying disease (diabetes mellitus).

2. The postoperative period in patients who underwent a foot operation in conditions of regional anesthesia is 
Table III. Blood glucose $(\mathrm{M} \pm \mathrm{m})$.

\begin{tabular}{|c|c|c|c|c|c|}
\hline \multirow{2}{*}{ Indicator } & \multicolumn{3}{|c|}{ Group of investigated patients } & \multirow{2}{*}{ p1-2 } & \multirow{2}{*}{ p1-3 } \\
\hline & 1 & 2 & 3 & & \\
\hline Before operation & $10,93 \pm 2,77$ & $11,33 \pm 4,13$ & $10,24 \pm 3,72$ & & \\
\hline 1 day after operation & $7,84 \pm 1,91$ & $8,81 \pm 2,64$ & $8,23 \pm 2,30$ & 0,10 & 0,46 \\
\hline 3 days after operation & $7,31 \pm 1,65$ & $8,37 \pm 2,92$ & $7,64 \pm 2,14$ & 0,08 & 0,50 \\
\hline
\end{tabular}

Table IV. Pain sensitivity in the operated foot on the VAS $(M \pm m)$.

\begin{tabular}{cccccc}
\hline \multirow{2}{*}{ Indicator } & \multicolumn{3}{c}{ Group of investigated patients } & \multirow{2}{*}{ p 1-2 } & p 1-3 \\
\cline { 2 - 5 } & $\mathbf{1}$ & $\mathbf{2}$ & $\mathbf{3}$ & 0,00 \\
\hline 1 hour of anesthesia & $0,00 \pm 0,00$ & $0,00 \pm 0,00$ & $0,84 \pm 0,68^{*}$ & 0,16 & 0,00 \\
\hline 4 hours of anesthesia & $0,19 \pm 0,40$ & $0,34 \pm 0,48$ & $1,03 \pm 0,59^{*}$ & 0,51 & 0,04 \\
\hline 10 hours of anesthesia & $2,53 \pm 0,67$ & $2,65 \pm 0,83$ & $2,91 \pm 0,82^{*}$ & 0 \\
\hline
\end{tabular}

${ }^{*} p<0,05$

not complicated by a violation of the normal diet, which does not require additional correction of the standard mode of insulin therapy.

3. Unilateral spinal anesthesia is subjectively perceived by patients better than traditional spinal anesthesia.

4. Unilateral spinal anesthesia is performed with smaller volumes of anesthetic than traditional spinal anesthesia and blockade of the peripheral nerve trunk.

5. In the performance of the sciatic nerve block, part of the patients does not receive $100 \%$ of surgical analgesia, which may lead to additional medical analgosedation.

\section{REFERENCES}

1. Ageel Ahmad, Khumair Asif, Muhammad Saleem. A Study of Risk Factors of Diabetic Foot Ulcers. P J M H S 2017; 11(1): 174 - 176.

2. Aikaterini Trikkalinou, Athanasia KPapazafiropoulou, Andreas Melidonis. Type 2 diabetes and quality of life. World J Diabetes 2017; 8(4): 120-129.

3. Shapoval S.D., Savon I.L., Maksymova 0.0. Vyrazhennya diabetychnoyi nejropatiyi u hvoryh na czukrovyj diabet 2 typu pry syndromi diabetychnoyi stopy. Shpytalna hirurgiya 2014; № 3: 16-21.

4. Calum D. Moulton, Christopher W.P. Hopkins, Khalida Ismail, Daniel Stahl. Repositioning of diabetes treatments for depressive symptoms: A systematic review and meta-analysis of clinical trials. Psichoneuroendocrinology 2018; 94: 91-103.

5. Wei Xuan, James Hankin, Hailin Zhao, Shanglong Yao and Daqing Ma. The potential benefits of the use of regional anesthesia in cancer patients. International Journal of Cancer 2015: 2774-2784.

6. Orudzheva S.A.,Zvyagin A.A. Osobennosti i vozmozhnosti anesteziologicheskogo obespecheniya pri hirurgicheskom lechenii sindroma diabeticheskoy stopyi. Regionarnaya anesteziya i lechenie ostroy boli 2015; IX(1): 14-25.

7. Yurchenko 0.P. Perioperatsionnaya profilaktika trombogemorragicheskih oslozhneniy u bolnyih $\mathrm{s}$ sindromom diabeticheskoy stopyi. Meditsina neotlozhnyih sostoyaniy 2014; 4 (59): 95-98.

8. Basithanova E. I., Saatov A. R., Soatov A. A., Mahmudov M. A. Sostoyanie gemodinamiki prioperatsiyah na nizhnih konechnostyah, vyipolnennyih pod unilateralnoy spinalnoy anesteziey u geriatricheskih bolnyih s nedostatochnostyu krovoobrascheniya. UkraYinskiy medichniy almanah 2012; 15(4): 34-35.
9. Savinov I.S., Ilchenko F.N., Butyirskiy A.G., Savinov S.G., KalachYov E.V. Sravnitelnaya otsenka metodov i parametrov anestezii pri hirurgicheskom lechenii varikoznoy bolezni s hronicheskoy venoznoy nedostatochnostyu klinicheskih klassov S4-S6. Tavricheskiy medikobiologicheskiy vestnik 2016; 19(3): 89-93.

10. Sanatkar M. The hemodynamic effects of spinal block with low dose of bupivacaine and sufentanil in patients with low myocardial ejection fraction. Acta Med Iran 2013; 7 (51): 438- 443.

11. Osipova N. A., Petrova V. V. Bol v hirurgii. Sredstva i sposobyi zaschityi. Meditsinskoe informatsionnoe agentstvo 2013: 235-253.

12. Kainzwaldner V, Rachinger-Adam B., Mioc-Curic T.,Wöhrie T., Hinske L. C., Luchting B., Ewert T., Azad S.C. Quality of postoperative pain therapy: evaluation of an established anesthesiology acute pain service. Anaesthesist 2013; 62(6): 453-459.

The research was carried out within the framework of the topic of the Dnipropetrovsk Medical Academy of the Ministry of Health of Ukraine "Determination of optimal methods of anesthesia and provision of perioperative period in various fields of surgery and development of new approaches to intensive care of patients in critical conditions, based on the study of pathophysiological changes in homeostasis," state registration number 0117 U004203.

\section{Authors' contributions:}

According to the order of the Authorship.

\section{Conflict of interest:}

The Authors declare no conflict of interest.

\section{CORRESPONDING AUTHOR}

Roman V. Filimonov

Tovarys'ka street 37, apt. 54, 69096, Zaporizhia, Ukraine

tel: +380502154900

e-mail: romanflimonov73@mail.ru

Received: 17.10 .2018

Accepted: 05.02.2019 


\title{
CHANGES OF PSYCHO-EMOTIONAL STATE IN THE INFERTILE PREGNANT FEMALES DUE TO THE ANAMNESIS AND IVF
}

\author{
Volodymyr K. Likhachov, Yanina V. Shymanska, Yulia S. Savelieva, Viktoriya L. Vashchenko, Ludmyla M. Dobrovolska \\ UKRAINIAN MEDICAL STOMATOLOGYCAL ACADEMY, POLTAVA, UKRAINE
}

\begin{abstract}
Introduction: During pregnancy in the body of a healthy woman there are physiological and psychological changes that contribute to the bearing a child and prepare the female for future labour and motherhood. In women who experience failure at the stage of fertilization or during pregnancy, as a result of prolonged negative emotional states, psycho-emotional stress develops.

The aim of the research was to study the psycho-emotional state of women with infertility in history, whose pregnancy resulted from extracorporal fertilization (IVF), and to develop methods for reducing their anxiety.

Materials and methods: At the first stage, the initial psycho-emotional state of 60 women in the second trimester, whose pregnancy resulted from IVF (Group I), was studied; the control group consisted of 20 healthy women with a physiological course of pregnancy (Group II). At the second stage, 10 art therapy exercises with a requestioning of pregnant women from Group I were conducted for improving their psycho-emotional state.

Results: Women of Group I had a high level of both situational anxiety (SA) and the personal one (PA). The prevalent type of the psychological component of gestational dominant was anxiety and euphoric types (58.3\%). In one third of women with burdened gynecological history examined mild or masked depression was diagnosed. 43 pregnant women from Group I used a method of psychocorrection - art therapy, which included colouring "antistress" pictures of perinatal topic, making flowers from paper and creating a collage of dreams.

Conclusions: After the art therapy course, a high level of SA (from 46.5\% to 7.0\%) and OA (from 48.8\% to 32.6\%) decreased, the index of the optimal type of the psychological component of gestational dominant increased from $25.6 \%$ to $53.5 \%$. The number of women without depression increased from $62.8 \%$ to $93 \%$.
\end{abstract}

KEY WORDS: infertility, preterm delivery risk depression, anxiety disorder, art-therapy

\section{INTRODUCTION}

The issue of infertility and miscarriage is the significant social and medical problem. Today in Ukraine there are about $20 \%$ infertile couples, i.e. every fifth family in the country [1]. A large number of couples apply to the clinics of assisted reproductive technologies for the procedure of extracorporal fertilization (IVF) with embryo transfer [2, 3].

During pregnancy in the body of a healthy woman there are psychological and physiological changes that contribute to the bearing a child and prepare the female for future labour and motherhood. The dominant component of pregnancy transforms the character, behavior, emotional background of a future mother, defining her mental condition [4]. Women who become pregnant as a result of IVF with embryo transfer are at high risk for stress. Psychoemotional stress, as a holistic reaction of the organism, is a cerebro-visceral syndrome, which is formed as a result of prolonged negative emotional states [5], leading to changes in neuroendocrine parameters. The implementation of this mechanism occurs through the cortex of the brain, subcortical nuclei, particularly the thalamic one, involving the autonomic nervous system and hormonal mechanisms; hormones of stress activating the metabolism are of particular importance as well $[3,5]$. Chronic stress and associated disorder of adaptation significantly worsens the prognosis of pregnancy $[5,6]$.

\section{THE AIM}

The purpose of the research: to study the psycho-emotional state of women with infertility in history, whose pregnancy resulted from IVF, and to reduce their level of anxiety by art-therapeutic methods.

\section{MATERIALS AND METHODS}

The ethics commission of Ukrainian Medical Stomatologycal Academy, Poltava, Ukraine (protocoil №170) decided: the materials of the scientific work in the form as scientific article "Changes of psycho-emotional state in the infertile pregnant females due to the anamnesis and IVF" editer by Volodymyr K. Likhachov can be published in free print.

At the first stage of the research, the initial psychoemotional state of 60 females in the second trimester of pregnancy resulting from IVF with a history of infertility and the threat of interruption of this pregnancy (Group I) 
Table I. Results of questioning pregnant women by State-Trait Anxiety Inventory for determining personal and situational anxiety

\begin{tabular}{|c|c|c|c|c|}
\hline & Indicators of anxiety & & Group I $n=60$ & Group II $n=20$ \\
\hline \multirow{6}{*}{ 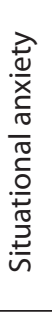 } & \multirow{2}{*}{ High level ( $\geq 46$ points) } & Number of people (\%) & $32(53.3 \%)$ & - \\
\hline & & Scores $(M \pm M)$ & $47.4 \pm 0.5$ & - \\
\hline & \multirow{2}{*}{ Mean level (31-45 points) } & Number of people (\%) & $22(36.7 \%)$ & $17(85.0 \%)^{*}$ \\
\hline & & Scores $(M \pm M)$ & $38.9 \pm 0.8$ & $35.9 \pm 0.9^{*}$ \\
\hline & \multirow{2}{*}{ Low level (1-30) } & Number of people (\%) & $6(10.0 \%)$ & $3(15.0 \%)$ \\
\hline & & Scores $(M \pm M)$ & $28.3 \pm 1.3$ & $25.0 \pm 1.2^{*}$ \\
\hline \multirow{6}{*}{ 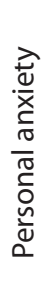 } & \multirow{2}{*}{ High level ( $\geq 46$ points) } & Number of people (\%) & $34(56.8 \%)$ & $1(5 \%)^{*}$ \\
\hline & & Scores $(M \pm M)$ & $48.4 \pm 0.6$ & 47,0 \\
\hline & \multirow{2}{*}{ Mean level (31-45 points) } & Number of people (\%) & $19(31.7 \%)$ & $18(90.0 \%)^{*}$ \\
\hline & & Scores $(M \pm M)$ & $39.0 \pm 1.0$ & $35.7 \pm 0.7^{*}$ \\
\hline & \multirow{2}{*}{ Low level (1-30) } & Number of people (\%) & $7(11.7 \%)$ & $1(5.0 \%)^{*}$ \\
\hline & & Scores $(M \pm M)$ & $29.6 \pm 0.7$ & $25^{*}$ \\
\hline
\end{tabular}

Note: * - an indicator of the statistical significance of the distribution difference by Mann-Whitney method $(p<0.001)$.

Table II. Analysis of assessing the psychological component of gestational dominant by V. I. Dobryakov's method

\begin{tabular}{|c|c|c|c|c|c|}
\hline Indicators & $\begin{array}{l}\text { Predominating the } \\
\text { optimal type }\end{array}$ & $\begin{array}{l}\text { Predominating the } \\
\text { euphoric type }\end{array}$ & $\begin{array}{l}\text { Predominating the } \\
\text { anxiety type }\end{array}$ & $\begin{array}{l}\text { Predominating the } \\
\text { depressive type }\end{array}$ & $\begin{array}{c}\text { Predominating the } \\
\text { hypogestognostic } \\
\text { type }\end{array}$ \\
\hline Group I & \multirow[b]{2}{*}{$15(25 \%)$} & \multirow[b]{2}{*}{$15(25 \%)$} & \multirow[b]{2}{*}{$20(33 / 3 \%)$} & \multirow[b]{2}{*}{$7(11.7 \%)$} & \multirow[b]{2}{*}{$3(5 \%)$} \\
\hline $\mathrm{n}=60$ & & & & & \\
\hline Group II & \multirow{2}{*}{$18(90 \%)$} & \multirow{2}{*}{$2(10 \%)$} & \multirow[b]{2}{*}{-} & \multirow{2}{*}{-} & \multirow{2}{*}{-} \\
\hline $\mathrm{n}=20$ & & & & & \\
\hline$p$ & & & $<0.001$ & & \\
\hline
\end{tabular}

Note: $p$ - an indicator of the statistical significance of the distribution difference between the indices of the groups I and II surveyed by Mann-Whitney method $(p<0.001)$.

was studied. As a control group, 20 healthy females with a physiological course of pregnancy were examined (Group II).

Quantitative expression of the influence of stress factors and their perceptions in pregnant women were assessed by the level of personal anxiety (PA) and situational one (SA), and the degree of depressive disorders, which were determined using the following questionnaires [5]:

- State-Trait Anxiety Inventory (STAI);

- "Pregnant woman relationship test" by V. I. Dobryakov;

- Zung Self-Rating Depression Scale.

Initial testing of women from Group I was conducted in a hospital setting, at the beginning of hospitalization, in the presence of a threat of premature birth. Healthy pregnant women from Group II (control group) were tested in women's consultation clinic.

At the second stage of the research, 10 art therapy classes (drawing with paints and pencils, making flowers from paper, creating a collage of dreams) were carried out in the hospital for the improving psychoemotional condition of pregnant women from Group I. This technique is based on the mobilization of human creative potential, internal mechanisms of self-regulation and healing [7]. In the process of creative activity, there is a feeling of emotional fullness, a deeper understanding of oneself and of the inner world of your own takes place, the relationships of a future mother and the child are harmonized [8]. Among pregnant women from Group I, 43 women from 60 pre-screened persons agreed on art therapy.

At the third stage of the research, a requestioning was completed by 43 pregnant women after the art therapy course.

State-Trait Anxiety Inventory (STAI) consists of individual statements allowing to assess situational anxiety (anxiety levels at the moment) and personal anxiety (anxiety as a stable personality trait). SA is characterized by tension, frustration, nervousness, PA is directly correlated with the presence of a neurotic conflict, emotional breakdowns and psychosomatic illnesses [6].

The result of this inventory is evaluated as follows: 30 points - low anxiety; $31-45$ points - moderate anxiety; 46 or more points - a high level of anxiety.

"Pregnant woman relationship test" by V. I. Dobryakov helps to determine the psychological component of gestational dominant (PCGD) - a set of mechanisms of psychic 
Table III. Assessment of depressive states in pregnant women (by Zung Self-Rating Depression Scale)

\begin{tabular}{ccc}
\hline Indicators & Group 1 $\mathbf{n = 6 0}$ & Group 2 $\mathbf{n = 2 0}$ \\
\hline Without depression & $40(66.7 \%)$ & $20(100 \%)^{*}$ \\
\hline Mild depression of situational or neurotic genesis & $18(30 \%)$ & - \\
\hline Subdepressive state (masked depression) & $2(3.3 \%)$ & - \\
\hline Note: ${ }^{*}$ - an indicator of the statistical significance of the distribution difference by Mann-Whitney method (p<0.001).
\end{tabular}

Note: * - an indicator of the statistical significance of the distribution difference by Mann-Whitney method $(\mathrm{p}<0.001)$.

Table IV. Results of requestioning by State-Trait Anxiety Inventory to determine personal and situational anxiety in pregnant women from Group I after the art therapy course

\begin{tabular}{|c|c|c|c|c|}
\hline \multicolumn{3}{|c|}{ Anxiety indicators } & \multirow{2}{*}{$\begin{array}{c}\text { Before art therapy } \mathbf{n}=\mathbf{4 3} \\
20(46.5 \%)\end{array}$} & \multirow{2}{*}{$\frac{\text { After art therapy } \mathbf{n}=\mathbf{4 3}}{3(7.0 \%)^{*}}$} \\
\hline \multirow{6}{*}{ 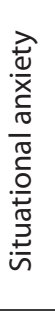 } & \multirow{2}{*}{ High level ( $\geq 46$ points) } & Number of people (\%) & & \\
\hline & & Scores $(M \pm M)$ & $47.9 \pm 0.7$ & $48.3 \pm 0.8$ \\
\hline & \multirow{2}{*}{ Mean level (31-45 points) } & Number of people (\%) & $18(41.9 \%)$ & $23(53.5 \%)^{*}$ \\
\hline & & Scores $(M \pm M)$ & $38.8 \pm 0.7$ & $38.9 \pm 1.0$ \\
\hline & \multirow{2}{*}{ Low level (1-30) } & Number of people (\%) & $5(11.6 \%)$ & $17(39.5 \%)^{*}$ \\
\hline & & Scores $(M \pm M)$ & $28.0 \pm 1.6$ & $30.2 \pm 0.8$ \\
\hline \multirow{6}{*}{$\begin{array}{l}\vec{\lambda} \\
\frac{d}{x} \\
\frac{c}{0} \\
\frac{0}{0} \\
\frac{0}{0} \\
0 \\
\frac{\omega}{d} \\
\square\end{array}$} & \multirow{2}{*}{ High level ( $\geq 46$ points) } & Number of people (\%) & $21(48.8 \%)$ & $14(32.6 \%)^{*}$ \\
\hline & & Scores $(M \pm M)$ & $49.2 \pm 0.8$ & $47.1 \pm 1.9$ \\
\hline & \multirow{2}{*}{ Mean level (31-45 points) } & Number of people (\%) & $17(39.5 \%)$ & $13(30.2 \%)^{*}$ \\
\hline & & Scores $(M \pm M)$ & $38.9 \pm 1.0$ & $40.4 \pm 1.9$ \\
\hline & \multirow{2}{*}{ Low level (1-30) } & Number of people (\%) & $5(11.7 \%)$ & $16(37.2 \%)^{*}$ \\
\hline & & Scores $(M \pm M)$ & $29.2 \pm 0.8$ & $28.9 \pm 1.7$ \\
\hline
\end{tabular}

Note: ${ }^{*}$ - an indicator of the statistical significance of the distribution difference by Mann-Whitney method $(p<0.001)$.

self-regulation, which are included into the development of pregnancy and form behaviour stereotypes in pregnant women aimed at preserving pregnancy and creating conditions for the development of the child [9].

Zung Self-Rating Depression Scale is designed and adapted to examine pregnant women for the diagnosing depression in them. The rate of depression (RD) is not more than 50 points means a state without depression; $\mathrm{RD}$ in the range of 50-59 points shows a slight degree of depression; RD from 60 to 69 points - sub-depressive state or disguised depression; RD more than 69 points demonstrates depressed state.

The obtained data were analyzed by methods of mathematical statistics. The statistical significance of the differences in the results obtained for the distribution of the indices of various groups was determined using the non-parametric Mann-Whitney criterion. The statistical significance of the differences between the distribution of indices before and after treatment was determined using the Wilcoxon method for bound choices.

\section{RESULTS}

The results of STAI are presented in Table I.

The high level of situational anxiety was registered in 32 pregnant women (53.3\%) from Group I with the score of $47.4 \pm 0.5$ points, whereas in Group 2 any woman showed high SA level. The mean SA level was found in 22 women
(36.7\%) from Group I with $38.9 \pm 0.8$ points and in the vast majority of women from the control group (85\%) with the score of $35.9 \pm 0.9$ points. Low SA levels were found in $10 \%$ of women from Group I ( $28.3 \pm 1.3$ points) and in $15 \%$ of pregnant women from Group II (25.0 \pm 1.2 points).

High personal anxiety is characteristic for the majority of surveyed pregnant women from Group I (56.8\%) and is $48.4 \pm 0.6$ points, whereas in the control group high level of PA was detected in only 1 woman (5\%) and was 47 points. The mean level of PA was found in $31.7 \%$ of pregnant women from Group I and in the vast majority of pregnant women from the control group (90\%), with a mean PA score higher in Group I ( $39.0 \pm 1.0$ points vs $35.7 \pm 0.7$ points in Group II, $\mathrm{p}<0.001$ ). Low PA levels were found in $11.7 \%$ of women from Group I and 5.0\% in pregnant women from the control group.

The mean level of anxiety is considered by most authors as normal (adaptive) during pregnancy, while a high level of anxiety is often accompanied by complicated pregnancy $[4,8]$. According to the data obtained, there are some features indicating serious psychological discomfort in women with reproductive problems. So, in pregnant from Group I high level of both personal and situational anxiety predominates. A high level of PA suggests that the women examined are more likely to be exposed to stress of strong emotions and frustration, they associate negative events entirely with their own personality. PA directly correlates with the presence of neurotic conflict and psychosomatic 
Table V. Analysis of assessing the psychological component of gestational dominant by V. I. Dobryakov's method in pregnant women from Group I after the art therapy course

Indicators Predominating Predominating Predominating Predominating the the optimal type the euphoric type the anxiety type depressive type
Predominating the hypogestogenic type

Before art therapy

$n=43$

11 (25.6\%)

11 (25.6\%)

14(32.6\%)

5(11.6\%)

$2(4.6 \%)$

After art therapy

$n=43$

$23(53.5 \%)^{*}$

$10(23.3 \%)$

$5(11.6 \%)^{*}$

$2(4.6 \%)^{*}$

$3(7.0 \%)^{*}$

Note: * - an indicator of the statistical significance of the distribution difference by Wilcoxon method $(\mathrm{p}<0.001)$.

Table VI. Assessment of depressive states (by Zung Self-Rating Depression Scale) in pregnant women from Group I after the art therapy course

\begin{tabular}{|c|c|c|c|}
\hline \multicolumn{2}{|c|}{ Indicators } & \multirow{2}{*}{$\begin{array}{c}\text { Before art therapy } n=43 \\
27(62.8 \%)\end{array}$} & \multirow{2}{*}{$\begin{array}{c}\text { After art therapy } \mathbf{n}=\mathbf{4 3} \\
40(93 \%)^{*}\end{array}$} \\
\hline Without denression & Number of people (\%) & & \\
\hline virtivat aepressiomi & Scores $(M \pm M)$ & $38.8 \pm 1.1$ & $39.9 \pm 0.9$ \\
\hline \multirow{2}{*}{$\begin{array}{l}\text { Mild depression of situational or } \\
\text { neurotic genesis }\end{array}$} & Number of people (\%) & $14(32.6 \%)$ & $2(4.7 \%)^{*}$ \\
\hline & Scores $(M \pm M)$ & $53.5 \pm 1.5$ & $51.9 \pm 0.5$ \\
\hline \multirow{2}{*}{$\begin{array}{l}\text { Subdepressive state (masked } \\
\text { depression) }\end{array}$} & Number of people (\%) & $2(4.6 \%)$ & $1(2.3 \%)^{*}$ \\
\hline & Scores $(M \pm M)$ & $63 \pm 0.0$ & 60.0 \\
\hline
\end{tabular}

Note: ${ }^{*}$ - an indicator of the statistical significance of the distribution difference by Wilcoxon method $(p<0.001)$.

illness. SA indicates emotional discomfort of women at the time of the research, associated with the expectations of discomfort, it is characterized by tension, anxiety and cause attention disorder.

Women with a high level of anxiety cannot be set categorical tasks and encouraged to promptly perform certain actions, as this can lead to a conflict or nervous excitation of the pregnant [10].

In women from Group II, who has had no history of infertility, has physiological pregnancy and are not in a hospital with the threat of premature birth, the adaptive (mean) level of anxiety (85\%-90\% of pregnant women) predominates, which is favorable for carrying pregnancy.

Table II presents the results of our research on the psychological component of gestational dominant (PCGD) in the women examined.

According to the results of this research, pregnant women can be related to one of the main subgroups, each of which requires different tactics of prenatal care. 15 women $(25 \%)$ from Group I included pregnant women with the best type of PCGD, and they are in a state of psychological comfort.

In 3 of the women under study from Group I (5\%) the hypogestognostic type of PCGD predominates. It indicates lack of awareness of their own pregnancy, unwillingness to abandon the lifestyle that was before pregnancy (studying, career). This psychological type is characterized by emotional alienation, undeveloped parental feelings.

The "risk group" should include women with euphoric, depressive and anxiety type of PCGD. In Group I anxiety
(20 women, $33.3 \%$ ) and euphoric (15 women, $25 \%$ ) types of PCGD predominates, and depressive type was in 7 pregnant women (11.7\%). The condition of women in these groups is characterized by a high level of anxiety, which affects their somatic status. A pregnant woman either overestimates existing problems or cannot explain what the anxiety she is constantly experiensing is associated with; anxiety is often accompanied by hypochondria. Any actions of the medical staff (laboratory research, doctor's examination) promote anxiety in pregnant women $[9,11]$.

In Group 2 (the control group) the optimal type of gestational dominant (18 women, 90\%) predominates, indicating the pregnant women treat their pregnancy responsibly, but without particular anxiety. The pregnant woman continues to lead an active lifestyle, follows the recommendations of physicians, takes care of her health, and is engaged into prenatal care courses [12].

Zung Self-Rating Depression Scale allowed to conduct diagnostics of depressive states in pregnant women surveyed. The results are presented in Table III.

The mean score according to Zung Self-Rating Depression Scale when calculating the rates in all 60 women from Group I was $44.8 \pm 1.0$ points, which falls into the category "state without depression". However, in a detailed analysis it was found that $66.7 \%$ of women (40 persons) actually showed no depression, but $30 \%$ ( 18 women) demonstrated a state of mild depression, and two pregnant women (3.3\%) were diagnosed with masked depression. In the control group all women were without depression. 
Found in 20 women from Group I (33.3\%) states of mild and masked depression may be explained by a history of infertility and a fear of failure of this pregnancy. Such women mark permanent irritability, mood swings, tearfulness, periodic headaches and sleep disturbances. They have an extremely developed feeling of inferiority due to women's subconscious persistent perceptions of their physical, mental and/or moral inferiority (often fictitious one).

After conducting 10 art therapy classes, a re-questioning was held among 43 women from Group I who agreed to the art therapy course (Table IV-VI).

According to State-Trait Anxiety Inventory, in pregnant women the mean (23 cases, $53.5 \%)$ and low (17 women, $39.5 \%$ ) situational anxiety became predominant, and only 3 persons (7\%) had a high level of SA. Such a change in the structure of levels of anxiety occurred due to a sharp decline in the number of pregnant women with high level of SA - from $46.5 \%$ to $7.0 \%$. The mean score of SA was $35.6 \pm 1.05$ points, while before the art therapy course it was $42.4 \pm 0.88$ points (in the control group $-34.3 \pm 1.2$ points).

The level of PA also became predominantly moderate and low - respectively, 13 women $(30.2 \%)$ and 16 women (37.2\%). High PA level was kept only in 14 women (32.6\%). The mean score of PA after art therapy classes was $38.0 \pm 1.3$, in comparison with the beginning of the course $-43.2 \pm 1.0$ points (in the control group it was $35.7 \pm 1.2$ points). Such results in women from Group I indicate the effectiveness of the applied method.

In the analysis of the PCGD indicator by V. I. Dobryakov (Table V), you could see the number of women of the optimal type increased from $25.6 \%$ before the art therapy course to $53.5 \%$ after it. The indicator of "risk group" after art therapy classes decreased from 30 to 17 pregnant women: euphoric type - 10 women (23.3\%); anxiety one - 5 women (11.6\%); depressive type -2 women (4.6\%). That is, in the groups of the surveyed the number of women with a predominantly anxiety (by almost three times) and depressive (twice) types decreased. There remains an almost constant number of women with hypogestogenic PCGD, since this indicator is a permanent personality trait [9].

When re-evaluating the state of depression in pregnant women from Group I by Zung Self-Rating Depression Scale after the art therapy course (Table VI), the overwhelming number of women were without depression (40 women, $93 \%)$; in mild depression - 2 women (4.7\%) and only 1 woman $(2.3 \%)$ was diagnosed with masked depression. The mean score by Zung after art therapy classes was $40.5 \pm 1.05$ points, compared with the state before $-44.8 \pm 1.0$ points. The given data indicate the efficiency of the applied method.

\section{DISCUSSION}

In women with reproductive loss, infertility in the history and IVF pregnancy changes of the psychoemotional and psychosomatic character have been revealed: the pregnant have showed a high prevalence of situational and personal anxiety. It indicates the emotional discomfort of women at the time of the research, associated with the expectations of ill-being. The tendency of the women surveyed to the influence of stress, strong feelings and anxiety has been revealed. The dominant type of psychological component of the gestational dominant is the anxiety and euphoric types (58.3\%) that are characterized by high levels of anxiety in the pregnant woman, which affects her somatic state. This is due to the presence of infertility in history, multiple unsuccessful attempts at pregnancy, acute or chronic illness, disharmonious family relationships, dissatisfaction with material needs, and so on. In one third of the women with aggravated history examined mild or masked depression was diagnosed.

After the initial testing of patients, the method of psycho-correction - art therapy, which consisted in painting "I and my baby" picture, colouring "antistress" pages with perinatal themes, making flowers from paper, creating a collage of dreams, was applied. With repeated testing, we received the following results: the level of SA decreased from $46.5 \%$ to $7.0 \%$, and PA level - from $48.8 \%$ to $32.6 \%$, the indicator of the optimal type of the psychological component of the gestational dominant increased from $25.6 \%$ to $53.5 \%$. The number of women without depression increased from $62.8 \%$ to $93 \%$. The given data indicate the effectiveness of the applied method of psychocorrection. One of the indicators was the fact that, in the course of medical treatment of the threat of preterm birth and art therapy classes in women who agreed to work with a psychologist, pregnancy lasted for up to 35 weeks. And in women who refused the art therapy course, childbirth occurred in 32-33 weeks of pregnancy.

\section{CONCLUSIONS}

1. In women with reproductive loss, infertility in the history and IVF pregnancy violations of the psycho-emotional state with a high level of situational and personal anxiety were revealed.

2. In $70 \%$ of women with aggravated obstetric history the euphoric, anxiety and depressive type of the psychological component of gestational dominant are prevalent, and only the fourth of the surveyed has the optimal type.

3. The state of mild and masked depression was found in $33.3 \%$ of the examined pregnant women with infertility in history, extracorporal fertilization and the threat of preterm labour.

4. After 10 art therapy classes the number of women with high level of situational anxiety decreased by 7 times and by 1.5 - with high level of personal anxiety; the number of pregnant women with the optimal type of psychological component of gestational dominant doubled with a significant reduction in the number of women with anxiety type; the majority of the surveyed (93\%) showed no depression.

5. In the group of women undergoing the art therapy course (with the course of appropriate medical treatment of the threat of preterm labour) pregnancy was prolonged on average up to 35 weeks. And in women who refused this psychocorrection childbirth occurred in 32-33 weeks of pregnancy. 


\section{REFERENCES}

1. Zhuk C.I. Shchurevskaya 0.D. Psikhosotsial'nyye aspekty zahrozy peredchasnykh polohiv. [Threat of premature birth:psycho-social aspects] Zhenskoye zdorov'ye. 2016; 6(112):86-89. (In Ukrainian).

2. Vorobyova I.I., Skrypchenko N.Ya., Tkachenko V.B., et al. molekulyarno-henetychnykh ta psykho-sotsialnykh aspektiv rozvytku nevynoshuvannya vahitnosti u zhinok ukrayinskoyi natsiyi. [The role of molecular-genetic and psycho-social aspecs of the development of pregnancy loss in Ukraine women's national] Slovo o zdorovie. [Internet].2018 Lypen. [tsytovano 2019 berezen'];15. (In Ukrainian). Dostupno: http://ozdorovie.com.ua/rol-molekulyarno-genetichnihta-psiho-sotsialnih-aspektiv-rozvitku-nevinoshuvannya-vagitnostiu-zhinok-ukrayinskoyi-natsiyi/?utm_source=eSputnik-promo\&utm_ medium=email\&utm_campaign=Anons\%3A_Slovo_pro_Zdorov_ ja_3\%2815\%29\&utm_content $=298936773$

3. Rudenko I.V.,LikhachovV.K.,Mishchenko V.P., etal. Mediko-genetic diagnostics of hereditary predisposition to non carry pregnancy and reproductive losses]. World of Medicine and Biology. 2018; 2(64):75-77. (In English).

4. Tatarchuk T.F., Kosey N.V., Reheda S.I., ey al. Stresove bezpliddya. [Stress infertility]. Reproduktyvna endokrynolohiya. [Internet]. 2016. [tsytovano berezen' 2019]; 5(31):12-21. Dostupno: http://dx.doi. org./10.18370/2309-4117.2016.31.12-21. (In Ukrainian).

5. Rollo Mey, Zavalova M.I.,Siburina A.U., redaktory. Smysl trevogi. [The sens of anxiety]. Moskva. Nezavisimaya firma «Klass»;2001.258s. (In Russian).

6. Misyuk M.N., Kovalenko E.S. Trevozhnost' i strakhi kak proyavleniye emotsional'noy sfery beremennykh zhenshchin. [Anxieties and fears as a sign of emotional sphere of pregnance women] Susha NV, redaktor pravleniye v sotsial'nykh i ekonomicheskikh sistemakh: Materialy XVII mezhdunarodnoy nauchno- prakticheskoy konferentsii; 2-6 iyunya 2008. Minsk. Minskiy institut upravleniya; 2008, s.413-414. (In Russian).

7. Kopytin A.I. Art-terapiya-novyye gorizonty. [Art-therapy - new horizons] Moskva: Kogito-Tsentr; 2006, 336s. (In Russian).
8. Dobryakov I. V. Perinatal'naya psikhologiya.[Perinatal psychology]. Sankt-Peterburg: 000 Izdatel'stvo Piter, 2015, 328 s. (In Russian).

9. Potapov V.0., Zharkykh A.V., Syusyuka V.H., etal. Mekhanizmy adaptatsiy u vahitnykh z nevynoshivannyam u dynamitsi zberihalnoyi terapiyi. [Mechanisms of adaptation of the pregnant women with miscarriage in the dynamics of the saving therapy]. Zdorovya zhinky. 2016;111:77-81. (In Ukrainian).

10. Bozhuk 0.A.,BozhukB.S. Hestatsiyna dominantayak markervyznachennya stanovlennya materyns'koyi sfery. [Gestational dominant as a marker of determination formality of maternity sphere]. Ukrayins'kyi naukovomedychnyi molodizhnyi zhurnal. 2012;3:100-102. (In Ukrainian).

11. Pushkarova T.M., Skrypchenko N.Ya. Alhorytm skryninhovoyi diahnostyky depresyvnykh i tryvozhno-depresynnykh rozladiv u zhinok pid chas vahitnosti ta pislya polohiv. [Screening diagnostic algorithm of anxiety and anxiodepressive disorders in women dyring pregnancy and postpartum period]. Perynatolohiya ta pediatriya. 2017;1(69):74-78. (In Ukrainian).

12. Ancheva I.A. Suchasnyy pohlyad na psykholohichnu hotovnist zhinky do materynstva [ Modern view of the psychological preparedness of a woman to maternity] Zdorovyazhinky. 2017;6(122):50-52. (In Ukrainian).

The theme of the scientific and research work of the Department of Obstetrics and Gynaecology 2 of Ukrainian Medical Stomatological Academy "The role of chronic infection of the uterus and lower sections of the genital tract in the formation of obstetric and gynaecological pathology" (number of state registration is 0117U005276, 2017-2022).

\section{Authors' contributions:}

According to the order of the Authorship.

\section{Conflict of interest:}

The Authors declare no conflict of interest.

\section{CORRESPONDING AUTHOR Volodymyr K. Likhachov}

42 Stritenska Str., app. 19, Poltava 36011, Ukraine.

tel: +380952212112 .

e-mail:vladimir.lihachov@gmail.com

Received: 10.12 .2018

Accepted: 05.03.2019 
PRACA ORYGINALNA

ORIGINAL ARTICLE

\title{
АСОЦІАЦІЯ LYS198ASN-ПОЛІМОРФИЗМУ ГЕНА ЕНДОТЕЛІНУ-1 (EDN1) 3 РОЗВИТКОМ АРТЕРІАЛЬНОÏ ГІПЕРТЕНЗІЇ В УКРАїНСКІЙ ПОПУЛЯЦІї
}

\author{
THE ASSOCIATION OF LYS198ASN -POLYMORPHISM OF \\ ENDOTHELIN-1 GENE (EDN1) WITH DEVELOPMENT OF ARTERIAL \\ HYPERTENSION IN UKRAINIAN POPULATION
}

\author{
Юлія О. Сміянова, Людмила Н. Приступа, Вікторія Ю. Гарбузова, Єлізавета А. Гарбузова \\ СУМСЬКИЙ ДЕРЖАВНИЙ УНІВЕРСИТЕТ, СУМИ, УКРӒ̈НА
}

\author{
Ylia 0. Smiianova, Ludmyla N. Pristupa, Viktoriia Yu. Harbuzova, Yelizaveta A. Harbuzova \\ SUMY STATE UNIVERSITY, SUMY, UKRAINE
}

\section{PEЗЮME}

Вступ: Артеріальна гіпертензія - мультифакторіальне захворювання, яке розвивається під впливом чинників зовнішнього середовище і $є$ генетично детермінованим. Одним із генетичних маркерів, що має провідне значення в розвитку захворювання $\epsilon$ ген ендотеліну-1 (EDN1). Сьогодні доведена асоціація поліморфних варіантів цього гена, зокрема Lys198Asn-поліморфізму, з розвитком артеріальної гіпертензії у різних популяціях світу.

Мета: Вивчити асоціацію Lys198Asn-поліморфізму гена ендотеліну-1 з розвитком артеріальної гіпертензії в українській популяції.

Матеріали і методи: Визначення генотипів пацієнтів здійснювали методом полімеразної ланцюгової реакції з наступним аналізом довжини рестрикційних фрагментів (PCR-RFLP) із венозної крові 160 пацієнтів з артеріальною гіпертензією (АГ) та 110 осіб контрольної групи. Статистичний аналіз виконаний за допомогою програми SPSS-17.0.

Результати: У результаті проведеного генотипування показано, що в групі пацієнтів з АГ співвідношення гомозигот за основним алелем (Lys/Lys), гетерозигот (Lys/Asn) і гомозигот за мінорним алелем (Asn/Asn) склало 74 (46,3\%), 73 (45,6\%), 13 (8,1\%), а у контролі - 66 (60,0\%), 41 (37,3\%), 3 (2,7\%) відповідно. Розподіл генотипів у групах порівняння був статистично значущим $(X 2=6,66 ; \mathrm{P}=0,036)$. Методом бінарної логістичної регресії у рамках домінантної та адитивной моделей успадкування був встановлений достовірний зв'язок генотипів за Lys198Asn-поліморфізмом гена EDN1 з р0звитком артеріальної гіпертензії $\left(\mathrm{PH}_{\mathrm{H}}=0,01\right)$. Показано, що носії мінорного алеля (Lys/Asn+Asn/Asn) мають в 1,7 (95 \% Cl=1.066 - 2.851), а гомозиготи Asn/Asn - у 3,9 (95 \% Cl = 1,016 - 9,566) раза більший ризик виникнення артеріальної гіпертензії у порівнянні з особами з Lys/Lys-генотипом. Крім того, пацієнти, що палять 3 Lys/ Asn та Asn/Asn-генотипами мають у 2,6 (95\% Cl=1.224-5.488), а гомозиготи за мінорним алелем (Asn/Asn) у 7,3 (95\% Cl=1.295-41.639) раза вищий ризик настання АГ у порівнянні з гомозиготами Lys/Lys.

Висновки: Lys198Asn-поліморфізм гена ендотеліну-1 асоційований з розвитком артеріальної гіпертензії в українській популяції - носії мінорного алеля (Lys/Asn+Asn/ Asn) мають в 1,7, а гомозиготи Asn/Asn мають у 3,9 раза більший ризик виникнення артеріальної гіпертензії, ніж особи з Lys/Lys-генотипом.

КЛЮЧОВІ СЛОВА: артеріальна гіпертензія, поліморфізм генів, ендотелін-1.

\footnotetext{
ABSTRACT

Introduction: Arterial hypertension is a multifactorial disease developing under the influence of environmental factors and is genetically determined. One of the genetic markers that is of primary importance in the disease development is endothelin-1 gene (EDN1). Today the association between the polymorphic variants of this gene, particularly Lys198Asn-polymorphism, and the development of arterial hypertension in different populations of the world has been proved.

The aim: To study the association between the Lys198Asn-polymorphism of the endothelin-1 gene and the development of arterial hypertension in Ukrainian population.

Materials and methods: The genotypes were determined by the polymerase chain reaction method, followed by the analysis of the restriction fragment length (PCR-RFLP) in venous blood of 160 patients with arterial hypertension and 110 people in the control group. The statistical analysis was performed using SPSS-17.0.

Results: As a result of genotyping, it was found that in the group of patients with arterial hypertension the ratio of homozygote of the major allele (Lys/Lys), heterozygote (Lys/Asn) and homozygote of the minor allele (Asn/Asn) was 74 (46.3\%), 73 ( 45.6\%), $13(8.1 \%)$, while in control - 66 (60.0\%), 41 (37.3\%), $3(2.7 \%)$ respectively. The distribution of genotypes in the experimental groups was statistically significant $(X 2=6.66 ; P=0.036)$. By the method of binary logistic regression within the dominant and additive model of inheritance, a reliable association between the genotype of the Lys198Asn-polymorphism of the ET-1 gene and the development of arterial hypertension was established.

It was shown that carriers of minor allele (Lys/Asn+Asn/Asn) have a risk of arterial hypertension $1.7(95 \% \mathrm{Cl}=1.066-2.851)$, and homozygotes Asn/Asn $3.9(95 \% \mathrm{Cl}=1.016-9.566)$ times higher than people with Lys/Lys genotype.

In addition, smoking patients with Lys/Asn and Asn/Asn- genotypes have a risk of arterial hypertension 2.6 (95\% of SI =1.224-5.488), and homozygotes of the minor allele (Asn/Asn) 7.3 (95\% of $\mathrm{SI}=1.295-41.639)$ times higher than the Lys/Lys homozygotes.
} 
Conclusions: Lys198Asn-polymorphism of the endothelin-1 gene is associated with the development of arterial hypertension in Ukrainian population. Carriers of minor allele (Lys/Asn+Asn/ Asn) have a risk of arterial hypertension 1.7, and homozygotes Asn/Asn 3.9 times higher than people with Lys/Lys genotype.

KEY WORDS: arterial hypertension, gene polymorphism, endothelin-1

Wiad Lek 2019, 72, 4, 568-574

\section{ВСТУП}

Артеріальна гіпертензія (АГ) є однією з найважливіших проблем сучасної медицині та основним фактором ризику серцево-судинних захворювань (СС3) і смерті. АГ діагностується в третини населення планети і щороку призводить до смерті майже 7 млн. людей [1]. Незважаючи на значні досягнення в лікуванні та профілактиці артеріальної гіпертензії, захворюваність на АГ продовжує зростати. Так, чисельність хворих з артеріальною гіпертензією в Україні у 2016 р. сягнула понад 10 млн 421 тис.

На даний час, АГ розглядається як мультифакторіальне захворювання, що виникає під впливом факторів зовнішнього середовища разом із генетично-детермінованими особливостями конституціїлюдини. Важливими чинниками уїі розвиткує гіподинамія, надлишкова маса тіла, неправильне харчування, психоемоційне напруження, вік, стать та інші.

Важливою ланкою у розвитку артеріаальної гіпертензії $€$ зміни стану ендотелію кровоносних судин. Серед чинників, що регулюють функціонування ендотелію безумовно одними із найбільш значимих є ендотеліни - біологічно активні пептиди, що впливають на стан системної та регіональної гемодинаміки [2,3]. Найвідоміший серед них - ендотелін-1 (EDN1) - вазоактивний петид, вазоконстрикторна дія якого в 10 разів сильніша за ангіотензин II і в 100 разів перевищує ефект норадреналіну [4].

EDN1, володіючи вазоконстрикторною дією, бере участь в регуляції судинного тонусу, підвищення якого відіграє важливу роль у розвитку іпрогресуванні ряду ССЗ. Існують різні механізми, за участю яких EDN1 викликає порушення в судинах, такі як індукція запалення і окисного стресу, збільшення утворення факторів росту (PDGF, FGF, EGF), синтез колагену і позаклітинного матриксу та стимуляція проліферації ГМК [5]. EDN1 також підсилює судинозвужувальні ефекти інших нейрогуморальних і ендокринних чинників. Так, було показано, що EDN1 індукує перетворення ангіотензину I в ангіотензин II [6], сприяючи при цьому розвитку АГ [7]. Так чи інакше, ендотелін-1 сьогодні розглядають як маркер і предиктор важкості та результату ішемічної хвороби серця, зокрема інфаркту міокарда, порушень ритму серця, легеневої ісерцевої гіпертензії, атеросклеротичного ушкодження судин та ін. Також вважають, що він причетний до несерцевої патології - післяпологові судинні ускладнення, ураження нирок (гломерулонефрит), ішемічні ураження мозку, цукровий діабет та ін. [8].

Останнім часом показано, що активність функціонування EDN1 залежить від генетичного поліморфізму його гена. Так, Lys198Asn-поліморфізм багатьма дослідниками розглядається як можливий генетичний маркер розвитку серцево-судинних захворювань [9,10]. Протягом останніх років упублікаціях зарубіжних дослідників активно висвітлюються результати досліджень зв'язку Lys198Asn-поліморфізму гена $E D N 1$ з рівнем ендотеліну в крові та перебігом АГ і серцево-судинних захворювань. Дані літератури досить неоднорідні і суперечливі, що може бути пов'язано з генетичною різноманітністю вибірок, а також різними параметрами порівняння.

\section{МЕТА ДОСЛІДЖЕННЯ}

Метою даного дослідження є вивчення асоціації Lys198Asn-поліморфізму гена EDN1 з розвитком артеріальної гіпертензії в українській популяції.

\section{МАТЕРІАЛИ I МЕТОДИ}

У дослідженні брали участь 160 пацієнтів із верифікованим діагнозом АГ I, II, III стадії 1,2,3 ступеня (основна група) та 110 практично здорових осіб (група контролю), що проходили обстеження та лікування на базі КЗ « Сумська міська клінічна лікарня № 1» за період з 2015-2017рр. Основою діагностики АГ були рекомендації адаптованої клінічної настанови «Артеріальна гіпертензія» (Наказ МОЗ України №384 від 24.05.2012 р.) за результатами детального клініко - інструментального обстеження хворих.

Серед обстежених хворих було 83 жінки (51,9 \%) і 77 чоловіка ( $48,1 \%)$ у віці 38 - 89 років. У групу контролю увійшло 110 практично здорових осіб , серед них 78 жінок ( $70,9 \%$ ) і 32 чоловіків ( $29,1 \%$ ) у віці $20-82$ роки. Усі пацієнти основної групи та групи контролю були обстежені за єдиним планом, що включав наступні етапи: опитування скарг, збір анамнезу, проведення фізикального обстеження пацієнта, вимірювання АТ, антропометричні дослідження, проведення лабораторних досліджень: загальний аналіз крові,біохімічний аналіз крові з визначенням концентрації глюкози та ліпідного спектру, креатиніну; проведення інструментальних досліджень: електрокардіографія (ЕКГ), ехокардіоскопія (ЕхоКС), офтальмоскопія; проведення медико-генетичних досліджень: визначення поліморфізму генів за допомогою полімеразної ланцюгової реакції (ПЛР) з наступним аналізом довжини рестрикаційних фрагментів.

Дослідження проводили з дотриманням основних положень Конвенції Ради Європи про права людини і біомедицини, Гельсінської декларації Всесвітньої медичної асоціації про етнічні принципи проведення наукових медичних досліджень за участі людини і Наказу МОЗ України № 690 від 23.09.2009 р. Всі пацієнти підписали інформовану згоду 
Таблиця І. Розподіл алелей і генотипів за Lys196Asn поліморфізмом гена END1y групах порівняння

\begin{tabular}{|c|c|c|c|c|c|c|}
\hline \multirow[t]{2}{*}{ Генотип } & \multicolumn{2}{|c|}{$\begin{array}{c}A \Gamma \\
(n=160)\end{array}$} & \multicolumn{2}{|c|}{$\begin{array}{c}\text { Контроль } \\
(n=110)\end{array}$} & \multirow[t]{2}{*}{$\mathbf{P}_{\mathrm{HWE}}$} & \multirow[t]{2}{*}{$\mathbf{P}$} \\
\hline & $\mathbf{n}$ & $\%$ & $\mathbf{n}$ & $\%$ & & \\
\hline Lys/Lys & 74 & 46,3 & 66 & 60,0 & & \multirow{3}{*}{0,036} \\
\hline Lys/Asn & 73 & 45,6 & 41 & 37,3 & & \\
\hline Asn/Asn & 13 & 8,1 & 3 & 2,7 & & \\
\hline \multicolumn{7}{|l|}{ Алель } \\
\hline Lys & 221 & 69,1 & 173 & 78,6 & \multirow{2}{*}{0.252} & \multirow{2}{*}{0,014} \\
\hline Asn & 99 & 30,9 & 47 & 21,4 & & \\
\hline
\end{tabular}

Примітка: $\mathrm{n}$ - кількість пацієнтів. АГ - артеріальна гіпертензія

Таблиця II. Аналіз асоціації поліморфних варіантів Lys196Asn гена END-1 з розвитком артеріальної гіпертензії з урахуванням різних моделей успадкування

\begin{tabular}{cccc}
\hline $\begin{array}{c}\text { Модель } \\
\text { успадкування }\end{array}$ & $\mathbf{P}$ & OR $(\mathbf{9 5 \%} \mathbf{C I})$ & AIC \\
\cline { 1 - 3 } Домінантна & 0.027 & $1.743(1.066-2.851)$ & 19.32 \\
\hline Рецесивна & 0.079 & $3.154(0.877-11.343)$ & 20.53 \\
\hline Наддомінантна & 0.173 & $1.412(0.86-2.319)$ & 22.4 \\
\hline \multirow{2}{*}{ Адитивнаа } & 0.041 & $3.865(1.055-14.16)$ & \multirow{2}{*}{19.29} \\
\cline { 2 - 3 } & 0.073 & $1.588(0.957-2.635)$ & \\
\hline
\end{tabular}

Примітка: CI - довірчий інтервал, OR - відношення шансів, AIC - інформаційний критерій Айкайке, а - верхній ряд в адитивній моделі містить результати порівняння між Asn/Asn- i Lys/Lys-генотипами, нижній ряд - між Lys/Asn- i Lys/Lys-генотипами

на участь у дослідженнях із подальшим забором венозної крові на генетичний аналіз.

Венозну кров у хворих на АГ та практично здорових осіб набирали в стерильних умовах у моновети об'ємом 2,7 мл із калієвою сіллю етилендіамінтетраоцтової кислоти $(11,7$ мM) в якості антикоагулянту (“Sarstedt”, Німеччина), заморожували та зберігали при температурі $-20^{\circ} \mathrm{C}$. ДНК виділяли 3 цільної крові із використанням наборів “ThermoFisher Scientific” (США) згідно протоколу виробника.

Поліморфізм 5-го екзону гена EDN1 (rs 5370) визначали методом полімеразної ланцюгової реакціїз наступним аналізом довжини рестрикційних фрагментів за Fleury I. et al. [74] із модифікаціями. Для цього ампліфікували ділянку екзону вказаного гена за допомогою пари специфічних праймерів: прямого (sence) - 5' TCTTGCTTTATTAGGTCGGAGACC 3' і зворотного (antisense) - 5’ TTTGAACGAGGACGCTGGTC 3' ("Metabion” (Німеччина). Для ампліфікації брали 50-100 нг ДНК і додавали до суміші, що містила 5 мкл 5-кратного ПЛР-буферу, 1,5 мМ сульфату магнію, 200 мкМ суміші d-NTP, по 20 рМ кожного з праймерів і 1,0 ОД Таq-полімерази (Thermo Scientific, США), об’єм доводили до 25 мкл деіонізованою водою. ПЛР проводили в термоциклері GeneAmp PCR System 2700 («Applied Biosystems», США). Ампліфікація фрагмента 5-го екзону складалася з 35 циклів: денатурація $-94^{\circ} \mathrm{C}\left(60\right.$ c), гібридизація праймерів $-61,0^{\circ} \mathrm{C}$ $\left(60\right.$ c) і елонгація $-72^{\circ} \mathrm{C}$ (45 c). Потім 6 мкл продукту ампліфікації інкубували при $37^{\circ} \mathrm{C}$ протягом 18 годин з 2 ОД рестриктази Cac81 (Thermo Scientific, США) у буфері G такого складу: 10 мМ трис- $\mathrm{HCl}$ ( $\mathrm{pH}$ 7,5), 10 мМ хлориду магнію, $50 \mathrm{mM} \mathrm{NaCl} \mathrm{i} \mathrm{0,1} \mathrm{мг/мл} \mathrm{альбуміну.}$

За наявності у 5665-й позиції гена EDN1 гуаніну (G), ампліфікат, розщеплювався рестриктазою на два фрагменти - 189 i 73 п.о. У разі заміни $\mathrm{G}$ на тимін сайт рестрикції для Саc81 втрачався. Ампліфікати після рестрикції розділяли в 2,5 \% агарозному гелі, що містив 10 мкг/мл бромистого етидію. Горизонтальний електрофорез $(0,13 \mathrm{~A} ; 160 \mathrm{~V})$ проводили протягом 35 хв. Візуалізацію ДНК після електрофорезуздійснювали за допомогою трансілюмінатора («Біоком», Росія).

Статистичне опрацювання одержаних результатів здійснювали задопомогою програми SPSS-17.0. Відповідність розподілу алелів рівновазі Харді-Вайнберга перевірена за допомогою он-лайн додатку Online Encyclopedia for Genetic Epidemiology studies (http://www.oege.org/software/hwe-mr-calc.shtml).

\section{РЕЗУЛЬТАТИ ТА ОБГОВОРЕННЯ}

Частоту дикого (Lys) та мінорного (Asn) алелів, а також розподіл гомозигот за основним алелем (Lys/Lys), гетерозигот (Lys/Asn) та гомозигот за мінорним алелем (Asn/Asn) за Lys198Asn-поліморфизмом гена EDN1 у хворих з артеріальною гіпертензією та представників контрольної групи наведено в табл. І. Показано, що частоти наведених генотипів контрольній групі відповідали рівновазі Харді - Вайнберга (Р > 0,05).

У результаті аналізу даних генотипування встановлено, що співвідношення генотипів Lys/Lys, Lys/Asn та Asn/Asn у групі пацієнтів з артеріальною гіпертензією становило 74 (46,3 \%), $73(45,6 \%)$ і 13 (8,1\%), а у контролі - 66 (60\%), 41 (37,3\%), 3 $(2,7 \%)$ відповідно. Показник $\mathrm{P}$, розрахований за $\chi^{2}$-критерієм Пірсона, дорівнював 0,036, що свідчить по існування різниці розподілу поліморфних варіантів гена EDN1 за Lys198Asn-поліморфизмом у хворих на артеріальну гіпертензію та практично здорових осіб.

Результати регресійного аналізу асоціації генотипів за Lys198Asn-поліморфним сайтом гена EDN1 з розвитком артеріальної гіпертензії в рамках домінантної, рецесивної, наддомінантної та адитивної моделей успадкування наведені 
Таблиця III. Розподіл генотипів за Lys196Аsn-поліморфізмом гена END1 у пацієнтів з різними факторами ризику артеріальної гіпертензії (АГ)

\begin{tabular}{|c|c|c|c|c|c|}
\hline \multirow{2}{*}{ Група } & \multirow{2}{*}{$\mathbf{n}$} & \multicolumn{3}{|c|}{ Генотип, n (\%) } & \multirow{2}{*}{$\mathbf{P}$} \\
\hline & & Lys/Lys & Lys/Asn & Asn/Asn & \\
\hline \multicolumn{6}{|c|}{$\mathrm{IMT} \geq 25 \mathrm{~K} \Gamma / \mathrm{M}^{2}$} \\
\hline $\mathrm{A} Г$ & 85 & $4(4,7 \%)$ & $68(80 \%)$ & $13(15,3 \%)$ & \multirow{2}{*}{$<0.001$} \\
\hline Контроль & 77 & $48(62,3 \%)$ & $27(35,1 \%)$ & $2(2,6 \%)$ & \\
\hline \multicolumn{6}{|c|}{ Тютюнопаління } \\
\hline $\mathrm{A} \Gamma$ & 46 & $16(34,8 \%)$ & $25(54,3 \%)$ & $5(10,9 \%)$ & \multirow{2}{*}{0.015} \\
\hline Контроль & 81 & $47(58 \%)$ & $32(39,5 \%)$ & $2(2,5 \%)$ & \\
\hline \multicolumn{6}{|c|}{ Холестерин $\geq$ 5,2ммоль/л } \\
\hline $\mathrm{A} \Gamma$ & 113 & $33(29,2 \%)$ & $67(59,3 \%)$ & $13(11,5 \%)$ & \multirow{2}{*}{0.166} \\
\hline Контроль & 26 & $3(11,5 \%)$ & $20(76,9 \%)$ & $3(11,5 \%)$ & \\
\hline
\end{tabular}

Примітка. $\mathrm{n}$ - кількість пацієнтів; ІІМТ - індекс маси тіла, ЦД-2 - цукровий діабет 2-го типу

Таблиця IV. Аналіз асоціації поліморфних варіантів Lys196Asn гена END-1 з розвитком артеріальної гіпертензії (АГ) у пацієнетів, що палять

\begin{tabular}{cccc}
\hline Модель успадкування & $\mathbf{P}$ & OR (95\% CI) & AIC \\
\hline Домінантна & 0.013 & $2.592(1.224-5.488)$ & 17.04 \\
\hline Рецесивна & 0.067 & $4.817(0.895-25.915)$ & 19.66 \\
\hline Наддомінантна & 0.108 & $1.823(0.877-3.788)$ & 20.85 \\
\hline Адитивнаа & 0.024 & $7.344(1.295-41.639)$ & 17.01 \\
\cline { 2 - 4 } & 0.035 & $2.295(1.061-4.965)$ & \\
\hline
\end{tabular}

Примітка: С - довірчий інтервал, OR - відношення шансів, AIC - інформаційний критерій Акайке, а - верхній ряд в адитивній моделі містить результати порівняння між Asn/Asn- i Lys/Lys-генотипами, нижній ряд - між Lys/Asn- i Lys/Lys-генотипами

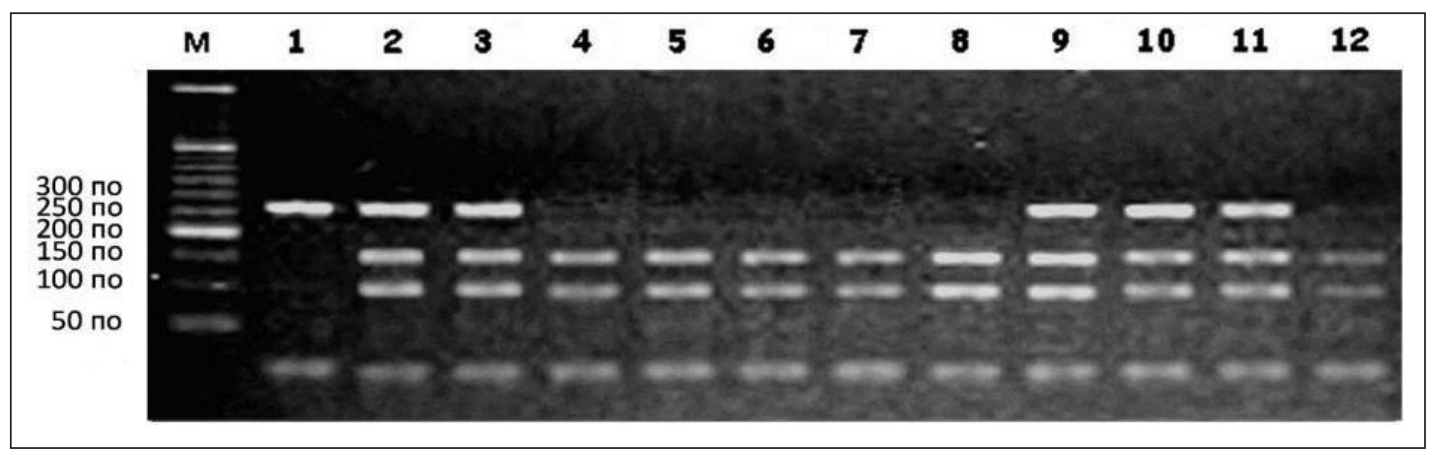

Рисунок 1. Результати рестрикційного аналізу Lys198Asn-поліморфизму гена EDN1. M - маркер молекулярної маси (по - пари нуклеїнових основ), доріжки 4, 5, 6, 7, 8, 12 відповідають Lys/Lys-генотипу; доріжки 2, 3, 9, 10, 11 - Lys/Asn-генотипу; доріжка 1 - Asn/Asn-генотип.

в табл. II. Статистично значущий зв'язок був встановлений для домінантної $(\mathrm{P}=0,027)$ та адитивної $(\mathrm{P}=0,041)$ моделей. Найменші значення показника критерію Акайке мала адитивна модель (ІКА = 19,29). Таким чином, відповідно до результатів бінарної логістичної регресії в українській популяції носії мінорного алеля (Lys/Asn+Asn/Asn) мають в 1,7 (95 \% CI = 1.066 - 2.851), а гомозиготи Asn/Asn - y 3,9 (95 \% CI = 1,016 - 9,566) рази більший ризик виникнення артеріальної гіпертензії у порівнянні з особами з Lys/Lys-генотипом.

Наступним етапом аналізу стало вивчення розподілу генотипів за Lys196Asn-поліморфізмом гена END1 у пацієнтів 3 різними факторами ризику артеріальної гіпертензії, такими як підвищений індекс маси тіла (IMT), тютюнопаління та підвищений рівень холестеролу плазми крові (табл. III). Нами виявлено, що серед осіб з підвищеним індексом маси тіла $\left(\mathrm{IMT} \geq 25 \mathrm{\kappa г} / \mathrm{M}^{2}\right.$ ) співвідношення генотипів у групі пацієнтів 3 АГ та контролі достовірно відрізнялось: 4 (4,7\%), 68 (80\%), 13 (15,3\%) проти 48 (62,3\%), 27 (35,1\%), 2 (2,6\%) (P <0.001). Подібний висновок отриманий і для осіб, що палять. Розподіл генотипів серед пацієнтів з АГ становив 16 (34,8\%), 25(54,3\%), 5 (10,9\%), тоді як у контрольній групі - 47 (58\%), 32(39,5\%), 2 $(2,5 \%)(\mathrm{P}=0,015)$. Статистично достовірних відмінностей у групах порівняння серед осіб з підвищеним рівнем холестеролу ( $\geq 5,2$ ммоль/л) виявлено не було $(\mathrm{P}=0,166)$. Методом 
Таблиця V. Аналіз асоціації поліморфних варіантів Lys196Asn гена END-1 з розвитком артеріальної гіпертензії (АГ) у пацієнетів 3 гіперхолестеролемією (рівень холестеролу $\geq 5,2$ ммоль/л)

\begin{tabular}{cccc}
\hline Модель успадкування & $\mathbf{P}$ & OR $(\mathbf{9 5} \% \mathbf{C I})$ & AIC \\
\hline Домінантна & 0.076 & $0.316(0.089-1.126)$ & 14.42 \\
\hline Рецесивна & 0.996 & $0.997(0.262-3.786)$ & 18.34 \\
\hline Наддомінантна & 0.1 & $0.437(0.163-1.172)$ & 15.37 \\
\hline Адитивна & 0.29 & $0.394(0.07-2.209)$ & 16.27 \\
\cline { 2 - 4 } & 0.069 & $0.305(0.084-1.099)$ & \\
\hline
\end{tabular}

Примітка: Cl - довірчий інтервал, OR - відношення шансів, AIC - інформаційний критерій Акайке, а - верхній ряд в адитивній моделі містить результати порівняння між Asn/Asn- i Lys/Lys-генотипами, нижній ряд - між Lys/Asn- i Lys/Lys-генотипами

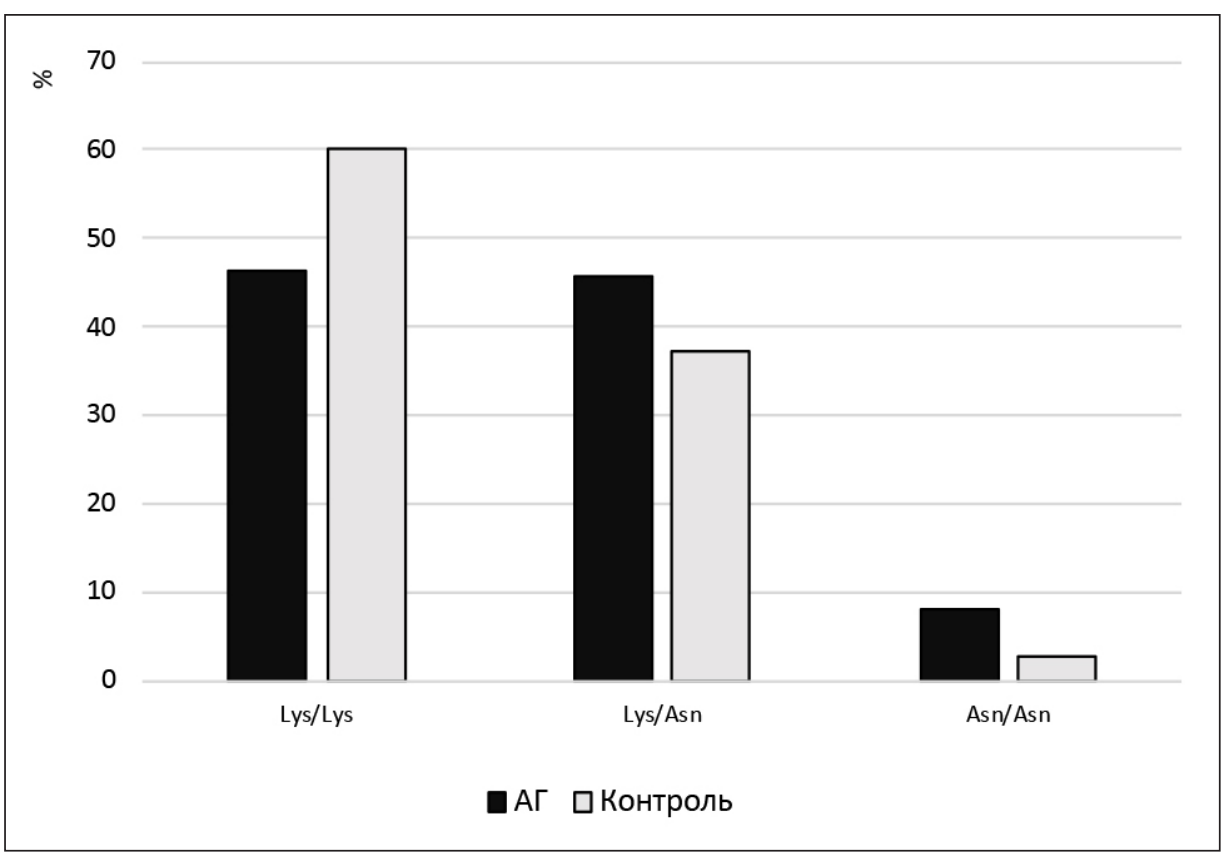

Рисунок 2. Частота генотипів за Lys198Asn-поліморфизмом гена EDN1 серед хворих з артеріальною гіпертензією та контролем.

бінарної логістичної регресії встановлено, що серед пацієнтів, що палять, носії Asn-алелю (Lys/Asn та Asn/Asn-генотипи) мають у 2,6 (95\% CI = 1.224-5.488) рази вищий ризик розвитку АГ порівняно з особами, що мають Lys/Lys-генотип відповідно до домінантної моделі успадкування ( $\mathrm{P}=0.013)$. Більш того, за даними адитивної моделі успадкування у цій групі пацієнтів гомозиготи за Asn-алелем (Asn/Asn) мають у 7,3 (95\% $\mathrm{CI}=1.295-41.639)$ рази вищий ризик настання АГ $(\mathrm{P}=0.024)$ у порівнянні з гомозиготами за Lys-алелем (Lys/Lys) (табл. IV). Результати аналізу асоціації генетичного поліморфізму Lys196Asn гена END-1 з розвитком артеріальної гіпертензії у пацієнетів з гіперхолестеролемією представлені у Таблиці V. Встановлено відсутність статистично значимого зв'язку між алельним поліморфізмом Lys196Asn та настанням АГ серед осіб, що мають підвищений рівень холестеролу крові (Р > 0.05) у даній групі пацієнтів.

Підвищення рівня ендотеліну-1 було доведено у багаточисельних експериментальних і кліничних дослідженнях при серцевій недостатності [11,12], інфаркті міокарду [13], аритміях [14], атеросклерозі [15]. Показано, що при прогресуванні стенокардії одночасно з підвищенням рівня ендотеліну-1 суттєво погіршується ендотелійзалежна вазодилятація судин [16]. $€$ дані про те, що за умов хронічної артеріальної гіпертензії, що супроводжується порушеннями функцій нирок, підвищується утворення і секреція ендотеліну-1 [17.]

Ген EDN1 локалізований на хромосомі 6p24-p23 і складається з 5 екзонів та чотирьох інтронів $[18,19,20]$. На сьогодні відомо понад 2 тисячі однонуклеотидних поліморфізмів гена EDN1 (згідно з даними National Center for Biotechnology Information (NCBI)). Доведена асоціація поліморфізмів гена EDN1 3 артеріальною гіпертензією [21,22,23], легеневою гіпертензією [24], гострим коронарним синдромом [25,26.], серцевою недостатністю [27], інфарктом міокарда [28], ішемічним інсультом [29]. Одним із клінічно важливих $€$ Lys198Asn-поліморфний сайт. Припускають, що заміна G/T у 5-у екзоні у 5665-й позиції нуклеотидної послідовності, що призводить до заміни амінокислоти лізин (Lys) на аспарагін (Asn) 198 позиції амінокислотної послідовності, змінює білкову структуру і активність ферменту. У наших дослідженнях було доведено, що Lys198Asn-поліморфізм асоційований 3 розвитком артеріальної гіпертензії в українській популяції. Подібні дослідження проведені іншими вченими для різних 
популяцій. Так, група вчених T. Rankinen et al. досліджувала вплив Lys198Asn-поліморфізму гена EDN1 на артеріальний тиск залежно від рівня фізичної активності людини. Автори показали, що в осіб із низьким рівнем фізичної активності, якіє гомозиготами за мінорним алелем, ризик розвитку АГ більший майже вдвічі (P = 0,0003), проте такого зв’язку не встановлено у фізично активних і тренованих осіб [30]. У праці V. Adámková et al. підтверджено асоціацію Lys198Asn поліморфного сайта з функцією ендотелію та розвитком артеріальної гіпертензії [31]. За даними Dzholdasbekova A. U., Gaipov A. Е. Asn-алель i Asn/Asn-генотип за Lys198Asn-поліморфізмом гена EDN1 є маркером підвищеного ризику розвитку артеріальної гіпертензії [32]. В іншому дослідженні виявлено залежність ризику виникнення підвищеного артеріального тиску та коронарного синдрому від генотипів за Lys198Asn-поліморфним варіантом гена ендотеліну-1 [33]. За результатами досліджень А. U. Joldasbecova у казахській популяції генотип Asn/Asn у 6 разів частіше зустрічався серед пацієнтів 3 артеріальною гіпертензією, ніж в осіб контрольної групи $(\mathrm{P}=0,012)$ [34]. Проте, на відміну від інших, група вчених на чолі з S. Wiltshire вивчаючи зв'язок поліморфізму п'ятого екзона гена EDN1 з механізмами розвитку артеріальної гіпертензії, рівнем ліпопротеїдів, метаболічним синдромом і серцево-судинними захворюваннями, не одержали жодних достовірних результатів [35].

\section{ВИСНОВКИ}

1. Поліморфізм Lys198Asn гена EDN1 асоційований з розвитком артеріальної гіпертензії в українській популяції.

2. Носії мінорного алеля (Lys/Asn+Asn/Asn) мають в 1,7,а гомозиготи Asn/Asn - y 3,9 раза більший ризик виникнення артеріальної гіпертензіі, ніж особи з Lys/ Lys-генотипом.

3. Пацієнти, що палять з Lys/Asn та Asn/Asn-генотипами мають у 2,6, а гомозиготи за мінорним алелем (Asn/ Asn) у 7,3 раза вищий ризик настання АГ у порівнянні з гомозиготами Lys/Lys.

\section{REFERENCES}

1. Bochkareva Yu.V. Effektivnost kombinirovanoy terapii gipertonicheskoy bolezni u patsientov s trevozhno-depresivnyimi rasstroystvami. Aktualnyie voprosy diagnostiki, lecheniya i reabilitatsii bolnyh. Materialy XVII nauchno-prakticheskoy konferentsii s mezhdunarodnyim uchastiem 10 sentyabrya 2014 goda. GBOU DPO PIUV Minzdrava Rossii. 2014;p.30-37

2. Yanagisava M. et al. A novel potent vasoconstrictor peptide produced by vascular endothelial cells. Nature. 1988; 6163(332):411 - 415

3. Timasheva Ya.R., Nasibullin T.R., Imaeva E.B., et al. Polimorfizm genov sistemyi endotelina - $1 \mathrm{i}$ risk essentsialnoy gipertenzii.- Meditsinskaya genetika. 2015;10:29- 35

4. Stewart D.J. Increased plasma endothelin-1 in pulmonary hypertension: marker or mediator of disease. Annals of internal medicine. 1991;114:464-469

5. Caprioli J. et al. Polimorphisms of EDNRB, ATG and ACE genes in salt-sensitive hypertension. Canadian journal of physiology and pharmacology. 2008;8(86):505-510

6. Khimji A.K., Rockey D.C. Endothelin-biology and disease. Cell Signal. 2010;22:1615-1625
7. Hynynen M.M., Khalil R.A. The vascular endothelin system in hypertension-recent patents and discoveries. Recent Pat Cardiovasc Drug Discov. 2006;1:95-108

8. Gozmakov 0.A. Sistema endotelinovyih peptidov: mehanizmyi endovaskulyarnyih patologiy. Kardiologiya. 2000;1:32-39

9. Berezikova E.N. Kliniko-geneticheskie i neyrogormonalnyie mehanizmyi razvitiya ishemicheskogo remodelirovaniya, apoptoza miokarda i serdechnoy nedostatochnosti: innovatsionnaya strategiya personalizirovannoy diagnostiki, profilaktiki i lecheniya : avtoref. dis. na soiskanie uchenoy stepeni d.med.n. : 14.01.05. Tomsk, 2014;p. 49

10. Jin J.J., Nakura J, Wu Z. et al. Association of Endothelin-1 Gene Variant With Hypertension. Hypertension. 2003;41:163-167

11. Vizir V.A., Berezin A.E. Rol endotelina-1 v progressirovanii serdechnoy nedostatochnosti. Ukr. med. chasopis. 2003:3(35):5-16

12. Munter K, Kirchengast M. The role of endothelin receptor antagonists in cardiovascular pharmacotherapy. Expert. Opin. Emerg. Drugs. 2001;6:3-11

13. Knyazkova I.I., Tsyigankov A.I., Dalashzade S.R. Vliyanie kaptoprila na izmenenie endotelialnyih faktorov u bolnyih s ostryim infarktom miokarda. Ukr. kardlol. zhurn. 2004;7:34-38

14. Luster T.F., Barton M. Endothelins and endothelin receptor antagonists: therapeuttic considerations for a novel class of cardiovascular drugs. Circulation. 2000;102:2434-2440

15. Spinar J., Spinarova L., Vitovec J. et al. Big endothelin and chronic heart failure. Vnitr. Lek. 2002;48:3-7

16. Yip H.K., Wu C.J., Chang H.W. et al. Prognostic value of circulating levels of endothelin-1 in patients after acute myocardial infarction undergoing primary coronary angioplasty. Chest. 2005;127:1491-1497

17. Zateynikov D.A., Minushkina L.0., Kudryashova 0.Yu. i dr. Funktsionalnoe sostoyanie endoteliya u bolnyih arterialnoy gipertoniey i ishemicheskoy boleznyu serdtsaю Kardiologiya. 2000;6:14-17

18. Arinami T., Ishikawa M., Inoue A., et al. Chromosomal Assignments of the Human Endothelin Family Genes: the Endothelin-1 Gene (EDN1) to 6p23-P24, the Endothelin-2 Gene (EDN2) to 1p34, and the Endothelin-3 Gene (EDN3) to 20q13.2-013.3. Am J Hum Genet. 1991;48:990-969

19. Inoue A., Yanagisawa M., TakuwaY., etal. The human préproendothéline-1 gene: complete nucleotide sequence and regulation of expression. J. Biol. Chem. 1989;264:14954-14959

20. Kenneth D.B., Friedrich S.P., Lee M.E., et al. Structural Organization and Chromosomal Assignment of the gene encoding endothelin. The journal of biological chemistry. 1989;18(264):10851-10857

21. Fan X.H. et al. The association of an adenine insertion variant in the $5^{\prime}$ UTR of the endothelin-1 gene with hypertension and orthostatic hypotension. Arch. Med. Sci. 2012;2(8):219-226

22. Fang Z. et al. Association of endothelin-1 gene polymorphisms with essential hypertension in a Chinese population. Genet. Mol Res. 2017;3(16)

23. Tobe S.W. et al. The impact of endothelin-1 genetic analysis and job strain on ambulatory blood pressure. Journal of Psychosomatic Research. 2011;71:97-101

24. Emad I., Abeer K., Nermin Z. The role of the biomarker and the genetic polymorphism of endothelin-1 in pulmonary arterial hypertension among Egyptians. Egyptian Journal ofChestDiseases and Tuberculosis. 2012;61:495-500

25. Vargas-Alarcon G. et al. The -974C>A (rs3087459) gene polymorphism in the endothelin gene (EDN1) is associated with risk of developing acute coronary syndrome in Mexican patients. Gene. 2014;2(542):258-262

26. Ahmed M., Rghigh A. Polymorphism in Endothelin-1 Gene: An Overview. Curr. Clin. Pharmacol. 2016:3(11):191-210 
27. Kitsios G., Zintzaras E. Genetic variation associated with ischemic heart failure: a HuGE review and meta-analysis. Am. J. Epidemiol. 2007;6(166):619-633

28. Palacín M. et al. Lack of association between endothelin-1 gene variants and myocardial infarction. J. Atheroscler. Thromb. 2009;4(16):388-395

29. Zhang L., Sui R. Effect of SNP Polymorphisms of EDN1, EDNRA, and EDNRB Gene on Ischemic Stroke. Cell. Biochem. Biophys. 2014;70:233-239

30. RankinenT.etal.Effect of endothelin 1 genotype on blood pressure is dependent on physical activity or fitness levels. Hypertension. 2007;50:1120-1125

31. Minushkina L.0. et al. Angiotensin converting enzyme, N0-synthase, and endothelin-1 genes and left ventricular hypertrophy in natives of Yakutia with hypertensive disease. Kardiologiia. 2005;1(45):41-44

32. Dzholdasbekova A. U., Gaipov A. E. The association between polymorphism of Lys198Asn of endothelin-1 gene and arterial hypertension risk in Kazakh people. Eur. J. Gen. Med. 2010;2(7):187-191

33. Popov A.F. et al. Impact of endothelin-1 Lys198Asn polymorphism on coronary artery disease and endorgan damage in hypertensives. Coronary Artery Disease. 2008;(19): 429-434
34. Joldasbecova A. U. candidate-genes of cardiovascular diseases in Kazakh population. Eur. Asian. Journal of BioMedicine. 2008;1(3)28-30

35. Wiltshire S. et al. Investigating the association between K198N coding polymorphism in EDN1 and hypertension, lipoprotein levels, the metabolic syndrome and cardiovascular disease. Hum Genet. 2008;123:307-313

Представленна работа виконана в рамках теми наукових досліджень з держбюджетним бінансуванням «Молекулярно-генетичні та морфологічні особливості регенерації тканин нижньої кінцівки в умовах хронічної гіперглікемї̈, № держ. реєстрації $0117 \mathrm{U} 003926$.

\section{Вклад авторів:}

В порядку черговості авторства.

\section{Конфлікт інтересів:}

Автори не заявляють про конфлікт інтересів.

\author{
АВТОР ДО КОРЕСПОНДЕНЦІї \\ Юлія 0. Сміянова \\ Сумський державний університет \\ вул. СКД 10/3, Суми, Україна \\ тел: +380996098329 \\ e-mail:smijanova@ukr.net
}

Надіслано: 12.02.2019

Затверджено: 29.03.2019 
PRACA ORYGINALNA

ORIGINAL ARTICLE

\title{
ANALYSIS OF THE PHYSICAL DEVELOPMENT OF YOUTH AND THE STATE OF ITS HEALTH
}

\author{
Oleksandr V. Kharchenko ${ }^{1}$, Nataliya V. Kharchenko ${ }^{2}$, Inna Y. Shaparenko ${ }^{1}$, Lyudmyla M. Sakharova ${ }^{3}$, \\ Yulia P. Yushchenko \\ 'POLTAVA NATIONAL PEDAGOGICAL UNIVERSITYNAMED AFTER V. H. KOROLENKO, POLTAVA, UKRAINE \\ ¿UKRAINIAN MEDICAL STOMATOLOGYCAL ACADEMY, POLTAVA, UKRAINE \\ ${ }^{3}$ POLTAVA STATE AGRARIAN ACADEMY, POLTAVA, UKRAINE
}

\begin{abstract}
Introduction: The sharp deterioration in the physical development of the younger generation is worrying. The morbidity of youth has increased by $29.9 \%$ compared with the last century. More than $33 \%$ of boys and girls, among first-year students with chronic diseases.

The aim: Assessing the state of the students'body by examining the results of a survey among the second- and third-year students of the university using a specially designed questionnaire.

Materials and methods: The material on the assessment of the state of health and the characteristics of the organism has been processed by studying the results of a survey of young men and women aged 20-23, obtained on the basis of using the developed questionnaire.

Results: Physical development has been studied in accordance with the state of health of the students, as well as a thorough study of a number of criteria: diseases of the musculoskeletal system were $37.1 \%, 49.7 \%$ and 43.45 among boys aged 20,22 and 23 and respectively $33.3 \%, 38.6 \%$ and $47.7 \%$ among girls in their 20 s, 22 s and 23 s. The morbidity of eye was $18.0 \%, 3.8 \%$ and $9.9 \%$ among boys aged 20,22 and 23 years and $17.7 \%, 17.1 \%$ and $7.7 \%$ among girls aged 20,22 and 23 years.

Conclusions: In the structure of morbidities are diseases of the musculoskeletal system, diseases of the nervous system and the organ of vision. Correlation of the characteristics of the level of students' health and their physical development have indicators on the level of educational adaptation and the number of diseases.
\end{abstract}

KEY WORDS: health, student, physical development, morbidity

Wiad Lek 2019, 72, 4, 575-578

\section{INTRODUCTION}

The Charter of the World Health Organization (WHO) states that health is a state of complete physical, mental and social well-being. This concept has many aspects and is due to many factors, so a clear, acceptable to all definition of the concept of "health" does not exist. It is believed that health is a normal state of the body, which is characterized by optimal self-regulation, complete consistency in the functioning of all organs and systems, the balance between the body and the external environment in the absence of painful manifestations.

Indicators of physical health are the individual characteristics of the anatomical structure of the body, the perfect (normal) physiological functioning of the body in various conditions of rest, movement, environment, genetic heritage, the level of physical development of organs and body systems.

Physical development is a process of formation and changes of biological forms and functions of the human body and is assessed by the level of development of physical qualities, anthropometric and dynamometric indicators, indicators of posture formation. It is next to the birth rate, morbidity and mortality, is one of the most important indicators. The processes of physical and sexual development reflect the general patterns of growth and development, but at the same time substantially depend on social, economic, sanitary and hygienic and other conditions, the influence of which is largely determined by the person's age.

Under the physical development is to understand biological processes which occur continuously. At each age stage, they are characterized by a certain complex of morphological, functional, biochemical, mental and other properties of the organism. A high level of physical development is combined with high levels of physical fitness and performance.

Analysis of the scientific literature shows that for Ukraine the problem, which is connected with the future of the state, is the preservation and strengthening of the health of young people. Its health is one of the main sources of power of the society as a whole. Anxiety causes a sharp deterioration in the physical development of the younger generation. The incidence of youth has increased by $29.9 \%$ compared with the last century. Among first-year students, more than $33 \%$ of boys and girls have chronic diseases. The physical development of 
student youth has such negative tendencies to asthenia, reduction of the chest perimeter, lung capacity and muscle strength [1].

According to the monitoring study, it can be seen that the number of healthy young people is decreasing. So in the 2016-2017 school year, $42.7 \%$ of healthy youth were recorded, in the 2017-2018 school year, the number of practically healthy youth does not exceed $30 \%[2,3,4]$.

The most likely causes of this situation are environmental problems in the country, sanitary culture, reduced attention to social problems, weakening state policy in the field of preventive medicine, reducing the number of research on growth, the development of healthy young people and their health management. When a healthy lifestyle is observed, which is confirmed by the correlation analysis of its components, the efficiency of young people increases [5].

It cannot but be disturbed by the fact that the indicator of excess weight among representatives of student youth is growing every year. This indicates a lack of nutritional culture. This situation cannot but worry teachers and doctors, because young people, coming to the university, already have deviations in health. For the prevention of obesity in the organization and selection of physical culture it is necessary to take into account the physiological mechanisms and features of motor activity [6]. Therefore, the main task in the activity of pedagogical teams of educational institutions at the present stage should be the preservation and strengthening of health, the formation of positive motivation for a healthy lifestyle of the younger generation [7].

So, a healthy lifestyle helps to strengthen the social health of the individual and society as a whole. It includes values of a high order, since it is aimed at humanizing and activating human activity, improving individual personal qualities [8].

\section{THE AIM}

The aim of the study is to assess the morpho-functional state of the body of students by examining the results of a survey of boys and girls of III - IV university courses based on the use of a specially designed questionnaire.

\section{MATERIALS AND METHODS}

Material for assessing the health status and characteristics of the morpho-functional state of students aged 20-23 years was collected as a result of surveys that have been conducted using a specially designed questionnaire. Questions were proposed for processing by students, in order to obtain adequate both subjectively and objectively significant answers were clearly structured and provided an opportunity to get comprehensive answers on such problem blocks: data on a generalized assessment of living conditions of the living environment ( 1 block of questions), data to determine the features of social and living conditions of permanent residence of boys and girls
(2 sets of questions), data on the features of the regime for students with the obligatory consideration of the factors that can cause and A degree of mental or physical activity (3 sets of questions), data on the detailed characteristics of features of educational-relevant adaptation with the determination of the severity of general fatigue (4 blocks of questions), data on the assessment of the health status and characteristics of the morpho-functional state of the body of young men and women (5 blocks of questions). In general have been surveyed 53 students among whom were 27 boys and 26 girls.

Ethics Commission of the Poltava National Pedagogical University named after V.H.Korolenko noted that the study was carried out without violations by the students studied. The latter were fully aware of the methods and scope of research. The survey has been conducted voluntarily and anonymously in accordance with the requirements and standards, model regulations on ethics issues of the Ministry of Health of Ukraine No. 690 of September 23, 2009.

\section{RESULTS AND DISCUSSIONS}

In the course of assessing the spread of diseases with temporary disability, we found that $17.6 \%$ and $24.3 \%$ of boys and girls aged 20 years were ill more than 4 times a year, $3.3 \%$ and $17.6 \%$ of boys and girls aged 22 years and $11.0 \%$ and $6.6 \%$ of boys and girls aged 23 years, 3 times a year - respectively $14.3 \%$ and $25.5 \%$ of 20 -year-old boys and girls, $21.2 \%$ of 22 -year-old boys and girls and $3.3 \%$ and $21.3 \%$ of 23 -year-old boys and girls, 2 times a year $-24.3 \%$ and $15.3 \%$ of boys and girls aged 20, respectively, $15.6 \%$ and $25.5 \%$ of boys and girls aged 22 years and $23.1 \%$ and $30.5 \%$ of boys and girls aged 23 once a year - from $20.3 \%$ and $27.6 \%$ of 20 -year-old boys and girls, $44.4 \%$ and $22.2 \%$ of 22 -year-old boys and girls, and $41.3 \%$ and $23.1 \%$ of 23-year-old boys and girls, were not ill at all - respectively $26.6 \%$ and $10.0 \%$ of boys and girls aged 20 years, $13.3 \%$ and $16.6 \%$ of boys and girls aged 22 years and $20.0 \%$ and $16.6 \%$ of boys and girls aged 23 years.

In the structure of chronic diseases, the most common among students were diseases of the musculoskeletal system and connective tissue, namely flatfoot and poor posture, second place eye disease, among the latter, accommodation spasm and astigmatism prevailed, and in the third place girls had circulatory system diseases due to systolic noise and vegetative-vascular dystonia, young men had eating disorders and metabolic disorders due to diffuse non-toxic goiter, testicular hypoplasia and physical development. In the age group of 20 years among girls, the structure of diseases remained similar to the previous one, among young men endocrine diseases, eating disorders and metabolic disorders took the second place, diseases of the digestive organs due to functional stomach disorders and biliary tract dyskinesia took the third place.

Among the 23-year-old boys and girls, regardless of sexual differences, the first place was left for diseases of the musculoskeletal system and connective tissue, due to 
flat-footedness, scoliosis and other posture disorders, the pathology of the circulatory system due to vegetative circulatory dystonia remained in the third place, eye diseases due to myopia and accommodation spasm.

The proportion of diseases of the musculoskeletal system was $37.1 \%, 49.7 \%$ and 43.45 among boys aged 20,22 and 23 , and respectively $33.3 \%, 38.6 \%$ and $47.7 \%$ among girls 20 and 22 and 23s. The incidence of eye diseases was $18.0 \%, 3.8 \%$ and $9.9 \%$ among boys aged 20,22 and 23 years and $17.7 \%, 17.1 \%$ and $7.7 \%$ among girls aged 20,22 and 23 years.

The proportion of persons distinguished by the presence of chronic pathology of the endocrine and digestive systems was somewhat less. Endocrine diseases, eating disorders and metabolic disorders were characteristic of $13.3 \%$ and $13.1 \%$ of 20 -year-old boys and girls, $20.6 \%$ and $7.7 \%$ of 22 -year-old boys and girls, $10.4 \%$ and $4.4 \%$ of 23 -year-old boys and girls, diseases digestive organs - for $8.0 \%$ of boys at the age of $20,11.3 \%$ of boys at the age of 22 years, $10.5 \%$ of boys at the age of 23 years and $7.0 \%$ of girls at the age of 23 years. The proportion of chronic diseases of the circulatory system was $8.0 \%$ and $15.8 \%$ among boys and girls aged 20 years, $4.5 \%$ and $9.3 \%$ among boys and girls aged 23 years. The proportion of chronic respiratory diseases is $11.0 \%$ and $9.3 \%$ among 20 -year-old boys and girls, $7.5 \%$ and $4.8 \%$ among 22 -year-old boys and girls, and $7.9 \%$ and $8.9 \%$ among 23 -year-old boys and girls. The proportion of diseases of the excretory system ranged from $0 \%$ to $3.1 \%$ among boys and from $4.2 \%$ to $5.1 \%$ among girls.

The correlation components of the health status of boys and girls aged 20,22, 23 years studying at the III-IV courses of the University showed that the indicators on the level of academic adaptation $(r=0.52-0.71, p<0.05-0.01)$, the number of diseases with temporary disability $(r=0.72-0.75$, $\mathrm{p}<0.001$ ), the presence of the frequency of recording exacerbations of chronic pathology $(\mathrm{r}=0.78-0.79, \mathrm{p}<0.001)$, features of the nature of schooling $(r=0.49-0.72, p<0.05$ 0.001 ) and neuro-emotional stress during the execution of daily training activities $(r=0.52-0.68, p<0.05-0.01)$, general assessment of living conditions $(\mathrm{r}=0.62-0.73, \mathrm{p}<0.05)$, peculiarities of relationships in the family $(r=0.65-0.66$, $\mathrm{p}<0.01)$, the duration of a night's sleep $(\mathrm{r}=0.52-0.67, \mathrm{p}$ $<0.05-0.01$ ), the peculiarities of state of health at the end of the school day and the school week $(\mathrm{r}=0.55-0.77$, $\mathrm{p}$ $<0.05-0.001)$ as smoking $(\mathrm{r}=0.60-0.72, \mathrm{p}<0.05-0.001)$.

When studying the mode of daily activities of the students studied, the presence of significant deviations of the leading indicators from generally accepted hygienic standards and regulations was revealed.

According to WHO data in the developed countries of Europe, in the structure of general morbidity of the adult population, the first places are: respiratory diseases (about $26 \%$ ), diseases of the circulatory system (about 17\%), diseases of the musculoskeletal system and connective tissue (about 12\%), injuries and poisoning (about 12\%), diseases of the digestive system (about 9\%), diseases of the eye and its appendage apparatus (about 8\%).

According to our research, diseases of the musculoskele- tal system are three times higher than those in Europe, eye diseases are also dominated by European indicators, diseases of the digestive organs show similar results to $\mathrm{WHO}$.

Most of the boys and girls identified the nature of the educational process at the university as intense or moderately tense, linking the main problems that arose with a sense of fatigue, with the level of teaching and features of the educational process and the state of their own health.

Young adulthood, between the ages of 18 and 26, is a critical period for a person.

What happens at a young age has deep and long-term implications for the future of young people.

A higher incidence rate at a young age has important implications for future health, education, and economic well-being. Rapid technological change, economic problems and a long transition to adulthood, obviously contribute to health problems in young people, increasing their stress and sedentary habits, while at the same time reducing their likelihood to participate in work and family roles, which serve as powerful social control risk perception. That is, it can be expected that these alarming trends in relation to the health of young people have to continue and worsen.

The connection between physical health and physical development has been noted by a number of authors, especially from countries with a high level of economic development, studying the effect of physical exercises on the physical development of young people [9]. Exercise has a positive effect on the risk factors for cardiovascular diseases [10]. In recent decades, there has been a rapid development of high technology, affecting the adaptive capabilities of young people. Adaptive abilities of young people leading a sedentary lifestyle decrease [11]. And it cannot but be disturbed by the fact that over the past decades a tendency of deterioration in the physical development and health of this generation of the population has occurred among the young population of the world and in our country [12]. The group of young people we study has a sedentary lifestyle, the presence of chronic diseases of various etiologies, varying degrees of severity, which affect the level of efficiency and significantly impair the qualit

\section{CONCLUSIONS}

It was established that with age, the proportion of diseases characterized by the chronic course of the pathological process gradually increased. In their structure, the most common diseases of the musculoskeletal system, diseases of the nervous system and sensory organs, among the latter, violations of the functional state of vision prevailed. In the structure of morbidity with temporary disability, respiratory diseases, diseases of the digestive organs, and skin diseases significantly prevailed.

The correlation of the characteristics of the level of health and physical development of students had indicators on the level of educational adaptation, the number of diseases with temporary disability, the presence and frequency of registration of exacerbations of chronic pathology, features of the nature of education at the 
university and the level of neuro-emotional stress when performing daily educational activities, features of relationships in the family, the duration of the night's sleep, the characteristics of well-being at the end of the school day and the school week, the level I am a student in such an unhealthy habit like smoking.

\section{REFERENCES}

1. Hreyda B. Fizichnyi rozvytok ditey i pidlitkiv is urakhuvanyam stanu yih zdorovya. [The physical development of children and adolescents, taking into account their health.] Luck. VAT «Volynska oblasna drukarnya». 2005: 188. (in Ukrainian)

2. Osadchuk N.I., Gonchar 0.0. Dosligenya stanu zdorovya shkolyariv ta osoblyvosti yoho zvyazku z pokaznykamy fizychnoho rozvytku. [A study of the health status of schoolchildren and the characteristics of its connection with the indicators of physical development.] Biomedikal and biosocial antropology. 2014; 22: 264 - 268. (in Ukrainian)

3. Kharchenko 0.V. Fizichnyi rozvytok studentiv ta yoho zvyazok is stanom yihnyoho zdorovya. [The physical development of students and their relationship with their state of health.] Visnyk problem biologyi i medyciny. 2015; 1(118): 313 - 316. (in Ukrainian)

4. Kharchenko 0.V. Analiz stanu zdorovya ta yoho vplyv na fizychniy rozvytok studentiv pershykh kursiv. [Analysis of the health status and its impact on the physical development of freshmen students] Materialy IV Mizhnarodnoyi nauk. prakt. konf. Aktualni problemy fizychnoyi kultury, sportu ta zdorovya ludyny; 2015 Lyst. 5-6; Chernivci: 277 - 279. (in Ukrainian)

5. Kharchenko 0.V., Shaparenko I.Y. Stan zdorovya studentiv ta yoho zvyazok z yihnim fizychnym rozvytkom. [The state of health of students and its relationship with their physical development.] Materialy Vseukrayinskoyi nauk. prakt. konf. Istorychni, teoretyko-metodychni, medyko-biologichni aspekty fizychnoyi kultury i sportu; 2016 Kvit. 6-7; Chernivci: 121 - 125. (in Ukrainian)
6. Shaparenko I.Y. Providna rol rukhovoyi aktyvnosti v profilaktyci nadlyshkovoyi masy tila ta ojyrinia ditey i pidlitkiv. [The leading role of motor activity in the prevention of body weight and obesity in children and adolescents.] Materialy Mizhnarodnoyi nauk. prakt. konf. Biologichni, medychni ta naukovo-pedagogichni aspekty zdorovia ludyny: 2018 Jovt. 4-5; Poltava. Astraya:172-173. (in Ukrainian)

7. Kharchenko O.V. Monitoring zdorovya studentiv. [Monitoring of students' health.] Fizychne vyhovanya: teoriya i praktyka: Chasopys kafedry teoryi i metodyky fizychnoho vyhovanya, adaptyvnoyita masovoyifizychnoyikultury PNPU imeni V,H. Korolenka. Poltava: 2018; 4: 132 - 134. (in Ukrainian)

8. Kharchenko N.V. Zdorovyi sposib jittia yak proces upravlinia zdoroviam. [Healthy lifestyle as a process of health management.] Materialy Mizhnarodnoyi nauk. prakt. konf. Biologichni, medychni ta naukovopedagogichni aspekty zdorovia ludyny: 2018 Jovt. 4-5; Poltava. Astraya: 171-172. (in Ukrainian)

9. ClarkME, TobiasJH, Murray L, Boreham C.Children with low musclestrength are at an increased risk of fracture with exposure to exercise. Journal of Musculoskeletal and Neuronal Interactions. 2011; 11(2):196-202.

10. Malina R. Physical fitness of children and adolescents in the United States: Status and secular change. Medicine and Sports Science. 2007; 50:67-90.

11. Gutin $B, 0$ wens $S$. The influence of physical activity on cardiometabolic biomarkers in youths: A review. Pediatric Exercise Science. 2011; 23(2):169.

12. Bauman AE, Reis RS, Sallis JF, Wells JC, Loos RJ, Martin BW. Lancet Physical Activity Series Working Group. Correlates of physical activity: Why are some people physically active and others not. Lancet. 2012; 380(9838):258-271.

The work is a fragment of the research and development project "Realization of Health Savings Technologies in Physical Education in the Conditions of European Integration of Ukraine", state registration No. 0117 U003236.

\section{Authors' contributions:}

According to the order of the Authorship.

\section{Conflict of interest:}

The Authors declare no conflict of interest.

\author{
CORRESPONDING AUTHOR \\ Oleksandr V. Kharchenko \\ Poltava National Pedagogical University \\ named after V. H. Korolenko \\ 20 strohradskyi Street, \\ 36003 Poltava, Ukraine \\ tel. +380507404749 \\ e-mail:kharchenk07591@gmail.com
}

Received: 23.11.2018

Accepted: 14.02 .2019 
PRACA ORYGINALNA

ORIGINAL ARTICLE

\title{
SOCIAL- PSYCHOLOGICAL FEATURES OF VALUE ORIENTATIONS OF PATIENTS WITH ALCOHOL DEPENDENCE
}

\author{
Ulyana B. Mykhaylyshyn \\ UZHHOROD NATIONAL UNIVERSITY, UZHHOROD, UKRAINE
}

\begin{abstract}
Introduction: The article considers social-psychological features of value orientations of patients with alcohol dependence. The state of the problem under consideration in the psychological literature has been studied.

The analysis of empirical research of value orientations of patients with alcohol dependence has been conducted.

The aim: The aim of the paper is to identify social-psychological features of value orientations of patients with al cohol dependence.

Materials and methods: The research has been conducted at full-time treatment department of Transcarpathian Oblast Narcological Dispensary (Uzhhorod, Ukraine). The experiment involved 42 respondents ( 29 men and 13 women) of different age, the department patients, suffering on alcoholism. The techniques have been performed individually with each patient.

The following methods have been used:

1. Method of «Valuable Orientation» by M. Rokich.

2. Questionnaire on Terminal Values (QTV) by I.G.Senin.

3. Purpose-life orientation test (method of PLO) by D.A. Leontiev.

Results: It has been found out that the group hierarchy of values in cases with chronic alcoholism is characterised by an explicit orientation to specific vital values. There is a characteristic reverse development of the value sphere of an individual in cases with chronic alcoholism, which is displayed in the formation of orientations on the lower levels of the value system.

The results of empirical research have shown that among the patients with alcohol dependence the preference is given to terminal values, values - goals.

Conclusions: It has been generalised that value orientations are the component of the structure of an individual, which reflects the life experience gained by an individual in the individual development, and represents the core of consciousness, taking into account how personality makes decisions on important vital issues.
\end{abstract}

KEY WORDS: alcoholism, value orientations, terminal values, instrumental values, personality structure

Wiad Lek 2019, 72, 4, 579-583

\section{INTRODUCTION}

The problem of alcoholism is a danger not only for an individual, but also for the health of the nation as a whole, contributing to the increase in crime, the deterioration of physical and mental health of the population.

Nowadays, the number of patients with alcohol dependence increases, but there are no systematic studies of social-psychological aspects of lifestyle of patients with alcohol dependence, which represent a specific, large social group, characterised by a special system of values, and relationships.

Dependence of personality on psychoactive substances cannot but influence his/her value orientation, motivational structure, communication, system of relations with others, position, status in large and small social groups and other social-psychological characteristics that determine the lifestyle of an individual in a society.

The topic of value orientations for persons suffering from alcoholism is not sufficiently studied and described in scientific literature. Psychology is far behind the needs of practice, both in the study of social-psychological problems of alcoholism, and in the development of the most effective prophylactic and rehabilitation programmes for patients with alcohol dependence.

\section{ANALYSIS OF RECENT RESEARCHES AND PUBLICATIONS ON THE PROBLEM UNDER CONSIDERATION}

Values in psychology have been studied by B.G. Ananiev, M.Ya. Boryshevskyy, Z.S. Karpenko, S.L. Rubinstein, V.O. Yadov, T.S. Yatsenko. In particular, B.G. Ananiev, S.L. Rubinstein, M. Rokich point out that the mastery of the system of values is closely linked with the direction of activity of an individual. Researchers point out that values, being central personal entities, express the conscious attitude of an individual towards social reality. And through this quality they determine the broad motivation of behaviour and affect all aspects of activity. In this regard, S.L.Rubinstein notes that social scale of values is displayed in the human activity to meet the immediate social needs. In satisfaction of personal and individual needs through the socially useful activity, the attitude of an individual towards society and, accordingly, to oneself as a part of society is realised [1, p. 615].

M. Rokich considers values as abstract ideas, positive or negative, not related to a particular object or situation, which express human beliefs about types of behaviour and actual goals and do 
not have an independent motive force. According to his studies, values are divided into two groups: terminal (define long-term prospects of life and established norms of behaviour based on socially defined standards) and instrumental (characterising means of realisation and achievement of terminal values) [2, p. 543].

In some studies the concept of «value orientations» is essentially identical to the terms describing the motivational-needy or sense field [3, p. 28]. For example, A. Maslow actually does not share the concept of «values», «needs» and «motives». In A. Maslow's theory groups of values constitute a vertical hierarchy. According to him, the needs and values «are not the dichotomy, but a coherent hierarchy, that is, they depend on each other2 [4, p.301]. Maslow distinguishes two main groups of values: (i) B-values (values of being) - higher values, inherent in people who are inclined to self-actualisation (truth, goodness, beauty, integrity, overcoming the dichotomy, vitality, uniqueness, perfection, completeness, fairness, order, simplicity, ease, without effort, etc.); (ii) D-values (deficient values) - lower values, directed to meet specific frustrated needs (peace, rest, sleep, rest, reliance, security, etc.).

"D-values», occupying the subordinate position, are chosen by people «for the sake of survival», the achievement of the state of homeostasis. Their implementation is «an absolute necessity» and a prerequisite «feeling and functioning» of higher «B-values» or «values of development» [2, p.303].

D.A. Leontiev is one of the representatives of domestic psychology in the study of value orientations. He notes that the individual hierarchy of value orientation, as a rule, is a sequence of rather well-delineated «blocks». T.O. Leontiev provides possible grouping of values, united into blocks for various reasons, which are a kind of polar value systems. [5, p.17].

The problem of values is central in the studies by T.S. Yatsenko - Academician of the National Academy of Sciences of Ukraine The author argues that perceived and proclaimed values cannot fully determine human behaviour in society. At the same time, the scientist focuses on identifying of discrepancies between what a person deliberately declares and the results of actions performed contrary to the declared goals and values [6, p.57].

Thus, value orientations represent special psychological formations and are the elements of the structure of an individual.

With regard to studies of value orientations in patients with alcohol dependence, one can conclude that, nowadays, this topic is not sufficiently studied and described in the scientific literature. Domestic scientists - V.A. Khaschenko, N.I. Lapin, L.N. Sobchyk, M.S. Yanytsky, V.A. Zhmurov, N.A. Zhuravleva - work out problem.

B.S. Bratus points to the «reduction» of motivational and semantic sphere of «alcoholic personality». According to him, patients with alcoholism «... can realise the incompatibility of their behaviour with the former semantic attitudes and values. But unfortunately, this awareness is rarely complete, it remains only as «understanding», which can lead to temporary repentance, but is deprived of real active force. B.S. Bratus explains this by the gradual destruction of the former motivational-semantic hierarchy and the formation of a new one. Group hierarchy of values in chronic alcoholism is characterised by explicit orientation to specific vital values. Analysis of representations about the implementation of certain vital values indicates the uncriticality of their self-perception and anosognosy, as the respondents tend to consider themselves healthy, free in choosing a life strategy, responsible, honest, sensitive, neat and tidy, etc.

Thus, we can speak of characteristic reverse development of the value sphere of personality in chronic alcoholism, which is displayed in the formation of orientations on the lower levels of the value system [7, p.247].

\section{THE AIM}

The aim of the paper is to identify social-psychological features of value orientations of patients with alcohol dependence.

\section{MATERIALS AND METHODS}

The research has been conducted at full-time treatment department of Transcarpathian Oblast Narcological Dispensary (Uzhhorod, Ukraine).

The experiment involved 42 respondents $(29$ men and 13 women) of different age, the department patients, suffering on alcoholism. The techniques have been performed individually with each patient.

The following methods have been used:

1. Method of «Valuable Orientation» by M. Rokich.

2. Questionnaire on Terminal Values (QTV) by I.G.Senin.

3. Purpose-life orientation test (method of PLO) by D.A. Leontiev.

\section{RESULTS AND DISCUSSION}

Having applied the method of «Valuable Orientation» by M. Rokich, the following results are obtained (Figure 1, Figure 2):

- among the terminal values occupy: the first place - health (11 respondents, 26\%); the second - love (10 respondents, 24\%); the third - happy family life (8 respondents, $19 \%)$; the fourth - life wisdom and having good and faithful friends (3 respondents, 7\%).

- among the instrumental values occupy: the first place - independence and honesty (8 respondents, 19\%), the second - upbringing ( 7 respondents, $17 \%$ ), the third - responsibility and effectiveness in deeds (3 respondents, $7 \%$ ). Having applied the Questionnaire on Terminal Values (QTV) by I.G.Senin, according to the key of the technique, the following results are obtained.

In the first place indicators beyond the range of 4 to 7 stens are interpreted, because all the indicators in this range can be considered close to the average.

In our case, out of bounds are the indicators of terminal values, such as creativity and self development (see Figure 4), as well as the indicators of life spheres - the sphere of professional life and the sphere of education and training (see Figure 3). In this case, the indicators are below the norm.

According to the key, the low score on the scale of creativity reflects the lack of a person's desire to realise own creative potential, to make various changes in all spheres of life. Respondents with low points for this indicator do not avoid stereotypes. Such people usually prefer the measured pace of their lives. In the field of professional life this is displayed in 


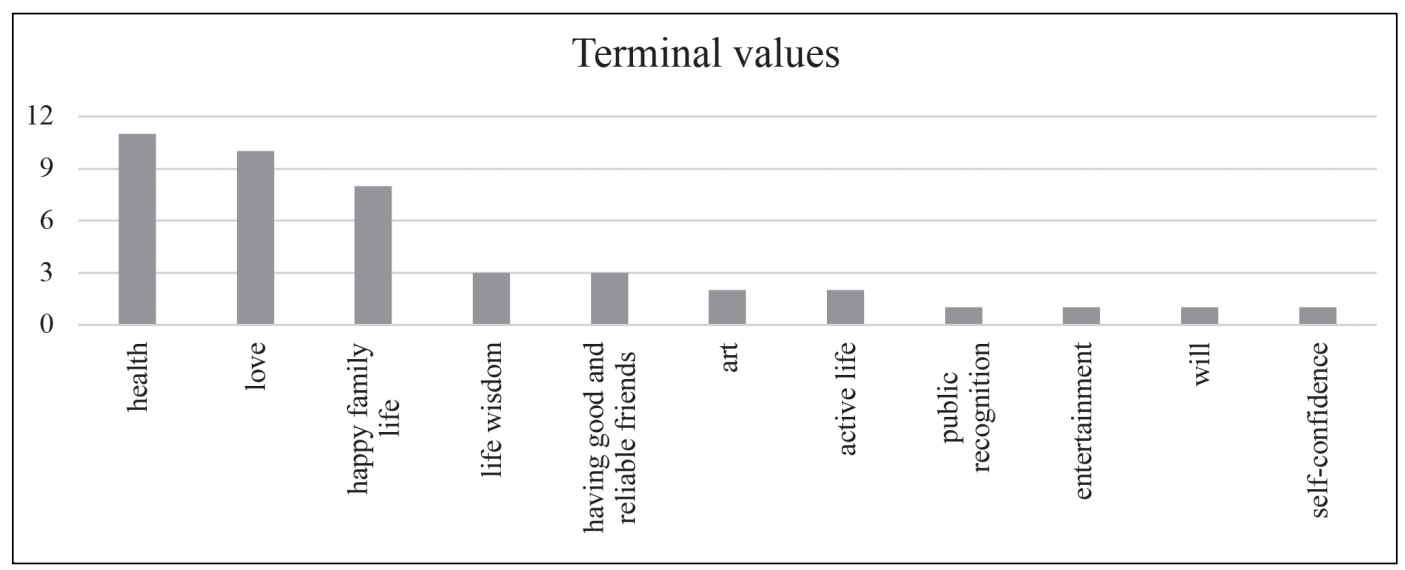

Figure 1. Graphic presentation of the hierarchy of terminal values

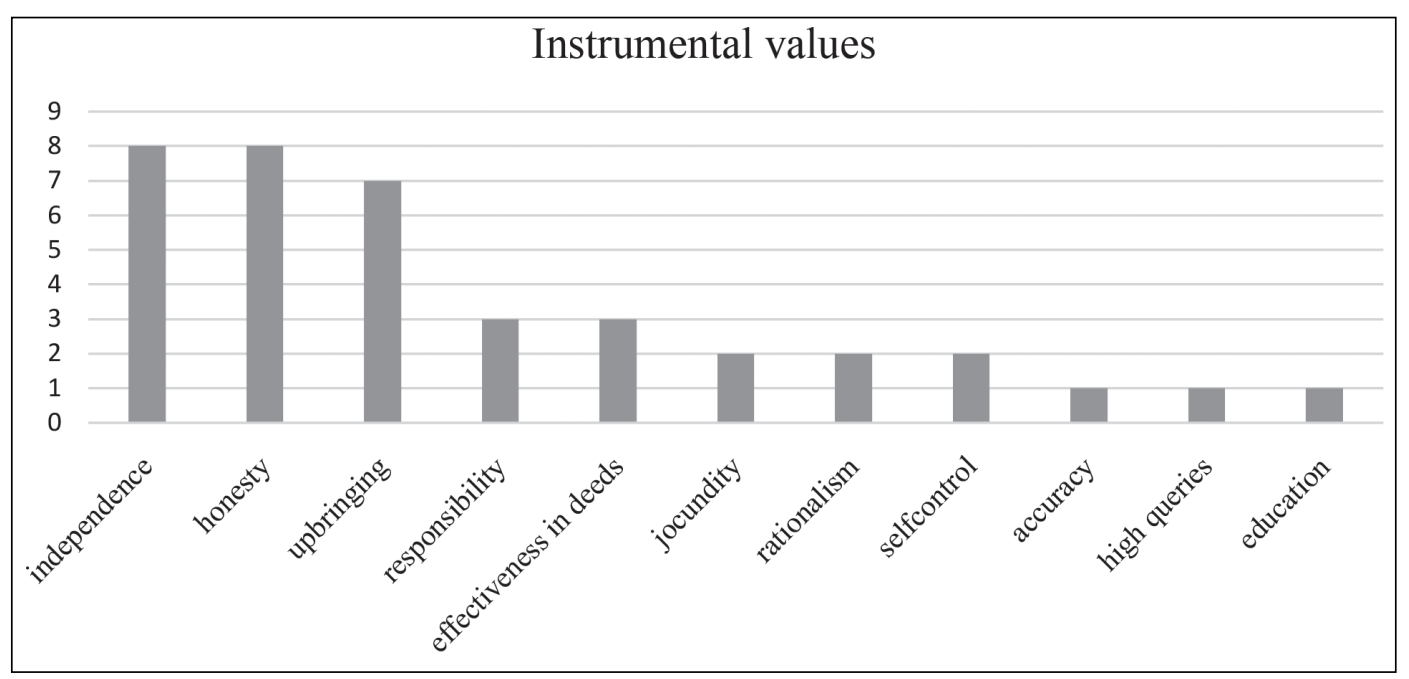

Figure 2. Graphic presentation of the hierarchy of instrumental values

the fact that the respondents prefer the usual ways of work organising and methods of its conducting, they are not characterised by the desire to make various changes and improvements in the work. In the field of education and training the lack of interest in the learning process and gaining of new information is observed.

Low points on the scale of «self-development» - is the lack of interest of a person in objective information about the peculiarities of his/her character, abilities, and other characteristics of personality. Such people, as a rule, do not seek self-improvement, thinking that potential human capabilities are limited. In the field of professional life this is expressed in the absence of desire to realise own abilities and to increase own professional qualifications. In the field of education and training this is expresses in the lack of human desire to master the level of education in order to develop own abilities.

Among the terminal values the result on the scale of:

- «own prestige»: below the norm - 7 respondents (17\%), within the norm -32 respondents $(76 \%)$, above the norm -3 respondents $7 \%$;

- «high financial position»: below the norm - 1 respondent (2\%), within the norm -40 respondents (96\%), above the norm -1 respondent $(2 \%)$;
- «creativity»: below the norm - 34 respondents $(81 \%)$, within the norm -8 respondents (19\%);

- «active social contacts»: below the norm -5 respondents (12\%), within the norm -37 respondents $(88 \%)$;

- «self-development»: below the norm - 20 respondents (48\%, within the norm -22 respondents (52\%);

- «achievement»: below the norm - 8 respondents (19\%), within the norm -27 respondents (64\%), above the norm -7 respondents (17\%);

- «spiritual satisfaction»: below the norm - 15 respondents $(36 \%)$, within the norm -22 respondents (52\%), above the norm -5 respondents (12\%);

- «preserving own individuality»: below the norm - 13 respondents $(31 \%)$, within the norm -28 respondents (67\%), above the norm -1 respondent $(2 \%)$.

Among the life values the result on the scale of:

- «professional life»: below the norm - 32 respondents (77\%), within the norm -10 respondents $(23 \%)$;

- «education and training»: below the norm - 32 respondents (77\%), within the norm - 10 respondents (23\%);

- «family life»: below the norm -21 respondents (50\%), within the norm -13 respondents (31\%), above the norm -8 respondents (19\%); 


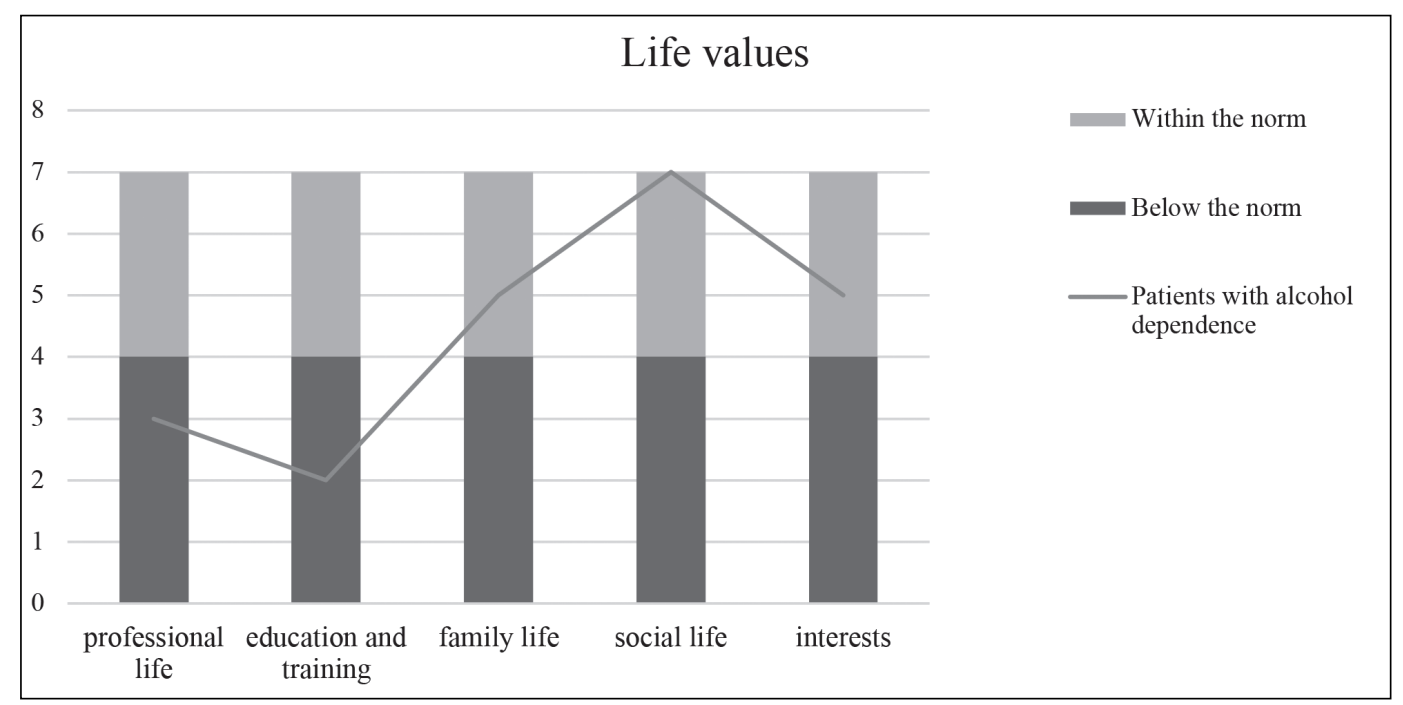

Figure 3. Graphic presentation of the results of studying the life spheres of patients with alcohol dependence

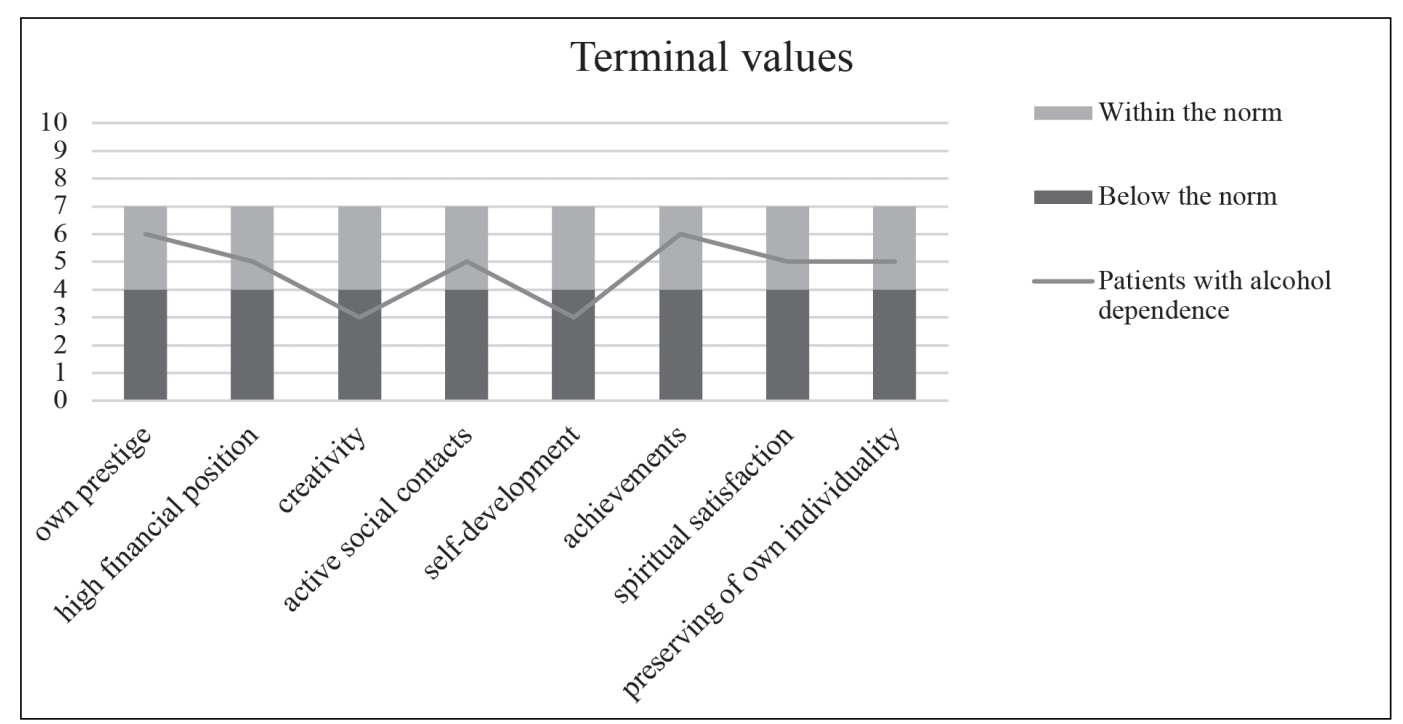

Figure 4. Graphic presentation of the results of the study of terminal values of patients with alcohol dependence

- «social life»: within the norm - 37 respondents (88\%), above the norm -5 respondents $(12 \%)$;

- «interests»: within the norm - 35 respondents (83\%), above the norm -7 respondents (17\%).

Having applied the Purpose-life orientation test (method of PLO) by D.A. Leontiev, the following results are obtained (Figure 5):

(i) average values of formation of purpose-life orientations of patients with alcohol dependence in comparison with average values after the test by D.A. Leontiev are within the norm; (ii) the result on the subscale of:

- «Goals in life»: below the norm - 16 respondents (38\%), within the norm - 24 respondents (57\%), above the norm -2 respondents (5\%);

- «Process of life»: below the norm - 21 respondent (50\%), within the norm - 13 respondents $(31 \%)$, above the norm -8 respondents $(19 \%)$;

- «Effectiveness of life»: below the norm -23 respondents (55\%), within the norm -17 respondents $(40 \%)$, above the norm -2 respondents (5\%);
- «Locus control-I»: below the norm - 15 respondents $(36 \%)$, within the norm -22 respondents $(52 \%)$, above the norm -5 respondents $(12 \%)$;

- «Locus control-Life»: below the norm - 27 respondents $(65 \%)$, within the norm -14 respondents (33\%), above the norm -1 respondent (2\%);

- «Overall indicator of life consciousness»: below the norm -23 respondents (55\%), within the norm -17 respondents (40\%), above the norm -2 respondents (5\%).

\section{CONCLUSIONS}

Theoretical and methodological analysis of approaches to the study of social-psychological features of value orientations in patients with alcohol dependence has shown that alcoholism is a chronic disease characterised by passion for alcohol, loss of control over its use and distortion of thinking.

It has been found out that the group hierarchy of values in cases with chronic alcoholism is characterised by 


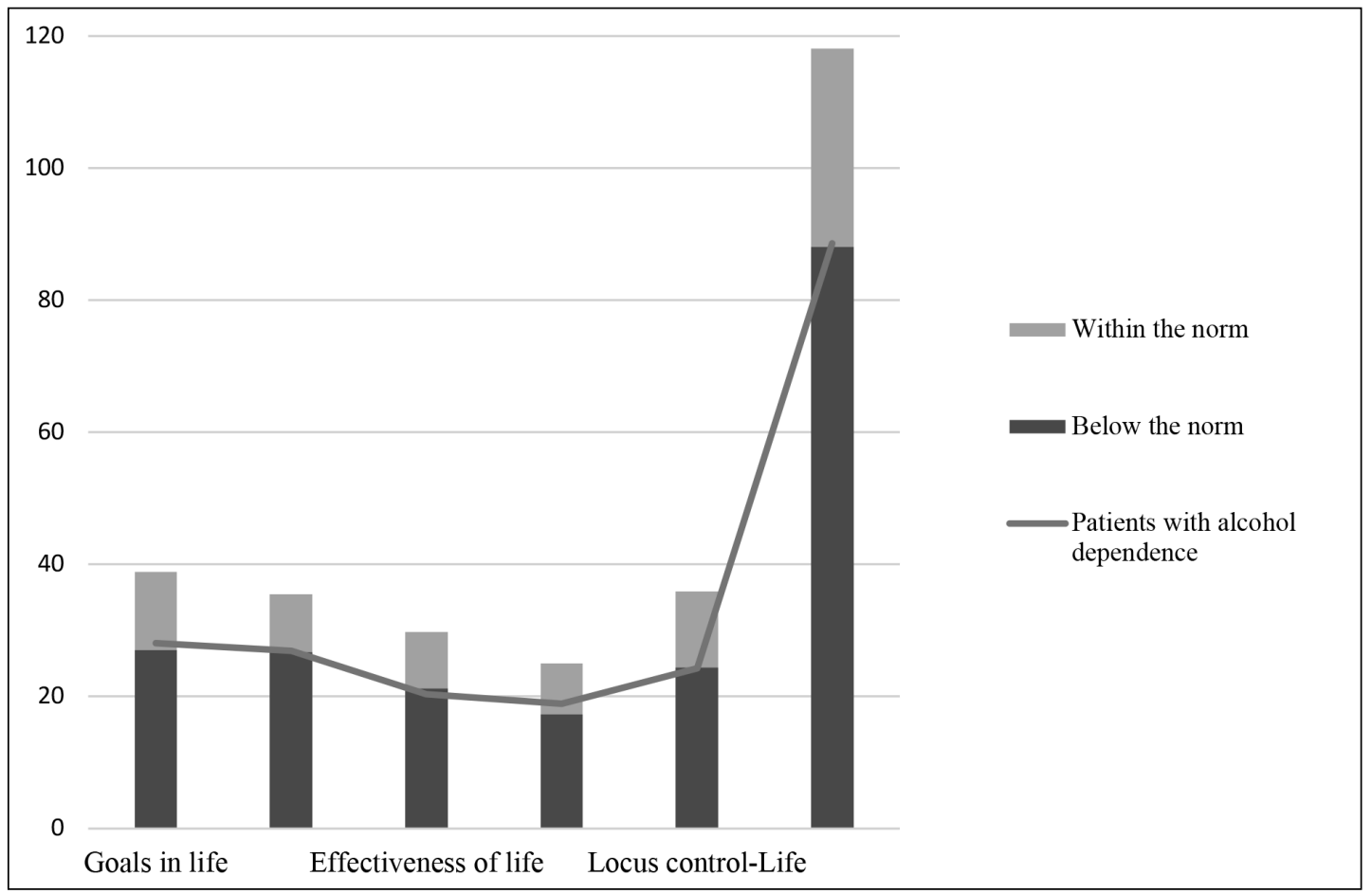

Figure 5. Average values of formation of purpose-life orientations of patients with alcohol dependence in comparison with average values after the test by D.A.Leontiev

an explicit orientation to specific vital values. There is a characteristic reverse development of the value sphere of an individual in cases with chronic alcoholism, which is displayed in the formation of orientations on the lower levels of the value system.

The results of empirical research have shown that among the patients with alcohol dependence the preference is given to terminal values, values - goals. This can be explained by the fact that these are the terminal values - the goals of the existence of an individual, his/her convictions - which relate to the goals or end states an individual seeks. In terms of the issues addressed in this article, the problem of social-psychological features of value orientations of patients with alcohol dependence is not definitely studied. Prospecting areas for the further research are: the deepening of theoretical and experimental data on the topic under consideration, namely, the statistical analysis of the data obtained in order to identify the features; the development of a corrective programme aimed at acquiring skills for correcting personal deficiencies, developing ideas about own values, reducing the level of aggressiveness, increasing the self-esteem, developing of communicative culture, forming of motivation for self-education of patients with alcohol dependence.

\section{REFERENCES}

1. Rubinshteyn, S.L. (1999). Osnovy obshchey psykholohyy [Fundamentals of general psychology]. SPb.: Pyter Kom.

2. Yadov, V.A. (2000). Stratehyya sotsyalnoho yssledovanyya: opysanye, obyasnenye, ponymanye sotsyalnoy realnosty [Strategy of sotsial research: description, explanation, understanding of social reality]. Moscow: Dobrosvet.
3. Barabanshchykov, B.A. (2003). Systemnaya orhanyzatsyya y razvytye psykhyky [System organization and development of the psyche]. Psykholohycheskyy zhurnal [Psychological Journal], 1, 28-38.

4. Maslow, A. (1999). Novye rubezhy chelovecheskoy pryrody [The Farther Reaches of Human Nature]. Moscow: Smysl.

5. Leontiev, D.A. (1992). Metodyka yzuchenyya tsennostnykh oryentatsyy [The method of studying value orientations]. Moscow: Vlados.

6. Yatsenko, T.S. (1987) Sotsyalno-psykholohycheskoe obuchenye v podhotovke budushchykh uchyteley [Social-psychological teaching in the training of future teachers]. Kyiv: Vyshcha shkola.

7. Bratus, B.S. (1988). Anomalyy lychnosty [Anomalies of personality]. Moscow: Mysl.

\section{Conflict of interest:}

The Author declare no conflict of interest.

\section{CORRESPONDING AUTHOR}

Ulyana B. Mykhaylyshyn

Uzhhorod National University

Universitetskaya street, 14, 88000 Uzhhorod, Ukraine

tel: +380506991399

e-mail:myb69@ukr.net

Received: 20.02 .2019

Accepted: 01.04.2019 


\title{
CHANGES IN THE SECRETARY ABILITY OF MONONUCLEAR CELLS IN PATIENTS WITH ATHEROSCLEROSIS AND ACCOMPANYING PATHOLOGY, DEPENDING ON THE C-PEPTIDE BLOOD PLASMA
}

\author{
Olena 0. Karlova', Olena V. Kuzminska' ${ }^{2}$, Alina I. Baryshnik² \\ P.L. SHUPYK NATIONAL MEDICAL ACADEMY OF POSTGRADUATE EDUCATION, KYIV, UKRAINE \\ 20.0. BOGOMOLETS NATIONAL MEDICAL UNIVERSITY, KYIV, UKRAINE
}

\begin{abstract}
Introduction: Atherosclerosis is a trigger in the development of cardiovascular disease. Complications of atherosclerosis give reason to search for new criteria, diagnostic concepts, treatment methods and active preventive measures.

The aim of our work is to study of the structural changes in the intima-media complex of the common carotid artery, pro-inflammatory cytokines (TNF-a, IL-6) secreted by mononuclear cells; the level of the intercellular adhesion molecule (according to sICAM-1), the level of the C-peptide of the blood, as well as the study of the relationship between these factors affecting the development of atherosclerosis.

Materials and methods: In the group of 110 patients are studied the levels of secretion of TNF- $a$, IL-6, the soluble intercellular adhesion molecule-1, the level of blood C-peptide, performed of duplex scanning of the brachiocephalic vessels, studied of biopsy of the skin.

Results and conclusions: In the group of patients with atherosclerosis and the accompanying metabolic syndrome, endothelial activation is noted under the influence of risk factors (hyperinsulinemia, arterial hypertension, hypercholesterolemia), accompanied with the activation of mononuclear cells (with marked hyperproduction of proinflammatory cytokines (IL-6) and thickening of the intima-media complex of the common carotid artery with an increase in body weight. Patients with metabolic syndrome develop microangiopathy (edema of endothelial cells, thickening and reduplication of the basement membranes, focal reaction of the pericytes).
\end{abstract}

KEY WORDS: atherosclerosis cytokines, C-peptide, intima-media, microangiopathy, metabolic syndrome

\section{INTRODUCTION}

Atherosclerosis (AS) is a trigger in the development of cardiovascular disease. The literature data indicate that atherosclerotic changes in the main arteries are more and more common at a young age, thereby justifying the need to identify these changes in the early stages of development. Complications of atherosclerosis, leading to disability of the working population, give reason to search for new criteria, diagnostic concepts, treatment methods and active preventive measures. In this regard, the development and implementation of effective prevention to identify risk factors for atherosclerosis, the implementation of preventive and therapeutic measures is quite relevant $[1,2,3,4,5,6]$.

One of the conditions causing a high risk of atherosclerosis is metabolic syndrome (MS). The components of this syndrome, on the one hand, are arterial hypertension (AH) and coronary heart disease (CHD), on the other -diabetes mellitus (DM) and obesity $[1,7,8,9]$.

The initiating moment of the development of MS is hyperinsulinemia and insulin resistance of tissues. In clinical practice, along with standard methods for eval- uating hyperinsulinemia, the determination of the level of C-peptide in the blood plasma is used. C-peptide is a stable fragment of endogenously produced proinsulin, which is cleaved from the proinsulin molecule to form insulin. Increasing the level of C-peptide (hyper-C-peptidemia) on an empty stomach or after glucose loading may be evidence of insulin hypersecretion by the pancreas. The content of insulin in serum depends on the clearance of insulin by the liver. Unlike insulin, C-peptide, having become detached from the proinsulin molecule, is not extracted from the blood plasma by the liver and reflects the "true" insulin secretion by the pancreas [9, $10,11,12,13,14]$.

In the pathological chain of formation of endothelial dysfunction, the first reaction is the reaction of the endothelium with the altering factors. The factors of activation and prolongation of endothelial dysfunction can be hyperglycemia, reactive free radicals, oxidized low-density lipoproteins, hypercholesterolemia, high hydrostatic pressure arising from arterial hypertension. This is accompanied by an increase in the permeability of the endothelium for immunocompetent cells (lymphocytes, 
monocytes, neutrophils), their metabolic products, the expression of adhesive molecules (EIAM-1, ICAM-1, VCAM-1). There is a subsequent active proliferation of smooth muscle cells and the production of connective tissue, which forms the basis of the fibrous capsule, which in turn contributes to the progression of atherogenesis, which ultimately leads to the development of vascular thrombosis $[3,13,15,16]$.

The immunological markers of atherosclerosis, the clinical significance of which is the subject of the most intensive studies, include pro-inflammatory cytokines (interleukins IL-1, IL-6; tumor necrosis factor - TNF, etc.), affecting the nature, depth and duration of the immune-inflammatory process.

The nature of the atherosclerotic process in clinical practice is judged by studying the structure of the intima-media complex (IMC) of the common carotid artery $[8,17,18]$. Structural changes in the vascular wall of the common carotid artery are extrapolated to the vascular regions of the body, which indicates the presence of a morphological reorganization of the vascular wall.

A complex of interrelated changes (structural changes in the vascular wall, the formation and development of an immunoinflammatory reaction, hyperinsulinemia, obesity, morphogenesis of angiopathy) in MS and became the subject of our study.

\section{THE AIM}

The aim of our work is to study the structural changes in the intima-media complex of the common carotid artery; pro-inflammatory cytokines (TNF- $\alpha$, IL-6) secreted by mononuclear cells; the level of the intercellular adhesion molecule (according to sICAM-1); the level of the C-peptide of the blood, as well as the study of the relationship between these factors affecting the development of atherosclerosis.

\section{MATERIALS AND METHODS}

The study was based on 110 patients who were divided into 3 groups. The first group - 40 patients with MS (mean age $53.2 \pm 4.0$ years); the second - 40 patients with coronary artery disease (stable angina II-III FC (functional class) in combination with hypertension (GB) II degree and MS (average age $55.0 \pm 1.5$ years); the third group 30 patients with GB II degrees in combination with MS (mean age $45.4 \pm 4.1$ years). The control group consisted of 20 healthy individuals matched by age and sex with the main group.

All patients gave written consent to participate in the study, in accordance with the requirements of the WHO Ethics Committee.

The diagnosis of coronary heart disease (CHD), hypertensive heart disease (HD), metabolic syndrome (MS) was established on the basis of history, physical examination, laboratory and instrumental (ECG-electrocardiography, VEM-cycle ergometry) methods, in accordance with the recommendations of the expert group $\mathrm{WHO}$ and the Ukrainian Cardiology Association.

Duplex scanning of the brachiocephalic vessels was performed using a $7.5 \mathrm{~mm}$ linear transducer using an Aloka 3500 apparatus using a standard technique.

To establish the functional ability of immune cells (monocytes, lymphocytes) that participate and initiate immuno-inflammatory reactions, the levels of secretion of TNF- $\alpha$, interleukin 6 (IL-6) in serum were determined using enzyme immunoassay PgoCon. The presence of a soluble intercellular adhesion molecule-1 (sIAM-1) in the serum was also studied using the enzyme immunoassay test system Diaclone (France).

The determination of the level of blood C-peptide was carried out by immunoradiometric method using reagents of the company IMMUNOTECH (Czech Republic).

For histological examination, pieces of organs were removed, which were fixed in $10 \%$ formalin solution and embedded in paraffin. Subsequently, paraffin sections of 5-7 $\mu \mathrm{m}$ thick were stained with hematoxylin and eosin, with picrofuchsin according to Van Gieson, Sudan black, on Weigert elastic, with silver impregnation along Foot.

Statistical data processing was performed using standard techniques. The calculation of the degree of deviation from the norm (DDN) of each indicator was estimated using the formula: $\mathrm{DDN}=(\mathrm{n} / \mathrm{N}-1) \times 100 \%$ (n- indicators of results in the group of subjects, $\mathrm{N}$ - indicators of results in the group of donors).

DDN was assessed by the following indicators: I stage-a deviation from 0 to $33 \%$, II stage-34-66\%, III stage-67-100\%, IV stage > 100\%, V Art. > 150\%, VI Art. > $200 \%$. Correlation analysis was performed by the Pearson method.

\section{RESULTS AND DISCUSSION}

Our studies showed that the level of C-peptide in the total group of patients with atherosclerosis was $1301.50 \mathrm{pM}$, which is significantly higher than the results in the control group (Table I).

Given the diversity, heterogeneity and wide variation of indicators characterizing the amount of C-peptide, this became the basis to analyze what characteristics were found in patients with hyperinsulinemia (high levels of C-peptide in the blood) and without the presence of such (C-peptide is normal). In this regard, we divided all the studied patients with atherosclerosis into two groups: patients with elevated levels of C-peptide ( $1^{\text {st }}$ group) and patients with normal levels of C-peptide ( $2^{\text {nd }}$ group).

We found that the first group consisted of patients with clinical manifestations of atherosclerosis and MS, who had a high level of IL-6 in vitro (VI DDN), a significant inhibition of the complex intima-media carotid complex with a high level of IL-6. arteries (III DDN) at normal levels of TNF- $\alpha$. In this group, patients with obesity grade III predominate (70\%). In patients of this group, the level of sICAM-1 was moderately elevated, which can be considered as depletion of the secretory ability of endothelial 
Table I. The distribution of patients in groups depending on the level blood peptide

\begin{tabular}{|c|c|c|c|}
\hline & $\begin{array}{l}\text { Increased blood } \\
\text { C-peptide }\end{array}$ & $\begin{array}{l}\text { Normal level } \\
\text { blood peptide }\end{array}$ & Control \\
\hline TNF- $a$, in vitro & $141,2 \pm 23,8$ & $115,6 \pm 76,1$ & $122,3 \pm 11,93$ \\
\hline IL-6 In vitro, pg/ml & $906,2 \pm 35,0 *(\mathrm{VI})$ & $573,2 \pm 41,9 *(I I I)$ & $293,2 \pm 13,49$ \\
\hline IL-6 in vivo, pg/ml & $4,8 \pm 0,4$ & $4,8 \pm 1,3$ & $5,5 \pm 0,39$ \\
\hline sICAM-1, pg/mg & $768,4 \pm 41,5^{*}(I)$ & $870,2 \pm 95,2 *(I I)$ & $647,5 \pm 19,29$ \\
\hline C-peptide, pmol & $1802,1 \pm 40,9 *(V)$ & $675,8 \pm 92,3$ & $601,7 \pm 86,6$ \\
\hline Disease duration, years & $9,4 \pm 1,5$ (II) & $7,7 \pm 1,96$ (II) & - \\
\hline Obesity,\% & $\begin{array}{l}70 \% \text { III st., } \\
30 \% \text { II st. }\end{array}$ & $\begin{array}{c}25 \%, \text { I st., } \\
\text { II st., } 30 \%, 45 \%\end{array}$ & - \\
\hline $\mathrm{IMC}, \mathrm{mm}$ & $0,7 \pm 0,14$ (III) & $0,5 \pm 0,22$ & $0,37 \pm 0,02$ \\
\hline Body weight, kg & $116,8 \pm 25,2$ & $80,2 \pm 22,4$ & $69 \pm 12,4$ \\
\hline
\end{tabular}

Note. ${ }^{*}$ significant differences between groups $(p<0.05)$.

cells relative to adhesive molecules, due to the long course of the disease (the disease is 5-10 years old).

In the second group of patients, we observed a statistically significant increase in the level of IL-6 in-vitro (III) and sICAM (II) at the normal thickness of the intima-media complex and the level of TNF- $\alpha$. This group included patients with clinical manifestations of atherosclerosis, coronary heart disease, as well as atherosclerosis and hypertension. The duration of the disease in the group of these patients was up to 5 years.

To establish the relationship between the studied parameters characterizing the secretory ability of mononuclear cells (IL- 6 and TNF- $\alpha$ ), the degree of endothelial activation (sICAM-1) with the clinical manifestations of atherosclerosis (IMC, disease duration, C-peptide level, degree of obesity), we conducted a correlation analysis in the group of patients with AS.

Direct correlations were established between the number of intercellular adhesion molecules and the common carotid artery intima-media complex (IMC) $(\mathrm{r}=0.5)$, the level of blood C-peptide and IMC ( $\mathrm{r}=0.8)$, C-peptide and disease duration $(\mathrm{r}=0.41)$, IMC and the duration of the disease $(r=0.57)$ only in the group of patients with metabolic syndrome.

Thus, according to the literature and according to our data, in the group of patients with atherosclerosis and the accompanying metabolic syndrome, endothelial activation is noted under the influence of risk factors (hyperinsulinemia, hypertension, hypercholesterolemia), accompanied by activation of mononuclear cells with pronounced hyperproduction of proinflammatory cytokines (IL 6). These changes are accompanied by a thickening of the intima-media complex of the common carotid artery and an increase in body weight corresponding to the III degree of obesity. The established relationships between proinflammatory interleukin-6, blood C-peptide level, degree of obesity and IMC indicate not only the participation of these factors in the development of the pathological process, but also the possibility of using them as reliable markers for the development and progression of the atherosclerotic process.
These pathogenetic links in the pathogenesis of the metabolic syndrome with concomitant pathology can cause morphological, structural changes in various organs and systems, including the skin, which is the first to ensure communication of the organism with the environment. Therefore, morphological studies were aimed at identifying changes in skin vessels during MS.

Considering the important role of angiopathy as a pathogenetic component of MS, an in vivo histological examination of skin biopsy specimens was performed in 10 patients with this syndrome. Examples of skin biopsies are presented in Figures 1 and 2.

One can see swelling of the endothelial cells of the dermis, focal proliferation of pericytes around the vessels of the microvasculature, the beginning of the development of focal sclerosis.

It has been found that the skin of the skin has a thickness of about $10 \mathrm{~cm}$ (Fig. 1). Significant changes have been developed, which has swelled, prolobiet into the lumen of the blood vessels of the microcircular channel, often almost completely closed it.

Established significant thickening and branching layers of the basement membrane and proliferation of pericytes. Edema was observed in the surrounding connective tissue vessels. A microscopic examination revealed that sclerosis was attached to the above-described changes, which was noted in many vessels and had a focal character.

Histological examination in the capillaries of the dermis observed thickening and reduplication of the vascular wall basal membranes (Fig. 2), which are the result of the long-term influence of the pathological effects of hyperinsulinemia, oxidized LDL, activation of lipid peroxidation (LPO), as well as the reaction of the microcirculation.

One can see a thickening and reduplication of the basement membranes of the capillaries of the skin.

Thus, the formation of microangiopathy in patients with MS begins already at the initial stages of development of the pathological process and is manifested by the presence of changes in the form of moderate proliferation of the 


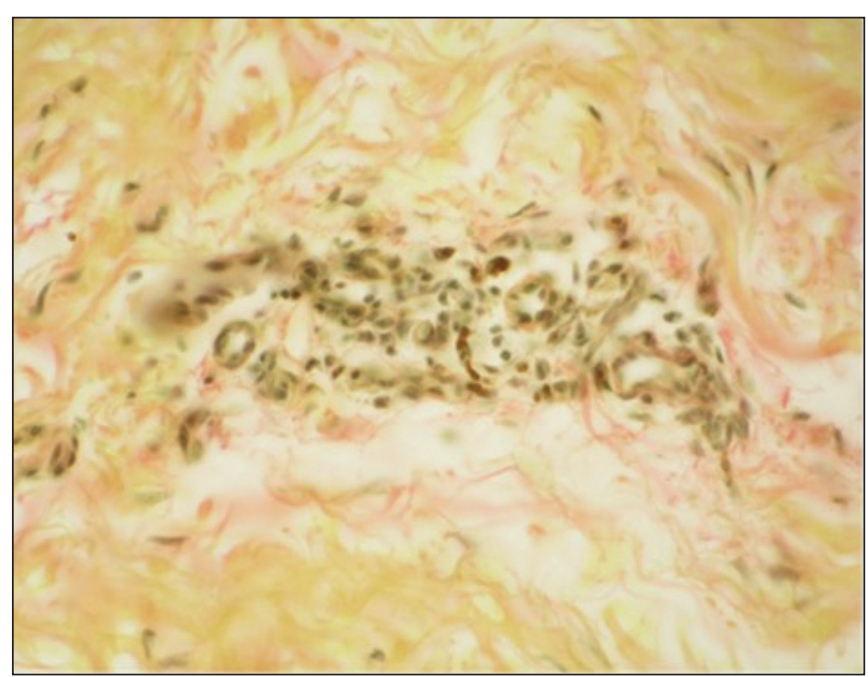

Fig. 1. Biopsy of the skin of the patient 55 years old with MS (light microscopy, (h400, color by Van Gieson).

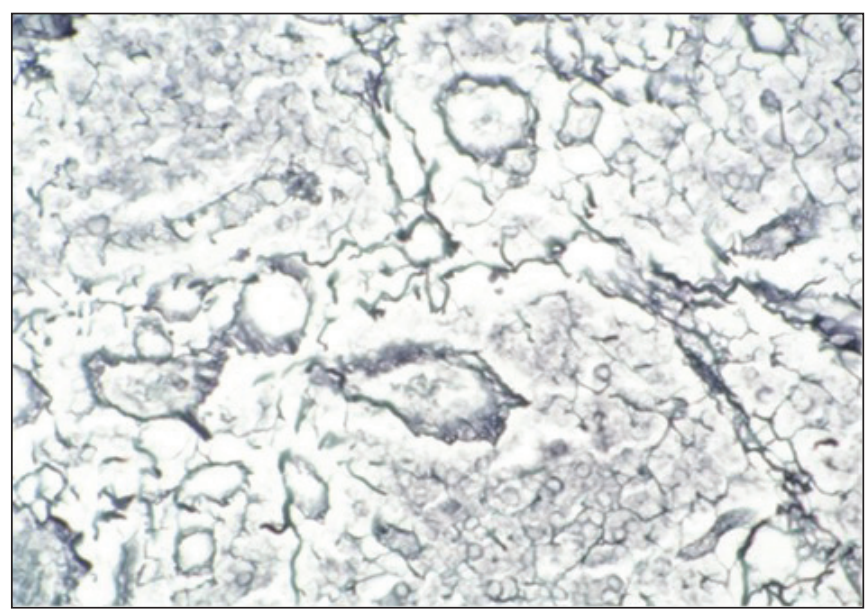

Fig. 2. Biopsy of the skin of the patient 45 years old with MS (light microscopy Ch 400, impregnation with silver on Foot).

endothelium, plasma impregnation of the vascular wall, thickening and branching of the basal membrane layers, and pericyte proliferation.

\section{CONCLUSIONS}

1. In the group of patients with atherosclerosis and the accompanying metabolic syndrome, endothelial activation is noted under the influence of risk factors (hyperinsulinemia, arterial hypertension, hypercholesterolemia), accompanied with the activation of mononuclear cells (with marked hyperproduction of proinflammatory cytokines (IL-6) and thickening of the intima-media complex of the common carotid artery with an increase in body weight (corresponding to grade III obesity).

2. Patients with metabolic syndrome develop microangiopathy, which manifests as edema of endothelial cells, thickening and reduplication of the basement membranes and focal reaction of the pericytes of the vascular wall as a result of the action of alterating factor agents.

\section{REFERENCES}

1. Berezin A.E. Diagnostic informatively and prognostic value of intestinal regulatory neuropeptides in patients with metabolic syndrome. Ukrainian Medical Chronicle. 2013; 1 (93): 23-28 (In Ukrainian).

2. Bokova T.A. Modern view on the etiopathogenesis of metabolic syndrome in children. The attending physician. 2013; 2: 74-77.

3. Diagnosis and treatment of metabolic syndrome, diabetes, prediabetes cardiovascular diseases. Methodical recommendations of the work group on metabolic syndrome problems, tactile diabetes and cardiovascular diseases of the Ukrainian Cardiovascular Cardiology Association and Ukrainian Associated Association of Endocrinologists. Kyiv, 2009:40 p. (In Ukrainian).

4. Oslopov V.N. Metabolic syndrome in cardiovascular diseases. The possibility of using the drug Cardionat (meldonium). Russian Medical Journal. 2013; 19: 956 (in Russian).

5. Unified clinical protocol of primary and secondary (specialized) medical aid “Type 2 diabetes mellitus". Order Ministry of Health of Ukraine. 2012; 1118. Access mode: http://www.dec.gov.ua/mtd/reestr_r.html.

6. Unified clinical protocol of primary, emergency and secondary (specialized) medical aid "Arterial hypertension". Mandate of the Ministry of Health Protection of Health of Ukraine. 2012; 384. - Access mode: http://www.dec.gov.ua/mtd/reestr_r.html.

7. Militsia K.M. Multidisciplinary approach to therapy metabolic syndrome and obesity as a guarantee of their effectiveness treatment. Family medicine. 2015; 4 (60): 38-40.

8. Miloslavsk Yu.0. Influence of biochemical markers on the course of hypertonic disease of the II stage in conjunction with metabolic syndrome. Ukrainian Medical Chronicle. 2012; 5 (91): 129-133.

9. Oshakbayev K.P. Metabolic syndrome: etiology, pathogenesis, diagnosis, clinical management and prognosis. Author. dis. ... Dr. med 14.00.05. Internal disease Almaty. 2010 (in Russian).

10. Goldibi S. Diabetes mellitus and alpha lipoic acid (review). Diabetes. Obesity. Metabolic syndrome. 2012; 1: 48-58.

11. Management of patients with diabetes mellitus. Recommendations of the American Association for the Study of Diabetes. Rational Pharmacotherapy. 2010; 2 (15). P. 69-76.

12. Mankovsky B.N. Metabolic syndrome: is there a solution to the problem. Medical aspects of women's health. 2007; 3: 4-12.

13. Recommendations of experts of the All-Russian Scientific Society of Cardiology for the diagnosis and treatment of metabolic syndrome. The second revision. Practical medicine. - 2010; 5 (44): 81-105.

14. Reytberg G.E. Metabolic syndrome.Ed. Corr. RAMS G.E. Roetberg. M.: MED press-inform. 2007: 224.

15. Michchenko 0.I. Leptin resistance, profile of blood pressure and structural-functional characteristics of the myocardium in patients with hypertension and metabolic syndrome. Ukrainian Medical Chronicle. 2015; 4 (108): 91-94 (In Ukrainian).

16. Piatnitsa-Gorpinchenko N. Maintaining patients with diabetes mellitus in outpatient practice. Zdorov'ya Ukrainy. 2013; 3 (304): 1-3.

17. Michchenko 0.I., Romanov V.Yu. Optimization of treatment and correction of cardiovascular risk in patients with arterial hypertension and metabolic syndrome. Ukrainian Medical Chronicle. 2015; 2 (106): 667-670 (In Ukrainian). 
18. Rahman S.T. Effect of a-lipoic acid on endothelial function and proteinuria when quinapril is taken by patients with diabetes and hypertension: results of treatment a QUALITY. Diabetes. Adiposity . Metabolism syndrome. 2013; 2: 65-71.

\section{Authors' contributions:}

According to the order of the Authorship.

\section{Conflict of interest:}

The Authors declare no conflict of interest.

\section{CORRESPONDING AUTHOR}

Olena 0. Karlova

Maiakovskogo avenue 8/122, 02217 Kyiv, Ukraine e-mail: el-kuz@ukr.net

Received: 14.02 .2019

Accepted: 03.04.2019 
PRACA ORYGINALNA

ORIGINAL ARTICLE

\title{
COMBINED DIFFERENTIATED THERAPY IN PATIENTS WITH URTICARIA
}

\author{
Orysya 0. Syzon, Tetyana I. Rudnyk, Marianna 0. Dashko \\ DANYLO HALYTSKY LVIV NATIONAL MEDICAL UNIVERSITY, LVIV, UKRAINE
}

\begin{abstract}
Introduction: The necessity of the study of urticaria is called for by its high specific gravity in the structure of dermatoses, lack of effective therapies and, consequently, negative impact on the quality of life of patients and members of their families.

Among the factors that initiate clinical manifestations of urticaria are autoimmune disorders, diseases of the gastrointestinal tract, nervous system, bacterial and viral infections, helminth infestation. However, the state of the internal secretion glands in such patients is understudied. Although, it is recognised that thyroid gland plays an important role in the development of allergic dermatitis, but its role in the formation of autoimmune processes at urticaria is still unclear. Such diversity of mechanisms of urticaria development considerably complicates the choice of rational ways of effective therapy. In particular, traditional agents (antihistamine and other hyposensitizing ones) often do not have the desired effect. Due to such complicated current condition of treatment of patients with urticaria, non-medicated methods of treatment seem to be getting more and more prospective.

The aim:To develop differentiated treatment of urticaria patients, taking into account the functional state of the thyroid gland and its participation in the formation of autoimmune processes.

Materials and methods: We had been supervising 127 patients with chronic idiopathic urticaria (49 men and 78 women) of the age range from 15 to 67 years old with the disease duration from 5 months to 29 years. The control group consisted of 20 healthy individuals. The mild degree of severity of dermatosis was diagnosed in 43 (33.9\%) patients, the average degree of the disease severity - in 41 (32.2\%), and severe form of the disease was observed in 43 (33.9\%) patients.

The functional state of thyroid gland was evaluated by determining the level of thyroxine, triiodothyronine, thyroglobulin, and autoantibodies to thyroperoxidase and thyroglobulin in serum.

Results: It was discovered that in patients with urticaria, dysfunctional state of thyroid gland is observed, which is manifested by a probable increase in thyroxine content up to $107.52 \pm 4.20 \mathrm{nmol} / \mathrm{l}$ (in healthy individuals $-78.13 \pm 3.65 \mathrm{nmol} / \mathrm{l} ; \mathrm{p}<0.05$ ) and thyroglobulin - up to $29.73 \pm 2.51 \mathrm{ng} / \mathrm{ml}$ (in healthy individuals $-20.16 \pm 1.34 \mathrm{ng} / \mathrm{ml} ; \mathrm{p}<0.05$ ) which is associated with a decrease in the level of triiodothyronine - up to $1.33 \pm 0.06 \mathrm{nmol} / \mathrm{l}$ (in healthy individuals $-1.52 \pm 0.04 \mathrm{nmol} / \mathrm{l} ; \mathrm{p}<0.05$ ).

In order to evaluate the effectiveness of this approach, all patients were divided into 4 groups. The first group, with the total amount of 32 patients were prescribed only traditional standard treatment, according to the guidelines. The pations of second group (31 patients) were prescribed specific phototherapy (once a week, 6-8 sessions) after traditional medication and afterward absence of clinical manifestations of pathological process. 31 patients of the third group were prescribed balneo- and halotherapy after traditional medication and no afterward clinical manifestations of urticaria. The fourth group (33 patients) prescribed combined treatment in the way of combined application of specific therapy, phototherapy, balneotherapy and halotherapy, after the elimination of clinical manifestations of dermatosis by means of 2 month traditional medication.

It was established that patients with mild dermatosis were exposed to a probable correction of the functional state of the thyroid gland, improved clinical course and quality of life after medication, balneo- and halomethods of treatment, patients with moderate and severe degree - after combined application of medication, specific photo-, balneoand halotherapy

Conclusions: Thus, the therapy of patients with urticaria requires a differentiated approach. Patients with mild dermatosis, after traditional medication, should be prescribed balneo- and halomethods of treatment. Patients with moderate to severe degree of the disease require more intensive medical intervention. They should be prescribed a combined application of specific photo-, balneo- and halotherapy. This approach allows eliminating the pathological process.
\end{abstract}

KEY WORDS: urticaria, thyroid gland, autoimmune disorders, therapy

Wiad Lek 2019, 72, 4, 589-594

\section{INTRODUCTION}

The necessity of the study of urticaria is called for by its high specific gravity in the structure of dermatoses, lack of effective therapies and, consequently, negative impact on the quality of life of patients and members of their families [1-4].

Among the factors that initiate clinical manifestations of urticaria are autoimmune disorders, diseases of the gastrointestinal tract, nervous system, bacterial and viral infections, helminth infestation [5]. However, the state of the internal secretion glands in such patients is understudied. Although, it is recognised that thyroid gland plays an important role in the development of allergic dermatitis $[6,7]$, but its role in the formation of autoimmune processes at urticaria is still unclear. 
Such diversity of mechanisms of urticaria development considerably complicates the choice of rational ways of effective therapy. In particular, traditional agents (antihistamine and other hyposensitizing ones) often do not have the desired effect $[8,9]$.

Due to such complicated current condition of treatment of patients with urticaria, non-medicated methods of treatment seem to be getting more and more prospective. In particular, it is believed that recurrence of clinical manifestations of dermatosis and the elimination of functional disorders of the macroorganism in general, and of the skin in particular may be faster under the influence of balneological and climatic procedures than under the influence of allopathic remedies $[10]$. It is known $[11,12]$ that mineral baths have undoubted therapeutic properties. They affect macroorganism by a combination of factors. To their non-specific effects refer: hydrostatic (promoting blood to heart), mechanical (the effect of which is particularly perceptible while applying shower or shower with massage), temperature (having an effect on skin receptors area and processes of thermoregulation). The specific factors of balneotherapy are manifested by selective influence of procedures on different systems of macroorganism, depending on physical, chemical and other properties of mineral water. The significance of the latter is determined by its mineral and ionic composition, presence of gases and gas saturation, content of organic compounds and microelements with bio-and radioactivity, $\mathrm{Ph}$, temperature $[10,12]$.

In particular, expediency of including balneotherapy in the basic program of rehabilitation of such patients it is indicated [10] (sodium chloride baths of small or medium mineralization at the $36-38^{\circ} \mathrm{C}$, for 15 minutes; hydrogen sulfide baths with the ions concentration 80-120 $\mathrm{mg}$ at the $\mathrm{t} 36-37^{\circ} \mathrm{C}$ for 5 minutes; radon baths of small and medium concentrations at the $36^{\circ} \mathrm{C}$ for $10-15$ minuntes). However, the data on the effectiveness of balneotherapy for patients with urticaria are quite controversial.

Significant attention in the treatment of patients with allergic dermatoses is paid to UVR. Its influence can be direct, humoral, and reflexive [13]. The antiproliferative effect of the UVR on the skin lies in reduction of the amount of Langerhans antigen-presenting cells in the dermis and epidermis, by interacting with T-lymphocytes, which leads to suppression of functional activity of the cellular elements and causes skin activity decrease in reactions to contact hypersensitivity. It has been proved that UVR not only depresses the functionality of lymphocytes, but it can also destroy them. In addition, the activity of these immunocompetent cells decreases due to the elimination of the epidermis associated macrophages. Also, UVR leads to the formation of dendritic cells in the skin, which are more resistant to the effects of damaging factors. Having direct suppressing effects on the synthesis of nuclear DNA of keratinocytes, UVR reduces their mitotic activity. Moreover, UVR is characterized by dermotropism which depends on the wave length. Several variants of phototherapy of patients with skin pathology have been developed so far, for instance: selective, embodying the combination of UVB
(295-330 nm) and UVA; photochemotherapy (PUVA), narrow-wave UVB with a wave length of $311 \mathrm{~nm}$, and phototherapy with the appointment of UVA narrow spectrum $(370 \mathrm{~nm})$. The most expedient in terms of efficiency, convenience and safety is the use of UVB with the length of $311 \mathrm{~nm}$ [14-16]. However, there is no data available as to their appointment to patients with urticaria.

Thus, all the above facts testify a number of unexplained pathogenetic mechanisms of urticaria aas well as ways of treatment of such patients. There are no targeted studies concerning the role of thyroid gland in the development of dermatosis.

\section{THE AIM}

To develop differentiated treatment of urticaria patients, taking into account the functional state of the thyroid gland and its participation in the formation of autoimmune processes.

\section{MATERIALS AND METHODS}

We had been supervising 127 patients with chronic idiopathic urticaria (49 men and 78 women) of the age range from 15 to 67 years old with the disease duration from 5 months to 29 years. The control group consisted of 20 healthy individuals. The mild degree of severity of dermatosis was diagnosed in $43(33.9 \%)$ patients, the average degree of the disease severity - in 41 (32.2\%), and severe form of the disease was observed in 43 (33.9\%) patients (figure 1).

The functional state of thyroid gland was evaluated by determining the level of thyroxine, triiodothyronine, thyroglobulin, and autoantibodies to thyroperoxidase and thyroglobulin in serum. The content of thyroxine was studied using the test kit RIO-T4-IOP (Republic of Belarus), and triiodothyronine - using the test kit RIOT3-IPR (Republic of Belarus). The results were expressed in $\mathrm{nmol} / \mathrm{l}$. The level of thyroglobulin was detected using the test kit RIO-TG ${ }^{125} \mathrm{I}$, with employment of thyroglobulin labeled with iodine 125 (Republic of Belarus). The results were expressed in $\mathrm{ng} / \mathrm{ml}$. The research was carried out on the radio-immunoassay "Gamma-12".

The autoantibodies to thyroperoxidase and thyroglobulin were determined using the sandwich method of the solid phase enzyme-linked immunosorbent assay using reagent kits, AT-TPO-IFA and AT-TG-IFA respectively, and their values were expressed in $\mathrm{MO} / \mathrm{ml}$.

\section{RESULTS AND DISCUSSION}

Among the factors that initiate clinical manifestations of urticaria are some internal disease[ 1,5$]$. Also in some literary data there information about thyroid gland and there role in the development of allergic dermatitis[4]. It was discovered that in patients with urticaria, dysfunctional state of thyroid gland is observed, which is manifested by a probable increase in thyroxine content up to $107.52 \pm 4.20$ $\mathrm{nmol} / \mathrm{l}$ (in healthy individuals $-78.13 \pm 3.65 \mathrm{nmol} / \mathrm{l} ; \mathrm{p}<0.05$ ) 
and thyroglobulin - up to $29.73 \pm 2.51 \mathrm{ng} / \mathrm{ml}$ (in healthy individuals - $20.16 \pm 1.34 \mathrm{ng} / \mathrm{ml} ; \mathrm{p}<0.05$ ), which is associated with a decrease in the level of triiodothyronine - up to $1.33 \pm 0.06 \mathrm{nmol} / \mathrm{l}$ (in healthy individuals $-1.52 \pm 0.04$ $\mathrm{nmol} / \mathrm{l} ; \mathrm{p}<0.05)$. However, the degree of severity of dermatosis did not differ significantly in terms of statistic changes from the average values of the entire number of patients.

However, we can not omit the fact of the lack of dependence of the content of thyroxin, thyroglobulin and triiodothyronine on the course of the pathological process. Quite a different situation was observed while analysing the effect of the duration of the last clinical remission at the level of these compounds. So, at the absence of remissions and their duration up to 3 months, the thyroxine content increased significantly, in comparison with the average values of the entire number of patients up to - $114.75 \pm 1.32$ $\mathrm{nmol} / \mathrm{l}(\mathrm{p}<0,05)$ and up to $-113.98 \pm 1.45 \mathrm{nmol} / \mathrm{l}(\mathrm{p}<0.05)$ respectively. The levels of triiodothyronine in these groups of patients decreased up to $-1.15 \pm 0.03 \mathrm{nmol} / \mathrm{l}(\mathrm{p}<0.05)$ and up to $-1.20 \pm 0.04 \mathrm{nmol} / \mathrm{l}(\mathrm{p}<0.05)$ respectively. The content of thyroglobulin increased significantly only in the absence of remissions - up to $35.49 \pm 1.65 \mathrm{ng} / \mathrm{ml}(\mathrm{p}<0.05)$.

Investigating the role of thyroid gland in the development of autoimmune processes at urticaria has made it possible to calculate the probable increase in the levels of autoantibodies to thyroperoxidase and thyroglobulin in such patients: to $27,18 \pm 2,23 \mathrm{mo} / \mathrm{ml}$ (in healthy individuals - $14.47 \pm 0.55 \mathrm{mo} / \mathrm{ml}, \mathrm{p}<0.05)$ and up to $159.70 \pm 8.05 \mathrm{mo} /$ $\mathrm{ml}$ (in healthy individuals $-76.12 \pm 3.42 \mathrm{mo} / \mathrm{ml}, \mathrm{p}<0.05$ ) respectively. In addition, an essential dependence of the content of these compounds on the clinical manifestations of the pathological process has been established. In particular, if, at a mild degree of dermatosis, the values of autoantibodies to thyroperoxidase and thyroglobulin were significantly reduced, compared to the average values the entire number of patients, and were, corresponding up to $20.35 \pm 1.14 \mathrm{mo} / \mathrm{ml}(\mathrm{p}<0,05)$ and to $126.94 \pm 4.83 \mathrm{mo} / \mathrm{ml}$ $(p<0.05)$, at moderate level they were within their norms, i.e. $26.73 \mathrm{mo} / \mathrm{ml}(\mathrm{p}>0.05)$ and $149.08 \pm 6.12 \mathrm{mo} / \mathrm{ml}(\mathrm{p}>$ 0.05 ) respectively. Severe urticaria was characterized by a significantly high content of autoantibodies to thyroperoxidase and thyroglobulin, compared with average value of the entire number of patients - up to $34.13 \pm 1.35 \mathrm{mo} /$ $\mathrm{ml}(\mathrm{p}<0.05)$ and $197.65 \pm 7,94 \mathrm{mo} / \mathrm{ml}(\mathrm{p}<0,05)$ respectively.

The dependence of the levels of these compounds on the duration of the pathological process was not detected. However, there was a certain dependence in case of the duration of the process up to 3 months the content of autoantibodies to thyroperoxidase significantly exceeded the average values of the entire number of patients, reaching $35.04 \pm 1.19 \mathrm{mo} / \mathrm{ml}(\mathrm{p}<0.05)$ and $33.74 \pm 0.89 \mathrm{mo} / \mathrm{ml}$ $(\mathrm{p}<0.05)$. The level of autoantibodies to thyroglobulin was obviously increasing, comparing with the average values of the entire number of patients, only in the absence of remissions, up to $174.38 \pm 5.67 \mathrm{mo} / \mathrm{ml}(\mathrm{p}<0.05)$.

The study of the interrelation between the functional state of the thyroid gland and the autoimmune linkage of urticaria revealed the greatest association between the levels of thyroxine and thyroglobulin and the content of autoantibodies to thyroperoxidase, which is characterized by $r=+0.62$ and +0.60 , respectively.

We have resorted to the combined use of narrow-spectral phototherapy, balneotherapy and microclimate chambers, which have a multidirectional effect on the course of the pathological process, as a method of treatment that corrects the functional state of the thyroid gland, autoimmune disorders and clinical manifestations of urticarial. In order to evaluate the effectiveness of this approach, all patients were divided into 4 groups ( 3 comparative groups and 1 main group).

The first group, with the total amount of 32 patients, included 10 people with mild degree of urticaria, 11 - with moderate degree, and 11 - with severe degree. The second group, with the total number of 31 patients, included, respectively, 10, 10 and 11 patients. In the third group (consisting of 31 patients), 11 patients were with mild degree of dermatosis, 10 - with moderate, 10 - with severe urticaria. The fourth group (33 patients) consisted of 12 , 10 and 11 patients, respectively.

The first group of patients were prescribed only traditional standard treatment, according to the guidelines: antihistamines and hypoxibles, and enterosorbents. In special cases of severe, resistant to the above mentioned medications, pathological process, systemic glucocorticosteroids were recommended. Duration of the treatment was $2-4$ weeks.

In patients of the first group of comparison, absence of probable correction of the functional state of thyroid gland was observed. The content of autoantibodies to thyroperoxidase and thyroglobulin was statistically significantly suppressed, regardless of the degree of urticaria severit, but remained outside the limits of physiological values. The quality of life of patients of this group has not significantly improved.

Patients of the second group of comparison were prescribed specific phototherapy (once a week, 6-8 sessions) after traditional medication and afterward absence of clinical manifestations of pathological process. It has been shown that in these patients, the functional state of thyroid gland was likely to improve, but only in case of mild urticaria. However, if the content of triiodothyronine and thyroglobulin was within the range of control deviations, reaching $1.49 \pm 0.02 \mathrm{nmol} / \mathrm{l}(1.38 \pm 0.07 \mathrm{nmol} / \mathrm{l}, \mathrm{p}<0.05)$ and $21.74 \pm 0.92$ $\mathrm{ng} / \mathrm{ml}$ (before treatment $-25.42 \pm 1.73 \mathrm{ng} / \mathrm{ml}, \mathrm{p}<0.05$; in healthy individuals $-20.16 \pm 1.34 \mathrm{ng} / \mathrm{ml} ; \mathrm{p}>0.05$ ) then the level of thyroxin remained outside its limits $91.25 \pm 3.73$ $\mathrm{nmol} / \mathrm{l}$ (before treatment $-103.04 \pm 2.80 \mathrm{nmol} / \mathrm{l} ; \mathrm{p}<0.05$; in healthy individuals $-78.43 \pm 3.65 \mathrm{nmol} / \mathrm{l} ; \mathrm{p}>0.05)$. More emphasis was paid to the depressing effect of narrow-spectral phototherapy on autoimmune processes. In particular, at mild degree of dermatosis, the values of autoantibodies to thyroperoxidase and thyroglobulin decreased to physiological ones, i.e., corresponding to $15.32 \pm 0.63 \mathrm{mo} / \mathrm{ml}$ (before treatment $-20.35 \pm 1.14 \mathrm{mo} / \mathrm{ml}, \mathrm{p}<0.05$; in healthy individuals $-14.47 \pm 0.55 \mathrm{mo} / \mathrm{ml} ; \mathrm{p}>0.05$ ) and to $79.80 \pm 2.61$ $\mathrm{mo} / \mathrm{ml}$ (before treatment $-126.96 \pm 4.83 \mathrm{mo} / \mathrm{ml}, \mathrm{p}<0.05$; in 
healthy individuals $-76.12 \pm 3.42 \mathrm{mo} / \mathrm{ml} ; \mathrm{p}>0.05$ ); and at the average, respectively, up to $16.01 \pm 2.13 \mathrm{mo} / \mathrm{ml}$ (before treatment $26.73 \pm 1.28 \mathrm{mo} / \mathrm{ml}, \mathrm{p}<0.05$, in healthy individuals $-14.47 \pm 0.55 \mathrm{mo} / \mathrm{ml} ; \mathrm{p}>0.05)$ and to $81.37 \pm 5.92 \mathrm{mo} / \mathrm{ml}$ (before treatment $-143.08 \pm 6.12 \mathrm{mo} / \mathrm{ml} ; \mathrm{p}<0.05$; in healthy individuals $-76.12 \pm 3.42 \mathrm{mo} / \mathrm{ml} ; \mathrm{p}>0.05$ ). At a severe degree of the disease, the values were beyond the index of control deviations, reaching correspondingly $23.54 \pm 1.89 \mathrm{mo} / \mathrm{ml}$ (before treatment $-34.13 \pm 1.35 \mathrm{mo} / \mathrm{ml}, \mathrm{p}<0.05$, in healthy individuals - $14.47 \pm 0.55 \mathrm{mo} / \mathrm{ml} ; \mathrm{p}>0.05)$ and $118.14 \pm 6.18$ $\mathrm{mo} / \mathrm{ml}$ (before treatment $-197.65 \pm 7.94 \mathrm{mo} / \mathrm{ml} ; \mathrm{p}<0.05$; in healthy individuals $-76.12 \pm 3.42 \mathrm{mo} / \mathrm{ml}, \mathrm{p}>0.05$ ). The quality of life of patients of the second group of comparison was likely to improve at mild and moderate degrees of urticaria, forming, respectively, dermatology life quality index (DLQI) $7.5 \pm 0.3$ points (before treatment $-10.2 \pm 1.9$ points $\mathrm{p}<0,05$ ) and $9,2 \pm 0,6$ points (before treatment $-14.3 \pm 2.1$ points, $\mathrm{p}<0,05)$. At severe urticarial the DLQI was characterized by an unreliable correction $17.9 \pm 1.2$ points (before treatment - 19.7 \pm 1.6 points, $\mathrm{p}<0,05)$.

Patients of the third group of comparison were prescribed balneo- and halotherapy after traditional medication and no afterward clinical manifestations of urticaria. We recommended low-mineralized chloride-sodium baths and a chamber of artificial microclimate 1 time a week. The course of therapy lasted $1.5-2$ months. It was ascertained that these patients feel significant correction and improvement of the functional of thyroid gland. In particular, at mild to moderate degrees of dermatosis, its values were reaching the physiological limits. In particular, the thyroxin content was $82.17 \pm 4.01 \mathrm{nmol} / 1$ (before treatment - 103.04 $\pm 2.80 \mathrm{nmol} / \mathrm{l}, \mathrm{p}<0.05$; in healthy individuals $-78.43 \pm 3.65 \mathrm{nmol} / \mathrm{l} ; \mathrm{p}>0,05)$ and $84.27 \pm 5.16 \mathrm{nmol} / \mathrm{l}$ (before treatment $-106.38 \pm 3,94 \mathrm{nmol} / 1 ; \mathrm{p}<0,05$; in healthy individuals $-78.43 \pm 3.65 \mathrm{nmol} / \mathrm{l} ; \mathrm{p}>0.05)$, triiodothyronine $-1.53 \pm 0.03 \mathrm{nmol} / \mathrm{l}$ (before treatment $-1.38 \pm 0.07 \mathrm{nmol} / \mathrm{l}$; $\mathrm{p}<0.05$; in healthy individuals $-1.52 \pm 0.04 \mathrm{nmol} / \mathrm{l} ; \mathrm{p}>0,05$ ) and $1.48 \pm 0.06 \mathrm{nmol} / \mathrm{l}$ (before treatment $-1.30 \pm 0.05$ $\mathrm{nmol} / \mathrm{l} ; \mathrm{p}<0.05$; in healthy individuals $-1.52 \pm 0.04 \mathrm{nmo-}$ 1/l; $\mathrm{p}>0,05$ ); tireoglobulin $-20.95 \pm 1.87 \mathrm{nmol} / \mathrm{l}$ (before treatment $-25.42 \pm 1.73 \mathrm{nmol} / \mathrm{l} ; \mathrm{p}<0.05$; in healthy individuals - $20.16 \pm 1.34 \mathrm{nmol} / \mathrm{l} ; \mathrm{p}>0.05), 22.05 \pm 1.96 \mathrm{nmol} / 1$ (before treatment $-28.91 \pm 2.27 \mathrm{nmol} / \mathrm{l} ; \mathrm{p}<0.05$; in healthy individuals $-20.16 \pm 1.34 \mathrm{nmol} / \mathrm{l} ; \mathrm{p}>0.05)$. The values changed slightly differently at severe degree of urticaria. Thus, if the levels of thyroxine and thyroglotin were decreasing correctly, they were not included in the control data range, as congruent to $93.19 \pm 2.97 \mathrm{nmol} / \mathrm{l}$ (before treatment $-109.87 \pm 4.15 \mathrm{nmol} / \mathrm{l} ; \mathrm{p}<0.05$; in healthy individuals $-78.43 \pm 3.65 \mathrm{nmol} / 1 ; \mathrm{p}>0,05$ ) and up to $25.00 \pm 1.50$ $\mathrm{nmol} / \mathrm{l}$ (before treatment $-31.06 \pm 2.42 \mathrm{nmol} / \mathrm{l} ; \mathrm{p}<0,05$; in healthy individuals - 20.16 $\pm 1.34 \mathrm{ng} / \mathrm{ml} ; \mathrm{p}>0.05$ ), no significant increase in the content of triiodothyronine was observed - $1.41 \pm 0.03 \mathrm{nmol} / \mathrm{l}$ (before treatment $-1.35 \pm 20.08$ $\mathrm{nmol} / \mathrm{l} ; \mathrm{p}>0.05$; in healthy individuals $-1.52 \pm 0.04 \mathrm{ng} / \mathrm{ml}$; $\mathrm{p}<0.05)$. The levels of autoantibodies to thyroperoxidase and thyroid glands were probably suppressed in patients of this group, regardless of the clinical course of pathological process, and were included into the amplitude of physiological oscillations. The quality of life in these patients also obviously improved, reaching at mild urticaria the DLQI $5.0 \pm 0.4$ points (before treatment $10.2 \pm 1.9$ points $\mathrm{p}<0.05$ ), at average urticarial $-8.5 \pm 0.5$ points (before treatment $-14.3 \pm 2.1$ points, $\mathrm{p}<0.05$ ) and at severe degree of the disease $-15.1 \pm 0.7$ points (before treatment $-19.7 \pm 1.6$ points, $\mathrm{p}<0,05$ )

Taking into account the results of the rehabilitation of patients of the three groups of comparison, patients of the main group were prescribed combined treatment in the way of combined application of specific therapy, phototherapy, balneotherapy and halotherapy, after the elimination of clinical manifestations of dermatosis by means of 2 month traditional medication. These patients proved to feel obvious improvement in the functional of thyroid gland. With mild to moderate degrees of urticaria, it reached its physiological limits. In particular, the thyroxin content was $83.22 \pm 5.31$ $\mathrm{nmol} / \mathrm{l}$ (before treatment $-103.04 \pm 2.80 \mathrm{nmol} / \mathrm{l}, \mathrm{p}<0.05$, in healthy sindividuals $-78.43 \pm 3.65 \mathrm{nmol} / \mathrm{l} ; \mathrm{p}>0.05)$ and $80.75 \pm 4.90 \mathrm{nmol} / \mathrm{l}$ (before treatment - $106.23 \pm 3.94 \mathrm{nmol} / \mathrm{l}$; $\mathrm{p}<0.05$; in healthy individuals $-78.43 \pm 3.65 \mathrm{ng} / \mathrm{ml} ; \mathrm{p}>0.05$ ), triiodothyronine $-1.55 \pm 0.02 \mathrm{nmol} / \mathrm{l}$ (before treatment $1.38 \pm 0.07 \mathrm{nmol} / \mathrm{l} ; \mathrm{p}<0.05$; in healthy individuals $-1.52 \pm 0.04$ $\mathrm{ng} / \mathrm{ml} ; \mathrm{p}>0.05$ ) and $1.49 \pm 0.09 \mathrm{nmol} / \mathrm{l}$ (before treatment $1.30 \pm 0.05 \mathrm{nmol} / \mathrm{l} ; \mathrm{p}<0.05$; in healthy individuals $-1.52 \pm 0.04$ $\mathrm{nmol} / \mathrm{l} ; \mathrm{p}>0.05$ ), thyroglobulin - $19.13 \pm 1.32 \mathrm{ng} / \mathrm{ml}$ (before treatment $-25.42 \pm 1.73 \mathrm{ng} / \mathrm{ml} ; \mathrm{p}<0.05$; in healthy individuals $-20.16 \pm 1.34 \mathrm{ng} / \mathrm{ml} ; \mathrm{p}>0,05$ ) and $22.04 \pm 2.14 \mathrm{ng} / \mathrm{ml}$ (before treatment $-22.91 \pm 2.27 \mathrm{ng} / \mathrm{ml} ; \mathrm{p}<0.05$; in healthy individuals $-20.16 \pm 1.34 \mathrm{ng} / \mathrm{ml} ; \mathrm{p}>0.05)$. At severe degree of dermatosis, despite probable correction, the values remained outside the range of control deviations. Thus, the level of thyroxine was $95.19 \pm 3.08 \mathrm{nmol} / \mathrm{l}$ (before treatment $-109.87 \pm 4.15 \mathrm{nmol} / \mathrm{l}$; $\mathrm{p}<0.05$; in healthy individuals $-78.43 \pm 3.65 \mathrm{nmol} / \mathrm{l} ; \mathrm{p}>0.05$ ) of triiodothyronine $-1.45 \pm 0.01 \mathrm{nmol} / \mathrm{l}$ (before treatment $1.35 \pm 0.08 \mathrm{nmol} / 1 ; \mathrm{p}<0.05$; in healthy individuals $-1.52 \pm 0.04$ $\mathrm{ng} / \mathrm{ml} ; \mathrm{p}>0.05$ ) thyroglobulin $-26.53 \pm 1.2 \mathrm{ng} / \mathrm{ml}$ (before treatment $-31.06 \pm 2.42 \mathrm{ng} / \mathrm{ml} ; \mathrm{p}<0.05$; in healthy individuals $-20.16 \pm 1.34 \mathrm{ng} / \mathrm{ml} ; \mathrm{p}>0.05)$. The content of autoantibodies to thyroperoxidase and thyroglobulin in such patients was probably suppressed and included in the amplitude of physiological oscillations, regardless of clinical manifestations of pathological process, namely: at mild urticaria, it was $15.19 \pm 0.75 \mathrm{mo} /$ $\mathrm{ml}$ (before treatment $-20.35 \pm 1.14 \mathrm{mo} / \mathrm{ml} ; \mathrm{p}<0.05$; in healthy individuals - $14.47 \pm 0.55 \mathrm{mo} / \mathrm{ml} ; \mathrm{p}>0.05)$ and $78.61 \pm 4.22$ $\mathrm{mo} / \mathrm{ml}$ (before treatment $-126.96 \pm 4.83 \mathrm{mo} / \mathrm{ml}, \mathrm{p}<0.05$; in healthy individuals $-76.12 \pm 3.42 \mathrm{mo} / \mathrm{ml} ; \mathrm{p}>0.05$ ) respectively; at moderate degree of urticaria $-13.02 \pm 1.30 \mathrm{mo} / \mathrm{ml}$ (before treatment $26.73 \pm 1.28 \mathrm{mo} / \mathrm{ml}, \mathrm{p}<0.05$, in healthy individuals $-14.47 \pm 0.55 \mathrm{mo} / \mathrm{ml} \mathrm{p}>0.05$ ) and $80.35 \pm 5.19 \mathrm{mo} / \mathrm{ml}$ (before treatment $-149.08 \pm 6.12 \mathrm{mo} / \mathrm{ml}, \mathrm{p}<0.05$; in healthy individuals $-76.12 \pm 3.42 \mathrm{mo} / \mathrm{ml} ; \mathrm{p}>0.05)$; and at severe urticaria - $16.04 \pm 1.97 \mathrm{mo} / \mathrm{ml}$ (before treatment $-34.13 \pm 1.35 \mathrm{ng} / \mathrm{ml}$; $\mathrm{p}<0.05$; in healthy individuals $-14.47 \pm 0.55 \mathrm{mo} / \mathrm{ml} ; \mathrm{p}>0.05$ ) and $81.72 \pm 6.15 \mathrm{mo} / \mathrm{ml}$ (before treatment $-197.65 \pm 7.94$ $\mathrm{mo} / \mathrm{ml} ; \mathrm{p}<0.05$, in healthy individuals $-76.12 \pm 3.42 \mathrm{mo} / \mathrm{ml}$, $\mathrm{p}>0.05)$. The quality of life of these patients has also improved, 


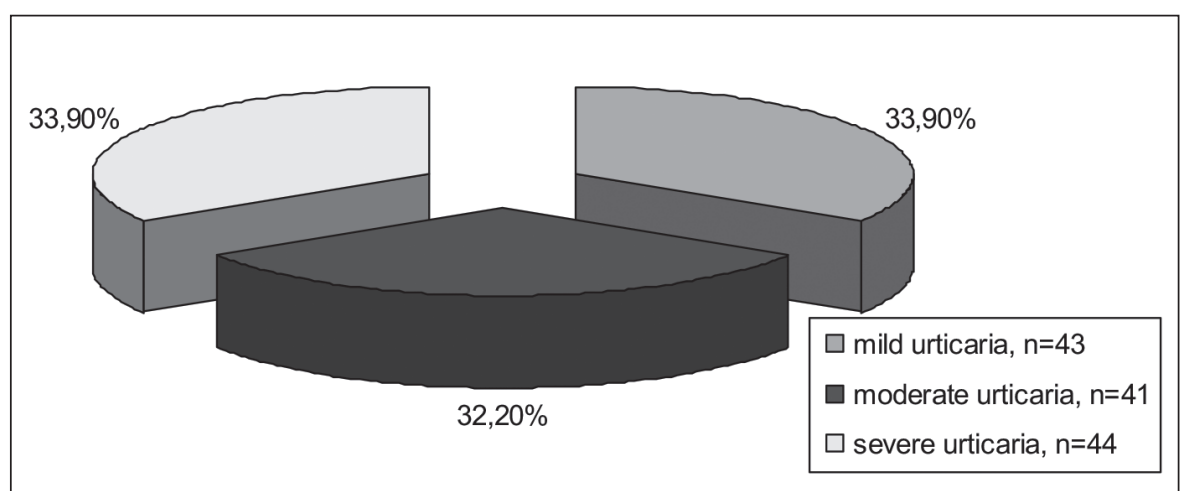

Figure 1. Distribution of patients with different degree of urticaria severity

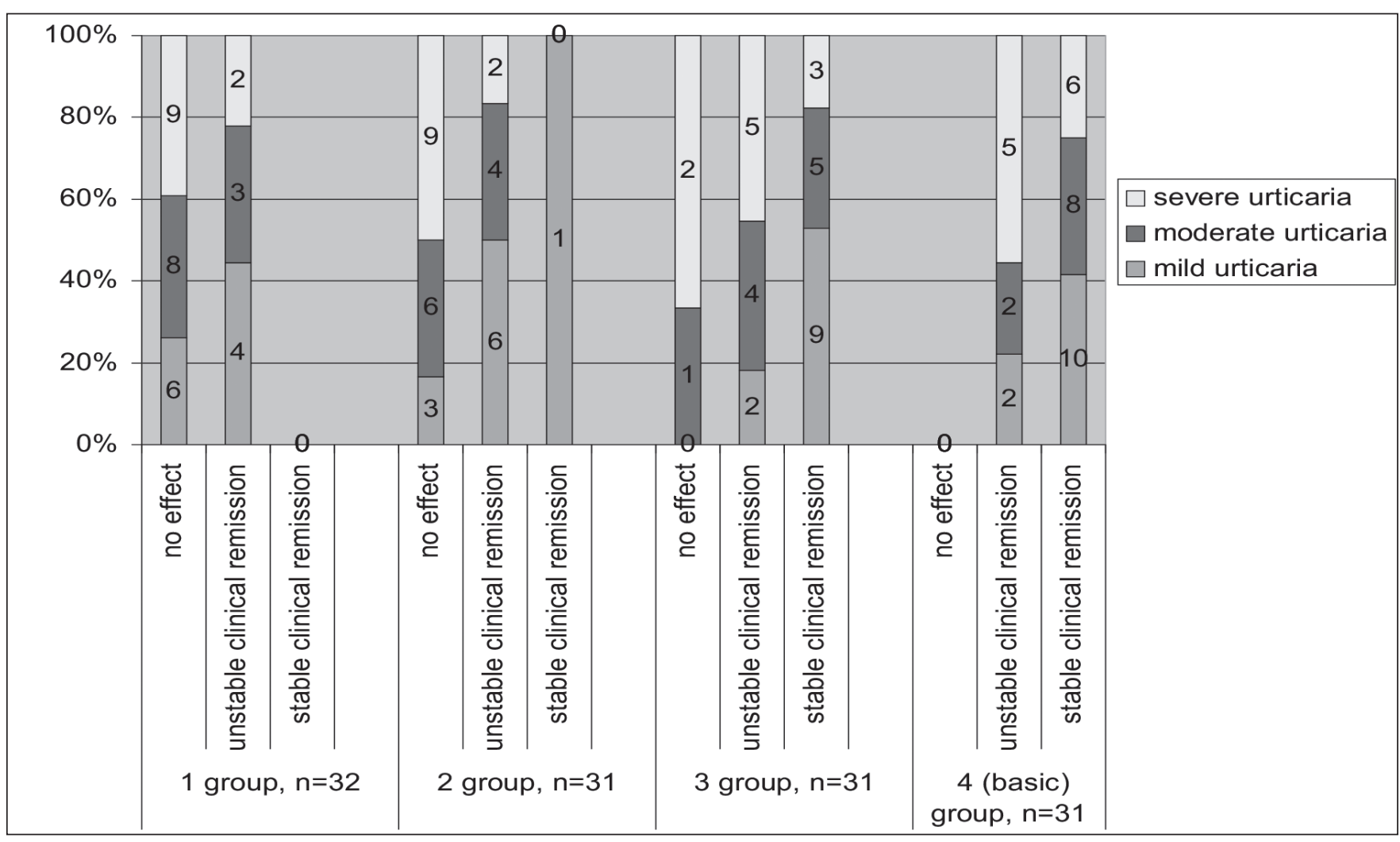

Figure 2. Clinical efficacy of treatment the patients with urticaria

regardless of the clinical manifestations of dermatosis. Thus, at mild urticaria the DLQI decreased to $4.9 \pm 0.3$ points (before treatment $-10.2 \pm 1.9$ points $\mathrm{p}<0.05)$, at moderate degree of disease - to $7.8 \pm 0.6$ points (before treatment $-14.3 \pm 2.1$ points, $\mathrm{p}<0.05)$, and at severe urticaria - to $14.2 \pm 0.5$ points (before treatment $-19.7 \pm 1.6$ points, $\mathrm{p}<0.05$ ).

Clinical effectiveness of therapy in all groups of patients had been evaluating for 1.5 years, in the course of patients monitoring. The criteria were considered as following: duration of clinical remission and severity of relapses. If the duration of remission did not exceed a month, then the treatment was evaluated as non-effective. If the duration of remission was from 6 to 12 months, such condition was regarded as an unstable clinical remission, and if it was more than 12 months - as stable clinical remission. The results are presented in figure 2 .
The severity of relapse did not significantly change before and after treatment in patients of group 1, but in patients of group 2 it was significantly suppressed by reducing the number of blisters (per 4-35 elements) and their size (not exceeding $3-5 \mathrm{~cm}$ ), in the third group of reduction comparison, the severity of relapse was observed only in patients with mild degree of dermatosis, and only in patients from the main group relapses were characterized by a significant severity decrease.

\section{CONCLUSIONS}

Thus, the therapy of patients with urticaria requires a differentiated approach. Patients with mild dermatosis, after traditional medication, should be prescribed balneo- and halomethods of treatment. Patients with moderate to severe 
degree of the disease require more intensive medical intervention. They should be prescribed a combined application of specific photo-, balneo- and halotherapy. This approach allows eliminating the pathological process.

\section{REFERENCES}

1. Trevisonno J., Balram B., Netchiporouk E., Ben-Shoshan M., Physical urticaria: review on classification, triggers and management with special focus on prevalence including a meta-analysis. Postgrad Med. 2015;127(6):565-570.

2. Bloom M.: Safety of desloratadine syrup in children. Curr. Med. Res. Opin. 2004;20(1):1959-1965.

3. Yaig P., OlonabM., Munoz Lejarazuetal D.: Epidemiology of urticaria in Spain. J. Invest. Allergol. Clin. Immunol. 2004;14(3): 214 - 220.

4. Zuberbier T., Maurer M.: Urticaria: current opinions about etiology, diagnosis and therapy. Acta Dermatol. Venerol. 2007;87(2): 196-205.

5. Kolkhir P, Balakirski G, Merk HF, Olisova 0, Maurer M. Chronic spontaneous urticaria and internal parasites - A systematic review. Allergy 2016;71:308-322.

6. Lachapelle J.M., Deeroix J., Henri Jeanetal A.: Desloratadine $5 \mathrm{mg}$ once daily improves the quality of life of patients with chronic idiopatic urticarial. J. Eur. Acad. Dermatol. Venerol. 2006;20(1): 288-292.

7. Hay RJ., Johns NE., Williams HC., et al.:The global burden of skin disease in 2010: an analysis of the prevalence and impact of skin conditions. J Invest Dermatol. 2014;134(6):1527-1534.

8. Guillén-Aguinaga S., Jáuregui Presa I., Aguinaga-Ontoso E., GuillénGrima F., Ferrer M.: Updosing nonsedating antihistamines in patients with chronic spontaneous urticaria: a systematic review and metaanalysis. Br J Dermatol. 2016;175(6):1153-1165.
9. Asero R. Serial D-dimer plasma levels in a patient with chronic spontaneous urticaria developing resistance to omalizumab. Clin Exp Dermatol. 2017;42:667-669.

10. Holiachenko H. B.: Medical rehabilitation of chronic dermatoses in children and teenagers in sanatorium conditions. Dermatovenereology, cosmetology, sex pathology 2010; 1-2: 222-226.

11. Zakachurina I.V., Khan M.A., Korbkina I.P.: Hydrocarbonate-chloride sodium mineral water in the rehabilitation of children with atopic dermatitis. Problems of the health resort treatment 2002;1:42-45.

12. Monakhov SA.: Thermal springs and their use in dermatology and cosmetology. Russian Journal of Skin and Venereal Diseases 2004;1:69-75.

13. AbdullaS.J,Desgroseilliers.P.:Treatment ofvitligo withnarrow-bandultraviolet B: advantages and disadvantages. J. Cutan. Med. Surg 2008;12 (4):174-179.

14. Antonello C., Baccichetti F., Carbassareetal C.: Photoreactions between furocoumarins: the molecular basic of the photo chemotherapy of psoriasis. Med. Biol. Enverons. 2000;28(1):157-167.

15. Kishan Kumar G.H., Rao J.R., Gopaletal K.V.: Evacuation of narrow-band UVB phototherapy in 150 patients with vitiligo. Indian J. Dermatol. Venerol. Leprol. 2003;75(2):162-165.

16. Vallat V.B., Gilleaudeau P., Battat L., et al: PUVA. Therapy strongly suppresses immunologic and epidermal activations in psoriasis: a possible cellular basic for remissive therapy J. Experim. Med. 1994;180(1):283-296.

\section{Authors' contributions:}

According to the order of the Authorship.

\section{Conflict of interest:}

The Authors declare no conflict of interest.

\section{CORRESPONDING AUTHOR \\ Marianna Dashko}

Department of Dermatology, Venereology

Danylo Halytsky Lviv National Medical University

Konovalets str., 1, 79014, Lviv, Ukraine

tel: +380677691977

e-mail:mariannadashko@gmail.com

Received: 01.03.2019

Accepted:02.04.2019 


\title{
SPECIFIC ASPECTS OF CLINICAL COURSE IN CASE OF COMBINATION OF CHRONIC PANCREATITIS AND CONCOMITANT VIRAL HEPATITIS C
}

\author{
Liliya S. Babinets, Olena R. Shaihen, Halyna OI. Homyn, Iryna M. Halabitska \\ STATE HIGHER EDUCATIONAL INSTITUTION, "TERNOPIL I. HORBACHEVSKII STATE MEDICAL UNIVERSITY, MINISTRY OF HEALTHCARE OF UKRAINE», \\ TERNOPIL, UKRAINE
}

\begin{abstract}
Introduction: In this publication we analyzed the specific aspects of clinical course in case of combination of chronic pancreatitis and concomitant viral hepatitis $C$. The aim: Discover the clinical course of chronic pancreatitis with concomitant viral hepatitis C.

Materials and methods: 57 patients with chronic pancreatitis and concomitant viral hepatitis c were examined. Diagnosis of chronic pancreatitis and viral hepatitis c was verified based on disease history, clinical symptoms and the results of clinical-instrumental tests. Clinical and biochemical investigations in people with chronic pancreatitis were done in exacerbation and unstable remission phases and for people with viral hepatitis C - in stable remission phase.

Results: In patients, who have chronic pancreatitis with concomitant hepatitis C, pain, dyspeptic syndromes and defecation disturbances take the major place in clinical course of the disease. These symptoms were more severe than in the control group (possible difference in numbers in the group of patents with isolate viral hepatitis $C$ ( $p<0,05)$. Conclusions: According to the studies data-the negative influence of concomitant viral hepatitis C in clinical course of chronic pancreatitis was identified.
\end{abstract}

KEY WORDS: chronic pancreatitis, viral hepatitis C, clinical course

Wiad Lek 2019, 72, 4, 595-599

\section{INTRODUCTION}

Chronic pancreatitis is very actual problem in modern medicine. In Ukraine the prevalence of GI disorders has been significantly increased during past few years. The prevalence of chronic pancreatitis from 2008 to 2012 has been increased by 2,2 times, the pancreas disorders - by 3,2 times. According to statistical data from Ministry of healthcare in Ukraine during the period from 2006 to 2013 the numbers of admissions with chronic pancreatitis was increased by $30,2 \%$. The combination of few diseases has palace in the majority of cases in gastroenterology clinics. Chronic pancreatitis is one of the most common disorder that have been diagnosed with chronic hepatitis and liver cirrhosis.

In case of combination of liver and pancreas damage the prognosis of recovery is unfavorable due to the complicated treatment plan. Under the circumstances that have occurred during last decades: epidemic viral hepatitis, alcohol abuse, increased obesity and dysmetabolic syndrome prevalence as well as non-alcoholic fatty liver disease leading to increased amount of patients with terminal liver conditions and according to the epidemiological analysis it reached it's peak in 2010-2020 [1].

During the past few years attention to the pathogen, that can cause the inflammation in pancreas, has increased . Hepatitis due to HCV is the progressive disease that leads to chronic active hepatitis, cirrhosis and hepatocellular carcinoma. Chronic hepatitis $\mathrm{C}$ may have persistent course with the minimum of clinical symptoms and biochemical changes causing late diagnostic of active process. Morphological changes in liver occur asymptomatically. Most often after the exposure to the pathogen it takes the long time to develop first signs of infection. Negative risk factors in natural course of disease include: age over 40 at the moment of exposure, non-Caucasian race, alcohol abuse, obesity, ferrous dysmetabolism an dysmetabolic syndrome [2].

According to the experts around 160 billion people, $2,35 \%$ of all world population are infected with HCV. Besides that, liver failure as a result of HCV infection is one of leading causes for liver transplantation. Usually immunological disorders are extra hepatic symptoms of chronic hepatitis $\mathrm{C}$ infection, however virus may have direct cytopathic effect and can infect many other tissue, besides liver [3].

Many people with Chronic hepatitis $\mathrm{C}$ develop diabetes mellitus type ll. This prevalence is much higher compared with general population and with group of patients suffering from other chronic liver disorders, such as HBV infection, alcohol liver disease and primary biliary cirrhosis. There is the possibility of biological reason for correlation between HCV and chronic pancreatitis. As it is known the patients who are diagnosed with acute hepatitis $\mathrm{C}$ also suffer from acute pancreatitis. Besides that in patient who were diagnosed with viral hepatitis the level of the pancreatic enzymes in serum increases with 
the progression of liver disorder. Significant prevalence of $\mathrm{HCV}$ infection in population, high level of process chronization with cirrhosis formation and hepatocellular carcinoma development as well as variety of extra-hepatic symptoms determine topicality of the HCV problem. At the same time the insufficiency in evolution of primary and secondary preventions of chronic pancreatitis motivates to deeper discovery of it's physiological mechanisms with concomitant chronic hepatitis $\mathrm{C}$, as well as to new approaches to develop prevention, treatment and rehabilitation $[4,5]$.

\section{THE AIM}

To discover the clinical aspects of chronic pancreatitis course in patients with concomitant viral hepatitis C.

\section{MATERIALS AND METHODS}

57 patients with chronic pancreatitis and concomitant chronic hepatitis C (group I) were examined, they were under outpatient observation at the Ternopil Primary Care Center and admitted to gastrointestinal department at Ternopil Hospital №2. Comparison group consisted of 20 patients with chronic pancreatitis (group II). The ambulatory charts of the patent were the souses of information. To diagnose chronic pancreatitis and viral hepatitis $C$ all patients were examined according to the protocols (Ministry of Healthcare in Ukraine orders №638 from 10.09.2014 and №729 from 18.07.2016). Average age of the patients was $53,5 \pm 22,5$ years. Number of People in retirement prevailed. Diagnoses of chronic pancreatitis an viral hepatitis $C$ were verified based on disease history, clinical symptoms as well as clinical and instrumental tests results. General clinical and biochemical tests were performed for patients with chronic pancreatitis in exacerbation phase and non-stable remission, for the patient with viral hepatitis C - in stable remission (ALT level remains normal). Results of coprological examination were analyzed in both groups. Each abnormal characteristic of comrogram was rated as one point with he following normal value: daily amount of stool - 120-200g, SAUSAGE-LIKE shape, homogeneous consistency, brown color, absence of undigested food, absence of mucus, blood and pus, normal flora, parasites-absent, ph-6-8, muscle fibers-absent, neutral fat-absent, fatty acids-few, starch and soup -small amount, undigested cellulose-few, oxalates-absent, stercobilin - small amount, bilirubin absent. To interpret the result of Ultrasound diagnostic in points we use Marsel- Cambrige classification visualization criteria.

The arithmetic mean (M) with mean square deviation $(\mathrm{m})$ were calculated. To verify statistical hypothesis we used parametric and nonparametric methods. In parametric distribution we used Student's T-criteria, in nonparametric-Manna-Uitni's U-criteria. For statistical hypothesis verification null hypothesis was rejected at significance value $\mathrm{p}<0,05$.

\section{RESULTS}

Pain, dyspeptic syndromes and defecation disturbances take the major place in clinical course of chronic pancreatitis with concomitant viral hepatitis $\mathrm{C}$. These symptoms were more severe compared with patients who suffered from isolated chronic pancreatitis (see table I).

In patient with chronic pancreatitis and concomitant viral hepatitis $\mathrm{C}$ mild anemia with decreased level of albumin, hypebilirubinemia, hypercholesterolemia, elevated level of transaminases, amylase and urine diastase were detected (see table II).

Differences in value results reflect multiple dysmetabolic disorders in patient with chronic pancreatitis and concomitant viral hepatitis $C$, which were more reliably significant compared with group $\mathrm{ll}$ and have shown the aggravating role of concomitant viral hepatitis $\mathrm{C}$ on laboratory characteristics in patients suffering from chronic pancreatitis.

Benchmark score of total coprogram results and structural changes in pancreas as per Ultrasound tests data was the next step in investigation. In patients with concomitant viral hepatitis $C$ total score of coprogram was $5.20 \pm 0.82$ and in patient with isolated chronic pancreatitis - $3.1 \pm 0.32$, which showed deeper coprogram changes in patients with combination of chronic pancreatitis and viral hepatitis C. (see fig. 1). In both investigated groups steatorrhea type 2 prevailed.

In analysis of patient's coprogram with chronic pancreatitis and concomitant viral hepatitis $\mathrm{C}$ in comparison with group of patients who suffer from isolated chronic pancreatitis we noticed more severe pathological changes that have proved negative effect of viral hepatitis $C$ on clinical course of chronic pancreatitis. It was established based on worse value results, more expressed inflammation syndrome and signs of dysbacteriosis, which reflect more severe pancreas exocrine function disorder in case of combination of chronic pancreatitis and viral hepatitis C. The analysis of Ultrasound diagnostic results in both groups has shown: the depth of structural changes in patient with chronic pancreatitis and concomitant viral hepatitis $C$ was $4,56 \pm 0.55$ point, that reflect the moderate severity. In patients with isolated chronic pancreatitis $1,900 \pm 0,3$ points. (see fig. 2 ).

Compression of these two parameters $(\mathrm{p}<0,05)$ allowed us to show the contrast of more severe structural changes in pancreas (according to Ultrasound tests results data) in patients with concomitant viral hepatitis C.

\section{DISCUSSION}

Beyond the liver, HCV chronic infection leads to a multifaceted systemic disease. Some extrahepatic manifestations are immune mediated while others seem to be driven by chronic inflammation. Such extrahepatic manifestations should be well known by clinicians. They should have an impact on the care of patients with $\mathrm{HCV}$ infection. [6] So far more than 30 different conditions have been associated with chronic $\mathrm{HCV}$ infection. In general, the appearance of extrahepatic manifestations of $\mathrm{HCV}$ infection is unpredictable, that is, independent of the 
Table I. Main Gastrointestinal syndromes in groups of patient with Chronic pancreatitis depending on presence of concomitant Viral hepatitis C (M+m)

\begin{tabular}{ccc}
\hline Clinical syndrome and symptom & $\begin{array}{c}\text { Group I } \\
(\mathbf{n = 5 7 )}\end{array}$ & $\begin{array}{c}\text { Group II } \\
(\mathbf{n = 2 0 )}\end{array}$ \\
\hline Pain syndrome & $100,0 \% *$ & $80,0 \%$ \\
\hline Dyspeptic syndrome & $87,5 \% *$ & $70,0 \%$ \\
\hline Defecation disorders & $89,4 \% *$ & $65,0 \%$ \\
\hline Constipation & $33,3 \% *$ & $25,0 \%$ \\
\hline Diarrhea & $26,8 \% *$ & $15,0 \%$ \\
\hline Alternation of constipation and diarrhea & $45,6 \%^{*}$ & $45,0 \%$ \\
\hline
\end{tabular}

Note: Probability of value difference in group I in relation to group II $(p<0,05)$.

Table II. Main clinical and biochemical characteristics of blood in both groups (M+m)

\begin{tabular}{|c|c|c|}
\hline Laboratory characteristic & $\begin{array}{c}\text { Group I } \\
(n=57)\end{array}$ & $\begin{array}{c}\text { Group II } \\
(n=20)\end{array}$ \\
\hline Erythrocyte, women, /I & $4,02 \pm 0,33^{*}$ & $4,48 \pm 0,11$ \\
\hline Hemoglobin, women, g/l & $117,0 \pm 10,04^{*}$ & $132,0 \pm 9,48$ \\
\hline Erythrocyte, men, /I & $4,4 \pm 0,2^{*}$ & $4,58 \pm 0,13$ \\
\hline Hemoglobin, men, g/l & $140,0 \pm 7,6^{*}$ & $154,0 \pm 9,43$ \\
\hline Leucocytes / & $5,34 \pm 1,13^{*}$ & $5,27 \pm 1,06$ \\
\hline $\mathrm{ESR} \mathrm{mm} / \mathrm{hr}$ & $9,0 \pm 5,59 *$ & $8,0 \pm 5,47$ \\
\hline Total bilirubin mmol/l & $29,64 \pm 11,28^{*}$ & $15,83 \pm 3,76$ \\
\hline Total protein g/l & $58,02 \pm 6,67^{*}$ & $82,6 \pm 3,54$ \\
\hline Total cholesterol mg/dL & $5,52 \pm 0,83^{*}$ & $4,4 \pm 0,56$ \\
\hline ALT IU/L & $1,36 \pm 0,51^{*}$ & $0,47 \pm 0,14$ \\
\hline AST IU/I & $0,66 \pm 0,14^{*}$ & $0,26 \pm 0,11$ \\
\hline Blood amylase $\mathrm{mg} / \mathrm{hr} r^{*} \mathrm{ml}$ & $38,97 \pm 9,08^{*}$ & $26,73 \pm 3,83$ \\
\hline Urine diastase $\mathrm{mg} / \mathrm{hr} \mathrm{ml}^{*}$ & $168,6 \pm 97,34^{*}$ & $98,96 \pm 58,12$ \\
\hline
\end{tabular}

Note: Probability of value difference in group I in relation to group II $(p<0,05)$.

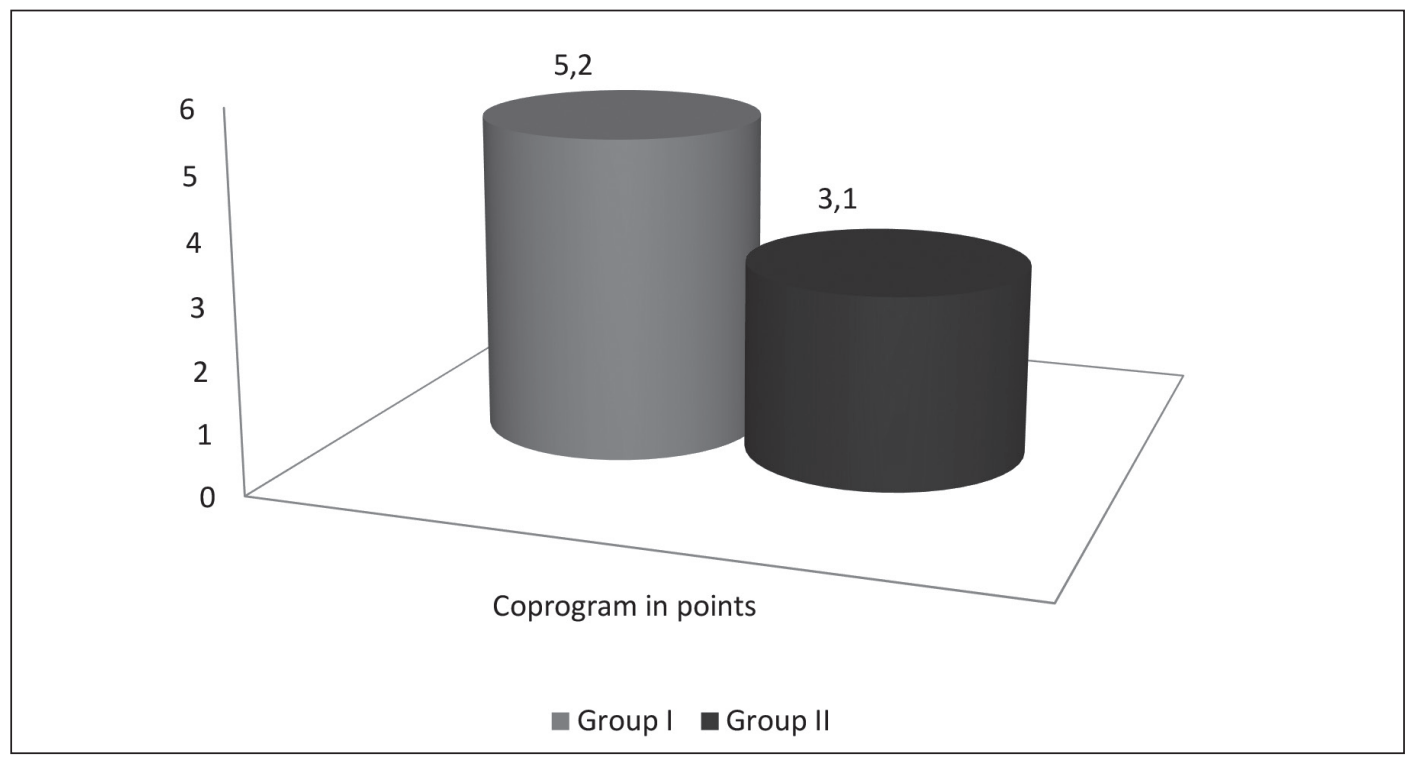

Pic. 1. Total score of coprogram in points in both groups

stage of the liver disease. A clear association with chronic hepatitis $\mathrm{C}$ has been established for many of these con- ditions, while, for some diseases, good-quality evidence linking them to HCV infection is still missing. [7] Finally, 


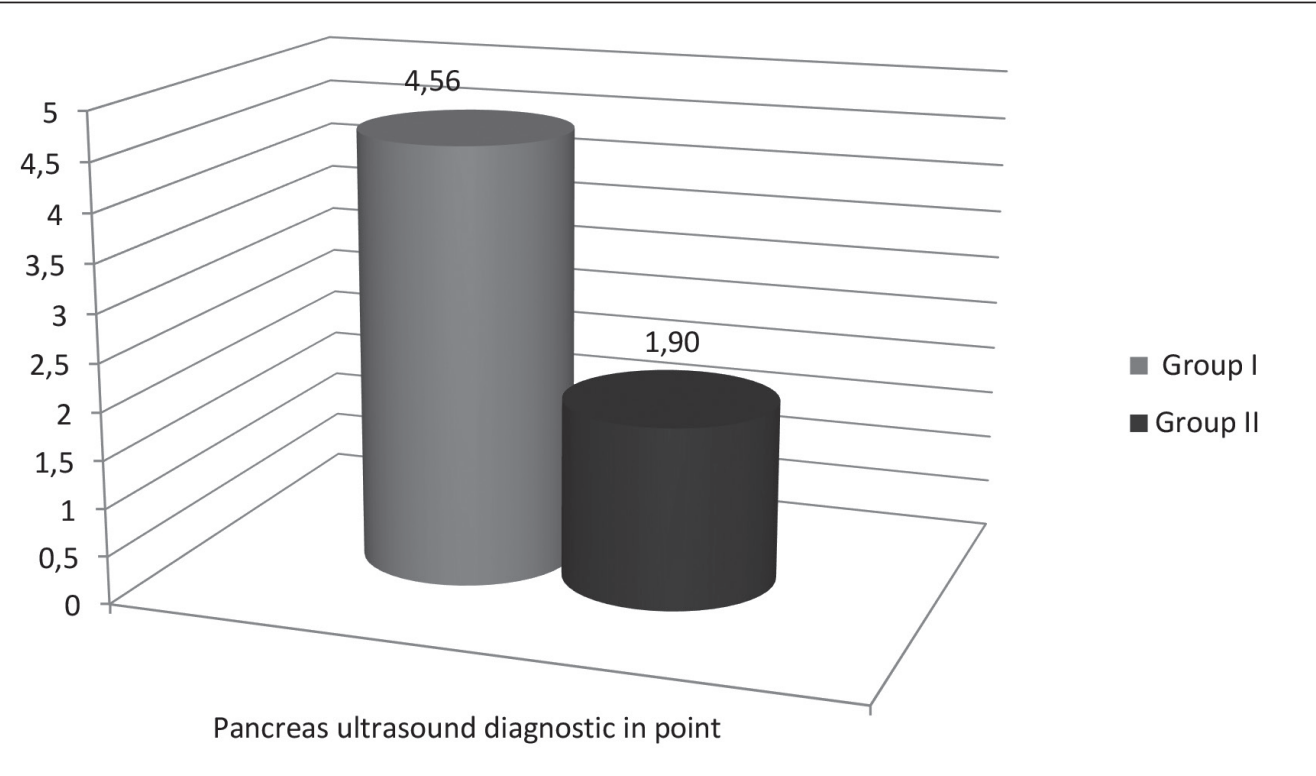

Pic. 2. Total score of pancreas ultrasound diagnostic in point in both groups.

there are three manifestations classically considered as $\mathrm{HCV}$-associated and whose relationship has not been established in the later publications: Thyroid manifestations (associated with interferon therapies and some age groups), pulmonary fibrosis and Mooren corneal ulcers. Finally, it is worth considering that the appearance of extrahepatic manifestations and positive immunological results can lead to the diagnosis of a specific system autoimmune disorder, according to the corresponding criteria. [8] Patients with $\mathrm{CHC}$ infection are at higher risk of developing CKD. Metabolic and cardiovascular factors need to be considered, as well as extrahepatic manifestations affecting the kidneys, in addition to the underlying liver disease. [9]

The extrahepatic manifestations of hepatitis $\mathrm{C}$ include effects on the central nervous system, which have been associated with the ability of hepatitis $\mathrm{C}$ virus ( $\mathrm{HCV}$ ) to replicate in microglial and endothelial cells and the chronic inflammation induced by HCV. HCV can induce impaired neurocognition, which is clinically manifested by impaired quality of life, fatigue, and brain fog. These cognitive defects can be present even in patients with mild histologic HCV and have been confirmed by neurocognitive testing and brain imaging by magnetic resonance spectroscopy. Neurocognitive defects include loss of functioning memory and subtle changes in attention and processing speed. [10]

\section{CONCLUSIONS}

Comparative analysis of clinical, laboratory and instrumental signs in patients with chronic pancreatitis depending on the presence of viral hepatitis $\mathrm{C}$ discovered the following aspects of this combination: more severe pain and dyspeptic syndromes, worsening of laboratory changes which include mild anemia, decreased blood albumin level, hyperbilirubinemia, hypercholesterolemia, elevated transaminases, blood amylase and urine diastase, increased total score of comprogram (more expressed inflammation syndromes and dysbacteriosis in colon), have shown higher level of pancreas exocrine function disorders as well as increased total score of Ultrasound diagnostic tests chances to moderate level of severity according to Marsel-Cembridge classification.

\section{REFERENCES}

1. Babinets L.S., Kytsai K.Yu., Kotsaba Yu.Ya., et al. Improvement of the complex medical treatment for the patients with chronic biliary pancreatitis. Wiadomosci lekarskie, 2017;2;213-216.

2. El-Serag H., Engels E. A., Landgren 0. Et al. Risk of Hepatobiliary and Pancreatic Cancers Following Hepatitis C Virus Infection. Hepatology. 2009;49(1):116-123. D0l: [10.1002/hep.22606].

3. Reshetilov Yu.I., Tokarenko A.I., Dmitrieva S.N., et al. Infektsii i ikh mesto sredi drugikh prichin vozniknoveniya pankreatita [Infections and their place among other causes of pancreatitis]. Suchasna hastroenterolohiya - Modern gastroenterology, 2002;2(8);24-29. (in Russian).

4. Unifikovanyy klinichnyy protokol pervynnoyi, vtorynnoyi (spetsializovanoyi) medychnoyidopomohy ta medychnoyi reabilitatsiyi [Unified clinical protocol of primary, secondary (specialized) medical aid and medical rehabilitation]. 2014. Ministry of Health of Ukraine, 638 (in Ukrainian).

5. Babinets L.S., Halabitska I.M., Maevska T.G. Zovnishn'osekretorna nedostatnist' pidshlunkovoyi zalozy ta dysbalans systemy prooksydantyantyoksydanty pry pervynnomu osteoartrozi z komorbidnymy stanamy [External-secretion pancreaticinsufficiency and an anti-oxidant antioxidant system imbalance in primary osteoarthritis with comorbid conditions]. Zdobutka klinichnoyi ta eksperymental'noyi medytsyny - Achievement of clinical and experimental medicine, 2017;3: 22-25 (in Ukrainian).

6. Cacoub P., Comarmond C., Domont F., et al. Extrahepatic manifestations of chronic hepatitis C virus infection. Therapeutic Advances in Infectious Disease, 2016;3(1):3-14.

7. Virović Jukić L., Kralj D. Extrahepatic Manifestations of Hepatitis C Virus Infection. 2017. https://www.intechopen.com/books/update-onhepatitis-c/extrahepatic-manifestations-of-hepatitis-c-virus-infection. 
8. Flores-Chávez A., Carrion J.A., Forns X., et al. Extrahepatic manifestations associated with Chronic Hepatitis C Virus Infection. Revista Española de Sanidad Penitenciaria, 2017;19:3.

9. Söderholm J., Millbourn C., Büsch K., et al. Higher risk of renal disease in chronic hepatitis ( patients: Antiviral therapy survival benefit in patients on hemodialysis. Journal of Hepatology, 2018;68:904-911.

10. Iriana S., Curry M. P., Afdhal N. H. Neurologic Manifestations of Hepatitis C Virus Infection. Clinics in Liver Disease, 2017;21:535-542

Research topic: 0118U000361, Comprehensive approach to the control of symptoms, direct and distant prognosis in conditions of comorbid pathology in the clinic of internal diseases and the practice of a family.

\section{Authors' contributions:}

According to the order of the Authorship.

\section{Conflict of interest:}

The Authors declare no conflict of interest.

\section{CORRESPONDING AUTHOR}

\section{Liliya Babinets}

14 Kupchyns'ky Str., 46400 Ternopol, Ukraine

tel: +380673520743

e-mail: lilyababinets@gmail.com

Received: 21.02.2019

Accepted: 29.03.2019 


\title{
CLINICAL AND AUDIOLOGICAL VALUES IN THE EARLY DIAGNOSIS OF HEARING IMPAIRMENTS AND RISK GROUPS AMONG SHIP REPAIR WORKERS
}

\author{
Olexander Ye.Kononov, Larysa F. Matiukha, Ganna V. Batsiura, Olha V. Protsiuk, Liliana V. Klymenko, Tatyana V. Veselova \\ SHUPYK NATIONAL MEDICAL ACADEMY OF POSTGRADUATE EDUCATION, KYIV, UKRAINE
}

\begin{abstract}
Introduction: The hazardous effect of industrial noise exposure on ship repair workers has been highlighted in a number of studies. However, no data are currently available for studying the effect of noise exposure on the auditory system and general health of ship repair workers.

The aim: The study is focused on the early diagnosis of hearing impairments and identifying risk groups among the workers.

Materials and methods: It was examined two groups of workers of approximately the same age and length of employment. The Group 1 included workers from the Azov Shiprepair Yard (Mariupol city, Ukraine) who were exposed to workplace noise impact of less than $80 \mathrm{dBA}$ threshold level, the workplace noise level in the Group 2 was above $80 \mathrm{dBA}$. Audiometric testing was conducted in a sound-treated room using the MA 31 clinical audiometer (Germany).

Results: Our findings indicate that all the noise-exposed groups of ship repair workers should be conducted audiometric testing. The hearing levels at the audiometric test frequencies of 4, 6 and $8 \mathrm{kHz}$, as well as differential thresholds at the audiometric test frequencies of $4 \mathrm{kHz}$ by the Luscher-Zwislocki method should be taken into account. Such complaints as increased annoyance, sleep disorder, tinnitus aurium, hypertension should be considered as most hazardous.

Conclusions: We recommend that the ship repair workers undergo routine medical check-ups and systematic prophylactic observation. All these preventive measures will contribute to the early detection of hearing impairments, thereby timely preventing the development and progression of occupational sensorineural hearing loss.
\end{abstract}

KEY WORDS: audiometry, early diagnosis, ship repair workers, occupational sensorineural hearing loss

Wiad Lek 2019, 72, 4, 600-603

\section{INTRODUCTION}

The hazardous effect of industrial noise exposure on ship repair workers has been highlighted in a number of studies $[1,2,3]$. The excessive noise at the workplace can cause both auditory system hearing impairments and diseases of the cardiovascular system and central nervous system [4]. The existing literature on occupational noise exposure on human health shows that ship repair workers who are subjected to excessive noise beyond tolerated levels at their workplace complain of hearing loss, tinnitus aurium, headache, dizziness, insomnia, etc. $[5,6,7,8,9,10,11]$.

However, no data are currently available for studying the effect of noise exposure on the auditory system and general health of ship repair workers who are exposed to the workplace noise levels of $80 \mathrm{dBA}$ limiting threshold and above $80 \mathrm{dBA}$, comparatively.

\section{THE AIM}

This study was aimed at assessing the effect of workplace noise of less than $80 \mathrm{dBA}$ (the Recommended Exposure Limit) and above $80 \mathrm{dBA}$ threshold levels on the noise-exposed ship repair workers by comparing values of their auditory analyzer and somatic status. The goals of the study included early diagnosis of hearing impairments and identifying risk groups among the workers.

\section{MATERIALS AND METHODS}

Considering the workplace noise intensity, we selected and tested two workers' groups of approximately the same age and length of employment (30 subjects in each group). The first group (Group 1) included workers from the Azov Shiprepair Yard (Mariupol city, Ukraine) who were exposed to workplace noise impact of less than 80 $\mathrm{dBA}$ threshold level, the workplace noise level in the second group (Group 2) was above $80 \mathrm{dBA}$. The age-related changes in hearing were taken into account in the further data analysis. We compared shipyard workers' complaints of general health and the values of their somatic status by the workplace noise level. Audiometric testing was conducted in a sound-treated room using the MA 31 clinical audiometer (Germany).

In the data analysis we excluded workers with previous craniocerebral trauma, infections, asymmetric hearing and those being routinely exposed to radiation. The control group included 15 healthy subjects aged between 20 and 
Table I. Noise-exposed groups of ship repair workers (Group 1 and 2) by their complaints of health.

\begin{tabular}{|c|c|c|c|c|c|c|c|c|c|c|c|}
\hline \multirow[b]{3}{*}{ 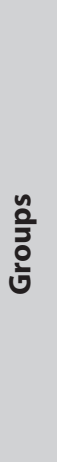 } & \multirow[b]{3}{*}{ 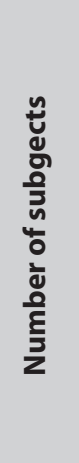 } & \multicolumn{10}{|c|}{ Workers' complaints } \\
\hline & & \multicolumn{5}{|c|}{ In absolute figures } & \multicolumn{5}{|c|}{ Percentage to the total number $\%$} \\
\hline & & 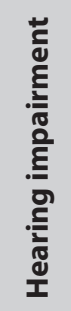 & 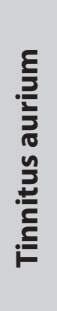 & 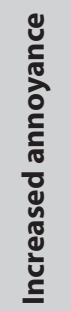 & 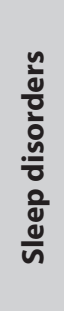 & 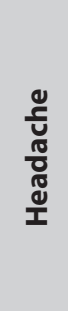 & 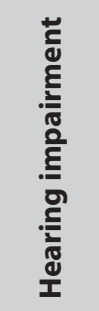 & 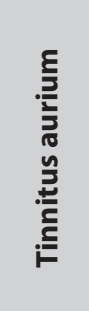 & 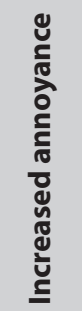 & 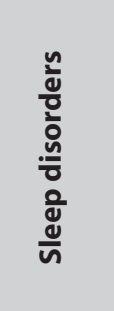 & 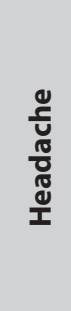 \\
\hline 1 & 30 & 4 & 17 & 21 & 18 & 5 & 13,3 & 56,7 & 70,0 & 60,0 & 16,7 \\
\hline 2 & 30 & 30 & 27 & 29 & 28 & 16 & 100,0 & 90,0 & 96,7 & 93,3 & 53,3 \\
\hline
\end{tabular}

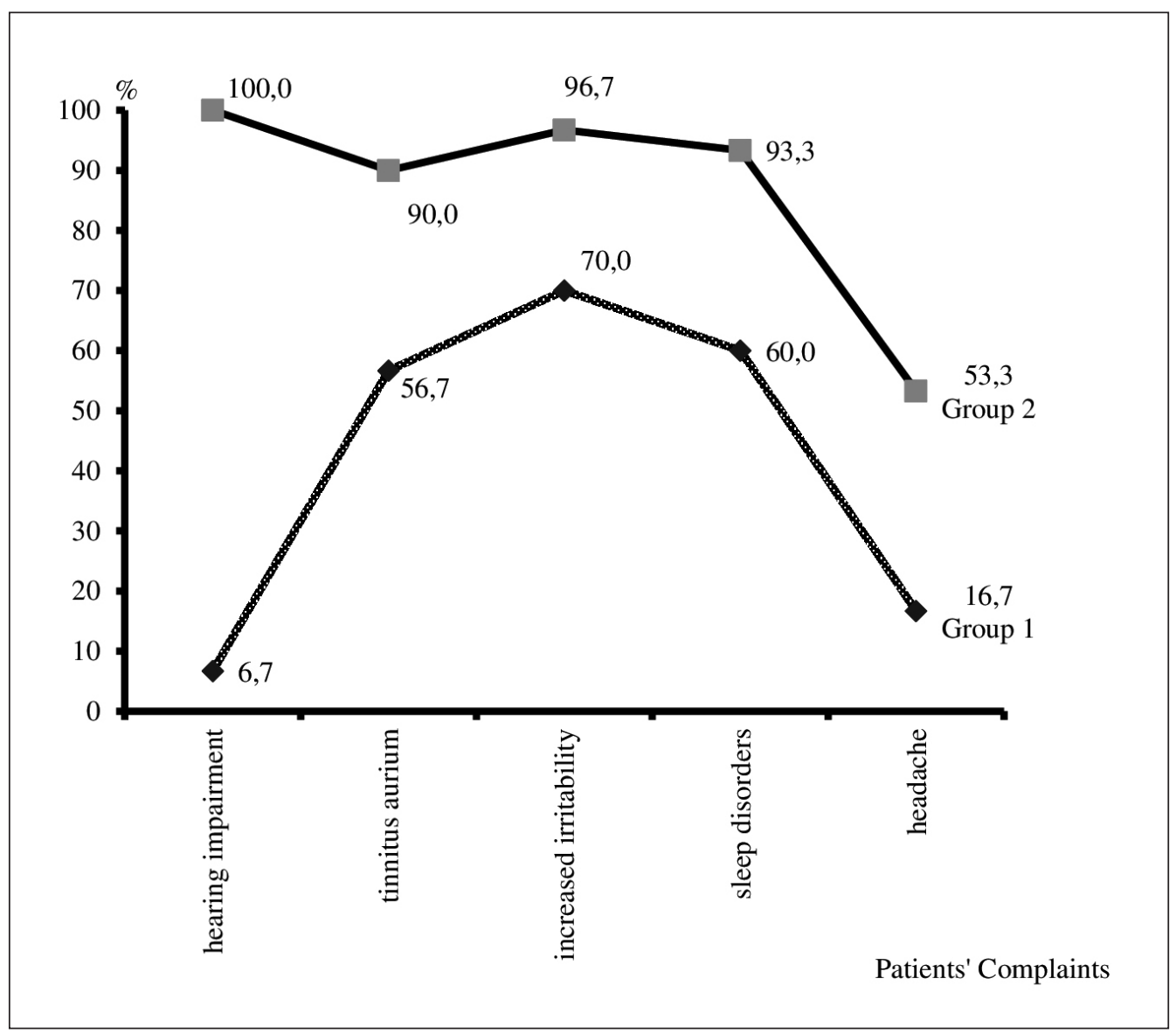

Fig. 1. Noise-exposed groups of ship repair workers (Groups I and II) by their complaints of general health.

30 years with normal hearing, without vascular diseases and who were not exposed to the excessive noise. All the subjects had no pathologies of the nose and paranasal sinuses and were not exposed to the radiation.

\section{RESULTS AND DISCUSSION}

Our findings revealed the following data. The majority of Group 2 workers, who were exposed to occupational noise impact of higher than $80 \mathrm{dBA}$ hearing threshold level, complained not only of hearing impairment $(100,0 \%)$, but also tinnitus aurium (90,0\%), increased annoyance $(96,7 \%)$, sleep disorders $(93,3 \%)$ and over half of them complained of headache $(53,3 \%)$.

However, the workers from Group 1, exposed to workplace noise of less than or equal to $80 \mathrm{dBA}$ threshold level, also complained of tinnitus aurium (56,7\%), increased annoyance $(70,0 \%)$, sleep disorders $(60.0 \%)$ but poorer hearing was reported only in $16,7 \%$ of cases. These data are shown in Table I and Figure 1. 
Table II. Noise-exposed groups of ship repair workers (Group1 and 2) by their somatic status.

\begin{tabular}{|c|c|c|c|c|c|c|c|}
\hline \multirow{3}{*}{ 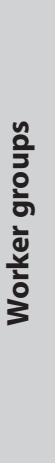 } & \multirow{3}{*}{ 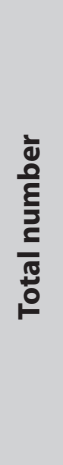 } & \multicolumn{6}{|c|}{ Somatic status of workers } \\
\hline & & \multicolumn{3}{|c|}{ In absolute figures } & \multicolumn{3}{|c|}{ Percentage to the total number $\%$} \\
\hline & & 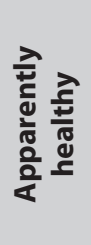 & 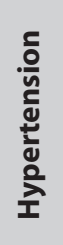 & 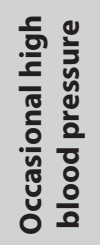 & 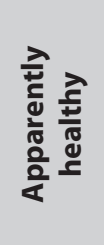 & 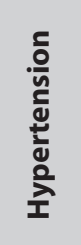 & 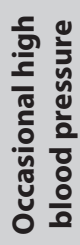 \\
\hline 1 & 30 & 3 & 10 & 17 & 10,0 & 33,3 & 56,7 \\
\hline 2 & 30 & - & 27 & 3 & - & 90,0 & 10,0 \\
\hline
\end{tabular}

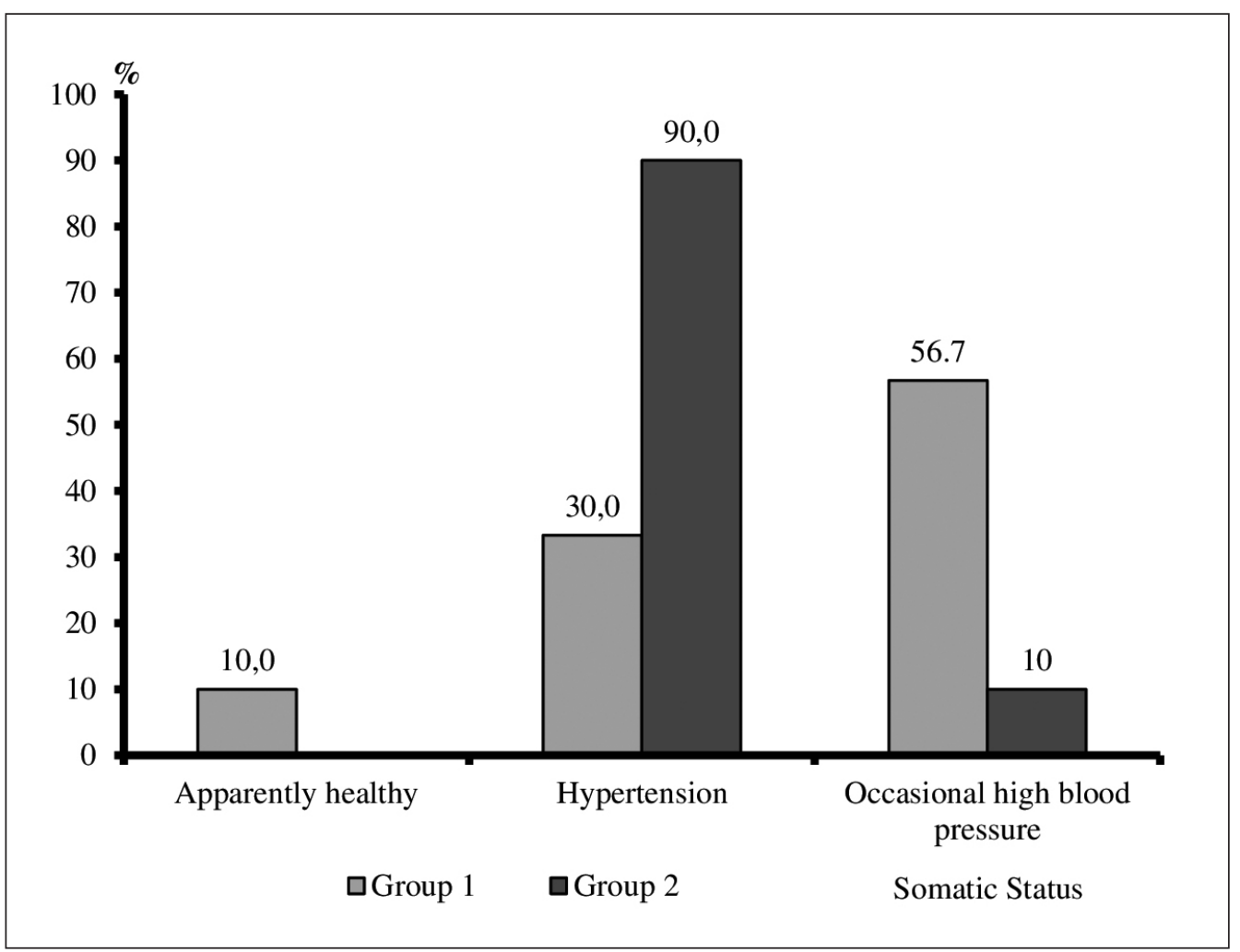

Fig. 2. Noise-exposed groups of ship repair workers (Groups I and II) by their somatic status.

Thus, during regular medical check-ups, audiometric testing should be performed for those noise-exposed workers who complain of increased annoyance and tinnitus aurium but their hearing level is considered to be normal. That is when the workplace noise doesn't exceed the Recommended Exposure Limit. Such workers are referred to the risk group and should be recommended regular clinical and audiometric testing.

These groups of workers often had slightly decreased hearing level at the audiometric test frequency of $8 \mathrm{kHz}$ and a relatively reduced differential threshold at the audiometric test frequencies of $4 \mathrm{kHz}$ by the Luscher-Zwislocki method. They should be referred to the risk group and timely undergo medical check-ups in order to prevent occupational sensorineural hearing loss.

Considering the somatic status of the noise-exposed groups of ship repair workers (Groups 1 and 2), the intensity of workplace noise exposure was taken into account (Table II and Figure 2). Hypertension of different stages was found in $90.3 \%$ of cases in Group 2. It should be noted that Group 2 workers also suffered from encephalopathy, vegetative-vascular dystonia of hypertensive type, peptic ulcer and other diseases. However, in the analysis we compared the somatic status of workers which was observed in both groups.

Group 1 workers had stage I hypertension in 33,3\% of cases. Stage II-III hypertension was present in the over- 
whelming majority of Group 2 workers $(90,0 \%)$. There were no apparently healthy subjects in Group 2, but $10 \%$ was observed in Group 1. Periodic rise in blood pressure mostly occurred in Group 1. As above mentioned, the workers mostly complained of increased annoyance $(70.0 \%)$, sleep disorders $(60,0 \%)$ and tinnitus aurium $(56,7 \%)$. Headache was observed in $16,7 \%$ of cases in Group 1, and only $13,3 \%$ of the subjects had hearing impairments. It should be also noted that the Group 1 workers had slightly decreased hearing level $(28,2 \pm 2,3$ $\mathrm{dB}, 21,8 \pm 2,4 \mathrm{~dB}$ and $22,7 \pm 2,1 \mathrm{~dB}$ ) at the audiometric test frequencies of 4,6 , and $8 \mathrm{kHz}$. And these workers had a relatively reduced differential threshold $(0,72 \pm 0,03 \mathrm{~dB})$ at the audiometric test frequencies of $4 \mathrm{kHz}$ by the Luscher-Zwislocki method. Consequently, the noise-exposed workers of both groups, regardless the workplace noise levels, who complain of tinnitus aurium, sleep disorders, increased annoyance, periodic rise in blood pressure should be referred to the "risk" group and recommended timely medical check-ups and systematic prophylactic observation.

It is of particular relevance the fact that among the workers from Group 1, exposed to the excessive workplace noise above $80 \mathrm{dBA}$ threshold level, there were no apparently healthy subjects. But Group 1 included 10\% of apparently healthy subjects, that is when occupational noise impact was less than $80 \mathrm{dBA}$ threshold level.

\section{CONCLUSIONS}

The study findings indicate that all the noise-exposed groups of ship repair workers regardless whether or not they are subjected to the workplace noise impact above the Recommended Exposure Limit should be conducted regular audiometric testing.

The hearing levels at the audiometric test frequencies of 4,6 and $8 \mathrm{kHz}$, as well as differential thresholds at the audiometric test frequencies of $4 \mathrm{kHz}$ by the Luscher-Zwislocki method should be taken into account. Besides, we recommend for the ship repair workers to undergo routine medical check-ups and systematic prophylactic observation. Such complaints as increased annoyance, sleep disorder and tinnitus aurium should be considered as most hazardous. There is also recommended regular monitoring of the noise-exposed ship repair workers' somatic status, their complaints of high blood pressure and hypertension are of the most alarming ones. All these preventive measures will contribute to the early detection of hearing impairments, thereby timely preventing the development and progression of occupational sensorineural hearing loss.

\section{REFERENCES}

1. Hederstierna C, Rosenhall U. Age-related hearing decline in individuals with and without occupational noise exposure. Noise Health. 2016;18(80):21-5. doi: 10.4103/1463-1741.174375.

2. Neitzel RL, Svensson EB, Sayler SK et al. A comparison of occupational and nonoccupational noise exposures in Sweden. Noise Health. 2014;16(72):270-8. doi: 10.4103/1463-1741.140503.
3. Lie A, Skogstad M, Johannessen HA et al. Occupational noise exposure and hearing: a systematic review. Int Arch Occup Environ Health. 2016;89(3):351-72. doi: 10.1007/s00420-015-1083-5.

4. Yousefi Rizi HA, Hassanzadeh A. Noise exposure as a risk factor of cardiovascular diseases in workers. J Educ Health Promot. 2013;2:14. doi: 10.4103/2277-9531.112683.

5. Shidlovska TA, Shidlovska TV, Kozak MS. et al. Kharacteristika stanu TSNS u chvorich z sensornonevralnaoy priglukhuvatistyu shumovogo i sudinnogo genezu [Characteristics of the state of the central nervous system in patients with sensorineural deafness due noise and vascular genesis]. Journal of the Ear, Nasal and Throat Diseases. 2017;3:107-108. (In Ukrainian).

6. Lindblad AC, Rosenhall U, Olofsson Å et al. Tinnitus and Other Auditory Problems - Occupational Noise Exposure below Risk Limits May Cause Inner Ear Dysfunction. PLoS One. 2014; 9(5): e97377. doi: 10.1371/ journal.pone.0097377.

7. Dzhambov AM, Dimitrova DD. Heart disease attributed to occupational noise, vibration and other co-exposure: Self-reported population-based survey among Bulgarian workers. Med Pr. 2016;67(4):435-45. doi: 10.13075/mp.5893.00437.

8. Lacerda A, Quintiliano J, Lobato D etal. Hearing profile of brazilian forestry workers' noise exposure. Int Arch Otorhinolaryngol. 2015;19(1):22-9. doi: 10.1055/s-0034-1382098.

9. Lie A., Skogstad M., Johnsen TS. et al. Noise-induced hearing loss in a longitudinal study of Norwegian railway workers. BMJ Open. 2016;6(9):e011923. doi: 10.1136/bmjopen-2016-011923.

10. Liu J, Xu M, Ding L et al. Prevalence of hypertension and noise-induced hearing loss in Chinese coal miners. J Thorac Dis. 2016;8(3):422-9. doi: 10.21037/jtd.2016.02.59.

11. Tessier-Sherman B, Galusha D., Cantley LF. et al. Occupational noise exposure and risk of hypertension in an industrial workforce. Am J Ind Med. 2017;60(12):1031-1038. doi: 10.1002/ajim.22775.

\section{Authors' contributions:}

According to the order of the Authorship.

\section{Conflict of interest:}

The Authors declare no conflict of interest.

\section{CORRESPONDING AUTHOR Olexander Ye. Kononov}

Shupyk National Medical Academy of Postgraduate Education

9 Dorohozhytska str., 04112 Kyiv, Ukraine

tel: + 38 (044) 288-10-34 (33)

e-mail:doctorkononov@yandex.ru

Received: 07.02.2019

Accepted: 01.04.2019 


\title{
PREVALENCE OF ACIDIC AND NON-ACIDIC REFLUXES IN PATIENTS WITH FUNCTIONAL DYSPEPSIA AND ITS RISK FACTORS INVESTIGATED BY MEANS OF MULTICHANNEL INTRALUMINAL PH-MONITORING
}

\author{
Sergii Melashchenko, Viacheslav Chernobrovyi, Oleg Ksenchyn \\ DEPARTMENT OF FAMILY AND INTERNAL MEDICINE, VINNYTSYA NATIONAL PIROGOV MEMORIAL MEDICAL UNIVERSITY, VINNYTSYA, UKRAINE
}

\begin{abstract}
Introduction: Previous studies performed by conventional pH-monitors showed that a significant proportion of patients with functional dyspepsia have abnormal acidic gastroesophageal reflux. The investigation, using advantages of multichannel intraluminal pH-monitoring, were not conducted.

The aim to reveal the prevalence of all types of refluxes in patients with functional dyspepsia and to estimate risk provoking factors for abnormal reflux.

Methods and materials: Patients were divided into 6 groups. The $1^{\text {st }}, 2^{\text {nd }}$ and $3^{\text {rd }}$ groups covered 127 adult patients with epigastric pain syndrome, postprandial distress syndrome and mixed variant respectively. The $4^{\text {th }}$ included 69 NERD patients suffered from frequent (more than one episode per week) heartburn. The $5^{\text {th }}$ group also consisted of 22 NERD patients without heartburn or with rare heartburn-regurgitation. The reference group included 30 subjects without dyspeptic complaint and established diagnoses of gastro-esophageal diseases. For all persons the 200-min MII-pH-monitoring was performed with standardized stimulating breakfast (507kcal, $100 \mathrm{mg}$ caffeine, $300 \mathrm{ml}$ ) recording basal and postprandial phases.

Results: It was found that the difference in comparison to the reference group in the number of refluxes is determined by the number of acid refluxes and not by weakly-acidic and weakly-alkaline refluxes. Patients with functional dyspepsia from all subgroups had an excessive amount of acidic refluxes in comparison with the reference group - $3.7 \pm 0.7$, $4.7 \pm 0.8$ and $2.8 \pm 0.7$ vs $1.8 \pm 0.3$ episodes ( $p<0.05$ ). Using the previously obtained threshold values for abnormal acidic reflux ( $>6$ episodes per 200 min.) and total refluxes (>17 episodes per $200 \mathrm{~min}$.) it was revealed that $22.8 \%$ patients with FD had abnormal GER. In addition, $16.5 \%$ had an isolated excess of non-acidic reflux. All three dyspeptic groups didn't have a significant difference in the distribution of patients among subtypes of abnormal presence or absence of acidic/non-acidic refluxes.

Conclusion: In functional dyspepsia abnormal acidic reflux are common and affect $22.8 \%$ of patients. It is independently associated with hiatal hernia ( $0 \mathrm{R}=4.17)$, previously healed a peptic ulcer $(0 R=3.90)$, occasional heartburn $(O R=1.25)$, body mass index $(O R=1.11)$, younger age $(O R=0.97)$.
\end{abstract}

KEY WORDS: functional dyspepsia; GERD; reflux; pH-monitoring; multichannel intraluminal impedance

Wiad Lek 2019, 72, 4, 604-612

\section{INTRODUCTION}

Functional dyspepsia (FD) is the most common upper gastrointestinal disorder affecting $11-29.2 \%$ of the population around the world [1]. So far, our knowledge of pathophysiological abnormalities in FD has been limited to functional changes in the gastrointestinal tract (visceral hypersensitivity, delayed gastric emptying, abnormal accommodation, gastric dysmotility), and only a small number of studies have investigated the co-existing gastroesophageal reflux (GER). Naturally, this disturbance is more relevant to GERD. Overlap of GERD and dyspepsia/FD is clearly a common situation and it is observed in 13-48\% of subjects with FD [2]. Excluding these cases, some types of dyspepsia have a GER as the main pathogenetic factor. For example, it is considered that the leading mechanism for the development of dyspepsia in pregnant women is an excessive GER, although this assumption has not been proven by instrumental research $[3,4]$. The regular workup protocols for uninvestigated dyspepsia don't generally include $\mathrm{pH}$-monitoring, that's why it is unclear how many of the dyspeptic patients had pathologic esophageal acid expo- sures. Previously performed studies in patients with FD show a prevalence of acid reflux 23-31.7\% [5,6]. However, researchers used conventional 24-hour pH-monitoring of esophagus. Multichannel intraluminal impedance (MII)-pH-monitoring allows to expand diagnostic possibilities due to the evaluation of non-acid and gas events.

\section{THE AIM}

We aim to reveal the prevalence of acidic and non-acidic refluxes in patients with functional dyspepsia and to estimate risk provoking factors for abnormal reflux including clinical features and demographic data.

\section{MATERIALS AND METHODS}

\section{IMPEDANCE AND pH RECORDING}

In our research we used ambulatory system of MII-pH-monitoring АГ-3pH-4R (“Start Ltd., Vinnytsia, Ukraine). We 
used a specialized catheter (lookalike ПЕ-2pH, Company with additional responsibility "Special construction bureau of medical electrical engineering", Kamianets-Podilskyi, Ukraine) with a 1.8 -mm diameter consisting of 1 tungsten oxide $\mathrm{pH}$-sensor and 6 electrodes that make up 4 measuring segments of impedance, located at 3,5,7 and $12 \mathrm{~cm}$ above the lower oesophageal sphincter (LOS) each $2 \mathrm{~cm}$ in length. Electrode pairs were connected to a transducer which delivered a measuring current of less than $6 \mu \mathrm{A}$ at a frequency of $1 \mathrm{kHz}$. Impedance was recorded continuously, digitized at $50 \mathrm{~Hz}$, and stored in a computer for subsequent analysis.

The probe is inserted through the inferior nasal conchae to the level of the distal esophagus with the $\mathrm{pH}$ sensor placed $5 \mathrm{~cm}$ above the LOS. Previously a location of the LOS was determined by the following formula:

$\mathrm{L}=45+((\mathrm{H}-175) / 4)(\mathrm{cm})$,

where L- distance from the patient's nostril $(\mathrm{cm})$; $\mathrm{H}$ - patients height $(\mathrm{cm})$.

After insertion of the probe, position of LOS was further defined by means of distal impedance electrode pair slipping along the esophagogastric junction. Resistance changes were displayed on the monitor of a connected laptop using a specialized program. The "jump" of impedance from $0.5-0.8 \mathrm{k} \Omega$ to $1.2-1.8 \mathrm{k} \Omega$ corresponds to the location of LOS [8].

After an overnight fast, each subject attended the motility laboratory between 9:00 and 9:30 AM.

Previously we tested reduced modification of MII-pH-monitoring instead of 24-hour variant and demonstrated its good diagnostic value in cases of non-erosive GERD [7]. Performing ROC-curve analysis we obtained the best cut-off point for acidic reflux $>6$ events per $200 \mathrm{~min}$. with $80,3 \%$ sensitivity and $82,0 \%$ specificity. For total number of liquid reflux the threshold value was $>17$ events per 200 min with same sensitivity $(81,8 \%)$ but with slightly less specificity $(73,0 \%)$ [7].

The 200-minute MII-pH-monitoring simulates usual digestive behavior including rest and postprandial phases. A design of recording is depicted on Fig.1. After placement of the probe, subjects remained in a sitting and a supine position alternately for 45 minutes to obtain a baseline recording. Stimulating breakfast was standardized by using McDonald's menu: a black currant muffin and a small cup of Americano coffee with sugar - $507 \mathrm{kcal}, 300 \mathrm{ml}$ volume, carbohydrates $72 \mathrm{~g}$, fats $27 \mathrm{~g}$, protein $6 \mathrm{~g}, 100 \mathrm{mg}$ caffeine.

All patients were instructed to keep a diary to record exact timing of symptoms such as heartburn, regurgitation and non-cardiac chest pain.

\section{GASTRO-ESOPHAGEAL REFLUX PARAMETERS}

The data received by the digitrapper were transferred to a computer where they were recorded and visualized using the graphical interface of the program. All data were analyzed by one physician who was blinded to patient's clinical information. The operator looked at all recording channels ( $1 \mathrm{pH}$ and $4 \mathrm{Z}$ ) with the subsequent analysis of events recorded on the charts. He identified a total number of reflux episodes separating theirs in terms of composition (liquid, gas, and mixed), and $\mathrm{pH}$ (acidic, weakly acidic, and non-acidic), AET (\% time with esophageal $\mathrm{pH}<4$ ), longest GER, symptom association probability (SAP), symptom index (SI). The criteria for these parameters were described previously in publication including Lyon consensus $2017[9,10]$.

\section{ASSESSMENT OF COMPLAINTS}

In this study, a face-to-face 30-min interview was conducted using a «Rome III Diagnostic Questionnaire» during the health examination visit. This tool was used as main criteria of FD, irritable bowel syndrome (IBS) and other co-existing digestive functional disorders. Another aim of using this questionnaire was to perform a quantitative assessment of complaints. They offered unified 7-point scale to estimate how often the patient suffered from disturbances of the digestive function within the last 3 months. We included in our analysis the answers on questions \#8 (Heartburn), \#39 (Belching), \#66 (Bloating), \#17 (Epigastric pain/ burning), \#13 (Postprandial fullness), \#15 (Early satiety). Last two questions described the intensity of same item - postprandial distress syndrome (PDS). The greater value from the two was used in assessment. Question \#8, describing the frequency of heartburn, gave opportunity to use the criteria of GERD according to the Montreal consensus 2006 and Vevey NERD consensus 2009 [11,12 ]. Occurrence of reflux symptoms more than once per week is considered as a threshold to include patients in clinical trials and population-based studies. It corresponds to answers of 5-6 points from question \#8 «Rome III Diagnostic Questionnaire».

\section{STUDY DESIGN}

The study was carried out in Diagnostic gastroenterological laboratory at Vinnytsia National Medical University within 2011-2016. Outpatients with upper gastrointestinal symptoms were recruited after referring for consultation by general practitioner. Preliminary checkup selected patients with FD and GERD. All patients were previously underwent esophagogastroduodenoscopy, ultrasound examination of the abdominal cavity, routine laboratory tests. The exclusion criteria were: age up to 20 years or above 76 years, pregnancy and lactation, peptic ulcer (active or healed less than 12 months ago), gastric lesions (polyp, cancer), reflux esophagitis, Barrett's esophagus, esophageal varices, evidence of cancer or mass lesion in the esophagus, resection of the stomach, previous esophageal or gastric surgery, Zollinger-Ellison syndrome, ulcerative colitis, Crohn's disease, chronic heart failure above IIIrd FC by NYHA, chronic kidney disease with GFR less than $30 \mathrm{~mL} / \mathrm{min}$, pulmonary failure above II st., hepatic encephalopathy above $1^{\text {st }}$ degree, portal hypertension II-IV Baveno stages.

All patients were divided into 5 groups: 1) FD-EPS - epigastric pain syndrome; 2) FD-EPS/PDS - co-existing EPS and PDS; 3) FD-PDS - postprandial distress syndrome; 4) 
Table I. Demographic Data

\begin{tabular}{|c|c|c|c|c|c|c|}
\hline & $\mathbf{N}$ & $\begin{array}{c}\text { Gender ratio } \\
\text { (M/F) }\end{array}$ & $\begin{array}{c}\text { Mean age, } \\
M \pm \mathbf{m}\end{array}$ & $\mathrm{HP}+, \%$ & IBS, $\mathbf{n}$ & $\begin{array}{c}\text { Healed } \\
\text { PU (HP+), n }\end{array}$ \\
\hline Functional dyspepsia (together): & 127 & $39 / 88$ & $44.8 \pm 1.5$ & 36.8 & 40 & 8 \\
\hline EPS & 34 & $11 / 23$ & $40.7 \pm 3.1$ & 36.7 & 9 & 0 \\
\hline co-existing EPS/PDS & 42 & $10 / 32$ & $45.5 \pm 2.4$ & 33.3 & 16 & 2 \\
\hline PDS & 51 & $18 / 33$ & $46.8 \pm 2.4$ & 40.0 & 15 & 6 \\
\hline NERD heartburn-positive & 69 & $25 / 44$ & $46.7 \pm 1.9$ & 32.1 & 18 & 11 \\
\hline NERD heartburn-negative & 22 & $12 / 10$ & $45.6 \pm 3.4$ & 22.7 & 7 & 5 \\
\hline Non-dyspeptic & 30 & $14 / 16$ & $42.6 \pm 3.1$ & - & - & - \\
\hline
\end{tabular}

Table II. GERs registered after 200-minute esophageal MII-pH-monitoring with provocative breakfast.

\begin{tabular}{ccccccc}
\hline Group & $\begin{array}{c}\text { Acidic } \\
\text { reflux, }(\mathbf{n})\end{array}$ & $\begin{array}{c}\text { Weakly } \\
\text { acidic, }(\mathbf{n})\end{array}$ & $\begin{array}{c}\text { Weakly } \\
\text { alkaline, }(\mathbf{n})\end{array}$ & $\begin{array}{c}\text { Total } \\
\text { liquid, (n) }\end{array}$ & $\begin{array}{c}\text { AET, } \\
\text { (\%) }\end{array}$ & $\begin{array}{c}\text { Longest } \\
\text { reflux, (sec) }\end{array}$ \\
\hline $\begin{array}{c}\text { Functional dyspepsia } \\
\text { (together): }\end{array}$ & $3.8 \pm 0.5^{*}$ & $9.7 \pm 0.5$ & $2.2 \pm 0.2$ & $15.7 \pm 0.6^{*}$ & $2.9 \pm 0.2$ & $57.3 \pm 8.8^{\circ}$ \\
\hline EPS & $3.7 \pm 0.7 \dagger$ & $8.7 \pm 0.7$ & $2.5 \pm 0.4$ & $14.9 \pm 1.0$ & $2.7 \pm 0.5$ & $35.4 \pm 9.3$ \\
\hline coex.EPS/PDS & $2.8 \pm 0.7$ & $10.6 \pm 0.9$ & $2.2 \pm 0.3$ & $15.6 \pm 1.2^{\circ}$ & $2.9 \pm 0.5$ & $41.3 \pm 12.6$ \\
\hline PDS & $4.7 \pm 0.8^{*}$ & $9.6 \pm 0.7$ & $2.0 \pm 0.2$ & $16.3 \pm 0.9^{*}$ & $3.2 \pm 0.4$ & $84.5 \pm 17.5$ \\
\hline NERD Hb-pos & $11.2 \pm 1.28^{*}$ & $10.0 \pm 0.7$ & $2.4 \pm 0.5$ & $23.6 \pm 1.3^{*}$ & $6.3 \pm 0.3$ & $205.0 \pm 32.9$ \\
\hline NERD Hb-neg & $13.4 \pm 1.8^{*}$ & $10.2 \pm 1.2$ & $1.9 \pm 0.5$ & $25.5 \pm 2.2^{*}$ & $7.0 \pm 0.7$ & $248.2 \pm 37.0$ \\
\hline Non-dyspeptic & $1.8 \pm 0.3$ & $8.8 \pm 0.7$ & $2.2 \pm 0.3$ & $12.8 \pm 0.7$ & $2.4 \pm 0.6$ & $29.4 \pm 7.3$ \\
\hline
\end{tabular}

Difference is significant vs reference control group (Non-dyspeptic): ${ }^{0}-p<0.05 ; \dagger-p<0.01 ;{ }^{*}-p<0.001$.

NERD heartburn positive (Hb-pos.); 5) NERD heartburn negative (Hb-neg.). In addition, a reference control group was collected from subjects without suspicious complaints or clinical signs of GERD and functional disorders of upper gastrointestinal tract. Detailed information on age and gender is presented in Table I. Diagnosis of GERD and FD were established by the criteria of the Montreal (2006) and Rome-III/IV (2005/2016) consensuses. NERD was diagnosed if there was confirmation either by MII-pH-monitoring including positive symptom association in cases with normal number GER or by subsequent positive PPI-test in mode describing by de Leone [13]. Subjects with esophageal hypersensitivity (positive symptom association with non-acidic reflux) were defined as NERD.

We separated a special subgroup of NERD if typical symptoms (heartburn and regurgitation) occurred less than once per week. In such cases atypical symptoms were frequent and there was a confirmation by MII-pH-monitoring and PPI-test. The necessity of such approach was caused by subsequent analysis of the triggering factors of the abnormal reflux in very close groups of FD. For example dyspepsia is regular and frequent manifestation of GERD. If frequent heartburn is present simultaneously with dyspepsia, gastroenterologists will define this case as GERD. Therefore, if heartburn is either absent or rare, it will be confusing diagnosis. In our "NERD Hb-neg." subgroup there were 14 persons from 22 suffered from dyspeptic symptoms at least once per week. All of them had other predominate manifestations (chronic cough, chest pain, lump, etc.) that's why they were diagnosed GERD. On the other hand, patients with severe dyspeptic complaints, with abnormal reflux and absence of heartburn will be very close to NERD, but formally they are diagnosed with FD by Rome III/IV consensuses.

\section{STATISTICAL ANALYSIS}

Data are expressed as mean \pm SEM (standart error of mean) for each of the measured parameters and age, body mass index (BMI). Gender, co-existing IBS, successfully healed HP-positive peptic ulcer in anamnesis and presence of hiatal hernia are expressed as ratio or absolute number. $H$. pylori infection rates are expressed as percentages of the total patient number. An independent t-test was used to analyze age, body mass index (BMI), number of refluxes, AET and longest reflux. To find out the relationship between data with a normal distribution, we used the Pearson's parametric correlation coefficient. Spearman's and Kendall's rank correlation coefficients were applied in cases with non-normal distribution. $\varphi$ (phi) Pearson's correlation coefficient was used for data with dichotomous distributions. A p-value below 0.05 was considered statistically significant (always two-sided).

The association between abnormal GER in groups without heartburn and potential risk factors was measured by odds ratio with $95 \%$ confidence intervals $(95 \% \mathrm{CI})$ as 


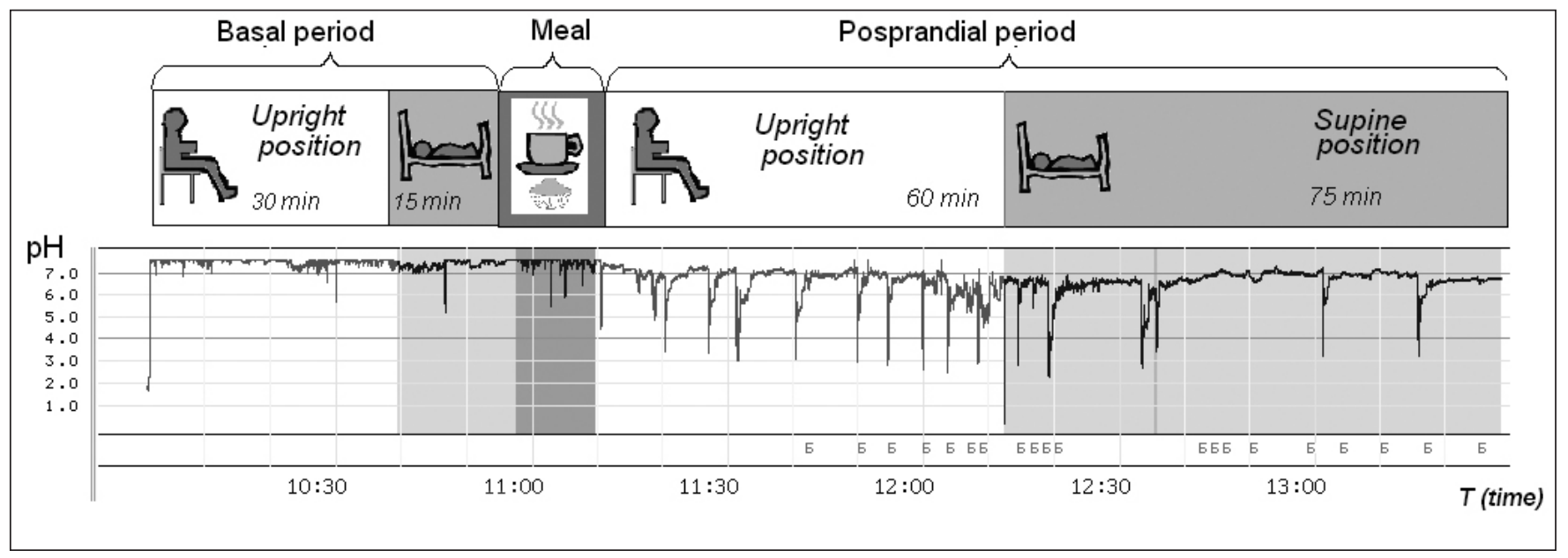

Fig.1 Design of 200-minute esophageal MII-pH-monitoring with provocative breakfast and sample pH-tracing. Marks «b» over timeline indicate symptom occurring (heartburn, chest pain, etc.).

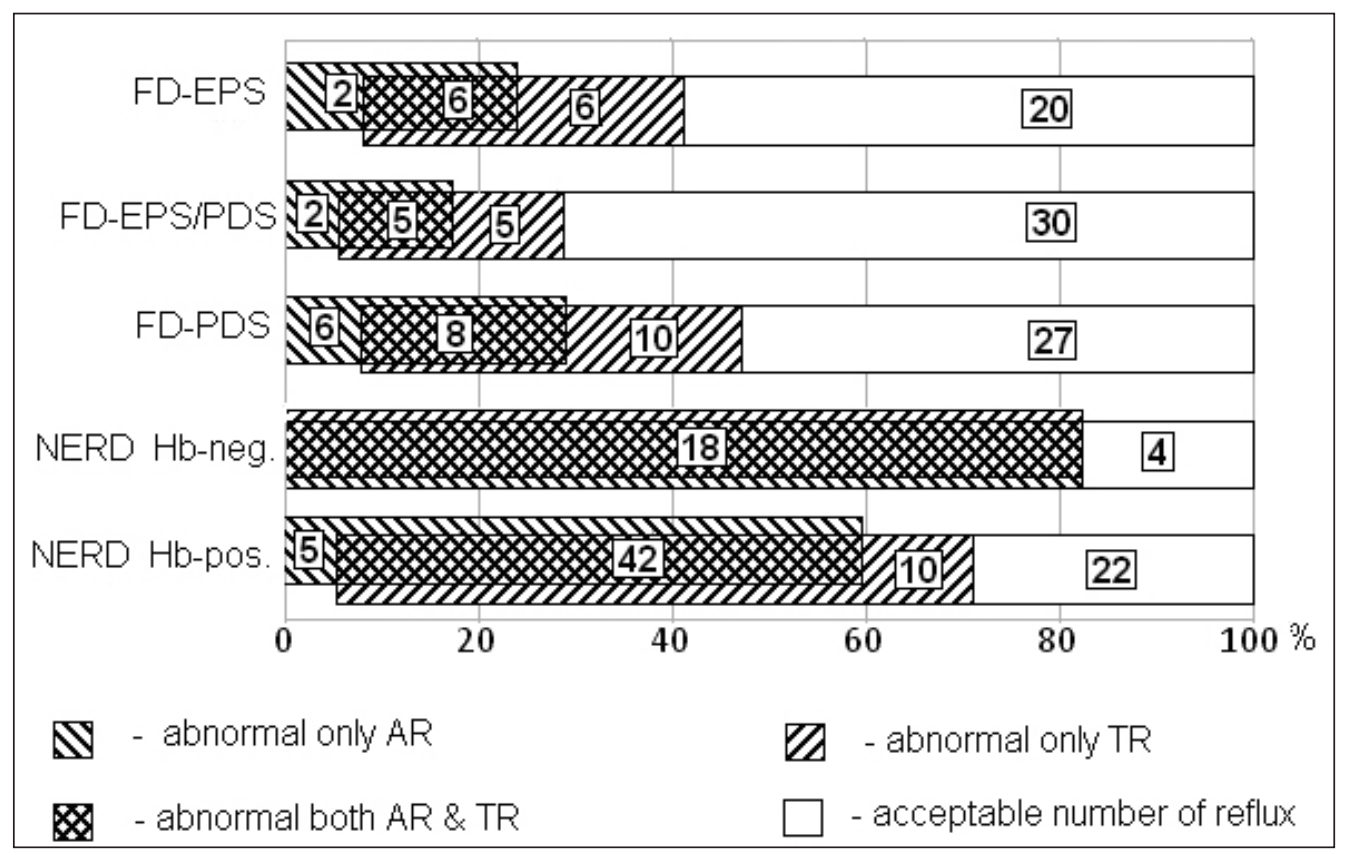

Fig.2. Patient distribution depending on the amount of reflux. In the squares it is shown the number of subjects with the corresponding distribution. AR - acidic refluxes; TR- total refluxes; FD-EPS - epigastric pain syndrome; FD-PDS - postprandial distress syndrome; FD-EPS/PDS - Co-existing EPS and PDS.

result of regression analysis by using logistic model (enter method). Statistical data processing was carried out using program «MedCalc 11.3.3.0» (MedCalc software bvba, Holland).

\section{RESULTS}

A total of 218 consecutive patients and 30 non-dyspeptic subjects were recruited for the study and completed protocol.

If we generally describe the number of weakly-acid and weakly-alkaline reflux in all groups, they will be equal (Table II). The arithmetic mean of the sum was 11-13 events. The difference was due to increasing number of acid refluxes in patients of certain groups. Unsurprisingly it was found that the most pronounced GER were observed in patients with NERD without frequent heartburn and regurgitation (group "NERD Hb-neg."). This was related to both - acidic and total number of liquid refluxes. The difference with NERD Hb-pos. was not significant. If we look at all MII-pH parameters, we will observe the same tendency of increasing duration of longest reflux and AET. In group "NERD Hb-pos." there were more persons with normal acidification of esophagus. Their diagnoses were confirmed either by SAP/SI or by PPI-test.

Patients from all groups of FD didn't have longer AET than reference "Non-dyspeptic" group. However, number of acidic refluxes and duration of the longest reflux were almost twofold higher $-3.8 \pm 0.5$ vs $1.8 \pm 0.3$ episodes $(\mathrm{p}<0.002)$ and $29.4 \pm 7.3$ vs $57.3 \pm 8.8 \mathrm{~s}(\mathrm{p}<0.02)$ respectively. 
Table III. Correlation between number of acidic GER and clinical manifestations, demographic data of patients with Functional dyspepsia ( $N=127)$ and Endoscopy-negative GERD without obvious heartburn (i.e. less than 1 time per week) ( $\mathrm{N}=22)$.

\begin{tabular}{|c|c|c|c|c|}
\hline Variables & $\begin{array}{l}\text { Number with abnormal } \\
\text { (acidic }>6 \text { ) and normal }(<7) \\
\text { GER among patients with } \\
\text { positive sign }\end{array}$ & $\begin{array}{l}\text { Correlation } \\
\text { coefficients }\end{array}$ & $\mathrm{Cl} 95 \%$ & $\mathbf{P}$ \\
\hline Age (years) & & $r^{\prime}=-0.177$ & -0.329 to -0.017 & 0.0306 \\
\hline Gender (male) & $15 / 36$ & $\varphi=-0.030$ & & 0.7169 \\
\hline BMI $\left(\mathrm{kg} / \mathrm{m}^{\wedge}{ }^{\prime}\right)$ & & $r=0.172$ & 0.012 to 0.323 & 0.0357 \\
\hline Healed PU in anamnesis & $7 / 6$ & $\varphi=0.150$ & & 0.0514 \\
\hline HP-positive status & $13 / 35$ & $\varphi=-0.116$ & & 0.1780 \\
\hline IBS & $17 / 30$ & $\varphi=0.070$ & & 0.3897 \\
\hline Hiatal hernia & $7 / 5$ & $\varphi=0.172$ & & 0.0372 \\
\hline Gallstones/ Cholecystectomy & $6 / 6$ & $\varphi=0.103$ & & 0.1480 \\
\hline Heartburn & & $r=0.219$ & 0.061 to 0.366 & 0.0072 \\
\hline Belching & & $r=-0.051$ & -0.209 to 0.110 & 0.5361 \\
\hline Postp. fullness/ early satiety & & $\tau=-0.142$ & -0.296 to 0.018 & 0.0821 \\
\hline Epigastric pain /burning & & $r=-0.129$ & -0.284 to 0.032 & 0.1151 \\
\hline Bloating & & $r=-0.005$ & -0.284 to 0.032 & 0.9485 \\
\hline
\end{tabular}

Correlation coefficients: $r$ - Spearman's rank; $\tau$ - (tau) Kendall's rank; $r$ - Pearson's parametric ; $\varphi$ - (phi) Pearson's for dichotomous distributions. Indicators «Heartburn», «Belching», «Postprandial fullness/ early satiety», «Epigastric pain», «Bloating» were used with value equal to points from answers of «Rome III Diagnostic Questionnaire».

Therefore, the total amount of liquid GER was significantly higher $-15.7 \pm 0.6$ versus $12.8 \pm 0.7(\mathrm{p}<0.0036)$.

Also in PDS group compared with the rest FD patients there was a significant time prolongation of longest reflux: $84.5 \pm 17.5 \mathrm{sec}$ vs $35.4 \pm 9.3 \mathrm{sec}$ in EPS $(\mathrm{p}<0.017)$ and vs $41.3 \pm 12.6 \mathrm{sec}$ in co-exist EPS/PDS ( $<<0.05)$.

As reported in part "Methods", the threshold values of the abnormal acidic and total refluxes after MII-pH-monitoring were $>6$ and $>17$ respectively. Only in the reference group no persons exceeding these threshold values were registered (Fig.2).

Groups with FD had approximately the same number of individuals exceeding the threshold for acid reflux. Such situation was observed almost in a quarter cases $22.8 \%$ (50 from 127). Attention was drawn to the fact that there were differences in the subgroups "EPS", "PDS" and "co-existing EBS/PDS" from other patients in terms of the distribution of persons with excessive acidic refluxes, total refluxes, and a combination of these two phenomena. Among patients with NERD, persons with pathological acidic reflux simultaneously demonstrated excess gain of total refluxes in the overwhelming majority of cases. In contrast, $16.5 \%$ of FD patients (21 from 127 ) had an isolated excess of total refluxes due to non-acidic events. Thus, there was a situation of an obviously increased number of weakly-acidic and weakly-alkaline refluxes.

The pathological GER is closely associated with typical GERD complaints - heartburn and regurgitation. If we deal with individuals without such complaints but with registered excessive reflux after functional tests, they will form a special phenotype of FD. It is fascinating what types of manifestations arise in such persons, what factors provoke the abnormal GER and how both relate to the problem of "silent GERD".

To find out the causes of pathological acid reflux, we conducted a correlation analysis of the assumed risk factors with the number of GERs in the groups of FD and NERD without frequent heartburn. For this and subsequent regression analysis we took patients from all groups excluding "NERD - Heartburn positive" and referent "Non-dyspeptic". In the analysis there were 149 dyspeptic persons.

We didn't find a significant effect on the frequency of acidic GER concomitant IBS, gender identity, Helicobacter infection, gallstones (Table III). The frequency of bloating, belching, postprandial filling, early satiety, epigastric pain and burning sensation didn't correlate with the frequency of reflux occurrence. Variables BMI, age, hiatal hernia, healed PU, occasional heartburn were associated with excess acidic GER $(\mathrm{P}<0.05)$.

A similar correlation analysis was performed for total refluxes and its results were less sensitive to the identification of provoking factors (Table IV). The relevance of calculating total refluxes for clinical practice remains unexplained. There is no pathogenetic pharmacotherapy of this disorder.

The best presentation of the interrelations between provoking factors is given by logistic regression analysis performed by the "enter" method (Table V). It makes possible to visually assess the degree of influence. Created regression model assumes the creation of an equation for calculating the risk of the occurrence of abnormal acidic 
Table IV. Correlation between Total number of liquid GER and clinical manifestations, demographic data of patients with Functional dyspepsia ( $N=127)$ and NERD without obvious heartburn (i.e. less than once per week) ( $\mathrm{N}=22)$.

\begin{tabular}{|c|c|c|c|c|}
\hline Variables & $\begin{array}{c}\text { Number with abnormal (total }>17 \text { ) } \\
\text { and normal }(<18) \text { GER among } \\
\text { patients with positive sign }\end{array}$ & $\begin{array}{l}\text { Correlation } \\
\text { coefficients }\end{array}$ & $\mathrm{Cl} 95 \%$ & $\mathbf{P}$ \\
\hline Age (years) & & $r^{\prime}=-0,243$ & $-0,389$ до -0,086 & 0,0028 \\
\hline Gender (male) & $21 / 30$ & $\varphi=0,027$ & & 0,7406 \\
\hline $\mathrm{BMI}\left(\mathrm{kg} / \mathrm{m}^{\wedge}{ }^{\wedge}\right)$ & & $r=0,198$ & 0,039 до 0,348 & 0,0149 \\
\hline Healed PU in anamnesis & $7 / 6$ & $\varphi=0,092$ & & 0,2641 \\
\hline HP-positive status & $18 / 30$ & $\varphi=-0,088$ & & 0,3085 \\
\hline IBS & $20 / 27$ & $\varphi=0,045$ & & 0,5863 \\
\hline Hiatal hernia & $7 / 5$ & $\varphi=0,115$ & & 0,1622 \\
\hline Heartburn & & $r=0,210$ & 0,051 до 0,358 & 0,0100 \\
\hline Belching & & $r=-0,019$ & $-0,179$ до 0,142 & 0,8181 \\
\hline Postp. fullness/ early satiety & & $r=-0,053$ & $-0,212$ до 0,108 & 0,5179 \\
\hline Epigastric pain /burning & & $r=-0,111$ & -0,266 до 0,0506 & 0,1781 \\
\hline Bloating & & $r=0,029$ & -0,132 до 0,188 & 0,7249 \\
\hline
\end{tabular}

Correlation coefficients: $r$ - Spearman's rank; $\tau$ - (tau) Kendall's rank; $r$ - Pearson's parametric ; $\varphi$ - (phi) Pearson's for dichotomous distributions. Indicators «Heartburn», «Belching», «Postprandial fullness/early satiety», «Epigastric pain», «Bloating» were used with value equal to points from answers of «Rome III Diagnostic Questionnaire».

reflux in patients with dyspeptic complaints but with rare heartburn. Logistic analysis, performed using selected five variables, demonstrated that all of them were significantly and independently associated with this condition $(\mathrm{P}<0.05)$. The area under the ROC curve $(A U C)$ of our model was 0,710 (CI95\% 0,630- 0,781) and the percentage of cases correctly classified $74.5 \%$.

\section{DISCUSSION}

Comparing the results obtained from patients with FD and from non-dyspeptic subjects, we saw significantly longer refluxes, a greater frequency of acid refluxes and, correspondingly, all liquid events. However, AET in both groups was not significantly different due to the fact that the fraction of time with reflux was relatively short - approximately $2 \%$ of the total test.

Thus there are serious abnormalities of esophagogastric motility in FD. Especially they were noticeable in the subgroup of the PDS, where we observed a twofold increase in time of the longest reflux. The following speculation can be made in connection with this issue. In a meta-analysis of Quartero with co-authors, it was proved that $40 \%$ of patients with FD had a significant delay of the food lump after ingestion [14]. Most of them had PDS. The delay will also contribute to a longer period during which there is an excessive amount of content in the stomach. Thus, the probability of GER will be increased. Gourcerol using the MII-pH-monitoring noted that the delayed gastric emptying provoked more proximal GERs and significantly retarded the clearance of the esophagus [15].
Refluxes are frequent occurrences in patients with FD but in comparison with patients with GERD, there is often an excess of the threshold values of total events with a normal amount of acidic ones. This discrepancy can be explained by several factors. Firstly, among persons with this disease there is a significant proportion of patients with hypoacidity. Subjects suffering from GERD usually have a normal or elevated level of acidity because this diagnosis is referred to the acid-related disorders. Thus, if a reflux occurs in person with hypoacidity, the content of esophagus will remain alkaline. Secondly, the thickness of acidic layer in "acid pocket" can influence the composition of refluxate. In patients with dyspepsia, the "acid pocket" is thinner, so there is a low likelihood of acidic reflux happening.

The distribution between the types of reflux in the subgroups of FD was the same with a trend toward a higher frequency of reflux in the PDS (N.S.). We didn't receive confirmation of a greater frequency of reflux in patients with EBS observed during conventional $\mathrm{pH}$ monitoring by Tack [5] and Xiao [6].

As mentioned above, FD is very heterogeneous by its pathogenesis. In clinical trials researchers try to identify potential associations between specific pathophysiological abnormalities and representative symptoms of dyspepsia [16]. For example, a delayed gastric emptying causes a feeling of postprandial fullness and nausea. Weakened accommodation is present in $40 \%$ of patients and causes early saturation. Hypersensitivity of the stomach occurs in $37 \%$ of patients and is linked with postprandial pain, eructation and loss of body weight [16].

Presumably, refluxes will occur in subjects with more prominent disorders of gastric motility, which is more 
Table V. Comparison of clinical factors provoking abnormal acidic GER in patients with FD and heartburn-negative NERD using multivariate logistic regression analysis. The Coefficients of regression equation.

\begin{tabular}{cccccc}
\hline Variable & Odds ratio & $\mathbf{9 5 \%} \mathrm{Cl}$ & Coefficient & Std. Error & P \\
\hline Age $($ years $)$ & 0,97 & 0,94 to 0,99 & $-0,03$ & 0,01 & 0,014 \\
\hline $\mathrm{BMI}\left(\mathrm{kg} / \mathrm{m}^{\wedge} 2\right)$ & 1,11 & 1,01 to 1,21 & 0,10 & 0,05 & 0,024 \\
\hline Healed PU in anamnesis & 3,90 & 1,13 to 13,49 & 1,36 & 0,63 & 0,032 \\
\hline Hiatal hernia & 4,17 & 1,10 to 15,82 & 1,43 & 0,68 & 0,036 \\
\hline $\begin{array}{c}\text { Frequency of Heartburn } \\
\text { (points 0-1-2-3-4) }\end{array}$ & 1,25 & 0,98 to 1,58 & 0,22 & 0,12 & 0,070 \\
\hline Constant & & $-2,41$ & & \\
\hline
\end{tabular}

typical of patients with PDS. In contrast to this the major element of the EPS pathogenesis is hypersensitivity. Thus, reflux activity with this subtype will not be pronounced.

In order to find out the factors that contribute to the appearance of excessive reflux, we carried out a correlation and regression analysis which identified the most significant 5 variables: BMI, hiatal hernia, age, healed PU, occasional heartburn. This agrees with the well-known facts that obesity, even without the presence of hernia, contributes to the development of GERD [17].

The damaged function of the LOS, which is a consequence of a sliding hiatal hernia, strongly associates with increasing reflux symptoms [18] and frequent backflow of gastric contents into the esophagus [19]. In the context of the problem being studied, a hernia can often be detected in subjects without clinical manifestations of GERD. Studies from the Western countries showed that 13-59\% of adult subjects without GERD had a hernia [20]. We revealed that people with hiatal hernias, but even without typical complaints of GERD, in most cases have pathological reflux. Nevertheless in some pH-metric studies authors observed that the absence of symptoms in hernial patients indicates a lack of abnormal reflux [21].

In our study the age correlated negatively with the risk of appearance of excessive reflux because there is an age-related lowering of gastric acidity [22]. This decrease in acid secretion is now thought to be the result of $\mathrm{H}$. pylori infection and not the result of physiological aging [23]. Thus, a negative correlation could be expected between the presence of HP and abnormal reflux. But we did not find a significant reduction of reflux activity among HP-positive patients. This coincides with the opinion of most gastroenterologists who conducted epidemiological, instrumental studies, including the most precise method of pH-monitoring [24]. Most researchers, who conducted $\mathrm{pH}$ monitoring in the same patients before and after HP eradication, did not find an increase in the number of refluxes and AET $[25,26]$. Although a small study from Hong Kong reported a worsening in the acid exposure among subjects of preceding esophagitis [27]. Two meta-analyses devoted to this issue didn't show any association between HP-eradication and the development or an aggravation of GERD [28, 29]. However, in cohort studies (not in RCT), there seems to be a twofold higher risk of development of erosive GERD in patients with PUD [29]. In our study it was interesting to reveal that persons who successfully healed a peptic ulcer by eradicating an HP-infection more often had abnormal GERs. It should be noted that we did not include all subjects with cleared HP infection, but only those who continued to suffer from dyspepsia. Former patients with duodenal ulcer are a special category with extremely high intragastric acidity and therefore a high probability of abnormal GERs.

Excessive number of refluxes in patients with FD forms a particular phenotype of the disease, which is very close to GERD but without the usual manifestations. The pathogenesis of «silent (oligosymptomatic) GERD» is an interesting and unexplored problem. Such GERD patients may actually experience some reflux symptoms, but do not complain about them, perhaps because of the lack of understanding that they are symptoms. Or they may have visceral symptoms, which are different from the typical symptoms of reflux, including dyspepsia. Traditional theory explains the burning of penetration of acid into the esophagus mucosa. However, not all facts corroborate this concept.

The new conceptual framework for esophageal perception is based on the involvement of not only peripheral, but also central mechanisms with a significant influence of psychosocial factors [30,31].

A well-known Japanese researcher Miwa proposes that individuals with GERD without heartburn and regurgitation have not only chemical hyposensitivity to acid but also overall. He found that in this cohort of patients, the quality of life suffered considerably less and less there were the atypical symptoms of GERD [32]. There is an assumption that perception depends on expression levels of capsaicin pain receptors, which, when re-exposed, become less sensitive, including to acid [33]. Unfortunately, we did not analyze the nutritional preferences of our patients and this could be a promising direction for further research.

\section{CONCLUSIONS}

Thus, in FD abnormal acid gastroesophageal refluxes are common and affect $22.8 \%$ of patients. In addition, an- 
other $16.5 \%$ have an isolated excess of non-acidic reflux. The risk factors of abnormal acid reflux are hiatal hernia, overweight, successfully healed HP-positive peptic ulcer in anamnesis. There is an inverse relationship between age and the risk of excess reflux. Occasional heartburn occurring less than once a week may indicates the pathological refluxes. Patients with isolated PDS-subtype of FD, in contrast to the EPS and the mixed variant of dyspepsia, tend to have longer acid refluxes.

\section{REFERENCES}

1. Mahadeva S, Goh K. Epidemiology of functional dyspepsia: A global perspective. World J Gastroenterol. 2006 May 7; 12(17): 2661-2666.

2. Vaezi MF., Pandolfino JE, Vela MF, Shaheen NJ.White Paper AGA:Optimal Strategies to Define and Diagnose Gastroesophageal Reflux Disease. Clin. Gastroenterol. Hepatol. 2017 Aug;15(8):1162-72. doi: 10.1016/j. cgh.2017.03.021.

3. Winbery SL., Blaho KE. Dyspepsia In Pregnancy, Obstetrics and Gynecology Clinics of North America, 2001 Jun;28(2):333-50.

4. Al-Amri SM. Twenty-four hour pH monitoring during pregnancy and at postpartum: a preliminary study.Eur J Obstet Gynecol Reprod Biol. 2002 May 10;102(2):127-30.

5. Tack J, Caenepeel P, Arts J, Lee KJ., Sifrim D, Janssens J. Prevalence of acid reflux in functional dyspepsia and its association with symptom profile. Gut. 2005;54:1370-76.

6. Xiao YL, Peng S, Tao J, Wang AJ, Lin JK, Hu PJ, Chen MH. Prevalence and symptom pattern of pathologic esophageal acid reflux in patients with functional dyspepsia based on the Rome III criteria. Am J Gastroenterol. 2010 Dec;105(12):2626-31. doi: 10.1038/ajg.2010.351.

7. Melashchenko S.H., Chernobrovyj V.M., Ksenchyn 0.0. Diahnostychni mozhlyvosti 200-khvylynnoho postprandialnoho multykanalnoho intraliuminalnoho impedans-pH-monitorynhu stravokhodu porivniano z dobovym variantom [Diagnostic value of 200 -minute postprandial multichannel intraluminal impedance-pH-monitoring in comparison with 24-hour variant]. Gastroenterolohiya. 2015; 56 (2):5-11(In Ukrainian)

8. Patent na korysnu model №90885 Ukraina, MPK G01N 31/00; Zayavl. 27.01.2014. Opubl. 10.06.2014, Biul. №11. / Melashchenko S.H., Kuzenko Yu.H. / Sposib diahnostyky gastroezofahealnoii refliuksnoii khvoroby [Method for the diagnosis of GERD]. - http://uapatents.com/790885-sposib-diagnostiki-gastroezofagealno-reflyuksno-khvorobi. html (In Ukrainian)

9. Sifrim D, Castell D, Dent J, et al. Gastro-oesophageal reflux monitoring: review and consensus report on detection and definitions of acid, nonacid, and gas reflux/ Gut 2004;53:1024-31

10. Gyawali CP, Kahrilas PJ, Savarino E, Zerbib F, Mion F, Smout AJPM, Vaezi $M$, Sifrim D et al. Modern diagnosis of GERD: the Lyon Consensus. Gut. 2018 Jul;67(7):1351-62. doi: 10.1136/gutjnl-2017-314722.

11. Vakil N, van Zanten S, Kahrilas P, Dent J et al. The Montreal definition and classification of gastroesophageal reflux disease: a global evidencebased consensus. Am. J. Gastroenterol. 2006; 101:1900-20.

12. Modlin IM, Hunt RH, Malfertheiner P, Moayyedi P, Quigley EM, Tytgat GN, Tack J, Heading RC, Holtman G, Moss SF. Diagnosis and management of non-erosive reflux disease--the Vevey NERD Consensus Group. Digestion. 2009;80(2):74-88. doi: 10.1159/000219365.

13. de Leone A, Tonini M, Dominici P, Grossi E, Pace F. The proton pump inhibitor test for gastroesophageal reflux disease: Optimal cut-off value and duration. Dig. Liver. Dis. 2010; 42 (11):785-90.
14. Quartero A.O., deWit N.J., Lodder A.C. et al. Disturbed solid-phase gastric emptying in functional dyspepsia: a meta-analysis. Dig. Dis. Sci.1998; 43:2028-33.

15. GourcerolG,BenanniY,BoueyreEetal.Influenceofgastricemptying on gastroesophageal reflux: a combined pH-impedance study. Neurogastroenterol Motil. 2013 0ct;25(10):800-e634. doi: 10.1111/nmo.12181.

16. Lee K.J., Kindt S., Tack J. Pathophysiology of functional dyspepsia. Best. Pract. Res. Clin. Gastroenterol. 2004 Aug;18(4):707-16.

17. Derakhshan MH, Robertson EV, Fletcher J, Jones GR, Lee YY, Wirz AA, McColl KE. Mechanism of association between BMI and dysfunction of the gastro-oesophageal barrier in patients with normal endoscopy. Gut. 2012 Mar;61(3):337-43. doi: 10.1136/gutjnl-2011-300633.

18. Zagari RM, Fuccio L, Wallander MA et al. Gastro-oesophageal reflux symptoms, oesophagitis and Barrett's oesophagus in the general population: the Loiano-Monghidoro study. Gut 2008;57:1354-1359.

19. YiZH, Feng L, Wen MY, Liu JR, Yang L. Association between acid reflux and esophageal dysmotility in patients with gastroesophageal reflux disease. Sichuan Da Xue Xue Bao Yi Xue Ban. 2014 May;45(3):480-3. (in Chinese)

20. Hyun JJ, Bak YT. Clinical significance of hiatal hernia. Gut Liver. 2011;5(3):267-77.

21. FranzénT,Tibbling L. Is the severity of gastroesophageal reflux dependent on hiatus hernia size?. World J Gastroenterol. 2014;20(6):1582-4.

22. lijima K, Ohara S, Koike T, Sekine H, Shimosegawa T. Gastric acid secretion of normal Japanese subjects in relation to Helicobacter pylori infection, aging, and gender. Scand. J. Gastroenterol. 2004 Aug;39(8):709-16. doi:10.1080/00365520410005911

23. Yakabi K, Sakurada T, Takabayashi H, Kani K, Kawashima J. [Change in function of gastric acid secretion by aging]. Nihon Rinsho. 2010 Nov;68(11):2001-5.(In Japan)

24. Grande M, Lisi G, De Sanctis F, Grande S, Esser A, Campanelli M, Balassone V, Milito G, Villa M. Does a relationship still exist between gastroesophageal reflux and Helicobacter pylori in patients with reflux symptoms? World J Surg Oncol. 2014 Dec 6;12:375. doi: 10.1186/14777819-12-375.

25. Tefera S, Hatlebakk JG, Berstad A. The effect of Helicobacter pylori eradication on gastro-oesophageal reflux. Aliment Pharmacol Ther. $1999 \mathrm{Jul} ; 13(7): 915-20$.

26. Güliter S., Kandilci U. The effect of Helicobacter pylori eradication on gastroesophageal reflux disease. J Clin Gastroenterol. 2004 $0 c t ; 38(9): 750-5$.

27. WuJC, Chan FK, Wong SK, LeeYT, Leung WK, Sung JJ. Effect of Helicobacter pylori eradication on oesophageal acid exposure in patients with reflux oesophagitis. Aliment Pharmacol Ther. 2002 Mar;16(3):545-52.

28. Qian B, Ma S, Shang L, Qian J, Zhang G. Effects of Helicobacter pylori eradication on gastroesophageal reflux disease.Helicobacter. 2011 Aug;16(4):255-65.doi: 10.1111/j.1523-5378.2011.00846.x.

29. Yaghoobi M, Farrokhyar F, Yuan Y, Hunt RH. Is there an increased risk of GERD after Helicobacter pylori eradication?: a meta-analysis. Am J Gastroenterol. 2010 May;105(5):1007-13; quiz 1006, 1014. doi: 10.1038/ajg.2009.734.

30. Drewes AM, Arendt-Nielsen L, Funch-Jensen P, Gregersen H. Experimental human pain models in gastro-esophageal reflux disease and unexplained chest pain. World J Gastroenterol. 2006 May 14;12(18):2806-17.

31. Rinsma NF, Farré R, Troost FJ, Elizalde M, Keszthelyi D, Helyes Z, Masclee $\mathrm{AA}$, Conchillo JM. Exploration of the esophageal mucosal barrier in non-erosive reflux disease. Int J Mol Sci. 2017 May 19;18(5). pii: E1091. doi:10.3390/ijms18051091. 
32. Miwa H, Kondo T, Oshima T, Fukui H, Tomita T, Watari J. Esophageal sensation and esophageal hypersensitivity - overview from bench to bedside. J Neurogastroenterol Motil. 2010 0ct;16(4):353-62. doi: 10.5056/jnm.2010.16.4.353.

33. Herrera-López J.A., Mejía-Rivas M.A., Vargas-Vorackova F., Valdovinos-Díaz M.A. Capsaicin induction of esophageal symptoms in different phenotypes of gastroesophageal reflux disease. Rev Gastroenterol Mex 2010;75:396-404.

\section{Authors' contributions:}

According to the order of the Authorship.

\section{Conflict of interest:}

The Authors declare no conflict of interest.

\section{CORRESPONDING AUTHOR}

\section{Sergii Melashchenko}

Vinnytsya National Pirogov Memorial Medical University

Pirogova str., buil. 56, 21018 Vinnytsya, Ukraine

tel: +380973912108; +380432690043

e-mail:melashk15@gmail.com

Received: 27.02.2019

Accepted: 29.03.2019 
PRACA ORYGINALNA

ORIGINAL ARTICLE

\title{
DYNAMICS OF HEART RATE VARIABILITY UNDER THE INFLUENCE OF COURSE YOGA BREATHING EXERCISES ON HEALTHY YOUNG PEOPLE
}

\author{
Nataliia I. Sheiko, Volodymyr P. Feketa \\ UZHHOROD NATIONAL UNIVERSITY, UZHHOROD, UKRAINE
}

\begin{abstract}
Introduction: Heart rate variability is a highly informative non-invasive method of research not only for the functional state of the cardiovascular system and also for the integrative regulatory activity of the autonomic nervous system. The positive effect of diaphragmatic breathing is positive in the mode of biological feedback using portable devices, but there is little evidence of the use of yoga breathing gymnastics in order to influence the heart rate variability.

The aim: To compare the possibilities of using courses of breathing gymnastics of yogis and diaphragmatic breathing sessions in the mode of biological feedback using a portable device.

Materials and methods: The study involved 70 practically healthy foreigners, who were divided into 2 groups of 35 people. Participants of the $1^{\text {st }}$ group daily engage in respiratory exercises pranayama for 15 minutes in 1 month. Participants in the $2^{\text {nd }}$ group used the MyCalmBeat portable device. Heart rate variability was registered by using the computer diagnostic complex "CardioLab" ("KhAl-Medika", Ukraine).

Results: In both groups there was similar dynamics of heart rate variability indices, but its severity was different. The common integral effect was a significant growth of heart rate variability both according to statistical and spectral indicators - total power increased, as well as high-frequency component. The power of the very-low frequency waves has probably decreased only in the group with the device. In the percentage structure of the cardiac rhythm spectrum, the specific weight of very-low frequency component and the percentage of high-frequency component increased.

Conclusions: Respiratory gymnastics yoga for 15 minutes daily contributes to the growth of heart rate variability through the suppression of the central link (very-low frequency component) of regulation of cardiac rhythm and increased activity of parasympathetic influences (high-frequency component), as well as the redistribution of regulatory activity of the central nervous system between the central and peripheral links of regulation of the cardiac rhythm in favor of the latter.
\end{abstract}

KEY WORDS: heart rare variability, yoga, diaphragmatic breathing, biological feedback

Wiad Lek 2019, 72, 4, 613-616

\section{INTRODUCTION}

It is known that the regulation of cardiac rhythm and respiration is closely linked to physiological processes, the coordination of which is an important condition for the adaptation of the human body to metabolic needs [1]. It manifests itself as a sinus respiratory arrhythmia - physiological fluctuations in the duration of the heart cycle associated with respiratory periodicity. When inhaling, the acupuncture part of the autonomic nervous system is activated, and when exhaled, on the contrary, the tone of the parasympathetic link of the autonomic nervous system increases. It is alternate activation of the autonomic nervous system units that causes dynamic changes in the heart rate from acceleration to slowing it down. These variations of heart rate contribute significantly to the overall heart rate variability, in particular in the high frequency region of its spectrum in the range of $0.15-0.4 \mathrm{~Hz}$ (HF). Therefore, the spectral energy of the heart rate variability curve in this frequency range is usually used as a non-invasive indicator of the activity of the parasympathetic chain of the autonomic nervous system [2,3]. According to many authors, a large heart rate variability is associated with an increase in the adaptive capacity of a person and has a positive effect on the course of various diseases and pathological conditions, such as stress, depression, autonomic dysfunction, bronchial asthma, etc.

According to a number of studies, the severity of respiratory sinus arrhythmia positively correlates with the tone of the parasympathetic link of the autonomic nervous system and is capable of modulating the psycho-physiological responses to mental stressors, as well as correcting a large number of pathological conditions and diseases. Therefore, the search for non-invasive methods of influencing the functional state of the autonomic nervous system seems physiologically grounded.

In recent years, special interest in this context is respiratory gymnastics. Deep breathing, which is consistent with the natural fluctuations of the heart rate, can substantially enhance both respiratory sinus arrhythmia and general heart rate variability $[2,3,4]$. Proved positive effect has diaphragmatic breathing in the mode of biological feedback 
using portable devices. However, there is little data of using yoga breathing gymnastics in order to influence the heart rate variability. With the development of civilization, the rhythm of life accelerated and breathing became consistent with him. The doctrine of yogis argues that nature has defined the number of respiratory cycles for each person and the more often it breathes, the earlier it dies. A slow, deep breath, on the contrary, lengthens it. Therefore, yogis consider only deep and rhythmic breathing as our ancestors breathed [5].

\section{THE AIM}

Compare the possibilities of using the courses of breathing gymnastics of yogis and diaphragmatic breathing sessions in the mode of biological feedback using a portable device.

\section{MATERIALS AND METHODS}

The study involved 70 healthy young men aged 18 to 25 years old, who were randomly divided into 2 groups of 35 people. All participants in the experiment did not complain about their health, had no deviations from the norm according to the data of the medical examination and professionally not engaged in sports and yoga. Participants of the first group daily engage in respiratory exercises of pranayama for 15 minutes ( 3 periods of 5 minutes, separated by 3 spontaneous breathing cycles) within one month. Participants in the second group used a portable biological feedback device MyCalmBeat, which after calculating the individual optimal respiratory rate on the basis of free breathing and pulse detection within 15 minutes provided the appropriate instructions for the beginning of inhalation and exhalation on the screen of the smartphone.

Heart rate variability was registered by using the computer diagnostic complex "CardioLab" ("KhAI-Medika", Ukraine). In particular, the mean square deviation of the duration of cardiointervals (SD, ms), which characterizes the total heart rate variability, is the square root of the mean square of the differences in the values of successive pairs of cardiointervals (RMSSD, ms), reflecting the influence of the parasympathetic link of the autonomic nervous system and the activity of the peripheral links of it - the number of consecutive pairs RR intervals with a duration of more than $50 \mathrm{~ms}$ (pNN50). Also the following spectral parameters of heart rate variability such as TP $\left(\mathrm{ms}^{2}\right)$, were determined - total energy of the heart rate spectrum, reflecting the total influence on the cardiac rhythm of all regulatory systems; $\mathrm{HF}\left(\mathrm{ms}^{2}\right)$ is a high-frequency component of the heart rhythm spectrum in the range of $0.15-0.4 \mathrm{~Hz}$, which mainly reflects the vagal effect on the heart rhythm associated with breathing; $\mathrm{LF}\left(\mathrm{ms}^{2}\right)$ is a low-frequency component of the heart rhythm spectrum in the range of $0.04-0.15 \mathrm{~Hz}$, which mainly reflects the effect of the sympathetic autonomic nervous system on the heart rhythm, including - activity of the vascular motor center and VLF $\left(\mathrm{ms}^{2}\right)$ - very-low frequency component of the heart rhythm spectrum in the range 0,003-0,04 $\mathrm{Hz}$, reflecting the total activity of the supersonic sections of the nervous system and neurohumoral effects on the heart rhythm. In addition, the sympathetic-parasympathetic balance $(\mathrm{LF} / \mathrm{HF})$ and the percentage contribution of each of the frequency components of the spectrum in TP (HF\%, LF\% and VLF\%) were calculated.

The obtained numerical data were processed by methods of variation statistics using Student's criterion. The dynamics of the heart rate variability indices were estimated by using the paired comparisons, and intergroup differences were determined using a single-factor dispersion analysis.

\section{RESULTS}

To assess the effect of deep diaphragmatic breathing, both in the breathing gymnastics of yoga, and in the mode of biological feedback on the heart rate variability index, $2^{\text {nd }}$ ECG withdrawal was recorded in all subjects under investigation using the computer diagnostic complex "CardioLab" ("KhAI-Medika ", Ukraine) in a position lying after a 10-minute adaptation to the conditions of registration. As background indicators data from the last 5 minutes of registration were used. Subsequently, during the course of a month, a session of respiratory gymnastics lasted for 15 minutes, which included 3 periods of 5 minutes, during which the subjects performed 5-6 respiratory cycles per minute. Each period was completed by 3 spontaneous breathing cycles. The participants of the second group followed the instructions of the portable biological feedback device once daily and adjusted the withdrawal ratio of inhalation and exhalation. In both cases, after completing a 30-day course of diaphragmatic breathing, ECG was continued for 5 minutes. The efficacy of diaphragmatic breathing in both cases was evaluated by comparing the first and second 5-minute intervals. The results are shown in the table I.

In both groups there was similar dynamics of heart rate variability indices, however, its severity was different. The overall integral effect was a significant increase in heart rate variability, both in terms of statistical and spectral indices - in particular TP increased (total energy of the heart rate spectrum (CR) in both groups by $927 \pm 231 \mathrm{~ms}^{2}(\mathrm{p}<0.01$ MyCalmBeat $)$ and $835 \pm 154 \mathrm{~ms}^{2}$ $(\mathrm{p}<0.05$ respiratory gymnastics). This was mainly due to the increase of the HF index by $993 \pm 198 \mathrm{~cm}^{2}(\mathrm{p}<0.05$ MyCalmBeat) and $784 \pm 173 \mathrm{~ms}^{2}(\mathrm{p}<0.05$ respiratory gymnastics).The power of the ultrasonic waves of the VLF band decreased significantly only in the group with the device at $252 \pm 33 \mathrm{~ms}^{2}(\mathrm{p}<0.05)$, while LF has not statistically significantly changed. In the structure of the cardiac rhythm spectrum, the specific gravity of VLF\% decreased by $10.7 \pm 1.8 \%(\mathrm{p}<0.05)$ in the group with the device and by $5.8 \pm 2.6 \%(\mathrm{p}<0.05)$ in the group, yoga, etc. It is commonly believed that the increase in this index and its specific gravity in the cardiac rhythm 
Table I. Dynamics of HRV indices under the influence of the course of yoga breathing gymnastics and in the mode of biological feedback by using the portable device MyCalmBeat

\begin{tabular}{|c|c|c|c|c|}
\hline \multirow[t]{2}{*}{ Indexes } & \multicolumn{2}{|c|}{$\begin{array}{c}\text { First group } \\
\text { (Yoga breathing gymnastics) } \\
\mathrm{n}=35\end{array}$} & \multicolumn{2}{|c|}{$\begin{array}{c}\text { Second group } \\
\text { (MyCalmBeat) } \\
n=35 \\
\end{array}$} \\
\hline & Background & After a training course & Background & After a training course \\
\hline SDNN, ms & $61 \pm 6,5$ & $72,3 \pm 2,6^{*}$ & $59,3 \pm 7,2$ & $70,1 \pm 2,3^{*}$ \\
\hline RMSSD, ms & $43 \pm 2,4$ & $44,9 \pm 1,8^{*}$ & $45,1 \pm 2,2$ & $46,8 \pm 1,7^{*}$ \\
\hline pNN50, \% & $22 \pm 1,5$ & $26,2 \pm 1,8$ & $20,7 \pm 1,6$ & $25,2 \pm 1,6^{*}$ \\
\hline TP, ms 2 & $3601 \pm 245$ & $4436 \pm 218^{*}$ & $3594 \pm 245$ & $4521 \pm 207^{* *}$ \\
\hline $\mathrm{HF}, \mathrm{ms} 2$ & $797 \pm 117$ & $1581 \pm 142^{*}$ & $815 \pm 113$ & $1808 \pm 119^{*}$ \\
\hline $\mathrm{LF}, \mathrm{ms} 2$ & $1451 \pm 212$ & $1442 \pm 209$ & $1462 \pm 201$ & $1617 \pm 187$ \\
\hline VLF, ms2 & $1353 \pm 121$ & $1413 \pm 135$ & $1348 \pm 134$ & $1096 \pm 113^{*}$ \\
\hline LF\HF & $1,82 \pm 0,1$ & $0,91 \pm 0,05^{*}$ & $1,79 \pm 0,1$ & $0,89 \pm 0,05^{* *}$ \\
\hline $\mathrm{HF}, \%$ & $22,1 \pm 1,6$ & $35,6 \pm 1,4^{*}$ & $22,7 \pm 1,5$ & $39,9 \pm 0,9^{*}$ \\
\hline $\mathrm{LF}, \%$ & $40,3 \pm 2,9$ & $31,8 \pm 3,7^{*}$ & $40,7 \pm 2,6$ & $35,7 \pm 2,5$ \\
\hline VLF, $\%$ & $37,6 \pm 3,1$ & $32,6 \pm 0,7^{*}$ & $36,6 \pm 2,0$ & $24,4 \pm 1,1^{*}$ \\
\hline
\end{tabular}

* - statistically significant difference compered to background index $\mathrm{p}<0,05$

** - statistically significant difference compered to background index $p<0,01$

spectrum (VLF\%) means "centralization" of heart rate control and is a sign of reducing the adaptive capacity of the body. The data obtained suggest that the 30-day A training course using deep diaphragmatic breathing reduces VLF and VLF\% against the background of the overall heart rate variability growth. This indicates the redistribution of the autonomic nervous system activity in favor of its peripheral divisions and therefore means an increase in the regulatory reserve of the organism. Also the sympathetic-parasympathetic balance of LF/HF decreased by $0.83 \pm 0.12$ ( $<<0.01$ MyCalmBeat) and 0.77 \pm 0.16 ( $<<0.05$ respiratory gymnastics). Such dynamics of heart rate variability indices can be interpreted as enhancement of the tonus of the parasympathetic link of the autonomic nervous system with simultaneous reduction of upersegmental regulation of the cardiac rhythm from the higher vegetative centers and humoral mechanisms.

\section{DISCUSSION}

By comparing the integral effect on heart rate variability of yoga breathing exercises and diaphragmatic breathing using the MyCalmBeat handheld device according to SD and TP it can be noted that it was more pronounced in the group that worked with this device and smaller in the second group, the participants which was used for respiratory gymnastics (see Table I). The mechanism of the positive influence of deep diaphragmatic breathing on the physiological state of the organism is seen in the redistribution of the activity of the peripheral parts of the autonomic nervous system in favor of the parasympathetic link, which manifests itself in increasing the overall heart rate variability and parasympathetic indexes $[6,7]$.
The findings confirm these beliefs as evidenced by the likely increase in SD and TP in both groups.

In conditions of relatively slow diaphragmatic breathing, whose frequency (5-7 respiratory movements per minute) is close to the low-frequency range of the heart rate rhythm LF $(0.1 \mathrm{~Hz})$, the $L F$ index does not reflect the activity of the sympathetic link, but the coordination of the baroreceptor reflex with the frequency of respiration and cardiac rhythm The frequency of breathing at which this agreement is achieved is called the resonant frequency (term proposed by Lehrer) [8]. It is shown that during a long breath (within about 5 seconds), due to the activation of the sympathetic link of the autonomic nervous system, the cardiac rhythm accelerates, while the activation of baroreceptors stimulates the heart rhythm in order to prevent the reduction of blood pressure. During exhalation processes develop in the opposite direction. Reducing the volume of the chest creates a tendency to increase blood pressure, reduces impulse from the baroreceptors and reflexively activates the parasympathetic link, decreasing the heart rate $[9,10]$. This explains why during respiration with the resonant frequency, heart rate variability increases. Exact synchronization of the cardiovascular, respiratory and autonomic nervous system creates a state of physiological coherence. The use of portable electronic biological feedback devices allows a person to visually observe the coherence of these systems during training and make the necessary adjustments to patterns of their own breathing. However, in the absence of a portable device, it is possible to regulate the functional state of the autonomic nervous system by breathing gymnastics of yoga, which is also based on deep diaphragmatic breathing. 


\section{CONCLUSIONS}

Respiratory gymnastics yoga for 15 minutes contributes to the growth of heart rate variability through the suppression of the central link (VLF) of regulation of cardiac rhythm and increased activity of parasympathetic influences (HF), as well as the redistribution of regulatory activity of the central nervous system between the central and peripheral links of regulation of the cardiac rhythm in favor of the latter. This technique can be used in the absence of portable devices for visualizing heart rate variability in order to improve it.

\section{REFERENCES}

1. Low A, McCraty R. Heart rate variability: New perspectives on assessment of stress and health risk at the workplace. Heart Mind 2018;2:16-27

2. NikhilS, Kegan JMetal. HeartRateVariability:AnOldMetricWith New Meaning In The Era Of Using MHealth Technologies For Health And Exercise Training Guidance. Arrhythmia \& Electrophysiology Review 2018;7(4):247-55.

3. Veyn A.Vegetativnyye rasstroystva: Klinika, diagnostika, lecheniye. Meditsinskoye informatsionnoye agentstvo.2003:752(In Russian).

4. Jerath R, Edry JW et al. Physiology of long pranayamic breathing: Neural respiratory elements may provide a mechanism that explains how slow deep breathing shifts the autonomic nervous system. MedHypotheses:2006;67:566-71.

5. Posadzki P, Kuzdzal A et al.Yoga for heart rate variability: A systematic review and meta-analysis of randomized clinical trials.Appl Psychophysiol Biofeedback.2015;40:239-49.
6. Aritzeta A, Soroa G, Balluerka N, Muela A, Gorostiaga A, Aliri J. Reducing anxiety and improving academic performance through a biofeedback relaxation training program. Appl Psychophysiol Biofeedback (2017) 42(3):193-202.

7. Tonhajzerova I, Mestanik M et al. Respiratory sinus arrhythmia as a non-invasive index of 'brain-heart' interaction in stress. Indian J Med Res. 2016; 144(6): 815-822.

8. Perrotta A, Jeklin A, Hives B, et al. Validation of the Elite HRV smartphone application for examining heart rate variability in a field-based setting. J Strength Cond Res.2017;31:2296-302.

9. Hamaideh SH, Al-Omari H, Al-Modallal H. Nursing students' perceived stress and coping behaviors in clinical training in Saudi Arabia. J Ment Health. 2017;26(3): 197-203.

10. Lehrer P,Gevirts R.Heart rate variability biofeedback: how and why does it work? Front Psychol. 2014; 5: 756.

Scientific research is a fragment of the SB topic 12A-2018 "Functional state of autonomous systems depending on the ratio of fat and muscle tissue in normal and in pathology" (state registration number 0118U000713)

\section{Authors' contributions:}

According to the order of the Authorship.

\section{Conflict of interest:}

The Authors declare no conflict of interest.

\section{CORRESPONDING AUTHOR \\ Nataliia I. Sheiko \\ Uzhhorod National University \\ Uzhanska st. 53, 88007 Uzhhorod, Ukraine \\ tel: +380508843978 \\ e-mail:n.molanich@gmail.com}

Received: 03.02.2019

Accepted: 27.03.2019 
PRACA ORYGINALNA

ORIGINAL ARTICLE

\title{
DYSLIPIDEMIA AS RISK FACTOR OF ATHEROSCLEROSIS IN PATIENTS WITH CHRONIC OBSTRUCTIVE PULMONARY DISEASE
}

\author{
Tetyana M. Ternushchak, Marianna I. Tovt-Korshynska \\ UZHHOROD NATIONAL UNIVERSITY, UZHHOROD, UKRAINE
}

\begin{abstract}
Introduction: Atherosclerosis is one of the most common co-morbidities observed in chronic obstructive pulmonary disease. A better understanding of mechanisms of atherosclerosis in patients with chronic obstructive pulmonary disease is needed to improve clinical outcomes.

The aim: to evaluate the plasma levels of lipid parameters, atherogenic indices, systemic inflammatory markers and to assess their relationship with the severity of chronic obstructive pulmonary disease.

Materials and methods: A total of 72 subjects diagnosed with chronic obstructive pulmonary disease and 41 healthy controls, the same gender and age categories, with $\geq$ 10 pack years smoking history, were followed-up of about 5.8 years. Blood tests with determination of lipid profiles, atherogenic indices and systemic inflammatory markers were conducted in remaining patients who fulfilled inclusion criteria of the study.

Results: Triglyceride, atherogenic index of plasma, cardiogenic risk ratio and atherogenic coefficient values were significantly higher, but high-density lipoprotein cholesterol - significantly lower in patients with chronic obstructive pulmonary disease than in controls. Lipid profiles were similar in lower-risk (stage A and B) and higher-risk (stage C and D) patients with chronic obstructive pulmonary disease. The analysis showed that atherogenic indices and serum high sensitive C-reactive protein were inversely correlated with forced expiratory volume in $1 \mathrm{sec}$, especially in higher-risk patients with chronic obstructive pulmonary disease $(r=-0.61 p<0.05 ; r=-0.57 p<0.05 ; r=-0.54 p<$ 0.05 and $r=-0.49 p<0.05$ respectively).

Conclusions: Atherogenic indices and serum high sensitive C-reactive protein can be considered as useful biochemical markers to predict an early stage of atherosclerosis especially in higher-risk patients with chronic obstructive pulmonary disease.
\end{abstract}

KEY WORDS: atherogenic indices, markers of systemic inflammation, chronic obstructive pulmonary disease

\section{INTRODUCTION}

Chronic Obstructive Pulmonary Disease (COPD) is currently the fourth leading cause of death in the world but is projected to be the third leading cause of death by 2020. More than 3 million people died of COPD in 2012 accounting for $6 \%$ of all deaths globally [1].

COPD often co-exists with other co-morbidities that may have a significant impact on prognosis. Cardiovascular disease (CVD) is a major cause of mortality and morbidity in patients with COPD [2].

Several epidemiological studies have also provided strong evidence that people with reduced lung function have an increased risk of CVD. Reduced $\mathrm{FEV}_{1}$ is associated with 2- to 3-fold greater risk of coronary artery disease (CAD), stroke, and sudden cardiac death, independent of cardiovascular risk factors. It has been also shown that COPD patients have increased arterial stiffness defined as increased aortic pulse wave velocity. Therefore, COPD appears to be an important risk factor for CVD [3].

Reduced $\mathrm{FEV}_{1}$ itself is a risk factor for cardiovascular mortality in patients of COPD irrespective of conventional risk factors. Every $10 \%$ decrease in $\mathrm{FEV}_{1}$ increases all cause mortality by $14 \%$, cardiovascular mortality by $28 \%$, and nonfatal coronary event by almost $20 \%$, after adjustments for relevant confounders such age, sex, smoking status, and treatment assignment [4].

It should be noted that there are several proposed mechanisms for the association of atherosclerosis with COPD and it remains possible that these mechanisms may co-exist in any individual. Cigarette smoking, and the repetitive injury associated with this, is recognized to lead to abnormal cell repair, increased airway inflammation, oxidative stress and extracellular matrix destruction [5].

Patients with COPD can have sustained (patients with chronic respiratory failure) or intermittent hypoxia (during exercise, exacerbations or during sleep). Hypoxia is known to induce an inflammatory response in immune cells, oxidative stress, foam cell production and upregulation of cellular adhesion molecules in endothelial cells, which may all contribute to progression of atherosclerosis, and thus CVD. Furthermore, it can induce hemodynamic stress by increasing the heart rate and activating the sympathetic nervous system [6].

Another putative mechanism is the effect of increased systemic inflammation, with airflow obstruction as an independent predictor of atherosclerosis; treatment to reduce systemic inflammation in COPD has yet to be successful. 
There are likely to be direct effects on cardiac function as a consequence of vascular remodeling and that of dynamic hyperinflation [7].

Inflammation has been increasingly recognized to have a role in atherosclerosis particularly in the context of coronary artery disease. Blood borne immune and inflammatory cells are an important component of atheroma [8]. Macrophages and T cells infiltrate atheroma with the production of inflammatory cytokines. Activated immune cells (macrophages and $\mathrm{T}$ cells) are abundant at sites of plaque rupture and appear to play an important role in acute thrombosis and coronary syndrome [9].

A better understanding of mechanisms of atherosclerosis in COPD patients is needed to improve clinical outcomes.

\section{THE AIM}

To evaluate the plasma levels of lipid parameters, atherogenic indices and systemic inflammatory markers as a predictor of atherosclerosis in subjects with chronic obstructive pulmonary disease and to investigate the relationship between these serum biomarkers and the severity of chronic obstructive pulmonary disease.

\section{MATERIALS AND METHODS}

We conducted a longitudinal study of patients with chronic obstructive pulmonary disease compared with healthy control group. A total of 72 subjects diagnosed with chronic obstructive pulmonary disease and 41 matched controls, the same gender and age categories, with $\geq 10$ pack years smoking history, were followed-up of about 5.8 years.

Chronic obstructive pulmonary disease was defined as a post-bronchodilator airflow limitation of forced expiratory volume in $1 \mathrm{~s}\left(\mathrm{FEV}_{1}\right)$ to forced vital capacity (FVC) of $<70 \%$.

According to the Global initiative for chronic obstructive lung disease (GOLD), the severity of chronic obstructive pulmonary disease was divided into 4 grades based on $\mathrm{FEV}_{1} \%$ predicted: stage I: $\mathrm{FEV}_{1} \geq 80 \%$, stage II: $80 \%<\mathrm{FEV}_{1} \geq 50 \%$, stage III: $50 \%<\mathrm{FEV}_{1} \geq 30 \%$ and stage IV: $\mathrm{FEV}_{1}<30 \%$.

All subjects with chronic obstructive pulmonary disease were categorized into groups $\mathrm{A}-\mathrm{D}$ according to combined chronic obstructive pulmonary disease risk assessment categories defined by GOLD (by using exacerbation risk [airway obstruction level according to $\mathrm{FEV}_{1}$, exacerbation, and hospitalization status within the previous year] and dyspnea score [Modified Medical Research Council dyspnea score]).

The primary outcome was the development of cardiovascular events. Subjects with exacerbation, with known cardiovascular diseases and other chronic diseases, receiving anti-hyperlipidemic treatment, without sufficient past medical history, and lacking needed laboratory data were excluded.

Statistical analyses were carried out in SPSS 22.0 Statistical Package Program for Windows (SPSS Inc., Chicago,
Illinois). Blood tests with determination of different parameters such as lipid profiles, systemic inflammatory markers were conducted in remaining patients who fulfilled inclusion criteria of the study.

Atherogenic indices (atherogenic index of plasma (AIP), cardiogenic risk ratio (CRR) and atherogenic coefficient (AC)) were calculated by using the value of lipid profile parameters according to the following formulas: AIP = log (triglyceride/high-density lipoprotein cholesterol (HDL-C)), where the concentrations of triglyceride and HDL-C are in $\mathrm{mmol} / \mathrm{L}$, and calculation of AIP was performed using an online calculator; $\mathrm{CRR}=$ total cholesterol (TC) / HDL-C; and AC = (TC - HDL-C) / HDL-C.

Continuous variables were presented as the mean \pm standard deviation (SD) and were compared using an independent samples $t$ test.

However, if the data were not accorded with normal distribution, nonparametric test should be used. Categorical variables were expressed as frequencies and percentages and were compared using Chi-square tests. The correlation between the atherogenic indices values and other variables were calculated by Pearson correlation analysis.

The adjusted odds ratio (OR) per $1 \mathrm{SD}$ increase in the corresponding lipid variable and $95 \%$ confidence intervals ( $95 \%$ CIs) were calculated. A value of $\mathrm{p}<0.05$ in a 2 -sided test was considered significant.

\section{RESULTS}

Triglyceride, AIP, CRR and AC values were significantly higher, but HDL-C - significantly lower in COPD patients than in controls $(\mathrm{p}<0.05)$ (Table I). This might partially explain the increased cardiovascular risk in patients with COPD.

We didn't find any statistically significant differences between total cholesterol and low-density lipoprotein cholesterol (LDL-C) levels in COPD patients and control subjects.

Lipid profiles were similar in lower-risk (stage A and $\mathrm{B}$ ) and higher-risk (stage $\mathrm{C}$ and $\mathrm{D}$ ) patients with COPD (Table I).

As AIP is a strong marker to predict the risk of atherosclerosis and coronary heart disease, we assessed the correlation between AIP and other important factors. AIP is calculated according to the formula, $\log$ (TG/HDL-C). It has been suggested that an AIP value of under 0.11 is associated with low risk of CVD; the values between 0.11 to 0.21 and upper than 0.21 are associated with intermediate and increased risks, respectively.

In clinical examination, the mean \pm SD of AIP was 0.42 \pm 0.15 and $0.07 \pm 0.14$ respectively in patients with COPD and controls, according to the AIP category that mentioned before, $4.17 \%(n=3)$ were in low risk group, $13.89 \%(n=10)$ were in intermediate risk and $81.94 \%(n=59)$ were in increased risk of CVD.

Pearson correlation analyses were performed to investigate the correlation of AIP with $\mathrm{FEV}_{1}$ 
Table I. Lipid profile, systemic inflammatory markers and atherogenic indices of lower - higher risk COPD patients and control subjects

\begin{tabular}{|c|c|c|c|c|c|}
\hline & $\begin{array}{c}\text { Control group } \\
(n=41) \\
\text { Mean } \pm \text { SD }\end{array}$ & $\begin{array}{c}\text { Group A } \\
(n=18) \\
\text { Mean } \pm S D\end{array}$ & $\begin{array}{c}\text { Group B } \\
(n=18) \\
\text { Mean } \pm \text { SD }\end{array}$ & $\begin{array}{c}\text { Group C } \\
(n=18) \\
\text { Mean } \pm \text { SD }\end{array}$ & $\begin{array}{c}\text { Group D } \\
(n=18) \\
\text { Mean } \pm S D\end{array}$ \\
\hline $\mathrm{TC}, \mathrm{mmol} / \mathrm{l}$ & $4.9 \pm 0.23$ & $5.5 \pm 0.25$ & $5.8 \pm 0.24$ & $6.3 \pm 0.27$ & $6.6 \pm 0.21$ \\
\hline LDL-C, mmol// & $2.3 \pm 0.27$ & $2.8 \pm 0.21$ & $3.1 \pm 0.22$ & $3.4 \pm 0.21$ & $3.7 \pm 0.20$ \\
\hline $\mathrm{HDL}-\mathrm{C}, \mathrm{mmol} / \mathrm{l}$ & $1.2 \pm 0.12 *$ & $1.0 \pm 0.11^{*}$ & $0.8 \pm 0.11^{*}$ & $0.7 \pm 0.13^{*}$ & $0.6 \pm 0.10^{*}$ \\
\hline Triglycerides, mmol/l & $1.4 \pm 0.10 *$ & $1.7 \pm 0.12^{*}$ & $1.9 \pm 0.13^{*}$ & $2.2 \pm 0.10^{*}$ & $2.3 \pm 0.11^{*}$ \\
\hline hsCRP, mg/l & $1.1 \pm 0.13^{*}$ & $2.4 \pm 0.15 *$ & $2.6 \pm 0.12 *$ & $3.7 \pm 0.11^{*}$ & $3.9 \pm 0.14$ * \\
\hline Fibrinogen, $\mathrm{g} / \mathrm{l}$ & $3.8 \pm 0.47$ & $3.9 \pm 0.49$ & $4.1 \pm 0.56$ & $4.2 \pm 0.70$ & $4.3 \pm 0.79$ \\
\hline AIP & $0.07 \pm 0.14 *$ & $0.23 \pm 0.15^{*}$ & $0.38 \pm 0.14 *$ & $0.50 \pm 0.13 *$ & $0.58 \pm 0.12^{*}$ \\
\hline CRR & $4.08 \pm 0.10 *$ & $5.51 \pm 0.17 *$ & $7.25 \pm 0.11 *$ & $9.01 \pm 0.15 *$ & $11.02 \pm 0.1^{*}$ \\
\hline$A C$ & $3.09 \pm 0.18 *$ & $4.50 \pm 0.15 *$ & $6.26 \pm 0.17 *$ & $8.04 \pm 0.12 *$ & $10.1 \pm 0.13^{*}$ \\
\hline
\end{tabular}

*: $p<0.05$ compared to the control group
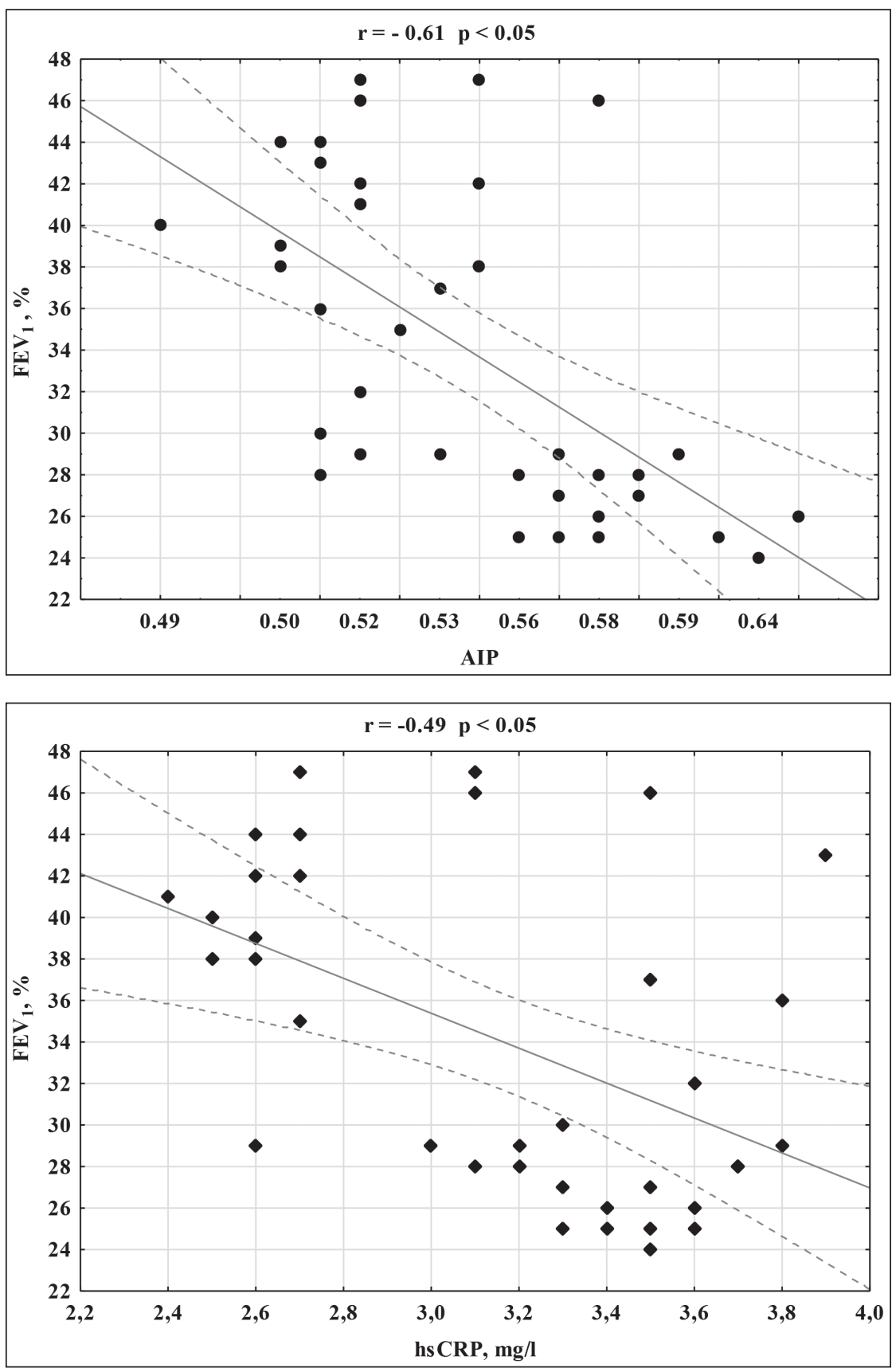

Fig.1. Correlation between AIP and FEV1 in higherrisk (stage $($ and D) patients with COPD
Fig. 2. Correlation between hsCRP levels and FEV1 in higher-risk (stage $C$ and D) patients with COPD 
Correlation analysis showed that AIP was strongly and negatively correlated with $\mathrm{FEV}_{1}$, especially in higher-risk (stage $\mathrm{C}$ and $\mathrm{D})$ patients with COPD $(\mathrm{r}=-0.61 \mathrm{p}<0.05)$ (Fig.1).

In lower-risk (stage A and B) COPD patients AIP was also inversely statistically significantly correlated with $\mathrm{FEV}_{1}$ but mildly $(\mathrm{r}=-0.27 \mathrm{p}<0.05)$.

CRR and AC values were moderately negatively correlated with $\mathrm{FEV}$ in all patients with COPD, especially in higher-risk COPD subjects $(r=-0.57 \mathrm{p}<0.05 ; \mathrm{r}=-0.54$ $\mathrm{p}<0.05$ respectively).

In lower-risk (stage $\mathrm{A}$ and $\mathrm{B}$ ) COPD patients CRR and $\mathrm{AC}$ values were also inversely correlated with $\mathrm{FEV}_{1}$ but mildly $(r=-0.24 p<0.05 ; r=-0.23 p<0.05)$.

As expected, serum high sensitive $\mathrm{C}$-reactive protein (hsCRP) level in patient group was significantly higher than in controls.

The mean \pm SD of hsCRP was $3.16 \pm 0.45 \mathrm{mg} / \mathrm{l}$ in patients with COPD compare to control subjects $(1.1 \pm 0.13 \mathrm{mg} / \mathrm{l})$.

The hsCRP is the most widely evaluated biomarker in the quest for an ideal biomarker for global CVD risk prediction. The AHA/CDC (American Heart Association/ Centers for Disease Control) Working Group on markers of inflammation in CVD has classified serum hsCRP levels $<1$ as low, 1-3 - intermediate and $>3 \mathrm{mg} / \mathrm{l}$ as high-risk groups for global CVD, respectively.

According to the serum hsCRP levels $2.78 \%(\mathrm{n}=2)$ of COPD patients were in low risk group $9.72 \%(n=7)$ were in intermediate risk and $87.5 \%(n=63)$ were in high risk group of CVD.

HsCRP was inversely correlated with $\mathrm{FEV}_{1}$ in all patients with COPD, especially in higher-risk subjects with COPD $(\mathrm{r}=-0.49 \mathrm{p}<0.05)($ Fig.2).

In lower-risk (stage A and B) COPD patients hsCRP values were also inversely correlated with $\mathrm{FEV}_{1}$ but mildly $(\mathrm{r}=-0.22 \mathrm{p}<0.05)$.

The mean $\pm \mathrm{SD}$ of fibrinogen was $4.1 \pm 0.56 \mathrm{~g} / \mathrm{L}$ in COPD group and $3.8 \pm 0.47 \mathrm{~g} / \mathrm{L}$ in control group. This difference was not statistically significant $(\mathrm{p}>0.05)$.

Also, correlation analysis showed that fibrinogen was not statistically significant correlated with $\mathrm{FEV}_{1}$ in patients with COPD and control subjects.

\section{DISCUSSION}

Overall, these data clearly demonstrated impaired cardiovascular risk markers in COPD, even in lower-risk patients without a history of CVD, and supported its potential usage in clinical practice.

The severity of COPD plays an important role in both systemic inflammation and dyslipidemia. Our study shows that reduction of $\mathrm{FEV}_{1}$ could promote disruption of lipid metabolism and increased hsCRP.

Previous studies have shown a link between atherosclerosis and systemic inflammation in COPD. One study showed that lower $\mathrm{FEV}_{1}$ was associated with higher levels of serum hsCRP and a higher frequency of coronary artery calcification. In another study, Kim et al., it was showed an inverse relationship between $\mathrm{FEV}_{1}$ and hsCRP level [10].

Our study revealed the increased hsCRP levels in COPD patients with increased airway obstruction severity, increased and degree of dyspnea with a significant negative correlation between hsCRP with $\mathrm{FEV}_{1}$. These results clearly confirm the fact that the intensity of the inflammatory process in COPD could be related to the severity of the underlying disease.

The strongest negative associations between $\mathrm{FEV}_{1}$ and hsCRP and higher CRP levels over time were associated with a faster $\mathrm{FEV}_{1}$ decline, indicating that CRP measurements might enable identification of patients at high risk of disease progression and mortality [11].

Hypoxia, cigarette smoking, as well as oxidative stress is possible mechanisms responsible for the development of dyslipidemia in COPD patients [12].

We suspect that the impact of smoking status on systemic inflammation differs according to the type of inflammatory marker analyzed.

Higher levels of hsCRP in current smokers and ex-smokers indicate that in patients with COPD inflammation continues for many years after smoking cessation, which is not true for fibrinogen levels [13].

Corticosteroids are widely used in patients with COPD, especially in those with acute exacerbations, stages $C$ and D. For example, one study reported that 7 weeks of dexamethasone treatment facilitated diet-induced dyslipidemia.

Another population based study showed that low-dose shortterm corticosteroids markedly affect plasma lipid levels [14].

However, the impact of corticosteroid use on lipid levels in patients with COPD is still unknown and requires further well-designed studies.

\section{CONCLUSIONS}

Atherogenic indices and serum high sensitive C-reactive protein can be considered as useful biochemical markers to predict the early stage of atherosclerosis and cardiovascular diseases especially in higher-risk patients with chronic obstructive pulmonary disease. Nevertheless, further prospective investigations on this issue are required.

\section{REFERENCES}

1. Lozano $R$, Naghavi M, Foreman $K$ et al. Global and regional mortality from 235 causes of death for 20 age groups in 1990 and 2010: a systematic analysis for the Global Burden of Disease Study 2010. Lancet. 2012; 380 (9859): 2095 - 2128.

2. Barnes PJ, Celli BR. Systemic manifestations and comorbidities of COPD. Eur Respir J. 2009; 33(5): 1165 - 1185.

3. Rabe. KF, Hurst JR, Suissa SC. Cardiovascular disease and COPD: dangerous liaisons? Eur Respir Rev. 2018; 27(149):180057.

4. Cavaille's A, Brinchault-Rabin G, Dixmier A et al. Comorbidities of COPD. Eur Respir Rev.2013; 22(130): 454 - 475.

5. Bafadhel M, Russell RE. Are COPD and cardiovascular disease fundamentally intertwined? Eur Respir J. 2016; 47(5): 1307-1309.

6. Portillo K, Abad-Capa J, Ruiz-Manzano J et al. Chronic Obstructive Pulmonary Disease and Left Ventricle. Arch Bronconeumol. 2015;51(5): 227-234. 
7. Chandra D, Gupta A, Strollo PJ Jr et al. Airflow Limitation and Endothelial Dysfunction. Unrelated and Independent Predictors of Atherosclerosis. Am J Respir Crit Care Med. 2016; 194(1): 38 - 47.

8. Cimmino G, Loffredo FS, Morello A et al. Immune-Inflammatory Activation in Acute Coronary Syndromes: A Look into the Heart of Unstable Coronary Plaque. Curr Cardiol Rev. 2017; 13(2): 110 -117.

9. Bergheanu SC, Bodde MC, Jukema JW. Pathophysiology and treatment of atherosclerosis. Current view and future perspective on lipoprotein modification treatment. Neth Heart J. 2017; 25(4): 231-242.

10. El-Shabrawy M, S.Eldamanhory A. Study of cardiovascular diseases in hospitalized AECOPD patients. Egyptian Journal of Chest Diseases and Tuberculosis. 2017; 66(1): 17-25.

11. Korani AY, Hassan AT, Tony AE. et al. The impact of smoking on inflammatory biomarkers in patients with chronic obstructive pulmonary disease. Egyptian Journal of Chest Diseases and Tuberculosis. 2016; 65(3): 597-603.

12. Okura Takafumi. Chronic Obstructive Pulmonary Disease and Atherosclerosis. Circ J.2017; 81:770-1771.

13. Ghobadi H, Fouladi N, Beukaghazadeh K et al. Association of High Sensitive CRP Level and COPD Assessment Test Scores with Clinically Important Predictive Outcomes in Stable COPD Patients. Tanaffos. 2015; 14(1): 34-41.

14. Li L, Yang G, Liao G, Mei J et al. Glucocorticoid treatment facilitates development of a metabolic syndrome in ovariectomized Macaca Mulatta fed a high fat diet. Steroids. 2017; 128: 105-113.
Authors' contributions:

According to the order of the Authorship.

\section{Conflict of interest:}

The Authors declare no conflict of interest.

\author{
CORRESPONDING AUTHOR \\ Tetyana Ternushchak \\ Internal Diseases Department, \\ Medical faculty 2, Uzhhorod National University \\ Gryboedova str., 20, Uzhhorod, Ukraine \\ tel: +380501499148 \\ e-mail: tatyana.xs38@gmail.com
}

Received: 01.02.2019

Accepted: 04.04.2019 
PRACA ORYGINALNA

ORIGINAL ARTICLE

\title{
ALLERGIC RHINITIS AND ASTHMA CO-MORBIDITY
}

\author{
Victoria S. Sukhan \\ UZHHOROD NATIONAL UNIVERSITY, UZHHOROD, UKRAINE
}

\begin{abstract}
Introduction: The combination of asthma and allergic rhinitis can affect the mutual encumbrance to which other pathogenetic mechanisms join, which worsen the course of both diseases.

The aim of work is to analyze the features of the genotype and phenotype in patients with a co-morbidity of asthma and allergic rhinitis.

Materials and methods: In order to detect the features of asthma and allergic rhinitis, 115 patients were examined. Patients were divided into two groups: the first included 58 patients with allergic asthma and allergic rhinitis co-morbidity, the second - 57 patients with non-allergic asthma morbidity.

Results: For the group of patients with allergic asthma with concomitant allergic rhinitis, the first manifestation of allergy in childhood is characteristic (allergic rhinitis, hay fever, atopic dermatitis). For this group of patients characterized by a heavy family allergic history. Symptoms of allergic rhinitis aggravate the course of asthma. Characteristic correlation of symptoms of allergic rhinitis with distal obstruction and pronounced lability of bronchi. In these patients, the total increase in lgE and blood eosinophilia, in 1,5 times increased blood histamine and the level of exhaled N02 have been increased. Also, asthma control with concomitant allergic rhinitis was significantly worse than in an isolated asthma group $(\mathrm{p}<0.05)$.

Conclusion: The obtained data allow to distinguishing the phenotype of patients with asthma and allergic rhinitis co-morbidity.
\end{abstract}

KEY WORDS: asthma, allergic rhinitis, co-morbidity

Wiad Lek 2019, 72, 4, 622-626

\section{INTRODUCTION}

Allergy in the twenty-first century. has become a global problem with significant medical, social and economic losses worldwide. Its prevalence increases with each passing year and becomes signs of a pandemic. Thus, according to the World Allergy Organization (WAO - 2013p.), 150 million Europeans suffer from allergic diseases, and by the beginning of 2025 half of the population in Europe will have one or another allergic disease [1].

Allergic respiratory diseases, asthma and rhinitis, are rightly called the $21^{\text {st }}$ century epidemic and modem age diseases. Although modern medicine offers a variety of preventive and therapeutic strategies, the prevalence of these diseases has been dramatically increasing in both developed and undeveloped countries across the world, especially in children and young adult. The WAO estimates there are 300 million asthmatics in the world, and 500 million people with the symptoms of rhinitis [1]. Very often, asthma and rhinitis coexist in one patient. Numerous contemporary studies, guided by the concept "one airway - one disease", have reveled the epidemiological, pathophysiological and clinical correlation of asthma and allergic rhinitis (AR) [2].

The most common chronic allergic diseases in the world today are asthma and allergic rhinitis (AR). According to epidemiological statistics, $44-68 \%$ of patients in AR have asthma, and in $76-80 \%$ of patients with asthma have comorbid AR [2]. There is also a chronological relationship between AR and asthma, which has been repeatedly confirmed by research. Data from the BAMSE cohort (Sweden, 2012) showed that in children aged 1 year, asthma is associated with rhinitis and / or atopic dermatitis (AD) in $38 \%$ of cases, and to 12 years of age, this figure increases to $67 \%$ [3]. AR is very often an initial manifestation of systemic allergy in the respiratory tract, and eventually the full allergic cascade starts to reach the lower respiratory tract «in the variant of the allergic march» $[2,3]$. Other authors note that in children of early age, AR is often not diagnosed due to frequent respiratory infections [4]. Asthma and AR as nosologies have always been considered in detail: diagnosed and treated in different ways, but recent studies have suggested that upper and lower respiratory tract on upper respiratory tract (URT) and lower respiratory tract (LRT) are a manifestation of a single inflammatory process (the hypothesis of «the only respiratory disease» ( united airway disease hypothesis)) $[5,6]$. The relationship between AR and asthma has been repeatedly found in scientific publications $[7,8]$, which confirmed the affinity of the anatomy of the mucous membrane of URT and LRT and the course of pathophysiological processes in them. Inflammation of $\mathrm{AR}$ and asthma occurs with the participation of identical triggers, immunocompetent cells, inflammatory mediators. Allergic respiratory syndrome - the phenomenon of allergic rhinitis and reverse broncho-obstruction is considered as a manifestation of the same disease in URT and LRT [9]. There are several mechanisms by which allergic inflam- 
mation spreads to LRT: allergic mediators from the nose penetrate the LRT with blood flow or by direct drainage, which leads to inflammation and hyperreactivity of the bronchi; through nasal sinus-bronchial reflexes - that is, stimulation of the receptors of the nose and the sinuses leads to reflex bronchospasm. During the symptoms of $\mathrm{AR}$, the inflow of allergens, cold and dry air through the mouth also increases, which also contributes to bronchospasm [10]. In 15-65\%, and according to some data [11], $80 \%$ of patients with AR have a typical functional marker of asthma - hyperractivity of the respiratory tract (HRT), where the severity of the course of nasal symptoms is closely correlated with the bronchial caliber and the degree of HRT. In clinical practice, there are frequent cases in which patients with isolated AR show a deterioration in spirometry and/or HRT [12]. It is proved that asthma with $\mathrm{AR}$ is characterized by a more pronounced lability of the bronchi due to the bronchodilation reaction to the short-acting $\beta_{2}$-adrenomimetic agent.

In some studies, the association between the presence of AR and the severity of asthma has been proved [13]. Patients with asthma with concomitant AR often needed unscheduled hospitalizations and higher economic costs for treatment. According to some studies, patients with asthma with comorbid AR had a significantly more inflammatory process than patients without AR. Thus, the level of nitric oxide and eosinophils in blood was 2 times higher, and the level of total serum IgE was significantly higher than in patients without AR [14].

Long-term observational studies have shown that AR often precedes asthma. Thus, according to data from 23 years of observation, patients with AR of asthma developed 3 times more often than in patients without $A R$, and the ratio of chances of association of AR-asthma after 7 years of observation was 7.1 versus 3.9 in control [11]

In most patients with asthma with concomitant $\mathrm{AR}$ (65.7\%), the course of asthma is uncontrollable. Significant frequency of cases $(81.0 \%)$ of subjective underestimation by patients in their state compared with the results of the ACT test $[15,16]$

One of the most important aspects of inadequate asthma control is its phenotypic heterogeneity. Clinical phenotypes of asthma are heterogeneous. Their formation depends on genetic and environmental influences and is determined by the interaction of the cellular elements of the respiratory tract and the immune system [17]. Phenotyping takes place in two directions: clinical, pathophysiological, molecular markers [17, 18] and options for response to therapy [17]. This explains a large number of genotypes and phenotypes of asthma. The genotype of asthma is determined by the type of inflammation: eosinophilic, neutrophilic, mixed, non-granulocytic.

\section{THE AIM}

The purpose of the work was to analyze the features of the genotype and phenotype in patients with a co-morbidity of bronchial asthma and allergic rhinitis.

\section{MATERIALS AND METHODS}

A total of 115 patients with asthma were examined on the basis of the SDC "Rehabilitation" of the Ministry of Health of Ukraine in Uzhhorod. All patients had a thorough allergy history, anamnesis of life and disease. Conducted general clinical and diagnostic examination. The function of external respiration (FER) was investigated using the computer spirograph «Pulmovent-2». To determine the features of the co-morbid flow of asthma from AR, all patients were divided into two groups. To the first (I) group included 58 patients with allergic asthma from $A R$, to the second (II) - 57 patients with asthma (non-allergic) without AR.

\section{RESULTS}

The average age in the group of patients with asthma in AR was $29.2 \pm 0.68$ years, and in the group of patients with isolated asthma was significantly higher and amounted to $38.2 \pm 0.76$ years. By gender, both groups were dominated by women. The duration of asthma in both groups was almost the same and was $11.1 \pm 1.87$ years in the first group and $11.6 \pm 1.96$ years in the second group. While the age of the debut of asthma varied. Thus, in the first group of patients, the age at which debuted asthma was $18.0 \pm 1.43$ years versus $26.6 \pm 1.66$ years - in the second group. Formation of asthma in patients with AR was characterized by the onset of symptoms of AR in $(2,5 \pm 0,55)$ years. These data are consistent with the literature data that asthma with $\mathrm{AR}$ is formed "in the alternative of an allergic march,» when the onset of the allergic process was AD and / or AR [19].

All patients had a thorough allergy history. In the I group of patients, a high indicator of sensitization to household and pollen allergens was established in $50(86.2 \%)$ patients. In the II group, the indicator was significantly lower and amounted to $36(63.2 \%)$ cases, mainly to household chemicals, sharp odors, food allergens.

With the study of hereditary history in patients with asthma with $\mathrm{AR}$, a variety of manifestations of allergy in the family were detected in $38(65.5 \%)$ cases. Among these patients, the presence of allergic diseases in relatives of the I-II line of mother affinity was detected in 22 (57.9\%) patients, from the father - in $15(39.4 \%)$ patients and from both parents in $1(2.7 \%)$ of the patient. In the group of patients with atopic asthma heredity was diagnosed in 24 (42.1\%) patients, mainly on the maternal line.

In the I group of patients, AR was more often combined with intermittent and persistent asthma of the lung in 42 $(72.4 \%)$ cases. In addition, in this group of patients also were diagnosed: in $12(20.7 \%)$ cases of professional asthma and $3(5.2 \%)$ - aspirin asthma. The second group consisted mainly of patients with persistent asthma of the mild and moderate course.

Medicinal allergy in the group of patients with asthma with AR was reported in 14 (24.1\%) cases to analgin, aspirin, anesthetics. In the comparison group, drug allergy was detected in 19 (33.3\%) cases of euphylline, the antibiotics of the penicillin number. 
$\mathrm{AR}$ in the I group of patients was divided into seasonal allergic rhinitis (SAR) in $48(82.8 \%)$ cases and year-round allergic rhinitis (YRAR) in $10(17.2 \%)$ cases. The YRAR was characterized by the presence of persistent symptoms. The main reasons were domestic dust, household dust mites, mold allergens, cockroaches and others. The cause of SAR was the seasonal appearance of allergenic particles in the air (pollen of plants, trees). It was sometimes difficult to diagnose SAR or YRAR. Thus, in patients with SAR as a result of the trigger action of several seasonal allergens, symptoms were manifested year-round. In turn, the YRAR was sometimes additionally accompanied by the effects of several seasonal allergens. Regardless of the type of AR, the clinical symptoms of the disease were not discrepancies. AR was manifested by symptoms such as difficult nasal breathing, abundant watery discharge from the nasal cavity (rhinorrhea), itching in the nasal cavity, swollen sneezing.

Clinical symptoms of AR were ranked according to the intensity of manifestations ( 0 absent, lung- 1 , average gravity-2, severe-3), with the total number of points deducted in accordance with the International Total Score System - Total Symptoms Score (TSS), as well as using the visual analog scale (VAS). TSS in the group of patients with asthma with AR was $8.75 \pm 2.01$ and VAS $-6.50 \pm 1.05$ points.

In the comparison group, non-allergic (vasomotor) rhinitis (NAR) was determined in 11 (19.3\%) patients. The NAR clinic was distinct from AR, first of all, in the absence of pruritus in the nasal cavity and an attack-like sneezing. NAR increased when the body position changed.

Among the causes of the first attack of myocardial infarction in the I group of patients dominated contact with pollen and everyday allergens in $52(89.7 \%)$ cases. In the II group of patients, the reasons for the formation of non-allergic asthma were called complications after transmitted pneumonia in $35(61,4 \%)$ patients.

The incidence of asthma in the group of patients with AR was $3.2 \pm 0.78$ times a year, whereas in the comparison group only $1.8 \pm 0.54$ times a year. Season of exacerbation of asthma in two groups varied. In group I, 48 (82.8\%) patients had asthma exacerbations in the spring and / or autumn, whereas in group II in $50(87.7 \%)$ patients - for the winter and autumn.

All patients were examined for the function of external respiration (FER). The lung of the forced vital capacity of the lungs (FVC) was lowered in the I group of patients in $32(52,2 \%)$ cases, and in the II group - in $38(66,7 \%)$ cases. The obstruction of distal bronchus in the group of patients with asthma with AR was 24 (41.4\%) cases and correlated with symptoms of difficult nasal breathing. For the II group of patients, generalized obstruction of the bronchi was characteristic in 27 (47.4\%) cases.

The bronchial lability was determined according to the recommendations [20] by assessing their response to metered physical activity and inhalation of short-acting $\beta_{2}$-adrenomimetic agents $(200 \mu \mathrm{g}$ of salbutamol), followed by the calculation of bronchial lability as a sum of components - the bronchoconstriction index (IBC) and bronchodilation (IBD ) Positive considered a sample of salbutamol with an index of IBD more than $12 \%$. The index of bronchospasm in the group of patients with asthma with $\mathrm{AR}$ was $11,7 \pm 1,82 \%$, and in the group of patients with atopic asthma $-10,9 \pm 2,01 \%$. The dilatation index in the I group of patients was $12.6 \pm 2.11 \%$, whereas in the II group $-6.8 \pm 1.90 \%$. Thus, the lability index in the first group was $24.3 \pm 2.74 \%$ against $-17.7 \pm 3.22 \%$ in the second group of patients.

Inflammation of the respiratory tract was determined by general clinical, biochemical and immunological methods. Thus, the titre of total serum $\operatorname{IgE}$ in the group of patients with allergic asthma with AR was $19.5 \pm 1.31$ IU against 8.6 $\pm 1.13 \mathrm{IU}$ in the comparison group. The level of eosinophils in the peripheral blood was also an order of magnitude higher in Group I compared with the II group of patients and was $9.8 \pm 0.62 \%$ and $3.8 \pm 0.44 \%$ respectively. Histamine of blood serum in the group of patients with allergic asthma with AR was significantly higher than that in the group of patients with non-allergic asthma and was 2.12 $\pm 0.05 \mu \mathrm{mol} / \mathrm{l}$ and $1.44 \pm 0.05 \mu \mathrm{mol} / \mathrm{l}$, respectively $(\mathrm{p}$ $<0.001)$. Histaminepsexation was decreased and in the I group it was $13,1 \pm 0,93 \%$, whereas in the II group it was at $19,0 \pm 1,19 \%$. Cholinesterase activity was decreased in the I group to $20.7 \pm 1.94$ and in the second group to 13.9 \pm 1.43 ( $p<0.05)$. Various violations and type of inflammation in the respiratory system correlated with changes in the NO - producing system. Thus, the level of $\mathrm{NO}_{2}$ in the condensate of exhaled air was $9.64 \pm 0.31 \mu \mathrm{mol} / \mathrm{l}$ in the I group, whereas in the second group it was only $3.20 \pm 0$. $14 \mu \mathrm{mol} / \mathrm{l}(\mathrm{p}<0.05)$.

The level of control of symptoms of asthma was determined by the Asthma Control (ACT) test. Patients were asked to answer 5 questions about asthma during the last 4 weeks. The score from 5 to 25 corresponded to different degrees of asthma control. So, the sum of points up to 20 indicated the uncontrollability of the course of the disease. In the I group, uncontrolled asthma was in 38 (65.5\%) patients, whereas in the second group only 19 (33.3\%). In addition, in patients with allergic asthma with AR, more pronounced nocturnal asthma symptoms 43 (74.1\%) versus $22(38.6 \%)$ in the non-allergic asthma group were more pronounced. The number of use of $\beta_{2}$ - adrenomimetics per day in group I was significantly higher - 286 inhalations versus 154 in group II, apparently due to symptoms of AR, which worsened the patient's condition, especially at night.

\section{DISCUSSION}

Thus, after the conducted studies it can be stated that the comorbidity of allergic asthma with AR has its own peculiarities and this group of patients can be considered as a separate phenotype of asthma [17]. This group of patients is characterized by the first manifestation of allergy in childhood. This, as a rule, is AR and / or AD, which is consistent with the data of literature $[2,3,4]$. For this cohort of patients also characterized by a burdened family allergic anamnesis [21]. The debut of allergic asthma in these patients begins at adolescence or adolescence against 
the background of diagnosed $\mathrm{AR}$ (pollen allergy), $\mathrm{AD}$ «in the variant of an allergic march $[4,19]$. Such patients often show sensitization to household and pollen allergens, drug allergy to non-steroidal anti-inflammatory drugs and anesthetics. Among the causes of allergic asthma, contact with household and pollen allergens is prevalent. Characteristic high frequency of exacerbations with seasonality - spring and / or autumn. The comorbidity of the two diseases also requires higher economic costs [13,21]. Symptoms of AR and asthma interact with one another. And as a result more often the use of medicines. Also, the correlation of AR symptoms with obstructive distal bronchus is characteristic, the lability of the bronchi is expressed.

Patients with allergic asthma with AR have a more pronounced IgE-dependent type of inflammatory process. Thus, the level of total serum IgE and blood eosinophils has increased by more than 2 times, which is in agreement with the data of other scientists $[5,8,22]$, that the clinical symptoms of AR and asthma (nasal congestion and bronchospasm) are caused by IgE - dependent inflammation in response to the action of allergens. For this cohort is also characterized by high levels of histamine, reduced histamine secretion and cholinesterase activity of almost 1.5 times. The level of $\mathrm{NO}_{2}$ in the condensation of exhaled air in patients with allergic asthma with AR is significantly higher than in patients with non-allergic asthma (2-3 times), which is confirmed by data from other studies [8, $14]$ and is explained by a significant level of allergy to the organism and manifestation of clinical symptoms of AR .

The presence of patients with allergic asthma in the associated AR affects the severity of asthma and the level of control. Asthma control is significantly worse (2 times) due to nightly, daytime symptoms of AR, which in turn increases the use of fast drugs in 1.9 times $[13,15,23,24]$.

\section{CONCLUSION}

All of the above suggests that patients with bronchial asthma with concomitant allergic rhinitis form a separate phenotype of asthma. Understanding the features of the course of asthma where allergic rhinitis initiates and complicates its course, taking into account the features of pathogenesis and functional unity of the respiratory tract allows us to work out the strategy of combined therapy of both diseases, aimed at optimizing the effectiveness, safety and cost savings for the treatment of this group of patients.

\section{REFERENCES}

1. Pawankar R. World Allergic Organization (WAO) White Book on Allergy: Update 2013; 239 p.

2. Turner P.J., Kemp A.S. Allergic rhinitis in children. J. of Pediatrics and Child Health. 2012; 48: $302-310$.

3. Ballardini N., Kull I., Lind T. et al. Development and co-morbidity of eczema, asthma and rhinitis to age 12 - data from the BAMSE birth cohort. Allergy. 2012; 67: 537 - 544.

4. Sarbacher G.B., Pharm D. BCACP Assosiate Professor of Pharmacy Practice University of the Incarnate World Feik School of Pharmacy San Antonio. Tehax US Pharmacst. 2016; 41 (7): 30 - 34.
5. Feschenko Yu.I.,Yashina L.A., Polyanskaya V.I., Ignateva V.I. Kompleksnyiy podhod k lecheniyu allergicheskogo rinita i bronhialnoy astmyi [An integrated approach to the treatment of allergic rhinitis and bronchial asthma] Astma ta alergiya. 2015; 4: 13 - 21. (In Russian).

6. Antipkin Yu.G., Umanets T.R., Lapshin V.F., Nakonechna A.A., Matveeva S.Yu., Pustovalova 0.I. Bronhialna astma, poednana zalergichnim rinitom, u ditey: mistse antigistaminnih preparativ u likuvanni. [Bronchial asthma, associated with allergic rhinitis, in children: place of antihistamines in the treatment.] Astma ta alergiya. 2014; 4: 60 - 65. (In Ukrainian).

7. Obimbo E.M., Levin M.E. Allergic rhinitis and asthma - evidence for an association. Current Allergy \& Clinical Immunology. 2013; 26, N1: $976-996$.

8. Romanyuk L.I. Allergicheskiy rinit kak komorbidnoe sostoyanie bronhialnoy astmyi.[Allergic rhinitis as a comorbid state of bronchial asthma] Astma ta alergiya. 2013; 2: 65 - 65. (In Russian).

9. Bourdin A. Upper airway 1: allergic rhinitis and asthma: united disease through epitelisl cells. Thorax. 2009; 64: 999 - 1004.

10. Potyazhenko M.M. Optimizatsiya likuvannya alergichnogo rinitu u hvorih na intermituyuchu bronhialnu astmu v ambulatorno - poliklinichnih umovahyu. [0ptimization of treatment of allergic rhinitis in patients with intermittent bronchial asthma in ambulatory - polyclinic conditions] Visnik vdnzu «Ukrayinska Medichna Stomatologichna Akademiya». 2017; 15, 3(51): 156 - 160. (In Ukrainian).

11. Compalati $E$. The link between allergic rhinitis and asthma: the united airways disease. Expert Rev Clin. Immunol. 2010; 6 (3): 413 - 423.

12. Bezrukov L.O., Garas M.N. Nespetsifichna giperreaktivnist bronhiv u shkolyariv iz atopichnim ta neatopichnim fenotipami bronhialnoyi astmi. [Non-specific hyperreactivity of bronchus in schoolchildren with atopic and non-atopic phenotypes of bronchial asthma.] Astma ta alergiya. 2015; 1: 13 - 16. (In Ukrainian).

13. Bousquet J. Allergic rhinitis and its impact on asthma. Achievements in 10 years and needs. J. Allergy Clin. Immunol. 2012; 130 (5): 1049- 1062.

14. Groot E., Nijkamp A. Allergic rhinitis is associated with poor asthma control in children with asthma. Tohorax. 2012; 67:582 - 587.

15. Ohta K., Bousquet J., Aizowa H. et al. Prevalence and impact of rhinitis in asthma. SACRA, a cross-sectional nation-wide study in Japan. Allergy. 2011; 66: $1287-1295$.

16. Zabolotniy d.i., Smagina t.v., Zabrodska I.v. Dosvid zastosuvannya levotsetirizinu dlya likuvannya patsientiv iztsilorichnim alergichnim rinitom. [Experience in the use of levocetirizine for the treatment of patients with year-round allergic rhinitis.] Apteka galitska. 2008; 15:52. (In Ukrainian).

17. Toloh 0.S., Rudnitska N.D., Chulovska U.B. Geterogennist bronhialnoyi astmi ta vibir terapevtichnoyi taktiki. [Heterogeneity of bronchial asthma and the choice of therapeutic tactics.] Klin. Immunologiya. Alergologiya. Infektologiya. 2015; 7: 17 - 25 (In Ukrainian).

18. Valovirta E. Managing Co-Morbid Asthma With Allergic Rhinitis: Targeting the One-Airway With Leukotriene Receptor Antagonists. WAO Journal.2012; 5: 210 - 211.

19. Koloskova O.K., Bllik G.A. Schodo pitannya komorbidnosti bronhialnoyi astmi y alergichnogo rinitu u shkilnomu vitsi. [Concerning the comorbidity of bronchial asthma and allergic rhinitis at school age] Scientific journal "sciencerise".2015; 10/3 (15): 47-51. (In Ukrainian).

20. Standartizatsiya legochnyih bronhialnyih testov. Doklad rabochey gruppyi: «Standartizatsiya testov issledovaniya legochnoy funktsii»». [Standardization of pulmonary bronchial tests. Report of the working group: "Standardization of Pulmonary Function Test".] Ofitsialnyiy otchet Evropeyskogo respiratornogo obschestva. Pulmonologiya. 1993;2: 96. (In Russian). 
21. Sakevich V.D., Shlikova 0.Yu., Bobrova N.0., Kaydashev I.P. Poshirenist polimorfnih aleley 2258G/A gena TLR2 ta yih zv'yazok z okremimi imunologichnimi pokaznikami sered hvorih na alergichniy rinit. [Prevalence of polymorphic 2258G/A alleles of the TLR2 gene and their association with individual immunological parameters among patients with allergic rhinitis.] Astma ta alergiya. 2013; 3:51 - 55. (In Ukrainian).

22. Umanets T.R., Lapshin V.Yu., Matveeva S.Yu., Pustovalova 0.I. Alergichniy rinit i bronhialna astma u ditey: otsinka efektivnosti levotsetirizinu. [Allergic rhinitis and bronchial asthma in children: evaluation of the effectiveness of levocytrizin.] Sovremennaya pediatriya. 2016; 3(75): 85 - 89. ( In Ukrainian).

23. RondonC. Local Allergic rhinitis: concept, clinical manifestations and diagnostic approach. J. Investig Allergol Clin. Immunol. 2010; 20 (5): 364 - 371.

24. Global Strategy for Asthma Management and Prevention (GINA) revised 2015. http://www/ginasthma.org/local/ uploads/files/GINA. Report 2015.pdf

\section{Conflict of interest:}

The Author declare no conflict of interest.

\section{CORRESPONDING AUTHOR}

\section{Victoria Sukhan}

Uzhhorod National University

Narodna Square, 3, 88000, Uzhhorod, Ukraine

tel: +38506738779

e-mail: viktorija.sukhan@uzhnu.edu.ua

Received: 17.02.2019

Accepted: 05.04.2019 
PRACA ORYGINALNA

ORIGINAL ARTICLE

\title{
IMPROVEMENT OF THE METHODS OF SURGICAL TREATMENT IN PATIENTS WITH INFRALENAL ANEURYSM OF THE ABDOMINAL AORTA
}

\author{
Oleksandr V. Liksunov, Nataliya R. Prysyazhna, Andriy V. Ratushnyuk, Pavlo I. Nikulnikov \\ NATIONAL INSTITUTE OF SURGERY AND TRANSPLANTATION OF THE NATIONAL ACADEMY OF MEDICAL SCIENCES OF UKRAINE NAMED AFTER \\ 0.0.SHALIMOV, KYIV, UKRAINE
}

\begin{abstract}
Introduction: Nowadays, there is an increase number of patients with abdominal aortic aneurysm. The disease has a constantly progressive nature, the result of which is the rupture of aneurysms and a high mortality rate. However, the technologies of operations are still controversial. Unidentified factors of complications and mortality remain with this pathology. The aim: to determine the risk factors of complications in patients with the aneurysm of the abdominal aorta

Materials and methods: Analyze data of the examination and treatment results of 117 patients with aneurysm of the abdominal aorta. 58 patients were examined and treated according to advanced methods in a treatment group. The control group consisted of 59 patients who were examined and operated according to standard, generally - accepted methods. Results: According to our observations after the planned operations, the most common were cardiac complications. Analyzing the frequency of complications depending on the type of surgical intervention, we have not established statistically significant differences. More significant volume of blood loss was observed when performing combined operations and aorto-bifem bypass in comparison with aortic bypass and aorto-biiliac bypass.

Conclusions: Combined operations result in a significantly higher blood loss compared to linear prosthetics. The level of intraoperative blood loss in patients with «large» aneurysms is significantly higher than in patients with «small» and «average» aneurysms.
\end{abstract}

KEY WORDS: aneurysm of the abdominal aorta, complications, factors of risk

Wiad Lek 2019, 72, 4, 627-630

\section{INTRODUCTION}

According to modern definition, aortic aneurysm is a progressive chronic degenerative aortic disease that can affect any part of it with life threatening complications [1].

World health statistics point to a steady increase in the incidence of AAA. Today, this pathology is no longer rare and holds a solid position among other cardiovascular diseases [2,3]. According to the data of modern domestic sources in the East European countries, the frequency of observation of aortic aneurysm is an average of 40 people per 100,000 population $[4,5]$. The disease has a constantly progressive nature, the result of which is the rupture of aneurysms and a high mortality rate. Gaps occur in 6.3 / 100,000 population and in $35.5 / 100,000$ populations over 65 years of age[6].

Over the past decade, a development of vascular surgery has led to optimistic results of planned operations with AAA - the numbers of postoperative lethality do not exceed 5-10\% [5]. With a development of complications such as aneurysm rupture, postoperative lethality ranges from $67 \%$ to $94 \%$ [7].

Despite the half-century history of resection of aneurysm, the technique of performing surgical interventions remains controversial. It includes: performing proximal anastomoses with a brittle wall of the aneurysm; methods of minimal dissection of aneurysm to avoid intraoperative trauma of major veins; revascularization of the extremities with combined aortic aneurysm with dilation or stenosis of iliac arteries.

A number of authors in their observations pay attention to the dependence of various risk factors for pre- and postoperative complications and mortality $[5,7]$.

\section{THE AIM}

The aim - to determine the risk factors of complications in patients with abdominal aortic aneurysm.

\section{MATERIALS AND METHODS}

The research is based on data analysis of the examination and treatment results of 117 patients suffering aneurysms of the abdominal aorta who were treated in the department of Major Vessel Surgery of the National Institute of Surgery and Transplantation of the National Academy of Medical Sciences of Ukraine named after O.O.Shalimov from 2008 to 2015 . The treatment group, consisting of 58 patients, was examined and treated according to advanced methods. The control group of 59 patients was examined and operated according to standard, generally - accepted methods. 
The duration of observation is from 1 to 9 years (average $4.7+2.4$ years). Males predominated in a general structure of patients with AAA. The male to female ratio was 12:1. Most of the patients with AAA complained about pain in the abdominal cavity, mainly in the mesogastric area. We have established a direct dependence of clinical manifestations on the size of the AAA in a diameter scale. Namely, the most symptomatic aneurysm appeared in those cases where the transverse diameter reached $80 \mathrm{~mm}$ or more.

A large number of concomitant diseases in patients with AAA increase the risk of complications of surgical treatment and can lead to their development, both during the operation and in the postoperative period. The most frequent concomitant pathology was coronary heart disease and arterial hypertension $(61.7 \%$ and $67.4 \%$ respectively). Occlusion-stenotic lesions were observed in 22 patients.

The diagnostic algorithm included general clinical laboratory tests (general blood and urine tests, blood biochemical analysis, lipid spectrum, coagulogram) and instrumental studies: duplex scan of the abdominal aorta and arteries of the lower extremities, ECG in 12 standard leads, X-ray. Additional studies were used when necessary: computer tomography - angiography of the abdominal aorta, visceral and renal arteries, arteries of the lower extremities; duplex scan of the main arteries of the head, determination of the function of external respiration, gastroscopy, echocardiography, measurement of segmental pressure on the lower extremities.

It was compulsory to study the coagulation and anticongestive systems of the blood before surgery and in the postoperative period.

In the general group of patients, the aortic bypass was performed most frequently, in $46(39.3 \%)$ patients; the aorto-bifem bypass in 31 (26.5\%) patients; the aorto-biiliac bypass in 25 (21.4\%); and the aorto-iliac-fem bypass- in $15(12,8 \%)$ cases.

The combination of operations for AAA with reconstructive operations in other arterial bases and arteries of the lower extremities was in 40 cases (34.2\%), including the reconstruction of visceral branches of abdominal aorta in 14 patients (12.1\%).

Due to concomitant diseases, after an additional examination of 17 patients, significant coronary artery lesions, major arteries of the head and renal arteries were detected. Such patients had done stage or onetime surgical treatment. The first stage was correction of coronary, cerebrovascular, renal blood circulation; the second stage included - the operation on the aneurysm of the abdominal aorta, which was individualized. Aortocoronar bypass surgery was performed in 3 patients, carotid endarterectomy in 4 patients, direct stenting of coronary arteries in 4 patients, direct stenting of the renal arteries in 2 patients. At the same time, aorto- coronary bypass and aortic bypass were performed in 2 patients. One patient had done carotid endarterectomy, aorta coronary bypass and aortic bypass.

\section{RESULTS AND DISCUSSION}

According to our observations after the planned operations, cardiac complications were most common. Acute coronary insufficiency, rhythm disturbances in the form of flashing arrhythmia and myocardial infarction were observed in 8 patients $(6.8 \%)$, which in 3 cases $(37.5 \%)$ resulted in a fatal outcome. Cardiac complications were observed in the main group of 3 patients (4.4\%), 1 of them (33.3\%) died. In the comparison group, such complications were observed in 5 patients (7.2\%), 2 of them (40\%) died. Neurological complications were observed in $4(3.4 \%)$ patients. In this group, an ischemic stroke was developed in 1 patient $(25 \%)$, which eventually led to long-term disability. Immediate acute violation of cerebral circulation was observed in 3 patients (75\%) of this group.

A development of acute ischemia of thelower extremities had been observed in 6 patients (5.1\%) in a postoperative period due to arterial embolism (thrombosis) and increased chronic arterial insufficiency, which required the implementation of another reconstructive operation.

One patient (16.7\%) of this group developed irreversible ischemia and contracture, followed by amputation of the lower limb.

Renal complications, such as development of acute kidney damage (GHP), which required dialysis therapy, were observed in 3 patients (2.6\%). 2 (66.7\%) patients in this group developed multiple organ failure with a fatal outcome.

Gastrointestinal complications were detected in 3 patients (2.6\%). One of them developed a colon infarction, due to which he was operated and died from multiple organ failure. 1 patient $(0.9 \%)$ had a gastrointestinal bleeding. There was eventration detected in 1 patient $(0.9 \%)$, who had a surgery on this. In this group we did not consider such complications as postoperative paresis of the intestine, since all patients had a comprehensive prevention of such a complication, but if they arose, they were short-lived and resolved by conservative treatment.

Analyzing the frequency of complications depending on the type of surgical intervention, we have not established statistically significant differences $(\chi 2=3.8 ; \mathrm{p}=0.27$ according to Pearson criteria). The data is presented in Table I.

It is well known that the larger volume of surgery, the greater blood loss. Such surgical intervention should be provided with a sufficient amount of donor blood or autologous dasgs, including using hardware reinfusion to fill the circulating volume in order to provide vital functions of the body.

We have analyzed a dependence of intraoperative blood loss on planned operations from the type of intervention and vascular graft that a re-used. It was established that more significant volume of blood loss was observed in performing combined operations and aorto-bifem bypass in comparison with aortic bypass and aorto-biiliac bypass $(\mathrm{H}=13.1 ; \mathrm{p}=0.004)$.

Since the essential factor determining a level of blood loss during a surgery is an aortic diameter, we analyzed volume of blood loss from a diameter of aneurysm (table II).

As it can be seen from the data presented, small (35-50 $\mathrm{mm}$ ) size of aneurysms were found in 18 patients, blood loss in the presence of aneurysms of a small diameter was $1133+$ $623 \mathrm{ml}$. Median size $(51-70 \mathrm{~mm})$ of aneurysms were found in 
Table I. Dependence on duration of surgical intervention, complications and bleeding from the variant of surgical intervention.

\begin{tabular}{|c|c|c|c|c|}
\hline \multirow[b]{2}{*}{ Parameters } & \multicolumn{4}{|c|}{ Operation } \\
\hline & $\begin{array}{c}1 \\
\begin{array}{c}\text { Aortic bypass } \\
\mathrm{N}=46\end{array}\end{array}$ & $\begin{array}{c}2 \\
\begin{array}{c}\text { Aorto-biilliac bypass } \\
\mathrm{N}=25\end{array}\end{array}$ & $\begin{array}{c}3 \\
\begin{array}{c}3 \\
\text { Aorto-iliac-fem bypass } \\
\mathrm{N}=15\end{array}\end{array}$ & $\begin{array}{c}4 \\
\text { Aorto-bifem bypass } \\
N=31\end{array}$ \\
\hline Duration of operation, min. & $201,9+38,9$ & $248,5+97,6$ & $242,9+39,7$ & $269,7+55,8$ \\
\hline \multicolumn{5}{|c|}{ Kruskal-Wallis test $\mathrm{H}=29,9 ; \mathrm{p}<0,00001$} \\
\hline Complication, \% & 15,2 & 24 & 13,3 & 29 \\
\hline \multicolumn{5}{|c|}{ Pearson criteria $x 2=3,8 p=0,27$} \\
\hline Bleeding, ml & $1165,2+627,6$ & $1672+791,4$ & $1377+559,2$ & $1603,2+877,7$ \\
\hline
\end{tabular}

Table II. Diameter of aneurysm and volume of blood loss.

\begin{tabular}{cccc}
\hline No & Diameter of aortic aneurysm $\mathbf{\text { MM }}$ & Bleeding, $\mathbf{~ l}$ & $\mathbf{p}<\mathbf{0 , 0 5}$ \\
\hline 1. & $\begin{array}{c}35-50 \text { (small) } \\
\mathrm{n}=18\end{array}$ & $1133+623$ & $1-3$ \\
\hline 2. & $\begin{array}{c}51-70 \text { (middle) } \\
\mathrm{n}=64\end{array}$ & $1235+695,2$ & $2-3$ \\
\hline 3. & $\begin{array}{c}71 \text { (big) } \\
\mathrm{n}=35\end{array}$ & $1902+830,5$ & $3-1$ \\
\hline
\end{tabular}

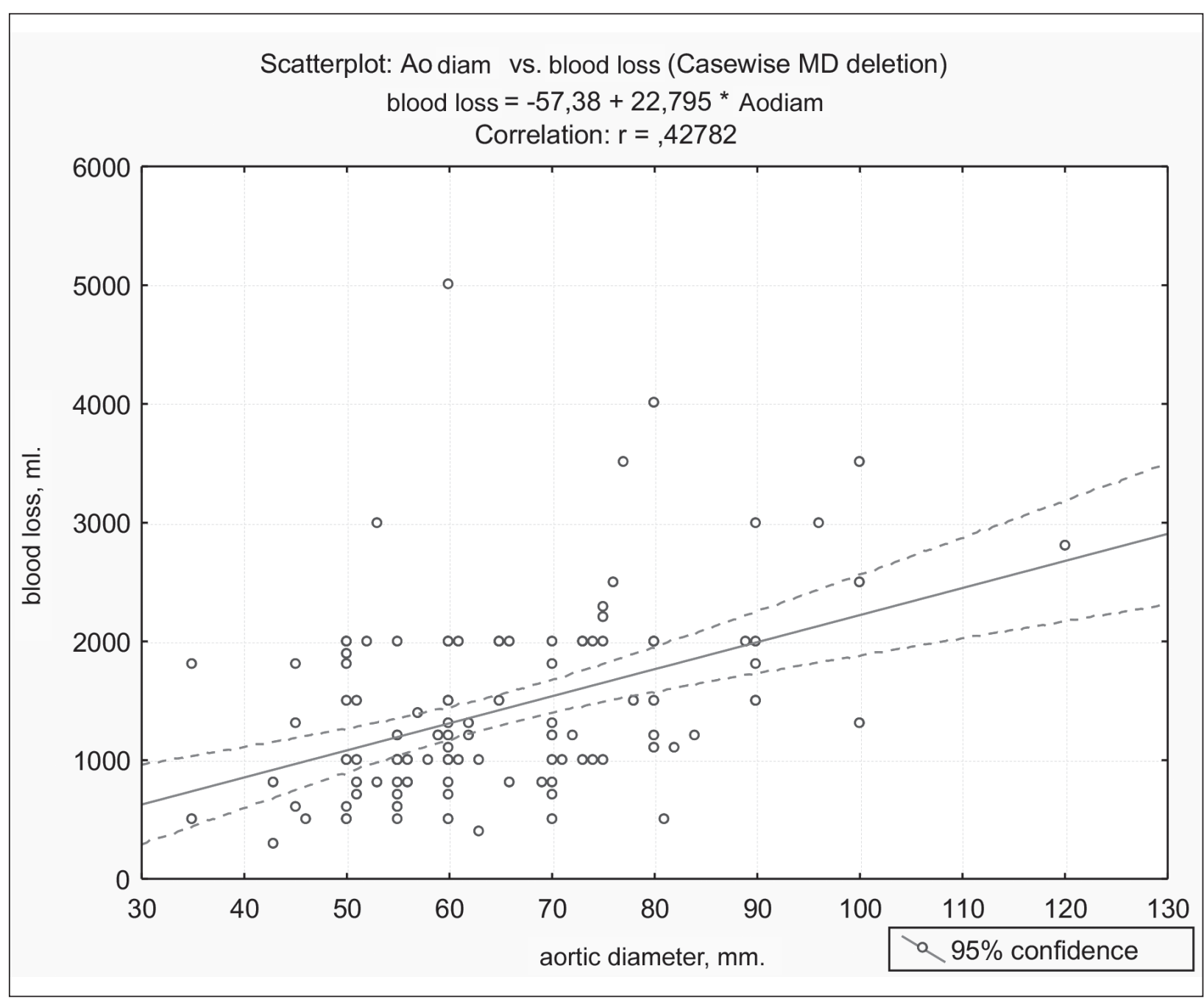

Figure 1. Correlation between aortic diameter and volume of blood loss 
64 patients. The level of blood loss in the presence of such an aneurysm diameter was $1235+695.2 \mathrm{ml}$. Large aneurysms $(>71 \mathrm{~mm})$ were diagnosed in 35 patients, and the level of inoperative blood loss in patients of this group was $1902+$ $830.5 \mathrm{ml}$, which was significantly higher than in patients with «small» and «average» aneurysms ( $\mathrm{p}<0.05)$.

In order to establish a direction and strength of the relationship between the diameter of an aneurysm of the aorta and intraoperative blood loss, we observed a positive correlation between these parameters $(r=0.43 ; p=0.001)$.

The operations performed for the AAA were accompanied by high blood loss. Necessary adequate hemotransfusion therapy had led to a coagulopathy development of varying degrees of severity in $4(3.4 \%)$ patients. 2 patients $(50 \%)$ had hematoma in a peritoneal space, requiring repeated operations to remove the hematoma and hemostasis correction. In 2 other cases (50\%), a development of syndrome of acute disseminated intravascular coagulation (DIC) in the phase of deep hypocoagulation and subsequent complete non-coagulation of blood was noted, which resulted in a fatal outcome.

Most cardiovascular events were observed in $6.8 \%$ of cases, of which $37.5 \%$ resulted in a patient's death. The second most frequent operation included complications of acute or increased critical chronic lower limb ischemia. Thrombectomy was performed in 3 patients, one patient was supplemented with profundoplastic, one with iliac-fem bypass, two with fem-pop bypass. Reconstruction operations were not always successful, in $16.7 \%$ of cases, limb amputation was inevitable.

In our observations neurological complications were less common; there were no lethal outcomes. However, in $25 \%$ of cases there were marked disability in patients after severe acute cerebrovascular accidents.

Renal complications were very dangerous and caused death in $66.7 \%$ patients. An extremely dangerous complication was a development of coagulopathy in the form of DIC in the phase of deep hypocoagulation with the development of multiple organ failure, which led to $50 \%$ lethality.

\section{CONCLUSIONS}

1. The structure and frequency of postoperative complications were distributed as follows: cardiological - $6.8 \%$, vascular - $5.1 \%$, neurological - $3.4 \%$, hematologic - $3.4 \%$, renal - $2.6 \%$, gastroenterological - 2, $6 \%$.

2. The frequency of complications was almost the same in each group and did not depend on the type of surgical intervention $\left(\chi^{2}=3.8 ; \mathrm{p}=0.27\right.$ according to Pearson criteria).

3. Completitions of combined operations is accompanied by significantly higher blood loss compared to linear prosthetics $(\mathrm{p}<0,05)$.

4. The level of intraoperative blood loss in patients with «large» aneurysms is significantly higher than in patients with «small» and «average» $(\mathrm{p}<0.05)$. A positive correlation between a diameter of an aneurysm and a level of intraoperative blood loss is established $(r=0.43 ; p=0,001)$. Therefore, the size of the aneurysm of the abdominal aorta may be a prognostic factor in massive bleeding. This should be taken into account during the preparation for the surgery and can contribute to a positive result, which is the prospect of further research.

\section{REFERENCES}

1. Mastracci TM. The progression of aortic aneurysms. J Cardiovasc Surg. $2016 ; 57: 221-3$

2. Zatevakhin I.I. i soavt. Anevrizmy abdominal'noy aorty kak problema ekstrennoi khyrurgii. Angiologiya i sosudistaya khirurgia 200;:2:332334. (in Russia).

3. Kazanchan P.0. I soavt. Razryvy anevrism bryushnoi aorty. Osobennosti klinicheskogo techeniya I klassificaciyi. Angiologiya i sosudistaya khirurgiya 2003:1:9:84-89.(in Russia).

4. Lemenev V.L. i soavt. K voprosu ob uluchshenii rezul'tatov lecheniya bol'nykh s razryvom anevrizmy bryushnoy aorty. Angiologiya i sosudistaya khirurgiya 2004;2:156-157. (in Russia).

5. TeunB.M.et al.The influence of screening on the incidence of ruptured abdominal aortic aneurysm. Jornal of Vasc.Surg.;2009;30(2):203-208.

6. Heikkinen M, SaleniusJP, Auvinen 0. Raptured abdominal aortic aneurysm in a well-definded geographic area. JVasc Surg 2002;36:2916.

7. De Martino R R, Goodney PP, Nolan BW,et al. Optimal selection of patients for elective abdominal aortic aneurysm repair based on life expectancy. JVasc Surg 2013;58:589-95.

The work was carried out within the framework of the scientific theme "Studying the factors of surgical risk in patients with aneurysm of the abdominal aorta and developing methods of their correction" (state registration number 0106Г011568, 2007-2009) based on the Department of Major Vessel Surgery of the National Institute of Surgery and Transplantation of the National Academy of Medical Sciences of Ukraine named after O.O. Shalimov

\section{Authors' contributions:}

According to the order of the Authorship.

\section{Conflict of interest:}

The Authors declare no conflict of interest.

\section{CORRESPONDING AUTHOR \\ Nataliya Prysyazhna}

30, Heroiv Sevastopolya Street, 03680 Kiev, Ukraine

tel: +380979396105

e-mail:dr.prysyazhna@gmail.com

Received: 04.02.2019

Accepted: 02.04.2019 
PRACA ORYGINALNA

ORIGINAL ARTICLE

\title{
ROLE OF THE FAMILY PHYSICIAN IN THE TREATMENT OF PATIENTS WITH POLYTRAUMA ON THE OBESITY BACKGROUND ON AN AMBULATORY STAGE
}

\author{
Sergii D. Khimich ${ }^{1}$, Orest M. Chemerys ${ }^{2}$ \\ 'NATIONAL PIROGOV MEMORIAL MEDICAL UNIVERSITY, VINNYTSYA UKRAINE \\ 2DANYLO HALYTSKY LVIV NATIONAL MEDICAL UNIVERSITY, LVIV UKRAINE
}

\begin{abstract}
Introduction: Obesity rates have continued to increase recently, what is connected to the reduction of physical activity of population.

The aim: To determine the peculiarities of treatment of patients with obesity, who sustained a severe concomitant body trauma on an outpatient basis by family physicians. Materials and methods: Clinical material composed of 67 patients who sustained severe concomitant body trauma.

Results: 0 the grounds of the long-term outcomes assessment cards developed by us, treatment of the severe concomitant trauma in persons with obesity, we found typical complications of the traumatic disease, which family physicians faced on an ambulatory stage. These cards contained by system analysis of consequences of the sustained polytrauma on the systems and organs respectively to the body mass index meaning. In general, treatment of such patients was complex and included applying of the diet therapy (a low-calorie diet with enough protein, vitamins and low levels of animal fats and carbohydrates, especially easily digestible), pharmacological therapy (antibiotics, mucolytics, solvents) as well as therapeutic exercise, which played almost dominant role. In particular, therapeutic massage was prescribed for improvement of general body tone, activation of peripheral circulation and lymph flow, oxidation-reduction and metabolic processes, retroaction to the impaired motor-evacuation function of the large intestine, eliminating fatigue and increasing muscle tone and functioning.

Conclusions: Role of the family physician in the process of traumatic disease treatment is especially important and lies in the organization of medical treatment of patients on an ambulatory stage.
\end{abstract}

KEY WORDS: obesity, polytrauma, family physician

\section{INTRODUCTION}

Obesity rates have continued to increase recently, what is connected to the reduction of physical activity of population [1]. Specific physiological processes of obesity form the basis for more severe injuries as a result of sustained traumas, as well as a high degree of risk of complications development, often even fatal outcomes [2]. Such peculiarities of the organism in case of high body mass index (BMI) directly influence the organization of medical provision, form specific technical manoeuvres in the tract of surgical interventions, and require specific post-surgery care, rehabilitation, both during the hospital stage as well as after discharge from the in-patient department $[3,4,5]$.

Patients who suffer from obesity take a special place among injured, what complicates the course of traumatic disease on its different stages [6]. Mostly phenomena of tissue hypoxia and ischemia, caused by inconsistency of oxygen supply and its consumption appear in this group of patients, what calls for respiratory support. Oxygen supply decreases by means of concomitant pathologies, verified almost in all the patients of this group, namely reduction of the cardiac output associated with chronic cardiac insufficiency, atherosclerosis, and chronic obstructive pulmo- nary disease. Taking into account the above-mentioned, it should be considered that such patients are significantly important for diagnostics and treatment of acute thoracic and abdominal trauma, what in its turn requires special approach in the selection of disease management as well as medical support of family physicians on an outpatient basis.

\section{THE AIM}

To determine the peculiarities of treatment of patients with obesity, who sustained a severe concomitant body trauma on an outpatient basis by family physicians.

\section{MATERIALS AND METHODS}

Clinical material composed of 67 patients who sustained severe concomitant body trauma. The age of patients was 18 - 68 years (mean and median - 46,9 $\pm 1,3$ year). Among them - 41 (61,2 \%)men, 26 (38,8 \%)women, 47 (70,1\%) persons of working age. Patients had traumas of variable localisation and severity.

The patients were divided into three clinical groups respectively to the BMI meaning. The first group consisted 
of $18(26,9 \%)$ patients with normal body mass (BMI $\geq$ $\left.24,9 \mathrm{~kg} / \mathrm{m}^{2}\right)$, the second- $28(41,8 \%)$ patients, which are overweight and have Ist obesity degree, $(\mathrm{BMI}=26,2-34,2$ $\mathrm{kg} / \mathrm{m}^{2)}$ and the third consisting of $21(31,3 \%)$ injured with II-III obesity degree. $\left(B M I=35,3-41,9 \mathrm{~kg} / \mathrm{m}^{2}\right)$.

All the patients underwent diagnostics and treatment of the concomitant body trauma according to the generally accepted and local protocol on the hospital stage. After discharge from the in-patient department, patients were directed for case follow-up by a family physician.

\section{RESULTS}

On the grounds of the long-term outcomes assessment cards developed by us, treatment of the severe concomitant trauma in persons with obesity, we found typical complications of the traumatic disease, which family physicians faced on an ambulatory stage. These cards contained by system analysis of consequences of the sustained polytrauma on the systems and organs respectively to the BMI meaning. Patients of the III clinical group were the most difficult for treatment in the practice of the family physician, as they had more complications developing, which required appropriate medical support. Therefore, family physicians verified pneumonia of variable localisation in $18(85,7 \% ; \mathrm{p}<0,02)$ patients, who sustained closed chest injury, diagnosed with respiratory distress syndrome in the in-patient department. The appearance of such changes was associated with the influence of metabolites of damaged cells, inflammation products, proteins, and other biologically active agents, which get into lungs by the venous system, where their specific pathological activity is realized on alveolar-capillary membrane $[7,8]$. The main criteria were presence of periodical cough with insignificant sputum production, bubbling rales were heard auscultatively, in lower parts of lungs as a rule. Patient with bilateral lower lobe pneumonia at the moment of discharge (Figure 1).

Treatment of such patients on an ambulatory basis is a real challenge for a family physician. Firstly, these are peculiarities of care, as obesity is caused by sedentary lifestyle, and presence of the sustained severe, often skeletal, trauma, which makes early active mobilization of the patient impossible, often complicates lung pathology treatment. It is impossible to transport such patients to polyclinic department or family outpatient department, and therefore, to prescribe additional instrumental examination methods, such as chest X-ray examination, ultrasound examination of internal organs.

The other difficulties family physicians faced in the process of medical care provision were stipulated by the selection of the method of administration and adequate dosage of medication. It is necessary to indicate that it is inappropriate to apply intramuscular injection for patients with obesity, as their subcutaneous tissue is so expressed, that it was impossible to reach the muscle with a needle almost in $100 \%$ events $(\mathrm{p}<0,01)$. Therefore, meditation should be prescribed in the form of tablets, and in the event, when this is not enough, it is necessary to conduct catheterization of peripheral vein for further drop or bolus medication administration.

In general, treatment of such patients was complex and included applying of the diet therapy (a low-calorie diet with enough protein, vitamins and low levels of animal fats and carbohydrates, especially easily digestible), pharmacological therapy (antibiotics, mucolytics, solvents) as well as therapeutic exercise, which played almost dominant role. In particular, therapeutic massage was prescribed for improvement of general body tone, activation of peripheral circulation and lymph flow, oxidation-reduction and metabolic processes, retroaction to the impaired motor-evacuation function of the large intestine, eliminating fatigue and increasing muscle tone and functioning.

$9(42,9 \%)$ of the III clinical group were diagnosed with thromboembolism of small pulmonary arteries on an ambulatory basis by family physicians. Such complication was associated with both trauma presence and obesity, which could be stipulated by the creation of specific prothrombotic factors of adipose tissue, as well as thrombocyte dysfunctions. This was a consequence of post-traumatic deep venous thrombosis and risk of stroke or acute myocardial infarction. Therefore, all the patients with concomitant body trauma, especially suffering from obesity, should continue prophylactics of a thromboembolic complication of concomitant body injury after discharge from the in-patient department.

The other, equally important issue, family physicians faced, is the problem of nutritional support of patients. Nutrition of patients of the Ist clinical group was conducted according to the generally-accepted standards via a combination of a balanced diet. Patients with outcomes of the sustained craniocerebral injury with the deglutitive problem were administered food via nasogastric tube.

Patients with obesity were added balanced mixes for enteral nutrition to the ration, what is related to the necessity of constant stimulation of stomach and bowel motor activity. We admitted late paresis of the gastrointestinal tract in $29(43,3 \% ; \mathrm{p}<0,03)$ patients (II-III clinical groups) and interpreted them as a result of intra-abdominal hypertension because of intra-abdominal fat present in this group of patients.

The other late complication in 37 (55,2\%; p > 0,02) patients of II and III clinical groups were decubitus in the tail bone area, and 12 (17,9\%; III clinical group) were diagnosed with suture sinuses in the areas of post-surgery wound of variable localisation. In such cases, family physicians engaged surgeons to the treatment process, as they gave recommendations concerning topical treatment, which mostly was in applying salve dressings.

Summing up the above-mentioned, we want to draw the attention of the medical community to obesity, as not only social but directly medical problem, as a share of people, suffering from it, increases recently [5,9]. Such patients require special differential approach, as overweight creates additional difficulties in both diagnostic-treatment process 


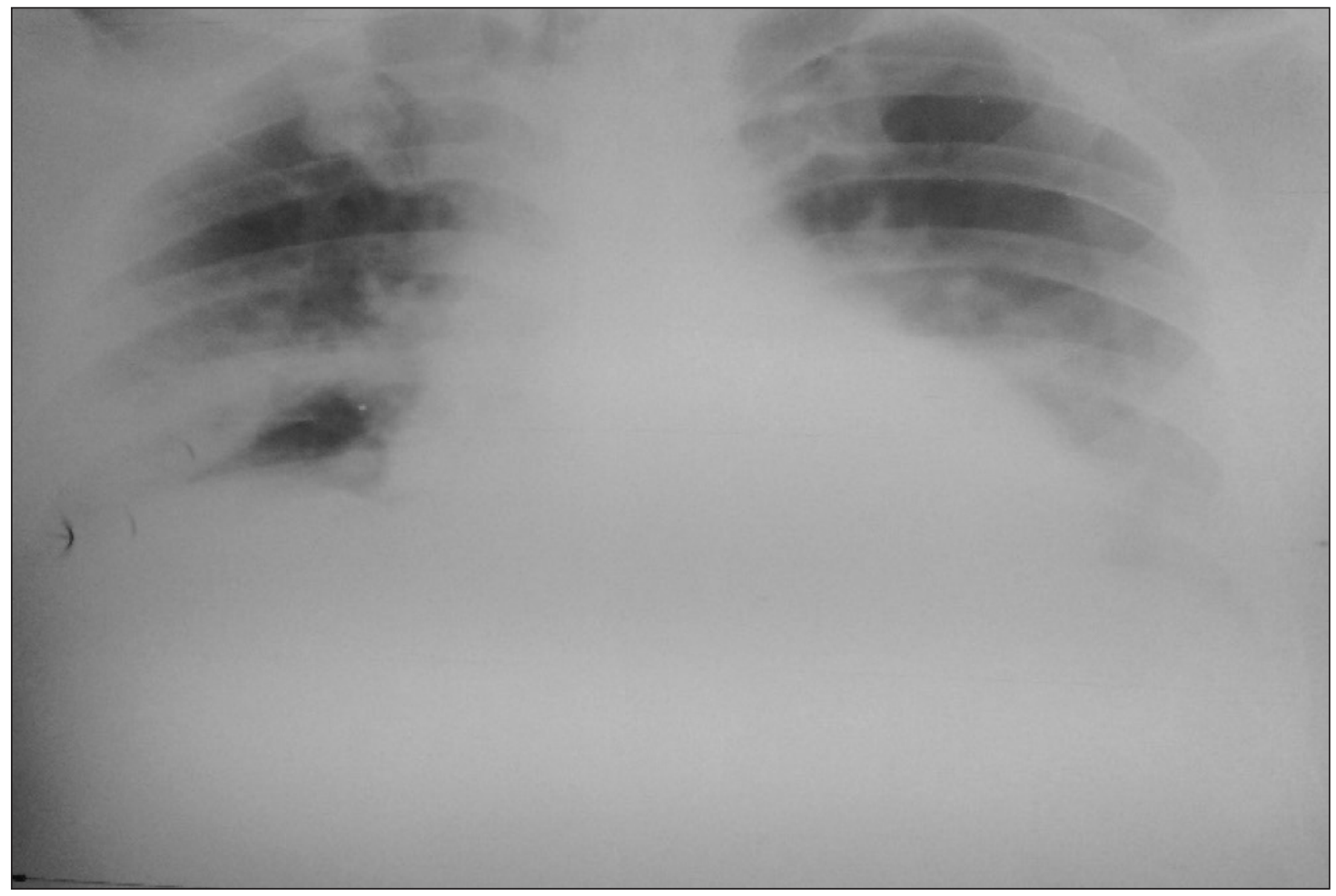

Fig. 1. Patient $K$., 62 years old $B M I=30,1 \mathrm{~kg} / \mathrm{m}^{2}$

and medical care. Consideration of appearance of the above-mentioned difficulties of such patients on the obesity background, improvement of skills of adequate complex medication support, rational diets allows us to form the basis for the creation of a better diagnostic and treatment strategy, and, thus, to improve results and long-term outcomes during care provision to patients with polytraumas.

\section{DISCUSSION}

Treatment of the patients with outcomes of the sustained trauma on the obesity background is quite a serious challenge for a family physician. Firstly, this is stipulated by complications of different nature within injured anatomical parts of the body, as well as peculiarities of care for such patients, what directly influences the quality of the treatment process on hospital and ambulatory stages, according to its duration. According to the data provided by Jung-Fang Chuang [et al] (Thailand, 2016), the term of treatment of patients with concomitant body trauma on the background of obesity is approximately $30 \%$ longer compared to patients with normal body mass $[4,9]$. High frequency of respiratory complications, frequent thromboembolism of small pulmonary arteries and different infectious components of wound surfaces are distinguished among the reasons for such phenomena [10]. Severe traumatic disease in patients with high $\left.\mathrm{BMI} 35,0 \mathrm{~kg} / \mathrm{m}^{2}\right)$ is also associated with concomitant chronic pathology. Obesity causes anatomical and physiological changes in the form of endocrinological, electrolyte, hematological and metabolic abnormalities, which prevent body reaction to trauma as well as form basis for the frequent appearance of complications $[8,10]$.
It should be noted that the results of our study correspond the data of world scientific literature concerning the description of early and long-term complications in different periods of traumatic disease among patients with polytrauma on the obesity background. Presented data correlates with data given by the other authors $[1,2,9]$, who emphasize attention of the medical community to the problem of treatment process organization for patients with obesity, determined challenges for family physicians, as the leading link in the final stage of the treatment of traumatic disease.

\section{CONCLUSIONS}

Role of the family physician in the process of traumatic disease treatment is especially important and lies in the organization of medical treatment of patients on an ambulatory stage. Above all, this is the treatment of late respiratory, abdominal dysfunctions, as well as infectious inflammatory soft tissues damage, severity, and course of which is directly proportional to the body mass index meaning.

\section{REFERENCES}

1. Marina I., Grintescu I.L., Cucereanu V.I., Badica M. The influence of parenteral glutamine supplementation on glucose homeostasis in critically ill polytrauma patients - A randomized-controlled clinical study. J. Clinical Nutricion. 2015: 34(3): 377-382.

2. Wagner E.R., Kamath A.F., Fruth K.M., Harmsen W.S. Effect of Body Mass Index on Complications and Reoperations After Total Hip Arthroplasty. J Bone Joint Surg Am. 2016; 98(3): 169-179. 
3. Mica L., Vomela J., Keel M., Trentz 0 . The impact of body mass index on the development of systemic inflammatory response syndrome and sepsis in patients with polytrauma. J. Injuty. 2014; 45(1): 253-258.

4. Chuang J.F., H.T. Liu., Ch. Sh. Rau. Obese patients who fall have less injury severity but a longer hospital stay than normal-weight patients. World J Emerg Surg. 2016; 11: 11-14.

5. Weinlein J.C., Deaderick S., Murphy R. Morbid Obesity Increases the Risk for Systemic Complications in Patients With Femoral Shaft Fractures. J. Orthopaedic Trauma. 2015; 29(3): 91-95.

6. Neville A, Brown CV, Weng J, Demetriades D, Velmahos G. Obesity is an independent risk factor for mortality in severely injured blunt trauma patients. Arch Surg. 2004; 139: 983-987.

7. Byrnes MC, McDaniel MD, Moore MB, Helmer SD, Smith RS. The effect of obesity on outcomes among injured patients.J Jrauma. 2005;58:232-237.

8. Schemitsch, E.H., Bhandari, M., Guyatt, G. [et all], Prognostic factors for predicting outcomes after intramedullary nailing of the tibia. J Bone Joint Surg Am Vol. 2012; 94: 1786-1793.

9. Doak C. M., Wijnhoven T. A., Schokker D. F. [et all]. Age standardization in mapping adult overweight and obesity trends in the WHO European. Obesity Reviews. 2012; 13: 174-191.

10. Licht H, Murray M, Vassaur J, Jupiter DC. The Relationship of Obesity to Increasing Health-Care Burden in the Setting of Orthopaedic Polytrauma. J Bone Joint Surg Am. 2015; 18; 73-81.
This article is part of the topic of research work of the General Surgery Department of National Pirogov Memorial Medical University "Prevention and complex treatment of postoperative complications and purulent-inflammatory diseases".

\section{Authors' contributions:}

According to the order of the Authorship.

\section{Conflict of interest:}

The Authors declare no conflict of interest.

\section{CORRESPONDING AUTHOR}

\section{Sergii D. Khimich}

Memorial Medical University

56 Pirogov str., 21018 Vinnitsa, Ukraine

tel: +380679622339

e-mail:s-khimich@ukr.net

Received: 07.02.2019

Accepted: 02.04.2019 
PRACA ORYGINALNA

ORIGINAL ARTICLE

\title{
INTERACTION BETWEEN CLINICAL AND PSYCHOLOGICAL CHANGES AMONG PATIENTS WITH CHRONIC OBSTRUCTIVE PULMONARY DISEASE AND PULMONARY TUBERCULOSIS CO-MORBIDITY
}

\author{
Natalia V. Zhovanyk, Mariana I. Tovt-Korshynska \\ UZHGOROD NATIONAL UNIVERSITY, UZHHOROD, UKRAINE
}

\begin{abstract}
Introduction: The association of chronic obstructive pulmonary disease and pulmonary tuberculosis is an important medical and social problem with a significant burden in terms of morbidity and mortality. The course and prognosis of chronic diseases such as chronic obstructive pulmonary disease and pulmonary tuberculosis is greatly influenced not only by the clinical features but also by the psychological characteristics of the patient.

The aim: To study the interaction between clinical changes and psychological characteristics considering gender differences among patients with chronic obstructive pulmonary disease in association with pulmonary tuberculosis.

Materials and methods: We studied 41patients with chronic obstructive pulmonary disease (grade 2, 3, groups A, B, C, D) and infiltrative pulmonary tuberculosis co-morbidity (11 women and 30 men). All patients underwent general clinical examination, Acid-Fast Bacillus Testing, spirometry, Spielberg anxiety scale, Beck depression scale.

Results: Patients with chronic obstructive pulmonary disease and pulmonary tuberculosis co-morbidity with more severe symptoms (according to Assesment Test scores) were older and, regardless of it, showed elevated depression and personal anxiety scores while situational anxiety scores were significantly lower compared to those with less severe symptoms. The correlation between symptoms severity and airflow limitation or smoking history was very mild. The elevated depression and personal anxiety could cause more severe symptoms. The revealed discrepancy between the symptoms severity and low levels of situational anxiety may be due to adaptation with displacement mechanisms to illness related chronic life stressors. We also observed elevated personal anxiety and depression scores together with less severe symptoms among female versus male chronic obstructive pulmonary disease/pulmonary tuberculosis patients, possibly reflecting physically ill women's higher risk for depressive and anxiety related symptomatology relative to ill men.

Conclusions: We revealed that among patients with chronic obstructive pulmonary disease and pulmonary tuberculosis co-morbidity symptoms severity was largely influenced by the patients' age, gender and psychological factors (depression and personal anxiety), but, unexpectedly, much less - by airflow limitation and smoking history. We also found higher emotional distress, namely elevated personal anxiety and depression scores, in combination with less severe symptoms among female versus male patients with chronic obstructive pulmonary disease and pulmonary tuberculosis co-morbidity.
\end{abstract}

KEY WORDS: chronic obstructive pulmonary disease, pulmonary tuberculosis, depression, anxiety

Wiad Lek 2019, 72, 4, 635-638

\section{INTRODUCTION}

According to the World Health Organization, chronic obstructive pulmonary disease (COPD) is a leading cause of morbidity and mortality worldwide inducing an economic and social burden that is both substantial and increasing [1], the same time, pulmonary tuberculosis $(\mathrm{TB})$ is one of the top 10 causes of death and the leading cause from a single infectious agent, millions of people continue to fall sick with TB each year [2]. COPD is a common comorbidity in patients with $\mathrm{TB}$, and $\mathrm{COPD}$ patients are also at high risk of developing pulmonary TB. The history of TB negatively impacts the long-term course of COPD with increased frequency of exacerbations and early mortality $[3,4]$

Somatopsychic and psychosomatic disorders have a mutually burdensome effect on the course of both somatic and psychoemotional pathology. According to the literature, there is a significant prevalence of somatopsychic disorders with negative impact on the course and prognosis of both COPD and TB $[5,6,7,8]$. Information about the frequency of their discovery and severity, as well as the relationship between their presence and the clinical and functional manifestations of COPD or TB, are rather contradictory $[1,7,9,10,11,12]$. However, in available literature we did not find research where the psychological state, its gender characteristics and the effect on the underlying disease in patients with combined pathology of COPD and TB were studied. Thus, the issue of the psychological disturbances' influence on the course of COPD and TB co-morbidity remains unclear and needs further study.

\section{THE AIM}

To study the interaction between clinical changes and psychological characteristics considering gender differ- 
ences among patients with chronic obstructive pulmonary disease in association with pulmonary TB.

\section{MATERIALS AND METHODS}

A total of 41 patients with a combination of chronic obstructive pulmonary disease and pulmonary tuberculosis were examined, including 11 women $(39.5 \pm 3.8)$ years old and 30 men $(43.9 \pm 2.3)$ years old. chronic obstructive pulmonary disease diagnosis was assigned according to the Global Initiative for Chronic Obstructive Lung Disease 2018 report [1]. Clinical data on disease history and current status were collected by direct interviews, and by evaluation of medical case histories, utilizing the chronic obstructive pulmonary disease Assesment Test and the Modified British Medical Research Council Questionnaire [13]; all the patients underwent complete blood count test and biochemical blood analysis, Acid-Fast Bacillus Testing; spirometry; Beck Depression Inventory and Spielberger State-Trait Anxiety Index [13]. The control group included 23 healthy persons ( 12 women, mean age $(36.1 \pm 2.1)$ years, and 11 men, mean age (39.5 \pm 3.2$)$ years).

Statistical analysis was performed using StatSoft "STATISTICA" (version 10.0.1011.0) and Microsoft Excel (version 2010). Data were presented as mean \pm standard deviation. P-values $<0.05$ were considered statistically significant.

\section{RESULTS AND DISCUSSION}

In all $41 \mathrm{COPD} / \mathrm{TB}$ co-morbidity patients we revealed spirometric grade 2 and 3 airflow limitation (GOLD grade 2,3). Almost in all these patients COPD was diagnosed for the first time. Only in two of them (from the first study group) COPD was diagnosed few years before, they have received a combination of short acting beta-agonists and anticholinergics on per needed basis, had two or more exacerbations per year. Others have not reported history of earlier exacerbations (development or acute worsening of respiratory symptoms that resulted in therapy with short acting bronchodilators and/or oral corticosteroids), but the received information could be insufficiently reliable due to the patients' low range of socioeconomic status.

Looking for factors which could influence the elevated symptomatology of the COPD/TB patients, we revealed moderate positive correlation of symptoms severity (according to CAT scores) with patients' age $(\mathrm{r}=0.45)$, depression $(\mathrm{r}=0.46)$ and trait anxiety ( $\mathrm{T}$-anxiety) scores $(\mathrm{r}=0.44)$, while the correlations with FEV1 $(\mathrm{r}=0.10)$ and pack-years of smoking $(r=0.07)$ where unexpectedly very mild. Correlation between symptoms severity and state anxiety ( $\mathrm{S}$-anxiety) scores was mild and negative ( $\mathrm{r}$ $=-0.10)$. Similar relationships we found regarding mMRC questionnaire.

To confirm the revealed correlates, patients with COPD/ TB regarding the symptoms severity were stratified into two groups: the first group involved 24 patients with CAT scores $\geq 10$; the second -17 patients with CAT scores $<10$. $\mathrm{COPD} / \mathrm{TB}$ patients from the first group were older than in the second ((50.1 \pm 2.5$)$ and $(37.9 \pm 2.8)$ years respectively, $\mathrm{p}<0.05)$. In both groups there were more men than women, though the percentage of women in the first group was smaller than in the second (female $16.7 \%$ and 41.2 $\%, \mathrm{p}<0.05$; male $83.3 \%$ and $68.8 \%$ respectively, $\mathrm{p}<0.05$ ). No significant differences were found between the study groups with respect to smoking duration or smoking history $((15.7 \pm 2.6)$ and $(10.8 \pm 2.1)$ pack-years respectively), and FEV1 $((44.1 \pm 2.7) \%$ and $(43.9 \pm 1.7) \%$ respectively).

As the patients' age could influence further study results, to clarify the interaction between clinical changes and psychological characteristics we excluded patients who were 60 years or older from the study groups (all these patients were men) and as a result we received no significant differences between these two groups $(n=18$ and $n=17$ respectively) regarding age $((44.1 \pm 3.5)$ and $(37.9 \pm 2.8)$ years respectively) or gender (female $36.7 \%$ and $41.2 \%$ respectively). In these groups $\mathrm{COPD} / \mathrm{TB}$ patients with more severe symptoms (first group) showed elevated depression and T-anxiety scores compared to those with less severe symptoms (second group), while $\mathrm{S}$-anxiety rates were significantly lower (table I). Elevated depression scores were revealed among $88 \%$ of more severe COPD/TB patients $(50 \%$ - mild, $33.3 \%$ - moderate and $4 \%$ - severe level), while among less severe patients - in $29.4 \%, \mathrm{p}<0.01(11.8 \%$ - mild, $11.8 \%$ - moderate and $6.3 \%$ - severe level). Elevated T- anxiety scores were revealed among $39 \%$ of more severe COPD/TB patients, among less severe patients - $18 \%$. It is also noteworthy, that depression and $\mathrm{T}$-anxiety scores in the first group were higher than among healthy persons, in the second - were within expected normative levels, while S-anxiety scores in both groups were unexpectedly low in comparison with the healthy persons.

As the level of airflow limitation (FEV1) was approximately the same in the two study groups $((42.1 \pm 3.7) \%$ and $(43.9 \pm 1.7) \%$ respectively), the elevated depression and T-anxiety scores (anxiety level as a personal characteristic) in the first group could cause more severe symptoms. The revealed discrepancy between the severity of the clinical symptoms and low levels of S-anxiety rates (is considered as a response to a particular stressful situation) may be due to adaptation with displacement mechanisms to illness related chronic life stressors. Such reaction can also reveal a failure of adaptive abilities, reflecting distress in areas of anxiety and health concern. These findings are consistent with our previous studies results where we observed alike reactions among asthmatic patients $[15,16,17]$. As the S-anxiety scores were decreased in both study groups (with more and less severe symptoms), it could be also explained by the patients' low range of socioeconomic status and unwillingness or inability to objectively evaluate their psychological state.

We also revealed gender-related differences in symptoms severity and their correlation with psychological features. Women with COPD/TB showed lower symptoms severity 
Table I. Depression and anxiety levels among patients with COPD and TB association in respect to COPD symptoms severity, $\mathrm{M} \pm \mathrm{m}$

\begin{tabular}{cccc}
\hline \multirow{2}{*}{ Psychological tests, scores } & \multicolumn{2}{c}{ Patients with COPD/TB } & \multicolumn{2}{c}{$\begin{array}{c}\text { Control group } \\
\text { (healthy persons) (n=23) }\end{array}$} \\
\cline { 2 - 4 } Depression (BDI) & more severe symptoms (n=18) & less severe symptoms (n=17) & $6.5 \pm 0.9$ \\
\hline S-anxiety & $17.6 \pm 2.1^{\circ}$ & $8.8 \pm 2.1^{* *}$ & $33.2 \pm 2.5$ \\
\hline T-anxiety & $6.9 \pm 1.4^{\circ}{ }^{*}$ & $11.8 \pm 1.8{ }^{\circ *}$ & $38.3 \pm 2.2$ \\
\hline
\end{tabular}

${ }^{*}-p<0.05,{ }^{* *}-p<0.01$ vs. patients with more severe symptoms;

$0-p<0.05,{ }^{00}-p<0.01$ vs. healthy persons.

scores (CAT (10.1 \pm 1.2$)$ and mMRC $(0.7 \pm 0.1))$ than men (CAT (12.8 \pm 2.4$), \mathrm{p}<0.05$ and mMRC $(1.1 \pm 0.1), \mathrm{p}>0.05)$ though no differences were found with respect to airflow limitation - FEV1 ((42.1 \pm 2.9$) \%$ and $(39.9 \pm 1.6) \%$ respectively). The same time, $\mathrm{T}$-anxiety scores were significantly higher among women than men ((49.2 \pm 4.1$)$ and $(39.8 \pm 1.3)$ respectively, $\mathrm{p}<0.05)$, such correlation was revealed also regarding depression $((16.1 \pm 4.8)$ and $(13.2 \pm 1.4)$ scores respectively) and S-anxiety ((11.9 \pm 2.9$)$ and $(7.9 \pm 1.2)$ scores respectively) but the differences were not significant. The revealed higher emotional distress to less severe symptoms among female versus male COPD/TB patients is consistent with other studies of physically ill persons reporting women to be at higher risk for depressive and anxiety related symptomatology, relative to ill men $[15,16,17]$.

\section{CONCLUSIONS}

We revealed that among patients with chronic obstructive pulmonary disease and pulmonary tuberculosis co-morbidity symptoms severity was largely influenced by the patients' age, gender and psychological factors, but, unexpectedly, much less - by airflow limitation and smoking history. More severe symptoms were correlating with older age, increased level of depression and personal anxiety level, but - with lower rates of situational anxiety. The revealed discrepancy between severe symptoms and low Situational anxiety rates may reflect adaptation with displacement mechanisms to illness related chronic life stressors and/or distress with failure of adaptive abilities. We also observed higher emotional distress, namely elevated personal anxiety and depression scores, to less severe symptoms among female versus male chronic obstructive pulmonary disease/pulmonary tuberculosis patients, possibly reflecting women's higher risk for depressive and anxiety related symptomatology.

\section{REFERENCES}

1. Global Initiative for Chronic Obstructive Lung Disease (GOLD). Global Strategy for the Diagnosis, Management, and Prevention of Chronic Obstructive Pulmonary Disease 2018 report; 142.

2. World Health Organization. Global tuberculosis report 2018; 277 p.

3. Ghimire H.B., Li J.G. Impact of pulmonary tuberculosis infection on chronic obstructive pulmonary disease. European Respiratory Journal, 2011; 38: 4070.
4. Lee C.H., Lee M.C., Shu C.C., Lim C.S., Wang J.Y., Lee L.N., Chao K.M. Risk factors for pulmonary tuberculosis in patients with chronic obstructive airway disease in Taiwan: a nationwide cohort study. BMC Infect Dis., 2013; 13: 194.

5. Dovgan' A. O., Konstantinovich T. V., Mostovoi Yu. M. Poshirenist' ta struktura somatopsikhichnikh rozladiv u khvorikh na Kh0ZL.Ukraïns'kii pul'monologichnii zhurnal, 2014; 4: 16-20. (in Ukrainian).

6. Poyasnik I. M. Depresivnii sindrom u patsientiv z khronichnim obstruktivnim zakhvoryuvannyam legen' [Text]. Ukraïns'kii visnik psikhonevrologiii. 2014; 22; 4 (81): 94-96. (in Ukrainian).

7. Cheng K.C. Liao K.F., Lin C.L., Lai S.W. Increased Risk of Pulmonary Tuberculosis in Patients with Depression: A Cohort Study in Taiwan. Front Psychiatry. 2017; 8: 235.

8. Ambaw F., Mayston R., Hanlon C., Alem A. Depression among patients with tuberculosis: determinants, course and impact on pathways to care and treatment outcomes in a primary care setting in southern Ethiopia—a study protocol. Ment Health Fam Med. 2011; 8(4): $235-241$.

9. Iguchi A., Senjyu H., HayashiY., Kanada R. [et al.] Relationship between depression in patients with COPD and the percent of predicted FEV1, BODE Index, and Health-Related Quality of Life. Respiratory care. 2013; 58(2): 334-339.

10. Cavaille A. Comorbidities of COPD. European Respiratory Review. 2013; 22: 454-475.

11. Rabe K. F., Wedzicha J. A., Wouters E. F. M. COPD and Comorbidity. European Respiratory Monograph. 2013; 225.

12. Hillas G., Perlikos F., Tsiligianni I., Tzanakis N. Managing comorbidities in COPD. International Journal of COPD. 2015; 10: 95-109.

13. Ahaiev N. A., Kokun M. O., Pishko I. O., Lozinska N. S., Ostapchuk V. V. Zbirnyk metodyk dlia diahnostyky nehatyvnykh psykhichnykh staniv u viiskosluzhbovtsiv [Collection of methods for diagnosing negative mental states of servicemen], Metodychnyi posibnyk - Methodical manual, K.: NDTs HP ZSU. 2016; 97-129. (in Ukrainian).

14. http://www.alswh.org.au/images/content/pdf/InfoData/Data_ Dictionary_Supplement/DDSSection2SF36.pdf

15. Tovt-Korshynska M. I., Dew M. A., Chopey I. V., Spivak M. Ya., Lemko I. S. Gender differences in psychological distress in adults with asthma. Journal of Psychosomatic Research. 2001; 51: 629-637.

16. Tovt-Korshins'ka M. I. Statevi osoblivosti psikhologichnogo reaguvannya na riznikh etapakh patogenezu khronichnogo bronkhitu. Naukovii visnik Uzhgorods/kogo universitetu, seriya Meditsina. 2001; 16: 151-153. (in Ukrainian).

17. Tovt-Korshins'ka M. I. Osoblivosti psikhologichnoï reaktivnosti khvorikh na bronkhial'nu astmu, shcho postrazhdali vid stikhiinogo likha. Galits'kii likars'kii visnik 2001; 8(3): 114-115. (in Ukrainian). 
Authors' contributions:

According to the order of the Authorship.

Conflict of interest:

The Authors declare no conflict of interest.

\section{CORRESPONDING AUTHOR}

Nataliya Zhovanyk

Department of Internal Diseases,

Medical Faculty №2, Uzhhorod National University

Uzhhorod, Ukraine

e-mail: skripzhovanyk@ukr.net

Received: 11.02 .2019

Accepted: 03.04 .2019 
PRACA ORYGINALNA

ORIGINAL ARTICLE

\title{
THE PARAMETERS OF LIVER FUNCTIONAL STATE AS A RISK FACTOR OF EDEMATOUS PANCREATITIS DEVELOPMENT PROVIDING OF GENETIC DETERMINATION OF IL-4 PRODUCTION
}

\author{
Sergiy I. Ivashchuk, Larysa P. Sydorchuk \\ STATE HIGHER EDUCATIONAL INSTITUTION OF UKRAINE, "BUKOVINIAN STATE MEDICAL UNIVERSITY», CHERNIVTSI, UKRAINE
}

\begin{abstract}
Introduction: One of the main pathophysiological mechanisms of acute pancreatitis development is the damage of pancreas cells and hepatocytes with enzymes activation. Recently, a powerful mechanism of the immune system involvement in the acute pancreatitis pathogenesis, in particular, from the position of genes polymorphism influence attracts more attention.

The aim: To study the parameters of liver functional state as risk factors for the development of edematous pancreatitis under the conditions of genetic determination of IL-4 production. Materials and methods: The study involved 101 patients with acute and the exacerbation of chronic pancreatitis in whom the polymorphic variants of gene IL-4 (C-590T), the activity of ALT, AST, GGTP, LDG and bilirubin fractions levels were determined.

Results: Among the patients with $T$-allele of IL-4 gene was more commonly encountered the excess of the activity of AST and ALT standarts than those with CC-genotype - by $27.94 \%$ and $24.33 \%$ respectively. The increase of the GGTP concentration was recorded in $79.21 \%$ of patients. The serum GGTP level was significantly higher in the $T T$-genotype owners than in those with C-allele. Hyperbilirubinemia by the total bilirubin, indirect and direct fractions was diagnosed more often in $T T$-genotype carriers than in CC-homozygotes.

Conclusions: The dysfunction of hepatopancreatobiliary system is more significant in the TT-genotype carriers of IL-4 gene by the AST, ALT, bilirubin and its fractions high levels, however, were found to be risk factors the high levels of total bilirubin and its direct fraction.
\end{abstract}

KEY WORDS: pancreatitis, gene, IL-4, enzymes, bilirubin

\section{INTRODUCTION}

The main pathophysiological mechanisms of acute pancreatitis (AP) development are hypertension of the biliary system, difficulty of outflow, pancreatic secretion hyperproduction, duct hypertension, direct damage of the acinar cells of pancreas and hepatocytes by toxic substances (including alcohol), activation of pancreatic enzymes in ducts and parenchyma, which ultimately leads to autolysis, edema, necrotic changes, and in the future (for a recurrent course) - to the sclerosis and glandular fibrosis with the development of secretory insufficiency $[1,2,3,4,5,6]$. Due to the powerful protective inhibitory mechanisms of counteraction on aggressive pancreatic secretion, the pathological process can be limited to edema without the development of necrosis $[7,8]$. However, the hepatobiliary system is also involved in the pathogenetic mechanism of limiting the inflammation pathological process [9]. But, the questions of disintegration of the pancreas and hepatocytes functioning in patients with AP, or the exacerbation of the chronic pancreatitis (ECP), in particular on genetic determination are remain unresolved $[10,11,12]$.

Studies aimed at clarifying the role of hereditary factors of edematous AP or ECP, are relevant throughout the world. To date, the registry of hereditary pancre- atitis and pancreatic cancer has been even created in Europe [13].

In connection with the above, there was a need to investigate the liver functional state as a risk factor for the development of edema pancreatitis in the conditions of genetic determination of IL-4 products (rs2243250) to establish its role in the pathogenesis of edematous AP and ECP in order to determine high risk groups, early diagnostics, prognostication and prevention of the illness and its possible complications.

\section{THE AIM}

To study the parameters of liver functional state as risk factors for the development of edematous pancreatitis under the conditions of genetic determination of IL-4 production.

\section{MATERIALS AND METHODS}

The study involved patients with AP and ECP, admitted to the emergency hospital of Chernivtsi during the last five years. The screening and diagnosis of AP and ECP were carried out according to the current order of the Ministry 
of Health of Ukraine [Ministry of Health of Ukraine [14] and the recommendations of the European Societies of diagnosis and treatment of acute pancreatitis [15].

181 patients with edematous form of AP and ECP have passed the screening step, they have signed the informed consent of the patient to participate in the study, with the following complex of clinical-laboratory and diagnostic studies. Genetic studies have being performed on 101 patients, among whom were $19(18.8 \%)$ women and 82 (81.2\%) men.

Biochemical studies of the activity of certain cytolysis enzymes: aspartate aminotransferase (AST), alanine aminotransferase (ALT), gamma-glutamyl transpeptidase (GGTP) lactate dehydrogenase (LDH); and consist of bilirubin (total, unconjugated, conjugated) were performed with biochemical analyser KONELAB $20 \mathrm{i}$ with the set of reagents «Thermo Fisher Scientific» (Finland). The standard indexes for these enzymes were as follows: AST - men (M) - $35 \mathrm{U} / \mathrm{l}$, women (F) - $31 \mathrm{U} / \mathrm{l}, \mathrm{ALT}$ - M - up to $45 \mathrm{U} / \mathrm{l}, \mathrm{F}$ - up to $34 \mathrm{U} / \mathrm{l}$, GGTP - $\mathrm{M}$ - up to $55 \mathrm{U} / \mathrm{l}, \mathrm{F}$ - up to $38 \mathrm{U} / \mathrm{l}$, total bilirubin - $<20,5$ $\mathrm{mcmol} / \mathrm{l}$, conjugated bilirubin $-5,1 \mathrm{mcmol} / \mathrm{l}$, unconjugated bilirubin - $<15,4 \mathrm{mcmol} / \mathrm{l}[16,17,18]$.

Molecular genetic studies, which included the determining of polymorphic variants of gene $I L-4$ (C-590T), have being performed at the laboratory of the State institution "Reference centre of molecular diagnostics of the Ministry of Health of Ukraine" (Kyiv).

The polymorphic variants of analysed gene $I L-4$ (C-590T) were studied with polymerase chain reaction (PCR) method using oligonucleotide primers of the company "Metabion" (Germany) according to the modified protocols [19]. The amplification products of DNA fragments of gene were further digested with restriction endonuclease ("Thermo Scientific", USA): enzyme AvaII - for gene $I L-4$. The received fragments were analysed by agarose gel electrophoresis and stained with ethidium bromide, molecular weight marker GeneRuler 50 bp (DNA Ladder, "Thermo Scientific", USA), with further visualization by using transilluminator.

The statistical analysis was performed using MYSTAT 12 (Systat Software Inc., USA). The reliability of data for independent samples were calculated by t-test Student (with the distribution of ranges close to normal), or U-criterion Wilcoxon-Mann-Whitney (with uneven distribution). The analysis of qualitative features was performed by the $\chi^{2}$ criterion. The difference was considered reliable at $\mathrm{p}<0.05$.

The results of the study were revised by the Biomedical Ethics Commission of the Higher State Educational Institution of Ukraine "Bukovinian State Medical University".

\section{RESULTS AND DISCUSSION}

The distribution of genotypes among examined patients was as follows: the gene $I L-4$ (C-590T) among patients was represented in $58(57.43 \%)$ patients by $C C$-genotype, in $34(33.66 \%)$ - by CT-genotype, in $9(8.91 \%)$ - by mutation TT-genotype.
The increase of aminotransferases concentration in serum is evidence of hepatocytes cytolysis and confirmation of the important pathogenetic role of disintegration processes taking place in the hepatobiliary system in the development of active inflammatory process in the pancreas. The increase of the ALT and AST levels was found in $32.67 \%(n=33)$ and $65.35 \%(n=66)$ of patients with edematous pancreatitis, respectively (Table I): among the patients with «unfavorable» $T$-allele of $I L$ - 4 gene were more commonly encountered the individuals with the excess of the activity of enzymes AST and ALT standarts than those with CC-genotype - by $27.94 \%\left(\chi^{2}=8.52, p=0.003\right)$ and $24.33 \%\left(\chi^{2}=22.08, \mathrm{p}<0.0001\right)$ respectively.

However, the correlation analysis (Sp- $0.07 ; \varphi-0.092$; Table II), as well as the methods of clinical epidemiology $(R R$ 0.325; 95\% CI: 0.381-1.361; Table III) showed the lack of association between the ALT level in the peripheral blood and $C-590 T$ polymorphism of $I L-4$ gene. And, there is a weak positive relationship $(S p-0.11 ; \varphi-0.107)$ between the AST contents and the edematous AP development in $T$-allele carriers of $I L-4$ gene, which, however, was not confirmed as a risk factor for AP occurrence in the examined population ( $R R-1.412$; 95\% CI: $0.805-2.474)$ (Table III).

The increase of the GGTP concentration indicates the presence of intrahepatic cholestasis, as well as, indirectly, the activity of the inflammatory process including the pancreas. The increase of the GGTP concentration was recorded in $79.21 \%(n=80)$ of patients with AP. The frequency of the exceeding of the analyzed cholestasis index standart between the genotypes of $I L-4$ gene trustworthy did not differ ( $p>0.05$; Table I). However, serum GGTP level was significantly higher in the TT-genotype owners than in those with $C$-allele $(\mathrm{p}<0.05)$.

The correlation analysis method revealed a weakly unreliable relationship between the GGTP concentration in blood and the presence of mutation in the 590 position of the promoter of $I L-4$ gene $(S p-0.07 ; \varphi-0.170$; Table II). The GGTP concentration increase is associated with $C$-allele $C$-590T polymorphism of $I L-4$ gene by the ratio of chances and risks ( $R R-0.581)$, however, the $95 \%$ confidence intervals determination did not statistically confirm this assumption (95\% CI: 0.333-1.014; Table III).

LDG level, as an indicator of glycolysis activity, tissue respiration and the predictor of hepatocytes necrosis, was elevated in 44 patients with AP: $30.77 \%$ of thiamine carriers in 590 position of the promoter of $I L-4$ gene and $48.0 \%$ of the carriers of the wild allele of the selected polymorphism (Table I), without a statistically significant difference in the distribution of the index between the alleles ( $p>0.05)$. However, the analysis of individual polymorphic variants showed a higher frequency of excess of LDG standart in CC-genotype owners than in those with $C T$ - and TT-variants - by $31.64 \%\left(\chi^{2}=24.6 ; \mathrm{p}<0.001\right)$ and $32.95 \%\left(\chi^{2}=43.14 ; \mathrm{p}<0.001\right)$ respectively. A weak correlation was found between the LDG concentration in blood and the presence of mutation in the 590 position of the promoter of $I L-4$ gene $(S p-0.153 ; \varphi-0.153$; Table II). The ratio of chances and risks $(R R-0.592)$ of LDG elevation 
Table I. The liver function parameters depending on the allelic status of IL-4 gene in patients with edematous pancreatitis

\begin{tabular}{ccccc}
\hline Parameter & $\begin{array}{c}\text { Patients, } \\
\text { in general, } \\
\mathbf{n = 1 0 1}(\mathbf{\%})\end{array}$ & $\begin{array}{c}\text { Patients with } \\
\text { CC-genotype, } \\
\mathbf{n = 5 8}\end{array}$ & $\begin{array}{c}\text { Patients with } \\
\text { CT-genotype, } \\
\mathbf{n = 3 4}\end{array}$ & $\begin{array}{c}\text { Patients with } \\
\text { TT-genotype, } \\
\mathbf{n = 9}\end{array}$ \\
\hline The increasing of AST concentration & $66(65.35)$ & $31(53.45)$ & $28(82.35)$ & $7(77.78)$ \\
\hline The increasing of ALT concentration & $33(32.67)$ & $8(13.79)$ & $18(52.94)$ & $7(77.78)$ \\
\hline The increasing of GGTP concentration & $80(79.21)$ & $46(79.31)$ & $27(79.41)$ & $7(77.78)$ \\
\hline The increasing of LDG concentration & $44(43.56)$ & $32(55.17)$ & $8(23.53)$ & $2(22.22)$ \\
\hline
\end{tabular}

Note. AST - aspartate aminotransferase; ALT - alanine aminotransferase; GGTP - gamma-glutamyl transpeptidase; LDH - lactate dehydrogenase.

Table II. The matrix of correlations between some live function parameters and edematous pancreatitis development in the carriers of the mutant T-allele of gene IL-4

\begin{tabular}{|c|c|c|c|c|}
\hline \multirow{2}{*}{ Parameter } & \multicolumn{4}{|c|}{ Statistical evaluation criteria of the connection between parameters } \\
\hline & Sp & $x^{2}$ & TSFET & $\varphi$; connection power \\
\hline The increasing of ALT concentration & 0,07 & 1,077 & 0,40668 & 0,092; irrelevant \\
\hline The increasing of AST concentration & 0,11 & 1,454 & 0,23636 & 0,107; weak \\
\hline The increasing of GGTP concentration & 0,07 & 3,653 & 0,06693 & 0,170; weak \\
\hline The increasing of LDG concentration & 0,153 & 2,943 & 0,10939 & 0,153; weak \\
\hline
\end{tabular}

Note. AST - aspartate aminotransferase; ALT - alanine aminotransferase; GGTP - gamma-glutamyl transpeptidase; LDH - lactate dehydrogenase; $\mathrm{Sp}$ - Spearman's correlation coefficient; $\chi 2$ - criterion for assessing the significance of the difference of results depending on the risk factor action; TSFET - two-sided Fisher's exact test; $\varphi$ - the criterion for assessment of the connection power between the risk factor and the result; ${ }^{*}$ - the difference in the indicator distribution is statistically significant $(\mathrm{p}<0.05)$.

Table III. Epidemiological evaluation of some liver function parameters as risk factors of edematous pancreatitis development in the carriers of the mutant T-allele of gene IL-4

\begin{tabular}{ccccc}
\hline Sign & $\begin{array}{c}\text { The increasing of ALT } \\
\text { concentration }\end{array}$ & $\begin{array}{c}\text { The increasing of AST } \\
\text { concentration }\end{array}$ & $\begin{array}{c}\text { The increasing of GGTP } \\
\text { concentration }\end{array}$ & $\begin{array}{c}\text { The increasing of LDG } \\
\text { concentration }\end{array}$ \\
\hline EER & 0,222 & 0,333 & 0,218 & 0,200 \\
\hline CER & 0,309 & 0,236 & 0,375 & 0,338 \\
\hline RR & 0,720 & 1,412 & 0,581 & 0,592 \\
\hline S (RR) & 0,325 & 0,286 & 0,284 & 0,317 \\
\hline $95 \%$ Cl RR & $0,381-1,361$ & $0,333-1,014$ & 0,314 \\
\hline Se & 0,286 & $0,805-2,474$ & 0,486 \\
\hline Sp & 0,615 & 0,514 & 0,330 & 0,490 \\
\hline OR & 0,640 & 0,604 & 0,464 & 0,420 \\
\hline S (OR) & 0,432 & 1,618 & 0,405 & $0,215-1,116$ \\
\hline $95 \%$ Cl OR & $0,275-1,492$ & 0,400 & $0,210-1,028$ & $>0,05$ \\
\hline p & $>0,05$ & $0,738-3,546$ & $>0,05$ & 0 \\
\hline
\end{tabular}

Note. AST - aspartate aminotransferase; ALT - alanine aminotransferase; GGTP - gamma-glutamyl transpeptidase; LDH - lactate dehydrogenase; EER - experimental event rate; CER - control event rate; $R R$ - relative risk; $S$ (RR) - standard error of the relative risk; $95 \% \mathrm{CI} R \mathrm{R}-95 \%$ confidence interval of the relative risk; $\mathrm{Se}$ - sensitivity; $\mathrm{Sp}$ - specificity; $\mathrm{OR}$ - odds ratio; $\mathrm{S}(\mathrm{OR})$ - standard error of the odds ratio; $95 \% \mathrm{Cl} 0 \mathrm{R}-95 \%$ confidence interval of the odds ratio.

was associated with the CC-genotype of C-590T polymorphism of $I L-4$ gene, however, the determination of 95\% confidence intervals did not confirm this indicator as a risk factor for the AP development (95\% CI: 0.318 $-1,101$; Table III).

The determination of the the blood bilirubin fractions in patients with AP allows to analyze the hepatobiliary system work and the protein metabolism activity. Hyperbilirubin- emia by the total bilirubin content (within $25-30 \mathrm{mmol} / \mathrm{L}$ ) was diagnosed in one in five patients with AP: more often in $T T$-genotype carriers than in CC-homozygotes $\left(\chi^{2}=35.18\right.$, $\mathrm{p}<0.001)$ with respectively a higher indicator -25.33 versus $14.56 \mathrm{mmol} / \mathrm{l}$ (Mann-Whitney's criterion is $2.976 ; \mathrm{p}=0.022$; Table IV).

Correlation analysis showed a strong feedback between the total bilirubin concentration in blood and the AP 
Table IV. State of bilirubin fractions depending on the allelic status of IL-4 gene in patients with edematous pancreatitis

\begin{tabular}{ccccc}
\hline Parameter & $\begin{array}{c}\text { Patients, } \\
\text { in general, } \\
\mathbf{n = 1 0 1}(\mathbf{\%})\end{array}$ & $\begin{array}{c}\text { Patients with } \\
\text { CC-genotype, } \\
\mathbf{n = 5 8}\end{array}$ & $\begin{array}{c}\text { Patients with } \\
\text { CT-genotype, } \\
\mathbf{n = 3 4}\end{array}$ & $\begin{array}{c}\text { Patients with } \\
\text { TT-genotype, } \\
\text { n=9 }\end{array}$ \\
\hline $\begin{array}{c}\text { The increasing of total bilirubin } \\
\text { concentration }\end{array}$ & $22(21,78)$ & $10(17,24)$ & $3(26,47)$ & $3(33,33)$ \\
\hline $\begin{array}{c}\text { The increasing of unconjugated } \\
\text { bilirubin concentration }\end{array}$ & $14(13,86)$ & $10(17,24)$ & $3(8,82)$ & $1(11,11)$ \\
\hline $\begin{array}{c}\text { The increasing of conjugated } \\
\text { bilirubin concentration }\end{array}$ & $31(30,69)$ & $15(25,86)$ & $12(35,29)$ & $4(44,44)$ \\
\hline
\end{tabular}

Table V. The matrix of correlations between bilirubin fractions and edematous pancreatitis development in carriers of the mutant T-allele of gene IL-4

\begin{tabular}{|c|c|c|c|c|}
\hline \multirow{2}{*}{ Parameter } & \multicolumn{4}{|c|}{ Statistical evaluation criteria of the connection between parameters } \\
\hline & Sp & $x^{2}$ & TSFET & $\varphi$; connection power \\
\hline $\begin{array}{l}\text { The increasing of total bilirubin } \\
\text { concentration }\end{array}$ & 0,521 & $46,093^{*}$ & $0,00000^{*}$ & 0,605; strong \\
\hline $\begin{array}{l}\text { The increasing of unconjugated bilirubin } \\
\text { concentration }\end{array}$ & 0,094 & 1,110 & 0,51328 & 0,094, irrelevant \\
\hline $\begin{array}{l}\text { The increasing of conjugated bilirubin } \\
\text { concentration }\end{array}$ & 0,174 & $6,197^{*}$ & $0,02365^{*}$ & 0,$222 ;$ medium \\
\hline
\end{tabular}

Note. Sp - Spearman's correlation coefficient; $X 2$ - criterion for assessing the significance of the difference of results depending on the risk factor action; TSFET - two-sided Fisher's exact test; $\varphi$ - the criterion for assessment of the connection power between the risk factor and the result; * - the difference in the indicator distribution is statistically significant $(\mathrm{p}<0.05)$.

Table VI. Epidemiological evaluation of bilirubin fractions as risk factors of edematous pancreatitis development in carriers of the mutant T-allele of gene IL-4

\begin{tabular}{cccc}
\hline Sign & $\begin{array}{c}\text { The increasing of total bilirubin } \\
\text { concentration }\end{array}$ & $\begin{array}{c}\text { The increasing of unconjugated bilirubin } \\
\text { concentration }\end{array}$ & $\begin{array}{c}\text { The increasing of conjugated } \\
\text { bilirubin concentration }\end{array}$ \\
\hline$E E R$ & 0,675 & 0,154 & 0,441 \\
\hline$C E R$ & 0,093 & 0,292 & 0,217 \\
\hline$R R$ & 7,256 & 0,527 & 2,029 \\
\hline$S(R R)$ & 0,354 & 0,667 & 0,276 \\
\hline $95 \% C l R R$ & $3,625-14,526$ & $0,143-1,946$ & $1,181-3,488$ \\
\hline$S e$ & 0,771 & 0,057 & 0,429 \\
\hline$S p$ & 0,857 & 0,879 & 0,791 \\
\hline$O R$ & 20,250 & 0,441 & 2,842 \\
\hline$S(O R)$ & 0,502 & 0,796 & 0,502 \\
\hline $95 \% C I O R$ & $7,574-54,144$ & $0,093-2,098$ & $1,228-6,576$ \\
\hline$P$ & $<0,05$ & $>0,05$ & $<0,05$ \\
\hline
\end{tabular}

Note. EER - experimental event rate; CER - control event rate; RR - relative risk; $S$ (RR) - standard error of the relative risk; $95 \% \mathrm{Cl}$ RR - 95\% confidence interval of the relative risk; $\mathrm{Se}$ - sensitivity; $\mathrm{Sp}$ - specificity; $\mathrm{OR}$ - odds ratio; $\mathrm{S}(\mathrm{OR})$ - standard error of the odds ratio; $95 \% \mathrm{Cl} 0 \mathrm{R}-95 \%$ confidence interval of the odds ratio.

in the presence of mutation in the 590 position of the promoter of $I L-4$ gene $(S p-0.521 ; \varphi-0.605$; Table V). According to the definition of the ratio of chances and risks $(R R-7,256)$, the increase of the total bilirubin concentration is associated with the carrier of the mutant C-590T allele of IL-4 gene polymorphism (95\% CI: 3.625-14.526; $\mathrm{p}<0.05$; Table VI).

The concentrations of the indirect and direct bilirubin are also higher in the TT-genotype carriers of C-590T polymorphism of $I L-4$ gene (12.42 vs. $9.15 \mathrm{mmol} / \mathrm{l}$ in the CC-homozygotes of the selected polymorphism and $14.06 \mathrm{mmol} / \mathrm{L}$ against $5.41 \mathrm{mmol} / \mathrm{l}$, respectively; the Mann-Whitney criterion is 2.888 and 2.054; $\mathrm{p}=0.012$ and $\mathrm{p}=0.014$, respectively). However, the incidence frequency of high content of indirect and direct bilirubin ( $\mathrm{n}=14 \mathrm{vs}$. $\mathrm{n}=31$ ) was not significantly different between genotypes (Table IV).

The correlation analysis method did not establish a significant relationship between the concentration of indirect bilirubin in the blood and the mutation pres- 
ence in the 590 position of the promoter of $I L-4$ gene $(S p-0.094 ; \varphi-0.094 ; \mathrm{p}>0.05$; Table V) with the available medium reverse link with the contents of direct bilirubin $(S p-0.174 ; \varphi-0.222 ; \mathrm{p}<0.05)$. The increase of the indirect bilirubin concentration is not associated with the carrier of mutated $C-590 T$ polymorphism of $I L-4$ gene for AP (RR-0.667; 95\% CI: 0.143-1.946; p>0.05; Table VI). Instead, the increase of the direct bilirubin content is a risk factor for AP in patients with $T$-alleles of $I L-4$ gene (RR-2.029; 95\% CI: 1.181-3.488; $\mathrm{p}<0.05)$.

This found genotypes distribution of gene IL-4 (C-590T) corresponds to some studies for the healthy [20] but we did not find the data about this gene polymorphism in the patients with acute or chronic pancreatitis.

The bilirubin fractions research as some of specific indicators of cholestasis and toxic influence are the most evident. The level of bilirubin remains close to normal in patients with CC-genotype. But, in general, the carrying of T-allele is combined with the increase of norm indicator and the icrease of the bilirubin level in comparison with CC-genotype. We think that the last is caused by besides the toxic alcohol influence, more prominent edematous reaction of the pancreas and of parapancreatic tissue and also by the disfunction of bile outflow [21].

Thus, the AP course in the carriers of the homozygous mutant $T$-allele of $I L-4$ gene $(C-590 T)$ is associated with the high levels of total bilirubin and its fractions, however, the increased general and direct bilirubin levels are the risk factors. The implementation of acute inflammatory process in the pancreas in $T$-allele carriers of the same polymorphism variant is characterized by the higher levels of aminotransferases in the serum of peripheral venous blood, which although characterizing the activity of mesenchymal-inflammatory and cholestatic syndromes in the liver, however, did not appear to be the risk factors for the development of the AP.

The obtained results have the scientific novelty because they are received for the first time.

\section{CONCLUSIONS}

1. The increased concentration of aminotransferases, GGTP, LDG in blood serum of patients with AP confirmed the presence of mesenchymal-inflammatory, cholestatic and, somewhat less, cytolytic syndromes in the hepatopancreatobiliary system, confirming the presence of its dysfunction (more significant in the TT-genotype carriers of $I L-4$ gene by the AST and ALT levels - by $27.94 \%\left(\chi^{2}=8.52, p=0.003\right)$ and $24.33 \%$ $\left(\chi^{2}=22.08, \mathrm{p}<0.0001\right)$ respectively.

2. The course of AP in the homozygous mutant $T$-allele carriers of $I L-4$ gene $(C-590 T)$ is associated with the high levels of bilirubin and its fractions, however, were found to be risk factors the high levels of total bilirubin $(R R=7.26 ; O R=20.25 ; 95 \%$ CI OR: 7.57-54.14; $<<0.05)$ and its direct fraction $(R R=2.03 ; O R=2.84 ; 95 \% C I O R$ : 1.23-6.58; $\mathrm{p}<0.05)$.

\section{REFERENCES}

1. Abu-El-Haija M, Lin TK, Khan $S$ et al. Predictive biomarkers for acute gallstone pancreatitis in the pediatric population. Pancreatology. 2018 Jul;18(5):482-485.

2. Díaz DC, Otero Regino W, Gómez Zuleta M. Acute Pancreatitis and Elevated Aminotransferases: What to Think? A Case Report and Literature Review. Rev Col Gastroenterol. 2015 0ct./Dec;30(4):475-479.

3. da Costa DW, Schepers NJ, RömkensTHE et al. Endoscopic sphincterotomy and cholecystectomy in acute biliary pancreatitis. The Surgeon. 2016 April; 14(2):99-108.

4. Thomasset SC, Carter CR. Acute pancreatitis. Surgery. 2016 June; 34(6):292-300.

5. Hammad AY, M Ditillo, Castanon L. Pancreatitis. Surgical Clinics of North America. 2018 0ctober;98(5):895-913.

6. Stigliano S, Sternby H, de Madaria E et al. Early management of acute pancreatitis: A review of the best evidence. Digestive and Liver Disease. 2017 June;49(6):585-594.

7. Akshintala VS, Kamal A, Singh VK. Uncomplicated Acute Pancreatitis: Evidenced-Based Management Decisions. Gastrointestinal Endoscopy Clinics of North America. 2018 0ctober; 28(4):425-438.

8. Kim M-J, Bae G-S, Jo I-J et al. Fraxinellone inhibits inflammatory cell infiltration during acute pancreatitis by suppressing inflammasome activation. International Immunopharmacology.2019 April;69:169-177.

9. Hu N, Shen Y, Liu F et al. Morphological and immunobiochemical analysis of the liver in L-arginine induced experimental chronic pancreatitis. Pancreatology.2017 Mar-Apr;17(2):247-54. doi: 10.1016/j. pan.2017.01.006.

10. Gubergrits NB, Kishenya MS, Golubova OA. Polymorphism of ethanol metabolism genes in al coholic chronic pancreatitis. Therapeutic archive. 2014:2:49-55.

11. Ivashchuk S, Sydorchuk L. Level of Reactive Response of Peripheral Blood Neutrophil Granulocytes of Patients with Acute Pancreatitis Depending on Genes Polymorphism of CFTR (delF508C), PRSS1 (R122H), IL-4 (C-590T) and TNF- $a(\mathrm{G}-308 \mathrm{~A})$. The Pharma Innovation Journal. 2016;5(8):96-100.

12. Hasan A, Moscoso DI, Kastrinos F. The Role of Genetics in Pancreatitis. Gastrointestinal Endoscopy Clinics of North America. 2018 0ctober;28(4):587-603.

13. Nakano E, Masamune A, Niihori T et al. Targeted next-generation sequencing effectively analyzed the cystic fibrosis transmembrane conductance regulator gene in pancreatitis. Dig Dis Sci. 2015 May;60(5):1297-1307.

14. Ministry of Health of Ukraine. [The order of Ministry of Health of Ukraine from 02.04.2010 №297"About the confirmation of standards and clinical protocols of medical care providing in speciality "Surgery"] [Published in Ukrainian]. Kyiv: MOZ 2010. Available from: URL: http://www.moz. gov.ua/ua/portal/dn_20100402_297.html.

15. Pezzilli R, Andriulli A, Bassi Cet al. Exocrine pancreatic insufficiency in adults: a shared position statement of the Italian association for the study of the pancreas. World J. Gastroenterol. 2013 Nov; 19(44):79307946.

16. Burtis CA and Ashwood ER (ed.), Tietz Fundamentals of Clinical Chemistry, 5th edition. Philadelphia: WB Saunders Company, 2001: 354-356.

17. IFCC 2002/5: IFCC Primary Reference Procedures for the Measurement of Catalytic Activity Concentrations of Enzymes at $37^{\circ} \mathrm{C}$, Part. 4 Reference Procedure for the Measurement of Catalytic Concentrations of Alanine Aminotransferase. Clin Chem Lab Med. 2002;40(7):718-724. 
18. IFCC 2002/6: IFCC Primary Reference Procedures for the Measurement of Catalytic Activity Concentrations of Enzymes at $37^{\circ} \mathrm{C}$, Part. 5. Reference Procedure for the Measurement of Catalytic Concentrations of Aspartate Aminotransferase. Clin Chem Lab Med. 2002;40(7):725-733.

19. Abdi RI, Bagheri M, Rahimi-Rad MH, Moradi Z. IFN- $\gamma+874$ and IL-4 -590 Polymorphisms and Asthma Susceptibility in North West of Iran. Tanaffos. 2010;9(4):22-7.

20. Talebkhan Y, Doozbakhshan M, Saberi S et al. Serum Antibodies against Helicobacter pylori Neutrophil Activating Protein in Carriers of IL-4 C-590T Genetic Polymorphism Amplify the Risk of Gastritis and Gastric Cancer. Iran Biomed J. 2017 Sep;21(5):321-329.

21. Ivashchuk SI. [Disintegration mechanisms of functioning and structural changes of the pancreas in patients with acute pancreatitis considering the lipid profile and hepatocytes functions]. Ukrainian Journal of Surgery. 2014;2(25):76-82.
The presented research is a fragment of the planned comprehensive research work of the Department of Family Medicine of the Higher State Educational Institution of Ukraine «Bukovinian State Medical University" "on the theme "Hemodynamic, metabolic, genetic features of arterial hypertension in combination with ischemic heart disease and type 2 diabetes: the effectiveness of combined antihypertensive, metabolic and vasoactive therapy in the in-patient and out-patient stages of treatment "(state registration number 0113U004037), co-performers of which were the authors.

\section{Authors' contributions:}

According to the order of the Authorship.

\section{Conflict of interest:}

The Authors declare no conflict of interest.

\section{CORRESPONDING AUTHOR}

\section{Sergiy I. Ivashchuk}

Bukovinian State Medical University

Heroyiv Maydanu str. 174/3, 58029 Chernivtsi, Ukraine

tel: +380503743544

e-mail: ivserge@i.ua

Received: 03.02.2019

Accepted: 04.04.2019 


\title{
THE ROLE OF SMALL INTESTINAL BACTERIAL OVERGROWTH IN THE PATHOGENESIS OF HYPERLIPIDEMIA
}

\author{
Khrystyna B. Kvit ${ }^{1,3}$, Natalya V. Kharchenko², Vyacheslav V. Kharchenko ${ }^{2}$, Olga I. Chornenka ${ }^{3}$, Romania I. Chornovus ${ }^{3}$, \\ Uljana S. Dorofeeva ${ }^{3}$, Oksana B. Draganchuk ${ }^{3}$, Oksana M. Slaba ${ }^{4}$ \\ 'DEPARTMENT OF THERAPY №1 AND MEDICAL DIAGNOSTICS, FACULTY POSTGRADUATE TEACHING, DANYLO HALYTSKY LVIV NATIONAL MEDICAL \\ UNIVERSITY, LVIV, UKRAINE \\ 2DEPARTMENT OF GASTROENTEROLOGY, DIETOLOGY AND ENDOSCOPY, SHUPYK NATIONAL MEDICAL ACADEMY OF POSTGRADUATE TEACHING, KYIV, UKRAINE \\ 3MEDICAL DEPARTMENT,"MEDICOVER UKRAINE", LVIV, UKRAINE \\ ${ }^{4}$ DEPARTMENT OF THERAPEUTIC DENTISTRY, FACULTY POSTGRADUATETEACHING, DANYLO HALYTSKY LVIV NATIONAL MEDICAL UNIVERSITY, LVIV, UKRAINE
}

\begin{abstract}
Introduction: Small intestinal bacterial overgrowth may cause the hyperlipidemia appearance by enterohepatic circulation disturbance which evolves on the background of the early bile acids deconjugation with further endotoxin production and oxidative stress in the liver with hyperproduction of cholesterol and atherogenic lipoproteins.

The aim: the determination of prevalence and features of SIBO in a series of patients with hyperlipidemia and in control subjects.

Materials and methods: Nineteen patients with hyperlipidemia and ten control subjects were studied. Small intestinal bacterial overgrowth was assessed by a lactulose breath test. Such biochemical markers as CRP, ALT, AST, GGTP, apolipoprotein B, bilirubin, cholesterol and lipid profile were determined. Except the routine interpretation of lactulose breath test, which contains the SIBO detection, small intestinal transit time and hydrogen level evaluation with next comparison between groups of patients was realized.

Results: Small intestinal bacterial overgrowth was present in $78.9 \%$ of patients with hyperlipidemia and $40 \%$ in control subjects. The maximal dose of $\mathrm{H} 2$ was particularly higher in patients with hyperlipidemia in comparison with control group $(94,7 \pm 13,69$ vs. 36,13 15,4$)$. There was a strong correlation between AST level and SIB0 existence in both groups $(r=1)$. Positive connection between LDL, TG, VLDL and the dose of exhaled hydrogen on 120 minute $(r=0.6, r=0.62, r=0.7$ respectively) and strong negative correlation between HDL and 120 minute dose $(r=-0.74)$ in main group was marked.

Conclusions: Patients with hyperlipidemia have a higher prevalence of small intestinal bacterial overgrowth and there is a relationship between $\mathrm{H} 2$ rate and LDL, TG, VLDL.
\end{abstract}

KEY WORDS: hyperlipidemia; hypercholesterolemia; syndrome of bacterial overgrowth; small intestinal bacterial overgrowth; lactulose breath test

Wiad Lek 2019, 72, 4, 645-649

\section{INTRODUCTION}

Numerous studies in recent years have proved the pathogenetic relationship of the intestinal microbiota with such diseases as hyperlipidemia, atherosclerosis, arterial hypertension, steatohepatitis, diabetes mellitus [1]. It is known that on the background of the syndrome of excessive bacterial growth in the intestine, proatherogenic changes in lipid spectrum are possible [2].

Microorganisms which colonize the intestine are capable to impact on cholesterol metabolism by affecting the key stages of its synthesis. Excessive microbial growth of anaerobes in the jejunum, which is typical for syndrome of bacterial overgrowth (SIBO), leads to its damage, with the development of system inflammation, that causes early deconjugation of bile acids with the formation of their toxic salts and impaired enterohepatic circulation $[3,4]$. Deconjugated bile acids can also damage the epithelium of the small intestinal mucosa by its detergent properties.

As a result, synthesis and sorption of enzymes on its surface are reduced, which leads to disruption of mem- brane digestion and absorption of fats and fat-soluble vitamins $\mathrm{A}, \mathrm{D}, \mathrm{E}, \mathrm{K}$, amino acids and carbohydrates $[5,6]$. Moreover, there was a data, linking SIBO with subclinical atherosclerosis, through the vitamin K-dependent activity of the matrix Gla-protein (MGP), that maintains arterial structure and function through prevention of calcification of vessel walls and the regulation of the extracellular matrix [7].

Bile acids induce impaired sodium absorption, increase the secretion of chlorides and water into the intestinal lumen, accelerate peristalsis of the small intestine, which aggravates diarrhea syndrome [8]. It should also be noted that deconjugated bile acids are rapidly absorbed, which prematurely turns them off from digestion processes $[9,10]$. In this case, induction of hypercholesterolemia is possible, especially in individuals with hereditary predisposition [11].

The only class of lipids with anti-atherogenic activity is high-density lipoproteins (HDL), that are synthesized in the liver and small intestine. An increasing amount of 
endotoxins that is produced by gram-negative microflora of intestine, leads to declining the anti-atherogenic HDL $[12,13]$.

Permanent inflammation also causes the changes, that impact on cholesterol catabolism reducing and its excretion in the liver by decreasing the expression of matrix ribonucleic acids and the activity of bile acid synthesis key enzymes - CYP7A1, CYP27A1 and CYP7B1 [14,15].

Taking into account these facts, there is a big interest in searching the way of hyperlipidemia development, where the SIBO is one of the essential factors. The main attention is dedicated to enterohepatic circulation disturbance which evolves on the background of the early bile acids deconjugation with further endotoxin production and oxidative stress in the liver with hyperproduction of cholesterol and atherogenic lipoproteins $[16,17]$.

\section{THE AIM}

The aim of this study therefore was to determine the prevalence and features of SIBO in a series of patients with hyperlipidemia and in control subjects.

\section{MATERIALS AND METHODS}

Nineteen patients with hyperlipidemia (9 men and 10

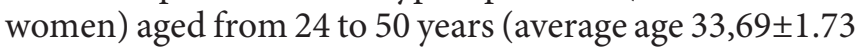
years) with average BMI 24,4 1.54 were examined in "Medicover Ukraine" (Lviv, Ukraine). The diagnostic criteria, except the hyperlipidemia, which were used for patient including into the program of examination were: BMI not more that 25, waist circumference $<94 \mathrm{~cm}$ for male, $<80 \mathrm{~cm}$ for female, no significant alcohol consumption, defined as no greater than $20 \mathrm{~g}$ of alcohol per day. Ten control subjects ( 4 men and 6 women) aged from 24 to 34 years (an average $29,9 \pm 0.68$ years) and average BMI 24,2 \pm 1.21 were matched with main group patients by age and metabolic characteristics. All control subjects had normal lipid range and no history of coronary disease. None of both groups subjects was taking drugs known to affect lipid profile or microbiota composition, including antibacterial medicines 1 month before and during the data.

Both groups of patients underwent biochemical evaluation of serum that included blood cell count and lipid profile. For the evaluation of the inflammation, as one of the pathogenetically ways for hyperlipidemia formation due the SIBO activity, C-reactive protein (CRP) was measured in serum, obtained on the day of SIBO testing. Another biochemical tests included alaninaminotransferase (ALT), aspartataminotransferase AST, gamma glutamyl transpeptidase (GGTP), bilirubin (total, direct, indirect), apolipoprotein B (apo B). Biochemical tests were carried out using commercially available test kits.

Additionally, the data plan involved the determination of calprotectin in feces, which positive result was the reason of excluding the patient from the data. Values $>50 \mu \mathrm{g} / \mathrm{g}$ were considered as increased.
Ultrasound examination was proved to all patients of both groups. with aim to exclude the patients with fatty liver disease as one of the reasons of increased cholesterol level and aggravation factor for SIBO presence. The ultrasound criteria for fatty infiltration existence was a diffuse increase in the echogenicity of the liver parenchyma, decreased attenuation on the liver and ratio between the brightness level of the liver and the right kidney that was calculated for the hepato-renal index (HRI) determination [18].

All subjects were examined by a lactulose breath test what is one of the most diagnostically valuable methods for determining excessive bacterial growth under clinical conditions [19]. The test allows to determine the concentration of hydrogen (H2) in exhaled air, what is growing up when there are a lot of hydrogen-producing bacteria in the small intestine $[20,21]$. The patient was given from $10 \mathrm{~g}$ of lactulose. A change in the level of exhaled hydrogen gas above 20 parts per million (ppm) within 120 minutes from a basal value was the basis for SIBO diagnosis [22,23]. Furthermore, after the recording SIBO by enormous $\mathrm{H} 2$ growing (more than 30 points), the test could be stopped before 120 minute [24,25]. Before the test, subjects were asked to brush their teeth and rinse mouth with antiseptic mouth wash and tap water, to eliminate an early hydrogen peak due to action of oral bacteria on test sugars $[26,27]$. Patients were required to comply with a low residue diet the day before the test and not to smoke within two hours of the test to prevent high basal levels of H2 [28,29].

Lactulose breath test was carried out on the "Gastro+Gastrolyzer" (Bedfont ${ }^{\circledR}$ Scientific Ltd) device in the laboratory of "Medicover Ukraine". Except the standart interpretation, we have analyzed the difference between the basal and the highest range of exhaled $\mathrm{H} 2$ during the 120 minutes of test in subjects of both groups. An estimate of small intestinal transit time was calculated, where possible, by observing the time taken from ingestion of lactulose to the appearance of the $\mathrm{H} 2$ peak, indicating colonic catabolism of lactulose.

Statistical analysis was carried out using Statistica 5.0 for Windows software (Statsoft Inc, Tulsa, USA). Comparisons between groups for parametric data were performed using the Student's t test. Differences were considered statistically significant for $\mathrm{p} £ 0,05$. The correlation between the values was measured by Person correlation coefficient.

\section{RESULTS}

Patient characteristics are shown in Table I. Due to the results, the statistically significant difference was matched between the cholesterol level, low density lipoproteins, very low density lipoproteins of main and control groups. The level of CRP was more than in 1,4 significantly higher in group with hyperlipidemia in contrast to the controls.

The measurement of SIBO by lactulose test showed the equal result of the basal dose of hydrogen in both groups. In contrast, the maximal dose was particularly higher in 
Table I. Clinical and biochemical variables for patients with hyperlipidemia $(n=19)$ and controls $(n=10)$

\begin{tabular}{|c|c|c|c|}
\hline Variable (normal range) & Main group (19) & Control group (10) & $\mathbf{p}$ \\
\hline Age (years) & $33,69 \pm 1.73$ & $29,9 \pm 0.68$ & ${ }^{3} 0,05$ \\
\hline $\mathrm{BMI}, \mathrm{kg} / \mathrm{m} 2$ & $24,4 \pm 1.54$ & $24,2 \pm 1.21$ & ${ }^{3} 0,05$ \\
\hline $\begin{array}{c}\text { Apo } B, g / l \\
\text { (normal range 0.66-1.33-men, 0,6-1,17 women) }\end{array}$ & $1.19 \pm 1.03$ & $0.81 \pm 1.6$ & ${ }^{3} 0,05$ \\
\hline Bilirubin total, $\mathrm{mmol} / \mathrm{l}$ (normal range $<21$ ) & $15.13 \pm 1.83$ & $12.53 \pm 0.85$ & ${ }^{3} 0,05$ \\
\hline Direct bilirubin, $\mathrm{mmol} / \mathrm{l}($ normal range $<5$ ) & $3.47 \pm 0.48$ & $4 \pm 0.14$ & ${ }^{3} 0,05$ \\
\hline $\begin{array}{c}\text { Indirect bilirubin, } \mathrm{mmol} / \mathrm{l} \\
\text { (normal range }<75 \% \text { of bilirubin total) }\end{array}$ & $12.03 \pm 1.7$ & $9.2 \pm 0.07$ & ${ }^{3} 0,05$ \\
\hline AST, IU/L (normal range $<40$ ) & $29.6 \pm 3.5$ & $23 \pm 1.35$ & ${ }^{3} 0,05$ \\
\hline ALT, IU/L (normal range <41) & $43.54 \pm 10.35$ & $29.13 \pm 3.52$ & ${ }^{3} 0,05$ \\
\hline AST/ALT ratio (normal range $0,91-1,75$ ) & $1.05 \pm 0.14$ & $0.94 \pm 0.35$ & ${ }^{3} 0,05$ \\
\hline $\begin{array}{c}\text { GGTP, IU/L } \\
\text { (normal range }<55 \text { men, }<38 \text { women) }\end{array}$ & $41,78 \pm 11.03$ & $23.45 \pm 2.48$ & ${ }^{3} 0,05$ \\
\hline CRP, mg/l (normal range $£ 5$ ) & $2,75 \pm 0,36$ & $1,9 \pm 0,03$ & $£ 0,05$ \\
\hline Cholesterol, mmol/l (normal range $£ 5,2$ ) & $6,71 \pm 0,27$ & $4,63 \pm 0,23$ & $£ 0,05$ \\
\hline Triglycerides, $\mathrm{mmol} / \mathrm{l}$ (normal range $\mathrm{n} £ 1,7$ ) & $1.45 \pm 0,25$ & $1,12 \pm 0,1$ & ${ }^{3} 0,05$ \\
\hline LDL, mmol/l (normal range $£ 2,59$ ) & $4,14 \pm 0,25$ & $2,45 \pm 0,1$ & $£ 0,05$ \\
\hline VLDL, mmol/l (normal range $=0.26-1,0)$ & $0,93 \pm 0,13$ & $0,47 \pm 0,01$ & $£ 0,05$ \\
\hline $\mathrm{HDL}, \mathrm{mmol} / \mathrm{l}$ (normal range $\left.={ }^{3} 1,56\right)$ & $1,44 \pm 0,05$ & $1,58 \pm 0,06$ & ${ }^{3} 0,05$ \\
\hline
\end{tabular}

Table II. H2 level during the lactulose breath test in patients of main and control groups

\begin{tabular}{|c|c|c|c|}
\hline & Main group (19) & Control group (10) & $\mathbf{p}$ \\
\hline Basal dose, ppm & $10,7 \pm 0,93$ & $11,1 \pm 1,2$ & ${ }^{3} 0,05$ \\
\hline Maximal dose, ppm & $94,7 \pm 13,69$ & $36,13 \pm 5,4$ & $£ 0,05$ \\
\hline
\end{tabular}

patients with hyperlipidemia in comparison with control group $(94,7 \pm 13,69$ vs. $36,13 \pm 5,4)$ (Table II).

According to the fact, that SIBO existence is based on the hydrogen level increasing more that $20 \mathrm{ppt}$, not depending the amount of $\mathrm{H} 2$, we have analyzed the prevalence of intestinal bacterial overgrow and the small intestinal transit time in both groups. On the other hand, the fact of difference in result of $\mathrm{H} 2$ between group of patients with hyperlipidemia and without was essential.

The prevalence of SIBO in hyperlipidemia group was 78.9\%. Small intestinal transit time amounted 100 minutes. Meanwhile, the SIBO occurrence in controls was $40 \%$ with average time of small intestine transit 140 minutes.

We have analyzed the data, where different methods of small intestine transit time were compared and found the substantial remark, that lactulose is non-physiologic for small intestine time transit measurement since it accelerates small bowel transit, presumably due its osmotic activity. Based on this evidence, we did not accent on the difference of transit time between both groups, because in both groups it was shorter than normal range. On the other hand, we could not ignore the fact of meaningful difference in SIBO existence between main and control groups.

In accordance to this result, we have calculated the cor- relation coefficient between different biochemical markers and lactulose test results with the purpose to find the influencing factors in each group that could be the reason of SIBO occurrence.

The results showed that there is a strong correlation between AST level and SIBO existence in both groups $(\mathrm{r}=1)$. Moreover, the correlative connection was marked between AST/ALT ratio and bacterial overgrowth in main group $(r=0,59)$. An interesting detail was found during the correlation analysis - CRP, that is strongly connected with SIBO in different data, did not interrelate with bacterial overgrowth in both groups. On the other hand, the relationship between cholesterol, LDL and CRP in patients with hyperlipidemia has been found $(r=0.58, r=0.59$ respectively). Regarding to lipid profile - there was remarkable positive connection between LDL, TG, VLDL and the dose of exhaled hydrogen on 120 minute $(r=0.6, r=0.62, r=0.7$ respectively) and strong negative correlation between HDL and 120 minutes dose $(r=-0.74)$ in main group.

\section{DISCUSSION}

One of the essential findings of this study was a significantly higher prevalence of SIBO in patients with 
hyperlipidemia compared with controls (78.9\% vs. $40 \%$ ). Furthermore, an interesting point was found during the analysis of main and control group results - the highest range of exhaled hydrogen during the lactulose test in patients with hyperlipidemia was in above 2.5 times higher than in controls $(94,7 \pm 13,69$ compared to $36,13 \pm 5,4$ $\mathrm{ppm})$, in while the basal level was equal in both groups $(10,7 \pm 0,93$ and $11,1 \pm 1,2 \mathrm{ppm})$.

Apparently, the way of hyperlipidemia development on the SIBO background could be realized by next steps. Under the influence of SIBO, the protective mechanisms of small intestine mucous membrane are injured, which causes both local and systemic pathological processes, complemented by inflammation, that are closely interrelated. The bacterial pool of colonic flora, which has, in case of SIBO, the properties of conditionally pathogenic flora, by causing the violation of the small intestine barrier function on the background of inflammation, induces the bacterial hydrolysis of proteins with the formation of ammonia and ketone acids, the oxidation of fatty acids, deconjugation of bile acids and the formation of short-chain fatty acids from carbohydrates.

However, CRP, as one of the main markers of system inflammation, that could impact on SIBO occurrence, did not exceed the upper limit of norm, in both groups, not depending the significant difference between it in patients of main and control groups. Thus, the way of SIBO development could be connected not only with injured intestine, but with another way of pathological process that is associated with liver. Due the results of this study, the singular sign that had strong correlation with SIBO presence or absence was AST, which is always associated not only with cardiac muscle, but with liver parenchyma injuring. This indicator was connected with bacterial overgrowth in both groups, but there was more specific strong correlation between de Ritis ratio and SIBO existing in patients of main group, that could be the second point of definitely including liver and cardiovascular system in SIBO manifestation in patients with hyperlipidemia.

Finally, the analysis of correlation between the lipids, CRP and SIBO demonstrated, that increasing of LDL, TG and VLDL is interlinked with higher dose of exhaled hydrogen in main group and with CRP increasing. In contrast, there was no connection in both groups between CRP and $\mathrm{H} 2$ growth on any minute of lactulose test. It could be the explanation of considerably higher rate of $\mathrm{H} 2$ in patients with hyperlipidemia - there are strong connection between the lipoproteins and SIBO manifestation. Between this, maybe CRP increasing is not before SIBO occurrence, but after its development and is the result of SIBO, not the reason.

That could be the answer for the relationship presence between LDL, VLDL, TG with H2 and CRP, with absence of correlation between CRP and SIBO. High hydrogen rate leads to LDL, VLDL and TG increasing, and HDL decreasing, that provokes the inflammation with next CRP growing. In that way, the main target organ becomes the liver. Thus, it could be the next "vicious circle": disruption of intestinal microecology ${ }^{\circledR}$ SIBO occurrence ${ }^{\oplus}$ accumulation of endotoxins in the intestine ${ }^{\otimes}$ violation of enterohepatic circulation of bile acids ${ }^{\circledR}$ impairing of liver function ${ }^{\circledR}$ impairing of lipid metabolism ${ }^{\circledR}$ impairing of liver structure (fatty infiltration, fibrosis) ${ }^{\circ}$ impairing of lipid metabolism ${ }^{\bullet}$ maintaining (aggravating) disturbed intestinal dysbiosis.

\section{CONCLUSIONS}

1. The prevalence of SIBO in patients with hyperlipidemia is predominantly higher than in patients without lipid metabolism disturbance.

2. The hydrogen level is significantly higher in patients with hyperlipidemia in comparison with controls.

3. There is an axis between high LDL, VLDL and TG level and hydrogen rate in patients with hyperlipidemia.

4. CRP is not interrelated with SIBO, but is strongly connected with LDL and cholesterol level in patients with hyperlipidemia.

\section{REFERENCES}

1. Wigg A., Roberts-Thomson I., Dymock R., Mccarthy P., Grose R., Cummins A. The role of small intestinal bacterial overgrowth, intestinal permeability, endotoxemia, and tumour necrosis factor alpha in the pathogenesis of non-alcoholic steatohepatitis., Gut, 2001, 48(2) : 206-211.

2. Adkins c., Rezaie A. Small intestinal bacterial overgrowth and coronary artery disease: what is in the cards? Digestive diseases and sciences, 2018, 63(2) : 271-272

3. OlofH, Sundin A., Zeng M. The humanjejunal microbiome has a distinctive bacterial flora, with streptococcus tigurinus as its signature species, and an increased fraction of gram-negative phyla in patients with small intestinal bacterial overgrowth. Gastroenterology, 2016, 150:689.

4. Ferolla S., Armiliato G., Couto C., Ferrari T. The role of intestinal bacteria overgrowth in obesity-related nonalcoholic fatty liver disease. Nutrients, 2014, 6(12): 5583-5599.

5. Jung S., Joo Ns, Han Ks, Kim Kh. Obesity is inversely related to hydrogen-producing small intestinal bacterial overgrowth in nonconstipation irritable bowel syndrome. J korean med sci., 2017, 32(6) :948-953.

6. Lefebvre P, Cariou B, Lien F, Kuipers F, Staels B. Role of bile acids and bile acid receptors in metabolic regulation. Physiol rev., 2009; 89:147-191.

7. Ponziani F, Pompili M, Di Stasio E, Zocco M, Gasbarrini A, Flore R. Subclinical atherosclerosis is linked to small intestinal bacterial overgrowth via vitamin $\mathrm{k} 2$-dependent mechanisms. World $\mathrm{j}$ gastroenterol., 2017; $23: 1241-1249$.

8. Thomas C, Auwerx J, Schoonjans K. Bile acids and the membrane bile acid receptor tgr 5 - connecting nutrition and metabolism. Thyroid 2008;18: 167-174.

9. Kvit K., Kharchenko N. Gut microbiota changes as a risk factor for obesity. Wiadomosci lekarskie, 2017, 70(2) : 231-235.

10. Thomas C, Pellicciari R, Pruzanski M, Auwerx J, Schoonjans K. Targeting bile-acid signalling for metabolic diseases. Nat rev drug discov., 2008; 7: 678-693.

11. Trauner M., Claudel T., Fickert P., Moustafa T., Wagner M. Bile acids as regulators of hepatic lipid and glucose metabolism. Dig dis., 2010; 28(1): 220-224 
12. Bures J., Cyrany J., Kohoutova D., Förstl M., Rejchrt S., Kvetina J. Small intestinal bacterial overgrowth syndrome. World jgastroenterol., 2010, $16(24): 2978-2990$.

13. Kvit K., Kharchenko V. Role of gut microbiota in lipid metabolism. Asian journal of pharmaceutical and clinical research, 2018, 11(4) : 4-8.

14. Libby P. History of discovery: inflammation in atherosclerosis. Arterioscler thromb vasc biol., 2012, 32(9) : 2045-2051.

15. Dukowicz A., Lacy B., Levine G. Small intestinal bacterial overgrowth. A comprehensive review. Gastroenterol hepatol., 2007, 3(2): 112-122.

16. Chu H., Williams B., Schnabl B. Gut microbiota, fatty liver disease, and hepatocellular carcinoma. Liver research., 2018, 2(1) : 43-51

17. Kvit K., Kharchenko V. The influence of environmental factors on nonalcoholic fatty liver disease and obesity. In : development trends in medical science and practice: the experience of countries of eastern europe and prospects of ukraine. Latvia : izdevnieciba baltija, 2018: 96-115.

18. Muriel Webb, Hanny Yeshua, Shira Zelber-Sagi. Diagnostic Value of a Computerized Hepatorenal Index for Sonographic Quantification of Liver Steatosis Muriel Webb1, Hanny Yeshua 12, Shira Zelber-Sagi. American Journal of Roentgenology., 2009.- 192 (4).-909-914.

19. Rhodes Jm, Middleton P, Jewell Dp. The lactulose hydrogen breath test as a diagnostic test for small-bowel bacterial overgrowth. Scand $j$ gastroenterol., 1979; 14:333-336.

20. Pimentel $\mathrm{M}$, Chow Ej, Lin Hc. Normalization of lactulose breath testing correlates with symptom improvement in irritable bowel syndrome. A double-blind, randomized, placebo-controlled study. Am j gastroenterol., 2003; 98 : 412-419

21. Gasbarrini A, Corazza Gr, Gasbarrini G. Methodology and indications of h2-breath testing in gastrointestinal diseases: the rome consensus conference. Aliment pharmacol ther., 2009; 29 (1) : 1-49.
22. Khoshini R, Dai Sc, Lezcano S. A systematic review of diagnostic tests for small intestinal bacterial overgrowth. Dig dis sci., 2008; 53: 1443-1454

23. Donald Ip, Kitchingmam G, Donald $F$ et al. The diagnosis of small bowel bacterial overgrowth in elderly patients. J am geriatr soc., 1992; 40 : 692-696

24. Riordan Sm, Mciver Cj, Walker BM. The lactulose breath hydrogen test and small intestinal bacterial overgrowth. Am j gastroenterol., 1996; $91: 1795-1803$.

25. Ghoshal U. How to interpret hydrogen breath tests. I neurogastroenterol motil., 2011, 17(3) : 312-317

26. Rezaie A., Buresi M., Lembo A., Lin H., Mccallum R., Rao S. Hydrogen and methane-based breath testing in gastrointestinal disorders: the north american consensus. Am j gastroenterol., 2017, 112(5) : 775-784

27. Jacobs C., Coss Adame E., Attaluri A., Valestin J., Rao S. Dysmotility and ppi use are independent risk factors for small intestinal bacterial and/or fungal overgrowth. Aliment pharmacol ther., 2013, 37(11): 1103-1111.

28. Pourmorady J, Shah E, Rezaie A. Breath testing for small intestinal bacterial overgrowth in irritable bowel syndrome: a meta-analysis. Am j gastroenterol., 2015; $110: 762$.

29. Ghoshal Uc, Ghoshal U, Das K. et al. Utility of hydrogen breath tests in diagnosis of small intestinal bacterial overgrowth in malabsorption syndrome and its relationship with oro-cecal transit time. Indian j gastroenterol., 2006; $25: 6-10$.

\section{Authors' contributions:}

According to the order of the Authorship.

\section{Conflict of interest:}

The Authors declare no conflict of interest.

\author{
CORRESPONDING AUTHOR \\ Khrystyna Kvit \\ Pekarska Str., 69, Lviv, 79010, Ukraine \\ tel: +380674788881 \\ e-mail:akskris88@gmail.com
}

Received: 13.01.2019

Accepted: 01.04.2019 


\title{
COMORBIDITY SEVERITY INDEX AS A NEW TOOL FOR ASSESSMENT OF CO-EXISTING DISEASES IN PATIENTS WITH NON-ALCOHOLIC FATTY LIVER DISEASE AT THE CARBOHYDRATE METABOLISM DISORDER BACKGROUND AND CONCOMITANT SUBCLINICAL HYPOTHYROIDISM
}

\author{
Snizhana V. Feysa, Ivan V. Chopei \\ UZHHOROD NATIONAL UNIVERSITY, UZHHOROD, UKRAINE
}

\begin{abstract}
Introduction: Non-alcoholic fatty liver disease (NAFLD) is the most common disease which is characterized by comorbidity. However, no comorbidity index for its assessment has been described yet.

The aim of this study was to develop a new index for evaluation of comorbidity in patients with NAFLD.

Materials and methods: 226 patients with NAFLD and associated carbohydrate metabolism disorders were examined. Besides, 60 persons with subclinical hypothyroidism, 30 patients with type 2 diabetes mellitus (T2-DM) and 30 NAFLD patients were examined. 30 healthy persons formed the control group. Clinical diagnoses were based on the laboratory tests and liver sonography. A new index of comorbidity has been used. Calculation of comorbidity severity index (ComSI) includes the possible presence of NAFLD, thyroid disorders, abdominal obesity, dyslipidemia, anemia, chronic complications of T2-DM, aggravated anamnesis.

Results: The contradiction in the calculation of the well-known comorbidity indices values (CIRS - Cumulative illness rating scale, CCI - Charlson's comorbidity index, Kaplan-Feinstein index) was shown. So, their limited suitability for using in patients with carbohydrate metabolism disorders who have NAFLD was detected. According to our results an increasing of patients' age is associated with the increasing of concomitant diseases number and with deteriorating of the patients' general condition, which is reflected in an increasing of the ComSI value. The increasing of concomitant diseases number is associated not only with the higher ComSI, but also with the number of persons with a severe comorbidity according the ComSI value. Instead, the persons without comorbidity (groups 6, 7, 8) were marked as the patients with mild or moderate disease according the ComSI.

Conclusions:The new ComSI index can be used to evaluate the severity of comorbidity in patients with NAFLD.
\end{abstract}

KEY WORDS: non-alcoholic fatty liver disease, comorbidity severity index, ComSI, severity course evaluation

Wiad Lek 2019, 72, 4, 650-653

\section{INTRODUCTION}

Non-alcoholic fatty liver disease (NAFLD) is the most common chronic liver condition worldwide [1]. In the general population, the prevalence of NAFLD has been reported to widely range from $6.3 \%$ to $51 \%$ related to the different population/ethnicity evaluated as well as to the diagnostic methods used to measure the amount of intrahepatic fat content [2-4]. The prevalence of NAFLD among patients with carbohydrate metabolism disorders (type 2 diabetes mellitus - T2-DM; pre-diabetes - PD) is more than 75\% [5]. NAFLD as a liver manifestation of metabolic syndrome (MS) is related to insulin resistance and associated with co-existing cardiovascular diseases, chronic kidney diseases, T2-DM, obesity. Approximately $90 \%$ of patients with NAFLD have more than one component of MS and about one-third of patients meet the criteria of MS [6]. That is why the NAFLD is a typical example of comorbidity.
Comorbidity has been defined as the "existence or occurrence of any additional entity during the clinical course of a patient who has the index disease under study". Comorbidity (multimorbidity) is considered to be one of the important problems of modern medicine, since the combination of diseases that compete in its diagnostic and prognostic significance requires the appointment of many (often incompatible) drugs [7]. This fact leads to polypharmacy and, due to the possibility of interactions between drugs, often changes the response to therapy, reducing the results of treatment [8].

The use of different comorbidity indices was proposed for standardization of the combined diseases researches. 12 methods of comorbidity estimation [9] have been described, each of which has its advantages and disadvantages. The most popular and well-known among them are Cumulative illness rating scale (CIRS), Kaplan-Feinstein index, Charlson comorbidity index 
(CCI), multimorbidity index (MMI). However, there is no perfect index that can measure comorbidity. The Medline database (English-language segment) does not contain information about using of comorbidity indices to determine the severity of the NAFLD patients' condition. The Kaplan-Feinstein index, which is designed to evaluate the comorbidity in patients with T2-DM, also does not include the possible presence of NAFLD which is very often combined with T2-DM. Such disorders as possible thyroid disorder, hyperglycemia (PD), dyslipidemia, anemia, hyperuricemia, which aggravate patient's condition and decrease the effectiveness of treatment are also not taken into account.

The wideworld prevalence of NAFLD and its frequent combination with hypothyroidism [10], including subclinical ones, as well as the absence of comorbidity indices that take into account the presence of these diseases, necessitate the development of a new tool for assessing the health status of such patients.

\section{THE AIM}

The aim: to develop a new method for evaluating comorbidity in patients suffering from NAFLD, by improving the Kaplan-Feinstein scale, adapting it to a greater number of possible comorbid states.

\section{MATERIALS AND METHODS}

This study is a part of common scientific theme of Therapy and Family Medicine Department «Optimization of prevention and treatment of obesity and diabetes mellitus in cases of Helicobacter pylori associated diseases». The article is also a part of scientific research work for obtaining a Doctor of Medicine degree "Non-alcoholic fatty liver disease and concomitant subclinical hyperthyroidism". The study was carried out in accordance with the requirements of the Helsinki Declaration. The Ethical Committee of the Therapy and Family Medicine Department approved the study protocol, and informed consent was obtained from the participants.

226 patients with NAFLD and carbohydrate metabolism disorders were examined. Diagnosis of T2-DM or PD were confirmed according to the criteria of American Association of Clinical Endocrinologists and American College of Endocrinology (ACE / ACE) (2015 p.) [11]. Criteria of pre-diabetes include the following: increasing fasting plasma glucose to $5.6-6.9 \mathrm{mmol} / \mathrm{l}$; impaired glucose tolerance: fasting plasma glucose level $\leq 7.0$ $\mathrm{mmol} / \mathrm{l}$, 2-hour postprandial glucose level (random plasma glucose) $7.8-11.0 \mathrm{mmol} / \mathrm{l}$, HbA1C $5.7-6.4 \%$. The diagnosis of NAFLD [3] was based on the results of abdominal ultrasonography, after excluding heavy alcohol consumption, and viral, or other liver diseases. NAFLD patients were subjected to a full assessment of medical history, physical examination, abdominal ultrasonography as well as routine laboratory tests. Assessment of thyroid function was performed using the following: thyroid stimulating hormone (TSH), free serum tri-iodothyronin (FT3) and free serum thyroxine (FT4) were measured by the method of immuno-chemoluminescence using automatic laboratory system Roche Hitachi Cobas e411 (Switzerland, Japan). The following interpretation of TSH was used: level of TSH from 0.4 to $4.0 \mathrm{mU} / \mathrm{l}$ describes normal thyroid function, i.e. euthyroidism; level of TSH more than $4 \mathrm{mU} / \mathrm{l}$ is considered to be a clinical manifestation of hypothyroidism; level of TSH from 4.01 to 10.0 $\mathrm{mU} / \mathrm{l}$ detects subclinical hypothyroidism $(\mathrm{SH})$; increase of TSH more than $10 \mathrm{mU} / \mathrm{l}$ shows manifestative (overt) hypothyroidism $(\mathrm{OH})$.

According to the thyroid function all the patients were divided into some clinical groups. The first group consisted of 32 patients with NAFLD, T2-DM and concomitant subclinical hypothyroidism (NAFLD+T2-DM+SH), the second group included 40 patients with NAFLD at the background of pre-diabetes and concomitant SH (NAFLD+PD+SH). The 73 patients with NAFLD, T2-DM and normal thyroid function belonged to the third group (NAFLD+T2-DM+Euthyroid), and 55 patients with NAFLD at the background of pre-diabetes and normal thyroid function were included into the forth group (NAFLD+P$\mathrm{D}+$ Euthyroid). The fifth group consisted of 26 patients with NAFLD at the background of T2-DM or PD and concomitant overt hypothyroidism (NAFLD+T2-DM/DM+OH). The 60 persons with $\mathrm{SH}$ formed the sixth group. The seventh group consisted of 30 euthyroid patients suffering from T2-DM without NAFLD, the $8^{\text {th }}$ group was formed by NAFLD patients without T2-DM or PD. The control group consisted of 30 almost healthy persons (without NAFLD, T2-DM or PD), there were no statistically significant difference between the patients and the controls regarding age and sex.

The Kaplan-Feinstein index and a new Comorbidity Severity Index (ComSI) were calculated for each examined patient. To calculate ComSI, the Kaplan-Feinstein index was used after its supplementing by the following pathological conditions: NAFLD; thyroid gland disorders (hypothyroidism, including subclinical; hyperthyroidism); abdominal obesity (waist circumference over $80 \mathrm{~cm}$ in women and more than $94 \mathrm{~cm}$ in men and / or body mass index greater than 30); dyslipidemia; anemia; diabetic microangiopathy (retinopathy, nephropathy); diabetic neuropathy; presence of acute cerebrovascular accident and / or acute myocardial infarction, pulmonary artery thromboembolism in the anamnesis; allergic diseases; connective tissue disease (systemic diseases).

\section{METHODIC OF CALCULATING ComSI}

To calculate the index, we should evaluate the severity of all diseases and pathological conditions in the patient according the following score: "0" - no disease, " 1 " - disease at the preclinical stage, subclinical condition or mild course, "2" - moderate disease compensated or subcompensated by medication, " 3 " is a serious illness in the stage of subor decompensation despite the treatment by medications 
Table I. The course severity of comorbidity (according to ComSI) for patients of different clinical groups

\begin{tabular}{|c|c|c|c|c|c|c|}
\hline $\begin{array}{l}\text { Clinical groups of } \\
\text { patients }\end{array}$ & $\mathbf{n}$ & $\begin{array}{l}\text { Mean } \\
\text { ComSI }\end{array}$ & $\begin{array}{c}\text { Mild severity } \\
\text { (ComSI } \leq 10) \\
(\mathrm{n} ; \%)\end{array}$ & $\begin{array}{c}\text { Moderate severity } \\
\text { (ComSI 11-20) } \\
\text { (n; \%) }\end{array}$ & $\begin{array}{l}\text { Severe comorbidity } \\
\text { (ComSI 21-35) } \\
\text { (n; \%) }\end{array}$ & $\begin{array}{c}\text { Very severe } \\
\text { comorbidity } \\
\text { (ComSI } \geq 36) \\
(n ; \%)\end{array}$ \\
\hline $\begin{array}{c}\text { Group } 1 \\
\text { (NAFLD+T2-DM+ SH) }\end{array}$ & 32 & $27,7 \pm 3,1$ & $1(3,125 \%)$ & $11(34,375 \%)$ & $18(56,25 \%)$ & $2(6,25 \%)$ \\
\hline $\begin{array}{c}\text { Group } 2 \\
(\mathrm{NAFLD}+\mathrm{PD}+\mathrm{SH})\end{array}$ & 40 & $21,4 \pm 2,8$ & $6(15 \%)$ & $19(47,5 \%)$ & $14(35 \%)$ & $1(2,5 \%)$ \\
\hline $\begin{array}{c}\text { Group } 3 \\
\text { (NAFLD+T2-DM) }\end{array}$ & 73 & $21,8 \pm 2,1$ & $7(9,59 \%)$ & $34(46,58 \%)$ & $30(41,1 \%)$ & $2(2,74 \%)$ \\
\hline $\begin{array}{c}\text { Group } 4 \\
\text { (NAFLD+PD) }\end{array}$ & 55 & $17,5 \pm 2.6$ & $8(14,5 \%)$ & $40(72,7 \%)$ & $7(12,7 \%)$ & 0 \\
\hline $\begin{array}{c}\text { Group } 5 \\
\text { (NAFLD+T2-DM/PD+OH) }\end{array}$ & 26 & $23,5 \pm 3,1$ & 0 & $12(46,15 \%)$ & $12(46,15 \%)$ & $2(7,7 \%)$ \\
\hline Group 6 (SH) & 60 & $5,2 \pm 1,3$ & $55(91,7 \%)$ & $5(8,3 \%)$ & 0 & 0 \\
\hline Group 7 (T2-DM) & 30 & $14,3 \pm 2,7$ & $11(36,7 \%)$ & $18(60 \%)$ & $1(3,3 \%)$ & 0 \\
\hline Group 8 (NAFLD) & 30 & $9,7 \pm 1,3$ & $23(76,7 \%)$ & $7(23,3 \%)$ & 0 & 0 \\
\hline $\begin{array}{c}\text { Control group } \\
\text { of healthy persons }\end{array}$ & 30 & $2,3 \pm 0,2$ & 30 (100\%) & 0 & 0 & 0 \\
\hline Total account & 376 & & & & & \\
\hline
\end{tabular}

Note: $n$ - number of people in the group

in accordance with the current protocols. After that we should add all the points and evaluate the course severity of the comorbidity according to the obtained index value. Index value less than 10 points indicates mild course of comorbidity and needs to lifestyle modification and glycemic control. Index value from 11 to 20 points indicates moderate course of comorbidity and needs treatment by using medications for diseases which are marked as 2 or 3 point (dominated pathology). Index value from 21 to 35 points indicates severe comorbidity and more than 36 describes very severe course of comorbidity. In these cases, all prescribings should be reviewed in order to avoid polypharmacy, drug interactions and the possible side effects development. Correction of treatment should be done according to cardiovascular risk level.

\section{STATISTICAL ANALYSIS}

The statistical analysis was made using «Statistica 10.0» after making of database in tables Excel.

\section{RESULTS AND DISCUSSION}

The age of the patients that were included in the study varied from 35 to $73(57.8 \pm 4.1)$ years. As the age increased, the number of comorbid diseases increased and the general condition deteriorated. As an example of the ComSi index application, we describe here its calculation for a patient V., aged 46 . The patient has the following diseases: arterial hypertension ( 2 points), heart and vascular diseases (2 points), diseases of the central and peripheral nervous system (1 point), respiratory system diseases (1 point), kidneys problems ( 2 points), digestive system diseases ( 2 points), abdominal obesity ( 3 points), dyslipidemia ( 2 points), anemia (1 point), subclinical hypothyroidism (1 point) and exacerbation of chronic sinusitis and tonsillitis (marked as 2 points in the row "different"). The total value of the index is 21 points, indicating a severe clinical course of comorbid pathology. The treatment of the patient was revised: the main attention was paid to the abdominal obesity treatment, the recommendations for the elimination of modified cardiovascular risk factors were made, and medical treatment with taking into account possible risk of side effects development and drug interactions was recommended.

The calculation of other comorbidity indices was carried out for the same patient V., 46 years old. His CIRS index was 17 and pointed to moderate comorbidity. The calculation of the Kaplan-Feinstein index gave 14 points, indicating the patient's mild comorbidity. Concomitant hypothyroidism, II degree of obesity and dyslipidemia are serious pathological conditions in case when patient suffer from subcompensated diabetes mellitus and non-alcoholic steatohepatosis. However, during calculating of Kaplan-Feinstein index, these factors have been indicated only as 1 point (as "different"), resulting in a comorbidity of this patient was assessment as "light" or "mild" with a value of index 14. At the same time, the Charlson Index has been calculated as 5 points, corresponding to severe comorbidity, indicating a $21 \% 10$-year survival rate for such patients.

The course severity of comorbidity (according to ComSI) for patients who were included in our study is illustrated by the Table I. 
As can be seen from Table I, with the increase of the number of concomitant diseases, not only the value of ComSI was increasing, but the number of persons with a severe course of comorbidity was increasing too. Instead, in groups $6,7,8$, where there was no combination of the studied diseases, the index value in majority cases indicated a mild or moderate course of comorbidity

The analyzed example of assessing the state of severity by calculating various comorbidity indexes showed contradictory data. Analyzing the comorbid status of the patient V., 46 years old, by using of the most known international comorbidity scales, we obtained fundamentally different results. Their ambiguity hinders the objective assessment of the patient's condition severity and complicates the prescribing of rational pharmacotherapy. The new index of comorbidity assessment, proposed by us, not only assesses the severity of the condition, but can also be used to determine the further tactics of patient management. The advantages of the ComSI index are the following: index can be used for persons with diabetes, because it takes into account the possible presence of T2-DM chronic complications (microangiopathy, neuropathy), NAFLD, hypothyroidism (including subclinical), anemia (tissue hypoxia worsens the condition of the patient), dyslipidemia (a factor of cardiovascular risk), and also gives the doctor the opportunity to review the treatment management of a comorbid patient taking into account all the factors of comorbidity.

\section{CONCLUSIONS}

Considering the prevalence of non-alcoholic fatty liver disease in patients with diabetes mellitus, the severity of complications and high cardiovascular risk of comorbid patients, taking into account the disadvantages of existing methods for assessing the severity of the disease and the benefits of the proposed method, it is advisable to implement the new comorbidity index, which is unique for such a contingent of patients, into practice.

\section{REFERENCES}

1. BellentaniS. The epidemiology of non-alcoholic fatty liver disease. Liver Int. 2017;37(1):81-84. Doi: 10.1111/liv.13299.

2. Buzzetti E, Pinzani M, Tsochatzis EA. The multiple-hit pathogenesis of non-alcoholic fatty liver disease (NAFLD). J Metabol. 2016;65(8):10381048. Doi:10.1016/j.metabol. 2015.12.012.
3. Clinical Practice Guidelines for the management of non-alcoholic fatty liver disease. Clinical recommendations of EASL-EASD-EASO. J Hepatol. 2016;64(6):1388-1402. Doi: 10.1016/j.jhep.2015.11.004.

4. Perazzo H, Dufour JF. The therapeutic landscape of non-alcoholic steatohepatitis. Liver Int. 2017;37(5):634-647. Doi: 10.1111/liv.13270.

5. Hazlehurst JM, Woods C, Marjot T et al. Non-alcoholic fatty liver disease and diabetes. J Metabol. 2016;65(8):1096-1108. Doi:10.1016/j. metabol.2016.01.001.

6. Ballestri S. Nonalcoholic fatty liver disease is associated with an almost two-fold increased risk of incident type 2 diabetes and metabolic syndrome. Evidence from a systematic review and meta-analysis. J Gastroenterol Hepatol. 2016;31(5):936-944. Doi: 10.1111/jgh.13264.

7. Campbell-Scherer D. Multimorbidity: a challenge for evidence-based medicine. Evid Based Med. 2010;15:165-166.

8. PatelPJ, HaywardKL,RudraRetal.Multimorbidityand polypharmacyindiabetic patients with NAFLD: Implications for disease severity and management. Med Baltimore. 2017;96(26):e6761. Doi: 10.1097/MD.0000000000006761.

9. Fawad Aslam, Nasim Ahmed Khan. Tools for the assessment of comorbidity burden in rheumatoid arthritis. Front Med (Lausanne) 2018;5:39. Doi: 10.3389/fmed.2018.00039.

10. Arafat Kassem, Farag Khalil, Mokhtar Ragab Ramadan, et al. Association and impact of non-alcoholic fatty liver disease on thyroid function. Int. J Curr Res Med Sci. 2017;3(7):94-107.DOl: http://dx.doi.org/10.22192/ ijcrms. 2017.03.07.016.

11. Handelsman Y, Bloomgarden ZT, Grunberger G et al. American association of clinical endocrinologists and american college of endocrinology-clinical practice guidelines for developing a diabetes mellitus comprehensive care plan-2015. Endocr Pract. 2015;21(1):1-87. Doi: 10.4158/EP15672.GL.

\section{Authors' contributions:}

According to the order of the Authorship.

\section{Conflict of interest:}

The Authors declare no conflict of interest.

\author{
CORRESPONDING AUTHOR \\ Snizhana V. Feysa \\ Uzhhorod National University \\ Sobranecka, 148, 88017, Uzhhorod, Ukraine \\ tel: +380505600847 \\ e-mail:snizhana.feysa@uzhnu.edu.ua
}

Received: 10.02 .2019

Accepted: 05.04.2019 


\title{
THE LEVEL OF SOME HORMONES IN THE BLOOD WOMEN WITH ENDOMETRIOSIS WHICH ASSOCIATED WITH INFERTILITY
}

\author{
Oksana V. Bakun, Oksana I. Yurkiv, Ksenia V. Slobodian, Oksana V. Kolesnik, Aliona V. Maruschak \\ HIGHER STATE EDUCATIONAL INSTITUTION OF UKRAINE"BUKOVINIAN STATE MEDICAL UNIVERSITY", CHERNIVTSI, UKRAINE
}

\begin{abstract}
Introduction: The work has been dedicated the study of pituitary hormone concentration in the blood of women with endometriosis-associated infertility on 2-3 days of the menstrual cycle and the day of the puncture of ovarian stimulation superovulation in the cycle.

The aim of our study was to examine the concentration of pituitary hormones in the blood of women with endometriosis associated with infertility.

Materials and methods: For the purpose of the research we have conducted a special study of protein (lutropin - LH, folitropin -FSH) hormones level in the blood plasma of women with endometriosis associated with infertility, which formed the main group of 20 people. Similar studies of protein hormones level were performed in the control group, which made somatically healthy women of reproductive function preserved, whose age corresponded to the age of patients of the main group.

The value of $p$ (authenticity difference) was determined by Student's table-Fischer. Differences between contrasting averages were considered significant at $p<0.05$.

Results and conclusions: Analized the results of our research stated that women with endometriosis associated with infertility 2-3 days of the menstrual cycle endocrine function of gonadotropocites anterior pituitary did not differ from that of the control group. This fact appeared to have an additional criteria for the formation of a main group. In patients with endometriosis associated with infertility found significant violation of rhythm and secretion of blood gonadotropin hormones that are proportionate to the degree of severity of the disease.
\end{abstract}

KEY WORDS: pituitary hormones lutropin, folitropin, infertility, endometriosis

Wiad Lek 2019, 72, 4, 654-656

\section{INTRODUCTION}

Most authors consider that the products lutropina (LH) and folitropi (FSH) is different types of cell functional activity which is controlled by a common releasing hormone [1].

Despite the existence of a general stimulator of the hypothalamic gonadotropin products, the degree of response of the pituitary to effect uniform for LH and FSH $[2,3]$. These differences are found in the analysis of the dynamics of gonadotropin secretion during the menstrual cycle. The secretion of FSH are known to actively growing at the beginning of the menstrual cycle, so that the value of the basal secretion of the hormone in the early foliculin phase of the cycle several times higher than that in the luteal phase [4]. In preovulation period under the influence of higher concentrations of estradiol concentration of FSH falls, then there ovulatory hormone release. In contrast, $\mathrm{FSH}, \mathrm{LH}$ secretion increases slightly at the beginning of the cycle and is virtually identical to the luteal phase [3]. One of the reasons disorders inducing folliculogenesis in vitro fertilization programs are spontaneous $\mathrm{LH}$ secretion peak, accompanied by accelerated maturation of oocytes and consequently the start of luteinization before the estimated time of ovulation $[5,6]$. This may be accompanied by the abolition treatment cycle due to the inability of oocyte insemination or embryo transfer rejection of due to their possible morphological defects $[1,3,7]$.

\section{THE AIM}

The aim of our study was to examine the concentration of pituitary hormones in the blood of women with endometriosis associated with infertility.

\section{MATERIALS AND METHODS}

For the purpose of the research we have conducted a special study of protein (lutropin - LH, folitropin -FSH) hormones level in the blood plasma of women with endometriosis associated with infertility, which formed the main group of 20 people. Similar studies of protein hormones level were performed in the control group, which made somatically healthy women of reproductive function preserved, whose age corresponded to the age of patients of the main group.

In the study (women with infertility) and control groups conducted a special study of protein (lutropin - LH, folitropin -FSH) hormones level in the blood plasma of 2-3-day menstrual cycle - basic and on the day of the puncture of ovarian stimulation cycle in superovulation. The level of hormones measured by ELISA using a set of reagents for quantitative ELISA determination of hormones in blood serum:

- „IFA gonadotropin-FSH”;

- „Gonadotropin-LH ELISA.”

The value of $\mathrm{P}$ (authenticity difference) was determined by Student's table-Fischer. Differences between contrasting averages were considered significant at $\mathrm{P}<0.05$. 
Table I. The concentration of pituitary hormones level in the blood of women on 2-3 days of the menstrual cycle $(M \pm m)$

\begin{tabular}{cccc}
\hline Index & $\begin{array}{c}\text { Main group } \\
(\mathbf{n = 2 0 )}\end{array}$ & $\begin{array}{c}\text { Control group } \\
(\mathbf{n = 2 0 )}\end{array}$ & $\mathbf{p}$ \\
\hline $\mathrm{LH} \mathrm{pg} / \mathrm{ml}$ & $5,8 \pm 1,70$ & $6,22 \pm 1,21$ & $>0,05$ \\
\hline $\mathrm{FSH} \mathrm{pg} / \mathrm{ml}$ & $10,0 \pm 1,10$ & $9,92 \pm 1,03$ & $>0,05$ \\
\hline $\mathrm{LH} / \mathrm{FSH}$ & 0,58 & 0,63 & \\
\hline
\end{tabular}

Table 2. The concentration of pituitary hormones in the blood of women on the day of the puncture of ovarian stimulation superovulation in the cycle $(M \pm m)$

\begin{tabular}{|c|c|c|c|}
\hline Index & $\begin{array}{l}\text { The main group in stimulated cycle } \\
\qquad(n=20)\end{array}$ & $\begin{array}{l}\text { Control group } \\
(n=20)\end{array}$ & $\mathbf{p}$ \\
\hline $\mathrm{LH} \mathrm{pg} / \mathrm{ml}$ & $1,08 \pm 0,06$ & $16,2 \pm 5,27$ & $<0,001$ \\
\hline $\mathrm{FSH} \mathrm{pg} / \mathrm{ml}$ & $10,7 \pm 1,16$ & $7,05 \pm 0,8$ & $<0,05$ \\
\hline
\end{tabular}

\section{RESULTS AND DISCUSSION}

The results that we obtained in the study of basic hormones are presented in Table I.

Analized the results of our research are presented in table I stated that women with endometriosis associated with infertility 2-3 days of the menstrual cycle endocrine function of gonadotropocites anterior pituitary did not differ from that of the control group. This fact appeared to have an additional criteria for the formation of a main group.

LH level at 2-3 second day of the menstrual cycle in women with infertility different from indicators in the control group slightly. LH to FSH ratio in the study and control groups was within 0,58-0,63.

According to the literature $[1,7]$ ratio $\mathrm{LH} / \mathrm{FSH}$ ranges in healthy women within 1.5-2.0. In our patients as the control group and the main factor is now slightly below that can explain the features of the methodology for determining the level of hormones in blood plasma. We used method of determining the amount of hormone $(\mathrm{pg} / \mathrm{ml})$, while in a number of laboratories measured activity in international units (IU / L).

Changes in hormonal profile in women with endometriosis associated with infertility and the control group in the study day puncture of ovarian stimulation superovulation in the cycle shown in Table 2.

Attention is drawn to the fact that our patients at an altitude of superovulation stimulation stated statistically significant reduction in the level of luteinizing hormone $16,2 \pm 5,27$ to $1,08 \pm 0,06 \mathrm{pg} / \mathrm{ml}$.

This reduction in blood lutropin be explained reciprocal dependence between synthesis and activity of estradiol vertical luliberin-lutropin-progesterone.

Along the surveyed women was found a slight increase of folitropin of 7,05 $\pm 0,8$ to $10,7 \pm 1,16$ likely due to circulating levels of outside administered hormone. Value LH / FSH was respectively: 0.1 stimulated cycle; 2.2 in the control group. This is quite important because the normal functioning of the ovaries is possible only at a ratio of LH / FSH 1-1.5.

Reduced secretion of $\mathrm{LH}$ in patients with infertility weakens the predecessor synthesis of steroid hormones. Consequently, reduced production of androgens in the ovary.
It is known [5] that ovulatory peak corresponded almost 6-fold increase in the concentration of estradiol. Increased concentrations of estrogen and could be seen as an incentive to the sharp increase in the secretion of $\mathrm{LH}$ and FSH, which appears on the before of ovulation.

But in our studies LH level, on the contrary, decreased FSH and elevated, suggesting the lack of response to ovarian stimulation, and the possibility of damage to the follicular unit by chronic inflammation and autoimmune process.

Reducing the concentration of LH in patients with infertility of tubal origin in folikulin phase of the menstrual cycle and lack of concentration of FSH lead to a breach of folliculogenesis, ovulation and subsequent rearrangements of secretory endometrium. This, in turn, may still be one of the causes of infertility. Reducing LH can be explained by the fact that necessary for secretion of FSH and LH should pulsing emissions gonadotropin-releasing hormones by hypothalamus is not all gonadotrophic adenohypophysis receptors connected to one pulse of gonadotropin-releasing hormone and adenohypophysis cells are able to respond to further release of gonadotropin-releasing hormone. Due to reduction of LH levels there is blockage of the functional activity of the ovaries, which may be accompanied by a further decline in estradiol concentrations in the blood.

\section{CONCLUSIONS}

Thus, in patients with endometriosis associated with infertility found significant disorders of rhythm and secretion of blood gonadotropin hormones that are proportionate to the degree of severity of the disease. Thus, basal levels of LH and FSH hardly different from the targets, and the foliculin phase of the menstrual cycle decreased concentrations of LH to normal levels of FSH background. However, despite the presence of abnormalities in the secretion of gonadotropin hormones compensation body's response in this disease provide a state of homeostasis because ovulation in $2 / 3$ patients retained, while the reproductive function is much impaired. 


\section{REFERENCES}

1. SmolnykovV.Yu., Fynohenova E.Ya. Ekstrakorporalnoe oplodotvorenye y eho novve napravlianyia v lechenyy zhenskoho besplodyia. Pod red. V.Y. Kulakova, B.V. Leonova. 2000; 91-135

2. Эkstrakorporalnoe oplodotvorenye y eho novbe napravlenyia v lechenyy zhenskoho y muzhskoho besplodyia Pod red. V.Y. Kulakova, B.V. Leonova: MYA, 2000; 781

3. Nazarenko T.A., Durynian E.R., Zuriaeva N.A. Endokrynnoe besplodye u zhenshchyn: dyahnostyka y lechenye. Praktycheskoe rukovodstvo. 2010;80

4. Yavorskaia K.A. Ekstrakorporalnoe oplodotvorenye y eho novye napravlenyia v lechenyy zhenskoho y muzhskoho besplodyia. Pod red. V.Y. Kulakova, B.V. Leonova. 2000; 12: 291-317.

5. Kalynyna E.A. Optymyzatsyia protsedury ekstrakorporalnoho oplodotvorenyia y perenosa embryona pry syndrome polykystoznykh yaychnykov. Probl. reproduktsyy. 2002;(3): 81-83.

6. Leonov B.V., Kulakov V.Y., Fynohenova U.Ya., et al. Yspolzovanye preparata rekombynantnoho FSH (follytropyna- ) pry lechenyy besplodyia v prohrammakh EKO y PE. Akush. y hyn.2001;(6):35-40.

7. Smolnykova V.Yu. Opyt prymenenyia honadolyberyna dyferelyna v prohramme ekstrakorporalnoho oplodotvorenyia. Hynekolohyia.2004;.6 (3): 109-111.

\section{Authors' contributions:}

According to the order of the Authorship.

\section{Conflict of interest:}

The Authors declare no conflict of interest.

\section{CORRESPONDING AUTHOR}

\section{Oksana Bakun}

Bukovinian State Medical University

Pavla Chubinskogo Street 7/12,58000 Chernivtsi, Ukraine

tel: +380505627338

e-mail: kupchank006@gmail.com

Received: 09.03.2019

Accepted: 05.04.2019 
PRACA ORYGINALNA

ORIGINAL ARTICLE

\title{
PSYCHOEMOTIC FEATURES, STATUS OF COGNITIVE FUNCTIONS AND ASSESSMENT OF BRONCHIAL ASTHMA PATIENTS' QUALITY OF LIFE
}

\author{
Valentyna I. Velichko, Yana I. Bazhora, Galyna O. Danilchuk, Larysa I. Kolotvina \\ ODESSA NATIONAL MEDICAL UNIVERSITY, ODESSA, UKRAINE
}

\begin{abstract}
Introduction: The worldwide pandemic of bronchial asthma $(B A)$ is creating severe challenges for health care specialists. Asthma patients feature a number of psycho-emotional and cognitive impairments, mark the reduction of quality of life which limits response to therapy.

The aim: to investigate psycho-emotional features, state of cognitive function and assess bronchial asthma patients quality of life.

Materials and methods: 142 patients (61 men and 81 women) with bronchial asthma aged $19-57$ y.o. were examined. The main group consisted of 78 patients with an uncontrolled course of asthma (UCBA). 64 patients with controlled asthma (CBA) were included in the comparison group. The subjective assessments of quality of life by questionnaire SF-36, assessment of asthma-dependent quality of life (AQLQ) was made. The patients' emotional and psychological profile was assessed using the following tests and scales: MMSE, Montreal Scale for Assessing Cognitive Function, Hospital Alert and Depression (HADS) scale with a qualitative and quantitative assessment of the results.

Results: According to the results obtained, the averaged profiles of the patients' quality of life demonstrated the negative effects of asthma, especially its uncontrolled form. There were statistically significant differences in the quality of life in patients with UCBA according to the five criteria of the MOS SF-36 questionnaire as compared to the CBA group ( physical functioning, role-playing, caused by physical condition, general health, social functioning, viability). A comparison of the specific quality of life with the help of the AQLQ questionnaire revealed a significant negative effect of the uncontrolled course of the illness on the patients' quality of life. The correlation analysis of the relationship between the course of asthma and the parameters of a specific life qality showed a close correlation between the level of asthma control and the overall evaluation of specific quality of life $(r=0,62 ; p<0.001)$. The results of neuropsychological examinations in UCBA patients showed the presence of light predemention cognitive impairments. Manifestations of anxiety-depressive disorders were found in 44 (56.41\%) patients in the main group, while in the comparison group, the symptoms of anxiety and depression were observed in $14(21.88 \%)$ cases. Patients with UCBA noted a higher level of anxiety ( $11.5 \pm 1.2$ versus $6.9 \pm 1.4, p<0.05)$, depression $(8.3 \pm 2.3$ versus $5.6 \pm 3.9)$ on the HADS scale compared with patients with CBA

Conclusion: The psycho-emotional features revealed in UCBA patients can determine the prognosis of the disease and justify the expediency of additional diagnostic and therapeutic psychotherapeutic measures.
\end{abstract}

KEY WORDS: bronchial asthma, cognitive functions, quality of life, anxiety-depressive disorders

Wiad Lek 2019, 72, 4, 657-663

\section{INTRODUCTION}

Travails of patients with chronic somatic diseases are not only corporeal. Any serious and prolonged somatic disease is a significant psycho-traumatic factor that consistently worsens the mental and general health of the patient $[1,2,3]$. At the present time, research the quality of life of patients with various somatic diseases and under the influence of physical, psychological and emotional factors becomes of great importance $[4,5]$. The further increase in BA morbidity rate, chronic-recurrent course of pathology and often inadequate effectiveness of medical treatment require new methods for assessing the health status, determining the degree of effectiveness of their treatment.

It is known that almost all diseases develop gradually through the stages of pre-morphological and premorbid conditions and are a manifestation, result of the reduction of body's adaptive capacity, which $\mathrm{H}$. Selye equated with viability. Under today's conditions, the problem of adaptation to external factors became especially relevant. This is due, in particular, to the poor ecological situation in a number of regions of Ukraine, their radioactive and industrial pollution, and the increase of the negative impact on the person who fell ill of chronic-crisis state of the national economy and politics. The whole complex of these stress factors leads to a further chronization of asthma's course with a tendency to recurrence, to the fall of ability to work, which, in turn, significantly decreases the patients' quality of life (QOL).

Anxiety and mental stress are the result of the prediction of a subjective threat, prediction of a possible traumatic situation and difficulty in creating a "model of the future», which may lead to a lack of one's "route plan" that may depend on individual premorbid personality traits. 
Experts of the international research center of quality of life consider the QOL as integral characteristic of the physical, psychological, emotional and social functioning of the patient, based on his subjective perception $[4,5]$. In turn, the deterioration of mental health as a result of the combined effects of multi-level psychogenic factors negatively affects the course of somatic illness. This creates a «closed circle» of mutual pathoplastic obstruction, which greatly reduces the sanogenic potential of patients, impairs their QOL, and narrows the prospects of recovery [6].

At the same time, the QOL's features in comorbid pathology have not been studied sufficiently: it is unclear how significant is the contribution of the most crucial, from the clinical and pathogenetic point of view, factors (bronchial obstruction, increase in blood pressure, etc.).

That is why the complex assessment and correction of psychopathological manifestations and psychological peculiarities of patients with disabilities due to chronic somatic diseases is not less important than adequate diagnostics and therapy of the proper main somatic disease $[2,3,6]$.

For pulmonary system chronic diseases patients, the most frequent are disturbing (31.6\%) manifestations and two types of personality profiles that are indicative of irritability, anxiety, depression, propensity to complain about state of somatic health, fixation on bodily sensations, asthenicity, vegetative lability, predominantly depressed mood, nervousness, fatigue, intrusive fears for their health, lack of initiative, decreased productivity and self-confidence $[7,8,9,10]$.

Thus, the psychological diagnosis of emotional features, identification and qualification of existing psychopathology, psychological diagnosis, assessment of the patients' QOL can change the mode of medical therapy and the choice of the most effective psychotherapeutic intervention, as an ideal approach to the primary provision of medical care by a family doctor in collaboration with a psychotherapist.

\section{THE AIM}

Therefore, the objective of the work presented is to diagnose psycho-emotional features, state of cognitive functions and assess the quality of life of patients with bronchial asthma.

\section{MATERIALS AND METHODS}

142 patients (61 man and 81 women) with bronchial asthma aged $19-57$ years old were examined. The average age of the subjects was $40.52 \pm 1.09$ years. The total duration of the disease was $13.9 \pm 1.08$ years. The main group consisted of 78 (54.93\%) patients with uncontrolled course of asthma (UCBA). 64 patients (45.07\%) with controlled asthma (CBA) were included in the comparison group. In both groups, women were marginally dominant $(52.56 \%$ and $60.60 \%$, respectively).

For the purpose of subjective evaluation of the patients' asthma-dependent QOL, the MOS SF-36 (short form of health assessment) questionnaire and the Asthma Quality of Life Questionnaire (AQLQ) were used.

The patients' emotional and psychological profile was assessed using the following tests and scales: MMSE Score, Montreal Scale for Assessing Cognitive Function (Mosayev), Hospital Alert and Depression (HADS) with a qualitative and quantitative assessment of the results.

The MOS SF-36 questionnaire consisted of 36 questions in 8 areas: Physical Functioning (PF); Role-based functioning, conditioned by physical condition (RP), - Limitation of the daily activity associated with health problems; general health (GH); pain intensity (BP); social functioning (SF) - limitation in social activity due to physical or emotional problems; emotional functioning (RE) - restriction of the usual activity connected with emotional problems, viability (VT) (level of energy, presence of fatigue); mental health assessment $(\mathrm{MH})$. In addition to these areas, two scales were used: the Physical Health Component (PCS) and the Psychological Health Component (MCS).

The AQLQ questionnaire belongs to the category of special tools for QOL assessing, exclusively for patients with asthma. The questionnaire contains 32 questions, grouped into 4 blocks that affect the most significant for patients with asthma life areas ( symptoms, activity limitation, emotional sphere, environmental impact). Depending on how often during the last two weeks the patient experienced some or all of asthmatic symptoms, a score was made on Likert's scale from 1 (all time) to 7 (never). Indicators for each section were obtained by calculating the average. The total QOL was calculated as the average of all sections. The number of points is directly proportional to QOL, that is, the higher the indicator of QOL, the higher it is.

Also, the control of asthma course was assessed by subjective methods: history taking (duration of the disease, causes of exacerbations, frequency of exacerbations, frequency of appeals to the doctor), analysis of complaints (the presence of difficult breathing, breathlessness, wheezing, cough, sputum number, color), analysis of therapies used (dose, multiplicity, duration of administration of each agent), physical examination for the presence of concomitant pathology (cardiovascular system, gastrointestinal tract, genitourinary system, endocrine system), as well as filling the ACT questionnaire (Asthma Control Test), which is a short questionnaire and contains 5 questions with a 5 -point evaluation of responses. The sum of 25 marks means complete control of asthma, 20-24 - incomplete control, 19 points or less - indicates lack of control. The ACT assessed the level of asthma control over the last 4 weeks.

Mathematical processing of results is carried out with the help of Statistica StatSoft Inc. computer packages and Excel $\mathrm{XP}$ for Windows on a personal computer using parametric and nonparametric computing methods.

\section{RESULTS AND DISCUSSION}

The results of our study showed that 72 patients (92.31\%) of the main group and $29(45.31 \%)$ of the comparison group have a comorbidity. The most commonly occurring 
Table I. Indicators of quality of life in patients with bronchial asthma with different levels of control according to the questionnaire MOSSF-36 (M $\pm \mathrm{m}$ )

\begin{tabular}{ccc}
\hline & & Groups \\
\cline { 2 - 3 } Indicator & $\begin{array}{c}\text { Main group } \\
(\mathbf{U C B A}, \mathbf{n = 7 8 )}\end{array}$ & $\begin{array}{c}\text { Comparison group } \\
\text { (CBA, } \mathbf{n = 6 4 )}\end{array}$ \\
\hline $\mathrm{PF}$ & $36.4 \pm 2.8^{*}$ & $65.7 \pm 3.2$ \\
\hline $\mathrm{RP}$ & $22.8 \pm 4.1$ & $47.2 \pm 4.3$ \\
\hline $\mathrm{BP}$ & $66.6 \pm 5.6$ & $72.9 \pm 6.4$ \\
\hline $\mathrm{GH}$ & $31.5 \pm 3.3^{*}$ & $56.3 \pm 2.9$ \\
\hline $\mathrm{VT}$ & $32.1 \pm 3.4^{*}$ & $46.4 \pm 2.2$ \\
\hline $\mathrm{SF}$ & $48.3 \pm 3.0^{*}$ & $64.7 \pm 4.6$ \\
\hline $\mathrm{RE}$ & $37.2 \pm 6.2$ & $52.5 \pm 8.9$ \\
\hline $\mathrm{MH}$ & $39.1 \pm 3.1$ & $46.8 \pm 4.2$
\end{tabular}

Note: * changes significant with the indicators of CBA patients $(p<0.05)$

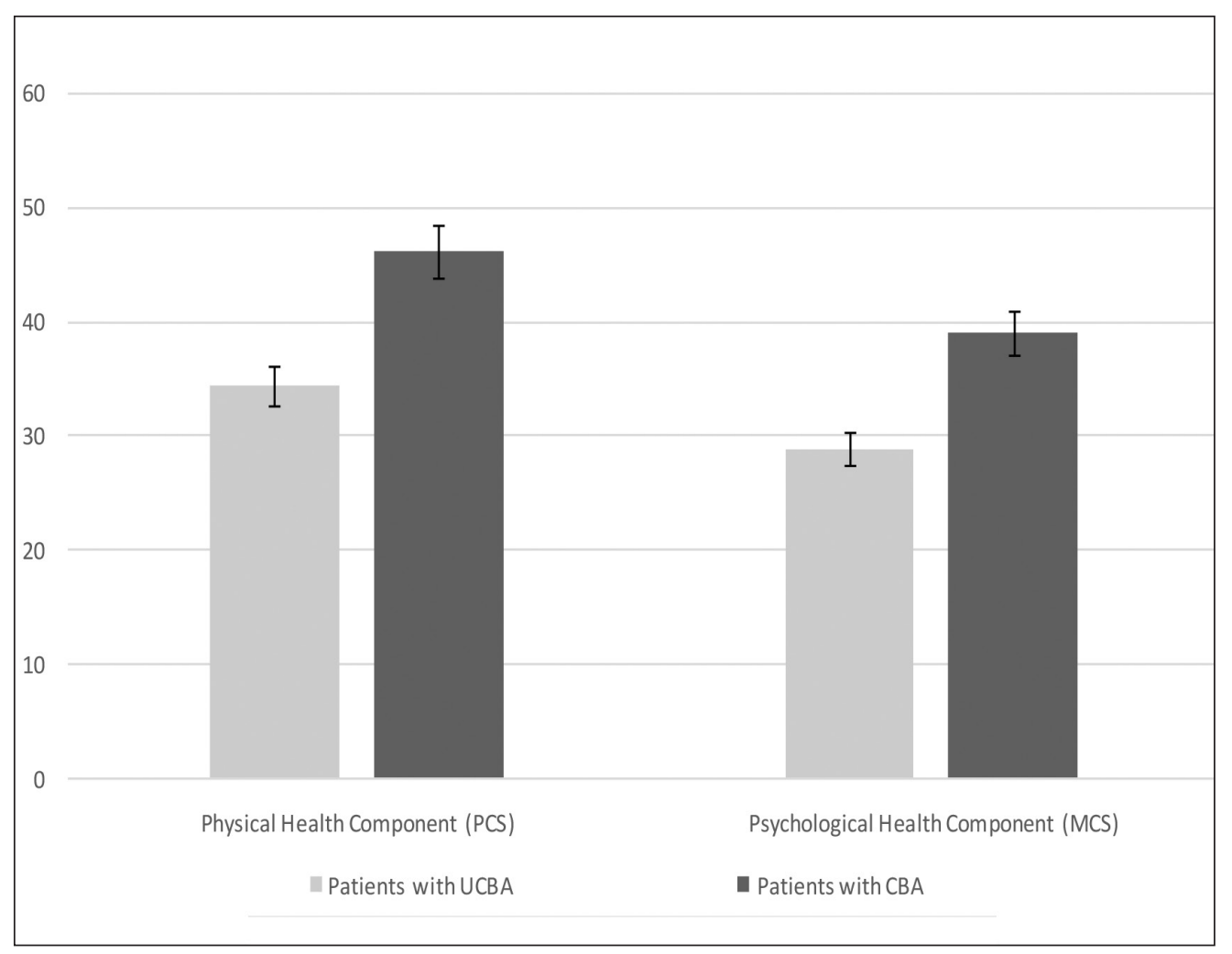

Fig.1. Integral indicators of quality of life

concomitant disease is overweight or obesity.

The main group was diagnosed with obesity in $41.03 \%$ of cases (32 patients) versus $10.94 \%$ of cases ( 7 patients) in the comparison group. Excessive body mass was observed approximately equally: in the main group - 41.03\% (32 patients), in the comparison group - 42.19\% (27 patients). More than three concomitant diseases were observed in 27 (34.61\%) patients in the main group and only in $4(6.25 \%)$ in the comparison group.

Hypertension was in the second place among the comorbid pathology, which aggravated the course of asthma. In the main group there were 37 patients $(47.43 \%)$ and 5 patients in combination with IHD, in the comparison group - there were 22 patients ( $34.38 \%$ ). UCBA patients often suffered GERD - in $42.31 \%$ of cases, compared with $29.69 \%$ in the comparison group.

Chronic obstructive lung disease was found in 7 main group patients $(8.97 \%)$. Almost identically frequent was polyposis rinosinusitis and allergic rhinitis ( almost $28 \%$ of cases in both groups). Diabetes mellitus was detected in 2 patients $(2.56 \%)$ in the main group. Approximately the same frequency was observed in a cohort of patients with severe asthma symptoms suspected of obstructive sleep apnea syndrome, were detected in $31 \%$ of cases, while in polysomnography, it was detected in $88-92 \%$ of patients.

The socio-epidemiological significance of BA in combi- 
Table II. Indicators of specific quality of life in patients with bronchial asthma with different levels of disease control by questionnaire $A Q L Q(M \pm m)$

\begin{tabular}{ccc}
\hline & & Group \\
\cline { 2 - 3 } Scale & $\begin{array}{c}\text { Main group } \\
\text { (uncontrolled BA, } \mathbf{n = 7 8 )}\end{array}$ & $\begin{array}{c}\text { Group of comparison } \\
\text { (controlled BA, } \mathbf{n = 6 4 )}\end{array}$ \\
\hline Activity & $3.9 \pm 0.2^{*}$ & $5.9 \pm 0.5$ \\
\hline Symptoms & $3.4 \pm 0.2^{*}$ & $6.1 \pm 0.8$ \\
\hline Emotions & $3.6 \pm 0.3^{*}$ & $5.3 \pm 0.2$ \\
\hline Surrounding & $3.3 \pm 0.1^{*}$ & $5.4 \pm 0.6$ \\
\hline General quality of life & $3.6 \pm 0.2$ & $5.8 \pm 0.3$ \\
\hline
\end{tabular}

Note: * - changes are probable compared to those in patients with CBA $(p<0.05)$

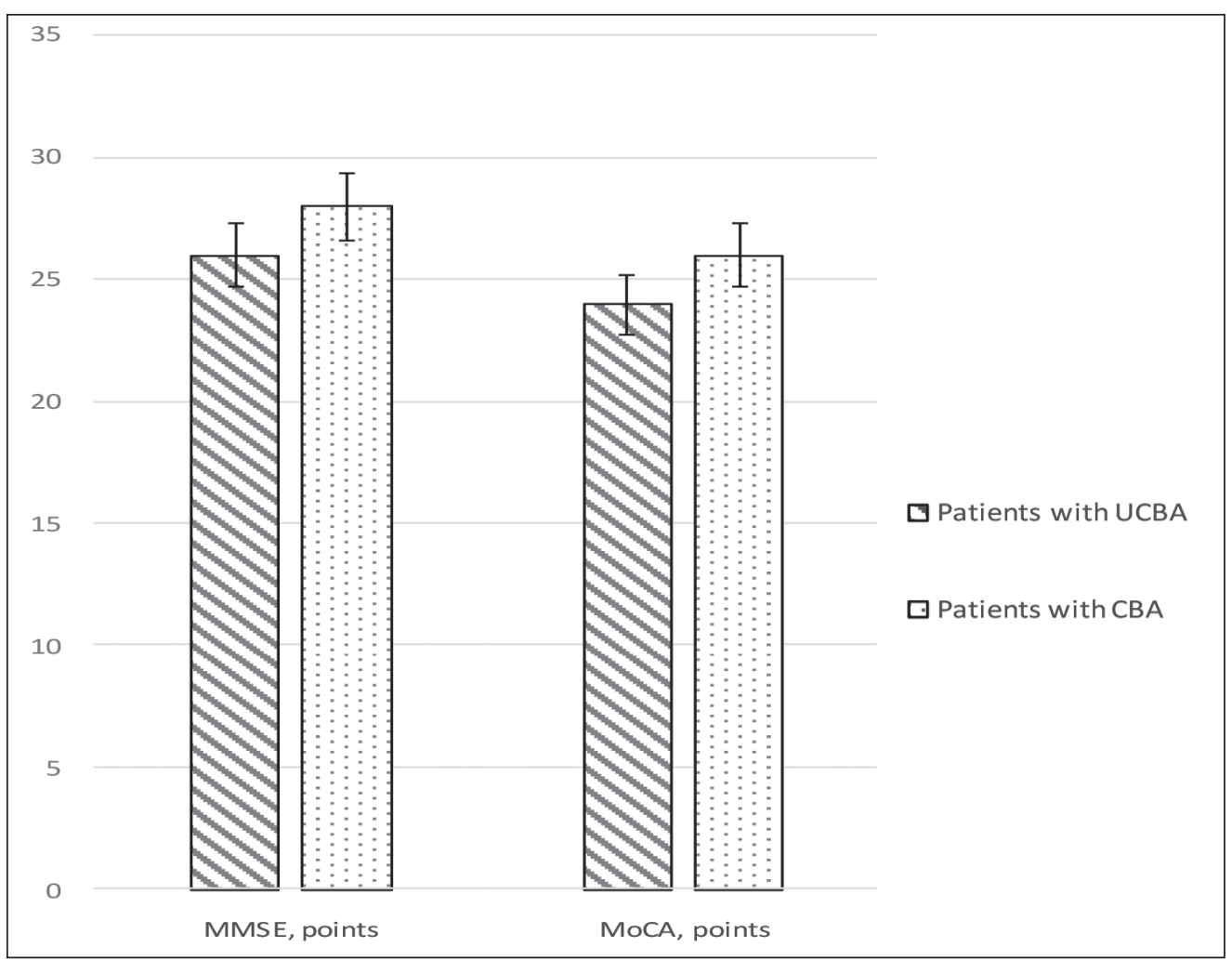

Fig. 2. Indicators of cognitive function in patients with bronchial asthma with different levels of disease's control

nation with comorbidity is not limited to adverse effects. Equally important is the decrease in QOL, an integral indicator of the degree of adaptation to the disease, the ability to perform the usual functions at work and at home.

The results of asthma patients QOL study with varying degrees of control are presented in Table 1. According to its data, the averaged profiles of the patients under study QOL demonstrated the negative impact of asthma, especially of its uncontrolled form. There are statistically significant differences in the quality of life in patients with UCBA according to the five criteria of the questionnaire MOSSF-36 in comparison with CBA group (physical functioning; role function, caused by physical condition, general health, social functioning, viability). Thus, the index of physical functioning (PF) in patients with CBA amounted to $65.7 \pm 3.2$ points, whereas in patients with UCBA it was 1.8 times lower $-36.4 \pm 2.8$ points. The daily viability (RP) also suffered in both groups of the patients under examination and was reduced to $22.8 \pm 4.1$ points in the main group and to $47.2 \pm 4.3$ in the comparison group. The most significant decline in the daily viability was observed in patients with UCBA.

Pain is not a hallmark of asthma, so the frequency of "pain intensity" (BP) was almost the same in the range $(66.6 \pm 5.6)$ in patients in the main group and $(72.9 \pm 6.4)$ in patients in the group comparison ( $p>0.05)$.

The uncontrolled course of BA imposes a significant limitation on the viabilbity (VT) of patients, which is manifested by a substantial decrease in this index in patients in the main group (32.1 \pm 3.4 points) compared with the group of CBA patients $(46.4 \pm 2.2)(\mathrm{p}<0.05)$. Loss of viability should be considered as a risk factor for the development of various depressive states associated with asthma, especially in an uncontrolled course. 


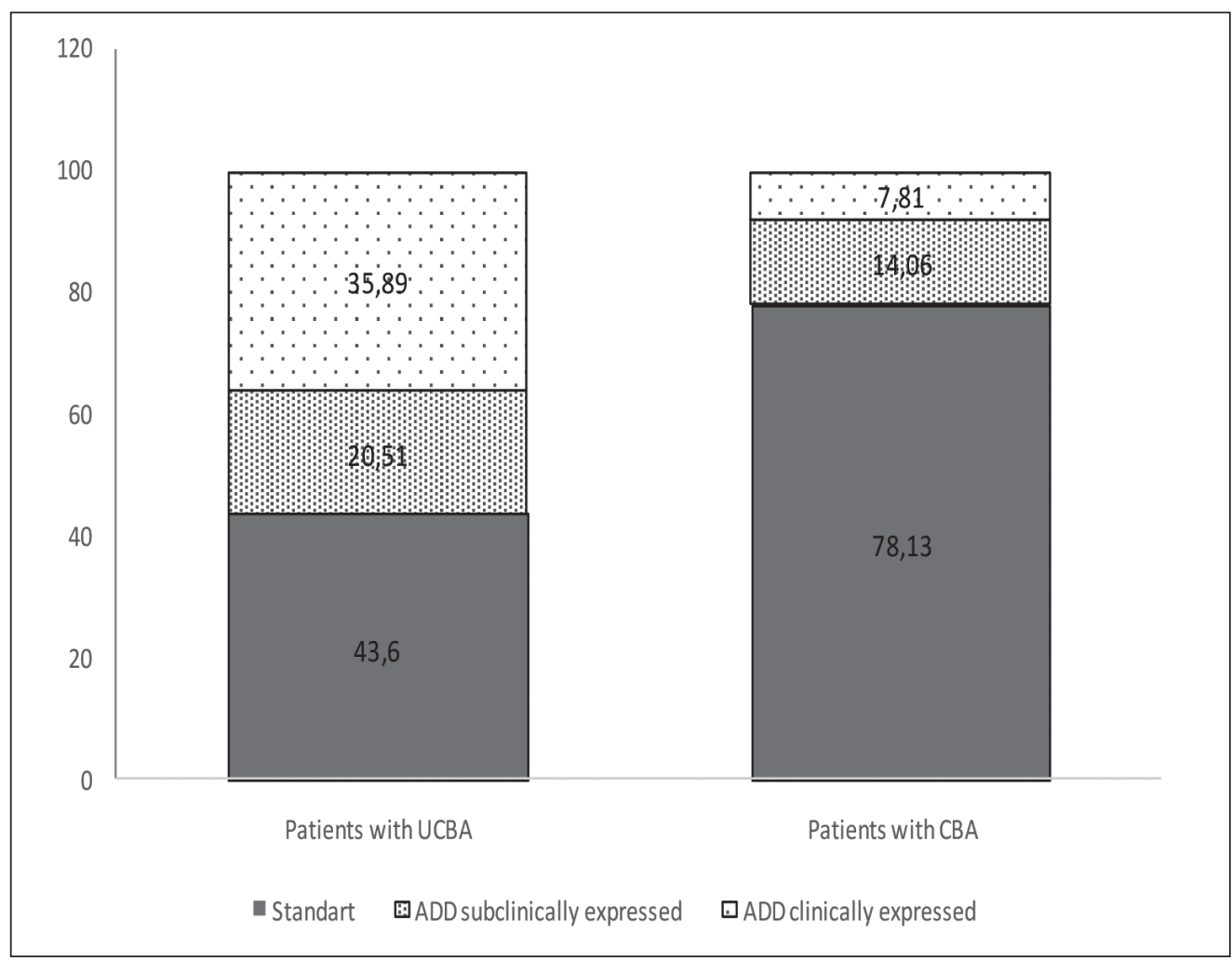

Fig. 3. Anxiety-depressive disorders in patients with bronchial asthma of different levels of disease control according to HADS questionnaire.

In both experimental groups there is a decrease in social activity of patients (SF), which indicates that patients are unable to fully socialize in accordance with age, social status and needs. However, the most pronounced decrease in this indicator was observed in patients with UCBA.

Patients in the main group are also found to be lower than those in the comparison group. Subjective perceptions of BA patients generalized state of health $(\mathrm{GH})$, was lower in main group $-1.5 \pm 3.3$ and $56.3 \pm 2.9$ points $(\mathrm{p}<0.05)$ respectively. Mental status (MH) was lowered in patients of both groups: in the main group to $(39.1 \pm 3.1)$ points, in the comparison group to $(46.8 \pm 4.2)$ points $(\mathrm{p}>0,05)$. The decrease of this indicator was due to emotional problems, as in the main group and in the comparison group (37,2 \pm $6,2)$ and $(8,3 \pm 16,7)$ points respectively $(p>0,05)$.

The integral indices of PCS and MCS were statistically significantly different in the groups of patients under study the worst state of the physical and mental health component of the main UCBA group (Fig. 1).

Correlation analysis between the values of the parameters of QOL and the level of control of asthma showed the presence of clinically and statistically significant relationship between them. The most strong connections with the level of control over BA are defined in the parameters of "viability" $(\mathrm{r}=0.63, \mathrm{p}<0.0001)$ and "physical activity" $(\mathrm{r}=0.61, \mathrm{p}<0.001)$. Other parameters of QOL have less binding power with the level of asthma control, but also are influential: the role of physical problems in limiting life - $(\mathrm{r}=0.46, \mathrm{p}<0.001)$; emotional problems in limiting life $-(\mathrm{r}=0.42, \mathrm{p}<0.001)$, general health $-(\mathrm{r}=0.39$, $\mathrm{p}<0.0001)$, mental health $-(\mathrm{r}=0.36 \mathrm{p}<0.0001)$ and social activity - $(\mathrm{r}=0.32, \mathrm{p}<0.001)$.

A comparison of the specific QOL index with the help of the AQLQ questionnaire revealed a significant negative impact of the uncontrolled course of the illness on the QOL of patients (Table 2). Uncontrolled asthma patients activity was touched to a lesser extent, Thus, the indicator of activity limitation in the main group equals $(3.9 \pm 0.2)$ points in comparison with the same indicator of patients in the comparison group $(5.9 \pm 0.5)$ points $(p<0.05)$. Indicators of symptoms, emotions, environments, and general QOL in UCBA group were significantly lower than in CBA group ( $<<0.05 ; \mathrm{p}<0.05 ; \mathrm{p}<0.05 ; \mathrm{p}<0.05)$.

The correlation analysis of the relationship between the course of asthma and the parameters of specific QOL indicates a close correlation between asthma's control level and the overall assessment of specific QOL $(\mathrm{r}=0.62 ; \mathrm{p}<0.001)$.

Thus, the dependences obtained have determined the possibility of some QOL parameters searching, that have independent predictive value and are informative factors of the prognosis of asthma control level.

Neuropsychological examinations showed that there were no cognitive impairments in CBA patients: the total score on the MMSE scale was 28 (27-29), on the MoCA scale it equaled $26(26 ; 26)$ (Fig. 2). The results of neuropsychological examinations in UCBA patients showed the presence of slight predemention cognitive impairments. The overall score on the MMSE scale was significantly different from the calculated norm ( 28 -30 points) - 26 ( 25 ; 27) points $(\mathrm{p}<0.001)$ due to the subtests "attention and 
count" and "memory" ( $\mathrm{p}<0.05)$. The difference between the scores was statistically significant on MoCA scale, too: $24(24 ; 25)$ points $(\mathrm{p}<0,05)$ (Figure 2$)$. The formation of moderate cognitive impairments in UCBA patients may be due to frequent hypoxia and with a more common prevalence of comorbidity among these patients.

The psychological testing with the use of the questionnaire "Hospital scale of anxiety and depression" in the general population of asthma examined patients revealed anxiety and depression in $40.84 \%$ of cases.

UCBA patients demonstrated a higher level of anxiety (11.5 \pm 1.2 versus $6.9 \pm 1.4, p<0,05)$, depression $(8,3 \pm 2,3$ versus 5,6 $\pm 3,9$ ) on HADS scale compared with CBA patients.

Manifestations of anxiety-depressive disorders (ADD) were detected in $44(56.41 \%)$ patients of the main group, while in the comparison group, the symptoms of ADD were observed in $14(21.88 \%)$ cases.

At the same time, clinically expressed ADD according to the scale HADS in the main group were observed in $35.89 \%$ of patients, subclinically expressed - in $20.51 \%$ (mean score $21.7 \pm 1.4$ and $9.4 \pm 1.2$, respectively), whereas in the second group, the symptoms of clinical ADD occurred only in $7.81 \%$ of cases, subclinical - in $14.06 \%$ of patients (mean score $16.1 \pm 1.1$ and $8.2 \pm 1.3$, respectively) (Fig. 3).

The average inverse correlation between depression severity and the integral index of $\mathrm{QOL}(\mathrm{r}=-0,67, \mathrm{p}<0.001)$, as well as between the severity of depression and the patients' assessment of asthma control in asthma control test have been established, i. e. the more pronounces is depression, the worse is self - esteem of BA control level $(r=-0.49$, $\mathrm{p}<0.001$ ).

Thus, the identified psycho-emotional features in patients with UCBA can determine the prognosis of the course of the disease and justify the expediency of additional diagnostic and psychotherapeutic measures.

\section{CONCLUSIONS}

1. The influence of clinical manifestations on the subjective reflection of health in patients with asthma uncontrolled course was reflected by changes in the physical and mental component by the questionnaire MOS SF- 36 . It is the reduction of viability, physical and social functioning is to be considered as a risk factor for the development of various depressive states associated with asthma and is an informative factor for predicting the level of disease control $(\mathrm{r}=0.63, \mathrm{p}<0.001, \mathrm{r}=0.61, \mathrm{p}<0.001 ; \mathrm{r}=0.32$, $\mathrm{p}<0.001)$.

2. In patients with bronchial asthma, an increase in the severity and frequency of anxiety and depressive disorders was found, depending on the level of disease control. The average force inverse correlation between the degree of depression and the integral index of QOL $(r=-0,67$, $\mathrm{p}<0.001)$ is established.

3. The average force inverse correlation between the degree of depression and the patient's assessment of the level of asthma control was found: the more severe is depression, the lower is the self-esteem of the control level of the disease $(\mathrm{r}=-0.49, \mathrm{p}<0.001)$, which in its turn reduces asthma's treatment perception and quality due to the fact that the patient does not adhere to the regime of taking medications, etc.

4. In the program for the management of BA patients it is necessary to include in the diagnostic test the detection of anxiety and depression and to assess the quality of life. In the case of violations detected, the inclusion of psychotherapeutics counselings in order to appoint psychopharmaceutical means is necessary.

\section{REFERENCES}

1. Moroz S.M. Psykhopatolohiia i patopsykholohiia invalidnosti vnaslidok somatychnykh zakhvoriuvan (fenomenolohiia, mekhanizmy formuvannia, pryntsypy psykhosotsialnoi reabilitatsii): avtoref. dys. dok. med.nauk. Kharkiv, 2010; p. 41. [Psychopathology and pathophysiology of disability due to somatic diseases (phenomenology, mechanisms of formation, principles of psychosocial rehabilitation): Synopsis for Doct. thesis (Med.). Kharkiv, 2010; p. 41 ] (In Ukrainian).

2. Medvedev V.E. Psychosomaticheskie zabolevania koncepciya i sovremennoe sostoyanie problem [Medvedev V.E. Psychosomatic disesses: concept and current state of the problem] Archiv vnutrenney medicini. 2013;6(14):37-40. (In Ukrainian).

3. Kharchenko D.M. Psykhosomatychni rozlady. Teorii, metody diahnostyky, rezultaty doslidzhen: navchalnyi posibnyk [Kharchenko DM Psychosomatic disorders. Theories, methods of diagnostics, research results: textbook] Kyiv. Vydavnychyi Dim «Slovo», 2015, p. 280. (In Ukrainian).

4. Surmach M. Yu. Kachestvo zhizni, svyazannoe so zdorovem, kak predmet izucheniya sotsiologii meditsinyi [Surmach, M. Yu. Quality of life related to health as a subject of study of the sociology of medicine] Sotsiologiya. 2011;2:100-104 (In Russian).

5. Vorob'ev A. A. Kachestvo zhyttya yak pokaznyka efektyvnosti derzhavnoho upravlinnya [The quality of life as an indicator of the Efficiency of public administration] Mezhdunarodnyy nauchnoissledovatel'skyy zhurnal. 2016;6(48):8-21. URL: https://researchjournal.org/economical/kachestvo-zhizni-kak-pokazatel-effektivnostigosudarstvennogo-upravleniya/ (In Ukrainian).

6 .Mihaylov B. V., Vitenko I. S., Serdyuk 0. I. ta in, Eksperimentalnopsihologlchne doslidzhennya vagalniy praktitsi — simeyniy meditsini: navch. posibnik dlya likariv- interniv i likariv — sluhachiv zakladiv (fakultetiv) pislyadiplomnoyi osviti [Experimental-psychological research in general practice - family medicine: teaching. a manual for doctors ininterns and doctors - students of institutions (faculties) of postgraduate education] for community edit B.V. Mikhailova; Kh. KhMAP0, 2011, p. 136 (In Ukrainian).

7. Karavaeva T.A., Vasyl'eva A.V., Myzynova E.B., i dr. Alhorytmy diahnostyky trevozhnykh rozladiv nevrotychnoho rivnya: metodychni rekomendatsiyi [Algorithms for the diagnosis of anxiety disorders of the neurotic level: methodical recommendations] NMYTS PN ym. V.M. Bekhtereva; SPb, 2018, p. 40 (In Russian).

8. Antonovich Zh. V., Evchenko A.Yu., Tsyirulik A.A. Osnovnyie aspektyi kachestva zhizni patsientov $s$ bronhialnoy astmoy i hronicheskoy obstruktivnoy boleznyu legkih [The main aspects of quality of life with bronchial asthma and chronic obstructive pulmonary disease]. Meditsinskiy zhurnal. 2013;3:44-48. (In Russian).

9. Medvedev V.E. Diagnostika i lechenie trevozhnyih rasstroystv [Diagnosis and treatment of anxiety disorders]. Voprosy vrachebnoy praktiki; 2011;2:52-55. (In Russian). 
10. Brodskaya 0.N. Komorbidnie zabolevaniya pri bronchialnoi astme [Comorbid deseases in bronchial astma] Prakticheskaya pulmonologia; 2017;2:3-13. (In Russian).

\section{Authors' contributions:}

According to the order of the Authorship.

\section{Conflict of interest:}

The Authors declare no conflict of interest.

\section{CORRESPONDING AUTHOR}

Yana I. Bazhora

Odessa National Medical Univercity

Uspenskaya street, 123, flat 3, 65007 0dessa, Ukraine

tel:+380674891155

e-mail:Yana19_91@ukr.net

Received: 07.02.2019

Accepted: 03.04.2019 


\title{
INTEGRAL SCORING SCALE AS A BASIS FOR AN OBJECTIVE ASSESSMENT OF THE STATE OF PATIENTS WITH CHRONIC TONSILLITIS AND THE EFFECTIVENESS OF THEIR TREATMENT
}

\author{
Oleksandr Bredun', Oleg Melnikov'², Oleksandr Kononov' \\ 'SHUPYK NATIONAL MEDICAL ACADEMY OF POSTGRADUATE EDUCATION, KYIV, UKRAINE \\ IIMMUNOLOGY AND PATHOPHYSIOLOGY LABORATORY, O. KOLOMIYCHENKO OTOLARYNGOLOGY INSTITUTE, KYIV, UKRAINE
}

\begin{abstract}
Introduction: Currently, the methods of integrated assessment of patient's condition based on scoring of separate multidirectional changes in subjective clinical and objective laboratory parameters are used in medical science more and more often.

The aim: Based on the identified differences in clinical manifestations and immunological indicators of patients of different age with chronic tonsillitis and patients with no signs of ENT pathology, to develop an integral scoring scale as a basis for an objective assessment of the state of patients with CT and the effectiveness of their treatment.

Materials and methods: The clinical signs and immunological factors were evaluated. Patient's general information, such as age, the presence of allergies, was also taken into account. Based on the analysis of the data array, a scoring system for assessing the clinical and immunological state of patients was proposed.

Results: The abnormalities in clinical and immunological assessment in adult population with no signs of ENT pathology (control group) are 2.75 times higher than in healthy children, while in case of chronic tonsillitis the differences between children and adults in terms of integral abnormalities are $1.66(\mathrm{p}<0.05)$.

Conclusions: Integral scoring assessment of clinical and immunological tests makes it possible to provide more objective evaluation of the state of lymphoid tissue of tonsils and the immunity in patients with chronic tonsillitis, which may become an objective basis for choosing patient management strategy, as well as for estimating treatment efficacy.
\end{abstract}

KEY WORDS: Chronic tonsillitis (CT), scoring system

Wiad Lek 2019, 72, 4, 664-669

\section{INTRODUCTION}

Currently, the methods of integrated assessment of patient's condition based on scoring of separate multidirectional changes in subjective clinical and objective laboratory parameters are used in medical science more and more often $[1,2]$. At the same time, the majority of studies assessing the patient's condition are not carried out comprehensively, and the abnormal findings are presented only in descriptive form without any total integration of clinical and laboratory signs and a graded assessment of the severity of abnormalities, which contributes to subjectivity in the choice of therapy. Working towards the progress and objectification in assessing the condition of patients with ENT diseases, we tried to describe patient's condition using the case of assessing clinical and immunological parameters in patients of different age with chronic tonsillitis (CT) and patients with no signs of ENT pathology. It is based on scoring method of assessing the state of patients with chronic rhinosinusitis suggested by G.D. Tarasova [2], which we adapted in clinical aspects and significantly expanded in immunological aspects. The same as in the parent study, a 4-point scale (from 0 to 3 points) is used for assessment.

\section{THE AIM}

Based on the identified differences in clinical manifestations and immunological indicators of patients of different age with chronic tonsillitis and patients with no signs of ENT pathology, to develop an integral scoring scale as a basis for an objective assessment of the state of patients with $\mathrm{CT}$ and the effectiveness of their treatment.

\section{MATERIALS AND METHODS}

127 patients with CT and 30 patients of control group (patients with no signs of ENT pathology) were recruited in the study. The age of children was 5-18 years, and the age of adults - 19-55 years.

Radial immunodiffusion technique was used to quantitate serum immunoglobulin ( $\operatorname{Ig} A, \operatorname{IgM}, \operatorname{IgG}), \operatorname{sg} A$ in the oropharyngeal secretion. Coon's method was used to detect antibodies to connective tissue antigens in patients with chronic tonsillitis and normal patients.

Test for detection of circulating immune complexes is based on sedimentation of coarsely dispersed complex conglomerates of protein origin under the influence of polyatomic alcohol, namely polyethyleneglycol at a concentration of $3.75 \%$. After sedimentation and subsequent 
Table I. Degree of hyperemia of palatine arches

\begin{tabular}{cc}
\hline Severity of signs & Point \\
\hline No hyperemia & 0 \\
\hline Mild hyperemia of palatine arches & 1 \\
\hline $\begin{array}{c}\text { High-grade hyperemia of palatine arches and } \\
\text { mucous membrane of tonsils }\end{array}$ & 2 \\
\hline $\begin{array}{c}\text { Hyperemia of palatine arches, mucous membrane } \\
\text { of tonsils, lateral and posterior pharyngeal walls }\end{array}$ & 3 \\
\hline
\end{tabular}

Table II. Caseous detritus in tonsillar lacunae

\begin{tabular}{cc}
\hline Severity of signs & Point \\
\hline No lacuna content & 0 \\
\hline Very few caseous plugs & 1 \\
\hline $\begin{array}{c}\text { Mild caseous and purulent discharge from lacunae } \\
\text { on palpation }\end{array}$ & 2 \\
\hline Purulent content in lacunae & 3 \\
\hline
\end{tabular}

Table III. Tonsillar size

\begin{tabular}{cc}
\hline Severity of signs & Point \\
\hline Within the arch line & 0 \\
\hline Slightly extending beyond the palatine arches & 1 \\
\hline $\begin{array}{c}\text { Different sizes of the right and left tonsils extending } \\
\text { beyond the palatine arches }\end{array}$ & 2 \\
\hline Severe tonsil atrophy & 3 \\
\hline
\end{tabular}

Table IV. State of the anterior lymph nodes

\begin{tabular}{cc}
\hline Severity of signs & Point \\
\hline Within normal limits & 0 \\
\hline Mildly enlarged lymph nodes & 1 \\
\hline $\begin{array}{c}\text { Occasionally enlarged and painful } \\
\text { Continuously enlarged lymph nodes, occasional } \\
\text { tenderness on palpation }\end{array}$ & 2 \\
\hline
\end{tabular}

centrifugation, the optical density of the precipitate was measured using spectrophotometric techniques and evaluated in optical-density units.

T-lymphocyte count of different subpopulations was determined by the method of homogeneous spotting of antibodies (Ortho, USA) in fluorescence microscope Olympus (Japan).

The content of nonspecific protective factors in the oropharyngeal secretion, such as lysozyme, lactoferrin, IL-1, IL-8, $\gamma$-IFN, a-IFN, as well as $\operatorname{IgE}_{1} \mathrm{IgG}_{4}$ in blood serum was detected by immunoenzyme method using Stat-Fax 2100 analyzer (USA) and corresponding reagents kit produced by Cytokine (Russian Federation), Vector-Best (Russian Federation), Hyman (Germany), Assauro (Netherlands). Nephelometer was used to determine lysozyme concentrations in the oropharyngeal secretion.

All the materials were collected in clinical remission at 8-9 oclock in the morning in the fasted state. The super-
Table V. Number of exacerbations per year

\begin{tabular}{|c|c|}
\hline Severity of signs & Point \\
\hline No exacerbations & 0 \\
\hline $\begin{array}{c}1 \text { exacerbation per year without ARVI (acute } \\
\text { respiratory viral infection) }\end{array}$ & 1 \\
\hline Exacerbation 2-3 times per year & 2 \\
\hline Exacerbation $>3$ times per year & 3 \\
\hline
\end{tabular}

Table VI. Concomitant diseases

\begin{tabular}{cc}
\hline Severity of signs & Point \\
\hline No metatonsillar pathology & 0 \\
\hline Chronic diseases of gastrointestinal tract, thyroid gland & 1 \\
\hline $\begin{array}{c}\text { Chronic kidney diseases, chronic joint diseases with } \\
\text { negative rheumatoid factor test }\end{array}$ & 2 \\
\hline $\begin{array}{c}\text { Diseases of heart, joints, connective tissues with } \\
\text { positive rheumatoid factor test }\end{array}$ & 3 \\
\hline
\end{tabular}

Table VII. Body thermometry in case of exacerbation of CT

\begin{tabular}{cc}
\hline Severity of signs & Point \\
\hline Normal temperature & 0 \\
\hline Subfebrile temperature & 1 \\
\hline Temperature is about 38 OC & 2 \\
\hline Temperature is $>38$ & 3 \\
\hline
\end{tabular}

Table VIII. Local immunity (immunoglobulins, lactoferrin, antiinflammatory cytokines, interferons)

\begin{tabular}{cc}
\hline $\begin{array}{c}\text { Severity of signs } \\
\text { No definite abnormalities from age-appropriate } \\
\text { normal value }\end{array}$ & Point \\
\hline Abnormality in one of the parameter & 1 \\
\hline Abnormalities in two parameters & 2 \\
\hline Abnormalities in three or more parameters & 3 \\
\hline
\end{tabular}

natant fraction was obtained by centrifugation $(120 \mathrm{~g})$ and stored at $-20^{\circ} \mathrm{C}$ for 20 days.

In carrying out the research, the principles of bioethics and the legal requirements and requirements for conducting biomedical research were respected, namely: the Helsinki Declaration (2000), the Constitution (1996) and the Civil Code of Ukraine (2006), the Fundamentals of Ukrainian Health Law (1992), Guidelines for clinical investigations of the Ministry of Health of Ukraine No. 42-7.0: 2005 "Medicines. Appropriate clinical practice "(2005), Order of the Ministry of Health of Ukraine No. 66" On Approval of the Procedure for Conducting Clinical Trials of Medicinal Products and Examination of Materials for Clinical Trials and Model Regulations on the Ethics Commission "(2006), Law of Ukraine No. 3447-IV" On the Protection of Animals from ill-treatment "(2006), which is confirmed by the corresponding 
Table IX. Systemic humoral immunity (antibodies to Streptococcus pyogenes, levels of immunoglobulins of various classes)

\begin{tabular}{cc}
\hline Severity of signs & Point \\
\hline No definite downward abnormalities & 0 \\
\hline Abnormality in one of the parameter & 1 \\
\hline Abnormalities in 2-3 parameters & 2 \\
\hline Abnormalities in more than three parameters & 3 \\
\hline
\end{tabular}

Table X. Systemic cellular immunity (T-lymphocytes and their subpopulations; functional activity of T-lymphocytes, production of cytokines by mitogens in vitro)

\begin{tabular}{cc}
\hline Severity of signs & Point \\
\hline Nothing abnormal detected & 0 \\
\hline Abnormality in one of the parameter & 1 \\
\hline Abnormalities in two parameters & 2 \\
\hline Abnormalities in more than two parameters & 3
\end{tabular}

Table XI. Factors of innate immunity (number of monocytes, neutrophils, eosinophils, natural killers, natural killers activity, phagocytic activity)

\begin{tabular}{cc}
\hline Severity of signs & Point \\
\hline No definite downward abnormalities* & 0 \\
\hline Abnormality in one of the parameter & 1 \\
\hline Abnormalities in two parameters & 2 \\
\hline Abnormalities in more than two parameters & 3
\end{tabular}

* - upward abnormalities in case of CT occur very rarely, and in our opinion only during exacerbation

Table XII. Immunopathological factors (circulating immune complex, antibodies to DNA (Ana-sreen), antibodies to protein-polysaccharide antigen of connective tissue such as (ole)

\begin{tabular}{cc}
\hline Severity of signs & Point \\
\hline No positive response & 0 \\
\hline Abnormality in one of the parameter & 1 \\
\hline Abnormalities in two parameters & 2 \\
\hline Abnormality in three or more parameters & 3 \\
\hline
\end{tabular}

conclusion of the Ethical Committee of Shupyk National Medical Academy of Postgraduate Education, Kyiv, Ukraine (2015).

Clinical assessment of the patient's state was based on the following signs (Tables I; II; III; IV; V; VI; VII).

Immunity status assessment was carried out by analyzing immunograms in accordance with the immunoassay protocols of ENT patients [3]. We investigated 20 different immunological parameters to identify the most informative (Tables VIII; IX; X; XI; XII).

Patient's general information (Tables XIII, XIV).

Student's t-test was used for statistical analysis.
Table XII. Patient's age (according to the recommendations of the European Association of Otolaryngologists and Clinical Immunologists, tonsillectomy is not indicated for children under 5 , Gent, 1999).

\begin{tabular}{cc}
\hline Severity of signs & Point \\
\hline Mature age (41-55 years) & 0 \\
\hline From 19 to 40 years & 1 \\
\hline From 8 to 18 years & 2 \\
\hline From 5 to 7 years & 3
\end{tabular}

Table XIV. Allergy of any localization

\begin{tabular}{cc}
\hline Severity of signs & Point \\
\hline No allergy & 0 \\
\hline Mono-allergy & 1 \\
\hline Poly-allergy & 2 \\
\hline History of severe allergic reactions & 3 \\
\hline
\end{tabular}

\section{RESULTS}

The integral data of clinical and immunological studies of various parameters obtained in analyzing patients of each group and shown in points are summarized in Tables XV and XVI. The comparison was made in the following groups: children with no signs of ENT pathology (under 18 years), children with CT at the age of 5-18 years, adult patients with no signs of ENT pathology and adult patients with CT.

The presented data show that patients of the control group at an early age have no significant abnormalities in clinical state of tonsils (mean score - 0.32), while in children with CT the average score is 1.38 . The ratio of these indicators is 1:4.31. Adult patients with no signs of ENT pathology have abnormalities in clinical state of tonsils upon a range of parameters in comparison with a similar group of an early age, and the average score of clinical signs is 0.28 . The number of clinical abnormalities increases in adult patients with $\mathrm{CT}$ and is 1.52 . The ratio of these indicators is 1:5.42.

The most prominent clinical feature of the state of tonsil in children with no signs of ENT pathology was tonsillar size (1.6 points). Hyperemia of the arches ( 0.3 points) and caseous detritus in lacunae (0.4 points) were less prominent features. In adult patients with no signs of ENT pathology the following clinical features of the state of tonsils were the most prominent: hyperemia of the arches (1.0 point), caseous detritus ( 0.5 points), enlarged anterior cervical lymph nodes ( 0.3 points) and tonsillar size ( 0.2 points) (Figure 1$)$.

The data presented in Figure 1 indicate that the leading clinical sign in healthy donors at an early age is the tonsillar size, and in adult donors it is hyperemia of the arches.

In children and adults with CT, the severity of clinical signs of the state of tonsils significantly differed only upon one criterion - hyperemia of the anterior palatine arches (1.2 points and 2.2 points, respectively). There were no significant differences in other clinical signs (Figure 2).

As can be seen from Figure 2, the leading clinical sign in patients with CT at an early age is the presence of caseous 
Table XV. Scoring of clinical signs of patients of different age with no ENT pathology and patients with CT

\begin{tabular}{ccccc}
\hline \multirow{2}{*}{ Signs } & \multicolumn{3}{c}{ Mean score } \\
\cline { 2 - 5 } & $\begin{array}{c}\text { Children of control } \\
\text { group }\end{array}$ & Children with CT & $\begin{array}{c}\text { Adults of control } \\
\text { group }\end{array}$ & Adults with CT \\
\hline Hyperemia of arches & 0.3 & 1.2 & 1.0 & 2.2 \\
\hline Caseous detritus & 0.4 & 2.1 & 0.5 & 2.1 \\
\hline Tonsillar size & 1.6 & 0.9 & 0.2 & 1.1 \\
\hline Lymph nodes & 0 & 1.8 & 0.3 & 0.8 \\
\hline Exacerbation & 0 & 0.5 & 0 & 0.6 \\
\hline Concomitant diseases & 0 & 0.6 & 0 & 2.0 \\
\hline Temperature & 0 & 2.1 & 0.28 & $1.52^{*}$ \\
\hline Average & 0.32 & $1.31^{*}$ & & 0 \\
\hline
\end{tabular}

Note: * reliable in relation to the control group in each age group $(p<0.02)$.

Table XVI. Scoring of abnormal findings in immunograms of patients of different age with no signs of ENT pathology and patients with CT

\begin{tabular}{ccccc}
\hline \multirow{2}{*}{ Signs } & \multicolumn{3}{c}{ Mean score } \\
\cline { 2 - 5 } & $\begin{array}{c}\text { Children of } \\
\text { control group }\end{array}$ & Children with CT & $\begin{array}{c}\text { Adults of } \\
\text { control group }\end{array}$ & Adults with CT \\
\hline Local immunity & 0 & 1.7 & 0.8 & 2.3 \\
\hline Systemic humoral & 0 & 0.9 & 0.6 & 2.1 \\
\hline Systemic cellular & 0.2 & 0.8 & 0.7 & 2.8 \\
\hline Innate immunity & 0.2 & 0.9 & 1.2 & 2.6 \\
\hline Immunopathological factors & 0 & 0.2 & 0.8 & 2.1 \\
\hline Average & 0.08 & $1.04^{*}$ & 0.82 & $2.38^{*}$ \\
\hline
\end{tabular}

Note: * reliable in relation to the control group in each age group $(p<0.02)$.

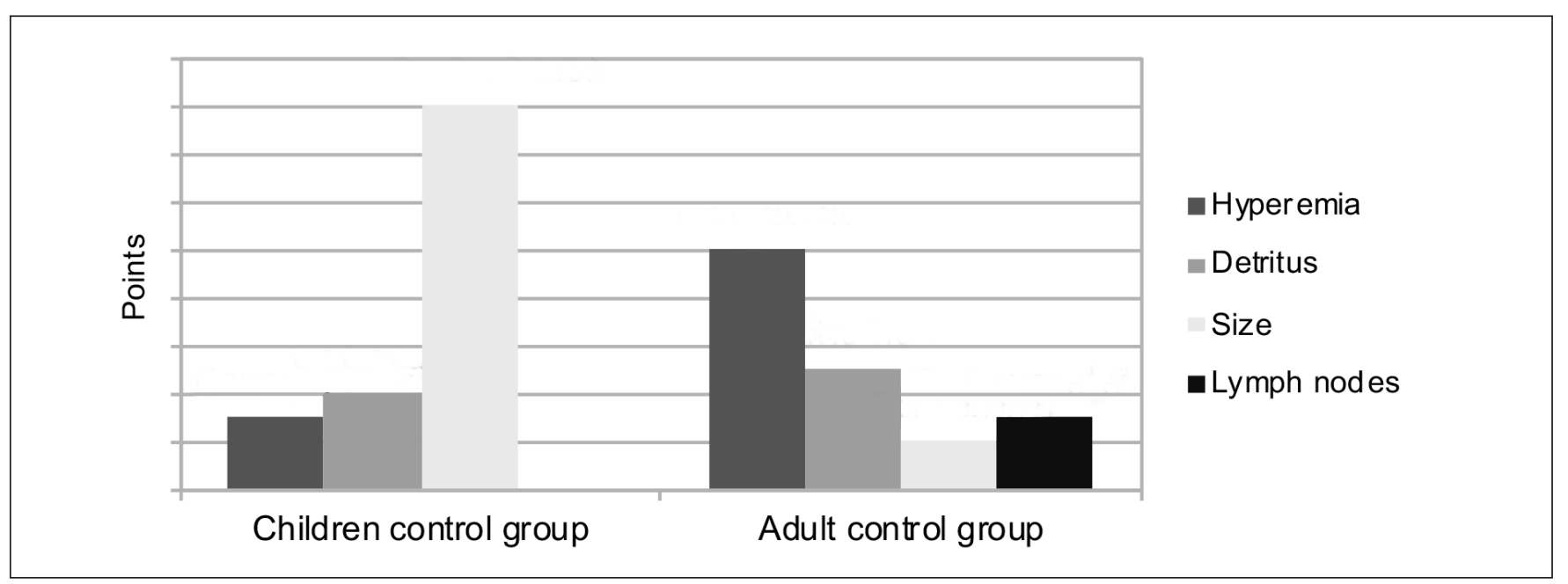

Figure 1. Differences in clinical signs of tonsils in healthy children and adults.

detritus of tonsils and fever response, and in adult patients with CT it is hyperemia of the arches.

More distinct differences between patients with no signs of ENT pathology were revealed while studying the immunological parameters of the local and systemic immunity (Table 16). If children with no signs of ENT pathology had minor abnormalities (mean value of the scoring assessment of abnormalities in immunograms -0.08 points), then in adult patients with no signs of ENT pathology this value was 0.82 points $(\mathrm{p}<0.001)$. In patients with $\mathrm{CT}$, the abnormalities in all parameters of the immune system exceeded by 2 points ( 2 or more abnormalities in the indicators of the state of the immune system), the mean score was 2.38 $(\mathrm{p}<0.01)$.

The summing up of the scores of clinical and immunological studies show the same tendency - the abnormal- 


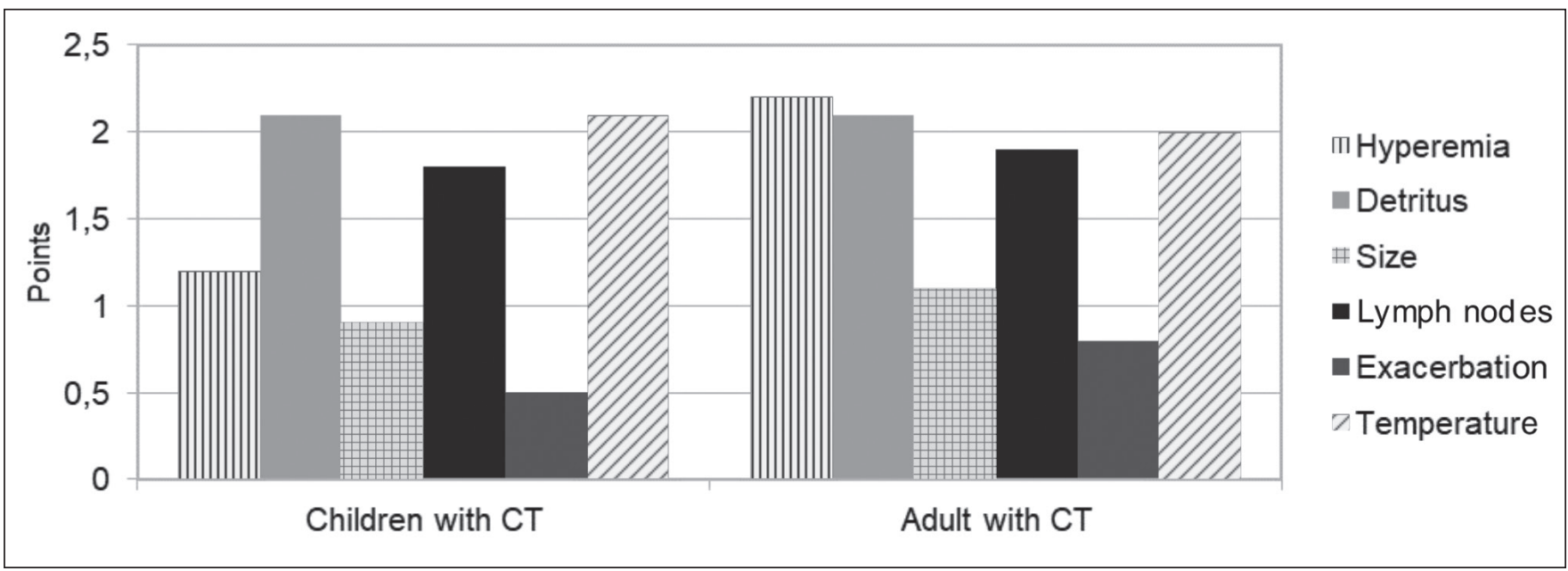

Figure 2. Differences in clinical signs of tonsils in children and adults with CT.

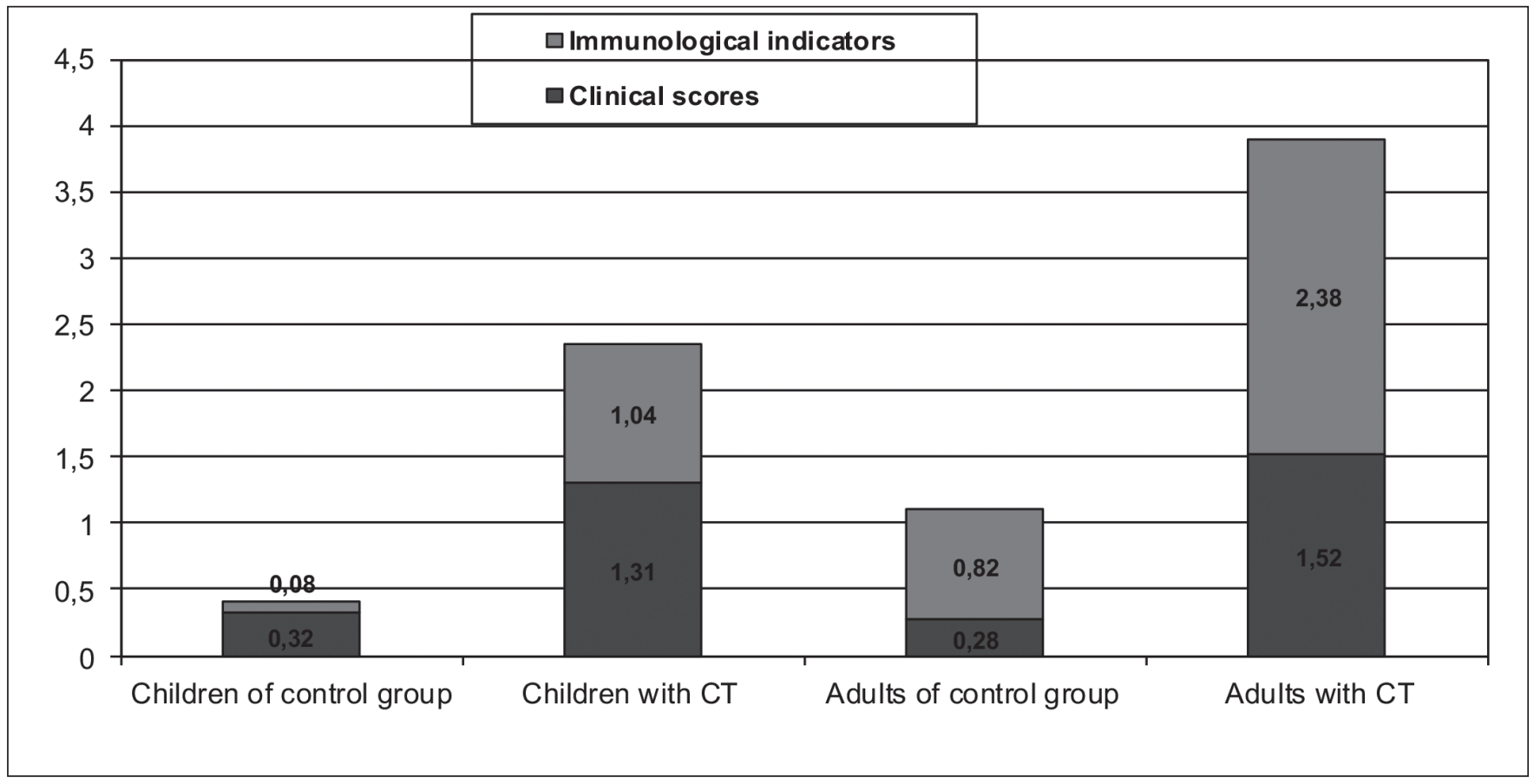

Figure 3. Integral expression of abnormalities in clinical and immunological parameters in patients with CT and patients of control groups of different age.

ities in clinical and immunological assessment in adult population with no signs of ENT pathology (control group) are 2.75 times higher than in healthy children, while in case of CT the differences between children and adults in terms of integral abnormalities are $1.66(\mathrm{p}<0.05)$ (Figure 3).

It can be also noted that in integral clinical and immunological assessment of functional state of tonsils in children with CT, immunological signs are of the same importance as clinical ones, and in adult patients with CT they are even more important than clinical signs. Taking notice of these signs in diagnosis of CT can more accurately identify the functional reserve of tonsils, and therefore more objectively determine the indications for surgical treatment.

\section{DISCUSSION}

In our opinion, the revealed abnormalities in clinical signs and immunological parameters in children and adults with no signs of ENT pathology can be due to individual characteristics of the immune system. These abnormalities can also be a physiological reaction of the lymphoid tissue of the pharynx to a constant antigen load $[4,5]$, or as a consequence of recurrent diseases of the pharynx (for example ARI), and can serve as an initial level of reference.

Clinical manifestations of chronic tonsillitis are often subjective. Unbiased evaluation of the general immunological status is difficult due to a large number of tests that do not determine definite changes in chronic tonsillitis. The author realizes that abnormalities in immunological parameters may 
also be due to another (non-tonsillar) pathology, therefore, the study involved tests that were more specific and informative for inflammatory diseases of the oropharynx: a-IFN, sIgA and antibodies to Streptococcus pyogenes (since the determination of the total amount of IgA, IgM, IgG is indicative) [5].

The presented materials indicate that using scoring system of assessment of clinical and immunological signs one can integrally and therefore more objectively evaluate the state of patients with pathological processes of tonsils and the efficacy of their treatment. In our opinion, integral scoring assessment can also help in choice of treatment strategy; however it does not exclude further development and implementation of other tests.

\section{CONCLUSIONS}

1. The mean score of clinical signs in children with CT is 4 times higher than that in children with no signs of ENT pathology $(\mathrm{p}<0.02)$. The average score of clinical signs in adult patients with CT is 5 times higher than that in adults with no signs of ENT pathology $(\mathrm{p}<0.02)$.

2. The mean score of immunological manifestations in children with CT is 13 times higher than that in children with no signs of ENT pathology $(\mathrm{p}<0.01)$. The average score of immunological manifestations in adult patients with CT is 2.9 times higher than that in adult patients with no signs of ENT pathology $(\mathrm{p}<0.01)$.

3. The mean integral score in children with CT is 5.85 higher than that in children with no signs of ENT pathology $(\mathrm{p}<0.05)$. The mean integral score in adults with CT is 3.5 times higher than that in adult patients with no signs of ENT pathology $(p<0.05)$.

4. Integral scoring assessment of clinical and immunological tests makes it possible to provide more objective evaluation of the state of lymphoid tissue of tonsils and the immunity in patients with CT, which may become an objective basis for choosing patient management strategy, as well as for estimating treatment efficacy.

\section{REFERENCES}

1. Windfuhr J., Toepfner N., Steffen G., et al. Clinical practice guidline: tonsillitis 1. Diagnostics and nonsurgical management. Eur Arch Otorhinolaryngol. 2016; 273: 974-989.

2. Tarasova G. Vozmoghnosti profilaktiki recidivov chronicheskogo rhinosinusita. [Possibilities of preventing recurrence of chronic rhinosinuitis]. Ros. Med. Gurnal. 2007; 1: 1-5. (in Russian).

3. Melnikov 0., Zabolotny D. Diagnostica immunodeficitov pri patologii slizistoy obolochki na osnove opredeleniya immunoglobulinov v secretah (concepciya). [Diagnosis of immunodeficiencies in pathology of the mucosa based on the definition of immunoglobulins in biological fluid (concept)]. Kiev: Inst. Otolaringol; 2003, p. 30.(in Russian).

4. Traschtenberg I., Polyakov A. Ocherki fiziologii i gigiyeni truda pozgilogo cheloveka. [Essays on the Physiology and Hygiene of the Elderly Person]. Kiev: «Avicenna»; 2007, p. 272. (in Russian).

5. Melnikov 0., Zabolotny D., Kischuk V., Bredun 0., Ryilska 0. Immunologiya chronicheskogo tonzillita. [Immunology of Chronic Tonsillitis]. Kiev: «LOGOS»; 2017, p. 192. (in Russian).

The research was carried out within the framework of the research work of the Department of Pediatric Otorhinolaryngology of the Shupyk National Medical Academy of Postgraduate Education, Kyiv, Ukraine - "Diagnosis and treatment of diseases of ear, throat and nose in children" (State registration number 0113U002213).

\section{Authors' contributions:}

According to the order of the Authorship.

\section{Conflict of interest:}

The Authors declare no conflict of interest.

\section{CORRESPONDING AUTHOR Oleksandr Bredun}

Shupyk National Medical Academy of Postgraduate Education

9 Dorohozhytska Str., 04112 Kyiv, Ukraine

e-mail: t.duxowi41992@gmail.com

Received: 01.12.2019

Accepted: 05.04.2019 


\title{
CARDIOVASCULAR REMODELING IN PATIENTS WITH HYPERTENSION WITH DIFFERENT DEGREES OF COGNITIVE IMPAIRMENT
}

\author{
Natalia Y. Osovska, Yulia V. Mazur, Olga M. Bereziuk, Serhii P. Dmytryshyn, Maryna M. Velychkovych, \\ Larysa A. Perebetiuk, Olena V. Temna, Oksana M. Honcharenko, Oksana V. Furman, Oleksiy R. Balatskyi \\ NATIONAL PIROGOV MEMORIAL MEDICAL UNIVERSITY, VINNYTSYA, UKRAINE
}

\begin{abstract}
Introduction: Recently, the concept of vascular cognitive impairment, combining all variants of cognitive decline due to cerebrovascular insufficiency, is actively being developed. This concept goes far beyond traditionally existing ideas about the problem of vascular cognitive disturbances.

The aim of the study is to demonstrate the correlation between the indices of structural and functional rearrangement of the cardiovascular system and the state of intellectualmnemonic functions in patients with hypertension.

Materials and methods: A comprehensive survey of 146 patients with hypertension of the II and III stage according to ESH / ESC 2013, 2017, 2018 has been performed. The study included patients with mild and moderate cognitive impairment (Cl). Depending on the state of the cognitive sphere and on the basis of the results of the neuronpsychological testing, The patients were divided into 3 groups depending on the state of the cognitive sphere and on the basis of the results of the neuron-psychological testing with further comparisons of their clinical and instrumental data.

Results: According to the results of our study, it has been found that an increase of the signs of cardiovascular remodeling was observed in patients with more pronounced changes in cognitive activity. The analysis of intracardiac hemodynamic parameters in patients of the studied groups revealed more significant pathological changes in patients with cognitive impairments than in patients without them. Patients with mild and moderate Cl had significantly higher heart rates, left ventricular wall thickness (LV) which led to impairment of the diastolic function of LV and had already been registered in patients without cognitive dysfunction. Moreover, it increased with the appearance (mild) and growth of the degree (moderate) cognitive impairment.

The average daily values of $\mathrm{BP}(\mathrm{SBP}, \mathrm{DBP})$ in patients of all studied groups significantly exceeded the recommended norms, while in patients with moderate $\mathrm{Cl}$ these rates were significantly higher than those in the group with mild $\mathrm{CI}(\mathrm{p}=0.028)$. In addition, the variability of systolic blood pressure was increasing simultaneously with the deterioration of cognitive function of our patients. Also, signs of remodeling were being observed during the study of the state of peripheral vessels (increase of peripheral resistance, pulsation index, linear velocity and thickening of the intima-media complex), which is the main cause of cognitive impairment and causes their appearance and reflects their degree.

Conclusions: The presented study revealed a clear correlation between the degree of cognitive impairment and the degree of changes in the daily blood pressure profile, the most important of which were the average daily systolic blood pressure and systolic blood pressure variability.

On the basis of the conducted research, in the future it will be possible to predict the level of the cognitive sphere involvement, depending on the state of the daily blood pressure profile, changes of the ventricle and vessels geometry, which will enable timely diagnosis of cognitive impairment and the prescription an adequate therapy.
\end{abstract}

KEY WORDS: cardiovascular remodeling, cognitive impairment, antihypertensive therapy

Wiad Lek 2019, 72, 4, 670-676

\section{INTRODUCTION}

Over the last decades hypertensive and ischemic heart diseases have become the worldwide epidemic, being risk factors for the development of cerebrovascular complications [1,2]. According to epidemiological data, at least $50 \%$ of people over 55 complain of decreased memorization ability [3]. Moreover, $1 \%$ of them progress to dementia during one year, and $12-42 \%$ - within 1-5 years [4].

Recently, the concept of vascular cognitive impairment (CI), combining all variants of cognitive decline due to cerebrovascular insufficiency, is actively being developed. This concept goes far beyond traditionally existing ideas about the problem of vascular cognitive disturbances [4]. Arterial hypertension (AHT) and atherosclerosis are the main causes of vascular brain damage, leading not only to acute cerebrovascular accidents, but also to chronic progressive brain damage, impairment of cognition being one of its major symptoms $[5,6]$. Hypertension is considered to be a risk factor not only for stroke but also for memory troubles and impaired cognitive functions, representing one of the most common abnormalities in elderly and senile individuals $[1,7,8]$.

The magnitude of cerebral blood flow is directly proportional to perfusion pressure, which is determined by the difference between average values of arterial blood pressure 
and intracranial pressure. High instability and variability of blood pressure, high pulse pressure, frequent hypertensive crises, and, consequently, chronic uncontrolled arterial hypertension are the main factors leading to the development of multiple severe disturbances in cerebral vessels $[9,10,11]$.

In patients with hypertension neuropsychological tests demonstrate decreased cognitive function as compared to individuals with normal blood pressure (BP) $[12,13$, $14,15,16]$.

Structural and functional changes of vessels in AHT are independent causes of cardiovascular complications and adverse prognosis. Development of vascular remodeling is determined by interaction between components of hemodynamic load and activation of neurohumoral systems related to inherited predisposition of polygenic nature $[7$, $17,18,19]$.

In long-term hypertension, multiple structural and functional changes in the heart and vessels develop, reflecting both compensation mechanisms of hemodynamic disorders and their pathological changes [17, 20]. Myocardial remodeling develops already at the earliest stages of cardiovascular disease continuum, being one of independent risk factors for cardiovascular morbidity and mortality [15, 21]. According to Y.N.Belenkov (2002), remodeling of the left ventricle (LV) implies its structural and geometrical changes, including hypertrophy and dilatation processes, which lead to changes in geometry, sphericity as well as systolic and diastolic dysfunction.

Morphological changes in LV remodeling process - activation of certain genome units, molecular, cellular and interstitial changes - occur at all levels of structural organization of the heart. Cardiac remodeling leads to the development of heart failure, increased electrical instability of myocardium and, consequently, the development of fatal arrhythmias as well as significantly increased risk of cardiovascular mortality $[8,15,22]$. Processes occurring in blood vessels are similar to those in heart muscle: hypertrophy of smooth muscle cells, increase in fibroblast number, collagen structure changes with resultant thickening of all vessel wall layers, increased stiffness and rigidity, endothelial dysfunction and atherosclerotic lesion $[9,10,11,23]$. Remodeling of cerebral blood vessels causes the damage of brain as a target organ in hypertension. Chronic decrease of cerebral perfusion as a result of both ischemic and hypertensive diseases results in cognitive disorders, their severity determining the patients' social adaptation and quality of life $[17,24,25$, 26]. Considering the similarity of pathological processes occurring both in heart vessels and cerebral and peripheral blood vessels in cardiovascular disease (in the context of understanding of cardiovascular disease continuum), it is reasonable to suggest the existence of certain correlations between the processes of cardiovascular remodeling and their direct consequences - cognitive impairment.

\section{THE AIM}

The aim of the work is to study parameters of cardiovascular remodeling in the patients with hypertension depending on the presence of cognitive impairment and the degree of their severity.

\section{MATERIALS AND METHODS}

146 patients with hypertension (HT) took part in the study. 100 patients $(68.5 \%)$ had HT of the second stage and 46 patients $(31.5 \%)$ had the third stage, besides, in the history of $20(13.7 \%)$ of them there was a sharp violation of cerebral circulation and in $18(12,3 \%)$ patients had myocardial infarction. Heart failure (HF) of stage I was diagnosed in 87 patients (59.6\%), HF of stage III was diagnosed in patients (31.5\%) in 46 patients and 14 (9.6\%) had no HF symptoms. The average age was 53.4 \pm 0.9 years

The study did not include patients with a «fresh" stroke (not less than 6 months), craniocerebral trauma, severe renal and liver disorders, HF and the III stage, with existing hereditary diseases with a clinical picture of intellectual disorder, with symptoms of the II and III of dementia, as well as patients who have been abusing alcohol, drugs or excessive use of drugs that can provoke cognitive impairment.

The patients with cognitive impairment (CI) of mild and moderate degree were the main criteria for the inclusion into the study. The diagnosis of $\mathrm{CI}$ and the determination of its degree were carried out on the basis of generally accepted criteria as the patients were included into the study. The following methods were used: a short scale for assessing the psychological status of the MMSE (according to Folsteinetal., 1975) $[3,5]$ which can be used to diagnose the presence of cognitive impairment, score outcomes in the range of 24 to 30 points and Schultt's tables to determine the stability of attention, dynamics of efficiency, efficiency of work and degree of development.

The initial blood pressure level and antihypertensive effect of therapy were evaluated using daily blood pressure monitoring (DMBP). Outpatient monitoring of BP was performed using AVRM-04 ("Mediteh", Hungary). The intervals between measurements were 15 minutes from 7.00 to 22.00 and 30 minutes at night - from 22.00 to 7.00 . The following indicators were evaluated: the average daily systolic blood pressure (SBP), the average daily diastolic blood pressure (DBP), the time index for the increase of systolic and diastolic blood pressure (TI SBP, TI DBP) - «pressure load», a percentage of measurements from the total amount at which the value of BP exceed «normal» values - in the daytime $-140 / 90 \mathrm{~mm} \mathrm{Hg}$., at night it is $120 / 80 \mathrm{~mm} \mathrm{Hg}$. Accordingly, the daily indexes of BP (TI SBP, TI DBP), the variability of systolic and diastolic blood pressure per day (VBP BP, VBP DBP), respectively, the speed of morning rise ( SMR SBP, SMR DBP) from 5 to 10 a.m., which was calculated as the difference between the maximum and the minimum values. The analysis of the DMBP indicators for determining the degree of hypertension was conducted in accordance with the recommendations of the European Union of Cardiologists.

The determination of the morphological and functional state of the vessels was carried out by the duplex scanning 
and color Doppler blood flow mapping in a generally accepted manner [27]. Common, internal and external carotid arteries (CA) were investigated. The artery passage, vascular geometry, the state of the intima-media complex of CA, the presence of changes, their severity and structure, as well as the linear and volumetric speed of blood flow in the common CA (CCA). The vessel diameter $(\mathrm{mm})$, the thickness of intima mediums (IMT) of the vessel ( $\mathrm{mm}$ ), the presence, localization and size (diameter) of atherosclerotic plaques $(\mathrm{mm})$, maximal stenosis of carotid arteries in\%, linear velocity of blood flow $(\mathrm{V}, \mathrm{m} / \mathrm{c})$, pulsation index $(\mathrm{Pi})$, index of peripheral resistance $(\mathrm{Ri})$ were determined in every patient.

The following echocardiographic parameters were determined for evaluation of the state of the left ventricle: end-diastolic dimensions and volumes with indices determination (iEDV, iESV), the ejection fraction (EF), the interventricular septal thickness (IST) and the posterior wall thickness of the left ventricle in the diastole (LVPWTd). With the same purpose the relative wall thickness (RWT) and the heart beat index (iB) using the standard calculation methods, the transverse size of the left atrium with the definition of the index (iLA) and the index of the myocardial mass of the left ventricle (iLVMM ) were calculated.

Left ventricle diastolic function was evaluated according to the pulsed Doppler echocardiography. The following indiced of transmitral blood flow were determined: the maximum velocity of early diastolic filling (VE), late diastolic filling (VA) and their ratio (VE / VA), the retardation time of early diastolic filling (Tdec) and the isovolumic relaxation time (IVRT).

The patients were divided into 3 groups depending on the state of the cognitive sphere and on the basis of the neuron-psychological testing results. The first group of 30 patients with HT who did not have signs of cognitive impairment were included in the study as a "comparison group». The second one included 78 patients $(53.4 \%)$ who had mild cognitive impairment (MCI), the third group 38 patients $(26 \%)$ with moderate cognitive impairment (MCI) [14].

Statistical processing of the study results was conducted using the variation statistics method and the program StatSoft «Statistica» v. 6.0 due to the recommendations [28]. The obtained results were presented: 1) quantitative values - in the form of median and interquartile scale (25 and 75 percentiles); and 2) relative values (reflecting the sign frequency in the sample) in the form of percentages (\%).The indicator dynamics against the background of treatment was presented as a percentage of indicators increment, which was calculated according to the formula - indicator increment $(\%)=[($ initial value - value after the treatment) / value after the treatment] $\cdot 100 \%$.

\section{RESULTS AND DISCUSSION}

The analysis of the parameters of intracardiac hemodynamics in patients of the studied groups revealed more significant pathological changes in patients with cognitive impairment (the $2^{\text {nd }}$ and $3^{\text {rd }}$ groups) than in patients without them (group 1 (Table I)). Patients with mild and moderate CI had significantly higher heart rates, which was manifested in relatively large indexes of $\mathrm{iEDV}(\mathrm{p}=0.040)$, $\operatorname{iESV}(p=0.038)$, and iLA $(p=0.048)$. These indicators clearly highlighted the presence of the heart remodeling in patients with cognitive impairment. Interestingly, these rates were significantly higher in patients with moderate cognitive impairment than in patients with mild changes in intellectual-mnemonic activity. That is, in these patients the degree of remodeling of both LV and LA was increasing simultaneously with cognitive changes. These changes were confirmed by the existence of close correlations between iLA and iEDV and the degree of cognitive impairment $(p<0.0001)$. The changes of the size and volume of the left ventricular cavities were accompanied by changes of the wall thickness of the lungs in patients with HT with varying degrees of cognitive impairment: the WT score was significantly higher in patients with moderate CI than in patients with mild CI $(p=0.011)$, which also indicates on a more significant remodeling of LV in patients with more severe cognitive dysfunction.

The increase of the left ventricular cavity size and thickening of its walls in patients with HT resulted in a disturbance of the diastolic function of $\mathrm{LV}$, which was already registered in patients without cognitive dysfunction and was increasing due to the appearance (mild) and increased degree of cognitive impairment (moderate) (Table I). These particular changes were presented by the time parameters of transmitral blood flow which characterize diastole (iVRT and Tdec).

The ratio of the rate of early and late diastolic filling E / A became reliable only while comparing the $2^{\text {nd }}$ and $3^{\text {rd }}$ groups, that is in patients with mild and moderate CI $(p=0.017)$. There was no significant difference between the study groups in terms of the contractile function of LVEF \%, which is probably due to a more significant vascularization of patients with intellectual-mnetic disorders than to heart muscle damage.

The real picture of the digital values of blood pressure received at DBPM is significantly different from the values of «office» BP at the reception of a doctor, which is confirmed by numerous studies. Therefore, DBPM was performed in order to determine the degree of hypertension to all patients. The average daily values of $\mathrm{BP}$ (SBP, DBP) in patients of all studied groups significantly exceeded the recommended norms. Moreover, in patients with moderate $\mathrm{CI}$ these rates were significantly higher than those in the group with mild CI ( $\mathrm{p}=0.028)$ (Table II). Average indicators of 24-hour monitoring obtained in normal conditions of life clearly correlate with organ effects such as acute (stroke, heart attack) and chronic (cognitive dysfunction, cardiac remodeling and vessel nephropathy, retinopathy) $[6,7,9,29]$. Thus, in our study, we found close correlations between the daily average systolic blood pressure and the severity of cognitive impairment $(\mathrm{p}=0.041)$.

Many systems of the body participate in the formation of the variability of BP (VAR SBP, VAR DBP), though the 
Table I. Echocardiographic parameters in patients with hypertension and different degrees of cognitive impairment

\begin{tabular}{|c|c|c|c|c|c|c|}
\hline \multirow{2}{*}{ Index } & 1st group & 2nd group & 3rd group & \multirow{2}{*}{ P1-2 } & \multirow{2}{*}{ P1-3 } & \multirow{2}{*}{ P2-3 } \\
\hline & (No Cl) & (light CI) & (moderate $\mathrm{Cl}$ ) & & & \\
\hline iLV & \multirow{2}{*}{$20,5(19,0 ; 23,0)$} & \multirow{2}{*}{$21,0(19,0 ; 23,5)$} & \multirow{2}{*}{$23,2(22,0 ; 26,6)$} & \multirow{2}{*}{0,37} & \multirow{2}{*}{0,037} & \multirow{2}{*}{0,048} \\
\hline $\mathrm{mm} / \mathrm{m} 2$ & & & & & & \\
\hline $\mathrm{iEDV}, \mathrm{ml} / \mathrm{m} 2$ & $65,7(58,0 ; 85,3)$ & $63,0(54,0 ; 75,0)$ & $59,7(54,0 ; 72,0)$ & 0,21 & 0,025 & 0,04 \\
\hline iESV, ml / m2 & $30,0(21,0 ; 35,0)$ & $27,0(21,0 ; 33,0)$ & $25,5(20,0 ; 29,5)$ & 0,38 & 0,023 & 0,038 \\
\hline $\mathrm{iHB}, \mathrm{ml} / \mathrm{m} 2$ & $33,4(29,0 ; 41,0)$ & $36,0(30,0 ; 42,0)$ & $35,0(27,3 ; 42,4)$ & 0,79 & 0,68 & 0,61 \\
\hline $\mathrm{EF}, \%$ & $56,8(52,7 ; 71,0)$ & $55,6(49,7 ; 64,4)$ & $58,5(50,0 ; 64,0)$ & 0,26 & 0,61 & 0,36 \\
\hline LVPWTd, mm & $12,0(11,0 ; 13,0)$ & $12,0(11,0 ; 13,0)$ & $12,1(11,3 ; 13,0)$ & 0,89 & 0,77 & 0,43 \\
\hline IVSTd, mm & $13,0(11,0 ; 13,0)$ & $12,0(11,0 ; 13,0)$ & $12,4(12,0 ; 13,6)$ & 0,67 & 0,59 & 0,43 \\
\hline iLVMM, g/m2 & $124,2(102,0 ; 140,0)$ & $130,0(105,2 ; 149,1)$ & $131,6(117,3 ; 141,1)$ & 0,65 & 0,36 & 0,51 \\
\hline RVT, unit & $0,47(0,46 ; 0,54)$ & $0,47(0,43 ; 0,52)$ & $0,51(0,47 ; 0,56)$ & 0,61 & 0,022 & 0,011 \\
\hline E/A, unit & $1,2(0,80 ; 1,9)$ & $1,1(0,58 ; 2,1)$ & $0,81(0,51 ; 1,4)$ & 0,46 & 0,009 & 0,017 \\
\hline Tdec, Mc & $153,0(135,0 ; 171,0)$ & $172,5(143,0 ; 188,0)$ & $188,0(165,0 ; 206,0)$ & 0,041 & 0,007 & 0,036 \\
\hline IVRT, мс & $77,0(62,0 ; 100,0)$ & $85,0(65,0 ; 101,0)$ & $92,0(61,0 ; 110,0)$ & 0,04 & 0,039 & 0,043 \\
\hline
\end{tabular}

Notes: the data of quantitative indicators are presented as $\mathrm{M} \pm \mathrm{m}$ - the average value is the mathematical error of the average and as Med (per25; per75) - the median and interquartile scale ( 25 and 75 percentiles).

Table II. DBPM indices in patients with hypertension and various degrees of cognitive impairment.

\begin{tabular}{|c|c|c|c|c|c|c|}
\hline \multirow{2}{*}{ Index } & 1st group & 2nd group & 3rd group & \multirow{2}{*}{ P1-2 } & \multirow{2}{*}{ P1-3 } & \multirow{2}{*}{ P2-3 } \\
\hline & (No Cl) & (light Cl) & (moderate CI) & & & \\
\hline $\mathrm{SBP}, \mathrm{mm} \mathrm{Hg}$ & $142,0(125,0 ; 150,0)$ & $\begin{array}{c}144,0 \\
(136,0 ; 160,0)\end{array}$ & $\begin{array}{c}151,0 \\
(136,0 ; 172,0)\end{array}$ & 0,42 & 0,011 & 0,028 \\
\hline DBP, $\mathrm{mm} \mathrm{Hg}$ & $82,0(74,0 ; 91,0)$ & $84,9(76,7 ; 92,0)$ & $89,5(78,0 ; 97,1)$ & 0,3 & 0,02 & 0,028 \\
\hline TI SBP, \% & $26,5(16,0 ; 40,0)$ & $33,0(27,0 ; 51,0)$ & $38,5(22,0 ; 51,0)$ & 0,026 & 0,039 & 0,017 \\
\hline TI DBP, \% & $18,0(12,0 ; 30,0)$ & $19,5(14,0 ; 36,0)$ & $28,0(7,0 ; 41,0)$ & 0,09 & 0,007 & 0,012 \\
\hline$\frac{\text { VAR }}{\mathrm{SBP}, \mathrm{mm} \mathrm{Hg}}$ & $14,5(12,5 ; 18,0)$ & $15,9(14,2 ; 20,0)$ & $17,4(12,5 ; 25,1)$ & 0,014 & 0,0007 & 0,005 \\
\hline $\begin{array}{c}\text { VAR } \\
\mathrm{DBP}, \mathrm{mm} \mathrm{Hg}\end{array}$ & $12,6(9,9 ; 15,0)$ & $12,1(9,9 ; 15,2)$ & $13,7(11,9 ; 16,9)$ & 0,21 & 0,09 & 0,18 \\
\hline$\frac{\mathrm{SMR}}{\mathrm{SBP}, \mathrm{mm} \mathrm{Hg}}$ & $10,0(7,0 ; 15,0)$ & $10,5(7,0 ; 14,0)$ & $14,5(10,0 ; 19,0)$ & 0,74 & 0,018 & 0,031 \\
\hline $\begin{array}{c}\text { SMR } \\
\mathrm{DBP}, \mathrm{mm} \mathrm{Hg}\end{array}$ & $10,0(6,0 ; 14,2)$ & $9,0(5,0 ; 13,0)$ & $10,0(6,0 ; 14,0)$ & 0,23 & 0,85 & 0,52 \\
\hline DI SBP, \% & $8,6(5,5 ; 12,0)$ & $8,2(3,7 ; 12,2)$ & $8,3(4,4 ; 11,9)$ & 0,84 & 0,68 & 0,91 \\
\hline DI DBP,\% & $13,5(8,0 ; 15,7)$ & $12,3(9,8 ; 16,5)$ & $11,4(8,9 ; 13,0)$ & 0,16 & 0,044 & 0,08 \\
\hline
\end{tabular}

Notes: the data of quantitative indicators are presented as $\mathrm{M} \pm \mathrm{m}$ - the average value is the mathematical error of the average and as Med (per25; per75) - the median and interquartile scale(25 and 75 percentiles).

dominant role is given to the central nervous mechanisms, that is to the daily periodicity of excitation and inhibition in the cerebral cortex. The variability of the general peripheral blood vessel resistance, cardiac output, heart rate plays the role in the formation of fluctuations of blood pressure at the systemic level. At the regional level it is a change in the need for blood supply to the brain and other organs during the day. At the molecular level, the variability of blood pressure is influenced by circadian activity of baro- and chemoreceptors, alpha and, especially, beta adrenergic receptors. In $75 \%$ of patients with $\mathrm{HT}$ there is an increased VAR of BP at night, which decreases with the progression of the disease and the involvement of target organs. Investigating the role of $\mathrm{BP}$ variability, it has been shown that the increase in VAR BP has a strong correlation with the severity of $\mathrm{BP}$, the early development of left ventricular hypertrophy and its diastolic dysfunction, as well as the retinopathy and angiopathy of vessels of the brain that is the 
Table III. The indicators of Doppler study of extracranial vessels in patients with hypertension and different degrees of cognitive impairment

\begin{tabular}{|c|c|c|c|c|c|c|}
\hline & 1st group & 2nd group & 3rd group & & & \\
\hline Index & (No Cl) & (light CI) & (moderate $\mathrm{Cl}$ ) & P1-2 & P1-3 & P2-3 \\
\hline $\mathrm{V}, \mathrm{m} / \mathrm{s}$ & $0,70(0,63 ; 0,79)$ & $0,77(0,67 ; 0,88)$ & $0,82(0,78 ; 0,99)$ & 0,012 & 0,004 & 0,028 \\
\hline $\mathrm{Ri}$ & $0,71(0,68 ; 0,73)$ & $0,72(0,69 ; 0,75)$ & $0,72(0,68 ; 0,76)$ & 0,14 & 0,08 & 0,64 \\
\hline $\mathrm{Pi}$ & $1,60(1,34 ; 1,75)$ & $1,74(1,49 ; 1,82)$ & $1,77(1,58 ; 1,84)$ & 0,009 & 0,0007 & 0,07 \\
\hline IMT, mm & $0,80(0,80 ; 1,05)$ & $0,92(0,84 ; 1,12)$ & $0,95(0,90 ; 1,20)$ & 0,005 & 0,001 & 0,031 \\
\hline $\begin{array}{c}\text { Total amount of atherosclerotic } \\
\text { plaques }\end{array}$ & $1(0 ; 2)$ & $2(1 ; 2)$ & $3(3 ; 4)$ & 0,14 & 0,007 & 0,022 \\
\hline $\begin{array}{l}\text { Frequency of registration of } \\
\text { atherosclerotic plaques in } \%\end{array}$ & $12(40,0 \%)$ & $54(69,2 \%)$ & $32(84,2 \%)$ & 0,005 & $<0,0001$ & 0,08 \\
\hline Maximal stenosis of carotid arteries in\% & $20(0 ; 40)$ & $25(15 ; 40)$ & $30(30 ; 60)$ & 0,09 & 0,006 & 0,01 \\
\hline
\end{tabular}

CI basis $[16,17,30]$. Thus, there is every reason to consider increased VAR SBP as an independent risk of affecting target organs and the development of complications in hypertension. According to the received data, the variability of the systolic blood pressure increased concurrently with the deterioration of the cognitive function. In addition, we have received a close correlation between the degree of $\mathrm{CI}$ and VAR SBP $(\mathrm{p}<0.001)$.

The increase of the average daily SBP and VAR SBP in patients with cognitive impairments also led to an increase in the time index (IT SBP) in these patients. What is more, the degree of CI growth correlated with the magnitude of IT SBP. The duration of the increase of the blood pressure during the day (IT) characterizes the hyperbaric load on target organs more accurately than the mean values of blood pressure. Numerous studies have shown that the duration of the increase of $\mathrm{BP}$ is a more important risk factor for cardiovascular complications: a close correlation between the iLVMM, the maximum left ventricular filling rate and left ventricular index $[15,16,17,25,26]$ has been established.

The Framingham study, which is considered to be a benchmark for epidemiological studies, has revealed the importance of the early rise of BP in the occurrence of such complications of hypertension as strokes, heart attacks and sudden death, the risk of which was $70 \%$ higher in the early hours compared to other periods of the day. According to data of our study, the value of the speed of morning rise (SMR) in patients with the moderate CI was significantly higher than in patients of the first two groups $(\mathrm{p}=0.031)$ (Table II). Thus, the deepening of the daily profile of blood pressure in patients with HT resulted in an increase of cognitive impairment, which can possibly be considered as a brain damage during hypertension.

The combination of elevated blood pressure with atherosclerotic damage of carotid arteries which often coexists and determines the high risk of cardiovascular complications in such patients is particularly unfavourable. There is evidence that even a small amount of their atherosclerotic lesions has the same importance in the development of cerebral complications, as well as hemodynamic-significant stenosis [17. 19, 20].
The index of «intima-media», which is measured during sonography or duplex examination of extracranial vessels, is the most important and the earliest indicator of the development of the atherosclerotic process $[19,20,31]$. The peculiarities of the vascular bed remodeling in patients with coronary artery disease and HT can, in turn, determine the likelihood of the development of cerebrovascular complications in this category of patients [24]. There is information about the correlation between the thickness of intima-media (IMT) and the type of ischemic stroke, the size of the ischemic focus and its localization [29]. It is believed that the more IMT is the higher the probability of stroke. In addition, the absolute magnitude of IMT progressively increases in proportion to the age and the duration of hypertension.

The indices of the pulsation index $(\mathrm{Pi})$ and index of peripheral resistance $(\mathrm{Ri})$, which are indirect evidence of the increase in the value of peripheral resistance of the brain vessels, increased with the extent of the occurrence and growth of violations of the cognitive sphere in the studied groups. In addition, the linear velocity of blood flow in the carotid arteries increased with the same regularity $(\mathrm{V}, \mathrm{m} / \mathrm{s})$. The mutual growth of vascular resistance and blood flow velocity in them due to vascular remodeling as a result of both excessive pressure and atherosclerosis is the leading pathogenetic mechanism of occurrence of both chronic cerebral hypoperfusion and acute cerebrovascular disorders.

There also were IMT different values in the studied patients with different degrees of cognitive impairment: this rate increased with the increase of these violations with significant differences between all groups $(p=0.005$, $p=0.001, p=0.031)$. Importantly, if the IMT did not exceed the norm $(0.8 \mathrm{~mm})$ in patients without deviations of the cognitive activity, it was already greater than normal $(0.92 \mathrm{~mm}$ at normal to $0.9 \mathrm{~mm}$ ) in patients with mild $\mathrm{CI}$ and even more $(0.95 \mathrm{~mm})$ in patients with moderate cognitive impairment even more ( $0.95 \mathrm{~mm}$ ) (Table III). According to the presented study, close correlation between IMT and the degree of cognitive impairment ( $\mathrm{p}<0.0001$ ), as well as between the total number of atherosclerotic 
plaques $(\mathrm{p}=0.0008)$ and maximal stenosis of carotid arteries $(\mathrm{p}<0.0001)$ with the presence and degree of $\mathrm{CP}$ have been received.

\section{CONCLUSIONS}

1. The current study revealed a clear correlation between the degree of cognitive impairment and the degree of changes in the daily blood pressure profile, the most important of which were the average daily systolic blood pressure and systolic blood pressure variability.

2. The occurence and the degree of cognitive impairment closely correlate with changing the geometry of the left ventricle, which confirms the existence of a common process of cardiovascular remodeling, the manifestation of which is the hypoperfusion of target organs with the development of their dysfunction.

3. Remodeling of brain vessels due to arterial hypertension and atherosclerosis, determined by the vascular Doppler, is the main cause of cognitive impairment, causes the appearance and reflects their degree.

On the basis of the conducted research, in the future it will be possible to predict the level of the cognitive sphere involvement, depending on the state of the daily blood pressure profile, changes of the ventricle and vessels geometry, which will enable timely diagnosis of cognitive impairment and the prescription an adequate therapy.

\section{REFERENCES}

1. Parfenov V.A. Kognitivnyie rasstroystva pri tserebrovaskulyarnyih zabolevaniyah: diagnozi lechenie [Cognitive disorders in cerebrovascular diseases: diagnosis and treatment]. Russian Medical Journal. 2009; 11(18):1650-1660. (In Russian).

2. Skvartsova V.I. Hronicheskaya ishemiya mozga [Chronic cerebral ischemia]. Russian Medical Journal. 2008; 16(26):1762-1770. (In Russian).

3. Zaharov V.V. Printsipyi vedeniya patsientov s kognitivnyimi narusheniyami bez dementsii [Principles of managing patients with cognitive impairment without dementia]. Russian Medical Journal. 2009; 16(12):1645-1650. (In Russian).

4. Damulin I.V. Sosudistyie kognitivnyie narusheniya u pozhilyih [Vascular cognitive impairment of the elderly people]. Russian Medical Journal. 2009; 7(11):721-726. (In Russian).

5. Parfenov V.A. Kognitivnyie rasstroystva pri tserebrovaskulyarnyih zabolevaniyah: diagnozi lechenie [Cognitive disorders in cerebrovascular diseases: diagnosis and treatment]. Russian Medical Journal. 2009; 11(18):1650-1660. (In Russian)

6. Mancia G, R. Fagard R, Narkiewicz K et al. 2013 ESH/ESC Guidelines for the management of arterial hypertension. The Task Force for the management of arterial hypertension of the European Society of Hypertension (ESH) and of the European Society of Cardiology (ESC). J Hypertension. 2013; 31:1281-1287.

7. $0^{\prime}$ Donnell M.J, Xavier D, Liu L et al. Risk factors for ischaemic and intracerebral haemorrhagic stroke in 22 countries (the INTERSTROKE study): a case-control study. Lancet. 2010;376(9735):112-123.

8. Muela $\mathrm{H}$, Costa-Hong V, Yassuda $\mathrm{M}$ et al. Hypertension severity is associated with impaired cognitive performance. J Am Heart Assoc. 2017;6(1):45-59.
9. Kearney-Schwartz A, Rossignol P, Bracard S et al. Vascular structure and function is correlated to cognitive performance and white matter hyperintensities in older hypertensive patients with subjective memory complaints. Stroke. 2009;40:1229-1236.

10. Parfenov V.A. Kognitivnyie narusheniya u patsientov $s$ arterialnoy gipertenziey $i$ in lechenie. [Cognitive impairment in patients with arterial hypertension and their treatment]. Neurology, neuropsychiatry, psychosomatics. 2011; 3(1):27-33. (In Russian).

11. Zaharov V.V. Kognitivnyie narusheniya pri arterialnoy gipertenzii. [Cognitive impairment in arterial hypertension]. Nervous diseases. 2013; 3(18):16-21. (In Russian).

12. Zaharov V.V. Vserossiyskaya programma issledovaniy epidemiologii i terapii kognitivnyih rasstroystv v pozhilom vozraste («Prometey»). [All-Russian program of research on epidemiology and therapy of cognitive disorders in the elderly ("Prometheus")]. Neurology Journal. 2006; 11:27-32. (In Russian).

13. Yahno N.N. Sosudistyie kognitivnyie rasstroystva [Cognitive vascular disorders]. Russian Medical Journal. 2005; 13(12):2-7. (In Russian).

14. Dart AM, Gatzka CD, Kingwell B.A et al. Brachial blood pressure but not carotid arterial waveforms predict cardiovascular events in elderly female hypertensives. Hypertension. 2006;47:785-790.

15. Orlova Ya.A. Zhestkost arteriy, kak prediktor serdechno-sosudistyih oslozhneniy pri IBS. [Artery rigidity as a predictor of cardiovascular complications in coronary heart disease]. The therapist. Arch. 2010; 82(1):68-73. (In Russian).

16. Mathiassen ON, Buus NH, Sihm IJ et al. Small artery structure is an independent predictor of cardiovascular events in essential hypertension. Hypertens. 2007;25:1021-1027.

17. Ostroumova 0.D. Zhestkost sosudistoy stenki u patsientov s arterialnoy gipertoniey. [Rigidity of the vascular wall in patients with arterial hypertension]. Systemic hypertension. 2015; 11(2):43-51. (In Russian).

18. Lacolley $\mathrm{P}$, Challande $\mathrm{P}$, Osborne-Pellegrin $\mathrm{M}$ et al. Genetics and pathophysiology of arterial stiffness. Cardiovasc Res. 2009;81:637-648.

19. Polivoda S. N. Porazhenie organov-misheney pri gipertonicheskoy bolezni. Prakticheskoe rukovodstvo [Defeat of target organs with hypertension. Practical Guide]. Kyiv: The Fourth Wave; 2005, p 800. (In Russian).

20. Belenkov Yu. N. Serdechno-sosudistyiy kontinuum [Cardiovascular continuum]. Cardiac insufficiency. 2002; 3(1):7-11. (In Russian).

21. Ivanov A. P. Remodelirovanie levogo zheludochka u bolnyih arterialnoy gipertoniey [Remodeling of the left ventricle in patients with arterial hypertension]. Clinical Medicine. 2006; 5:38-41. (In Russian).

22. Schmieder RE. Mechanisms for the clinical benefits of Angiotensin II receptor blockers. Am. J. Hypertens. 2005;18:720-730.

23. Bagmet A. D. Remodelirovanie sosudov i apoptoz v norme i pri patologii [Remodeling of vessels and apoptosis in norm and at pathology]. Cardiology. 2002; 3:83-86. (In Russian).

24. Boytsov S. A. Sosudyi kak platsdarm i mishen arterialnoy gipertonii [Vassels as a base and a target for arterial hypertension]. The actual questions of diseases of the heart and blood vessels. 2008: 1(3):35-40. (In Russian).

25. Vizir V. A. Remodelirovanie sosudov i endotelialnaya disfunktsiya u bolnyih gipertonicheskoy boleznyu [Remodeling of vessels and endothelial dysfunction in patients with hypertonic disease]. Zaporozhye Medical Journal. 2007; 4:11-13. (In Russian).

26. RyibakovaM.K. Ehokardiografiyavtablitsahishemah [Echocardiographyintables and circuits]. Moscow: Publishing House Vidar-M; 2016, p288. (In Russian). 
27. Rebrova 0. Yu. Statisticheskiy analiz meditsinskih dannyih. Primenenie paketa prikladnyih programm STATISTICA [Statistical analysis of medical data. Application of the program package STATISTICA]. Moscow: Media Sphere; 2006, p 312. (In Russian).

28. Den Hond E, Staessen JA. Relation between left ventricular mass and systolic blood pressure at baseline in the APTH and THOP trials. Blood Press Monit. 2003:8(4):173-175.

29. Fagard RH, Celis H. Prognostic significance of various characteristics of out-of-the-office blood pressure. J. Hypertens. 2004;22:1663-1666.

30. Maslyaeva L. V. K probleme sochetaniy arterialnoy gipertenzii s ishemicheskoy boleznyu serdtsa i serdechnoy nedostatochnostyu: vse li izucheno? Chast II. Arterialnaya gipertenziya i hronicheskaya serdechnaya nedostatochnost [To the Problem of Combinations of Arterial Hypertension with Ischemic Heart Disease and Heart Failure: has everything been studied? Part II. Arterial hypertension and chronic heart failure]. Ukr. therapist magazine. 2006; 4:96-103. (In Russian).

31. Goldstein LB, Hankey GJ. Advances in primary stroke prevention. Stroke. 2006;37:317-319.

\section{Authors' contributions:}

According to the order of the Authorship.

\section{Conflict of interest:}

The Authors declare no conflict of interest.

\section{CORRESPONDING AUTHOR}

\section{Yulia V. Mazur}

National Pirogov Memorial Medical University

Pirogov str. 56, 21018 Vinnytsya, Ukraine

tel: +380972693562

e-mail: Mazur_jylia@ukr.net

Received: 11.02.2019

Accepted:04.04.2019 
PRACA ORYGINALNA

ORIGINAL ARTICLE

\title{
EUTHANASIA OR PALLIATIVE CARE: LEGAL PRINCIPLES OF THE IMPLEMENTATION IN THE CONTEXT OF THE REALIZATION OF HUMAN RIGHTS TO LIFE
}

\author{
Iryna V. Chekhovska' ${ }^{1}$ Olha M. Balynska' ${ }^{2}$, Roman I. Blahuta ${ }^{2}$, Valeriy V. Sereda ${ }^{2}$, Serhii 0. Mosondz ${ }^{3}$ \\ 1 UNIVERSITY OF THE STATE FISCAL SERVICE OF UKRAINE, IRPIN, UKRAINE \\ ${ }^{2}$ LVIV STATE UNIVERSITY OF INTERNAL AFFAIRS, LVIV, UKRAINE \\ ${ }^{3}$ UNIVERSITY OF MODERN KNOWLEDGE, KYIV, UKRAINE
}

\begin{abstract}
Introduction: The right to life - is natural inherent human right, the fundamental principle of the existence of mankind, recognized by all civilized countries. It is enshrined in numerous international and national legal acts as the most important benefit of a man. However, there are discussions about the use of euthanasia. Therefore, the problem of the legalization of euthanasia requires careful study.

The aim: The purpose of this article is to analyze and systematize existing problems of the legalization of euthanasia. The main objective of the article is to study the legal grounds for the introduction of euthanasia in the context of realizing the right to life, to study the content of palliative care, to distinguish the barriers to its development, and to formulate propositions for their elimination.

Materials and methods: Theoretical (analysis, synthesis, generalization, systematization, etc.) and empirical methods (observation, survey, classification, etc.) were used in the course of the research.

Results: The author has revealed the negative attitude of medical staff to the possibility of using different forms of euthanasia during the study. The reasons for the positive attitude of patients, who were in the thermal stage to the euthanasia, have been determined. It has been established that the correction of most causes leads to a significant reduction in the percentage of positive attitude to euthanasia. The arguments of opponents and supporters of the legalization of euthanasia procedure have been analyzed. $\mathrm{On}$ this basis the author has proved the objective absence of legal grounds for the legalization of euthanasia procedure and direct violation of human rights to life.

Conclusions: The author has proved the expediency of the development of palliative care as an alternative to euthanasia, has outlined the obstacles to its development, has offered to develop regulatory base for the legal regulation of the provision of palliative care, to establish the National Coordination Council on palliative and hospice care, to form the system of state control over the quality of provision of palliative care and observance of the rights of patients.
\end{abstract}

KEY WORDS: euthanasia, palliative care, the right to life, the rights of patients

Wiad Lek 2019, 72, 4, 677-681

\section{INTRODUCTION}

The right to life - is natural inherent human right, the fundamental principle of the existence of mankind, recognized by all civilized countries. It is the greatest, the most important benefit and holds the key position in the system of human rights. It is enshrined in numerous international and national legal acts. Thus, the Art. 3 of the Universal Declaration of Human Rights states: "Everyone has the right to life, liberty and security of person" [1], the Art. 2 of the Convention for the Protection of Human Rights and Fundamental Freedoms states that the right to life is protected by law and no one can be deprived of it intentionally [2], the Art. 27 of the Constitution of Ukraine states: "Every person has the inalienable right to life. No one shall be arbitrarily deprived of life. Everyone has the right to protect his or her life and health, the lives and health of other persons against unlawful encroachments" [3]. The right to life is also guaranteed by the Art. 281 of the Civil Code of Ukraine [4]. The laws of most countries provide protection for the right of their citizens to life. The right of citizens to stop or restrict their own or another's life is not indicated anywhere. However, despite the above, as well as the position of the European Court of Human Rights on the inadmissibility of the euthanasia's legalization in recent decades, there are discussions about its application have revived in many countries $[5 ; 6$; $7 ; 8]$. We are talking about the practice of stopping a life of a person who has an incurable disease by a physician to meet his request in a painless or least painful form to stop the unbearable suffering. Of course, the increased interest in the issue of euthanasia can be attributed by the rapid progress in the development of technology and medicine, the introduction of robotics, methods of life support, etc. [5, p. 391]. However, the issues of the legalization of euthanasia require careful study. It should be noted that despite the liberal attitude of certain countries 
to euthanasia, most scholars and practitioners perceive it negatively $[9 ; 5 ; 8 ; 10 ; 11]$.

Euthanasia in most world countries is either not foreseen by law or prohibited by law $[10 ; 5]$. However, there are countries that have recognized the human right to death at the legislative level and do not consider euthanasia as a criminal offense (Netherlands, Belgium, Luxembourg, Federal Republic of Germany, Finland, Switzerland, Sweden, the states of Oregon, Missouri, New Jersey, Vermont, Washington, Montana, Georgia of the USA) [5; 10], and in this regard prompted a new wave of discussions on the legalization of euthanasia.

\section{THE AIM}

The purpose of this article is to analyze and systematize existing problems of the legalization of euthanasia. The main objective of the article is to study the legal grounds for the introduction of euthanasia in the context of realizing the right to life, to study the content of palliative care, to distinguish the barriers to its development, and to formulate propositions for their elimination.

\section{MATERIALS AND METHODS}

In October-November 2018, a survey was conducted, where 36 people at the age of 47 years and older were interviewed through a formal interview. Besides, based on the analysis of international standards, current national and international legislation, journalism, analytical materials, and sociological surveys, one systematized approaches of supporters and opponents of the legalization of euthanasia. The lack of legal grounds for legalizing the euthanasia procedure and a direct violation of the right of a person to life was also systematized. The scope of the rights for palliative patients was defined by the method of legal analysis. The comparative and legal method allowed to reveal the shortcomings of national legislation on the legal regulation of the provision of palliative care and to develop propositions for their elimination. The author of the article also used methods of statistical, comparative analysis, dialectic, extrapolation, etc.

\section{RESULTS AND DISCUSSION}

"Declaration on euthanasia", which stated that the deliberate deprivation of the patient's life at his request or at the request of his relatives should be considered unethical [12], was adopted in October 1987 by the 39th World Medical Assembly (Madrid, Spain). The official position of the medical community in the United States, expressed by the American Medical Association, also rejects euthanasia: "It is incompatible with the prohibition of using medical devices to cause the death to a patient". The American Medical Association by forbidding its members to participate in euthanasia put forward the following slogan: "Physicians should not be executioners" [13, p. 213].
The attitude of medical staff to the possibility of using different forms of euthanasia can be demonstrated by an example of a conducted in 2014 survey of doctors in Chernivtsi (Ukraine). 46\% of respondents were against euthanasia, and $17 \%$ of respondents refused to answer. $45 \%$ of the respondents expressed extremely negative attitude towards the use of any types and forms of euthanasia. Almost $64 \%$ of physicians were not personally ready to realize the request of a patient to go away from life. Consequently, every second respondent, in case of the adoption of the relevant law on euthanasia, is not ready for moral and legal liability for the possible consequences of the application of such a law. The vast majority of physicians do not at all imagine the circumstances and methods of implementing active euthanasia in their activities, considering it as dehumanised phenomenon. Even the formal permission of active euthanasia, according to physicians, can lead to a paralysis of the process of modernization in the health care sector [14, p. 151].

A study conducted in the Netherlands revealed the causes of the positive attitude of patients to euthanasia who were in the thermal stage. The data is presented in Fig. 1

Pain as the main reason for a favorable attitude to euthanasia was named by $56 \%$ of patients in Ivano-Frankivsk Regional Clinical Center for Palliative Care (a survey was conducted in October-November 2018, where 36 persons were interviewed by the method of formal interviewing at the age of 47 and older).

Palliative care, which in the modern sense is considered as a complex system of measures of medical, social, spiritual and psychological nature aimed at the comprehensive support of a patient, in case if the disease can not be treated, can be solved by the problems facing by incurable dying patients and their families. That is, palliative care is a legitimate alternative to euthanasia and one of the ways to realize the right of citizens to life and to receive adequate medical care in any illness or condition.

Unlike specialized medical intervention aimed at curing a disease, palliative care is aimed at alleviating the physical condition of a patient (overcoming the pain and eliminating other negative manifestations of the disease), maintaining his spiritual and emotional condition, as well as improving the living conditions of a patient and his environment.

Back in 1989, the WHO Committee of Experts stated in its official report: "With the development of modern methods of palliative treatment, the legalization of voluntary euthanasia is not mandatory. Today, when there is an alternative to death accompanied by a pain, it is necessary to focus on the implementation of the program of palliative care, but not to admire the struggle for the legalization of euthanasia" [15, 55-56].

The conducted studies allow us to make assumptions about the expediency of palliative care development as an alternative to euthanasia. Palliative medicine has a real opportunity to demonstrate the effectiveness of measures to minimize the pain, to correct the psychological state of both a patient and his family members. It should also be noted that medical technology today allows us to actively fight against pathological conditions, the treatment of which was quite problematic 10-15 years ago. It should also be noted that palliative medicine is not able to completely overcome suffering yet, but the correction of 


\section{Reasons of patients' positive attitude to euthanasia}
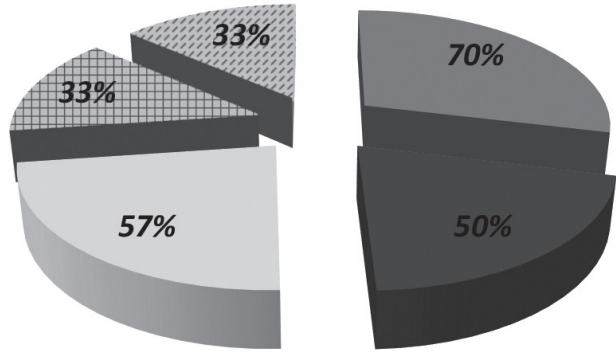

- Intolerable situation

Fear of future suffering

Loss of dignity

\# Dependence on others

Satigue from life

Fig. 1. Results of the patients survey

most causes leads to a significant reduction in the percentage of positive attitude to euthanasia.

In the context of the above, we consider it appropriate to systematize the positions of opponents to the legalization of euthanasia procedure. Arguments of supporters to the legalization of euthanasia are provided in previous works of scholars [5; 16], however, the arguments of opponents of the legalization of euthanasia procedure have not been practically revealed by them. So, why the majority opposes:

1. Through religious beliefs, which are the first inhibiting factors. Despite the difference in denominations in the world, virtually all of them prohibit intentional murder, suicide, arguing that "God gave life, and he disposes it" [17].

2. Permanent fight against fatal diseases allows medicine forge ahead, to develop, to seek new drugs and methods of treatment, and the introduction of euthanasia can greatly slow down this process.

3. Possible problems with physically disabled people, which are a "burden" for others. Their defects can serve as an occasion for social pressure and coercion for "light death".

4. Euthanasia can easily become one of the methods of killing, and also lead to abuse of official position, bribing of medical personnel, deliberate harm, etc.

5. It is extremely difficult to understand when a patient really wants to die. Stress, prolonged depression, public pressure or threats can all be the reason for applying for the procedure's permission. However, it is difficult to predict whether a person will refuse to go from life and will decide to continue it even in suffering, at the last moment of the procedure of euthanasia.

6. The cases of miraculous healing are completely excluded. Medicine counts hundreds of cases when a doomed patient suddenly got on his hind legs after a severe form of cancer or awoke after 20 years of coma: health returned when nobody had any hope.

7. It is worth saying that the murder of a patient is completely contrary to the Oath of Hippocrates, which says that a physician should not give a deadly mean and show the ways to achieve death. It is this factor that causes a lot of controversy in making decisions among physicians.
8. Relatives of persons, who are in a difficult situation, in case of the legalization of euthanasia, may abuse their rights for the purpose of property enrichment.

9. A formal permit for euthanasia may promote unfairness in the provision of medical care to such patients.

10. The decision about euthanasia can be done hastily and not balanced under the influence of the desire to get rid of suffering not so much yourself, but the people around you, first of all, their loved ones.

11. The criterion of incurability is difficult to determine, then one can expect from the science the healing from serious illness and reducing the suffering of patients.

12. One of the most serious arguments against euthanasia is the risk of misuse of medical personnel and neglect of their duties, as well as a particularly dangerous possibility of a diagnostic medical error.

"I am a handicapped person and I do not support the right to die for one very important reason" - this is the title of the article published in "The Independent". The author, James Moore, suffers from severe physical disabilities and drug and medical interventions in order to "live" and to make him pain-controlled. Despite this, he opposes the notion of so-called "right to death" [7]. The event, entitled "Deep End of Life in Europe", has been recently held in the European Parliament (EP). It was arranged by Hilda Wutmanns, a member of the Belgian Parliament and a member of the Alliance's Parliamentary Assembly (Alliance for Liberals and Democrats of Europe). Mrs. Wutmanns advocates euthanasia, namely the idea of "a decent end to life as the fundamental human right". According to her, countries that have legalized this right "more love their citizens", which leads to a more "positive approach" to death [7]. The question is how this love is expressed? Common sense says that loving someone means to be on his or her side, to take care, to support. People need more love when they are weak and vulnerable. How can one say that someone under the influence of this vulnerability knows that it is better to pass away, is it the so-called "act of love"?

Here is another argument that was used to justify euthanasia; it was associated with the idea of dying with dignity. Dr. Dieter Birnbacher, President of the German organization promoting euthanasia, emphasized the fact 
that we should take into account personal feelings of human dignity while popularizing euthanasia. In other words, if a person feels that in any way something affects his human dignity, he must have the opportunity to freely choose the path of euthanasia [18]. But how such an important decision as the end of life can be based on subjective feelings?

The Wutmanns supporters and representatives of pro-euthanasia organizations emphasize the fact that "right to death" should be regarded as "human right", which must be respected. However, this idea of having the "right to die" as the fundamental human right contradicts to international law $[1 ; 2 ; 5]$ and can not be used as a basis for legalizing the procedure of euthanasia.

Thus, the above suggests that there is an objective lack of legal grounds for legitimizing the euthanasia procedure and a direct violation of the right of a person to life, instead confirms the thesis on the expediency of further development of palliative care as an alternative to euthanasia.

Palliative care as an independent area of activity has been officially recognized at international level after the report of WHO experts "Cancer Pain Relief and Palliative Movement" in 1990 [16, p. 185]. An active process for the establishment of national unions and associations of hospice and palliative care has begun: the US National Hospice and Palliative Care Organization (NHPCO), the International Association for Hospice and Palliative Care (IAHPC), the EAPC (Italy), Help The Hospices (Great Britain ) and others. In 2002, national standards for the provision of palliative care were established in 8 countries of the world, and in 2003 the basic principles of palliative care were approved [16, p. 186]. However, there is currently no normative document that would specify a list of the rights of palliative patients. Carrying out the analysis of special international and legal standards in the field of palliative care (the Venice Declaration on the incurable diseases (1983), the Regulations on the care of patients with severe chronic pain in incurable diseases (1990), the Recommendations of the Committee of Ministers of the Council of Europe "On the organization of palliative care" (2003), I.Ya. Seniuta distinguishes such possibilities of palliative patients, as the right to: relieve of the symptoms of the disease, suffering; psychological, spiritual and emotional support; his family; the availability of palliative care regardless of the type of disease, geographical location, socio-economic status or any other characteristics; qualified palliative care provided with proper equipment and a multifunctional team of specialists; consideration of the patient's needs at his own discretion, but with an advantage in the context of providing better palliative care; respect for his rights; priority of his interests and their protection; a wide range of services in the field of palliative care, in particular to provide this type of aid in various forms, taking into account the needs and wishes of a patient; timeliness of receiving palliative care; availability of opium and other narcotic drugs for medical purposes; medical information provided in the light of the situation, in which a patient appeared, his needs, his emotional state and desire; medical secrecy; refraining from treatment with his consent as the method of relieving suffering from an incurable disease; obtaining necessary medicines to relieve the suffering from an incurable disease; obtaining extraordinary remedies only if there is evidence that they are beneficial to a patient; treatment that allows him to live last days with dignity and honor, which is a part of the care of the incurably ill patient with severe chronic pain [19, p. 235-236].

The analysis of these rights of palliative patients allows us to conclude that it is necessary to focus efforts on the development of palliative care, to identify the rights of palliative patients at the legislative level, to ensure the guarantees of the realization of such rights, and to inform the public about palliative care.

By the way, the low level of awareness in Ukraine (only $3 \%$ of the population understand the concept of "palliative care" [16, p. 190]) is the reason for the low activity of non-governmental organizations and philanthropists regarding participation in the realization of the tasks of palliative care, education, provision of psychological and social support to patients and their relatives.

Nowadays, the directed state policy that would be in line with international approaches in this field is almost absent in Ukraine, but the existing regulatory base does not yet define the principles and legal relations that would provide patients with the appropriate access to palliative care at the thermal stage. All this, as well as the extremely weak logistics of the existing several specialized departments of palliative care and undeveloped network of hospices for the dying people - in general, their complete absence in some regions, even for cancer patients - are the reasons that most patients of the specified category with severe chronic diseases in the thermal stage did not receive and still do not receive any care. Besides, the rigorous system of control over the circulation of opioid analgesics operating today in Ukraine makes it impossible to ensure the normal, civilized access to absolutely necessary painkillers for people suffering from unbearable pain. In addition, there are no institutional and human resources to establish a network of facilities and services for palliative care, methodological basis, standards and medical minutes, and there is no system of training and advanced training of medical and social employees who will provide palliative care [20]. The subdivision of health care and social protection establishments complicates the formation of a set of necessary medical and social measures that is involved by palliative care, and therefore the system of palliative care in general.

The above mentioned points to the need for state support, regulation and adequate financing of palliative care programs in order to achieve uniform accessibility for people with different types of diseases, if necessary, in different regions, at different levels of health care.

\section{CONCLUSIONS}

Deprivation of life (murder, suicide) is a criminal offense and any discussion on the legalization of euthanasia is deprived of legal grounds. Life is not the subject matter 
to legal regulation. It is the object that must be protected both by legal and medical means aimed at respecting each person's life.

Instead, palliative care with its "right-minded" ideology, which goal is to achieve the best quality of life for patients and their families, is an alternative to euthanasia. Therefore, it is necessary to develop, approve and finance the State Programs for the Development of Palliative and Hospice Care, to establish the National Coordination Council on Palliative and Hospice Care, to form regulatory base for the legal regulation of the provision of palliative care, to form the system of state control over the quality of the provision of palliative care and observance of the rights of patients in the process of providing palliative care through accreditation and licensing of institutions providing palliative care.

\section{REFERENCES}

1. Universal Declaration of Human Rights. United Nations. Available from: http://www.un.org/en/universal-declaration-human-rights/.

2. Convention for the Protection of Human Rights and Fundamental Freedoms as amended by Protocols No. 11 and No. 14. Council of Europe. European Treaty Series No. 5. Available from: https://rm.coe. int/1680063765.

3. Konstytutsiia Ukrainy [The Constitution of Ukraine]: zakon Ukrainy vid 28.06.1996 No. 254k/96-BP. Available from: http://zakon.rada.gov.ua/ laws/show/254\%D0\%BA/96-\%D0\%B2\%D1\%80 (In Ukrainian).

4. Tsyvilnyi kodeks Ukrainy (Civil Code of Ukraine) Zakon Ukrainy vid 16.01.2003 № 435-IV. Available from: http://zakon.rada.gov.ua/laws/ show/435-15 (In Ukrainian).

5. Stefanchuk R.0., Yanchuk A.O., Stefanchuk M.M., Stefanchuk M.0., Blazhivska N.Ye. Pravo na evtanaziiu: za chy proty? [The right to euthanasia: for or against?] Patolohiia. 2018;15(3):390-395. doi: 10.14739/2310-1237.2018.3.151873 (In Ukrainian).

6. Quill TE, Lo B, Brock DW. Palliative options of last resort: comparison of voluntarily stopping eating and drinking, terminal sedation, physician assisted suicide, and voluntary active euthanasia. JAMA. 1997;278(23):2099-104.

7. Bishop J.P. Euthanasia, efficiency, and the historical distinction between killing a patient and allowing a patient to die. Journal of Medical Ethics. 2006; 32(4):220-224, doi: 10.1136/jme.2005.013839.

8. Antonov $S$. Zabezpechennia prava patsiienta na hidnu ta bezbolisnu smert: pravovi ta etychni pytannia [Ensuring the right of a patient to dignified and painless death: legal and ethical issues]. Medychne pravo. 2011;7(1);7-13 (In Ukrainian).

9. Alpers $A, L O B$. Does it make clinical sense to equate terminally ill patients who require life sustaining interventions with those who do not? JAMA. 1997;277(21):1705-8.

10. Sereda S.V. Evtanaziia: dosvid pravovoho rehuliuvannia v inozemnykh krainakh ta dotsilnist dozvolu v Ukraini [Euthanasia: experience of legal regulation in foreign countries and expediency of its permission in Ukraine]. Medychne pravo Ukrainy: problemy paliatyvnoi dopomohy ta medyko-sotsialnoho obsluhovuvannia naselennia: Materialy IV Vseukrainskoi naukovo-praktychnoi konferentsii z medychnoho prava; 2010; Lviv: LOBF "Medytsyna i pravo", s. 196-200 (In Ukrainian).

11. Streltsov Ye. Evtanaziia: dukhovni, moralni ta pravovi skladovi [Euthanasia: spiritual, moral and legal components]. Yurydychnyi visnyk Ukrainy. 2009;16:4 (In Ukrainian).
12. E.E.Chernikov, M.M.Zaretskiy, N.M.Chernikova. Pravo likaria na evtanaziiu: problemy, sudzhennia, poshuk alternatyvy [Uthanasia: problems, judgements, search for alternative]. Ukrainskyi zhurnal ekstremalnoi medytsyny imeni H.0. Mozhaieva. 2008; 9(3):14-19 (In Ukrainian).

13. Annas G. Some Choice: Law, Medicine, and the Market. Oxford - New York, 1998.

14. Bezarov 0.T. Evtanaziia v konteksti medychnoi praktyky (za rezultatamy sotsiolohichnoho opytuvannia, provedenoho v m. Chernivtsi) [Euthanasia in the context of medical practice (according to the results of sociological survey conducted in Chernivtsi (ity)]. Bukovynskyi medychnyi visnyk. 2005;9(1):149-154.

15. Obezbolivanie pri rake i palliativnoe lechenie: doklad Komiteta ekspertov VOZ [Cancer Anaesthesis and Palliative Care: Report of the WHO Expert Committee].Seriia tekhnicheskikh dokladovV0Z; 804 Zheneva, $1992.77 \mathrm{~s}$.

16. Lavrynenko 0.0., Rohova 0.H., Panasiuk S.A. Komentar medychnoho zakonodavstva Ukrainy [Review of medical legislation of Ukraine]. Kyiv: Vydavnychyi dim "Profesional", 2017. 360 c. (In Ukrainian).

17. Janssens L. Ontic Evil, Moral Evil, in: Curran, C., McCormick, R.A. (eds.), Reading in Moral Theology: Moral Norms in the Catholic Tradition. No. 1. New York: Paulist Press; 1979. p. 40-93.

18. Maclntyre, Alasdair C. After virtue: a study of moral theory. Notre Dame, IN: Notre Dame Press. Available from: https://epistemh.pbworks. com/f/4.+Macintyre.pdf.

19. Seniuta I.Ya. Pravove rehuliuvannia nadannia paliatyvnoi dopomohy v Ukraini: deiaki aspekty [Legal regulation of providing palliative care in Ukraine: some aspects]. Medychne pravo Ukrainy: problemy paliatyvnoi dopomohy ta medyko-sotsialnoho obsluhovuvannia naselennia: Materialy IV Vseukrainskoi naukovo-praktychnoi konferentsii z medychnoho prava; 2010; Lviv: LOBF "Medytsyna i pravo", s. 234-237 (In Ukrainian).

20. Proekt Kontseptsii Derzhavnoi prohramy rozvytku paliatyvnoi ta khospisnoi dopomohy v Ukraini na 2010-2014 rr. [Draft Concept of the State program for the development of palliative and hospice care in Ukraine for 2010-2014] Available from: https://novitsky.livejournal. com/110991.html (In Ukrainian).

\section{Authors' contributions:}

According to the order of the Authorship.

\section{Conflict of interest:}

The Authors declare no conflict of interest.

\section{CORRESPONDING AUTHOR Iryna V. Chekhovska \\ University of the State Fiscal Service of Ukraine \\ 31, Universitetskaya str., Kyiv region, Irpin, 08201, Ukraine chekhovska_i@ukr.net}

Received: 11.02 .2019

Accepted: 03.04.2019 
PRACA POGLĄDOWA

REVIEW ARTICLE

\title{
EXPERIENCE IN TREATMENT OF PATIENTS WITH ESOPHAGEAL ACHALASIA
}

\author{
Volodymyr 0. Shaprynskyi, Oleg Y. Kanikovskyi, Yevhen V. Shaprynskyi, Yaroslav V. Karyi \\ DEPARTMENT OF SURGERY, MEDICAL FACULTY NO 2, NATIONAL PIROGOV MEMORIAL MEDICAL UNIVERSITY, VINNYTSYA, UKRAINE
}

\begin{abstract}
Introduction: Esophageal achalasia is a neuromuscular disease, which is characterized by persistent impaired reflex opening of esophageal sphincter. Disease incidence is 0.6-2.0 per 100000 population with no tendency to decrease.

The aim of the study was to improve the results of treatment in patients with achalasia of cardia by differentiated approach in the choice of therapy method. Materials and methods:148 patients with esophageal achalasia aged 18 - 67 were studied between 2003 and 2018. The following degrees of the disease were determined (by Petrovskyi's classification): first - in 8, second - in 59, third - in 70, fourth - in 11 patients. Drug therapy was administered in achalasia of first degree, and cardiodilatation courses - in second and third degree of the disease. Indications for surgical treatment were: impossibility to perform cardiodilatation, S-shaped esophageal deformation (stage IV), complications associated with cardiodilatation, achalasia combined with other surgical pathology, recurrence of disease.

Review: Cardiodilatation therapy resulted in sustained clinical effect in stages I and II of the disease. In case of unsatisfactory results of cardiodilatation patients underwent elective operations. 18 patients underwent Heller-Dor plastic surgery, 4 - Heller-Petrovskiy operation, 1 - Besley plastic repair, 2 - Nissen fundoplication. In early postoperative period no failure or perforation of the esophagus occurred. The following complications developed: seroma - in 3 patients, postoperative wound infection - in 1 case. In one patient (4\%) the recurrence of disease was due to scar deformation of esophagogastric junction after Heller-Petrovskiy operation on the cardia. Conclusions: Cardiodilatation is an effective method of conservative therapy in stages I and II of the disease, while in stages III and IV it is warranted as preoperative preparation measure. We think Heller-Dor operation to be the best method of plastic repair in esophageal achalasia.
\end{abstract}

KEY WORDS: esophageal achalasia, cardiodilatation, surgical treatment

\section{INTRODUCTION}

Esophageal achalasia, a neuromuscular disease, is characterized by persistent impaired reflex opening of esophageal sphincter in approaching food, as well as lost peristalsis of esophageal muscles, leading to impaired esophageal patency. Disease incidence is $0.6-2.0$ per 100000 population with no tendency to decrease. In early stages of esophageal achalasia (I, II), various cardiodilatation types are preferred methods of treatment [1]. Drug therapy implies administration of different groups of pharmaceutical agents: cholinolytics, alfa- and beta- adrenergic blocking agents, beta-adrenoceptor agonists, nitrates (nitroglycerine, nitrosorbide), calcium channel blockers, spasmolytics, insulin. When conservative methods of treatment prove to be ineffective, as well as in stages III and IV of the disease, esophagocardiomyotomy (Heller operation) is performed. Over 60 operative methods have been proposed for esophageal achalasia, but neither of them ensures the avoidance of recurrence of dysphagia, thus indicating unsolved problem in achalasia treatment. Nowadays modified Gottstein-Heller operation on anterior esophagus wall has gained wide popularity. Besides, in order to prevent reflux esophagitis, esophagofundoraphy by Lort-Jacob, Dor fundoplication, Toupet fundoplication are used $[2,3,4]$. There are minimally invasive therapy methods as well - laparoscopic esophagocardiomyotomy with subtotal fundoplication is among them. The latter method is rather promising due to the benefits of laparoscopic surgery $[5,6,7,8]$.

Some researchers state that laparoscopic cardiomyotomy can be performed without previous cardiodilatation in patients with achalasia of stages II-IV. Others believe that dilatation therapy should be performed in all stages of the disease, surgery is indicated to those with failure of endoscopy, and dilation therapy in such cases is administered as preoperative preparation procedure. Commonly patients with esophageal achalasia are hospitalized to the surgical in-patient department with stages II-IV of the disease after being treated by therapists and general practitioners, which poses certain problems in performing minimally invasive procedures.

\section{THE AIM}

The aim of the study was to improve the results of esophageal achalasia treatment by differentiated approach in the choice of therapy method.

\section{MATERIALS AND METHODS}

Biomedical Ethics Commission of Vinnytsya National Pirogov Memorial Medical University on observance of moral and legal rules in conducting medical research has established that 
clinical research were carried out in compliance with the main provisions of GCP (1996), Council of Europe Convention for Human Rights and Biomedicine (1997), World Medical Association Declaration of Helsinki on ethical principles for medical research involving human subjects (1964-2000) and Order of Ministry of Health of Ukraine № 281 of November 1, 2000.

148 in-patients with esophageal achalasia treated at Thoracic Surgery Department of Vinnytsia Regional Pirogov Memorial Clinical Hospital were studied between 2003 and 2018. The age of patients was between 18 and 67. There were 52 males and 96 females. The majority of patients had achalasia of stage II and III. The following degrees of the disease were determined: first - in 8 patients, second - in 59 , third - in 70 , fourth - in 11 patients.

All patients underwent comprehensive clinical and laboratory investigation including ultrasound examination of the cardia, fibroesophagogastroscopy, and barium sulfate radiographic contrast study.

The earlier patient with achalasia applies for specialized medical care, the easier it responds to treatment.

Treatment of stage I achalasia included administration of cholinolytics, sedatives and nitrates. In this stage of disease, as well as in all other stages the patients were administered cardiodilatation therapy.

Cardiodilatation was performed using Starck's dilatator and balloon pneumatic dilatators. Pneumatic balloons with the diameter of 3-4 cm, as well as Wilson-Cook balloons with the diameter of $1.5-2 \mathrm{~cm}$ were used. Pneumatic dilatation under endoscopy supervision was performed to 20 patients with esophageal achalasia in endoscopy rooms. The procedure was performed under the patient's sedation and local anesthesia. 50 patients underwent dilatation with Starck apparatus under combined anesthesia with mechanical lung ventilation in X-ray operation room. During the operation, cardiodilatator's position, procedure stages, degree of jaw expansion were under $\mathrm{X}$-ray control; cardiodilatator's position was changed according to the axis of esophagus deviation by original method. After the operation all patients were administered bed regimen, hunger and proper medication with subsequent radiological control. No complications after cardiodilatation were observed.

Indications for surgical treatment were: impossibility to perform cardiodilatation, S-shaped esophageal deformation (stage IV), complications of cardiodilatation (lacerations, esophageal perforation, bleedings unresponsive to conservative therapy), achalasia combined with other surgical pathology, recurrence of disease because of the failure of conservative therapy and dilatation techniques.

Because of severe general state, debilitation and cachexia in patients with achalasia, particularly in stages III and IV, they underwent intensive preoperative preparation, consisting of metabolism correction, hypoproteinemia in particular, and water and electrolyte imbalance.

\section{REVIEW AND DISCUSSION}

Cardiodilatation therapy resulted in sustained clinical effect in stages I and II of the disease. Long-term results of cardiodilata- tion therapy were studied in 59 patients. In stage II, treatment of achalasia using cardiodilatation technique led to direct positive satisfactory results in $94.29 \pm 3.92 \%$ of cases, and long-term positive results- in $80.2 \pm 5.2 \%$. In stage II of the disease, direct positive results were received in $65.71 \pm 8.02 \%$ of cases, and long-term positive results - in $54.17 \pm 10.17 \%$. The data obtained demonstrated cardiodilatation to be the most effective method of treatment in patients with achalasia of stage I and II. Patients with satisfactory results and periodical symptomatic dysphagia were recommended repeated courses of cardiodilatation or surgery. Elective surgery was indicated to those with unsatisfactory results of cardiodilatation. In patients with stage IV achalasia, cardiodilatation technique was used to relieve the symptoms of dysphagia and as preoperative preparation procedure.

25 patients underwent the following operations: Heller-Dor plastic surgery - 18, Heller-Petrovskyi operation - 4, Besley plastic repair - 1, Nissen fundoplication - 2 patients.

In clinical settings esophageal cardiomyotomy with Heller-Dor cardioplasty is preferred. This method of operative treatment consists of several stages. Upper midline laparotomy is done and left lobe of the liver is mobilized. Nasogastral tube is inserted. The esophagus is carefully separated, and a lengthwise cut is made in the muscular layer of the lower esophagus, leaving the inner lining intact, thus conducting esophageal cardiomyotomy $8-10 \mathrm{~cm}$ in length (5-6 cm over and 3-4 cm under the esophagogastric junction). After that plastic repair is performed: anterior part of the stomach is sewed with the muscular layer to the left of myotomy site. Esophageal mucosa is covered by gastric fundus using interrupted stitches. In case of intraoperative damage of the mucous "defect", sealing with atraumatic sutures $(4 / 0$ or $5 / 0)$ is performed $[9,10,11,12,13]$.

In postoperative period nasogastric enteral nutrition of highly caloric enteral feeds was provided, and infusion, antibacterial and anti-inflammatory therapy was continued. On the $7^{\text {th }}$ day water soluble contrast $\mathrm{X}$-ray examination was done .

In early postoperative period no failure or perforation of the esophagus occurred. The following wound complications developed: seroma - in 3 patients, postoperative wound infection - in 1 case. In one patient (4\%) there was the recurrence of disease in late postoperative period because of scar deformation of esophagogastric junction after Heller-Petrovskyi plastics of the cardia. That complication was eliminated with the course of cardiodilatation therapy. No lethal cases occurred postoperatively.

\section{CONCLUSIONS}

1. Thus, esophageal achalasia remains one of uncommon esophageal diseases of neuromuscular origin, leading to its obstruction and requiring careful approach to its treatment. Long-lasting remission and positive results of treatment are due to early diagnosis and early start of therapy.

2. Cardiodilatation is an effective method of conservative therapy in stages I and II of the disease, while it is warranted as preoperative preparation procedure in stages III and IV. 
3. We think the best method of plastic repair in esophageal achalasia is Heller-Dor operation.

\section{REFFERENCES}

1. Chernousov A. F., Gadzhiev A. N., Shestakov A. L. Lechenie kardiospazma i ahalazii kardii pnevmokardiodilatatsiey [Treatment of cardiospasm and esophageal achalasia using pneumocardiodilatation]. Annals of Surgery. 2000; 3:50-53.

2. Starkov Yu. G., Shihin K.V., Solodinina Ye. N. et al. Laparoskopicheskaya ezofagokardiomiotomiya, fundoplikatsiya po Dor pri lechenii ahalazii kardii [Laparoscopic cardiomyotomy, Dor fundoplication in treatment of esophageal achalasia]. Endoscopic Surgery. 2006; 2:128.

3. Oskretkov V. I., Gankov V. A., Gurianov A. A. Videolaparoskopicheskaya rastyazhnaya vneslizistaya ezofagokardiomiotomiya, fundoplikatsiya po Doru v lechenii ahalazii pischevoda [Video laparoscopic extensible extramucous esophagocardiomyotomy, Dor fundoplication in treatment of esophageal achalasia]. Endoscopic Surgery. 2006; 2:100.

4. Shulutko A.M., Moiseev A. Yu., Kazarian A. M. Endoskopicheskaya hirurgiya v lechenii ahalazii pischevoda [Endoscopic surgery in treatment of esophageal achalasia]. Endoscopic Surgery. 2001; 5:16-21.

5. CherkasovM.F.,StartsevYu.M.,PereskokovS.V. etal.Lechenieahalazii pischevoda $s$ primeneniem videoendoskopicheskoy tehniki [Treatment of esophageal achalasia using video endoscope system]. Endoscopic Surgery. 2006; 2:151.

6. Veligotskiy N. N., Gorbulich A. V., Ursol G. N. et al. Prognoz effektivnosti endoskopicheskih metodik v lechenii ahalazii pischevoda [Prognosis of effectiveness of endoscopic methods in treatment of esophageal achalasia]. Kharkiv Surgical School. 2010; 2(40):25-28.

7. Sigal Ye. I., Burmistrov M. V., Muraviov V. Yu. Maloinvazivnyie metodyi $\checkmark$ lechenii ahalazii kardii [Minimally invasive methods in treatment of achalasia of cardia]. Endoscopic Surgery. 2003; 6:26-28.

8. Dunst C. M., Kurian A. A., Swanstrom L. L. Endoscopic myotomy for achalasia. Adv. Surg. 2014; 48:27-41.

9. Salvador R, Spadotto L, Capovilla G et al. Mucosal perforation during laparoscopic Heller myotomy has no influence on final treatment outcome. J. Gastrointest. Surg. 2016; 20(12):1923-1930.

10. Hu JW, Li QL, Zhou PH et al. Peroral endoscopic myotomy for advanced achalasia with sigmoid-shaped esophagus: long-term outcomes from a prospective, single-center study. Surg Endosc. 2015; 29(9):2841-2850.
11. Familiari P, Gigante G, Marchese M et al. Peroral endoscopic myotomy for esophageal achalasia: outcomes of the first 100 patients with short-term follow-up. Ann Surg. 2016; 263(1):82-87.

12. Miller HJ, Neupane R, Fayezizadeh M, Majumder A, Marks JM. POEM is a cost-effective procedure: cost-utility analysis of endoscopic and surgical treatment options in the management of achalasia. Surg Endosc. 2017; 31(4):1636-1642.

13. Docimo SJr, Mathew A, Shope AJ, Winder IS, Haluck RS, Pauli EM. Reduced postoperative pain scores and narcotic use favor per-oral endoscopic myotomy over laparoscopic Heller myotomy. Surg Endosc. 2017; 31(2):795-800.

The article is a part of complex scientific research work at Surgery Department of National Pirogov Memorial Medical University, Vinnytsya, "Development and improvement of advanced technologies in surgical treatment and prevention of postoperative complications in patients with diseases of abdominal and chest cavities», state registration number 0113 U007692.

\section{Authors' contributions:}

According to the order of the Authorship.

\section{Conflict of interest:}

The Authors declare no conflict of interest.

\section{CORRESPONDING AUTHOR \\ Yevhen V. Shaprynskyi}

National Pirogov Memorial Medical University

56 Pirigova St., Vinnytsya, Ukraine

tel: +380632861199

e-mail: evgensh20078@gmail.com

Received: 10.11 .2018

Accepted: 27.02.2019 
PRACA POGLACDOWA

REVIEW ARTICLE

\title{
THE WAY THE HEALTH CARE SYSTEM IN UKRAINE LOOKS LIKE: INTERNATIONAL PRACTICES WITHIN NATIONAL REALITIES
}

\author{
Borys 0. Lohvynenko', Roman V. Myroniuk', Olexander P. Svitlychnyy ${ }^{2}$, Aleksey Y. Prokopenko ${ }^{3}$, Lidija I. Kalenichenko \\ 'DNIPROPETROVSK STATE UNIVERSITY OF INTERNAL AFFAIRS, DNIPRO, UKRAINE \\ ${ }^{2}$ NATIONAL UNIVERSITY OF LIFE AND ENVIRONMENTAL SCIENCES OF UKRAINE, KYIV, UKRAINE \\ ${ }^{3}$ KHARKIV NATIONAL UNIVERSITY OF INTERNAL AFFAIRS, KHARKIV, UKRAINE
}

\begin{abstract}
Introduction: Nowadays there is the transformation of the national health care system in Ukraine, the ultimate goal of which is to create a modern, competitive model of medical care of citizens on the basis of forming packages of free medical services. However, the model adopted by Ukraine is in contradiction with national legislation in part of free medical aid guaranteed by the Art. 49 of the Constitution of Ukraine, and fragmentary considers positive international practices.

The aim of the paper is to determine the mistakes of the reform of the Ukrainian health care system and to reveal the positive international practices of the organization of health care systems that can be implemented in Ukraine.

Materials and methods: National and international legislation, official web resources of the executive authorities of Ukraine, statistics of the World Health Organization, materials of journalistic and scientific periodicals are the materials for the research of the health care system in Ukraine in comparison with international practices. Research methods are cross-sectoral, complex statistical, comparative, generalization, analysis and synthesis. In order to obtain the results, the authors have conducted a critical analysis of the current norms of the national Ukrainian legislation in the health care sector.

Review: The authors of the article have studied the main disadvantages of the national health care system in accordance with the concept of reforming the medical sector. Positive international practices that can be implemented into Ukrainian system for the real improvement of medical human rights in Ukraine have been revealed.

Conclusions: It has been proved that the ongoing reform of the health care system in Ukraine needs to be reviewed and optimized. It has been offered to consolidate a perspective model of the Ukrainian health care system, its principles and guarantees of immunity at the legislative level.
\end{abstract}

KEY WORDS: health care system, the right to health care, reforming, health care principles, implementation, guarantees of immunity

Wiad Lek 2019, 72, 4, 685-691

\section{INTRODUCTION}

The health care system serves as a platform for the actual realization of medical rights by citizens in any state. Efficiently functioning health care system is the basis for successful economic development, high defense capacity of the state, welfare of the population. The health care reform has long been discussed in Ukraine however, the actual implementation of the changes has been constantly postponed due to the comprehensive and complex nature of the problems in the medical sphere. The first real steps took place only in August 2014, as a result of the deployment of the health care reform in Ukraine.

The urgency of this issue is due to the fact that the reform of the health care system initiated in 2015in Ukraine, is accompanied by numerous shortcomings. Supporters of the reform argue in its favor, while opponents have the contrary arguments and data. The truth is that the reform of the health care system in Ukraine is overt and necessary. At the same time, the effectiveness of the reform can be clarified only after its completion, since individual or intermediate results do not give an idea of positive changes in general. The speculative nature of the issue of determining the effectiveness of the health care reform in Ukraine does not allow for objective statistical data from national sociological services. Their indicators are always optimisticly high and backed up by visual means in the form of pilot projects, concepts and schedules. However, today there are such indisputable facts as: failure of vaccination procedures, ineffective medical care in the countryside, the lack of a truly functioning "E-Health" system, problems with the procurement of a number of medical products, etc.

According to the expansive ranking of the countries of the level of medical care for 2019 (Health Care Index for Country) provided by the Numbeo, Ukraine is ranked 77 with the indicator 50.95 among 76 states. For example, Japan is ranked $3^{\text {rd }}$ with 80.40 points, Finland $-17^{\text {th }}$ with 73.49 points [1]. It should be noted that this rating for 2018 was prepared by Bloomberg on the basis of data from the World Health Organization, the United Nations and the World Bank on the effectiveness of the health care system (The Most Efficient Health Care), Ukraine was not on the list at all because of low life expectancy of the population [2]. For comparison, Japan occupied $7^{\text {th }}$ position with 64.3 points, Finland $-19^{\text {th }}$ with 54.7 points. Also, the ongoing reform of health care system 
in Ukraine contradicts to the national legislation in part of free of charge medical aid guaranteed by the Art. 49 of the Constitution of Ukraine.

An efficiently organized health care system should ensure the realization of medical rights by citizens in Ukraine, as well as contribute to strengthening the economic potential of the state due to the population's ability to work. Consequently, the current state of the health care reform in Ukraine is characterized by inconsistency and miscalculations, when the forecasts, perspectives and expected results are perceived as real achievements. In order to minimize the negative consequences of such strategic mistakes, it is necessary to consolidate the perspective model of the health care system of Ukraine at the legislative level, to establish its principles and guarantees of inviolability.

\section{THE AIM}

The objective of the paper is to determine the shortcomings of the reform of the Ukrainian health care system and to reveal the positive foreign practices of health care organization that can be implemented in Ukraine.

The purpose of the article is to study the perspectives of Ukraine's adoption of positive international practices on the organization of health care systems to improve the legislation in the medical sphere and to clarify the vectors for reforming the health care system in Ukraine.

\section{MATERIALS AND METHODS}

The materials of the research are the provisions of national and international legislation, official web resources of the executive authorities of Ukraine, statistics of the World Health Organization (hereinafter - WHO), materials of journalistic and scientific periodicals, systematized approaches of supporters and opponents of the reform. The lack of a dominant point of view regarding the reform of the health care system in the Ukrainian society has been established. The methods of the presented research are cross-sectoral, complex statistical, comparative, analysis and synthesis. In order to obtain the results the authors have conducted the analysis of the norms of administrative and medical legislation. Analysis and synthesis allowed to consider the reform of the medical sphere as a complex phenomenon. With the help of the legal analysis method, the legislative provision for ongoing medical reform has been defined. The statistical method has allowed to determine the level of efficiency of the health care system in Ukraine. Comparative and legal method has allowed to reveal the shortcomings of the national legislation within the prism of the studied problem and to develop propositions for their elimination.

\section{REVIEW}

Article 1 of the Law of Ukraine "On the Basis of the Legislation of Ukraine on Health Care" dated 19 November
1992 No 2801-XII stipulates that the legislation of Ukraine on health care is based on the Constitution of Ukraine and consists of these Fundamentals and other legislative acts adopted in accordance with them, regulating public relations in the field of health care [3].

The Article 1 of the Law of Ukraine "On the Basis of the Legislation of Ukraine on Health Care" dated from November 19, 1992 No. 2801-XII stipulates that the legislation of Ukraine on the health care is based on the Constitution of Ukraine and consists of these Fundamentals and other legislative acts adopted in accordance with them, regulating public relations in the field of health care [3].

At the same time, the Laws of Ukraine "On Increasing the Availability and Quality of Medical Care in Rural Areas" dated from November 14, 2017 No. 2206-VIII, "On State Financial Guarantees of Medical Care of the Population" dated from October 19, 2017 No. 2168-VIII; Resolution of the Cabinet of Ministers of Ukraine "On Approval of the Methodology for Calculation of the Costs of the Medical Services" dated from December 27, 2017 No. 1075, "On the Establishment of the National Health Service of Ukraine" dated from December 27, 2017 No. 1101, "On Approval of the Procedure for the Implementation of State Guarantees for Medical Care of the Population for the Program of Medical Guarantees for Initial Medical Care for 2018" dated from April 25, 2018 No. 407; Decrees of the Cabinet of Ministers of Ukraine "On Approval of the Concept of Health Care Financing Reform" dated from November 30, 2016 No. 1013-r, "On Approval of the Plan of Measures for the Implementation of the Concept of Health Care Financing Reform for the Period up to 2020" dated from November 15, 2017 No. 821-r. do not comply with the Constitution of Ukraine and the Fundamentals of Ukrainian Health Care Legislation as the Basic Law. Their discrepancy is related, first of all, with the constitutionally guaranteed right to health care, medical care and medical insurance in the aspect of free-of-charge basis for the realization of this right (except for insurance, which is not obligatory).

Numerous problems that accompany the reform remain unresolved even with the adoption of the legal base adopted in support of medical reform in accordance with the medical legislation of Ukraine. Thus, purchase of medicines through international institutions, transparency of reimbursement schemes for medical products, availability of medical care in rural areas, and the protection of personal data of patients in information bases are under the question for reasoning their effectiveness.

Miscalculations in the implementation of medical reform in Ukraine, as well as positive international experience that can contribute to their elimination will be discussed below.

\section{DISCUSSION}

The imperfection of evaluating the effectiveness of the ongoing medical reform in Ukraine is confirmed by the statistics (Health Care Index for Country) from Numbeo. Suggested analysis system is based on the opinion of re- 
spondents regarding health care system satisfaction rather than on official statistical materials and is presented in dynamics, depending on the year and place of the state in the ranking: $2018-65 ; 2017-74 ; 2016-63 ; 2015-95$; $2014-75 ; 2013-71 ; 2012-65$ [1]. There are fluctuations up to 10 points during a simple analysis both before and after the introduction of medical reform in Ukraine. In general, Ukraine's indicators for the whole reporting period are approaching the lower bound of the ranking, and thus, are unsatisfactory and convincingly testify about ineffectiveness of the system in the whole and the absence of obvious changes for the better.

Regarding the reform itself, the introductory part of the Ordinance of the Cabinet of Ministers of Ukraine "On Approval of the Concept of Health Care's Financing Reform" dated from November 30, 2016 No. 1013-r states that international experience, recommendations of the World Health Organization, as well as research of the specifics of the current model of the health care system of Ukraine indicate that the only way to provide high-quality medical care without financial stress for citizens is to move to financing medicine according to the insurance principle [4]. The approved Concept also stipulates that we offer to implement the model of state joint medical insurance in Ukraine that will take into account the best modern practices and experience of the transformation of health care systems in the world, in particular in Central and Eastern Europe [4]. However, there is a question: whether we can consider the health care model as insurance one and whether it corresponds to advanced international practices. Nowadays, we created an agency that manages health care budget. However, the state medical fund was not created. Therefore, the concentration of financial leverages in the National Health Service of Ukraine (hereinafter - NHSU) will only contribute to corruption risks, where the system of public authority in Ukraine suffers from these risks.

Supporting the reform, the Ministry of Health of Ukraine (hereinafter - MHU) observes that various types of payment for medical services are fixed by the Law, which allows the National Health Service of Ukraine to make payments for the full or partial payment of medical services. The MHU emphasizes that the National Health Services of Norway, Canada, Italy and Spain pay for similar models [5]. This position of the MHU is controversial, since each of the above-mentioned states has its own peculiarities in the organization of the health care system, which are united only by the presence of a specially authorized medical agency (agencies) responsible for medical services.

O.V. Bohomolets emphasizes that the MHU has not determined the model of health insurance in Ukraine. Earlier Ukraine's acting Minister of Health, Uliana Suprun in her interview to BBC Ukraine, noted: "We are introducing something more like the British system, where every citizen of Britain has state insurance. They do not have to record anywhere, look for some kind of insurance; it just works automatically with each visit to a physician or a call for ambulance" [6]. However, citizens in Ukraine do not have a conditional "account", which holds funds set aside for treatment. Instead, health expenditures are distributed among institutions, where patients have applied, and the range of medical services that may be received for free or partly depends on the volume of services provided. It deprives a patient of the choice, because while choosing between institutions or specialists, he is not able to choose a more expensive / cheaper drug or hemanalysis, because the state has already decided on this matter.

We should agree with the opinion of V.M. Pashkov that the introduction of state health insurance in Ukraine does not contradict the constitutional prescription for the free of charge medical care within state and communal health care institutions only if the payers of compulsory insurance payments (contributions) are business entities, state funds, etc. The collection of such payments (contributions) from citizens in the system of state health insurance will not be in line with the constitutional provision, as it will be one of the forms of payment for providing them assistance in state and communal health care institutions [7].

However, it should be noted that, first, the Constitution of Ukraine should determine the obligatory nature of state health insurance, its scope and conditions of solidarity. Secondly, the Law of Ukraine "On State Financial Guarantees of Medical Care of the Population" dated from October 19, 2017 No. 2168-VIII should be amended in part of specification of the mechanism of state compulsory health insurance and its components. Thirdly, the Law of Ukraine "On the Basis of the Legislation of Ukraine on Health Care" dated from November 19, 1992 No. 2801-XII, needs to be supplemented with the provisions that take into account the Twelve Principles of the Organization of Health Care for any national health care system, adopted by the $17^{\text {th }}$ World Medical Assembly (New York, USA, October 1963, with edits of the $35^{\text {th }}$ World Medical Assembly, Venice, Italy, October 1983) [8]. None of these principles has been fully taken into account in the Ukrainian health system at the present time.

We believe that the preliminary creation of the legal basis with the consolidation of the latter at the legislative level will minimize speculation in determining the optimal model of health care and make it impossible that regulatory acts, adopted in support of the reform during the transformation of the national health care system in Ukraine, do not comply with the Constitution of Ukraine. At the same time, the guarantees of inviolability of the health care system chosen by Ukraine will be the legislative consolidation of the said propositions.

In order to reform the medical system in Ukraine, it is expedient to borrow the experience of the states that were part of the USSR, and now, thanks to successful reforms integrated into the European Union (hereinafter - the EU) as the actual participants. The experience of such countries is extremely useful in view of the identity of their former health care systems with Ukrainian one. Instead, attempts to imprint leaders in health care ratings on the matters of medical rights of citizens are possible only through 
individual programs or directions, since the difference in organizational, financial and legal components of health care systems is too great.

The Member States of the Organization for Economic Cooperation and Development (hereinafter - OECD) spend on the average $9 \%$ of the gross domestic product (hereinafter - GDP) on the health care sector. According to 2017 data, the United States of America (17.2\%), Switzerland (12.4\%) and Germany (11.3\%) ranked the leader on this indicator. Turkey (4.3\%) had the lowest health expenditure indicator in relation to GDP (9.3\%). For comparison, about $3.7 \%$ of GDP is planned in Ukraine in 2019, which is well below the UN recommended minimum level of $5 \%$. Some politicians emphasized on this inconsistency during the meetings of Verkhovna Rada of Ukraine, but traditionally, the health care sphere remained aside from full financing.

Here is a summary of the consolidated budget expenditures for health care in 2016-2019 (see Figure 1) [10]. However, the further reform of the health care system, which mitigates the increase in the quantitative indicators of financial support of the sector, should be provided by the budget funds. Consequently, the desire and perspectives in the medical sphere differ significantly from the real situation.

Let's consider the experience of medical reforms of the former USSR countries that have successfully integrated into the EU.

Latvia. Since 1990, the state has tried both the system of social health insurance (SHI) and the system of National Health Service (NHS) without an alternative possibility of returning to the Soviet system of health care. Uldis Mitenbergsa, Girts Brigis a, Wilm Quentinb in the work «Healthcare financing reform in Latvia: Switching from social health insurance to NHS and back?» note that governments that plan to implement state health insurance do this mainly on the basis of arguments that it will improve the ability to raise health revenues by making health care funding more predictable (irrespective of political interference) and that people will be more willing to contribute their percentage if the right to health care is related to such contributions. However, it is obvious that part of the health care budget can be increased regardless whether health care taxes are paid or not and that the combination of the right to health care and payment of contributions will create access problems for uninsured persons. Governments con-templating the introduction of SHI mostly do so basedon arguments that it would improve the ability of raisingrevenues for health, making healthcare financing more pre-dictable (independent of political interference), and thatpeople would be more willing to contribute if eligibilityfor healthcare services is linked to making contributions. However, it is clear that the healthcare budget couldalso be increased independently of whether income taxis earmarked for health or not, and that linking healthcare entitlement to the payment of contributions willcreate access problems for the uninsured [11]. However, the binding of each citizen to the personal account of the state health insurance fund will facilitate the withdrawal of part of the population from the shadow sector of wages.

According to the information from the booklet "State of Health in the EU. Latvia. Country Health Profile 2017", a part of the population of Latvia is dissatisfied with the level of health care provided by the state, although Latvia has the state health care system, the completeness of which is somewhat smaller than in other EU states. As a result, a large proportion of people report about the problems in obtaining assistance mainly because of financial barriers, as well as due to geographic reasons or long terms of waiting for medical care.

Latvia has universal health coverage, although the breadth and depth of coverage is more limited than in most other EU countries. As a result, a large share of people reports problems in obtaining care mainly because of financial barriers, but also because of geographic reasons or long waiting times [12].

Both health care systems have positive and negative aspects. It should be noted that Ukraine has been preparing for the introduction of compulsory state health insurance for a long time, and as a result, the Ministry of Health of Ukraine lobbies borrowing the system of state guarantees for the provision of a complex of medical services (NHS), the volume of which depends on budgetary infusions and the political situation, but not from the participation of each particular citizen in his own health care.

Lithuania. After the restoration of independence in 1989, Lithuania inherited a centralized system that mainly provided ineffective health care management and resources allocation. To correct the situation, restructuring and decentralization were identified as strategies that would enhance the effectiveness of providing health services. Decentralization of the health care system was achieved by segregation of primary health care (family doctors), secondary medical care (specialized physicians) and medical care of the highest level (university clinics of the highest specialization). The development and reform of the primary health care system were considered as the key factor in the reform of the health care system, however experience of other countries demonstrates that decentralization in practice does not necessarily increase the efficiency.

After the restoration of its independence in 1989, Lithuania inherited a centralized system that mainly delivered inefficient health care management and resource allocation. It opted for restructuring and decentralization as strategies that would to increase the efficiency of our health services. Decentralization of the health care system was achieved by segregating primary health care (family physicians), secondary health care (physicians - specialists), and tertiary health care levels (high specialization university clinics). The development and reformation of primary health care was seen as a key factor in the entire health care reform. However, the experience of other countries shows that in practice, decentralization does not necessarily enhance efficiency [13]. At the same time, the maximum effectiveness of the health care system is not achieved in those countries that are most successful within economic 


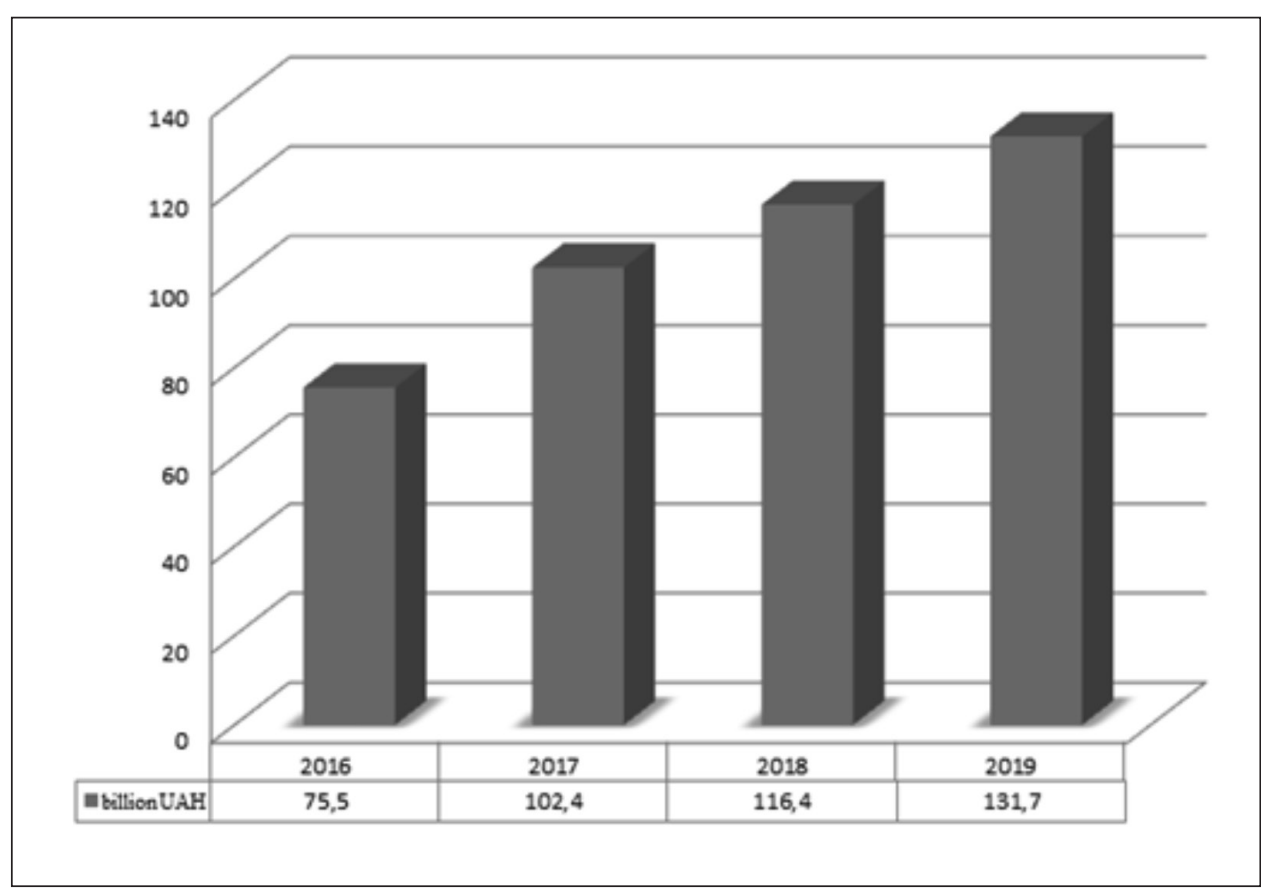

Figure 1. Here is a summary of the consolidated budget expenditures for health care in 2016-2019 potential, but where there is no significant difference between the richest and the poorest (strong middle class). Accordingly, the emphasis on socially vulnerable segments of the population, the balance between decentralization and centralization, between the state and private sectors in the health care sphere, improving governance, and assessing such changes should contribute to solving many medical problems, not only in terms of social ethics, but also in terms of justice [13].

There is a single contractor of medical services in Lithuania - it is the National Health Insurance Fund (NHIF), which is funded by mandatory income contributions and the central government for the unemployed population. The health insurance system in Lithuania has an effective preventive (anticyclic) mechanism and successfully protects state health expenditures during financial crises. At the same time, Lithuania has one of the highest mortality rates in the EU, indicating that the health care system should improve its effectiveness. Quality indicators provide an ambiguous picture, but both hospitals, and primary health care services improve their activities. Lithuania's exceptionally high level of suicide is noticeable, despite the efforts to reform the mental health system. Improvement of inpatient care and the improvement of the primary level of providing medical services are ongoing.

The NHIF, the single purchaser of personal health services, is funded by compulsory income-related contributions and the central government for the non-working population. The Lithuanian health insurance system has an effective counter-cyclical mechanism in place and was successful in protecting public spending on health at the time of the financial crises. Lithuania has among the highest amenable mortality rates in the EU, indicating that the health care system can improve its effectiveness considerably. Quality indicators provide a mixed picture, but both hospital and primary care services are improving their performance. Lithuania's exceptionally high suicide rate is notable, despite mental health reform efforts. Reforms are ongoing to cluster acute care in centres with larger catchment areas, create networks of hospitals to provide each service in a more limited number of locations and implement volume thresholds to increase both efficiency and quality. The progress in primary care is following several years of reform, with modernised general practitioner and nursing services and a comprehensive reimbursement system incentivising prevention [14].

Ukraine also makes an attempt to strengthen the primary level of providing medical care, but preventive mechanisms for guaranteeing the inviolability of the package of medical services during the period of economic crises, as well as the availability of medical services for the rural population or socially vulnerable groups have not been created.

Estonia. The Estonian Health Insurance Fund (EHIF), founded in 2001, is the sole payer on the market of providing compulsory health insurance. It is the public state institution that operates in accordance with the Estonian law.

EHIF, founded in 2001, is a single payer on the market who organises the mandatory social health insurance in Estonia. It is an independent public entity that owns its assets.

The Fund has covered more than $95 \%$ of the population of Estonia. Estonia's health insurance system is based on solidarity. About $49 \%$ of the insured persons are those who do not take part in the fund's filling, including children, students, retired people with disabilities and citizens over 65 who are subsidized by active employees. The state renders financial support for around $4 \%$ of all citizens, including persons on childcare leave, registered unemployed persons and persons providing care for disabled persons. This group of persons who do not take part in compulsory health insurance also includes persons covered by voluntary insurance 
medical agreements [15. p. 25-26]. This reflects the principle of solidarity of medical insurance in the act, when the working population covers a part of the needs of the disabled and socially vulnerable categories of the population.

Sandra Victoria Nei fairly points out that the health care system in Estonia functions in accordance with the Bismarck Model of Health Classification offered by the OECD. Based on this, the reforms implemented in Estonia recently implemented in health care system were appropriate. Considering this, as far as we know, they have demonstrated the best results for the current health care system in Estonia, but despite the above, the continued growth of funding for the health care system (fund filling) is the growing concern.

The health care system in Estonia functions according to the lines of the Bismarck model from the OECD health care classification. Based on this fact, it was established that the recent health care system reforms have been sensible. Considering what is known this far, they gave the best possible results to the present health care system in Estonia but in spite of this the sustainability of the healthcare system financing is an issue of growing concern [16, p.111].

Indeed, internal labor migration in the EU Member States, together with the general tendency towards ageing process of the European population, necessitates the financing of the medical sector to maintain the proper level of providing medical services to the population. It should be noted that family physicians in Ukraine can sign declarations with patients, who will soon leave for work in the EU, while the salaries of such physicians will be proportionally calculated to the number of signatories of the declarations. V.I. Teremetskyi, O. M. Muzychuk, E.Y. Salmanova ${ }^{2}$, D.V.Kaznacheyeva and S.V. Knysh focused attention to this issue in their works [17].

In general, the experience of these EU states demonstrates the positive and negative aspects of both organizational structures for building health care systems. We believe that the key aspect to implement the reform in Ukraine is the emphasis on a succession of changes and flexibility in finding the best possible directions for the development of the national system. Ukraine should pay attention to the possibility of creating a full-fledged state fund of compulsory health insurance instead of a service provided by the NSHU.

The key to the experience of foreign countries is to ensure human rights, especially its vulnerable groups: minors, handicapped persons, pensioners, etc. Therefore, it is advisable to develop and implement state medical programs for the support of pensioners in order to ensure an increase in the average life expectancy in Ukraine, as well as to support the active position of the population of Ukraine during the third age.

L.I. Danylchenko correctly noted: "The choice of the health care model must fully comply with the current situation in the country, in this regard the transition to insurance medicine should be implemented taking into account the welfare of the population, the possibility of paying a part of health services while maintaining appropriate social guarantees for the poor layers of the population" [18, p. 14]. Implementation of the medical reform in Ukraine, which in the perspec- tive should improve the health care, nowadays complicates the implementation of medical rights by citizens.

Thus, we may name the main miscalculations of the reform of the medical system in Ukraine, they are: a) the absence of a clear benchmark in the formation of a perspective health care model on the basis of compulsory medical insurance (SHI) or on the basis of state health care (NHS); b) the lack of practical implementation of the changes and innovations declared by the concepts and plans; c) insufficient provision of medical rights of citizens during the transition period.

\section{CONCLUSIONS}

The authors of the article have stressed the main mistakes of the national health care system in accordance with the concept of medical sector reform. The authors have revealed positive international practices that can be implemented for the real improvement of medical human rights in Ukraine, namely the experience of Lithuania, Latvia and Estonia. It has been proved that the ongoing reform of the health care system in Ukraine needs to be reviewed and optimized in order to achieve concrete practical results. It has been offered to consolidate a perspective model of the Ukrainian health care system, its principles and guarantees of immunity on the legislative level. Populism and speculations on individual achievements in the health care sector should not serve as a criterion for the effectiveness of the reform. The assessment of medical reform should characterize it in the complex dimension, rather than in accordance with certain stages.

Search for the optimal health care system for Ukraine is a perspective topic for scientific research, since Ukraine's national legislation is approaching the EU standards that requires greater integration of health care systems into a single European medical space.

\section{REFERENCES}

1. Health Care Index for Country 2019. Available from: https://www. numbeo.com/health-care/rankings_by_country.jsp.

2. These Are the Economies With the Most (and Least) Efficient Health Care Available from: https://www.bloombergquint.com/global-economics/ u-s-near-bottom-of-health-index-hong-kong-and-singapore-attop\#gs.18nk8nBloombergQuint.

3. Osnovy zakonodavstva Ukrainy pro okhoronu zdorovia [Fundamentals of the Legislation of Ukraine on Health Care]: Zakon Ukrainy vid 19.11.1992 №2801-XIl. Available from: http://zakon.rada.gov.ua/laws/show/280112 (In Ukrainian).

4. Rozporiadzhennia Kabinetu Ministriv Ukrainy «Pro skhvalennia Kontseptsii reformy finansuvannia systemy okhorony zdorovia» [0n Approval of the Concept of Health Care Reform Financing] vid 30.11.2016 № 1013-p. Available from: https://zakon.rada.gov.ua/laws/show/10132016-p. (In Ukrainian).

5. Kliuchovyi zakonoproekt medreformy: chy superechyt vin statti Konstytutsii pro «bezkoshtovnu» medytsynu? [Key reform bill. Does it contradict the articles of the Constitution on «free» medicine?] 17.03.2017. Available from:http://moz.gov.ua/article/news/kljuchovijzakonoproekt-medreformi-chi-superechit-vin-statti-konstitucii-probezkoshtovnu-medicinu (In Ukrainian). 
6. Roman Lebed. Medychna reforma: piat pryvodiv dlia superechok [Medical reform of five disputes] BBC Ukraina vid 09.07.2017. Available from: https://www.bbc.com/ukrainian/features-40191470 (In Ukrainian).

7. Pashkov Vitalii. Reformy vid MOZ, abo Una matta, matta, matta corsa in Ukraine [Reform from MOZ, or Una matta, matta, matta corsa in Ukraine] 11 (1082) 27.03.2017. Available from: https://www.apteka. ua/article/405003 (In Ukrainian).

8. Dvanadtsiat pryntsypiv orhanizatsii okhorony zdorovia dlia bud-yakoi natsionalnoi systemy okhorony zdorovia [12 principles of health care for any healthcare system] The World Medical Association. 01.10.1963. Available from: https://zakon.rada.gov.ua/laws/show/990_004/print (In Russian).

9. Sydorzhevskyi Maksym. Naibilshe na okhoronu zdorovia sered krain OESR vytrachaiut SShA. Zvit. 10.11.2017. Available from: https://p. dw.com/p/2nQsD (In Ukrainian).

10. \# Biudzhet 2019. Okhorona zdorovia. Available from: https:// budget2019.info/priority/7 (In Ukrainian).

11. Uldis Mitenbergsa, Girts Brigis, Wilm Quentinb. Healthcare financing reform in Latvia: Switching from social health insurance to NHS and back? Health Policy. 118. 2014. 147-152.

12. OECD/European Observatory on Health Systems and Policies. Latvia: Country Health Profile 2017. State of Health in the EU. OECD Publishing (2017). Paris/European Observatory on Health Systems and Policies. Brussels. Available from: http://dx.doi.org/10.1787/9789264283466-en.

13. Irayda Jakušovaitè, Žilvinas Darulis and Romualdas Žekas. Lithuanian health care in transitional state: ethical problems. BMC Public Health. 2005. 5:117. Available from: http://www.biomedcentral.com/14712458/5/117. doi:10.1186/1471-2458-5-117.

14. Murauskiene, L. et al., «Lithuania: Health System Review», Health Systems in Transition, Vol. 15 (2), pp. 1-150 0ECD/EU (2016), Health at a Glance: Europe 2016: State of Health in the EU Cycle. OECD (2013) Publishing. Paris. Available from: http://dx.doi. org/10.1787/9789264265592-en.

15. Hanna Engqvist. Health Care System Report - Poland \& Estonia. Master of Science Thesis. Department of signals and systems chalmers University of technology. Gothenburg, Sweden. 2012. Report №. EX002/2012. Available from: http://citeseerx.ist.psu.edu/viewdoc/ download?doi=10.1.1.882.3689\&rep=rep1\&type=pdf.
16. Sandra Victoria Nei. Estonian Health Care System: Accomplishments and Challenges, BSC, MA Faculty of Medicine, University of Tartu, Estonia, European Scientific Journal April 2017 /SPECIAL/ edition ISSN: 1857 7881 (Print) - ISSN 1857-7431 p. 111.

17. Teremetskyi V.Y., Muzychuk A.N., Salmanova E.Yu., Kaznacheeva D.V., Knysh S.V. Ukreplenye dohovornukh nachal v pravootnoshenyiakh mezhdu patsyentom y lechebnum zavedenyem pry reformyrovanyy systemu zdravookhranenyia v Ukrayne. Medytsynskye novosty Hruzyy. 2018;11(284):155-159 (In Russian).

18. Danylchenko L.I. Doslidzhennia osoblyvostei ta perspektyvy stanovlennia strakhovoi medytsyny v Ukraini v suchasnykh umovakh [Study of features and perspectives the establishment of insurance medicine in Ukraine in modern conditions]. Scientific Journal «ScienceRise: Medical Science». 2017;3(11):9-15. doi: 10.15587/25194798.2017.96222 (In Ukrainian).

\section{Authors' contributions:}

According to the order of the Authorship.

\section{Conflict of interest:}

The Authors declare no conflict of interest.

\section{CORRESPONDING AUTHOR Borys 0. Lohvynenko \\ Dnipropetrovsk State University of Internal Affairs \\ 26, Gagarin Avenue, 49005 Dnipro, Ukraine e-mail:bryntyr@gmail.com}

Received: 12.02 .2019

Accepted: 05.04.2019 


\title{
LEGAL ENFORCEMENT AND DEVELOPMENT DIRECTIONS OF HEALTH LAW IN UKRAINE
}

\author{
Tetyana B. Vilchyk, Hrihorii S. Krainyk, Oleksandr O. Shandula \\ YAROSLAV MUDRYI NATIONAL LAW UNIVERSITY, KHARKIV, UKRAINE
}

\begin{abstract}
Introduction: The development of medical law should take place systematically based on scientific basis and guided by international experience. The article describes the tendencies and prospects of the medical law development of Ukraine in the context of globalization and European integration processes.

The aim of this work is to investigate the problems of legal enforcement and directions of the medical law development in Ukraine

Materials and methods: We analyzed national and international acts that regulate community rights for medical care, protection of patient rights, which were studied using content analysis and analytical experience, as well as generalization of court practice and statistical data.

Review and conclusions: Violation of patient rights is a socially harmful act, impunity of which also affects social security. The quality control mechanism of medical care should be permanent and aimed at improving this quality. It is necessary to create a National Quality Control Agency that would be independent, not subordinate to the Ministry of Healthcare of Ukraine, with professional experts with experience in this direction. The problem of legal protection of patient and doctor rights, as well as provision of legal support to medical institutions and the creation of a regulatory framework to reform the health care system is relevant. It is necessary to create a register of medical lawyers. Creating a system for reporting and monitoring medical errors should be one of the priorities of health care reform in Ukraine.
\end{abstract}

KEY WORDS: medical law, rights of patients, knowledge of patients, right for health, health care quality, doctor error, control of medical reform quality, bioethics

Wiad Lek 2019, 72, 4, 692-696

\section{INTRODUCTION}

Currently, the development of the conceptual framework for the development of medical law and bioethics in Ukraine continues. Perception of the reform of the medical industry in society is rather ambiguous. And not only from a social point of view, but also in view of the constitutional guarantee of free medical care. The human right to health care is stipulated in Art. 49 of the Constitution of Ukraine, according to which state and communal health care facilities are provided free of charge, for the most part, is not fulfilled. Especially in the sense of providing such assistance "to all citizens fully", as stated in the decision of the Constitutional Court dated May 29, 2002 № 10-rp/2002 [1]. Unfortunately, more and more cases are known when the rights of patient are violated by doctors and other employees of medical institutions. The lack of quality standards for health care, the closure of the medical community, the availability of paid and «shadow» medical services, illegal medical and pharmaceutical activities are the main reasons for abusive and medical errors. Protecting the rights of patient, assessing the pre-trial and judicial prospects of resolving conflicts between the patient and the medical institution (physician), reimbursement of health damage (moral harm), legal support of medical organizations (especially private ones) are only a part of the questions related to new branches of law - medical law and bioethics. Therefore, the concept of a global right to health care needs further legal research.

\section{THE AIM}

The aim of this work - to analyze the national and international legislation to ensure patient rights and to study the main tendencies of the development of medical law in Ukraine and foreign countries.

\section{MATERIALS AND METHODS}

We analyzed national and international acts regulating the rights of citizens to health care, the protection of patient rights studied using the content analysis and analytical experience, as well as generalization of judicial practice and statistics.

\section{REVIEW AND DISCUSSION}

Human rights have come to the fore in many fields of law. However, health is a basic social good and ensures effective health protection and the availability/accessibility of adequate health care is a basic responsibility of the state. Health law is instrumental in the realisation of that responsibility and therefore the right to health care is always engaged in health law [2].

In the modern legal system, the issue of care, protection, order of realization of the right to life, health and the right to personal safety is devoted to the norms of the constitutional, administrative, civil, criminal and other branches of the law of Ukraine. The lack of a single 
definition of the right to life in various approaches to the scientific understanding of the phenomenon proves the need to isolate the constituent elements of the right to life into a separate component, in our case, in the block of medical reform [3]. The concept of «health protection law» (Health Law) is increasingly appearing in scientific circulation both abroad and in Ukraine, and receives more and more supporters. The substantive sphere of healthcare law includes proper health law, pharmaceutical law and legal support for the functioning of the health care system $[4,164]$.

L. Gostin and A. Talor defines global health care as an industry that encompasses the legal rules needed to create the conditions for reaching the highest possible level of physical and mental health. This sector is intended to promote a behavior towards health care by key players that significantly impact public health including international organizations, governments, business structures, foundations, media, and civil society [5].

Today, there is no doubt that health law and bioethics should be developed. The legal regulation of relations in this area is very important for their development. Health law is characterized by the presence of a large number of normative legal acts in the form of the Constitution of Ukraine, the Laws of Ukraine and the number of subordinate acts. The basic legislative act in the health care field is the Law of Ukraine about «Fundamentals of the Ukrainian legislation on health care» (1993). Many issues are regulated by special laws, for example: the Law of Ukraine «On Medicines», the Law of Ukraine «On Psychiatric Aid», there are a large number of Decrees of the Cabinet of Ministers of Ukraine and a huge mass of Decrees of the Ministry of Health, National Services and Departments. All this, along with the specifics of the industry, creates difficulties in protecting the rights of both patients and healthcare workers.

The basic principle of medical reform in Ukraine is that the state begins to pay for the medical service provided to the patient, rather than financing the number of bed places in hospitals. This will allow you to wisely spend your medical budget - to send funds to those who really need help. This is the principle - the money goes for the patient [6].

The Law of Ukraine «On Amendments to certain legislative acts of Ukraine on the legislation improvement regarding the activities of health care institutions» dated April 6, 2017 № 2002-VIII (hereinafter - the Law) intoruduces financing of a family doctor field in the front-line medicine who has the right to conclude contracts with 2,000 patients. A doctor will receive a certain amount per year to your account for each contract. The law provides the implementation of a number of measures aimed at creating a network of state and communal medical institutions with a sufficient level of autonomy for effective and timely health care of the population; it resolves separate issues related to the contracts on populaton health care, which will be made in accordance with the special order approved by the Cabinet of Ministers of Ukraine [7].
The Law contains a provision that health care is provided free of charge (at the expense of budgetary funds) in health care institutions and individuals entrepreneurs who have received the corresponding license. And it is specified at once: only those whom the main spending unit manager made contracts on population health care with. There are further certain financial limitations: such contracts are made only within the limits of budget funds provided for health care for the relevant budget period based on the cost and volume of medical services, a customer of which are the state or local authorities. Therefore, in the absence of such funds, the amount of guaranteed health care will be limited and reduced - according to the «limits» of the budget. From an economic point of view - it is a rational and logical approach, but from the standpoint of medicine - a significant risk. After all, taking into account the inability to accurately predict the course of a patient's illness, his recovery etc, the introduction of normalized distribution of costs and the normalization of medical interventions hides the danger of uncertainty. Even the strict implementation of treatment protocols and regulatory funding on their basis can significantly limit the physician's ability to make flexible decisions about patient treatment and turn it from a logical thinking specialist to a purely technical performer [5].

In the modern world, health care quality is considered as the main target function of the health care system and at the same time the determining criterion of its activity. In many countries, quality assurance programs have been adopted and implemented that underpin national health policies. This is the lever that influences the development of medicine, and is determined by many components - the quality of management (purpose, goals, principles, methods, structure, organization, planning), organization of the process of providing health care and its resource support (material, technical, methodological, personnel, financial, etc), the implementation of technology, modern guidelines, standards, clinical protocols [6].

According to the order of the Ministry of Healthcare of Ukraine dated August 1, 2011 № 454 «On approval of the Concept of management of health care quality in the healthcare system in Ukraine for the period up to 2020», the principle of continuous improvement of quality is proclaimed in the state, the key component of which is a clinical audit. The Concept states: the current analysis of the results of the work of health care institutions is based on the accounting and reporting documents (statistics and annual activity reports) approved by the state authorities, as well as on the results of individual studies, which is not enough to assess the quality of health care and determine its improvement directions. [7].

The order of the Ministry of Healthcare of Ukraine dated 05.02.2016 № 69 «On the organization of clinical and expert assessment of the quality of health-care provision and health care» «modernizes» the expert assessment of the second and third groups of expertise that is carried out in case of patient death, divergence of determined diagnoses, non-compliance with health care standards and health care, clinical local protocols, material and technical reports, as well as in cases that 
were accompanied by complaints from the applicant etc. Thus, although the modern quality control methods - clinical audit and monitoring are mentioned in the regulatory documents of the Ministry of Healthcare, in practice an expert assessment of the outcome and some unwanted cases is carried out using «organizational measures» to punish the perpetrators. While a clinical audit in a health institution is usually carried out once a quarter and is aimed at not penalizing individual workers for not achieving acceptable quality, but seeking opportunities to achieve it [8].

Effective quality control system of medical services provision is an important element in the implementation of the medical reform. The process by which the government grants permission to practice a practitioner or a health organization (usually after verifying compliance with minimum mandatory standards) is defined in the legislation as licensing. In Ukraine, licensing applies to all legal entities, regardless of their organizational and legal form, and individuals-entrepreneurs who conduct business activities in medical practice. If licensing guarantees minimum standards for patient safety and minimizes health risks, medical accreditation is intended to ensure continuous improvement of quality and aims at achieving optimal standards. The national accreditation body, through an independent external evaluation, publicly confirms the achievement of accreditation standards by one or another institution. For example, in the UK, this is the United Kigdom Accreditation Forum (UKAF), a volunteer network of NHS organizations that is accountable to the government; in France - HAS, a public health authority (an independent non-profit public scientific organization); in the United States, the Joint Commission on Accreditation of the Healthcare Organization (JCAHO, a national nonprofit organization). As in Ukraine, accreditation is carried out not by an independent structure, as is the case of most EU countries, but by the Ministry of Healthcare of Ukraine, which verifies subordinate institutions, it creates objective obstacles for ensuring the proper quality of medical care quality in health care [9].

The patient rights phenomenon is fundamental to modern law and medical ethics. The patient rights as a phenomenon, term and legal structure are derivatives of human rights to the extent that the patient is a person. The patient rights are inherent only to those who have the appropriate special legal status. Violation of the patinet rights is a socially harmful act, impunity of which also affects social security. Domestic legislation provides a whole range of patient rights (however, serious problems are often encountered when realizating these rights in practice), however, with some exceptions, it does not properly establish the patient responsibilities and responsibility for their failure [12]. According to M. Watad and R. Grevtsova, «it is important that in attempts to resolve various relations related to human health, the patient, the very person for whom these relations arise, will not be forgotton about». An important instrument for ensuring this is the international health law, which has a human-centric orientation $[13,460 ; 14]$.

The basiclegal document on the basis of which the concept of the patient rights is based is the Universal Declaration of Human Rights adopted by the General Assembly in 1948.
On November 4, 1950, the Convention for the Protection of Human Rights and Fundamental Freedoms was signed. At the beginning of the 1990s, almost everywhere, the fundamental patient rights of the patient were recongized, which continue to evolve to date (the «Lisbon Declaration on Patient Rights» of 1981, the «Declaration on a Policy for the Enforcement of Patient Rights in Europe» of 1994, «The European Charter of Patient Rights» of 2002): the right to information on the diagnosis and prognosis of their own illness; the right to choose a doctor; the right to preserve the confidentiality of medical information; the right to privacy; the right to ensure the rule of informing the consent.

The «Concept of Patient Rights in Europe: General Provisions» document adopted by the who European Patients' Consultative Meeting (Amsterdam, 28-30 March 1994), played an important role in defining key provisions in patient rights. The list of patient rights in this document reflects the progressive trends of today and corresponds to the development of modern law and health care. The purpose of this document is to guarantee the protection of fundamental human rights and promote the humanization of assistance to all categories of patients including the most vulnerable, such as children, psychiatric patients, the elderly and severely ill. In essence, this reflects the desire of people not only to improve the quality of their received treatment and preventive care, but also to more fully recognize their rights as patients.

Due to the need to preserve human identity, to ensure respect for human dignity and the availability of a «bioethical dimension» of issues to be resolved by the legislator or the court, the impact of bioethics on the right to health is increasing. Some researchers point out the «bioethisation» of the legislation and the rights of foreign countries in certain sectors, for example, in the field of criminal law, and its necessity in Ukraine [15, 140-145].

One of the most acute problems is the consent of the patient to participate in a medical study (medical biologic experiment). On the one hand, there is a need to revise certain standards of research aimed at preventing abuse of consent, especially by consent of vulnerable persons (incapable or incapable adults, minors). On the other hand, strict regulation of research, the trend of which has been observed lately, may lead to a restriction of research, despite the great role they play in meeting the needs of society in health care services. According to J. Dangati, it is now necessary to establish a balance between the protection of the rights of the subjects and the freedom to conduct research $[16,489]$.

At the same time, there is a problem of medical error, which is urgent not only for Ukraine. According to the European Commission «Special Eurobarometer» data (2006), 78\% of EU citizens consider medical errors to be a serious problem. National legislation does not define the term «medical error». The legal doctrine ambiguously understands it too. A similar situation is observed in many developed countries. In the report, «Man is Fallible: Building a Healthier Healthcare», published by the Institute of Medicine (now the National Academy of Medicine of the United States) in 1999, a definition that had already become classical was proposed. According to it, the error is «the failure of the planned action to be carried out as 
expected, or the use of an erroneous plan to achieve the goal». In general, the prevailing view is that a doctor (or rather medical) mistake is an act or omission of a health professional who is characterized by good faith and does not contain evidence of a criminal offense. It is also believed that medical errors include acts that result in harm to the patient. Overseas, doctor (medical) mistakes were paid particular attention to at the turn of the 2000s. The above-mentioned report became a push. It showed that from 44 thousand to 98 thousand Americans die from medical errors every year. And this is much more than due to accidents or industrial accidents.

The study of the Johns Hopkins University Faculty of Medicine, published in 2016, confirmed that approximately 9.5\% of Americans die from medical errors in the United States every year. According to the who, in most EU member states, medical errors and other adverse events are observed in 8-12\% of inpatient care cases.

In 2006, the Committee of Ministers of the Council of Europe issued the recommendation Rec (2006)7 on patient safety management and prevention of adverse health events. Among the proposed measures, there is the development of a system for reporting incidents involving patient safety. In this case, the system should not be punitive. It should encourage healthcare providers and healthcare professionals to report such cases (if possible, the message should be voluntary, anonymous and confidential). Information about medical errors is also available from other sources, such as patient complaints registration system. In some European countries (Great Britain, Denmark, Ireland), such systems already exist. In many others, they are only being organized. Creating a system for reporting and monitoring medical errors should be one of the priorities of health care reform in Ukraine [17].

In 2017, Doctor of Medical Sciences V. Franchuk published a study on medical errors in Ukraine. Out of the 112 cases of medical care in the Ternopil oblast, the professor found errors in 92 of them (82.1\%). Although in the same 2017, 91\% of doctors in Ukraine were certified. The high level of medical mistakes at a high level of qualification is connected with the corruption of the attestation system, - said O. Grishakov, a lawyer and managing partner of the law firm «Grishakov Law Company». At the same time, the qualification category does not mean that the doctor will be responsible. In Ukraine, there is simply no mechanism for prosecuting a specialist for incompetent provision of health care, said the lawyer [18].

Victimogenity of the absence of an effective criminal law response to the criminal misconduct of the patient rights is that, due to the systemic «blindness of the eyes» of the state authorities, the perception of the patient rights violation by doctors makes people believe that it is virtually impossible to bring the medical practitioner to criminal responsibility for committing a professional crime. Under such conditions, the patient, knowing that his rights are protected from medical arbitrariness, will not consider himself as a victim of the system and perceives a medical crime as a gift which he is «ready» for. In our opinion, the position of the necessity to meet the population social needs in the quality and safe provision of health care today is a radically different approach: without raising the role of the patient and shifting the attention of the state from the one who caused harm to the person who suffered from it, today, the criminal law will not get the trust of the society, which demands fair and proper satisfaction of its needs for proper legal guarantees of non-violation of human rights in Ukraine. Therefore, the proposal to supplement the Criminal Code of Ukraine with a norm that would include liability for the violation of patient rights by a medical or pharmaceutical worker that was known to such a worker could constitute or endanger the patient's life, health or reputation, is relevant $[19,136]$.

The practice of the European Court of Human Rights, which has touched upon a fairly wide range of bioethical issues (reproductive rights, the use of assisted reproductive technologies, assisted suicide, consent, for medical intervention, etc) [20] will play an important role in the search for legislative solutions to the problems within the right to health care, and also led to the spread of positive state obligations in the field of health raising the question about guarantees of health care, state responsibility for patient death and others [21, p. 15].

The issue of legal protection of patient and doctor rights, as well as provision of legal support to health institutions and the creation of a regulatory framework for reforming the health care system is relevant. As the Head of the Institute of Medical and Pharmaceutical Law and Bioethics of the Academy of advocacy of Ukraine R. Grevtsov states, in each region of the country, 40-80 civil cases are considered annually in the courts for compensation of property damage and moral damage caused to health due to providing health care of inadequate quality. However, there are not many lawyers who are capable of performing these tasks effectively. Among the important tasks faced by Ukrainian scholars, there is the study and generalization of judicial and investigative practices on «medical» cases, which was recognized as one of the areas of health law development of Ukraine, the creation of a register of lawyers in health law $[22,11]$.

\section{CONCLUSIONS}

1. The quality control mechanism of health care should be permanent and aimed at improving its quality. It is necessary to create a National Quality Control Agency that would be independent, not subordinate to the Ministry of Healthcare of Ukraine, staffed by professional experts with experience in this field.

2. The modern medical system, which can be described as a model of technocratic type, is not ready for an independent solution to a number of problems that affect a human as a person, his rights and freedoms. One of the fundamental problems of modern law and medical ethics is that health care should be a human right, and not a privilege for a limited number of people who are able to afford it. Violation of patient rights is a socially harmful act, impunity of which also affects social security.

3. The problem of legal protection of the patient and doctor rights, as well as legal support of health institutions and the creation of a regulatory framework for reforming the health care system is urgent. However, there are not many lawyers who are capable of performing these tasks 
effectively. It is necessary to create a register of health lawyers.

4. The establishment of a system for reporting and monitoring medical errors should be one of the priorities of health care reform in Ukraine.

5. Among the areas of health law development in Ukraine, there may be indicated: development of a generally accepted concept of health law of Ukraine; formation and recognition of health law as an independent branch of law and legal science; development of the concept of improveming Ukrainian legislation in the field of health care, including adoption of the Medical Code of Ukraine; study and generalization of judicial and investigative practice on «medical» cases; development of practical recommendations for the subjects of health law; methods of protecting the rights and legitimate interests of patients, health workers and health care institutions, tactics and methods of conducting «health» cases.

\section{REFERENCES}

1. The decision of the Constitutional Court of Ukraine in the case of the constitutional petition of 53 people's deputies of Ukraine regarding the official interpretation of the provision of part three of Article 49 of the Constitution of Ukraine «in state and municipal health care institutions, health care is provided free of charge» (case about free medical aid) dated 29.05.2002. Available at: https://zakon.rada.gov.ua/laws/show/ v010p710-02

2. Gevers S. Health Law in Europe: From the Present to the Future. European Journal of Health Law 15.2008;261-272. Available at: http://healthsci. stou.ac.th/UploadedFile/10.\%20Health\%20law\%20in\%20Europe.pdf

3. Punda 0.0 . Administrative and legal protection of personal non-property rights: monograph. Irpin - Khmelnitsky, PIF Melnyk AA, 2017; p.542.

4. Rogova 0.G. Conceptual basis of the development of the right of defense and the law of Ukraine on the protection of health. Chasopis Academy of Advocacy of Ukraine. 2014;1:163-164. Available at: http://nbuv.gov. ua/j-pdf/Chaau_2014_1_39.pdf.

5. Gostin, Lawrence 0. and Talor, Allyn L. Global Health Law: A Definition and Grand Challenges (2008). O'Neill Institute Papers, Paper 14 Available at: http://scholarship.law.georgetown.edu/ois_papers/14/

6. Bezrukov V.V., Voitenko V.P., Akhaladze N.G., Pisaruk A.V., Koshel N.M. Reforming medicine. Ukraine in the global and European context, 2017;p.127.

7. Doroshenko 0.0., Shevchenko M.V. An analysis of international experience in financing secondary health care. Economics and Health Law. 2017;1 (5):16-23.

8. Yamnenko T.M. Medical reform: Ukraine's realities and international experience. Yurydychnyi visnyk. 2018;2 (47):116-120.

9. Order of the Cabinet of Ministers of Ukraine dated November 30, 2016 №1013-p The Concept of Health Care Financing Reform. Available at: zakon.rada.gov.ua/go/1013-2016-p

10. European Information and Research Center. Available at: http:// euinfocenter.rada.gov.ua/

11. Health Authorities. Available at: http://bit.ly/2cj10MW; National Institute for Clinical Excellence Available at: https://www.nice.org.uk/
12. Grevtsova R.Yu., Chernenko Z.S. International health law: push for research. Advokat. 2012;3:11-14.

13. Wattad M. S., Hrevtsova R. Reflections on International Medical Law. The International Journal «Medicine and Law». 2011;30 (4):449-460.

14. Hrevtsova Radmyla. The Interplay of Health Law and Bioethics: A Few Thoughts on the Practical Implementation of Scientific Findings. European Journal of Health Law, 19-3 (2012): 225-229.

15. Trinova Ya.0. Bioethical problems of the criminal law of Ukraine: monograph. Kyiv: National Academy of Prosecutor's Office of Ukraine, 2014;p.398.

16. Дангата Й. Роль згоди у медичному дослідженні: ломаючи чи будуючи мури? - Заклик до законодавчих реформ [Dangata Y. The Role of Consent in Medical Research: Breaking or Building Walls? - A Call For Legislative]. Available at: https://www.ncbi.nlm.nih.gov/ pubmed/22397175

17. Grevtsova R. Worldwide, «health» cases are considered one of the most difficult. Law and business. V. 31 (1329) 07.08-13.08.2017.

18. The legal responsibility of doctors will grow this year. https://protocol. ua/ua/yuridicheskaya_otvetstvennost_vrachey_budet_rasti_uge_v_ etom_godu/

19. Dutchak S.R. Ensuring the protection of patient rights in Ukraine: the criminal-law aspect, dis.... candidate of legal sciences: 12.00 .08 / Criminal Law and Criminology; criminal enforcement law. Kyiv, 2018;p.252.

20. Bioethics and the case-law of the Court: Research report. Council of Europe / European Court of Human Rights, 2012 Available at: http:// www.coe.int (Case-law - Case-Law Analysis - Research Reports).

21. Buzadzhi K.M. Convention on protection of Human Rights and Fundamental Freedoms and the question of health law in Ukraine. The first All-Ukrainian Congress on Health Law and Social Policy April 14-15, 2007, Kyiv: Collection of Abstracts (Scientific and Practical Edition) / originated by Candidate of legal sciences Grevtsova R.Yu., Dr. of Medicine Stepanenko A.V. Kyiv: «Avitsena» Publishing House, 2007;96:15-16.

22. Grevtsova R.Yu. Health law of Ukraine: the current state and prospects of development. Collection of abstracts: The first All-Ukrainian Congress on Health Law and Social Policy April 14-15, 2007, Kyiv. Kyiv: Avicenna, 2007;p.96.

\section{Authors' contributions:}

According to the order of the Authorship.

\section{Conflict of interest:}

The Authors declare no conflict of interest.

\section{CORRESPONDING AUTHOR Tetyana B. Vilchyk}

Yaroslav Mudryi National Law University, Kharkiv, Ukraine

77 Pushkinska str., 6102 Kharkiv, Ukraine

tel: +380679727453

e-mail:Kafe-agata@i.ua

Received: 09.02.2019

Accepted: 03.04 .2019 
PRACA POGLĄDOWA

REVIEW ARTICLE

\title{
A MEDICAL ERROR: DOES LAW HELP OR HINDER
}

\author{
Nataliia V. Nikitchenko', Andrii M. Khankevych'², Dmytro V. Slynko², Tetiana I. Savchuk², Viktor V. Lazariev ${ }^{2}$ \\ ${ }^{1}$ NATIONAL UNIVERSITY OF STATE FISCAL SERVICE OF UKRAINE, IRPIN, UKRAINE \\ ${ }^{2}$ KHARKIV NATIONAL UNIVERSITY OF INTERNAL AFFAIRS, KHARKIV, UKRAINE
}

\begin{abstract}
Introduction: Health systems and health policies across the European Union are becoming more and more interconnected and also more complex. This increased interconnection raises many health policy issues, including health care quality. Mistakes in medical care can occur anywhere in the health care system - at hospitals, doctor's offices, nursing homes, pharmacies, or patients' homes - and in any part of the treatment process involving wrong medication, improper treatment, or incorrect or delayed test results.

The aim of the article is to develop adequate theoretical and scientific-practical proposals for the modernization of the legal regulation to protect patients' rights aimed at observance of constitutional rights and freedoms.

Materials and methods: In order to obtain the results the analysis of medical, labor and civil law norms are investigated. The article uses analysis and synthesis methods, as well as a comparative legal method.

Review: A number of proposals are given for improving legislation in the area of eliminating obstacles to provision of qualitative primary care / medical-preventive care, prevention of formal attitude towards the patient, the implementation of preventive protection measures which should notify in advance about the violation of the law in the medical sphere. Conclusions: Ukraine urgently needs a legal mechanism to protect the rights of patients; it will become a systemic phenomenon and will consist of legal means, forms, ways by which the restoration of violated patients' rights is provided, the support of protected interests by the law is maintained, legal disputes are resolved and other obstacles to realization of patients' rights are overcome.
\end{abstract}

KEY WORDS: patients' rights, responsibility, protection of patients' rights and interests, medical law

Wiad Lek 2019, 72, 4, 697-701

\section{INTRODUCTION}

Modern medicine has moved ahead. Particularly progressive is the change in patient's rights. One of the main achievements of modern medical legislation is to provide the patient with the right to freely choose a physician, methods of treatment, the right to receive reliable information about his/her health, the right to get qualified medical assistance, etc. Unfortunately, there are also numerous cases of medical errors, hospital malpractice that lead to serious and sometimes irreversible consequences. In Ukraine, there are no effective remedies available to patients. According to statistics, $70 \%$ of harmed patients do not even attempt to apply to court because they consider it meaningless. After all, it is almost impossible to win the process against the careless physician. Physicians also make a forensic examination of this medical error. And the honor of a white dressing gown is more important than the health of the patient [1, p. 308].

At the same time, it is a completely different situation in the EU countries. In particular, European countries often incriminate professional errors of physicians in the context of general crimes against the body and life - that is, wounding or causing grievous bodily harm, or causing the death of a person due to negligence - involuntary manslaughter. In this regard Slovenia is quite unique since the Slovenian Criminal Code contains a special offence of negligent treatment. A medical professional that violates the practices and rules of the medical science and profession, and whose conduct negligently causes a significant deterioration in health of a patient can be sentenced to imprisonment up to three years. If the patient dies, the sanction includes imprisonment from one to eight years. The offence is classified in Chapter 20 of Crimes against Human Health, where the central protected right is public health and public confidence in the health system.

From the point of view of the legal assessment of the medical assistance provided (in order to establish the grounds for bringing health professionals or the institution to responsibility), it was agreed to divide the adverse effects of treatment into: medical errors; medical accidents; medical malpractice (professional negligence).

It should be noted that today the well-balanced position regarding the concept of "medical error" has not been formulated yet. Despite the relevant questions were investigated by many scholars, including Bonetti M., Cirillo P., Komarov Yu.M., Leape L.L., Maidanyk N. I., Malein M. M., Martin M., Michael D., Raghuram R., Reason J., Ritchey F.J., Rykov V.A., Senders J.W., Seniuta I. Ya., Sonny B. Bal, Swaminath G., Stetsenko S.H. et al. 
The official interpretation of the notion of a medical error in Ukraine is absent. However, the responsibility of a health worker depends on the interpretation of this notion. If the medical error is to take unintentional minor harm to the patient's health, then the physician's responsibility should be appropriate. However, if the result of a medical error was the provision of improper treatment (untimely medical care) which resulted in a significant deterioration in the patient's health, then this is not a physician's mistake but the infliction of emotional and material distress to the patient. This mistake should be compensated by the physician in a way stipulated by Article 16 of the Civil Code of Ukraine. However, traditionally a medical error can not be the result of a careless attitude towards their professional activities. A large number of subjective factors complicate the understanding of this issue, such as lack of experience of the physician, stressful situations and human factor.

\section{THE AIM}

The aim of the article is to develop adequate theoretical and scientific-practical proposals for the modernization of the legal regulation to protect patients' rights aimed at observance of constitutional rights and freedoms.

\section{MATERIALS AND METHODS}

Materials for investigating the patients' rights are: national legislation, the Constitution of Ukraine, the Law of Ukraine "Fundamentals of the Ukrainian legislation on protection Health", "On the Protection of Consumer Rights", the Convention for the Protection of Human Rights. Materials for investigating the medical error are: the Civil Code of Ukraine, Declaration of policies in the field of patient rights in Europe, the Copenhagen Declaration, the Declaration of Tokyo, the Declaration of Lisbon on rights of the patient, the World Medical Association documents, the Declaration on Euthanasia, the Declaration on Human Organ Donation and Transplantation, the Declaration of Helsinki. In order to obtain the results the analysis of medical, labor and civil law norms are investigated. The article uses analysis and synthesis methods, as well as a comparative legal method.

\section{REVIEW}

For example, medical errors in the Republic of Kazakhstan will soon be investigated and combined in one registry. This step would distinguish the mistake from negligence. In addition, hospital ratings and patient reviews will be indicated here. Last year the physicians, by the way, paid for their mistakes more than 9 million tenges. Most patients complain about the physicians, such as anesthesiologists, obstetricians, gynecologists, resuscitators and surgeons. For example, in $201850 \%$ of complaints out of 3.5 thousand citizens were about the quality of medical care. As a result of consideration of these appeals 430 administrative protocols were drawn up, 299 individuals, 8 officials, 23 legal entities are brought to administrative responsibility [2].
In the world under the medical error scientists understand 1) an unintended act (either of omission or commission) or one that does not achieve its intended outcome $[3], 2)$ the failure of a planned action to be completed as intended (an error of execution), the use of a wrong plan to achieve an aim (an error of planning) [4] or 3) a deviation from the process of care that may or may not cause harm to the patient [5].

Modern medical law operates also with the notion of a medical accident - this is an adverse result of medical intervention. This result can not be predicted and therefore it cannot be prevented through a set of objectively compiled random circumstances (although the physician acts correctly and in full accordance with medical rules and standard treatment methods).

In the EU, a medical accident is understood as 1) an unplanned, unexpected and undesired event, usually with adverse consequences [6]; 2) as a commission or an omission, with potentially negative consequences for the patient, which would have been judged wrongly by skilled and knowledgeable peers at the time it occurred, independent of whether there were any negative consequences [7].

So, if I compare the definitions in different countries of the European Union I can assume that there is no standard definition of a medical error which varies widely in the scientific literature. Usually scientists guide on recording, coding, reporting and assessment of medical errors. These definitions are quite similar but they are divided differently into certain categories.

As for the concept of medical malpractice (professional negligence) - these are negligent or intentional actions of a medical worker that has caused damage to the life and health of the patient. Medical malpractice is defined as any act or omission by a physician during treatment of a patient that deviates from accepted norms of practice in the medical community and causes an injury to the patient. Medical malpractice is a specific subset of tort law that deals with professional negligence [8]. Medical malpractice involves patient damage, injury or death attributed to negligent behavior by a medical practitioner or other health care professions $[9 ; 10]$.

For example, a 24-year-old boy lost his life due to an incorrect diagnosis. An autopsy revealed that the cause of death was a stroke. As it turned out, after the next shift at the mine, Askar Khamzin began to complain of chest pain. Physicians' Ambulance Service diagnosed acute respiratory disease and prescribed treatment with injections. But this treatment did not help. After contacting a private clinic, he was diagnosed with pneumonia. And this time the treatment did not help. Physicians diagnosed a stroke only after the boy was unable to speak. Physicians decide to drive dying Askar 200 kilometers to the regional center. On the way to Aktobe the guy died. Then the physicians stated that the cause of death was the traumatic aortic rupture. But an autopsy proved that the young man died of a stroke. According to local newspapers, surveillance cameras are installed in the hospital reception. According to Askar's mother, the physicians had a record where Askar 
complained of heart pain and was waiting for an hour to be examined. But by a strange coincidence, this video has already been deleted [11].

As it was mentioned above, the difference between a medical error and an offense is in the causes and conditions of their occurrence. Medical errors are usually allowed due to objective reasons and circumstances (lack of appropriate conditions for providing assistance, lack of time, insufficiently qualified staff). Therefore, the distinguishing feature of medical errors is the integrity of the medical staff. However, these errors were the result of an unreasonable attitude to the work of medical staff, the medical institution is obliged to compensate for the damage caused to the health of the patient due to the fault of its employees.

\section{DISCUSSION}

Ukrainian legislation has a number of legal norms that must implement the patient's right to provide health care quality. The basic personal non-property rights of an individual are prescribed in the Constitution of Ukraine (the right to life, the right to health care, the right to medical care), the Civil Code of Ukraine (Articles 283, 284, 285), the Law of Ukraine "Fundamentals of the Ukrainian legislation on protection Health" (Articles 6, 38, 39, 40, 41, etc.). Every Ukrainian according to the Constitution of Ukraine has the right to health care quality but more and more often there can be seen medical errors that entail serious consequences for the patient. The right to life, the right to health care and the right to medical care are also provided by the Convention for the Protection of Human Rights and Fundamental Freedoms [12].

Typical causes of medical errors are: 1) the inconsistency of the actions of several physicians (if the patient undergoes treatment in several physicians);2) the improper use of medical equipment (most often these are mistakes in dentistry); 3) the negligence and non-compliance with sanitary norms; 4) the improper prescription of medicines (inappropriate drugs or careless attitude to contraindications); 5) low qualification of physicians.

Examples of medical error are numerous. According to the current legislation civil liability is provided by the Civil Code of Ukraine, the Law of Ukraine "On the Protection of Consumer Rights" (health minor damage, for example, an incorrect diagnosis and accordingly the appointment of incorrect treatment that led to deterioration in the condition of patients) and criminal provided by the Criminal Code of Ukraine (illegal abortion which resulted in the death of the patient or serious harm to her health; introduction of infection which includes HIV as a result of noncompliance with sanitary standards, private medical activity without a corresponding license that caused the death of a patient or harm to health; failure to provide assistance to a patient that has resulted in a fatal outcome or causing moderate or severe harm to the health), negligence, improper or poor-quality (careless, negligent) performance by the physician of his/her duties that has led to serious irreversible consequences.

Medical errors can occur at any stage of the medication process (prescription, delivery, dispensing, administration and monitoring). In Europe, researchers refer to the most common medical errors: management errors, investigation errors, decision making errors, missed diagnosis, omission or delayed evaluation of important parameters, unnecessary treatment, unnecessary tests and deadly procedures, uncoordinated care, infections, from the hospital.

As a rule, lawyers treat medical error as unintentional harm to health resulting from improper provision of medical care or inactivity of the physician. In practice, proving the presence of a medical error is difficult enough. The main problem in proving the existence of a medical error is the collection of the necessary evidence by the victim. It is practically unreal to bring the physician's guilt to court, only if the physician prescribes forbidden medicines, accidentally injured the patient during the surgery and forgot tools or a napkin in the patient's body. At the same time, the most important stage in the process of gathering evidence is a written confirmation that the health problem arose from the fault of the physician. This will require all records from a medical card, examination data, etc. The best way to confirm the existence of a health disorder after providing unskilled help is to conduct an examination. But there are also nuances: the forensic examination is carried out according to the decision of the investigator/inspector and it is carried out by medical workers who do not want to prove the error of their colleagues.

Despite the presence of a large number of normative legal documents in Ukraine there is no real mechanism for protecting the patients' rights. It negatively affects at the image of Ukraine. After all, in all democratic states special attention is paid to the issue of human rights observance and freedoms. The development of the legal system for the protection of human rights is in the direction of differentiation of certain groups that need special treatment (depending on their age, gender, health, etc.) In this regard, the importance of the legal protection of the patient increases. The need for a special legal protection of the patient's interests is documented in a number of declarations and conventions adopted by international medical associations. These documents are the World Health Organization (A Declaration on the Promotion of Patients' Rights in Europe, dated 1994 [13]; the Copenhagen Declaration, dated 1994 [14], etc.), the World Medical Association documents (The Declaration of Tokyo, dated 1975 [15], the Declaration of Lisbon on rights of the patient, dated 1981 [16], the Declaration on Euthanasia, dated 1987 [17], the Declaration on Human Organ Donation and Transplantation, dated 1987 [18], the Declaration of Helsinki, dated 1989 [19], etc.

Ukraine urgently needs a legal mechanism to protect the patients' rights that will become a systemic phenomenon and will consist of legal means, forms, ways in which the restoration of patients violated rights is ensured. The protection of humans' interests by the law, legal disputes are resolved and other obstacles to the realization of patients' rights are overcome. Essentially, this is a mechanism where the rights, duties, incentives and responsibility of the subjects of medical legal relations are combined. In order for the mechanism of protection to be effective, the synchronous actions of its components must be done. The qualitative legal norms are important but they are nothing when they can not be realized 
in practice. Thus, the impossibility for the patient to gather evidence by legal means, the lack of adequate professional expertise undermines the provisions of the Constitution of Ukraine regarding the necessity to observe the constitutional rights and freedoms of citizens.

The right to protection can not be declarative. The right to protection includes, on the one hand, the possibility of an authorized person's own actions and on the other hand, the ability to demand appropriate behavior from the obligated person, as well as the possibility to apply to the competent state bodies for the protection of rights and interests.

Thus, it can be stated that the traditional mechanism of protection of patients' violated rights is ineffective. Accordingly, it is necessary to introduce measures that would prevent the commission of an offense (preventive protection) or in other words, measures to advance.

\section{CONCLUSIONS}

The first is the implementation of measures for the development of legislation regulating relations in the medical sphere. In particular: the unification of legal regulation of medical workers, protocols of relations between a physician and a patient, treatment protocols, the creation of new model contracts for the provision of medical services by consulting the management of the Ministry of Healthcare with representative client groups in order to determine the conditions for the best provision of unified services, the creation in the structure state body of training centers, which will help to ensure the quality of services that will be provided in future by medical institutions of all levels [20, p. 14].

Secondly, to oblige the Ministry of Healthcare to monitor the multidirectional actions of normative legal acts, to prepare a generalization of enforcement practice and analytical work on eliminating gaps and conflicts in legislation and ways of harmonizing medical legislation.

Thirdly, it is appropriate to increase the level of personal responsibility of the chief medical officer for the response to the complaints of patients, excluding the cases of formal answers. At this stage the conflict between the physician and the patient can be resolved by mutual consent. In order for the application to protect the patient's rights had positive effects (timely and substantially considered) we should increase the personal interest of the chief medical officer. For example, it is necessary to formalize in legislation the duty of the medical centre administration to bring the person in charge (according to the results of the official investigation) to responsibility. It will increase the responsibility of the chief medical officer for taking concrete measures to eliminate the offense with the subsequent notification of the patient (the complainant) about the results. So, only the personal responsibility of physicians, medical centre administration and the prospect of being disqualified for some time (the inability to hold the corresponding posts) will promote the understandable result for the society. It will explain the mechanism for protecting patients' rights. This model will be perceived by patients as consolidating the real opportunities provided by the state. And inevitability of responsibility for the committed offenses will stimulate the representatives of the medical industry to legitimate actions.

Fourthly, in accordance with Article 22 of the Constitution of Ukraine: "human and citizen rights and freedoms affirmed by this Constitution shall not be exhaustive. The constitutional rights and freedoms shall be guaranteed and shall not be abolished. The content and scope of the existing rights and freedoms shall not be diminished by an adoption of new laws or by introducing amendments to the effective laws" it is necessary to introduce the notion of a primacy of the lawfulness of the patient. According to this the duty of the physician is to provide the evidence base on the merits of the conflict. As well as all the rules of law that are ambiguous should be treated in the best interests of the patient.

Fifthly, the preventive protection of the patients' rights can be realized through the participation of non-governmental organizations in making arrangements and implementation of medical services. At the same time, the list of such public organizations should be determined by a document at the level of the legislative act (the resolutions of the Cabinet of Ministers of Ukraine, Presidential Decree, etc.). This innovation will allow authorized non-governmental organizations to extend legislative safeguards for the observance of patients' rights by: 1) participating in the development of legal and regulatory framework of medical relations and standards for the provision of medical services; 2 ) harmonization of the standard terms of contracts that will be signed subsequently between the patient and the medical institution on provision of medical services (if they do not contravene the law); 3) public control over the actions of the administration of the medical institution and physicians on the application of the patient (victim) in case of violations of the requirements of the current legislation; 4) reverse control of the medical workers level of qualification, namely, participation in personnel attestation.

Sixthly, it would be advisable to introduce reformist principles in training physicians. Important and significant at the same time is the movement of the introduction of the principles of academic integrity, which is now gaining in popularity. The modern understanding of the concept of academic integrity is formulated in the document of the Centre for Academic Integrity in 1999. The basis of the definition is the phrase of fundamental virtues: honesty, trust, justice, respect, responsibility, courage. Thus, a conscious moral choice, care for reputation will become a solid basis for combating various abuses, corruption in the medical sector [21, p. 161].

The last and the most important issue that needs to be solved is increasing the competence of physicians and medical staff, encouraging and attracting health professionals to continuous professional growth. At the same time, it is important not only to acquire the necessary knowledge, skills, experience in professional occupation but also the ability to use them in practice for the benefit of patients. Modern medical education requires a systematic and conceptual approach to modernizing the learning process, taking into account new and advanced technologies, the latest innovations and borrowing the best foreign practices developed by the Accreditation Council for the Higher Medical School(USA), a toolkit for evaluation under the scheme called "Miller's Pyramid" etc. The general world tendencies in 
postgraduate education of physicians are its continuity. That is, medical workers are constantly updating their knowledge and practical skills from compulsory education to the end of their professional activity. Such actions are carried out in order to improve the quality of medical services provision and patient's safety (there are qualitative indicators of safety and effectiveness of treatment). The moral responsibility for a patient's share is a physician's commitment which is realized through the mechanisms of licensing and certification of physicians and other medical workers. Public information is available about the quality of physician's work and the ratings of a health facility.

The introduction of such an experience will be beneficial for Ukraine because this is not a necessity for patients, but a modern necessity. Recently, there have been serious changes, in particular: the medical information update has been speeded up, the number of highly effective medicines and diagnostic technologies has increased, advanced health care practices have emerged that require highly qualified physicians and medical services have risen in price. Accordingly, the measures should be introduced in Ukraine that will promote the reform of the medical sector, first of all, by increasing the competence of medical staff. Therefore, it would be advisable to introduce a post-graduate accumulative system of educational credits (hours) for the training of physicians and nurses. It would be appropriate to create modern laboratories, centers for working out practical skills, technical means for distance learning in universities and medical institutions and provide access to modern high-quality information sources. They will later become the basis for the creation of a single Ukrainian medical-information space with the ability to exchange and share data.

So, in the field of health care in Ukraine there are many unresolved problems and these drawbacks affect both the quality of health service provision and the effectiveness of the mechanism of protecting patients' rights. It is clear that such issues are not solved in one day. However, the reform of the medical sector is urgently needed in Ukraine because healthcare and well-being of all Ukrainian people depend on it.

\section{REFERENCES}

1. Lavrynenko 00, Rohova OH, Panasiuk SA. Komentar medychnoho zakonodavstva Ukrainy [Commentary on medical legislation of Ukraine]. Kyiv: Vydavnychyi dim Profesional; 2017, p. 360 (in Ukrainian).

2. Khalatnost ot oploshnosti:v Kazakhstane vrachebnyye oshibkizanesutv edinyy reyestr [Negligence of an oversight: in Kazakhstan, medical errors will be entered in a single registry]. Available from: https://almaty.tv/ news/arkhiv/khalatnost-ot-oploshnosti-v-kazakhstane-vrachebnyeoshibki-zanesut-v-edinyy-reestr (in Russian).

3. Leape LL. Error in medicine. JAMA. 1994;272:1851-7. doi: 10.1001/ jama.1994.03520230061039 pmid:7503827.

4. Reason J. Human error. Cambridge University Press. 1990. doi: 10.1017/ CB09781139062367.

5. Martin M, Michael D. Medical error - the third leading cause of death in the US. BMJ.2016; 353 doi: https://doi.org/10.1136/bmj.i2139.

6. Senders JW. Medical devices, medical errors, and medical accidents. Human error in medicine. Lawrence Erlbaum Associates, Hillsdale, New Jersey, 1994, p. 166.

7. Swaminath G, Raghuram R. Medical errors Indian Psychiatry. 2010 Apr-Jun; 52(2): 110-112. doi: 10.4103/0019-5545.64580.
8. Sonny B. Bal, An Introduction to Medical Malpractice in the United States. 2009 Feb; 467(2):339-347.Published online 2008 Nov 26. doi: 10.1007/ s11999-008-0636-2.

9. Ritchey FJ. Medical Malpractice. The Wiley Blackwell Encyclopedia of Health, Illness, Behavio, and Society. New York: Wiley. 2014:1387-1394.

10. Bonetti M, Cirillo P. An Analysis of the Number of Medical Malpractice Claims and Their Amounts. PLoS One. 2016 Apr 14;11(4) https://doi. org/10.1371/journal.pone. 0153362 .

11. Dvadtsat vrachebnykh oshibok kazakhstanskikh medikov [Twenty medical mistakes of Kazakhstan physicians]. Available from: http:// gonzo.kz/blog/2977-20_vrachebnyih_oshibok_kazahstanskih_ medikov (in Russian).

12. Convention for the Protection of Human Rights and Fundamental Freedoms. Available from: https://www.echr.coe.int/Pages/home. aspx?p=basictexts\&c.

13. The Declaration on the Promotion of Patients'Rights in Europe. Available from: https://www.who.int/genomics/public/eu_declaration1994.pdf.

14. The Copenhagen Declaration. Available from: https://www.echr.coe. int/Documents/Copenhagen_Declaration_ENG.pdf.

15. The Declaration of Tokyo. Available from: https://www.wma.net/whatwe-do/medical-ethics/declaration-of-tokyo/.

16. The Declaration of Lisbon on rights of the patient. Available from: https://www.wma.net/policies-post/wma-declaration-of-lisbon-onthe-rights-of-the-patient/.

17. The Declaration on Euthanasia. Available from: http://www.vatican. va/roman_curia/congregations/cfaith/documents/rc_con_cfaith_ doc_19800505_euthanasia_en.html.

18. The Declaration on Human Organ Donation and Transplantation. Available from: https://www.wma.net/policies-post/wma-statementon-human-organ-donation-and-transplantation/.

19. The Declaration of Helsinki. Available from: https://www.wma.net/ policies-post/wma-declaration-of-helsinki-ethical-principles-formedical-research-involving-human-subjects/.

20. Nykytchenko N V. Pravove rehuliuvannia derzhavnoho kontroliu u sferi hospodarskoi diialnosti [Legal regulation of state control in the field of economic activity]: avtoref. dys. na zdobuttia nauk. stupenia dok. yuryd. nauk. Kyiv, 2015. p. 36 (in Ukrainian).

21. Reformatsiia: uspikh Yevropy i shans dlia Ukrainy [Reformation: Europe's success and a chance for Ukraine]: kolektyvna monohrafiia, Kyiv: Sammit-Knyha; 2017 r. 256 (in Ukrainian).

Authors' contributions:

According to the order of the Authorship.

\section{Conflict of interest:}

The Authors declare no conflict of interest.

\section{CORRESPONDING AUTHOR \\ Nataliia V. Nykytchenko \\ National University of State Fiscal Service of Ukraine \\ 31 Universytetska str., Irpin, Kyiv region, 08200, Ukraine \\ e-mail:nykytchenko_n@ukr.net}

Received: 06.02.2019

Accepted: 05.04.2019 


\title{
MODERN METHODS OF GREAT OBSTETRICAL SYNDROMES PROGNOSTICATION (LITERATURE REVIEW)
}

\author{
Natalia Y. Lemish \\ DEPARTMENT OF OBSTETRICS AND GYNECOLOGY, FACULTY OF MEDICINE, UZHHOROD NATIONAL UNIVERSITY, UZHHOROD, UKRAINE
}

\begin{abstract}
Introduction: The term "Great Obstetrical Syndromes" (GOS) was widely implemented to clinical practice after 2009, due to publications of G. C. Di Renzo and R. Romero. The effective prognostical methods are still being searched for early correction of the disorders and decrease of negative consequences on mother and fetus.

The aim: To analyze the up to date data concerning prognostication of Great obstetrical syndromes.

Materials and methods: Used database Pubmed from 2004 up till 2019 to search clinical studies of great obstetrical syndromes.

Conclusions: The literature review summarizes the data about existing methods of prognostication of GOS based on history of the patient and the results of additional clinical and laboratory investigations.
\end{abstract}

KEY WORDS: great obstetrical syndrome, prognostication, preeclampsia

Wiad Lek 2019, 72, 4, 704-706

\section{INTRODUCTION}

Perinatal period is crucial for the formation of further health of an individual. Though the modern taxonomy of diseases in obstetrics is based on clinical symptoms of mother and not on the pathophysiological mechanisms that are in charge of clinical manifestation. For example, the term "preterm labour" is not indicating what is the cause - infection, disorders of placental blood flow, over distension of uterus, disorders of allogenic recognition, stress of other pathological processes. The same refers to preeclampsia, fetal growth restriction, antenatal fetal death, nausea and vomiting of pregnant, disorders of uterine contractile activity, so the manifestations, when the diagnosis just indicates the clinical symptoms without clarifying specific etiology.

Lack of understanding of these states leads to management of symptoms without treatment of mechanisms that caused the disease, this, in turn, leads to expectation that one diagnostic test or treatment may indicate or cure the other mentioned states. Oxford medical dictionary defines that syndrome is a group of symptoms which consistently occur together, or a condition characterized by a set of associated symptoms. The main in this definition is that a syndrome may be caused by more than one mechanism, or disease or etiology.

Obstetrical complications that cause perinatal morbidity and mortality are syndromes, though they may be named "Great Obstetrical Syndromes" (GOS). This term was widely implemented to clinical practice after 2009 , due to publications of G. C. Di Renzo and R. Romero.

\section{THE AIM}

The aim to analyze the up to date data concerning prognostication of Great obstetrical syndromes.

\section{MATERIALS AND METHODS}

Used database Pubmed from 2004 up till 2019 to search clinical studies of great obstetrical syndromes.

\section{REVIEW AND DISCUSSION}

GOS - is a name for a group of gestational complications that occur in approximately $15 \%$ of pregnancies. They may cause severe gestational period complications and lead to fetal and maternal mortality, so these syndromes require extraordinary attention, constant monitoring and treatment. The main characteristics of these syndromes are: [1,2]: multiple etiology; a long preclinical period; frequent fetal involvement; adaptive in nature.

The development of these syndromes is a result of complicated relationships between maternal and fetal genomes and the environment. The GOS include $[1,2]$ : preterm labour, premature rupture of membranes, preeclampsia, intrauterine growth restriction, macrosomy, missed pregnancy, antenatal fetal death, spontaneous abortions, placental abruption. Recent publications indicate gestational diabetes (GD) as one of the GOS [3].

GOS are characterized by generalized inflammation, endothelial dysfunction, increased trombine production, the prevalence of antiangiogenic factors that commonly lead to multiple organs and systems damage [4]. 
According to results of investigations, the main cause of GOS is pathology of deep placentation. Also, one of pathophysiological links in GOS development is dysfunction of haemostasis system.

\section{RISK FACTORS}

The risk factors of GOS development include anemia, endometriosis, polycystic ovarian syndrome, teenage age, chronic arterial hypertension, previous pregnancy complications by preeclampsia and preterm labour [5].

The recommendations of National Institute for Health and Clinical Excellence (NICE) include routine screening of specific preeclampsia risk factors (primipara, elderly age, increased body mass index $(\mathrm{BMI})$, preeclampsia in family history, chronic renal disease of chronic hypertension, multiple pregnancy, a long interval between pregnancies more than 10 years and preeclampsia in previous pregnancy). The estimated incidence of preeclampsia is from $3 \%$ in case of one risk factor up till $30 \%$ in case of combination of several risk factors mentioned above [6-9]. According to GOS study in nulliparous women, $\mathrm{BMI}$ is the most discriminant maternal characteristic for the prediction of preeclampsia. Maternal characteristics should not be used alone to identify nulliparous women at high risk of preeclampsia [10].

Canadian scientists concluded that the presence in primipara risk factors like age, ethnicity and history allows to determine $55 \%$ of women with early preeclampsia risk with specificity $90 \%$. In case of additional usage of biomarkers of blood serum the rate of determination was increased to $75 \%$. Taking into account the fact, that a number of medical centers offer determination of pregnancy-associated plasma protein-A (PAPP-A) in blood serum in the first trimester of pregnancy, at least $50 \%$ of all preeclampsia cases may be predicted and probably more than two thirds of severe cases with the rate of false-positive results less than $10 \%$. The value of determination of additional markers of first or early second trimester preeclampsia such as placental growth factor, ingibin, endogline, soluble fmf-like tyrosinkinase - 1 (sFlt-1) are being studied. Though, the answer to this question may be given only after the confirmation of action and benefits of these factors usage in large cohort studies and studies of cost-effectiveness ratio [11-15].

Yu et al. have offered ultrasound screening of first trimester in order to accurately determine the vascular pathology of placenta and for detection of women with increased risk of dangerous obstetrical complications [16]. The investigations proved that women with increased vascular resistance in uterine arteries have a 5 fold time's increased risk of preeclampsia, intrauterine growth restriction or antenatal death development compared to other pregnant. It is assumed, that the possible factors of pathological placentation development are increased cell death and decreased expression of insulin-like growth factor-2 [17].

\section{PROGNOSTICATION}

One of the glycoproteins which is synthesized by placenta and may have a prognostication value is PAPP-A. It is well known about the use of this marker for screening programs in the first trimester in order to diagnose aneuploidies. Nowadays it is studied as a marker of GOS $[18,19]$.

Furthermore, it was concluded that Dopplerometry of uterine arteries during pregnancy combined with determination of PAPP-A is connected to disorders of trophoblast development $[20,21]$ and is observed in case of small for gestational age fetuses, intrauterine growth retardation and antenatal fetal death [22-24]. These investigations resulted a confirmation of coherence between Dopplerometry of uterine arteries and levels of PAPP-A with small for gestational age fetuses and decreased fetal movements in case of an at term pregnancy. Pregnancies complicated by decreased fetal movements and/or small for gestational age fetuses were accompanied by decreased levels of PAPP-A and increased indexes in the uterine arteries in 11-13 weeks of gestation compared to uncomplicated pregnancies. Also, compared to cohort the frequency of small for gestational age fetuses was significantly higher among women with decrease fetal movements in case of an at term pregnancy. Even taking into account such variables as maternal age, BMI, ethnicity, smoking, logistical regress showed independent relationship between levels of PAPP-A, uterine arteries Dopplerometry indexes, small for gestational age fetuses and decrease fetal movements in case of at term pregnancy [25].

It was established that a combined estimation of placental growth factor (PlGF), PAPP-A and a heperclycosalated chorionic gonadotropin (hCG-h) to chorionic gonadotropin (hCG) ratio together with mean arterial pressure in primipara gave the opportunity to receive a test, where the prognostication value AUC was 0.870 for early manifestation of preeclampsia [26]. Though, a self assessment in the second trimester did not have a prognostication value [27].

European Society of Cardiology indicates, that Dopplerometry of uterine arteries after 20 weeks of gestation gives the opportunity to identify women with high risk of gestational hypertension, preeclampsia and intrauterine growth retardation. They also notice, that the rate ratio in patients with doubtful diagnosis indicates a low risk of preeclampsia development [28].

Also worth noting, that there are a number of investigations concerning the function of endoglin in the development of a cascade of pathological processes in case of preeclampsia [29]. Nowadays it is mostly used for evalulation of effectiveness of proton pump inhibitors for preeclampsia treatment on the stage of preclinical, double blind, randomized, placebo-controlled investigations [30] that is one of the new research areas [31,32].

Another biomarker, the role of which in preeclampsia pathogenesis is widely discussed is vascular endothelial growth factor. It is worth noticing, that it is one of the proteins, which is also in charge of the balance of agiogenic/antiangiogenic signals during placentation [33]. Though, the amount of relevant publications concerning perspectives of the usage of this parameter is minimal [34]. The proof of absence of adequate investigations of its prognostic value is "ignoring the biomarker" by most 
of recommendations of leading profile organizations [35]. Nevertheless, in one of recent publications there are data about a new predicting factor of preeclampsia - the ratio between pigment epithelium-derived factor (PEDF) and vascular endothelial growth factor [36].

One of the methods of GOS prognostication is a measurement of mean arterial pressure (MAP) in the first trimester. Recent investigations showed, that among 4700 pregnant women gestational hypertension was diagnosed in $250(5.3 \%)$, preeclampsia - in $241(5.1 \%)$, including preterm in $33(0.7 \%)$ and early in $10(0.2 \%)$ of women. Increased MAP in the first trimester was associated with increased incidence of gestational hypertension (OR 0.77; 95\% CI: $0.74-0.80)$, preterm preeclampsia (0.80; 95\% CI: $0.73-0.87)$, early (0.79; 95\% CI: $0.62-0.96)$ and at term preeclampsia $(0.73 ; 95 \% \mathrm{CI}: 0.70-0.76)$. The rates of false-positive results of MAP measurement in the first trimester was $10 \%$ with the prognostication rates of $39 \%$ for gestational hypertension, $34 \%$ for at term preeclampsia, $48 \%$ for early preeclampsia. In case of combination with pregnant data, the improvement of predicative parameters was observed till 40\%,37\%, 55\% and 70\% accordingly. Therefore it was proved that MAP in the first trimester is a valuable predictor of gestational hypertension and preeclampsia in primipara women [37].

Recent investigations established an important role in violation of estrogen levels in preeclampsia pathogenesis. During pregnancy, estrogen is produced by mainly placenta, unlike the predecessors of androgens, which are produced by adrenal glands of mother and fetus. These processes lead to increased estrogen levels in blood plasma, compared to levels of non pregnant women. Disorders of estrogen production may play a crucial role in appearance of preeclampsia symptoms, as they are exclusively produced by placenta and contribute to angiogenesis and vasodilatation. Previous investigations of estrogen synthesis in case of preeclampsia showed controversial results, probably due to insufficient specificity of the analyzes. Though by implementing reliable analytical protocols with liquid chromatography/mass-spectrometry or gas chromatography/mass-spectrometry, modern investigations indicate a significant decrease of estrogen levels in case of preeclampsia. Close connection between disorders of estrogen regulation and incidence of preeclampsia may substantiate the use of estrogen levels as a biomarker, and also may establish a potential approach to prophylaxes and treatment of preeclampsia.

Estradiol may modulate vascular endothelial functions and angiogenic and steressor factors synthesis. E2 is synthesized by placenta in big amount during pregnancy and causes angiogenesis and vascular dilation [38]. Indeed, E2 induces NO synthesis [39-41] and angiogenic factors levels, as vascular endothelial growth factor (VEGF) and placental growth factor inhibits Tumor Necrosis Factor- $\alpha$ (TNF- $\alpha$ ) synthesis by macrophages [42]. A number of recent studies with usage of up date analytical methods of investigation found low levels of estrogens in women with preeclampsia [43].
Pillar et al. conducted an investigation, aimed at detection of reliable markers of early preeclampsia and GD joining, which is based on research of micro RNA (miRNAs) in pathogenesis and their probable role as early biomarker of listed above pregnancy complications. Specific miRNAs are induced by hypoxia and in case of preeclampsia their regulation is often altered. So, probably these miRNAs mediate complications of placental hypoxia in case of preeclampsia. miRNAs, adipose tissue and insulinresistancy also play an important role in pathophysiology of GD. A number of investigations identified the highest expressed miRNAs, MiR-210, that are present in placenta and are predominantly synthetized by trophoblast cells and proved their role in control of trophoblast invasion and proliferation. The determination of placenta expressed miRNAs in maternal plasma indicates their potential role in non invasive prenatal diagnostics and indicates the type of therapeutic tactics [44].

Intravascular inflammation is observed in women with preeclampsia and small for gestational age fetuses (T helper-1 (Th-) mediated immune response). There is controversy about T-helper activity (Th-2) in women with preeclampsia and small for gestational age. CD30, one of the tumor necrosis factor receptor, is predominantly expressed in vitro and in vivo by activation of $\mathrm{T}$ cells, that produce cytokines of type $\mathrm{Th} 2$. The investigators propose to use their soluble form (sCD30) as a Th2 immune response index [45].

\section{A MOLECULAR THEORY OF PREECLAMPSIA}

Nowadays a molecular theory of preeclampsia development is widely investigated. In order to investigate the molecular interactions, the researchers used the systems of biological approach and different so called "omics", the results of clinical, placental and functional investigations of women with adverse preeclampsia phenotype. During investigation of proteome of these pregnant in first trimester the alteration in the levels of renin-angiotensin and immune system, complement and coagulation cascade in patients with at term and early preeclampsia. Also in blood of these patients in first trimester in vitro dysregulation of trophoblast gene expression were found. Due to placental transcryptomics of women with preterm preeclampsia specific genes that are associated with morbidity of mother and kids were found. "Virtual" liquid biopsy of placenta revealed that gene alterations occur in first trimester in case of these diseases. Investigations in vitro showed that hypermethylation of DNA in regulatory area ZNF554 causes suppression of gene and disturbances of trophoblast invasion, activation of BCL6 and ARNT2 sensitizes trophoblsat to ischemia and pre term preeclampsia. The results of epidemiologic investigations show, that pregestational disease of mother or disturbances of immune relationships of mother-fetus-placenta ply the major role in preeclampsia development. Careful study of these up to date mechanisms in «molecular phase» of preeclampsia and determination of main molecules may enable a molecular investigation 
of patients with a typical preeclampsia development phenotype [46].

\section{CONCLUSIONS}

As the incidence of Great Obstetrical Syndromes unfortunately still remains high it is crucial do find effective methods of prognostication of these states in order to influence pathophysiological mechanisms and decrease maternal and fetal morbidity and mortality. The effectiveness of combined evaluation of clinical, instrumental and serological markers in I trimester in order to prognosticate early onset preeclampsia s rather high.

\section{REFERENCES}

1. Di Renzo GC. The Great Obstetrical Syndromes. J Matern Fetal Neonatal Med. 2009; 22(8):633-635.

2. Romero R. Prenatal medicine: The child is the father of the man. J Matern Fetal Neonatal Med. 2009; 22(8):636-639.

3. Gabbay-Benziv R, Baschat A. Gestational diabetes as one of the "great obstetrical syndromes" - the maternal, placental, and fetal dialog. Best Pract Res Clin Obstet Gynaecol. 2015; 29(2):150-155.

4. Soto E, Romero R, Kusanovic JP et al. Late-Onset Preeclampsia is associated with an imbalance of angiogenic and antiangiogenic factors in patients with and without placental lesions consistent with maternal underperfusion. J Matern Fetal Neonatal Med. 2012; 25:498-507.

5. Tandu-Umba B, Mdangama AM. Association of maternal anemia with other risk factors in occurrence of Great obstetrical syndromes at university clinics, Kinshasa, DR Congo. BMC Pregnancy Childbirth. 2015; 15:183 doi: 10.1186/s12884-015-0623-z.

6. Duckitt K, Harrington D. Risk factors for preeclampsia at antenatal booking: systematic review of controlled studies. BMJ. 2005; 330:565-567.

7. Chappell LC, Enye S, Seed P et al. Adverse perinatal outcomes and risk factors for preeclampsia in women with chronic hypertension: a prospective study. Hypertension. 2008; 51:1002-1009.

8. Hernandez-Diaz S, Toh S, Cnattingius S. Risk of preeclampsia in first and subsequent pregnancies: prospective cohort study. BMJ. 2009; 338:b2255. doi:10.1136/bmj.b2255.

9. Sibai BM, Lindheimer M, Hauth J et al. Risk factors for preeclampsia, abruptio placentae, and adverse neonatal outcomes among women with chronic hypertension. National Institute of Child Health and Human Development Network of Maternal-Fetal Medicine Units. NEngl J Med. 1998;339:667-671.

10. Boutin A, Gasse C, Demers S et al. Maternal Characteristics for the Prediction of Preeclampsia in Nulliparous Women: The Great Obstetrical Syndromes (GOS) Study. J Obstet Gynaecol Can. 2018 May; 40(5):572-578.

11. Audibert F, Boucoiran I, An N et al. Screening for preeclampsia using first-trimester serum markers and uterine artery Doppler in nulliparous women. Am J Obstet Gynecol. 2010; 203:383. e1-e8. doi: 10.1016/j. ajog.2010.06.014.

12. Poon LC, Maiz N, Valencia C et al. First-trimester maternal serum pregnancy-associated plasma protein-A and pre-eclampsia. Ultrasound Obstet Gynecol. 2009; 33:23-33.

13. Poon LC, Stratieva V, Piras S et al. Hypertensive disorders in pregnancy: combined screening by uterine artery Doppler, blood pressure and serum PAPP-A at 11-13 weeks. Prenat Diagn. 2010; 30:216-223.
14. Gagnon A, Wilson RD, Audibert F et al. Obstetrical complications associated with abnormal maternal serum markers analytes. J Obstet Gynaecol Can. 2008; 30918-3949.

15. Poon LC, Akolekar R, Lachmann R et al. Hypertensive disorders in pregnancy: screening by biophysical and biochemical markers at 11-13 weeks. Ultrasound Obstet Gynecol. 2010; 35:662-670.

16. Yu CK, Smith GC, Papageorghiou AT et al. Fetal Medicine Foundation Second Trimester Screening Group. An integrated model for the prediction of preeclampsia using maternal factors and uterine artery Doppler velocimetry in unselected low-risk women. Am J Obstet Gynecol. 2005; 193: 429-436.

17. Leslie K, Whitley G, Herse F et al. Increased apoptosis, altered oxygen signaling, and antioxidant defenses in first-trimester pregnancies with high-resistance uterine artery blood flow. Am J Pathol. 2015; 185(10): 2731-2741.

18. Conde-Agudelo A, Bird S, Kennedy SH et al. First- and second-trimester tests to predict stillbirth in unselected pregnant women: a systematic review and meta-analysis. BJOG. 2015;122(1):41-55.

19. Odibo A0. Pregnancy associated-plasma protein-a (PAPP-A) and alfafetoprotein (AFP) associated with placental abruption. Am J Obstet Gynecol. 2014; 211(2):89-90.

20. Prefumo F, Sebire NJ, Thilaganathan B. Decreased endovascular trophoblast invasion in first trimester pregnancies with high-resistance uterine artery Doppler indices. Hum Reprod. 2004; 19(1):206-209.

21. Fournier T, Handshuh K, Tsatsaris V et al. Role of nuclear receptors and their ligands in human trophoblast invasion. J Reprod Immunol. 2008; 77(2):161-170.

22. Nicolaides KH. A model for an ewpyramid of prenatal care based on the11to 13 weeks' assessment. Prenat Diagn. 2011; 31(1):3-6.

23. Herraiz I, Arbues J, Camano I et al. Application of a first-trimester prediction model for pre-eclampsia based on uterine arteries and maternal history in high-risk pregnancies. Prenat Diagn. 2009; 29(12):1123-1129.

24. Melchiorre K, Leslie K, Prefumo F et al. First trimester uterine artery Doppler indices in the prediction if small for gestational age pregnancy and intrauterine growth restriction. Ultrasound Obstet Gynecol. 2009; 33:524-529.

25. Pagani G, D'Antonio F, Khalil A et al. Association between reduced fetal movements at term and first trimester markers of impaired placental development. Placenta. 2014; 35:606-610.

26. Keikkala E, Koskinen S, Vuorela P et al. First trimester serum placental growth factor and hyperglycosylated human chorionic gonadotropin are associated with pre-eclampsia: a case control study. BMC Pregnancy Childbirth. 2016 Nov 25; 16(1):378. PubMed PMID: 27887594; PubMed Central PMCID: PMC5124279.

27. Keikkala E, Ranta JK, Vuorela P et al. Serum hyperglycosylated human chorionic gonadotrophin at 14-17 weeks of gestation does not predict preeclampsia. Prenat Diagn. 2014; 34:699-705.

28. Regitz-Zagrosek V, Roos-Hesselink JW, Bauersachs J et al. 2018 ESC Guidelines for the management of cardiovascular diseases during pregnancy. Eur Heart J. 2018 Sep 7; 39(34):3165-3241. doi: 10.1093/ eurheartj/ehy340. PubMed PMID: 30165544.

29. NgeneNC, Moodley J. Role of angiogenic factors in the pathogenesis and management of preeclampsia. Int J Gynaecol Obstet. 2018; 141:5-13.

30. Cluver CA, Walker SP, Mol BW et al. Double blind, randomised, placebocontrolled trial to evaluate the efficacy of esomeprazole to treat early onset pre-eclampsia (PIE Trial): a study protocol. BMJ Open. 2015 0ct 28; 5(10):e008211. doi: 10.1136/ bmjopen-2015-008211. 
31. Armaly Z, Jadaon JE, Jabbour A et al. Preeclampsia: Novel Mechanisms and Potential Therapeutic Approaches. Front Physiol. 2018;9:973. doi:10.3389/fphys.2018.00973.

32. Saleh L, Samantar R, Garrelds IM et al. Low soluble fms-like tyrosine kinase-1, endoglin, and endothelin-1 levels in women with confirmed or suspected preeclampsia using proton pump inhibitors. Hypertension. 2017; 70:594-600.

33. Karumanchi SA. Angiogenic Factors in Preeclampsia: From Diagnosis to Therapy. Hypertension. 2016 Jun; 67(6):1072-1079.

34. Kleinrouweler C, Wiegerinck M, Ris-Stalpers C et al. Accuracy of circulating placental growth factor, vascular endothelial growth factor, soluble fms-like tyrosine kinase 1 and soluble endoglin in the prediction of pre-eclampsia: a systematic review and meta-analysis. BJ0G. 2012; 119(7), 778-787. doi:10.1111/j.1471-0528.2012.03311.x.

35. Gillon TE, Pels A, von Dadelszen P et al. Hypertensive disorders of pregnancy: a systematic review of international clinical practice guidelines. PLoS One. 2014; 9(12):e113715.

36. Zhang YG, Yang HL, Zhang YP et al. Pigment epithelium-derived factor/vascular endothelial growth factor ratio for early prediction of preeclampsia: A prospective multicenter study in China. Pregnancy Hypertens. 2018 0ct; 14:43-48. doi: 10.1016/j.preghy.2018.07.005. Epub 2018 Jul 27. PubMed PMID: 30527117.

37. Gassea C, Boutinb A, Cotéc M. First-trimester mean arterial blood pressure and the risk of preeclampsia: The Great Obstetrical Syndromes (GOS) study. Pregnancy Hypertension. 2018; 12:178-182.

38. Rosenfeld CR, Rivera R. Circulatory responses to systemic infusions of estrone and estradiol-17alpha in nonpregnant, 0ophorectomized ewes. Am J Obstet Gynecol.1978; 132(4):442-448.

39. Caulin-Glaser T, García-Cardeña G, Sarrel P et al. 7 beta-estradiol regulation of human endothelial cell basal nitric oxide release, independent of cytosolic Ca2+ mobilization. Circ Res. 1997; 81(5):885-892.

40. Hisamoto K, Ohmichi M, Kurachi H et al. Estrogen induces the Aktdependent activation of endothelial nitric-oxide synthase in vascular endothelial cells. J Biol Chem. 2001; 276(5):3459-3467.
41. Simoncini T, Genazzani AR, Liao JK. Nongenomic mechanisms of endothelial nitric oxide synthase activation by the selective estrogen receptor modulator raloxifene. Circulation. 2002; 105(11):1368-1373.

42. Shanker G, Sorci-Thomas M, Adams MR. Estrogen modulates the expression of tumor necrosis factor alpha mRNA in phorbol esterstimulated human monocytic THP-1 cells. Lymphokine Cytokine Res. 1994; 13(6):377-382.

43. Jobe SO, Tyler CT, Magness RR. Aberrant synthesis, metabolism, and plasma accumulation of circulating estrogens and estrogen metabolites in preeclampsia implications for vascular dysfunction. Hypertension. 2013; 61(2):480-487.

44. Pillar N, Yoffe L, Hod M, Shomron N. The possible involvement of microRNAs in preeclampsia and gestational diabetes mellitus. Best Pract Res Clin Obstet Gynaecol. 2014; 29(2):176-182.

45. KusanovicJP,Romero R, HassanSSetal.Maternal serum solubleCD30 is increased in normal pregnancy, but decreased in preeclampsia and small for gestational age pregnancies. J Matern Fetal Neonatal Med. 2007; 20 (12):867-878.

46. Than NG, Romero R, Laurentiu Tarca L et al. Integrated systems biology approach identifies novel maternal and placental pathways of preeclampsia. Front Immunol. 2018; URL - https://www.frontiersin. org/articles/10.3389/fimmu.2018.01661/full.

\section{Conflict of interest:}

The Author declare no conflict of interest.

\section{CORRESPONDING AUTHOR Nataliya Y. Lemish \\ Uzhhorod National University \\ Narodna square, 3, 88000 Uzhhorod, Ukraine \\ tel: +380505600517 \\ e-mail: lemishny@gmail.com}

Received: 17.02 .2019

Accepted: 02.04.2019 
PRACA POGLĄDOWA

REVIEW ARTICLE

\title{
LEGAL BASES FOR IMPROVING LEGISLATION ON THE TRANSPLANTATION OF HUMAN ANATOMICAL MATERIALS
}

\author{
Nadiia V. Shulzhenko \\ YAROSLAV MUDRYI NATIONAL LAW UNIVERSITY, KHARKIV, UKRAINE
}

\begin{abstract}
Introduction: From January 1, 2019, the Law of Ukraine "On application of the transplantation of anatomical materials to a human being" dated May 17, 2018, № 2427-VIII (hereinafter referred to as Law № 2427), which defined a new system of legal relationship in the field of transplantation and related activities. Simultaneously the validity of the Law of Ukraine "On transplantation of organs and other anatomical materials to a human being" adopted in July 16, 1999. № 1007-XIV was canceled. The development of medical science overlooks the prospect of humanity's salvation from many incurable diseases. One of the directions of medical advancing is the development of transplantation, which is special method of treatment that involves the transplantation of anatomical human material from a donor to a recipient and a focuses on the restoration of human health. Admitting the fact that life or health can be saved for hundreds of thousands of people with its' usage today and the need for it is growing relentlessly. Therefore, research and improvement of legislation on the transplantation of human anatomical materials is well-grounded and timely.

The aim: To establish and specify the problematic issues of legal regulation that arise in the transplantation of human anatomical materials sphere.

Materials and methods: During the study, international acts, national legislation and Conclusions of scientists were used. The article is based on dialectical, legal comparative, systemic, historical and complex methods of research.

Review: In this paper the main problems of legal regulation of transplantation of human anatomical materials according to the Ukrainian legislation are analyzed and specific suggestions for their solution are proposed.

Conclusions: The solution to this problem is to create a legislative framework and provide an effective and effective mechanism for regulating and implementing transplantation of human anatomical materials.
\end{abstract}

KEY WORDS: Medical law, transplantation, transplantation of human anatomical materials

\section{INTRODUCTION}

Adoption of the Law of Ukraine "On application of the transplantation of anatomical materials to a human being" [1] initiated a new stage of Ukrainian transplantology. This Law amended the Laws of Ukraine "On the transplantation of organs and other anatomical materials to a human being ", "The Fundamentals of the Legislation of Ukraine on Health care", "On Funeral and Burial services", and the Criminal Code of Ukraine on Improving the Regulation of Legal Relations in this area in accordance with International Standards and world practice, the introduction of the procedure for providing intravital consent to post-mortem donation, establishing more strict liability for legislation offenders, etc. In particular, the new revised edition includes Article 143 of the Criminal Code of Ukraine, which provides for liability for violations of the law of anatomical material transplantation.

It should be noted that since the adoption of the Law of Ukraine "On transplantation of organs and other anatomical materials to a human being" in 1999 [2], the legal sphere of transplantation practically did not change, although a number of subordinate legal acts were adopted that did not significantly affect advancing organ transplant procedures.
Ukrainian legislation, which regulates the transplantation of anatomical materials to a human being, is definitely far from perfect.

The importance of improving the legal framework for the transplantation of human anatomical materials is also caused by statistics. In particular, during 2018 there were only 89 transplantations of the kidney from a relative donor and 6 from a non-familial (deceased person); 9 transplantations of the liver from a family donor; more than 60 autologous bone marrow transplantations (transplantation of a person's own anatomical material) at the Kyiv City Transplantation Center; 12 allogeneic transplantations (from a family donor), 1 autologous and 4 transplantations from parent. The rates reported by me are really small and do not fully meet the needs of patients [3]. At the same time, according to various estimates, about five thousand patients annually require organ transplantation in Ukraine. According to the Global Observatory on Donation and Transplantation, 154 transplantations in 2013, 148 in 2014, and 136 in 2015 were made in our country. According to the Ministry of Health, in 2016119 transplants, 2017 - 118 operations, 2018 - 96 (as of October) took place [4]. 
Unfortunately, the situation with transplantation in Ukraine is quite critical. Despite the available human and scientific potential, in the last decade, the development of clinical transplantology has slowed down, and the industry is in fact stagnant. The rebirth of Ukrainian transplantation is possible only through the combination of state policy, the active activities of public and charitable organizations, the persistent work of practitioners and representatives of the Ministry of Health of Ukraine. All this testifies to the relevance of the study and its timeliness.

\section{THE AIM}

The main tasks are: to define of the current state of regulatory and legal support for the field of transplantology; to highlight the main updates in the transplant legislation and their thorough analysis; to compare legal provisions of old and new laws regulating relations in the field of transplantation of anatomical materials to a human being.

\section{MATERIALS AND METHODS}

During the study, dialectical, comparative, legal, systematic, historical, and integrated research methods are used. The systematization of the normative and legal framework in the field of transplantation of anatomical materials to a person has been carried out. Due to the analysis of national legislation, scientific literature, official statistics, the problems identified in this area and the ways of their solution are proposed.

\section{REVIEW AND DISCUSSION}

In view of all the above, one can conclude that only detailed regulation of transplantology in the norms of the relevant legislation will enable the development of this field of medicine.

Despite of such a huge need for organ transplantation, attempts at least something to change in the current situation were made only in 2018 because the previous bills were never adopted. The main changes to the legislation of Ukraine should be described:

1. The new law has made improvements to the terminology apparatus, in particular in the introduction of new concepts and changes to existing definitions of terms (transplantation, recipient, fetal human substances, deceased person) took place. In addition, the term "transplantation of organs or tissues", used in the old law, has been replaced in the new "transplantation of anatomical materials" in both the title and the text of the law. This is explained by the fact that the revised edition is more specific and does not include a tautology, since human anatomical materials also include organs, so there is no need to separate them. The same changes were made in the Criminal Code of Ukraine (Article 143) [5]. At the same time, the sanctions of Art. 143 of the Criminal Code of Ukraine also changed and became more stringent in order to prevent the illegal transplantation of human anatomical materials.
The new law introduced amendments to the Fundamentals of Ukrainian Health Law (Articles 47, 52) [6] and for the first time the definition of the concept of "the moment of irreversible death" was introduced, which should be understood as the moment of death of a human brain or human's biologic death. There was given the concept of "brain death", that is a complete and irreversible termination of all its functions, recorded with a working heart and artificial ventilation of the lungs. It is also determined and the order of the death of the human brain: "It is carried out by a consilium of physicians of the health institution in which the patient is based on the diagnostic criteria of death of the human brain. On the fact of the death of the human brain, a physician's consilium write an act signed by all members of the consilium and incorporated into the medical records of the patient."

The term "biological death" should be understood as the irreversible termination of blood circulation and respiratory functions, the appearance of early and/or late corpuscular changes [1].

In addition to the norms defined in the new law, these issues are regulated also by the Order of the Ministry of Health of Ukraine № 821 dated September 23, 2013 “On the establishment of diagnostic criteria for brain death and procedures for determining the time of death of a person" [7], changes in which have not been made. The postponement rules of the order are based on the old transplant law and contain obsolete provisions that are inadmissible. This leads to incorrect execution of procedural actions during transplants.

2. The next new concept in the Law is the concept of "cross-donorship ", Art. 1 defines it as the exchange of live immunologically compatible donors between recipients, where it is impossible to carry out transplantation from a living donor-relative or family member, since it is not suitable, for example, because of a blood group, then the consilium may decide to apply cross-donorship. The new law specifies that cross-donorship can be applied between patients waiting for transplantation and included in the Unified National Information System on Transplantation, and that the Cabinet of Ministers of Ukraine (Section 9, Article 13) approves the application of cross-donorship. However, this order has not been approved yet. And the order of its application is not much wider: "In case of acceptance by the consilium of doctors the decision on impossibility of application of transplantation to the recipient from a living donor from the number of his close relatives or family members by results of determination of immunological compatibility of the donor and the recipient [1].

3. Transplantation can not exist without a single information database, therefore the new law introduces the Unified National Information System on Transplantation, which is intended for the collection, registration, accumulation, storaging, processing of information and implementation of automated objective and impartial distribution of human anatomical materials, calculating of the couple "recipient donor", stored on state information resources. According to the new law, it will contain a number of registers: 
a register of human anatomical materials intended for transplantation; a register of living donors; register of recipients; information about the person's permission to give consent or disagreement to the post-mortem donation; the register of persons with transplanted anatomical material, etc. [1]. However, the Provisions on the Unified National Information System on Transplantation, the procedure and conditions for its financing, approved by the Cabinet of Ministers of Ukraine, have not yet been adopted. Moreover, software is not yet created. In what format it will exist, with which electronic resources will it function, how the access to information will be implemented, is unknown. Art. 11 of the new law gives only basic provisions and a reference to a Resolution that does not exist.

4. One of the updates of the law is inserting a mark of consent or disagreement on post-mortem donation and the change of this will to Ukrainian citizen's passport or certificate of the Ukrainian authorities on the right to manage vehicles. Such a note is entered into the document at the request of the person. This is preceded by the insertion of information about consent/disagreement on post-mortem donation to the Unified National Information System on Transplantation. But again, "the form and pattern of a written statement of consent or disagreement on post-mortem donation, a written declaration of previously granted consent or disagreement revocation, a written statement on the appointment, change or revocation of the representative and the procedure for their approving, the procedure for making a mark on the consent or disagreement with the post-mortem donation on the license of Ukraine on the right to drive vehicles and the change of this will are set by the Cabinet of Ministers of Ukraine "(Part 6 of Article 16) [1]. Sub-legislative normative legal act that regulates these issues has not yet been established.

The introduction of such a mark on a citizen document raises some difficulties, since it is not possible to replace the previous mark with another within a short period of time if the person has changed his/her mind regarding the removal of her anatomical materials. This can create a ground for misuse of the right of the person to be a donor and creates the basis for the incorrect understanding of the will of the person by the offenders.

5. One more recent law update is the introduction of transplantation coordinator post. This coordinator will become the main figure in the transplantation system. The transplantation coordinator must have a higher education not lower than the second (master's) level in the field of health care, be a health care worker who will have the right to carry out transplantation activities. An important guarantee is that he/she can not be part of a physician's consilium, which makes a statement on the death of a human brain, can not participate in the removal of anatomical material and carrying out transplantation. This unit has a fairly wide range of powers, but its legal status is not well known until there's no relevant Provision.

Transplantation coordinator activities necessarily involve communication with the donor's family, and therefore, according to the author, it is necessary, in addition to medical education, to undergo a course of psychological training. It is extremely important whether the transplant coordinator can find the right words to obtain the consent of the relative to extract the anatomical materials of their deceased relative.

6. No less innovative comparing to the old law is the norm that will allow healthcare institutions and scientific institutions of all forms of ownership to carry out transplantation activities, since until the entry into force of the new law such actions were carried out only by state and municipal health care institutions. There are enlisted in the "List of state and municipal health care institutions and state scientific institutions that have the right to carry out activities related to the transplantation of organs and other anatomical materials to a human being" [8]. The new law grants the right to all healthcare establishments licensed to conduct medical business practices (including the right to provide medical care using transplantation and/or transplantation related activities) to carry out such medical activities. The list of such establishments should be approved by the central executive body, which ensures the formation and implementation of state policy in the field of health care. Such a list has not yet been adopted, and there are no requirements for the technical equipment of these subjects of transplantation.

In addition, there are no Ukrainian medical protocols on withdrawal, order of transportation and transplantation of withdrawn anatomical materials. Currently, there is only the Order of the Ministry of Health of Ukraine "Conditions for ensuring the storage of anatomical materials during their transportation" [9], in which the requirements for transportation of withdrawn anatomical materials are prescribed only in part; it is indicated that "entrusted person should have documents of the established form", but facts who this person is and what documents should provide transportation were not prescribed.

7. Equally important is the introduction of a new law for the priority of obtaining consent from close relatives and family members of the donor of anatomical materials. These subjects include husband, wife, father, mother, stepfather, stepmother, son, daughter, stepchild, stepchild, brother, sister, grandfather, grandmother, grandfather, great-grandmother, grandchild, granddaughter, great-grandson, great-granddaughter, adopter or adopted, caretaker, or caretaken, as well as persons living together, are associated with a common life and have reciprocal rights and obligations, including those who live together, but not married (P. 4 of Art 1) [1]. However, the law does not explain how consent should be sought if there are several subjects from this list or if family members, who have fundamentally different views about the removal of the anatomical material of their deceased relative. In addition, the new law introduces amendments to Art. 6 of the Law of Ukraine "On Funeral and Burial services" and determines one more subject who can consent the withdrawal of anatomical materials, namely: "another person who has undertaken to bury the deceased and has a corresponding death certificate" [10]. It is unknown how to act in the case of the existence of such a person and living relatives. 
8. Changes in the concept of "opt-in" onto "opting (or contracting) out" did not happen. In the author's opinion, one of the reasons for such a low level of transplantology in Ukraine is the presumption of disagreement at the state level, or rather the "weak" model for the extraction of human anatomical materials.

\section{CONCLUSIONS}

After analyzing the Law of Ukraine "On application of the transplantation of anatomical materials to a human being" one can conclude that it is much better than the law on transplantation (old law and statutory legal acts) adopted before it. However, cardinal changes in transplantology should not be expected, because the law is incomplete and creates a number of problems that will arise after its introduction:

- a number of subordinate legal acts have not been adopted for its implementation;

- software for the Unified National Information System on Transplantation has not been created, the procedure for access to information is not defined, the electronic resources with which it will function are unknown;

- there is no existing transplantation coordination system in Ukraine;

- there is no designated responsible body that will implement the state policy in the field of medical care provision with the use of transplantation and carry out activities related to transplantation, its composition, the order of formation, subordination, etc.,

- the specific priority of obtaining consent from close relatives and members of the donor family in the event of the presence of several subjects with a statutory record or fully different views of family members regarding the removal of the anatomical material of their deceased relative is not specified;

- there is no Donor Card that would include marks for granting consent or disagreement on post-mortem donation;

- there is no List of health institution, that will carry out transplantations and/or activities related to it, the require- ments for the technical equipment of these institution, the list of accompanying documents;

- the concept of disagreement has not been changed for the concept of consent.

In this regard, it is worth to talk about further work on the improvement of the legislation on the transplantation of anatomical materials to a human being.

\section{REFERENCES}

1. «On application of the transplantation of anatomical materials to a human being» the Law of Ukraine, from May 17, 2018, № 2427-VIII

2. «On transplantation of organs and other anatomical materials to a human being» the Law of Ukraine, from July 16, 1999 № 1007-XIV

3. Ilyuk R. How and when transplantation will start in Ukraine [Electronic resource] / Roman llyk - Mode of access to the resource: https://life. pravda.com.ua/columns/2018/12/4/234431/

4. Statistics Global Observatory on Donation and Transplantation [Electronic resource] - Mode of access to the resource: http://www. transplant-observatory.org/summary/

5. The Criminal Code of Ukraine Code of Ukraine; Code, Law on April 5, 2001 № 2341-III

6. Fundamentals of Ukrainian Health Care Legislation: Law of Ukraine from November 19, 1992 № 2801-XII. Official transcript of Verkhovna Rada of Ukraine. 1993. No. 4. Art. 19th

7. Order of the Ministry of Health of Ukraine № 821 dated September 23, 2013 " 0 n the establishment of diagnostic criteria for brain death and procedures for determining the time of death of a person"

8. List of state and municipal health care institutions and state scientific institutions that have the right to carry out activities related to organ transplantation and other anatomical materials to a person: Resolution of the Cabinet of Ministers of Ukraine from April 24, 2000 № 695. URL: http://zakon.rada.gov.ua/ laws / show / 695-2000-\% D0\% BF.

9. Conditions for ensuring the storage of anatomical materials during their transportation:Order of the Ministry of Health of Ukraine from September 25, 2000 № 226. URL: http://zakon.rada.gov. ua / laws / show / z0703-00.

10. On Funeral and Burial services: Law of Ukraine, from July 10, 2003 No. 1102-IV. Reports of the Verkhovna Rada of Ukraine. 2004. No. 7. Art. 47

\section{Conflict of interest:}

The Author declare no conflict of interest.

\section{CORRESPONDING AUTHOR}

\section{Nadiia Shulzhenko}

The Department of Criminal Law

Yaroslav Mudryi National Law University

Pushkinskaya str., 77, 61024, Kharkiv, Ukraine

tel: +380971805840

e-mail:nevidoma_n@ukr.net

Received: 07.02 .2019

Accepted: 03.04.2019 
PRACA POGLĄDOWA

REVIEW ARTICLE

\title{
ORGANIZATIONAL AND LEGAL DETERMINANTS OF IMPLEMENTING INTERNATIONAL EXPERIENCE IN THE HEALTH CARE SECTOR OF UKRAINE
}

\author{
Vladislav I. Teremetskyi', Serhii V. Knysh' ${ }^{2}$, Vasyl M. Stratonov ${ }^{3}$, Oleksandr M. Khramtsov ${ }^{4}$, Mykola V. Stashchak ${ }^{4}$ \\ 'TERNOPIL NATIONAL ECONOMIC UNIVERSITY, TERNOPIL, UKRAINE \\ 2RIVNE INSTITUTE OF THE KIEV UNIVERSITY OF LAW OF THE NATIONAL ACADEMY OF SCIENCES OF UKRAINE, RIVNE, UKRAINE \\ ${ }^{3}$ KHERSON STATE UNIVERSITY, KHERSON, UKRAINE \\ ${ }^{4}$ KHARKIV NATIONAL UNIVERSITY OF INTERNAL AFFAIRS, KHARKIV, UKRAINE
}

\begin{abstract}
Introduction: The reform of the health care system, which is taking place in Ukraine today, is aimed at increasing the efficiency of providing timely and quality medical care. The aim of the paper is to provide theoretical and practical study of existing models of organizing the health care system in the leading foreign countries, as well as to substantiate the possibility of implementing the most optimal of them in Ukraine.

Materials and methods: The author of the article has used the methods of analysis and synthesis, as well as comparative and legal method. In particular, the author has carried out the analysis of the experience of different countries in organizing the health care system.

Review: The author has studied international experience of legal regulation of the relations in the health care sphere, which use private, state and mixed models of the organization and financing of the health care system.

Conclusions: The author has emphasized on the necessity of using the latest achievements of the leading foreign countries in the sphere of the organization of the health care system and the establishment of additional guarantees for the financially disadvantaged groups of citizens, through the development and financing of social programs for the availability of medical care (based on the model of existing Medicare and Medicade programs in the USA); the application of marginal maximum prices for health services provided by private health care facilities (Japan); introduction of compulsory payment to the insurance fund from the income of legal entities employing hired labor (Germany), etc.
\end{abstract}

KEY WORDS: medical insurance, health care system, model of organizing the health care system, disease prevention, family medicine

Wiad Lek 2019, 72, 4, 711-715

\section{INTRODUCTION}

Each state, which seeks to ensure a high living standard for its citizens, creates legal, organizational, economic and social principles for the functioning of the health care system.

Implementation of the European integration aspirations of Ukraine is impossible without the implementation of the principles existing in the Member States of the European Union (for example, the principles of full coverage of the population by health care, solidarity of financing, availability and high quality of medical care, etc.). For the implementation of these principles and in order to improve the health of the population of Ukraine, we search for an optimal model for the organization of the health care system. At the same time, health care legislation is being improved as the basis for increasing the level of providing medical care and creating conditions for maximum coverage of the population by affordable and quality medical care with minimal financial resources.

\section{THE AIM}

The objective of the paper is to provide theoretical and practical study of existing models of organizing the health care system in the leading foreign countries, as well as to substantiate the possibility of implementing the most optimal of them in Ukraine.

\section{MATERIALS AND METHODS}

The author of the article has used the methods of analysis and synthesis, as well as comparative and legal method. The analysis of the experience of different countries in organizing the health care system contributed to the definition of the issues of this publication, as well as the formulation of the author's vision of the ways to improve legal regulation of the organization of the health care system in Ukraine.

\section{REVIEW}

There are different health care systems, which depending on their organization and financing are divided into private, state 
and mixed (with the use of the mechanism of obligatory and voluntary medical insurance).

In order to determine the optimal model of the organization of the health care system for Ukraine, we will analyze each of them and consider the experience of their implementation in different countries of the world.

Thus, a private model is characterized by: decentralization of financing, extensive infrastructure of insurance companies, the lack of state regulation. When applying this model, medical services are goods that can be freely bought and sold. Financing the expenses for medical care is provided by citizens and partly by legal entities - employers as deductions from their income $[1$, p. 111].

In accordance with the market (private) model of the organization of the health care system, such a system was developed in the United States, which was represented by independent services at three main levels: family medicine, hospital care and public health care.

Family physicians provide services through private practice or are combined with other doctors and provide outpatient and emergency care to patients in hospitals. If necessary, family physicians guide their patients to narrow specialists. The services of family physicians are paid directly by patients. Family medicine in the United States is the primary source of health care. The activities of family physicians are controlled by several independent organizations. These organizations include: the American Academy of Family Physicians (responsible for defining the policy of family practice, has a decisive voice while discussing health care issues at all levels of the executive power, acts as a representative of the interests of family physicians and controls their education); American Committee on Family Practice (responsible for official certification of family physicians); Commission on the verification of the training of interns in the field of family practice at the Accreditation Council of graduates of medical health care institutions (controls the postgraduate education of family medicine specialists) [2, p. 220].

The main sources of financing the American health system are private and non-commercial insurance, which covers about $85 \%$ of the population (about $50 \%$ of them are insured by their employers, $10 \%$ are self-insured, the rest are insured within the framework of state programs) [3, p. 29].

Private health insurance funds in the general budget of the health care system in the United States is 33\%, funds from other private sources $-4 \%$, personal funds of citizens $-21 \%$. We note that there are more than 2,000 health insurance companies in the United States providing hospital and community health care services [1, p. 111].

State programs for supporting socially vulnerable groups play a significant role in providing medical care to the population. The most widespread among them are Medicare and Médicade $[4$, p. 28], which funds constitute respectively for about $10 \%$ and $17 \%$ in the general health care budget of the United States $[1, \mathrm{p} .111]$.

The Medicare state program is designed to provide medical assistance to patients aged from 65 (lawfully residing in the United States for at least 5 years and paid (or their spouses) taxes on Medicare needs for at least 10 years); older persons with disabilities (who receive disability assistance for at least 24 months); patients with chronic renal insufficiency or those who need a kidney transplant; patients with amyotrophic sclerosis and those having the right to social insurance in case of disability [3, p. 29-30].

The Medicare program is targeted at financially disadvantaged groups of citizens, funded jointly by the US government and the States, and its financial fund is formed from a special income tax of legal entities - employers and employee income. The federal government pays approximately half of all program costs at the expense of the general tax; the rest is paid by the State. Each State manages its Medicaid program, but the federal Medicaid Service Center controls this program and sets requirements for services, their quality, funding, and standards. We note that this program is cost-based program for the US government [2, p. 221].

The issue of health insurance in the United States up to 2010 was considered as a private affair of every person. Everything has been changed with the implementation of the medical reform aimed at reducing expenditures on the medical sector from the budget, mandatory provision of all layers of the population by health insurance and increasing state regulation of the health care sphere $[5 ; 6$, p. 5].

Complex reforms at the US health insurance market were to provide financial assistance to financially disadvantaged and average income individuals, who purchased insurance coverage, supporting the States that enlarged insurance coverage and their Medicaid programs for the elderly people with low incomes. At the same time, they improved the mechanism of medical insurance of people who had been already insured before the reform. The result of the reform was the inclusion of the basic set of health care services (care for childbirth, treatment of mental health and health problems due to the use of narcotic substances, services for the prevention of diseases, in particular, female) into the insurance coverage [5].

As a result of the reform, the number of uninsured persons in the United States declined from 49 million in 2010 to 29 million in 2015 [5]. Up to 2017, more than 20 million people had received health insurance through federal health insurance exchanges, the growth rate of health care costs somewhat slowed down, and the quality of insurance was generally improved $[7$, p. 2]. However, the workload of medical employees increased with the adoption of the reform, and insurance companies were forced to increase the value of insurance packages, which included a significant number of services [8, p. 260]. Therefore, about $16 \%$ of US citizens still do not have health insurance. Hence, the US health care system, based on market principles, has no such a property as the availability of medical care for all segments of the population [8, p. 260].

We note that the President $\mathrm{D}$. Trump attempted to abolish the health care reform introduced in 2010. In accordance with the Law on Reduction of Taxes and Jobs, adopted by the Congress and signed by D. Trump in 2019, the penalty for the lack of medical insurance was canceled. This may lead to the increase in the number of uninsured Americans and the growth in expenditures for health care, since uninsured people will address to urgent care rooms for primary care physicians [9]. 
Hence, the US government's health care system is characterized by: the availability of medical programs for financially disadvantaged citizens funded by federal, state budgets, by private individuals and employers; the prevailing financing of medical care by individuals through their contributions to health insurance funds.

However, this system also has such serious disadvantages as the high cost of medical services, which does not ensure the availability of medical care, the imperfection of the mechanisms for using financial resources, the lack of state regulation and control over the quality of medical services. Besides, the private system is characterized by free, unregulated formation of pricing for medical services and significant state expenditures for health care (for example, these costs in the United States are over 16\% of gross domestic product) [1, p. 113].

Consequently, the only way to use the US experience in Ukraine is through the improvement of the legislation on programs for financing medical assistance to financially disadvantaged groups of citizens, by expanding the network of medical institutions, by increasing the level and application of the optimal mechanism of remuneration for medical employees, and by covering the expenditures for disease prevention by the state programs.

The organization of health care system based on compulsory medical insurance of citizens is applied in such states as Germany, France, Austria, Belgium, the Netherlands, Sweden and Japan. Thus, Germany's health insurance system is characterized by high standards of medical care and is considered to be one of the best in the European Union. The model of the health care system existing nowadays in Germany was founded by Otto von Bismarck and was based on the principles of social solidarity, decentralization and self-regulation.

The financing of the health care sector is mainly carried out at the expense of obligatory state health insurance funds. Medical care is available to all people, regardless of their financial situation. Every German citizen must have health insurance. There are two types of health insurance: compulsory and private. The main principle is - the higher the income, the greater the insurance payments. Nowadays about $97 \%$ of German citizens have health insurance [10].

The control over the provision of services in the amount that is guaranteed by health insurance is provided by the sickness funds, which have the powers in the field of financial management transferred by the state authorities.

All sickness funds are non-profit organizations. To cover the expenditures for medical care, they collect contributions from the members, which are levied on wages, pensions, unemployment benefits, etc. Sickness funds have the right to set a deposit rate that is necessary to cover the expenditures. The state does not interfere in the management of sickness funds, but only supervises their activities [11, p. 120].

German model of the health care system is characterized by: the presence of non-governmental insurance companies and companies with legally defined status, regulated by the state; significant increase in demand for medical care and total health care expenditures while introducing insurance policies; the emergence of new purchasers of medical services in the state - insurance companies (funds) and competition between them; the presence of obligatory contributions of employees and employers or special taxes (25-35\% of state funding); conclusion of contracts with health care providers (and not with regional health care authorities) by the companies; payment of medical services by patients not covered by insurance, or part of their value (mean of reducing the demand) [1, p. 111].

The advantages of the German health care system include: compulsory health insurance and state-guaranteed level of health care for everyone; high level of medical care; sufficient amount of health care financing by the state, etc.

However, one of the problems of the German health care system of financing is the increase in the number of unemployed. This leads to the growth in the burden of insurance contributions paid by ablebodied citizens.

In regard to the introduction of insurance medicine in Ukraine, the increase in the tax burden on employers, in today's conditions of economic instability, will lead to negative economic consequences. At the same time, there is an experience in establishing sickness funds in Ukraine, but the insurance mechanism differs from that used in Germany, because insurance is voluntary and the state does not supervise them.

Ukraine has implemented the state (budget) model of financing the health care system, according to the Concept of Health Care Financing Reform, approved by the Cabinet of Ministers of Ukraine on November 30, 2016 No. 1013-p. This model involves financing the health care for all categories of people from the general tax revenues to the state budget. Therefore, we consider the financing and organization of the health care system in those states, where the state takes the main part in this process.

For example, in the United Kingdom, the availability and quality of medical care to the population is organized according to the Beveridge system principles, which was also developed in Greece, Denmark, Ireland, Canada, Norway, Sweden and other countries. Characteristic features of this model are: centralized oriented tax on health care; a significant role of the state in the distribution of medical resources; distribution of state funds between regional and central programs; availability of state standards for medical assistance; partial payment of medical services by patients that are not part of the state guarantees; availability of private insurance companies to insure individual cases of medical care; financing the medical care expenses mainly from expenditures of state or local budgets [1, p. 113].

Since 1948, the National Health Service operates in the UK, covering the entire population of the state, funded by $85-87 \%$ of taxpayers' money and providing free medical services to anyone legally resident in the country. The remaining funds come from private sources and voluntary health insurance sources [12, p. 11].

The health care budget is distributed by the government in accordance with the decisions of the Parliament through the central governing agency - the department of Health and Social Care. General practitioners work on the basis of individual contracts with family health care directorates. Applying for a general practitioner and for a specialist physician is free for a patient; and in the private sector patients pay for services they receive. Patients partially pay for some types of medical services - prescription of a recipe and preventive examination, with the exception of dental care, $80 \%$ of which is paid by a patient $[1, \mathrm{p} .113]$. 
A patient in the UK, like in Ukraine, has the right to freely choose a physician, the principle of "money goes with a patient" has been implemented, and thus, the salary of medical employees takes place according to the number of treated patients. If necessary, a general practitioner sends a patient to the specialists in different areas. Applying for a general practitioner is free.

Secondary medical care, including psychiatric care, is provided by hospitals. Trust hospitals are state-owned and are self-governing organizations subordinated to the Department of Health and Social Care and funded by local health care directorates [13].

Regarding the issues of the quality of providing medical care and patient rights protection there is the Action of Victims of Medical Accidents in the United Kingdom, which made the efforts to adopt the Proceedings Rules on Medical Errors that determine the special procedure for reviewing this category of cases [14, p. 109].

\section{DISCUSSION}

The medical reform was launched in Ukraine from January 1 , 2018. New bills have been developed and amendments made to the current legislation. The main aspect of the reform in the health care sphere has become the normative consolidation of the relations between a physician and a patient through the conclusion of a declaration on the provision of primary health care. The legislator has tried to introduce organizational and legal ways of improving the functioning of medical employees, increasing the efficiency and development of the market for medical services, as well as guaranteeing the protection of patients' rights [15, p. 155].

Ukraine, like in the UK, creates conditions for efficient and accessible medical care for all citizens. In particular, medical assistance within state and communal health care facilities is provided to all citizens, regardless of their volume and without the previous, current or subsequent payment for the provision of such assistance. Besides, the adopted Law of Ukraine "On State Financial Guarantees of Medical Care of the Population" dated from October 19, 2017, No. 2168-VIII, stipulates that citizens receive necessary medical services and medicines of the proper quality at the expense of the State Budget of Ukraine, aimed at the implementation of the program of medical guarantees, from health care providers. However, according to Part 3 of the Art. 4 of the same Law, medical services and medicines not included in the program of medical guarantees are not payable at the expense of the State Budget of Ukraine stipulated for the implementation of the medical guarantees program.

According to the Art. 10 of the above mentioned Law there are uniform tariffs for the whole territory of Ukraine for the provision of medical services, pharmaceuticals and medical products, the size of reimbursement of medicines provided to patients under the program of medical guarantees. Payment according to the tariff is guaranteed to all providers of medical services in accordance with the contracts on medical care of the population concluded with them [16].

However, the partial payment of medical services is established with the adoption of this Law. Therefore, in addition to the indicated tariffs, we should set the marginal maximum prices for health care services provided by private health care institutions. Such tariffs, for example, are regulated at the state level in Japan, so patients do not feel the difference by addressing to a public or private health care institution [17].

Besides, we must provide additional guarantees for financially disadvantaged citizens through the development and funding of social programs for the availability of medical care, based on the model of Medicare and Medicade programs introduced in the United States, taking into account the economic situation in Ukraine. In particular, for the financing of these programs, it is necessary to establish a mandatory payment from the income of legal entities employing hired labor in the number of not less than 100 people or whose total annual income exceeds UAH 5 million (at the end of the reporting period). The indicated changes may be one of the stages of the gradual introduction of the mixed model of financing the health care system in Ukraine and further coverage of health insurance of the entire working population.

It is believed that we should provide the state programs for the prevention of diseases in Ukraine, which would include general education of the population on hygiene and health care, consultations on health issues, compulsory medical examinations and control over certain types of diseases, vaccination, etc. This will reduce the morbidity of the population and reduce the expenditures for health care, while not reducing the quality of medical assistance. An example of the positive introduction of disease prevention programs is Japan, which has become one of the countries with the highest lifetime indicators (86 years for women and 79 for men) [17].

\section{CONCLUSIONS}

On the basis of the conducted research, it has been clarified that the mixed model of organization of the health care system is gradually being introduced in Ukraine, which will allow the state to formally guarantee every citizen the right to free medical care, to introduce additional mechanisms for financing medical care to those, who fully need it, without increasing the expenses from the state budget.

In this context, the experience of Germany is useful at the present time, which proves the expediency of establishing non-governmental insurance funds (like the German sickness funds) that are purchasers of health services from state or private health care institutions, which will increase the level of competition between them, will facilitate more operational provision of medical care, and the increase in the number of private medical institutions.

Taking into account the analysis of the experience of different world countries regarding the legal regulation of the health care system, the main measures for the introduction of an optimal model of the organization of the health care system in Ukraine should be:

1) establishment of additional guarantees for financially disadvantaged citizens through the development and funding the social programs for the availability of health care, in line with the model of Medicare and Medicade;

2) application of the marginal maximum prices for health services provided by private health care institutions; 
3) introduction of a mandatory payment to the insurance fund from the income of legal entities employing hired labor in an amount not less than 100 persons or whose aggregate annual income exceeds UAH 5 million with the gradual expansion of the group of contributors;

4) further coverage of the whole working population with the health insurance;

5) development of state programs for the prevention of diseases, etc.

To basic principles of the health care system, in order to ensure the right to affordable and quality medical care in Ukraine, should be the principles of providing compulsory medical care to all citizens, control by the state over the exercise of this right, protection of citizens, and the possibility of obtaining of both basic and additional health care in private medical institutions.

\section{REFERENCES}

1. Bondareva L. V. Zabezpechennia dostupnoi i yakisnoi medychnoi dopomohy na bazovomu rivni: mekhanizmy derzhavnoho rehuliuvannia [Provision of accessible and high quality medical aid on the basic level: mechanisms of state regulation]. D.Sc (Ph.D.) dissertation. Odessa. 2014: 263 (In Ukrainian).

2. Dichko H. 0. Teoretyko-pravovi zasady medychnoho prava v Ukraini $v$ konteksti pravovoi hlobalizatsii [Theoretical and legal principles of healthcare law in Ukraine in the context of legal globalization]. D.SC (Ph.D.) dissertation. Zaporizhzhia. 2017: 286 (In Ukrainian).

3. Stetsenko V. Yu. Orhanizatsiino-pravove zabezpechennia medychnoho strakhuvannia u SShA [The organizational and legal providing of medical insurance in the USA]. Publichne pravo. 2013. № 4: 28-37. Available from: http://nbuv.gov.ua/UJRN/pp_2013_4_6(In Ukrainian).

4. Ryzhkova Ye. Yu. Pravove rehuliuvannia pryvatnoho sektoru medytsyny vSShA [Legal regulation of the private sector of medicine in the United States]. Naukovyi visnyk Mizhnarodnoho humanitarnoho universytetu. Seriia: Yurysprudentsiia. 2014; Vol.10-1(2):27-31. Available from: http://nbuv.gov.ua/UJRN/Nvmgu_jur_2014_10-1(2)__10 (In Ukrainian).

5. Barack Obama. United States Health Care ReformProgress to Date and Next Steps. JAMA Network. Available from: https://jamanetwork.com/ journals/jama/fullarticle/2533698 (In USA).

6. Korolenko B. B. Reformuvannia systemy okhorony zdorovia v SShA: analiz peredumov, sutnosti reformy ta perspektyv dlia dermatolohichnoi dopomohy [Reforming the healthcare system in the United States: analysis of the preconditions, reform essence and prospects for dermatological care]. Ukrainskyi naukovo-medychnyi molodizhnyi zhurnal. 2013; № 4: 5-8 (In Ukrainian).

7. Berwick D. M. Understanding the American healthcare reform debate. BMJ. 2017 Jun 7;357:j2718. doi: 10.1136/bmj.j2718.

8. Moskalenko V.F., Hruzieva T.S., Haliienko L.I., Inshakova H.V., Hruzieva 0. V. Kompleksna otsinka medyko-demohrafichnoi sytuatsii yak skladova metodolohii rozrobky derzhavnykh tsilovykh prohram v okhoroni zdorovia [Comprehensive Assessment of Medical and Demographic Situation as a Component of the Methodology for Developing State Target-Oriented Health Care Programs]. Skhidnoievropeiskyizhurnal hromadskoho zdorovia. 2012. № 2-3(18-19):258-263 (In Ukrainian).

9. Beyond Obamacare:What's Ahead for U.S. Health Care in 2018. Available from: http://knowledge.wharton.upenn.edu/article/the-future-of-theaca (In USA).
10. Mykhayl Khetsuryany. Medytsynskaia systema v Hermanyy: strakhovka, statsyonar, neotlozhka. Likar.info. (Internet) Latvia. 2017. Available from: http://www.likar.info/coolhealth/article-79491-meditsinskayasistema-v-germanii (In Latvia).

11. Stetsenko V. Pravove zabezpechennia oboviazkovoho medychnoho strakhuvannia v Nimechchyni (kliuchovi zasady ta dosvid dlia Ukrainy) [Legal Guaranteeing of Compulsory Medical Insurance in Germany (Key Principles and Experience for Ukraine)]. Visnyk Akademii upravlinnia MVS. 2010; № 3(15):120-126.

12. Moskalenko V. F. Do pytannia klasyfikatsii system okhorony zdorovia [With question of Health protection system classification]. Skhidnoievropeiskyi zhurnal hromadskoho zdorovia. 2012. № 2-3(1819):10-19 (In Ukrainian).

13. Sistemy zdravookhraneniia: vremia peremen. Soedenennoe Korolevstvo: obzor sistemy zdravookhraneniia [Health Care Systems: period of change. The United Kingdom: Review of Health Care System]. World Health Organization: Regional Office for Europe. 2010;1-5. Available from:http://www.euro.who.int/_data/assets/pdf_file/0011/155558/ E94836sumR.pdf?ua=1 (In Denmark).

14. LashkulZ.V., Sizintsova Yu. Yu., Dichko H. O. Do pytannja pro znachennja ponjattja medychna pomylka [To the definition of "medical error"]. Suchasni medychni tekhnolohii. 2016; № 4 (31): 107-111 (In Ukrainian).

15. Teremetskyi V.I., Muzychuk 0.M., Salmanova 0.Yu., Kyrychenko 0.Yu., Ihonin R.V. Problemni pytannia medychnoho zabezpechennia osib, zasudzhenykh do pozbavlennia voli [Problems of medical protection of persons sentenced to imprisonment]. Wiadomości Lekarskie. 2018; tom LXXI, nr 9: 1777-1780 (In Poland).

16. Pro derzhavni finansovi harantii medychnoho obsluhovuvannia naselennia [On State Financial Guarantees of Public Health Care]: zakon Ukrainy vid 19.10.2017 № 2168-VIII. Available from: https://zakon.rada. gov.ua/laws/show/2168-19 (In Ukrainian).

17. Yurii Matviienko. Systema okhorony zdorovia v Yaponii [The Health Care System in Japan]. Medychnyi svit. Available from: http://msvitu.com/ archive/2013/november/article-10.php (In Ukrainian).

\section{Authors' contributions:}

According to the order of the Authorship.

\section{Conflict of interest:}

The Authors declare no conflict of interest.

\section{CORRESPONDING AUTHOR Vladyslav I. Teremetskyi \\ Ternopil National Economic University \\ 11 Lvivska str., Ternopil, 46009, Ukraine \\ tel: +380677625669 \\ e-mail:vladvokat333@ukr.net}

Received: 04.02.2019

Accepted: 05.04.2019 


\title{
THE ROLE OF INTERLEUKINS AND THEIR INHIBITORS IN THE DEVELOPMENT OF AUTOIMMUNE UVEITIS
}

\author{
Nadiya B. Kuryltsiv, Kateryna M. Halei \\ DANYLO HALYTSKY LVIV NATIONAL MEDICAL UNIVERSITY, OPHTHALMOLOGY DEPARTMENT, LVIV, UKRAINE
}

\begin{abstract}
Introduction: Autoimmune uveitis (AU) is an inflammation of the uvea due to an autoimmune reaction to self-antigens. There are no standardized treatment protocols for AU. A new class of drugs called biologics, that target the various mediators of the inflammation cascade, may potentially provide more effective and less toxic corticosteroids treatment of AU.

The aim: The aim of this review was to make the evaluatation of the interleukins influence on intraocular inflammation in available literature and summarize the expediency of using anti-interleukins agent in case of AU.

Material and methods: This article is a review and summary of the up-to-date results of pivotal experimental and clinical trials targeting the Interleukins (IL), including IL-6, IL-10, IL-17, IL-22, IL-23, and tumor necrosis factor alpha (TNF-a). Also reviews focus on the potential use of anti-interleukin therapy for the treatment of autoimmune diseases (AD). Conclusions: AU is an inflammation of the uvea due to an autoimmune reaction to self-antigens. The most important IL in the pathogenesis of AU are IL-6, IL-10, IL-17, IL-22, IL-23 and TNF-a. Anti-interleukin therapy is partially described. Future randomized controlled trials are urgently needed to be conduct.
\end{abstract}

KEY WORDS: autoimmune uveitis, Interleukins, anti-interleukin therapy, tumor necrosis factor alpha

Wiad Lek 2019, 72, 4, 716-722

\section{INTRODUCTION}

Uveitis is a general term for inflammatory disorders of the uveal tract, the vascular membrane of the eye, and encompasses a wide range of underlying etiologies. In fact, untreated uvea inflammation leads to $5-10 \%$ of visual impairment worldwide and it is one of the main cause of blindness [1-4]. The prevalence and phenotypic expression of various uveitis types depend on age, sex, race, geographic distribution, environmental influence, genetic factors, and social habits $[5,6]$. Since uveitis typically affects the working age group (20-60 years of age), not only may quality of life be severely impacted but there may also be profound socioeconomic consequences for affected patients. [7-10].

Uveitis may be idiopathic, associated with systemic diseases or result from a variety of infectious agents. Until recently, although uveitis was proposed to be frequently an autoimmune disease, repeated attempts to induce experimental uveitis with uveal antigens met with failure [11]. In the latter form, a uveal component, whether tissue damage or a microbial trigger, stimulates the generation of antigen-specific $\mathrm{T}$ cells and/or autoantibodies that are believed to play a pathogenetic role, hence the term autoimmune uveitis (AU) [12]. AU can present as an isolated entity or associated with a systemic autoimmune disorders. Diseases such as rheumatoid arthritis (RA) $[13,14]$, systemic lupus erythematous (SLE) [13], Vogt Koyanagi Harada Syndrome (VKHS) [15] are commonly associated with posterior type of uveitis. On the other hand, anterior uveitis typically appears as the initial manifestation in autoinflammatory diseases such as psoriatic arthritis (PA) [16, 17 ], Behcet's disease (BD) $[18,19,20]$, Juvenile idiopathic arthritis (JIA) [ 13, 21, 22], Crohn's disease (CD) [23], ankylosing spondilitis (AS) $[23,24]$ There is a clear association described with the HLA-B27 positivity and a higher risk of presenting recurrent anterior uveitis in AS [25].

There are no standardized treatment protocols for AU.Topical corticosteroids are the typical first-line agent, although systemic corticosteroids are used in intermediate, posterior intraocular inflamation, and panuveitis. Corticosteroids are not considered to be long-term therapy due to potential ocular and systemic side effects [26-28]. This impact has stimulated the development of more effective treatment strategies for uveitis.

Etiological treatments for autoimmune diseases affecting millions of patients worldwide are still lacking and current available therapies do not control satisfactorily the disease evolution [29]. Current therapeutic strategies for all autoimmune diseases rely on immunosuppressive and/ or symptomatic therapies that preserve only partially the patients' quality of life. Thus, new technological approaches to these disorders should be developed [30].

\section{THE AIM}

The aim of this review was to make the evaluatation of the interleukins influence on intraocular inflammation in 
available literature and summarize the expediency of using anti-interleukins agent in case of autoimmune uveitis.

\section{MATERIALS AND METHODS}

This article is a review and summary of the up-to-date results of pivotal experimental and clinical trials targeting the Interleukins (IL), including IL-6, IL-10, IL-17, IL-22, IL-23, and tumor necrosis factor alpha (TNF- $\alpha$ ). Also reviews focus on the potential use of anti-interleukin therapy for the treatment of autoimmune diseases $(\mathrm{AD})$. An extensive literature research was performed in the Medline database (PubMed) for articles, also some additional references were taken from books written on the subject. Additionally, attention was given to articles referenced in the selected articles.

\section{REVIEW AND DISCUSSION}

Immune-mediated inflammation can be tolerated in many organs, however in the eye it has devastating consequences, as many of the tissues in the visual axis have limited or no capacity for regeneration. Multiple mechanisms and anatomical adaptations limit the expression of immune-mediated inflammation in the eye. Among these is the generation of regulatory $\mathrm{T}$ cells (Tregs), which act to prevent the induction and expression of $\mathrm{T}$ cell inflammation [31]. Tregs formerly known as suppressor T cells, are a subpopulation of $\mathrm{T}$ cells that modulate the immune system, maintain tolerance to self-antigens, and prevent autoimmune disease. Tregs are immunosuppressive and generally suppress or downregulate induction and proliferation of effector T cells. [32]. T cells expressing the surface marker cluster of differentiation 4 (CD4) are known as T helper (Th) cells play important roles in the pathogenesis of autoimmune diseases including uveitis. Th cells can be classified into different functional categories: defined by the transcription factor T-bet and secretion of interferon gamma, were the dominant cell type 'helping' cellular immunity, and Th2 cells, defined by the transcription factor GATA binding protein 3 and secretion of IL -4 and IL-5, were responsible for helping humoral immunity [33].

Cytokines are made by many cell populations, but the predominant producers are Th and macrophages. Cytokines are small secreted proteins released by cells have a specific effect on the interactions and communications between cells. Cytokine is a general name; other names include lymphokine (cytokines made by lymphocytes), monokine (cytokines made by monocytes), chemokine (cytokines with chemotactic activities), and IL (cytokines made by one leukocyte and acting on other leukocytes). There are both pro-inflammatory cytokines and anti-inflammatory cytokines [34].

As a result of the analysis of many literary sources, it is known that the most important IL in the pathogenesis of uveitis are IL-6, IL-10, IL-17, IL-22, IL-23 and TNF- $\alpha$.

IL-6 stimulates the inflammatory and auto-immune processes in many diseases. There is evidence for the im- portant role of IL-6 hyperproduction not only in RA, but also in other immune inflammatory $\mathrm{BD}$, systemic lupus erythematosus, scleroderma systematica, idiopathic inflammatory myopathies, giant cell arteritis, etc.), also in diabetes, atherosclerosis, Alzheimer's disease, multiple myeloma and prostate cancer [35-43]. It is important mediator of AD including AU [44]. The binding of IL-6 to its receptor results in the activation of the mitogen-activated protein kinase pathways, ultimately leading to the expression of inflammatory cytokines, vascular endothelial growth factor and differentiation of naive $\mathrm{CD} 4^{+} \mathrm{T}$ cells into Th17 cells [45].

Some studies in mice with EAU found that inflammation is significantly attenuated in IL- 6 deficient animals and intravitreal anti-IL-6 reduces inflammation [46, 47]. Also, in human's studies, elevated levels of IL-6 have been detected in the aqueous humour of BD, VKHS, sarcoid, idiopathic uveitis, acute retinal necrosis and HLA-B27 mediated uveitis when compared with controls [48-50]. Futhermore, IL- 6 also plays a role in uveitis complications such as neovascularization and macular oedema [51-53].

IL-10, also known as human cytokine synthesis inhibitory factor, and it continues to be one of the more important immunoregulatory cytokines, controlling and moderating inflammatory responses [54]. It is secreted by activated $\mathrm{T}$ cells, macrophages, dendritic cells, natural killer (NK) cells and B-cells [55]. In patients and animals with uveitis, elevated intraocular IL-10 levels have been identified and it has protective roles. [56-58]. Moreover, in animal model with endotoxininduced uveitis protective role of local IL-10 was confirmed $[59,60]$. Correlation between level of IL-10 to level of IL-6 allows to determine the diagnosis (uveitis or intraocular tumor) $[61,62]$.

One of the main subunit of IL-10 is IL-22, that is produced by T cells, Th1 and Th17 cells, NK cells and innate lymphoid cells. IL-22 initiates innate immune responses against bacterial pathogens especially in epithelial cells such as respiratory and gut epithelial cells. Generally, IL-22 may primarily have immune regulatory rather than inflammatory functions in the eye [63]. In experimental model IL-22 developes worse inflammation and led to a reduced severity of uveitis. In humans elevated levels of serum IL-22 have been identified in patients with uveitis in case of $\mathrm{BD}$ and scleritis [64-67]. Some athours review, that IL-22 can contribute to immune disease through the stimulation of inflammatory responses, S100s and defensins. IL-22 also promotes hepatocyte survival in the liver and epithelial cells in the lung and gut similar to IL-10. In some contexts, the pro-inflammatory versus tissue-protective functions of IL-22 are regulated by the often co-expressed cytokine IL-17A $[68,69]$.

IL-17 is part of the IL-17 family of cytokines. IL-17 is secreted by Th17 cells as well as NK cells, gamma delta $\mathrm{T}$ cells and a subset of $\mathrm{CD} 8^{+} \mathrm{T}$ cells called Tc17 cells in response to their stimulation with IL-23 [70].

In experiments on mouse, both Th17 cells and IL-17 appear to have an important role in driving inflammation. In the adoptive transfer model of experimental AU, 
Table I. Spectrum of specific anti-interleukin drugs

\begin{tabular}{|c|c|c|c|}
\hline $\begin{array}{l}\text { Generic Name/ } \\
\text { Brand Name }\end{array}$ & Brand & Target & $\begin{array}{l}\text { Disease area } \\
\text { studied }\end{array}$ \\
\hline Tocilizumab /Actemra, RoActemra & La Roche & $\mathrm{IL}-6$ & $\begin{array}{c}\text { Registration with RA, } \\
\text { Juvenile Rheumatoid Arthritis }\end{array}$ \\
\hline Sirukumab & Centocor & IL - 6 & RA, SLE \\
\hline Sarilumab/ Kevzara & Regeneron and Sanofi & IL -6 & RA, Spondylitis \\
\hline Clazakizumab & Vitaeris & IL - 6 & RA, Spondylitis, \\
\hline Olokizumab & R-Pharm & IL - 6 & RA \\
\hline Secukinumab/ Consentyx & Novartis & $\mathrm{IL}-17$ & $\begin{array}{l}\text { phase III trials for Psoriasis, PA, RA, AS, } \\
\text { a phase II trial for chronic noninfecton uveitis }\end{array}$ \\
\hline Ixekizumab/Taltz & Eli Lilly & $\mathrm{IL}-17$ & $\begin{array}{c}\text { a phase II trial for psoriasis, a phase II trial for } \\
\text { PA, a phase I trial for RA }\end{array}$ \\
\hline Brodalimumab/ Siliq & bausch-health-companies & IL -17 & a phase II trial for psoriasis, (PA), RA, asthma \\
\hline RG4943 & Roche & $\mathrm{IL}-17$ & Psoriasis \\
\hline $\mathrm{NI}-1401$ & Roche's Genentech & IL -17 & Psoriasis \\
\hline SCH900117 & Merck & $\mathrm{IL}-17$ & Psoriasis \\
\hline Ustekinumab/ Stelara & Centocor, Janssen & IL -23 & $\begin{array}{c}\text { Psoriasis, PA, a phase II trial for AS, a phase III } \\
\text { trial for Crohn's disease, sarcoidosis, cirrhosis, } \\
\text { phase II trials for uveitis }\end{array}$ \\
\hline Tildrakizumab/ Ilymya & Sun Pharmaceuticals & IL-23 & Psoriasis \\
\hline Guselkumab/Tremfya & Janssen & IL-23 & Psoriasis, PA, RA \\
\hline Brazikumab & Amgen & IL-23 & Crohn's disease \\
\hline Risankizumab & Abbvie & IL-23 & Psoriasis, Crohn's disease, psoriatic arthritis \\
\hline CNTO 1959 & Johnson\&Johnson & IL -23 & a phase II trial for Psoriasis \\
\hline MK-3222 & Merck & $\mathrm{IL}-23$ & a phase II trial for Psoriasis \\
\hline AMG139 & Amgen/AstraZeneka & $\mathrm{IL}-23$ & Psoriasis, a phase II trial for Crohn's disease \\
\hline Adalimumab/ Humira & Abbvie & TNF & RA, noninfectious uveitis \\
\hline Infliximab/ Remicade & Janssen & TNF & noninfectious uveitis \\
\hline Golimumab/Simponi & Janssen & TNF & $\begin{array}{l}\text { PA, RA, AS, ulcerative colitis, noninfectious } \\
\text { uveitis }\end{array}$ \\
\hline Fezakinumab & Pfizer & IL-22 & $\begin{array}{c}\text { a phase I trial for psoriasis, a phase II trial for } \\
\text { RA, } \\
\text { a phase II trial for atopic dermatitis }\end{array}$ \\
\hline Etanercept/ ENBREL & AMgen & TNF & RA, AS, JIA, PA, chronic uveitis \\
\hline
\end{tabular}

interphotoreceptor retinoid binding protein specific Th 17 cells are sufficient to induce uveitis, and treatment with anti-IL-17 antibody is sufficient to block development of disease [71]. In humans, elevated levels of IL-17 were identified in the eyes of patients with immune-mediated uveitis, VKHS, birdshot chorioretinopathy, as well as in HLA-B27 and Behcet's uveitis [72-75]

IL-23 is a heterodimeric cytokine composed of an IL12B and the IL23A. Prior to the discovery of IL-23, IL-12 had been proposed to represent a key mediator of inflammation in mouse models of inflammation. However, many studies aimed at assessing the role of IL- 12 had blocked the activity of IL-12p40, and were therefore not as specific as thought. Studies which blocked the function of IL-12p35 did not produce the same results as those targeting IL-12p40 as would have been expected if both subunits formed part of IL- 12 only [76, 77]. Inflammatory cells that express the IL-23R include $\mathrm{CD}^{+}$and $\mathrm{CD} 8^{+} \mathrm{T}$ cells, group 3 innate lymphoid cells and invariant NK cell [78]. The results from different studies are varied. One study identified increased IL-23 in vitreous samples from patients with posterior uveitis [79]. Howewer, a results of analysing aqueous sample did not detect elevated IL-23 in patients with VKHS, Behcet's, idiopathic, HLA-B27 or sarcoid uveitis [80]. Single nucleotide polymorphisms in the IL-23R gene have also been associated with an increased risk of inflammatory disease, including ankylosing spondylitis associated uveitis, BD, VKHS, and sarcoid uveitis [81-83].

From literary sources it is known that TNFa is a cell signaling protein (cytokine) involved in systemic inflammation and is one of the cytokines that make up the acute 
phase reaction. It is produced chiefly by activated macrophages, although it can be produced by many other cell types such as $\mathrm{CD} 4^{+}$lymphocytes, NK cells, neutrophils, mast cells, eosinophils, and neurons. A local increase in concentration of TNFa will cause the cardinal signs of Inflammation to occur: heat, swelling, redness, pain and loss of function. Whereas high concentrations of TNFa induce shock-like symptoms, the prolonged exposure to low concentrations of TNFa can result in cachexia, a wasting syndrome. This can be found, for example, in cancer patients. TNFa has both a membrane bound form and a soluble form. TNF Receptor 1 is the main receptor for either form and it is ubiquitously expressed on all cells. Receptor 2 is only expressed on immune cells and only responds to membrane bound TNFa [84-86]. It is interesting fact, that in the experimental autoimmune uveitis model, neutralization of TNF $\alpha$ suppresses disease and mice deficient in TNF Receptor 1 are resistant to the development of uveitis $[87,88]$. Chen et al. showed that in patients with anterior uveitis (HLA-B27, idiopathic uveitis, VKHS and Behcet's uveitis) in aqueous humor elevated TNFa levels has identified [89]. In contrast, in one patients with intermediate uveitis aqueous levels of TNFa were similar to controls; however, serum TNFa was elevated [90].

Over the last two decades, advances in the understanding of the pathogenesis of inflammatory diseases, as well as improved biotechnology, have enabled selective targeting of the chemical mediators of diseases. Recently, a new class of drugs called biologics, that target the various mediators of the inflammation cascade, may potentially provide more effective and less toxic treatment [91]. There are a wide variety of new and emerging biological agents currently being used in the treatment of uveitis which has expanded the therapeutic horizons far beyond previous limitations [92].

A large number of scientific research gives us the opportunity to make quality conclusions about the possibility of using anti-interleukin therapies in some diseases, as evidenced by experimental and clinical studies (table I) The most studied agents among the anti-interleukins in case of autoimmune deseases are Tocilizumab, Sirukumab, Secukinumab, Ixekizumab, Brodalimumab, Ustekinumab, Risankizumab and Fezakinumab. Golimumab, Intliximab, Adalimumab, Ustekinumab, Secukinumab were studied in noninfection uveitis. Etanercept, although paradoxically responsible in very rare cases of the onset of uveitis in patients with inflammatory rheumatic conditions, is still an effective drug for the treatment of inflammatory ocular diseases [93-107].

It is extreamly important to understand the mechanisms underlying the pathogenesis of uveitis for create set-up innovative treatments aimed to reduce inflammation and prevent severe ocular complications, such as glaucoma, keratic precipitates, retinal (macular) oedema and neovascularization. Futhermore prospective randomized controlled trials for biologics are urgently needed to ascertain their actual role in the therapy of uveitis.

\section{CONCLUSIONS}

1. AU is an inflammatory process of the uveal components due to an autoimmune reaction to self-antigens. It can present as an isolated entity or associated with a systemic autoimmune disease. AU may lead to significant visual limitation or total blindness.

2. The most important interleukins in the pathogenesis of AU are IL-6, IL-10, IL-17, IL-22, IL-23 and TNF- $\alpha$.

3. Anti-interleukin therapy is partially described. Golimumab, Intliximab, Adalimumab, Ustekinumab, Secukinumab were studied in noninfection uveitis Just few agents (Golimumab, Intliximab, Adalimumab, Ustekinumab, Secukinumab) are showed positive therapeutic effect on uveitis. Future randomized controlled trials are urgently needed to be conduct to define both benefits and risks of these agents in the treatment of the autoimmune uveitis.

\section{REFERENCES}

1. Gritz D.C, Wong I.G. Incidence and prevalence of uveitis in Northern California; the Northern California Epidemiology of Uveitis Study. Ophthalmology.2004; 111:491-500.

2. Suttorp-Schulten M.S, Rothova A. The possible impact of uveitis in blindness: a literature survey. Br J Ophthalmol.1996; 80(9):844-8.

3. Miserocchi E, Fogliato G, Modorati G, et al. Review on the worldwide epidemiology of uveitis. Eur J Ophthalmol.2013; 23:705-17.

4. Thorne J.E, Suhler E, Skup M, et al. Prevalence of noninfectious uveitis in the United States: a claims-based analysis. JAMA ophthalmology.2016; 134(11):1237-45.

5. De Smet M.D, Taylor S.R, Bodaghi B, et al. Understanding uveitis: the impact of research on visual outcomes. Prog Retin Eye Res.2011; 30:452-70.

6. Tsirouki T, Dastiridou A, Symeonidis C, et al. Focus on the Epidemiology of Uveitis. Ocular Immunology and Inflammation.2016;1-15.

7. Durrani $0 . M$, Tehrani N.N, Marr J.E, et al. Degree, duration, and causes of visual loss in uveitis. Br J Ophthalmol.2004; 88(9):1159-62.

8. Chams H.R, Mohammadi S.F, Ohno S. Epidemiology and prevalence of uveitis: review of literature. Iranian J Ophthalmol.2009; 21:4-16.

9. Hassan A. Al Dhibi, Hanan N. Al Shamsi, Ammar M. Al-Mahmood, et al. Patterns of Uveitis in a Tertiary Care Referral Institute in Saudi Arabia. Ocular Immunology and Inflammation. 2016; 5: 1-8.

10. Miserocchi E, Fogliato G, Modorati G, Bandello F. Review on the worldwide epidemiology of uveitis. Eur J Ophthalmol.2013; 23(5):705-17.

11. Niederkorn J. Y, Kaplan H. J. Immune response and the eye. Karger; Basel. 2007:336 p.

12. Gritz D.C, Wong I.G: Incidence and prevalence of uveitis in Northern California; the Northern California Epidemiology of Uveitis Study. Ophthalmology.2004; 111:491-500.

13. Nussenblatt R, Whitcup $S$. Uveitis: fundamentals and clinical practice. Elsevier; Canada. 2010:263 p.

14. Munoz-Fernandez S, Martin-Mola E. Uveitis. Best Pract Res Clin Rheumatol. 2006; 20: 487-505.

15. Fang W, Yang P. Vogt-koyanagi-harada syndrome. Curr Eye Res.2008; 33:517-23.

16. Durrani K, Foster C.S. Psoriatic uveitis: a distinct clinical entity? Am J Ophthalmol.2005; 139:106-11.

17. Mercy K, Kwasny M, Cordoro KM, et al. Clinical manifestations of pediatric psoriasis: results of a multicenter study in the United States. Pediatr Dermatol.2013; 30:424-8. 
18. Davatchi F, Assaad-Khalil S, Calamia KT, et al. The International Criteria for Behçet's Disease (ICBD): a collaborative study of 27 countries on the sensitivity and specificity of the new criteria. J Eur Acad Dermatol Venereol.2014; 28(3):338-47.

19. Demiroglu H, Dundar S. Effects of age, sex, and initial presentation on the clinical course of Behçet's syndrome. South Med J.1997; 90:567.

20. Germain B.F, Moroney J.D, Guggino G.S, et al. Anterior uveitis in Kawasaki disease. J Pediatr.1980; 97:780-1.

21. Berntson L, Nordal E, Aalto K, et al. HLA-B27 predicts a more chronic disease course in an 8-year followup cohort of patients with juvenile idiopathic arthritis.2013; 40:725-31.

22. Amador-Patarroyo M.J, Rodriguez-Rodriguez A, Montoya-Ortiz G. How does age at onset influence the outcome of autoimmune diseases? Autoimmune Dis.2012; 2012:251-73.

23. Andrade F.A, Foeldvari I, Levy R.A. Diagnostic Criteria in Autoimmune Diseases. NJ: Humana Press.2008;461-5.

24. Sampaio-Barros P.D, Conde R.A, Bonfiglioli R, et al. Characterization and outcome of uveitis in 350 patients with spondyloarthropathies. Rheumatol Int.2006; 26:1143-6.

25. Chang J.H, McCluskey P.J, Wakefield D. Acute anterior uveitis and HLA-B27. Surv Ophthalmol.2005; 50:364-88.

26 Kara C. LaMattina, Debra A. Goldstein Adalimumab for the Treatment of Uveitis. Expert Review of Clinical Immunology.2017; 1:1-23.

27. LeHoang P. The gold standard of noninfectious uveitis: corticosteroids. Dev 0phthalmol.2012; 51:7-28.

28. Gregory 2nd A.C, Kempen J.H, Daniel E, et al. Risk factors for loss of visual acuity among patients with uveitis associated with juvenile idiopathic arthritis: The Systemic Immunosuppressive Therapy for Eye Diseases Study. Ophthalmology.2013; 120(1):186-92.

29. Adorini L. Cytokine-based immunointervention in the treatment of autoimmune diseases. Clin Exp Immunol.2003; 132:185-92.

30. Prud'homme G.J. Gene Therapy of Autoimmune Disease. Plenum Publishers Eurekah.com and Kluwer Academic; USA.2005:140 p.

31. Greiner K, Amer R. The role of cytokines for the diagnosis of uveitis. Klin Monbl Augenheilkd.2008; 225:564-569.

32. Bettelli E, Carrier Y, Gao W, et al. Reciprocal developmental pathways for the generation of pathogenic effector TH17 and regulatory T cells. Nature.2006; 441(7090):235-8.

33. Mosmann T.R, Coffman R.L. TH1 and TH2 cells: different patterns of lymphokine secretion lead to different functional properties. Annu Rev Immunol.1989; 7:145-73.

34. Jun-Ming Zhang, Jianxiong An. Cytokines, Inflammation and Pain. Int Anesthesiol Clin.2007; 45(2):27-37.

35. Nasonov YEL. Farmakoterapiya revmatoidnogo artrita-vzglyad v 21 vek. Klinicheskaya meditsina. [Pharmacotherapy for rheumatoid arthritis a look into the 21st century] 2005;6:8-12.

36. Kristiansen 0.P, Mandrup-Poulsen T. Interleukin- 6 and diabetes: the good, the bad, or the indifferent? Diabetes.2005; 114-24.

37. Dubinski A, Zdrojewicz Z. The role of interleukin-6 in development and progression of atherosclerosis. Polski Merkuriusz Lekarski (in Polish).2007; 22(130):291-4.

38. Dowlati Y, Herrmann N, SwardfagerW, et al. «A meta-analysis of cytokines in major depression». Biological Psychiatry.2010; 67(5):446-57.

39. Swardfager W, Lanctot $K$, Rothenburg $L$, et al. A meta-analysis of cytokines in Alzheimer's disease. Biological Psychiatry.2010; 68(10):930-41.

40. Tackey E, Lipsky P.E, Illei G.G (2004). Rationale for interleukin-6 blockade in systemic lupus erythematosus. Lupus.2004; 13(5):339-43.
41. Gado K, Domjan G, Hegyesi H, Falus A. Role of Interleukin- 6 in the pathogenesis of multiple myeloma. Cell Biology International.2000; 24(4):195-209.

42. Smith P.C, Hobisch A, Lin D.L, et al. Interleukin-6 and prostate cancer progression. Cytokine \& Growth Factor Reviews.2001; 12(1):33-40.

43. Hirohata S, Kikuchi H. Changes in biomarkers focused on differences in disease course or treatment in patients with neuro-Behçet's disease. Internal Medicine.2012; 51(24):3359-65.

44. Lin P. Targeting interleukin-6 for noninfectious uveitis. Clin Ophthalmol.2015; 9:1697-702.

45. Tanaka T, Narazaki M, Kishimoto T. IL-6 in inflammation, immunity, and disease. Cold Spring Harb Perspect Biol.2014; 6:286-95.

46. Yoshimura T, Sonoda K.H, Ohguro N, et al. Involvement of Th17 cells and the effect of anti-IL-6 therapy in autoimmune uveitis. Rheumatology.2009; 48:347-54.

47. Tode J, RichertE, Koinzer S, et al. Intravitreal injection of anti-interleukin (IL)-6 antibody attenuates experimental autoimmune uveitis in mice. Cytokine.2017; 96:8-15.

48. Abu El-Asrar A.M, Berghmans N, Al-Obeidan S.A, et al. The cytokine interleukin- 6 and the chemokines $C \mathrm{CL} 20$ and $C X C L 13$ are novel biomarkers of specific endogenous uveitic entities. Invest Ophthalmol Vis Sci.2016; 57:4606-13.

49. Chen W, Zhao B, Jiang $R$, et al. Cytokine expression profile in aqueous humor and sera of patients with acute anterior uveitis. Curr Mol Med.2015; 15:543-9.

50. De Visser L, H de Boer J, T Rijkers G, et al. Cytokines and chemokines involved in acute retinal necrosis. Invest Ophthalmol Vis Sci.2017; 58:2139-51.

51. Mansour A.M, Arevalo J.F, Ziemssen F, et al. Long-term visual outcomes of intravitreal bevacizumab in inflammatory ocular neovascularization. Am J Ophthalmol. 2009; 148:310-16.

52. Weiss K, Steinbrugger I, Weger M, et al. Intravitreal VEGF levels in uveitis patients and treatment of uveitic macular oedema with intravitreal bevacizumab. Eye.2009; 23:1812-8.

53. Valentincic N.V, de Groot-Mijnes J.D, Kraut A, et al. Intraocular and serum cytokine profiles in patients with intermediate uveitis. Mol Vis.2011; 17:2003-10.

54. Saraiva M, O'Garra A. The regulation of IL-10 production by immune cells. Nature Reviews. Immunology.2010; 10(3):170-81.

55. Verma R, Balakrishnan L, Sharma K, et al. A network map of Interleukin-10 signaling pathway. J Cell Commun Signal 2016; 10:61-7.

56. Foxman E.F, Zhang M, Hurst SD, et al. Inflammatory mediators in uveitis: differential induction of cytokines and chemokines in Th1- versus Th2mediated ocular inflammation. J Immunol.2002; 168:2483-92.

57. Sauer A, Villard 0, Creuzot-Garcher C, et al. Intraocular levels of interleukin 17A (IL-17A) and IL-10 as respective determinant markers of toxoplasmosis and viral uveitis. Clin Vaccine Immunol.2015;22:72-8.

58. Beebe A.M, Cua D.J, de Waal Malefyt R. The role of interleukin-10 in autoimmune disease: systemic lupus erythematosus (SLE) and multiple sclerosis (MS).Cytokine \& Growth Factor Reviews. 2003;13(4-5):403-12.

59. Broderick C.A, Smith A.J, Balaggan K.S, et al. Local administration of an adeno-associated viral vector expressing IL-10 reduces monocyte infiltration and subsequent photoreceptor damage during experimental autoimmune uveitis. Mol Ther. 2005; 12:369-73.

60. Agarwal R.K, Horai R, Viley A.M, et al. Abrogation of antiretinal autoimmunity in IL-10 transgenic mice due to reduced T cell priming and inhibition of disease effector mechanisms. J Immunol. 2008; 180:5423-9. 
61. Pochat-Cotilloux C, Bienvenu J, Nguyen A.M, et al. Use of a threshold of interleukin-10 and IL-10/LL-6 ratio in ocular samples for the screening of vitreoretinal lymphoma. Retina. 2018, 38(4):773-81.

62. Kuo D.E, Wei M.M, Armbrust K.R, et al. Gradient boosted decision tree classification of endophthalmitis versus uveitis and lymphoma from aqueous and vitreous IL-6 and IL-10 levels. J Ocul Pharmacol Ther.2017; 33:319-24.

63. Nikoopour E, Bellemore SM, Singh B. IL-22, cell regeneration and autoimmunity. Cytokine.2015; 74(1):35-42.

64. Caspi R.R, Mattapallil M.J, Rigden R, et al. Neuroprotective effects of IL-22 during CNS inflammation (CCR4P.203). J Immunol.2015; 175(2):268-84.

65. Sugita S, Kawazoe Y, Imai A, et al. Role of IL-22- and TNF-alphaproducing Th22 cells in uveitis patients with Behcet's disease. J Immunol.2013; 190:5799-808.

66. Kim Y, Kim T.W, Park Y.S, et al. The role of interleukin-22 and its receptor in the development and pathogenesis of experimental autoimmune uveitis. PLoS One. 2016; 11:154-64.

67. Sainz-de-la-Maza M, Molins B, Mesquida M, et al. Interleukin-22 serum levels are elevated in active scleritis. Acta 0phthalmol.2016;94:395-99.

68. Moore K.W, deWaal MalefytR, Coffman R.L, O'GarraA. Interleukin-10 and the interleukin-10 receptor. Annual Review of Immunology. 2001; 19:683-765.

69. Sonnenberg G.F, Nair M.G, Kirn T.J, et al. Pathological versus protective functions of IL-22 in airway inflammation are regulated by IL-17A. The Journal of Experimental Medicine.2010; 207(6): 1293-305.

70. Song X, Qian Y. The activation and regulation of IL-17 receptor mediated signaling. Cytokine. 2013; 62:175-82.

71. Zhang R, Qian J, Guo J, et al. Suppression of experimental autoimmune uveoretinitis by anti-IL-17 antibody. Curr Eye Res.2009; 34:297-303.

72. Kuiper J.J, Mutis T, de Jager W, et al. Intraocular interleukin-17 and proinflammatory cytokines in HLA-A29-associated birdshot chorioretinopathy. Am J Ophthalmol.2011; 152:177-82.

73. El-Asrar AM, Struyf S, Kangave D, et al. Cytokine profiles in aqueous humor of patients with different clinical entities of endogenous uveitis. Clin Immunol.2011; 139:177-84.

74. Jawad S, Liu B, Agron E, et al. Elevated serum levels of interleukin-17A in uveitis patients. Ocul Immunol Inflamm.2013; 21:434-9.

75. Na S.Y, Park M.J, Park S, Lee E.S. Up-regulation of Th17 and related cytokines in Behcet's disease corresponding to disease activity. Clin Exp Rheumatol.2013; 31:32-40.

76. Leonard J.P, Waldburger K.E, Goldman S.J. Prevention of experimental autoimmune encephalomyelitis by antibodies against interleukin 12 . Journal of Experimental Medicine.1995; 181(1):381-6.

77. Becher B, Durell B.G, Noelle R.J. Experimental autoimmune encephalitis and inflammation in the absence of interleukin-12. Journal of Clinical Investigation.2002;110(4):493-7.

78. Kastelein R.A, Hunter C.A, Cua D.J. Discovery and biology of IL-23 and IL-27: related but functionally distinct regulators of inflammation. Annu Rev Immunol.2007; 25:221-42.

79. Velez G, Roybal C.N, Colgan D, et al. Precision medicine: personalized proteomics for the diagnosis and treatment of idiopathic inflammatory disease. JAMA Ophthalmol.2016; 134:444-8

80. Abu El-Asrar A.M, Berghmans N, Al-Obeidan S.A, et al. The cytokine interleukin- 6 and the chemokines CCL20 and CXCL13 are novel biomarkers of specific endogenous uveitic entities. Invest Ophthalmol Vis Sci.2016; 57:4606-13.

81. Dong H, Li Q, Zhang Y, et al. IL23R gene confers susceptibility to ankylosing spondylitis concomitant with uveitis in a Han Chinese population. PLoS One.2013; 8:55-67.
82. Hou S, Kijlstra A, Yang P. Molecular genetic advances in uveitis. Prog Mol Biol Transl Sci.2015; 134:283-98.

83. Kim S.W, Kim E.S, Moon C.M, et al. Genetic polymorphisms of IL-23R and IL-17A and novel insights into their associations with inflammatory bowe disease. Gut.2011; 60:1527-36.

84. Locksley R.M, Killeen N, Lenardo M.J. The TNF and TNF receptor superfamilies: integrating mammalian biolog. Cell.2001; 104(4):487-501.

85. Horiuchi T, Mitoma H, Harashima S, et al. Transmembrane TNFalpha: structure, function and interaction with anti-TNF agents. Rheumatology.2010; 49:1215-28.

86. Dowlati Y, Herrmann N, Swardfager W. A meta-analysis of cytokines in major depression». Biol Psychiatry.2010; 67 (5): 446-57.

87. Dick A.D, Duncan L, Hale G, et al. Neutralizing TNF-alpha activity modulates $T$-cell phenotype and function in experimental autoimmune uveoretinitis. J Autoimmun. 1998; 11:255-264.

88. Raveney B.J, Copland D.A, Dick A.D, Nicholson L.B. TNFR1-dependent regulation of myeloid cell function in experimental autoimmune uveoretinitis. J Immunol.2009; 183:2321-9.

89. Chen W, Zhao B, Jiang $R$, et al. Cytokine expression profile in aqueous humor and sera of patients with acute anterior uveitis. Curr Mol Med.2015; 15:543-9.

90. Valentincic N.V, de Groot-Mijnes J.D, Kraut A, et al. Intraocular and serum cytokine profiles in patients with intermediate uveitis. Mol Vis.2011; 17:2003-10.

91. Servat J.J, Mears K.A, Black E.H, Huang J.J. Biological agents for the treatment of uveitis. Expert Opin Biol Ther.2012; 12(3):311-28.

92. Simon R Taylor. Biologic Therapy in Uveitis. European Ophthalmic Review.2016; 10(1):17-8.

93. Calabrese L.H, Rose-John S. IL-6 biology: implications for clinical targeting in rheumatic disease. Nat Rev Rheumatol.2014; 10(12): 720-7.

94. Sheppard M, Laskou F, Stapleton P.P, Hadavi S. Tocilizumab (Actemra). Hum Vaccin Immunother.2017; 13(9):1972-88.

95. Dalen C.I, Duny Y, Barnetche T, et al. Effect of TNF inhibitors on lipid profile in rheumatoid arthritis: a systematic review with meta-analysis. Ann Rheum Dis.2012; 71:862-8.

96. Paroli M.P, Abbouda A, Abicca I, Sapia A. Biological agents in the treatment of uveitis. Advances in Bioscience and Biotechnology.2013; 4: 64-72.

97. Aikawa E, de Carvalho N, Silva A.A, Bonfa C. Immunogenicity of AntiTNF- alpha agents in autoimmune diseases. Clinical Reviews in Allergy \& Immunology.2010; 38:82-9.

98. Aaltonen, K.J.,Virkki, L.M., Malmivaara, A., et al. Systematic review and meta-analysis of the efficacy and safety of existing TNF blocking agents in treatment of rheumatoid arthritis. PLoS One.2012; 7(1):194-56.

99. Evereklioglu C. Ocular Behcet disease: current therapeutic approaches. Current Opinion in Ophthalmol.2011; 22:508-16.

100. Rudwaleit M, Rodevand E, HolckP, et al. Adalimumab effectively reduces the rate of anterior uveitis flares in patients with active ankylosing spondylitis: Results of a prospective open-label study. Annals of the Rheumatic Diseases.2009; 68:696-701.

101. Schmeling H, Horneff G. Etanercept and uveitis in patients with juvenile idiopathic arthritis. Rheumatology.2005; 44:1008-11.

102. Tappeiner C, Heinz C, Ganser G, Heiligenhaus A. Is tocilizumab an effective option for treatment of refractory uveitis associated with juvenile idiopathic ar- thritis? The Journal of Rheumatology.2012; 39:1294-5.

103. William M, Faez S, Papaliodis G.N, Lobo A.M. Golimumab for the treatment of refractory juve-nile idiopathic arthritis-associated uveitis. Journal of Ophthalmic Inflammation and Infection.2012; 2:231-3. 
104. Langley R.G, Elewski B.E, Lebwohl M, et al. Secukinumab in plaque psoriasis - results of two phase 3 trials. N Engl J Med.2014; 371:326.

105. Lebwohl M, Strober B, Menter A, et al. Phase 3 studies comparing brodalumab with ustekinumab in psoriasis. N Engl J Med.2015; 373:1318-28.

106. Papp K.A, Blauvelt $A$, Bukhalo $M$, et al. Risankizumab versus ustekinumab for moderate-to-severe plaque psoriasis. N Engl J Med.2017; 376:1551-60.

107. Blauvelt A, Papp K.A, Griffiths C.E, et al. Efficacy and safety of guselkumab, an anti-interleukin-23 monoclonal antibody, compared with adalimumab for the continuous treatment of patients with moderate to severe psoriasis: results from the phase III, double-blinded, placebo- and active comparator-controlled VOYAGE 1 trial. J Am Acad Dermatol.2017; 76:405-417.

\section{Authors' contributions:}

According to the order of the Authorship.

\section{Conflict of interest:}

The Authors declare no conflict of interest.

\section{CORRESPONDING AUTHOR}

\section{Nadiya B. Kuryltsiv}

69 Pekarska str, Lviv, Ukraine

+380677506886

kuryltsivnb@gmail.com

Received: 15.02.2019

Accepted: 01.04.2019 
OPIS PRZYPADKU

CASE REPORT

\title{
CHURG-STRAUSS SYNDROME: CLINICAL CASE AND ITS FEAUTURES
}

\author{
Ivan P. Katerenchuk, Lidiya A. Tkachenko, Tetyana I. Yarmola, Viktoriya V. Talash, Savetik T. Rustamyan, \\ Anna L. Pustovoyt, Oleksandr I. Katerenchuk \\ UKRAINIAN MEDICAL STOMATOLOGICAL ACADEMY, POLTAVA, UKRAINE
}

\begin{abstract}
Introduction: The article describes the clinical case devoted to the features of the clinical course of Churg-Strauss syndrome (eosinophilic granulomatous with systemic necrotizing vasculitis). Churg-Strauss syndrome is a disease that is rarely diagnosed because of presenting by high-variability clinical syndromes, that causes difficulties in diagnostic process, especially on the first visit of patient to the general practioner.

The aim of the article is to show the clinical course feautures of the Churg-Strauss syndrome in the time of disease progression, as well as pecullarities and possibilities of in-time diagnosis of this disease.

Clinical case: It was described a clinical case of Churg-Strauss syndrome in a 46-year-old woman, presenting with successively appeared signs of the disease that resulted in some difficulties of making in-time diagnosis.

Conclusions: As Churg-Strauss syndrome is a low-spread disease presenting with high-variety of clinical signs and despite of the presence of clear diagnostic criterias Churg-Stross syndrome was diagnosed with delay in this clinical setting. General practitioner should remember that if the disease debuts by the signs of pneumonia with further appearance of signs of bronchial obstruction and eosinophilia, its necessary to perform diagnostic approaches with the aim to carry out the presence of the Churg-Strauss syndrome.
\end{abstract}

KEY WORDS: Churg-Strauss syndrome, diagnostic, treatment

Wiad Lek 2019, 72, 4, 723-726

\section{INTRODUCTION}

Nowadays, Churg-Strauss syndrome is considered as an inflammatory-allergic lesion of small and medium vessels (capillaries, venules, arterioles), which leads to the formation of necrotizing granules. It has typical clinical manifestations in the form of bronchial asthma, eosinophilia and pulmonary infiltrates [1].

It should be noted that there are some difficulties in diagnosing this pathology in our time. There are both clinical situations as with hyperdiagnosis as with the presence of a long-lasting course of the disease, when for some reasons this syndrome remains not diagnosed in time $[2,3]$.

Correct and in-time diagnosis of this disease is critically important to initiating and providing appropriate treatment. So it's necessary for practicing doctors to have relevant knowledges about Churg-Strauss syndrome and also to have some kind of alertness about the possibility of this disease.

From our point of view, described clinical case should be interesting and usefull, first of all, for general practitioners, as they predominantly have the first contact with patients suffering on Churg-Strauss syndrome. So, they should provide correct diagnostic approaches in a timely manner and forward patients to the next stage of medical care.

\section{THE AIM}

To describe the clinical case of Churg-Strauss syndrome, marking its clinical features, and emphasizing the attention of general practitioners to the possibility of early and timely diagnosis of this syndrome that is necessary for initiation of specific therapy.

\section{CLINICAL CASE}

Patient T., female, 1963 year of birth, having III-rd group of invalidity, considered herself as being ill since 2006 year when some complaints occurred for the first time. Patient suffered on dry cough, breathlessness during rigorous physical activity, elevated body temperature more than 37.5 C, general weakness, increased sweating, asthmatic attacks for up to 2 times / day (treated by taking 1 tablet of theofilline), pain-feeling in large joints, that increased during physical exertions.

After a first physical examination performed on out-ofpatient settings, it was diagnosed «Untreated pneumonia», but later diagnosis was changed to "Chronic obstructive pulmonary disease witn concomitant arthrosis, osteoarthritis and gonarthrosis". But as patient began to suffer on progressive shortness of breathing, predominantly in the morning hours, pulmonologist, changed the diagnosis to the «First occured bronchial asthma». 
On $12^{\text {th }}$ October 2016, chest MRI was performed. It showed slightly expressed fibrous lesions in the paramediastinal divisions of S5 of both lungs, solid calcifications at the level of S6 of the right lung and at the S9 of the left lung. Changes in pulmonary tissue were considered as the consequences of chronic bronchitis. Lipomas of the anterior cardio-diaphragmatic angles and atherosclerotic aortic cardiosclerosis were also found.

As the disease had progressive course a repeated review by the doctor-pulmonologist was performed on 24.10.2016. Diagnosis of «Bronchial asthma of moderate severity, mixed chronicall form with controlled course» was established. So, patient was referred to specialized pulmonological department of the regional hospital on 24.11.2016. There was established diagnosis of «Persistent form of bronchial asthma of moderate severity with partially controlled course. Pneumosclerosis. Gastroesophageal reflux disease. Erosive gastropathy. Reflux-esophagitis. Chronic hepatitis, persistent form, exacerbation phase. Primary osteoarthritis, polyostearthritis with lesions of the lower leg, shoulder and knee joints».

From 10.122016 to 20.12.2016, patient received treatment at the district hospital having the diagnosis of «Left-sided pneumonia». During this hospitalization it was found an increase in the number of eosinophils in blood sample up to $64 \%$ and increased ESR $35 \mathrm{~mm} / \mathrm{h}$. So, patient was referred to the hematologist for diagnosis clarification.

At that time several laboratory and instrumental diagnostic investigations were performed. Blood sample (22.12.2016): leukocytes - 29.6 $10^{9} / 1$, eosinophilic cells - 54\%, ESR-45 mm/h. Myelogram (22.12.2016) showed increased eosinophilic granulocytes presence up to $63 \%$. On ultrasound examination it was detected enlargement of the liver $(16.7 \times 3.4 \mathrm{~cm})$. Chest X-ray investigation (22.12.2016) showed the signs of chronic bronchitis and pneumosclerosis. Endoscopia of the stomach estimated erythematous gastropathy and gastro-esophageal reflux with $\mathrm{pH}$ 1.0.

On 12.22.2016 hematologist established the diagnosis of «Leukemoid reaction of eosinophilic type».

The patient's condition had no signs of improvement by the time goes. As progressiuon of arthritis syndrome occurred, patient was hospitalized to the rheumatologic department. Patient stayed there for more than 20 days, from 27.12.2016 till 18.01.2017. On 12.28.2016 MRI of the neck, thoracic cavity, abdominal cavity, retroperitoneal space, with contrast enhancement was performed. It found clinically significant enlargement of liver and spleen, pathological lesions in the spleen (one them with signs of calcification) and several liver cysts, But enlargment of lymphatic nodes within the scaned zones (neck, chest, abdomen) was not present.

On 12.30.2016 MRI of the brain was performed. It concluded the absence of signs of oncological, inflammatory and demyelinating processes of the brain. Cysts of the left maxillary sinus were found. Also MRI showed slightly expressed osteochondrosis, straightening of the cervical lordosis and right vertebral artery hypoplasia.
On 12.30.2016 MRI of the lumbar-sacral zone was performed. It was found the signs of diffuse explosions of intravertebral discs in segments L3-L4, L4-L5, L5-S1, numerous hemangiomas of the vertebras, osteochondrosis in the lumbar zone, deforming spondylosis and spondyloarthrosis.

On 30.12.2016 ultrasound examination was performed. Hepatomegaly splenomegaly, chronic cholecystitis and cysts of the spleen were detected

On 25.01.2017 patient was examined by hematologist. Leukemoid reaction of eosinophilic type was diagnosed. In blood cells analysis performed on 26.01.2017 number of eosiniphilic cells was $9 \%$.

After this examinations it was diagnosed «Deforming osteoarthrosis with lesions of the left knee and left shoulder joints. Endoprosthesis of the right knee joint (2014). Leukemoid reaction of eosinophilic type. Gastroesophageal reflux disease with esophagitis. Chronic gastroduodenitis with increased acid-secretion function of the stomach. Fatty liver dystrophy. Non-alcoholic steatohepatitis of moderate activity. Chronic cholecystitis on stage of unstable remission. Osteochondrosis. Primary hypothyroidism, first detected. Secondary iron deficiency anemia of mild degree. Eosinophilia (28.12.2016 - eosinophilic cells - 72\%, ESR 33 $\mathrm{mm} / \mathrm{h}, 10.01 .2017$ - eosinophilic cells - 9\%, ESR $24 \mathrm{~mm} / \mathrm{h}$ ).

At the same time the presence of Churg-Strauss syndrome was considered. So, patient was referred for an expert consultation to the National Scientific Centre «Institute Of The Cardiology named after M.D. Strazhesko». On 3 February 2017, after provided consultation by experts diagnosis was changed to «Systemic granulomatous vasculitis of Charg-Strauss, chronic disease course, II level of disease activity with lesions of the lungs vessels (a syndrome of bronchial asthma, with frequent attacks of suffocation (October-December 2016), allergic rhinitis, polyarthritis, blood eosinophilia (up to $72 \%$ in December 2016).

The prescribed treatment included $12 \mathrm{mg}$ of Medrol per day for duration of 1.5 months with further reduction of dose on $1 \mathrm{mg}$ every 2 weeks to the daily dose of $8 \mathrm{mg}$ / day.

In 2017 the patient was examined and treated twice in the rheumatologic department of the regional hospital, and quarterly consulted at the National Scientific Centre «Institute Of The Cardiology named after M.D. Strazhesko». Due to continuous observation and obtained results of repeated diagnostic investigations it was diagnosed «Systemic granulomatous vasculitis of Churg-Strauss, chronic course, activity II, with lesions of the lungs' vessels (a syndrome of bronchial asthma, with frequent attacks of breathlessness (October-December 2016), allergic rhinitis, cardiac arrhythmia (myocardiofibrosis, insufficiency of the tricuspid valve of II degree, pulmonary hypertension of the II degree, chronic heart failure). Polyarthritis. Arthralgia associated with polyostearthritis and spondylarthritis with secondary radicular syndrome, left gonarthrosis. left metatarsophalangeal arthritis with recurrent synovitis. Right knee arthroplasty (2011). Hypereosinophilia (up to $72 \%$ - December 2016). Subclinical hypothyroidism, moderate severity, stage of unstable sub- 
compensation. Discirculatory encephalopathy, II degree, with bilateral reflex-pyramidal insufficiency, vestibular dysfunction, persistent asthenoneurotic syndrome. Osteochondrosis with more predominant lesions in lumbar and sacral zones, deformating spondylosis, protrusions of L3-S1.

Patient received treatment with regularly titrated doses of Medrol.

During the first months of 2018, signs of the involvement of the kidneys to the pathological process have occurred and were associated with clinically significant progression of disease. Patient suffered on the pain in the lumbar region, frequent urination, puffiness of the face in the morning hours. It was found progressively increasing levels of protein in the urine samples (up to daily proteinuria - 0.450 g). At the same time blood pressure increased to $190 / 100$ $\mathrm{mmHg}$. Due to this findings it was concerned that patient had secondary nephropathy as a manifestation of kidney damage secondary to Churg-Strauss syndrome.

\section{DISCUSSION}

The Churg-Strauss syndrome was first described in 1951 as a triad of symptoms, which included hypereosynophilia, asthma and vasculitis, with asthma being the most typicall sign of this syndrome.

The first descriptions by Churg and Strauss distinguished the high spectrum of clinical and pathological signs. Nowadays, it is concerned that the definition of this disease is too narrow, so, resulting in dramatically limitation of diagnostic capabilities $[4,5]$.

In recent years the diagnostic criteria for Churg-Strauss syndrome were established. They include the presence of the following signs - asthma, the presence of more than 10\% of eosinophils in the blood sample, mono- or polyneuropathy due to systemic vasculitis, infiltration of the pulmonary tissue, anomalies of the nasal sinuses, extravascular eosinophils accumulation evaluated in samples obtained by tissue biopsy. By performing histological analysis it is usually observed necrotizing vasculitis of small vessels with inflammatory infiltration by eosinophils accompanied with necrotizing granulomas.

Anti-neurotrophic cytoplasmic antibodies (ANCA) can be detected in $40 \%$ of patients with Churg-Strauss syndrome. So, we can suggest the existence of 2 types of Charge-Strauss syndrome: ANCA-positive and ANCA-negative. ANCA-positive patients usually have renal impairment, neuropathy, alveolar hemorrhage and purulent vasculitis. ANCA-negative patients have predominantly lesions of heart and lungs. However, these two types are impossible to differentiate in many cases. Also, there is no evidence that these two types may have a different prognosis. Cerebrovascular complications (chronic brain ischemia and stroke) are on the first place among the other causes of death in patients suffering on Churg-Strauss syndrome [6,7]. Non-specific signs may also include such manifestations as fever, general feeling of weakness and fatigue, loss of appetite, weight loss and muscle pain. Peripheral nerves, kidneys and gastrointestinal tract may be also affected.

The average age of the disease debut is $38-49$ years of old [8].

It is important to notice that clinical symptoms are so non-specific in some clinical cases that simulate other pathological conditions and diseases..

Clinical course of Churg-Strauss syndrome is divided on three consecutive stages - prodromal stage, eosinophilic stage and vasculitis.

The prodromal stage, lasting from 6 months to two decades, may precede the development of the vasculitis and is characterized by a variety of allergic manifestations. Usually patients have signs of asthma with frequent cough, dry wheezing and shortness of breath (as described in this clinical case).

The eosinophilic phase is characterized by the accumulation of eosinophils in various tissues of the body as the consequence of continuous hypersynthesis of eosinophils with their infiltration of different tissues (predominantly, the lungs, the gastrointestinal tract, and the skin).

The third phase is vasculitis, that manifests as inflammation of various blood vessels and leads to the occurrence of cardiovascular disorders and to the development of aneurysms. So, the risk of bleeding is high.

In this clinical case, vasculitis manifested as involvement of renal vascular system (glomerulus) that resulted in secondary nephropathy with malignant arterial hypertension syndrome.

At the same time, we are sure that timely prescribed therapy prevented the development of severe complications of the Churg-Strauss syndrome and normalized the number of eosinophils in the blood.

Primary prevention for this disease is not established yet. Secondary prophylaxis consists of providng adequate supportive therapy and long-term observation $[9,10]$.

\section{CONCLUSIONS}

Due to the low-prevalence of this disease in general population and due to the variety of clinical signs, even despite the existence of clear diagnostic criteria, the true diagnosis for this patient was established with significant delay. General practitioner should be aware that if disease is beginning like pneumonia with symptoms of bronchial obstruction and hypereosinophilia, it's important to provide diagnostic examinations to carry out the presence of Churg-Strauss syndrome.

\section{REFERENCES}

1. Katerechuk I.P., Tkachenko L.A., Yarmola T.I. Urazhennia nyrok pry revmatychnykh zakhvoriuvanniakh. K. Medknyha.2017.s.72-77.

2. Adasheva T.V., Nesterenko 0.I.,Zadionchenko V.S. idr. Klinicheskiy sluchay sindroma Chardzha-Stross: trudnosti diagnostiki, terapevticheskaya taktika. Arhiv vnutrenney meditsinyi.2016; 5: 63-69.

3. Vaglio A., Busio C., Zwerina J. Eosinophilic granulomatosis with polyangiitis (Churg-Strauss): state of the art. Allergy. 2013:68;261-273. 
4. Churg J., Strauss L. Allergic granulomatosis, allergic angiitis, and periartritis nodosa. Am. J. Patol. 1951:27;277-301.

5. Churg A. Recent advances in the diagnosis of Churg-Strauss syndrome. Mod.Patol.2001:14;1284-1293.

6. Haubitz V. ANCA-associated vasculitis: diagnosis, clinical characteristics and treatment. Vasa.2007:36;81-89.

7. Keogh K.A.,Specks U. Churg-Strauss syndrome; update on clinical, laboratory and therapeutic aspects. Sarcoidosis Vasc.Diffuse Lung Dis. 2006:23;3-12.

8. Massi A.T., Hunder G.G.,Lie J.T., et al. The American College of Rheumatology 1990 criteria for the classification of ChurgStrauss syndrome (allergic granulomatosis and angiitis). Arthritis Rheum.1990:33;1094-1100.

9. Mi-Jeong Kim, Kyoung-HeeSohn, Woo-Jung Song et al. Clinical features and prognostic factors of Churg-Strauss syndrome. Korean J. Intern. Med.2014:29;2985-2995.

10. Martin R.V,Wiltn LW., Mann R.D. Prvalece of Churg-Stauss sindrome, vasculitis, eosinophilia and assjciated conditions: retrospective analysis of 58 prescripion-event monitoring cohort studies. Pharmacoepidemiol. Drug Saf. 1999:8; 179-189.

\section{Authors' contributions:}

According to the order of the Authorship.

\section{Conflict of interest:}

The Authors declare no conflict of interest.

\section{CORRESPONDING AUTHOR}

\section{Ivan P. Katerenchuk}

Department of Internal Medicine

Ukrainian Medical Stomatological Academy

23, Shevchenka str., Poltava, Ukraine

Tel +0380679132987

e-mail: ikaterenchuk@ukr.net

Received: 10.02 .2019

Accepted: 05.04.2019 